\title{
LA RESPONSABILIDAD PENAL DE LAS PERSONAS JURÍDICAS
}

PABLO GONZÁLEZ SIERRA

TESIS DOCTOAL

GRANADA, 2012 
Editor: Editorial de la Universidad de Granada Autor: Pablo González Sierra

D.L.: GR 2888-2012

ISBN: 978-84-9028-223-6 


\section{LA RESPONSABILIDAD PENAL DE LAS PERSONAS JURÍDICAS}

Tesis presentada para la obtención del grado de Doctor, presentada por el Licenciado en Derecho Don Pablo González Sierra y realizada bajo la dirección de los Profesores Doctor Don Esteban Pérez Alonso, Catedrático de Derecho Penal de la Universidad de Granada, y Doctora Elena Blanca Marín de Espinoza Ceballos, Profesora Titular de Derecho Penal de la Universidad de Granada.

Vo.Bo.

Los Directores

El autor

UNIVERSIDAD DE GRANADA

DEPARTAMENTO DE DERECHO PENAL

2012 


\section{LA RESPONSABILIDAD PENAL DE LAS PERSONAS JURÍDICAS}

INDICE GENERAL. . . . . . . . . . . . . . . . . . . . . . . . 15

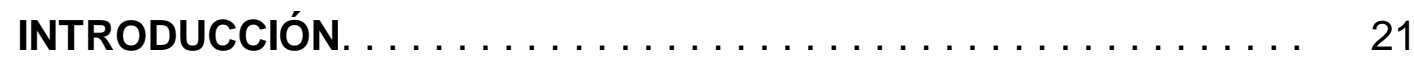

\section{PRIMERA PARTE \\ MODELOS DE RESPONSABILIDAD CRIMINAL DE LAS PERSONAS JURIDICAS}

\section{CAPTIULO I \\ ASPECTOS GENERALES}

1. PLANTEAMIENTO DEL PROBLEMA. . . . . . . . . . . . . . . . . 29

2. LOS CONTENIDOS Y NO CONTENIDOS DE LA INVESTIGACIÓN. 33

3. METOLOGÍA UTILIZADA. . . . . . . . . . . . . . . . . . 39

\section{CAPITULO II}

TRES DIMENSIONES DE LOS MODELOS DE RESPONSABILIDAD PENAL DE LAS PERSONAS JURÍDICAS . . . . . . . . . . . . . 53

1. DIMENSIÓN POLÍTICO CRIMINAL. . . . . . . . . . . . . . 56

1.1. Necesidades político criminales de responsabilizar

penalmente a las personas jurídicas. . . . . . . . . . . . 56

1.1.1. La persona individual como rélòsujeto r̃dañinoò . . . 57

1.1.2. La importancia de las personas jurídicas en el

tráfico social: el nuevo y más grave sujeto activo de

Derecho Penal. . . . . . . . . . . . . . . . . . . . 60

1.1.3. Irresponsabilidad individual organizada e irresponsabilidad estructural organizada. . . . . . . 69

1.1.4. Insuficiencia preventiva de otras sanciones (dere-

cho administrativo y derecho civil). . . . . . . . . 72

1.2. Hacia un sistema eficiente de responsabilidad penal de personas jurídicas. . . . . . . . . . . . . . . . . . 78 
2. DIMENSIÓN LEGITIMADORA O JURÍDICO PENAL...........

2.1. Obstáculos dogmáticos penales para la responsabilidad penal de las personas jurídicas. . . . . . . . . . . . 87

2.1.1. Modelos dogmáticos elaborados a la medida de rélò sujeto individual r̃dañinoò Breve reseña. . . . . . . . . . . 89

2.1.2. Obstáculos de imputación objetiva y de imputación subjetiva. ...................... 97

2.1.3. Obstáculos de culpabilidad. . ............ 100

2.1.4. Obstáculos de personalidad de las penas. ...... 101

2.2. Hacia un sistema garantista de responsabilidad penal de las personas jurídicas. . . . . . . . . . . . . . . . . . . . . . . . . . 104

3. DIMENSIÓN PRÁCTICA O DE APLICACIÓN. .............. 105 3.1. Injusto objetivo y subjetivo, y culpabilidad propios de la persona jurídica. ........................ 106

3.1.1. No necesidad (o menor necesidad) del injusto y culpabilidad de la persona física. .............. 106

3.1.2. Equilibrio en las cargas probatorias del órgano acusador........................ 108 3.2. Separación de responsabilidades de la persona física y la jurídica. . . . . . . . . . . . . . . . . . . . . . . . . . 109

3.2.1. Problemática de disparidad de procedimientos (persona física y jurídica). . . . . . . . . . . . . . . . . . . . . . 109

3.2.2. Problemática de intereses opuestos.......... 110

3.2.3. Problemática de obtención y legitimación de

Pruebas. . . . . . . . . . . . . . . . . . . . . . . . . . 111

\section{CAPTIULO III \\ EVOLUCIÓN DOGMÁTICA Y LEGISLATIVA DEL SOCIETAS DELINQUIERE NON POTEST}

1. EL PRINCIPIO SOCIETAS DELINQUERE NON POTEST O SOCIETAS NEMO PATITUR.

2. LEGISLACIÓN PENAL Y DOCTRINA ESPAÑOLA ANTERIOR A LA LO 10/1995, DE 23 DE NOVIEMBRE. . . . . . . . . . . . . . . 118

3. LA LO 10/1995, DE 23 DE NOVIEMBRE, DE CREACIÓN DEL NUEVO CÓDIGO PENAL ESPAÑOL. . . . . . . . . . . . . . .

4. LA IMPORTANCIA DE LOS COMPROMISOS INTERNACIONALES DE ESPAÑA QUE PROPICIARON LA REFORMA. . . . . . . . . . .

\section{CAPITULO IV \\ MODELOS DE RESPONSABILIDAD PENAL DE LAS PERSONAS JURÍDICAS}

1. MODELOS DE RESPONSABILIDAD PENAL DE LAS

PERSONAS JURÍDICAS SIN CULPABILIDAD. . . . . . . . . . 144 
2. EL MODELO DE LA RESPONSABILIDAD VICARIAL. . . . . . 150

2.1. La identification theory o respondant agent. ........ 150

2.2. Relajamiento de la identification theory o respondant superior. . . . . . . . . . . . . . . . . . . . . . . . . . . 154

2.3. El caso francés. . . . . . . . . . . . . . . . . 159

3. MODELO DEL HECHO DE REFERENCIA O HECHO DE CONEXIÓN SIN CULPABILIDAD PROPIA DE LA PERSONA

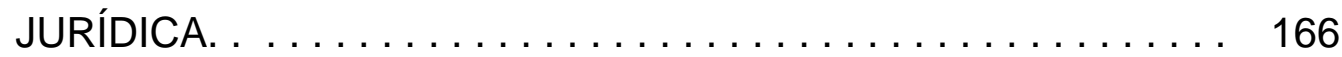

3.1. El caso alemán. . . . . . . . . . . . . . . . . 168

3.2. El caso holandés. . . . . . . . . . . . . . . . . . . . 172

4. MODELOS POR HECHO DE CONEXIÓN Y CULPABILIDAD PROPIA

DE LA PERSONA JURÍDICA

4.1. Culpabilidad por defecto de organización. . . . . . . 176

4.2. El caso italiano. . . . . . . . . . . . . . . . . . . 182

5. MODELOS DE INJUSTO Y CULPABILIDAD PROPIOS DE LA PERSONA JURÍDICA . . . . . . . . . . . . . . . . . . . . 189

5.1. Culpabilidad ético social. . . . . . . . . . . . . . . . 190

5.2. Culpabilidad por la conducción inadecuada de la empresa. . . . . . . . . . . . . . . . . . . . . . . . . 196

5.3. La culpabilidad constructiva. . . . . . . . . . . . . 202

5.4. El Manslaugther act inglés de 2007. . . . . . . . . . 210

5.5. El CP Australiano. . . . . . . . . . . . . . . . . . . . . . . 215

\section{SEGUNDA PARTE: \\ TEORÍA JURÍDICA DEL DELITO DE LAS PERSONAS JURÍDICAS A PARTIR DE LA LO 5/2010}

\section{CAPITULO V CONSTRUCCIONES TEÓRICAS A PARTIR DE LA LO 5/2010, DE 23 DE JUNIO}

1. INTRODUCCIÓN.

2. EL ART. 31 BIS CP COMO RESPONSABILIDAD PENAL SIN CULPABILIDAD DE LAS PERSONAS JURÍDICAS. . . . . . . .

2.1. El art. 31 bis CP como un modelo de responsabilidad objetiva del riesgo.

3. EL ART. 31 BIS CP COMO HETERO RESPONSABILIDAD PENAL DE LAS PERSONAS JURÍDICAS. . . . . . . . . . . . . 235 3.1. Exposición general de la tesis: injusto y culpabilidad de las personas jurídicas.......................... 235 3.2. Causas eximentes de responsabilidad de la persona 


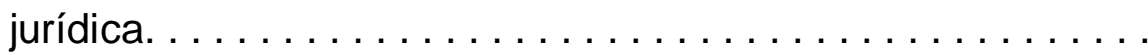

3.3. Ventajas del sistema de responsabilidad penal de la

persona jurídica por el hecho ajeno.

4. CONSTRUCCIONES CON INJUSTO POR EL HECHO DE CONEXIÓN Y CULPABILIDAD POR DEFECTO DE LA ORGANIZACIÓN

4.1. Exposición general de las tesis: el injusto personal de la persona jurídica. ........................ 243

4.2. La culpabilidad de la persona jurídica .............. 248

4.3. Causas que eximen la responsabilidad penal de la persona jurídica............................ 255

4.4. Ventajas del sistema de responsabilidad penal de la persona jurídica por el t̃echo de conexiónò .................

5. CONSTRUCCIONES CON INJUSTO Y CULPABILIDAD PROPIOS DE LA PERSONA JURÍDICA.

5.1. El injusto personal de la persona jurídica: el defecto de organización. . . . . . . . . . . . . . . . . . . . . . . . . 260

5.2. La culpabilidad propia de la persona jurídica. . . . . . . . . . 264

5.3. Causas que eximen la responsabilidad penal de la persona jurídica..............................

6. OTRAS POSICIONES DOCTRINARIAS

6.1. La comisión por omisión imprudente como título de imputación a la persona jurídica. . . . . . . . . . . . . . . . .

6.2. El art. 31 bis CP como numerus clausus de delito imprudente propio de las personas jurídica. .................. 6.3. Doble fundamentación del art. 31 bis CP y confusión de la culpabilidad con peligrosidad.

\section{CAPITULO VI}

\section{EL MODELO DE RESPONSABILIDAD PENAL DEL ART. 31 BIS CP:} TOMA DE POSICIÓN

1. EL MODELO DE RESPONSABILIDAD PENAL SEGUIDO POR EL LEGISLADOR ESPAÑOL DE $2010 \ldots \ldots \ldots \ldots \ldots \ldots \ldots \ldots \ldots$ 1.1. El art. 31 bis CP no expresa un sistema de autorresponsabilidad penal radical. . . . . . . . . . . . . . . . . . 1.2. El art. 31 bis CP como un sistema en camino hacia la autorresponsabilidad penal de las personas jurídicas. .... 1.3. Rechazo de las tesis interpretativas del hecho de conexión de la persona física como injusto de la persona jurídica. . . . . 1.4. Rechazo de las tesis que propugnan un modelo de responsabilidad vicarial en el art. 31 bis CP. ............ 1.5. Rechazo de las tesis del modelo de responsabilidad objetiva del riesgo.

2. TOMA DE POSICIÓN. . . . . . . . . . . . . . . . . . . . 301 


\section{CAPITULO VII \\ EL PRESUPUESTO DE LA RESPONSABILIDAD PENAL DE LAS PERSONAS JURÍDICAS: EL HECHO DE CONEXIÓN}

1. EL DELITO DE LA PERSONA FÍSICA . . . . . . . . . . . 308

2. LOS SUJETOS ACTIVOS COMPETENTES. .......... 315

2.1. Administrador de hecho y de derecho. ........ 316

2.2. Representante legal. ................ 319

2.3. Los sometidos a la autoridad de los anteriores. .... $\quad 320$

2.- EL INJUSTO DE LA PERSONA FÍSICA

3.1. La conducta de la persona física. . . . . . . . . . 323

3.1.1. La acción y la omisión de los administradores y de los representantes legales, y de los sometidos a su control. . . 324

3.2. Circunstancias normativas. . . . . . . . . . . . . 334

3.2.1. En nombre o por cuenta de la persona jurídica. . . . 334

3.2.2.. En ejercicio de actividades sociales. . . . . . . . 338

3.2.3. En provecho. ..................... 338

3.4. El injusto subjetivo de la persona física (dolo e imprudencia). . ...................... 340

3.5. Justificantes, atenuantes, agravantes y excluyentes de la persona física. ..................... 341

\section{CAPÍTULO VIII \\ LA PERSONA JURÍDICA}

1. LA PERSONALIDAD JURÍDICA COMO CRITERIO FORMAL. . 348

2. ENTES COLECTIVOS SIN PERSONALIDAD JURÍDICA (ART. 129 CP) . . . . . . . . . . . . . . . . . . . . . . 350

2.1. Agrupaciones incluidas en la hipótesis normativa. . . . 352

2.2. Naturaleza jurídica de las consecuencias accesorias. . 353

2.3. Numerus clausus de las consecuencias accesorias. . . 358

2.4. Consecuencias accesorias que pueden ser impuestas. 359

3. ¿IMPUTABILIDAD DE LAS PERSONAS JURÍDICAS? . . . . . 360

4. PERSONAS JURÍDICAS EXCLUIDAS. . . . . . . . . . . . 375

4.1. Estado, Administraciones Públicas territoriales e institucio-

nes y organismos reguladores . . . . . . . . . . . 376

4.2. Los organismos reguladores y las Agencias Estatales. 378

4.3. Organizaciones internacionales de derecho público. . 379

4.4. Entidades públicas empresariales. . . . . . . . . . 379

4.5. Sociedades mercantiles Estatales que ejecuten políticas públicas o presenten servicios de interés económico general.380

4.6. Partidos políticos y Sindicatos. . . . . . . . . . . . . 382

\section{CAPITULO IX}




\section{SISTEMA DE RESPONSABILIDAD PENAL DE LA PERSONA JURÍDICA}

1. EL INJUSTO OBJETIVO DE LA PERSONA JURÍDICA. . . . . . . 393

1.1. Breve reseña de las teorías de la organización. . . . . . . 395

1.2. El defecto de organización. . . . . . . . . . . . . 401

1.2.1.- El defecto de organización como conducta activa y conducta pasiva de la persona jurídica. . . . . . . . . . 407

1.2.2. La estructura formal y material de la persona jurídica como objeto de imputación penal ................ 411 1.2.3. El baremo para la recta y adecuada organización de la persona jurídica .......................... 425

1.2.4. Control sobre la organización o control sobre las

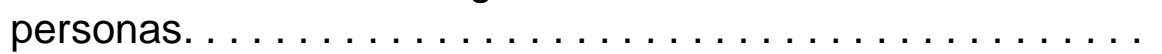
1.2.5. Un delito específico para la persona jurídica: delito de organización defectuosa. .................. 432

2. EL INJUSTO OBJETIVO DE LA PERSONA JURÍDICA. . . . . . . . 441

3. PARTICIPACIÓN DE PERSONAS Y TENTATIVA DEL DELITO. . . 449 3.1. Participación de personas en el delito de la persona jurídica............................. 449

3.2. Tentativa del delito del art. 31 bis CP .......... 458

4. CULPABILIDAD DE LA PERSONA JURÍDICA . ........... 460

4.1. Concepto y límites de la culpabilidad empresarial. . . . . . 460

4.2. Los compliance programs. ................. 466

4.2.1. La autorregulación regulada................. . 469

4.2.2. Los programas de cumplimiento............ 473

4.2.2.1. Los programas de cumplimiento sectoriales en el Derecho español. ...................... 476

4.2.2.2. Las experiencias de otros países. ........... 480

4.2.2.3. El contenido mínimo de los programas de cumplimiento........................... 487

4.2.2.3.1. Normativa del compliance. . . . . . . . . . . . . . . . 489

4.2.2.3.2. Análisis del riesgo. . . .............. 491

4.2.2.3.3. Creación de nuevos órganos y funciones. ..... . 492

4.2.2.3.4. Los whistleblowers o denunciantes internos. ..... . 493

4.2.2.3.5. Sistema de transparencia y comunicación. ..... 497

4.2.2.3.6. Sistema de implementación, ejecución y evaluación continua............................. 498

4.3. Atenuantes. . . . . . . . . . . . . . . . . . . 499

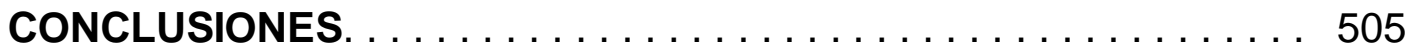

BIBLIOGRAFÍA. . . . . . . . . . . . . . . . . . . . . . . 509 


\section{INTRODUCCIÓN}

La LO 5/2010, de 23 de junio, de reforma a la L0 10/1995 de Código Penal ha significado en prácticamente la totalidad de la doctrina española la afirmación diáfana y sin tapujos de que la ley ha admitido la responsabilidad penal de las personas jurídicas: el principio romano societas delinquere non potest ha sido derrumbado. La reforma llega en un momento en que la doctrina española especializada en el tema estaba más relajada y eran cada vez más las voces que, en lugar de preguntarse si se podía y se debía admitir la responsabilidad criminal de las personas jurídicas, se ocupaban de estructurar un sistema jurídico penal de imputación a la persona jurídica respetuoso de los derechos fundamentales de las personas y de los principios básicos del Derecho Penal, reconociendo, sobre todo, las necesidades político criminales de criminalización en nuestra sociedad de riesgo. En ese momento, el legislador del 2010 contaba con la suficiente base científica suministrada por la doctrina para auxiliarse a contestar el cómo se haría la reforma.

Los compromisos internacionales de España (directivas y decisiones marco de la Unión Europea -sobre todo, la Directiva 2008/99/CE del Parlamento Europeo de 19 de noviembre, relativa a la protección del medio ambiente mediante el derecho penal, que daba un término que fenecía el 26 de diciembre de 2010) fueron la chispa que empujaron finalmente la reforma. De hecho, la exposición de motivos de la ley de reforma es clara en afirmar que fue el ordenamiento internacional de la Unión Europea el que le consignó la tarea apremiante de reformar la legislación penal interna. Ningún otro motivo expresó el legislador. Pero precisamente las directivas y decisiones marco tuvieron razones materiales que descasan en la importancia que han ido adquiriendo las personas jurídicas en el ámbito económico y social, fundamentalmente, en virtud de la adquisición de poder e 
influencia, y a la conciencia que se ha adquirido de la potencialidad lesiva de estas organizaciones: de lo que se trata, por tanto, es controlar y crear las condiciones para que el riesgo generado por las mismas se limiten a riesgos necesarios (permitidos).

La doctrina también lo consideraba así. Las personas jurídicas representan sujetos con un poder enorme de configuración de riesgos y el Derecho Penal era ajeno a su control. La irresponsabilidad individual organizada (o actitud crimina de grupo), observada por la totalidad de la doctrina, impedía la eficacia preventivo general de la pena sobre las personas físicas cuando se dirigía a éstas considerándolas con un déficit de socialización; y la irresponsabilidad estructural organizada, derivada de la descentralización de la decisión, información y operación en una empresa, obstaculizaba el éxito de un Derecho Penal que no estaba preparado para responder bajo un esquema empresarial. Era necesario romper el paradigma de la persona física como rélòsujeto de Derecho Penal.

Por otro lado, ante las actividades ilícitas y de incremento de riesgos no permitidos por parte de las personas jurídicas la forma de controlar dentro de lo necesario dichas actividades no se vuelve tan fácil: las consecuencias de carácter civil se consideraban (y consideran) insuficientes por su nimio poder preventivo y algo de ello se tiene que decir sobre las sanciones de carácter administrativo. En cambio, las sanciones de carácter penal, que podrían tener el suficiente contenido y forma expresivos como para prevenir la comisión de delitos podrían tener una justa medida en el tratamiento del problema.

La LO 5/2010, de 23 de junio, tuvo que enfrentar varios obstáculos de ninguna manera fáciles de superar 0 de menor importancia. Cierto, derivados del lluminismo alemán y de su plasmación en varios documentos que hoy se reputan de validez internacional generados a fines del siglo XVIII los principios del Derecho penal se han receptado hoy de tal manera que es inconcebible hablar de límites del ius puniendi sin ellos. Sobre todo, el principio de culpabilidad y de personalidad de la pena constituyeron (y constituyen hoy día, sin duda) los principales obstáculos para imaginar una 
responsabilidad criminal de las asociaciones que sea justa y controlada, así como coherente con el resto de las respuestas del ordenamiento jurídico penal. En un Estado Democrático y Social, se dice, no puede hoy renunciarse a esos principios.

En forma concreta las dificultades eran y siguen siendo las siguientes: la capacidad de acción, de culpabilidad y de soportar penas fueron pensadas, creadas y desarrolladas para la ñpersonaòidentificada con la persona física o humana, el sujeto, hombre o mujer, pero no para otro tipo de ñpersonasò como lo son, las personas jurídicas. Se piensa que la persona jurídica, por ser una r̃creaciónò o r̃construcciónò del orden jurídico simplemente, no puede tener jamás por sí sola esas capacidades de las que hablamos. Ni los animales, ni la naturaleza, ni las asociaciones pueden delinquir: societas delinquere non potest $\mathrm{o}$ universitas delinquere nequit.

Sin embargo, hoy ya no nos debemos de preguntar si se puede o si se debe imputar responsabilidad penal a las personas jurídicas, pues esa cuestión ya fue superada con el nuevo texto del Código Penal, sino que los derroteros inmediatos de la doctrina española deberán ser la construcción de sistemas de imputación penal para esa clase de personas acordes con la ley, respetando los límites del ius puniendi. Por descontado debe estimarse que el sistema de imputación penal que se construya, para la aplicación del nuevo texto legal, debe respetar el principio que proscribe responder por el hecho por otro, el principio de dolo y culpa, el de culpabilidad y de personalidad de las penas; pero también debe ser suficientemente practicable para equilibrar, mediante una justicia distributiva, los costes de la comisión de delitos (entre la persona jurídica, personas físicas de alta gerencia y personas físicas operativas de las empresas), con el fin de cumplir adecuadamente la función preventiva de la pena, además de tener condiciones óptimas para el equilibrio de fuerzas en el contradictorio procesal. Este trabajo de investigación pretende contribuir en algo a la urgente necesidad de la construcción de ese sistema.

Consta de dos partes. La primera, distribuida en cuatro capítulos, expondrá y sentará las bases con las que se habrá de trabajar en la 
segunda, que es donde se encuentra la propuesta de una teoría del delito de las personas jurídicas acorde a la interpretación y aplicación del nuevo texto legal. Por ello, en aquella ubicamos la expresión de los límites de este trabajo, esto es, se precisará el objeto de este estudio, así también los puntos de partida metodológicos, tan importantes si se quiere ser consecuente; además de exponer una breve evolución legislativa y doctrinaria en el entorno español del tema, desde las primeras codificaciones penales hasta el actual código penal y antes de la reforma 5/2010 de 23 de junio.

En virtud de ser una parte muy importante, sobre todo para poder interpretar la codificación actual, es menester tocar lo relativo a lo que llamamos las tres dimensiones de la responsabilidad penal de las personas jurídicas: la satisfacción de las exigencias de política criminal de responsabilizar penalmente a las personas jurídicas, las posibilidades de legitimación del texto legal, y la practicabilidad de la aplicación diaria del mismo. Un breve análisis de algunas importantes legislaciones de otros países no se echará de menos. La primera parte finalizará con la exposición de los modelos de imputación que ha elaborado la doctrina, y que será una base importante para construir el sistema derivado del texto legal vigente.

En la segunda parte habremos de analizar las construcciones dogmáticas que se han elaborado en España a partir de la LO 5/2010, de 23 de junio. Desde aquellas propuestas que interpretan que el art. 31 bis CP prevé consecuencias penales diferentes a la pena y más bien vinculadas a la peligrosidad del objeto del delito (la persona jurídica), hasta aquellas que lo interpretan como un sistema de simple responsabilidad vicarial, es decir, de responsabilidad objetiva por el hecho ajeno; y por supuesto, aquellas otras opciones de la dogmática que encuentran en el texto reformado una acción y culpabilidad propia de la persona jurídica.

Habremos de tomar partido y propondremos un modelo teórico de responsabilidad penal de las personas jurídicas que puede explicar mejor el texto legal que satisfaga, con mayor eficacia, las necesidades político criminales y de implementación práctica diaria, así como las 
exigencias de legitimación. Creemos que la acción propia de la persona jurídica es la organización empresarial defectuosa, mientras que su culpabilidad es la falta de disposición individual conforme a Derecho, sin embargo, estimamos que el art. 31 bis CP no es una norma penal de responsabilidad solidaria o subsidiaria con la responsabilidad de la persona física, ni tampoco una norma de similares características a las de participación de personas en el delito (autoría mediata o coautoría, o complicidad o inducción), sino una norma que prevé un específico tipo penal que solo pueden infringir las personas jurídicas.

Encontrará el lector los argumentos en que nos apoyamos para ofrecer esta opción interpretativa y aquellos otros de los que nos servimos para rechazar otras opciones diferentes. Además, puntos más importantes de la teoría del delito de la persona jurídica: desde la imputación objetiva del resultado, la tipicidad objetiva y subjetiva y la antijuridicidad, hasta la culpabilidad de la persona jurídica (sus causas de inculpabilidad, de disminución o aumento de la misma), transitando, por supuesto, por los casos de autoría y participación y tentativa del delito. En cada uno de los capítulos y subcapítulos se realizarán las conclusiones o propuestas específicas.

El presente trabajo de investigación pretende, pues, ofrecer una opción interpretativa del art. 31 bis CP, mediante la construcción de un sistema de responsabilidad penal de las personas jurídicas que creemos adecuado y viable, y puede inundar de sentido el texto normativo, y que pretende superar (así queremos creer) los obstáculos y contradicciones internas, tensiones de la legitimación constitucional y las insatisfacciones de necesidades político criminales que creemos poseen otras opciones de interpretación que se han realizado a raíz de la mencionada reforma.

Granada. Marzo de 2012 
PRIMERA PARTE

MODELOS DE RESPONSABILIDAD CRIMINAL DE LAS PERSONAS JURIDICAS 


\section{CAPITULO I}

\section{ASPECTOS GENERALES}

\section{PLANTEAMIENTO DEL PROBLEMA}

A manera de introducción vamos a plantear el problema central de esta investigación mediante la formulación de un caso hipotético:

Puede suceder que dentro de una gran compañía de investigación y elaboración de nuevas tecnologías, por ejemplo, una compañía farmacéutica, que está conformada por dos mil empleados, que tiene al menos una centena de departamentos diferentes (ventas, almacén, insumos, producción, contratación, imagen, innovación, departamento jurídico, entre muchos otros), que tiene por lo menos dos centenas de diferentes procedimientos escritos bien establecidos tanto para la producción como para ventas, tanto para la adquisición de insumos como para la puesta en práctica de los nuevos productos, que ha generado la dinámica de equipos inteligentes y con ello ha logrado un aplanamiento de su organigrama, lo que favorece la investigación, que por necesidades para la consecución de su objetivo tiene diferentes centros de desarrollo en distintos países, y que, por su mismo objeto de investigación, manipula y emite sustancias o materiales ionizantes en sí mismo peligrosas, y con ello, genera un aumento considerable del 
riesgo al medio ambiento, y por supuesto, a la salud o la vida de una o varias personas.

En el caso, por supuesto, que a la postre se pueda demostrar que esa emisión o ese vertido de los materiales puso en riesgo la vida o la salud de una o varias personas, y que para el caso sea aplicable el art. 343,1 CP, se imponen varios cuestionamientos:

¿Serán eficaces las investigaciones realizadas dentro de una organización con los niveles de complejidad organizativa antes esbozados de la compañía? ¿En caso de que sean eficaces y se logre demostrar la responsabilidad de las personas físicas que realizaron los hechos, será suficiente con imponerles a ellos, exclusivamente, las consecuencias del delito? ¿Se considerará suficiente o insuficiente la sola punición de las personas físicas; o será necesario también, que con una respuesta integral del Derecho Penal se impongan consecuencias jurídicas penales a la persona jurídica? Si las investigaciones no son eficaces y existe una ñrresponsabilidad estructural organizadaò precisamente por la complejidad de la empresa, por la descentralización de las funciones de decisión, operación e información, y en el caso de que no nos conformemos con la impunidad de los hechos, ¿son suficientes las medidas civiles o administrativas contra la empresa? ¿Cómo y en qué medida debe ser responsable la empresa por esos hechos? ¿De qué manera le es aplicable el art. 343,3 CP y cuál será, en específico, el sistema de imputación penal que se aplique vía art. 31 bis?

La respuesta a estos cuestionamientos focalizan el problema: Cómo, cuándo y en qué medida se debe imponer penas del Derecho Penal a la persona jurídica como tal. Hace todavía poco más de un año, a las preguntas anteriores debería añadírsele el ñSíò(esto es, si se debe imponer penas del Derecho Penal a la personas jurídica como tal), pero esa cuestión se ha resuelvo favorablemente. 
Si admitimos que el Derecho Penal debe enfrentar y controlar no sólo la criminalidad de las personas físicas sino otra clase de criminalidad entonces se estará tomando partido sobre la necesidad político criminal de criminalizar a las empresas. Esto implica salir a explorar aspectos del Derecho Penal que no estaban dados en el Derecho Penal clásico o tradicional. Éste se identifica más bien como un medio de control social relativo a las personas físicas, y en esa medida, ha sido creado y desarrollado, de forma tal que las categorías jurídico penales de acción, culpabilidad y pena también han sido pensadas y desarrolladas para la persona física. Aceptar a las personas jurídicas como personas idóneas de Derecho Penal es romper esquemas metodológicos y abrirse a los nuevos ámbitos de peligro generados por las personas jurídicas, significa romper paradigmas no siempre fáciles de dar de sí debido a la inercia del pensamiento filosófico y dogmático penal.

Pero el problema no termina ahí, sino que comienza ${ }^{1}$. Una vez que admitimos lo anterior debemos generar entonces el modelo de criminalización de las personas jurídicas. Esto es lo realmente difícil. $Y$ es que no se trata de simplemente ñmaginarnosò un modelo cualquiera $^{2}$, sino un modelo que sea coherente con los principios de

\footnotetext{
1 Cfr. ZAFFARONI, Eugenio Raúl, Derecho Penal, parte general, Porrúa, México, 2005, p. 427, señala que "para cualquier teoría de la acción cuya construcción no respete límites ónticos, la cuestión acerca de la posibilidad de ejercicio de poder punitivo sobre personas jurídicas es materia de pura decisión legal", con lo que no podemos estar de acuerdo, puesto que ni las construcciones que no sólo respetan, sino que se basan en planteamientos puramente ónticos no pueden sostener sus consecuencias sólo en planteamientos ónticos (por ejemplo, la autoría mediata y coautoría, o la imputación objetiva, que sostienen consecuencias en base a puntos de partida normativistas), y por otro lado, existen posiciones que admiten la responsabilidad de las personas jurídicas desde un perfil totalmente finalista (o sea, ontológico), Cfr. HIRSCH, Hans Joachim, "La cuestión de la responsabilidad penal de las asociaciones de personas", en ADPCP, 1993, páginas 1106 y 1110.

2 Cfr. BUSTOS RAMÍREZ J., y HORMAZÁBAL MALAREE, H., Lecciones de Derecho Penal, Parte General, tomo I, Madrid, Trota, 1997, página 246, "de ahí que su aplicación no pueda estar al margen de las garantías penales y de los principios que las informan, especialmente los de necesidad (en concreto su aspecto proporcionalidad) y dignidad de la persona... la aplicación de estas "consecuencias" está sujeta a ciertos condicionamientos garantistas que necesariamente deberán observarse si no se quiere que sean expresión de pura arbitrariedad".
} 
Derecho Penal que hoy son reconocidos por la totalidad de la ciencia del Derecho Penal: culpabilidad, personalidad de las penas, dignidad, proporcionalidad, última ratio, legalidad, entre otros. Cómo, cuándo y en qué medida deberán soportar una consecuencia jurídico penal las personas jurídicas es el reto de la ciencia jurídico penal.

Quienes se deciden por la no utilización del Derecho Penal para responder a la criminalidad de empresa entonces se tendrán que conformar con la respuesta del Derecho civil, pero se enfrentarán a la problemática de que en ese nivel los derechos dispositivos son los que se ponen en juego, y en consecuencia, la persona jurídica enfrentará una sentencia adversa si y sólo si la parte afectada sabe que ha sido afectada, que decide enfrentar un proceso civil contra una enorme empresa, que tiene la carga de la prueba y estará a costa de su bolsillo el proceso y la prueba, y que decidió no hacer caso a los intentos de la persona jurídica de llegar a un convenio de indemnización del daño. En cambio, quien se decide por el Derecho Administrativo enfrentará no sólo a la oportunidad y conveniencia que rigen como principios en la acción administrativa, sino además con problemas muy similares a los del Derecho Penal: fundamentar una culpabilidad de la persona jurídica como fundamento de la sanción administrativa. Además, ambas posiciones deberán superar que ninguna de ellas tiene el suficiente carácter expresivo de desaprobación social como lo tiene, a diferencia, el Derecho Penal.

Puede ser que se piense que el Derecho Penal es el instrumento perfecto para el combate a la llamada criminalidad económica, en forma específica, a la criminalidad de empresa; pero ante la difícil construcción de los contenidos de las categorías dogmáticas penales, en especial, la capacidad de culpabilidad de la persona jurídica, se opte por una respuesta diferente de la penal. En efecto, si el Derecho Penal es la respuesta con el suficiente contenido expresivo de desaprobación social, entonces es adecuado usarlo y no tanto el Derecho Civil ni el Derecho Administrativo, pero como la pena 
deberá fundarse en la culpabilidad de la persona, y ésta es imposible pensarla para la persona jurídica, entonces la respuesta podrá ser, o las medidas de seguridad o alguna f̃ercera víaòque se pueda generar por vía penal. El obstáculo que tendrán que superar estas posturas es, en

relación con las que proponen medidas de seguridad, el pensar en un concepto de p̃peligrosidadò de la persona jurídica diferente, pero funcionalmente similar, al que hoy en día la dogmática penal la usa para la persona física; y en relación con los que piensen en la tercera vía, el problema a superar será la fundamentación y limitación de esas consecuencias, así como el esquema de aplicación.

Quienes por el contrario consideran que es la pena del Derecho Penal la respuesta idónea a esa problemática deberán construir un sistema penal paralelo al de las personas físicas o un sistema penal omnicomprensivo tanto para personas físicas como jurídicas. De cualquier modo, el obstáculo que se antoja muy difícil de superar es la construcción de un contenido de culpabilidad acorde con las personas jurídicas. Este es el reto de la ciencia del Derecho Penal española en la actualidad: la LO 5/2010, de 23 de junio, de reforma del CP, incluye una verdadera responsabilidad para las personas jurídicas, y es necesario y urgente, desarrollar las bases para un sistema de responsabilidad penal de los entes colectivos a tono con la reglamentación vigente, un sistema eficaz, eficiente, conveniente, pero sobre todo, respetuoso de los derechos fundamentales de las personas jurídicas.

\section{LOS CONTENIDOS $Y$ NO CONTENIDOS DE LA INVESTIGACIÓN}

Es menester mostrar desde este primer momento cuáles son los límites de este trabajo de investigación, esto es, qué debe esperar el 
lector encontrarse dentro del presente texto y qué es lo que ya no pertenece aquí.

En principio, se distingue entre criminalidad de empresa y criminalidad en la empresa ${ }^{3}$. Este puede ser un buen comienzo para distinguir lo que habremos de tratar aquí, en primer lugar: solamente la llamada criminalidad de empresa que implica exclusivamente los modos en que se resuelven casos de verdadero contenido de dañosidad social y que son cometidos por una persona jurídica también llamada asociación o empresa u organización.

Esto implica prioritariamente la fundamentación y limitación de un sistema jurídico penal de imputación de una consecuencia por la actuación propia de una persona jurídica, y todo lo que ello lleva aparejado: la generación de contenidos para las categorías penales de acción, culpabilidad y pena que pueda ser adaptada o generada también para las personas jurídicas. Desde luego, se insiste, a tono con la legislación vigente a partir del 23 de diciembre de 2010.

En otras ramas del derecho, como la civil, existen tendencias aparentemente contrarias al sentido de esta investigación. La teoría del ñevantamiento del veloôt que se erige con el objetivo de, ante un hecho

\footnotetext{
${ }^{3}$ Así, SCHÜNEMANN, B., "Cuestiones básicas de la dogmática jurídico penal y de la política criminal acerca de la criminalidad de empresa", Trad. Brucker y Lascurain, $A D P C P, 1988$, página 570 y 571. Dice que criminalidad en la empresa está conformada por aquellos daños causados por colaboradores de la empresa a la misma o a otros colaboradores, mientras criminalidad de la empresa la concibe como la suma de delitos económicos cometidos a partir de una empresa, y que plantea problemas como la influencia criminógena de una "actitud criminal de grupo", las dificultades de determinación normativa de las competencias y de la imputación jurídico-penal y problemas de averiguación del verdadero responsable.

${ }^{4}$ En Derecho Civil no existe ningún obstáculo para reconocer a la persona jurídica el carácter de "persona en Derecho", de forma tal que es exactamente lo mismo ser eso o una persona física: ambos son centros de imputación de derechos y obligaciones. Así las cosas, si existe algún ilícito cometido en el seno de una persona jurídica, al Derecho Civil, interesado en la indemnización del daño, sólo le importa que la persona jurídica sea responsable y en todo caso se haga cargo de pagar el daño causado. Sin embargo, en esa materia se considera conveniente ir hacia las entrañas de la persona jurídica para encontrar y hacer responsable a la persona física realmente responsable del aumento del riesgo, pues si no fuera así,
} 
ilícito cometido en el seno de una empresa, desvelar a la(s) persona(s) física(s) verdaderamente responsable del mismo, en lugar de conformarse con la responsabilidad civil de la propia persona jurídica, tiene en apariencia la dirección opuesta a nuestro objetivo, pues lo que se pretende es saber si es posible que con las capacidades de nuestra dogmática penal se pueda también criminalizar a la empresa por ser también ella responsable a título propio del hecho ilícito. Es una oposición solo aparente porque, como se planteará, con el sistema de responsabilidad de las personas jurídicas que se propone no existe desinterés en las responsabilidades individuales de los miembros de la empresa, y además, el esquema de los programas de cumplimiento que los entes colectivos tendrían necesidad de gestionar necesitarán encontrar al responsable individual para disminuir sensiblemente su culpabilidad y su sanción eventual.

Por ello, no queremos decir con lo anterior que proclamamos una eliminación de toda clase de responsabilidades individuales de los miembros y órganos de la empresa. Junto a la edificación de la responsabilidad penal de la persona jurídica como tal, será necesario que también actúe y se ponga en evidencia las responsabilidades criminales de los individuos que tomando decisiones, manejando la información u operando, hayan cometido a título propio determinados delitos, sin embargo, esto no será tratado aquí. De qué forma responden los gerentes, administradores, órganos, socios, miembros o trabajadores y empleados de una empresa, por los delitos cometidos a título propio (como autores o partícipes) ${ }^{5}$, es contenido de este trabajo solamente en la medida que nos servirá para analizar la llamada "conexión" entre el hecho criminoso de la persona individual con la

no se alcanzaría la justicia, además de que seguramente continuaría el riesgo a los bienes jurídicos de las personas.

5 Estos aspectos son vistos por GARCIA CAVERO, Percy, La responsabilidad penal del administrador de hecho de la empresa: Criterios de imputación, Bosch Editor, Barcelona, 1999; MARIN DE ESPINOZA CEBALLOS, Elena B., Criminalidad de empresa, la responsabilidad penal en las estructuras jerárquicamente organizadas, Tirant lo blanch, Valencia, 2002, pássim; y NUÑEZ CASTAÑO, Elena, Responsabilidad penal en la empresa, Tirant lo blanch, Valencia, 2000, pássim. 
responsabilidad de la empresa (que lo consideramos solamente un presupuesto de responsabilidad, no su fundamento) y que lo previene el art. 31 bis del CP vigente; puesto que habremos de verificar las dificultades que existen para poder afirmar dogmáticamente cuál es en forma precisa el hecho que debe cometer el administrador de hecho o de derecho, y en su caso, bajo qué clase de participación, para afirmar que es suficiente para responsabilizar a la persona jurídica con la que está relacionado, y de la misma manera nos servirá para contestar cuestionamientos relativos a la autoría y participación entre dos personas jurídicas o entre una persona física que induce a una jurídica o cuando una persona jurídica auxilia al hecho delictuoso de una física.

En segundo lugar, tampoco será materia del presente análisis aquel tópico tan importante como es el rãctuar en nombre de otroò y que en un tiempo, fue considerado como la puerta de entrada de la responsabilidad penal de las personas jurídicas.

El art. 31 del CP señala textualmente riEl que actúe como administrador de hecho o de derecho de una persona jurídica, o en nombre o representación legal o voluntaria de otro, responderá personalmente, aunque no concurran en él las condiciones, cualidades o relaciones que la correspondiente figura de delito o falta requiera para poder ser sujeto activo del mismo, si tales circunstancias se dan en la entidad o persona en cuyo nombre o representación obre.ò Esta redacción es exactamente igual a su antecesor, el art. 15 bis del CP anterior (el de 1973) que la inauguró, y en un primer momento la interpretación jurisprudencial se decantó en el sentido de resolver la responsabilidad penal de las personas jurídicas; y es que se estimaba que un representante legal de una persona jurídica podía dar lugar a la responsabilidad de aquella, pues de otra manera, no tendría sentido el texto legal ${ }^{6}$. Por supuesto que la respuesta de la doctrina no se hizo

6 ZUGALDÍA ESPINAR, José Miguel, La responsabilidad penal de empresas, fundaciones y asociaciones, Tirant monografías, Valencia, 2008, p. 88. 
esperar y en múltiples aportaciones ${ }^{7}$ dejó claro que ese tal art. 15 bis del CP nada tenía que ver con la responsabilidad criminal de la empresa.

En realidad, el art. 31 del $\mathrm{CP}$ actual solamente es útil para colmar una laguna de punibilidad en aquellos casos en que el tipo penal exigiera una específica cualidad al sujeto activo del delito, sin la cual, sería imposible imponerle una sanción ni declararlo responsable por falta de tipicidad objetiva. Sucede en aquellos ejemplos donde para ser actor del delito de alzamiento de bienes del art. 257 del $\mathrm{CP}^{8}$ era necesario ser el titular de la obligación, esto es, el deudor, y tener una relación jurídica prestacional con r̃susò acreedores; pues bien, si la deudora era la persona jurídica (quien por cierto, no cometía delitos, según la legislación y la dominante doctrina del momento) y por tanto, en su contra se dirigía el mandamiento de la norma penal, era imposible que ella ñpersonalmenteò cometiera el delito, pues quien desplegaba la conducta de ocultamiento de los bienes era, en todo caso, su administrador o representante legal, en cuya persona no se podría imputar ningún delito puesto que no era sujeto activo idóneo para cometer ese delito especial. Hacía falta, entonces, una norma amplificadora de los tipos penales que previera la responsabilidad penal en aquellos casos en donde existía una laguna de punibilidad.

El art. 15 bis del CP de 1973, y su correlativo 31 del vigente, más que conmover el principio de que las sociedades no delinquen, confirmaba el añejo brocardo pues al crear una norma que extendiera la punibilidad a las personas físicas que actuaban en su lugar les negaba

\footnotetext{
7 Por todos, GRACIA MARTín, Luis, El actuar en lugar de otro en Derecho Penal, Tomo I y Tomo II, Zaragoza, 1985, pássim.

${ }^{8}$ Art. 257 CP: “1. Será castigado con las penas de prisión de uno a cuatro años y multa de doce a veinticuatro meses: 1 . El que se alce con sus bienes en perjuicio de sus acreedores. 2. Quien con el mismo fin, realice cualquier acto de disposición patrimonial o generador de obligaciones que dilate, dificulte o impida la eficacia de un embargo o de un procedimiento ejecutivo o de apremio, judicial, extrajudicial o administrativo, iniciado o de previsible iniciación.
} 
y desconocía la capacidad de acción y culpabilidad a las personas jurídicas. $^{9}$

Tampoco será materia de la presente investigación las cuestiones relativas al proceso penal específico que se tiene previsto en la ley para legitimar una sentencia de absolución o condena contra una persona jurídica. Fue el martes 11 de octubre de 2011 cuando se publicó en el Boletín Oficial del Estado la Ley Orgánica 37/2011, de 10 de octubre, de medidas de agilización judicial (de modificación a la Ley de Enjuiciamiento Criminal) donde se introduce todo un estatuto procesal para la adscripción de la responsabilidad criminal a la persona jurídica en sede judicial. El estudio y análisis de este rubro no podrá ser materia de un trabajo como éste.

Sin embargo, lo anterior no será óbice para adentrarnos a algunas dificultades o problemáticas que se suscitan, ya desde el modelo de responsabilidad penal construido, con las cuestiones relativas a la aplicación práctica del mismo, como podrían ser aquellas relativas a la presunción de la acusación respecto de la culpabilidad, y la necesidad, en cambio, de acreditar positivamente el injusto penal de la persona jurídica. El contenido del injusto penal y de la culpabilidad que el sistema de responsabilidad penal de la persona jurídica construido les otorgue, determinará problemas procesales que exige solución en esta misma investigación.

Debemos, por otro lado, dejar bien claro nuestro objeto de investigación. Trataremos los aspectos relacionados con los sistemas de imputación en la medida que la potencialidad de la dogmática jurídico penal alcance a cubrir la responsabilidad penal de las personas jurídicas, respetando los límites del ius puniendi, en la aplicación práctica del actual texto legal, pero siendo exigentes en responder

\footnotetext{
9 BACIGALUPO ZAPATER, Enrique, "Responsabilidad penal de órganos, directivos y representantes de una persona jurídica (el actuar en nombre de otro)", Comentarios a la Legislación Penal, Tomo V, Volumen I, Madrid, 1985, página 315 y siguientes.
} 
positivamente a las necesidades de política criminal que dio lugar a ella y a su practicabilidad; esto es, una propuesta práctica de una teoría jurídica del delito. No nos ocuparemos, por lo tanto, más que en la medida en que para el objetivo anterior nos hace falta, de las penas o las consecuencias accesorias que se encuentran incluidas en los arts. 33.7 y 129 del CP.

El tratamiento de las consecuencias del delito (como la multa, la disolución, suspensión de actividades, clausura de locales y establecimientos, prohibición de realizar actividades, inhabilitación para obtener subvenciones o la intervención judicial) son de capital trascendencia, y en más de un sentido, indispensable para comprender los contenidos de la acción y sobre todo de la culpabilidad de la persona jurídica; no obstante, no es nuestra intención desarrollarla en todo su alcance, sino que sería materia de otra investigación. Lo mismo se tendría que decir de las consecuencias accesorias del art. 129 CP.

Por ello, en la medida y profundidad en que el análisis de esas consecuencias jurídicas del delito de la persona jurídica (y en su caso, las consecuencias accesorias) sea útil para conseguir el entendimiento de la teoría jurídica del delito (sobre todo, de la culpabilidad) será de interés para este trabajo de investigación. Con otras palabras, solo en cuanto a su funcionalidad con los conceptos de la teoría jurídica del delito, las consecuencias del mismo nos harán falta y echaremos mano de ellas. El alcance de las consecuencias y la problemática de la aplicación de las mismas rebasa los objetivos planteados de la presente investigación.

Las precisiones conceptuales y el manejo claro de los contenidos de este trabajo son obligados si se quiere darle al lector las herramientas suficientes para comprender, desde inicio, la intención y la extensión del trabajo que ahora lee. Con ello evitamos sorpresas, y sobre todo, desilusiones. 


\section{METODLOGÍA UTILIZADA}

Es tan claro, como desafortunadamente no entendido, que no es posible asumir determinada solución a un problema de carácter penal, utilizando las categorías de la teoría jurídica del delito, si no se toma partido en las concepciones básicas del Derecho Penal. Dar respuesta a una cuestión penal sin estar consciente de la formulación sistemática adoptada daría lugar, muy probablemente, a incoherencias o inconsistencias, por lo menos. Por lo demás, no es serio ni tiene rigor científico la posición que se asuma si no se asumen conscientemente las consecuencias lógicas y coherentes de la sistemática adoptada.

La mejor forma de hacerlo, creemos, es mostrar la posición metodológica que se asuma para que nuestro desarrollo del tema y sus respectivas conclusiones sean consideradas y estimadas, analizadas y criticadas, dentro de un panorama que nos ubique.

Además, es una muestra de sinceridad científica: al ubicarnos, nos auto limitamos en nuestras posibilidades de respuesta, y desde inicio, le decimos al lector, a qué estamos dispuestos y a qué no, en materia de dogmática penal. Desde luego que ello será sólo con efectos de mostrar la metodología, no desarrollarla, pues eso podría ser labor de varias veces el volumen y el esfuerzo que el presente trabajo significa, pero que no tiene la intención de ser.

Todo esto se vuelve más importante cuando se trata un tema que obliga a voltear hacia los aspectos centrales del Derecho Penal, a su núcleo duro, a la revisión no sólo de cuáles y en qué orden serán las categorías de la teoría jurídica del delito, sino a la revisión de cuál será su contenido, si es que se quiere analizar la responsabilidad de las personas jurídicas. Este tema genera que los edificios conceptuales construidos hasta hoy, en materia de responsabilidad penal de la organización empresarial, se cimbren. 
Pues bien, como dice Zugaldía $^{10}$ rel problema del Derecho Penal, todo, en el fondo, comienza y se agota en la cuestión del fundamento y fines de la penaò Esto es, el por qué y para qué de la pena constituyen los temas que circulan y son base en la explicación de la Ciencia del Derecho Penal. Desde las concepciones absolutas ${ }^{11}$, hasta las de la prevención especial ${ }^{12}$, la prevención general ${ }^{13}$ y las mixtas o de la unión ${ }^{14}$ tratan de fundamentar la pena, y por consiguiente, el sistema del Derecho Penal.

10 ZUGALDÍA E., José M., “¿Otra vez la vuelta a Von Liszt?”, en la Introducción a VON LISZT, F., La idea del fin en el Derecho Penal, Comares, Granada, 1995, p. 11. En la nota 1 sigue diciendo "de ahí el error metodológico de quienes en sus exposiciones doctrinales se ocupan en primer lugar de la cuestión del fundamento y función del Derecho Penal y, sólo en última instancia, como algo desvinculado de lo anterior, del fundamento y función de la pena estatal".

${ }^{11}$ Las teorías absolutas de la pena fundamentan la pena en la justicia, y nada más en la justicia (de ahí, absolutas), de forma tal que el concepto de "retribución" se traduciría en la medida de la sanción al infractor. La retribución es regresar el mal que hizo en la misma medida en que lo hizo. No existe ninguna utilidad diferente de la pena, puesto que no es posible legitimar ninguna clase de prevención. Vid. por todos MIR PUIG, Santiago, Derecho Penal. Parte General, Reppertor, Madrid, 1999, p. 46 a 48; y QUINTERO OLIVARES, Gonzalo, Parte General del Derecho Penal, Aranzadi, Navarra, 2005, p. 109 y 110.

12 Las teorías de la prevención consideran que si es posible legitimar utilidad a la pena, es más, fundar y limitar la pena y su medida a través de las necesidades de prevención. La prevención especial (positiva o negativa) fundamentalmente propone la intervención del infractor de la norma penal (ya sea para resocializarlo o para inocuizarlo) con el fin de que no vuelva a delinquir o para que no delinca durante el tiempo de la condena. Vid. MIR PUIG, S., Ib Ídem, p. 49 y 50; y QUINTERO OLIVARES, G., Ib Ídem, p. 111 y 112.

$13 \mathrm{Ib}$ Ídem. Su diferencia con las de la prevención especial, es que no propone acciones de intervención al infractor, sino al resto de los ciudadanos que no han infringido la norma, ya sea para que sirva (la pena) de testigo de que la norma sigue siendo el criterio de conducta válido a pesar de la infracción (la pena es la negación del delito, que a su vez es la negación de la norma, con lo que la pena es la afirmación de la norma), ya sea para que los intimide y no delincan para no sufrir la suerte que sufrió el infractor.

14 Uno de los representantes de estas teorías, Claus Roxin, afirmaba que no reñían entre sí ninguna de las teorías, sino que era posible su vinculación funcional a través de considerar diferentes momentos de su validación: antes de cometerse el delito, funciona una prevención general pues intimida a quienes no han cometido el delito, al momento de imponerse la pena, su medida dependerá del criterio de la retribución, y al momento de sufrir la condena, será la prevención especial la que impere. Cfr. ROXIN, Claus, Derecho Penal. Parte general. Fundamentos, traducción LUZON PEÑA, D.M., DIAZ Y GARCÍA CONLLEDO, M, REMESAL, J., tomo I, Civitas, Madrid, 1999, p. 95 a 103; el mismo, "La determinación de la pena a la luz de la teoría de los fines de la pena", Culpabilidad y prevención en Derecho Penal, Reus, Madrid, 1981, p. 112 y 113. 
En los términos del art. 25.2 de la Constitución de 1978 la pena de prisión y las medidas de seguridad tienen una finalidad utilitaria que se ubica y se observa en la aplicación de la pena misma, es decir, una vez impuesta por el Juez penal en sentencia definitiva después de haber llevado un proceso penal. Dice el precepto señalado "Las penas privativas de libertad y las medidas de seguridad estarán orientadas hacia la reeducación y reinserción social y no podrán consistir en trabajos forzados. El condenado a pena de prisión que estuviere cumpliendo la misma gozará de los derechos fundamentales de este Capítulo...". Como se observa, el discurso constitucional toma expreso partido por una tesis preventiva especial positiva, que no es otra cosa que la intervención sobre el condenado: experimentar en él un cambio que se traduzca en la reeducación y en la reinserción social.

Empero nada obsta para que a nivel legislativo la norma penal misma cumpla ya ciertas funciones que son propias de la teoría de la prevención general negativa: la disuasión. De igual manera, en su aplicación la pena cumple funciones absolutas (retribución) y de prevención general positiva: asegurar que la norma penal sigue siendo el criterio general de conducta a seguir, a pesar, o precisamente por ello, de la violación de la misma por parte del infractor, y la pena, como consecuencia de la infracción, sea consecuencia también de su falta de medida de fidelidad al ordenamiento jurídico. Estimamos que no existe ningún obstáculo para considerar que la pena impuesta a una persona dentro de un proceso penal significa ya una autoconfirmación del sistema penal, y se proyecta, con un poder de significado, al resto de las personas que viven en sociedad dando testimonio y mensaje de que les es conveniente el respeto a los bienes jurídicos de los demás.

Como consecuencia casi obligada, la concepción de la pena que consideramos que mejor se adapta y explica a nuestro ordenamiento jurídico es una teoría mixta o de la unión, en donde la pena cumple varias funciones dependiendo del momento en que sea 
considerada $^{15}$ : función preventiva general negativa en la punibilidad, función retributiva y preventiva general positiva y especial al momento de la punición, y función preventivo especial al momento de la ejecución de la pena.

Habría que considerar, por lo que hace a la prevención general positiva, lo que de ella entiende Jakobs: la pena ré es siempre reacción ante la infracción de una norma. Mediante la reacción siempre se pone de manifiesto que ha de observarse la norma. Y la reacción demostrativa siempre tiene lugar a costa del responsable por haber infringido la norma (por r̃a costa del responsableòse entiende en este contexto la pérdida de cualquier bien)é La pena hay que definirla positivamente: Es una muestra de la vigencia de la norma a costa de un responsable. De ahí surge un mal, pero la pena no ha cumplido ya su cometido con tal efecto, sino sólo con la estabilización de la norma lesionadad̆ ${ }^{6}$.

El concepto y función de la pena nos servirá para tener un punto de partida en cuanto nuestro entendimiento por el concepto de persona y culpabilidad.

En efecto, como lo podremos de manifiesto infra ${ }^{17}$ la doctrina tradicional se ha elaborado y desarrollado entendiendo a un único sujeto de Derecho Penal, a una única persona en contra de la cual se dirija la norma y la amenaza penal, y también en cuya contra se aplique la pena (de prisión, fundamentalmente) que es la persona física. Esto se debió a aquella huida del movimiento de Ilustración en Francia de cualquier concepción de personas colectivas, y por lo tanto, con la exclusividad de ser sujeto penal del individuo o persona física, por un lado, y la aparición casi de la nada de la pena de prisión como

\footnotetext{
15 ROXIN, Claus, Fundamentos, Op. Cit., página 103.

16 Por el momento, sólo JAKOBS, G., Derecho Penal, parte general (Fundamentos y teoría de la imputación), Op. cit., p. 8 y 9.

${ }^{17}$ Capítulo III.2.1.1.
} 
consecuencia del delito ${ }^{18}$. Individuo o persona física y pena de prisión como conceptos antonomásticos del Derecho Penal fueron, en nuestra concepción, el binomio que produjeron, y siguen produciendo, la exclusión de la persona jurídica en el campo del Derecho Penal.

Si se sigue insistiendo que las personas jurídicas no deberían estar sometidas al Derecho Penal porque no tienen las características biosicológicas que en cambio sí tienen las físicas, entonces convertiríamos la discusión en un juego circular $^{19}$ del que no sería posible salir y daríamos razón a esas posiciones. Por ello, más que un problema jurídico o interno del Derecho Penal, consideramos que el problema del sujeto de derecho es de carácter supra jurídico o meta jurídico ${ }^{20}$, de decisiones político criminales, que implica reconocer que el trinomio persona física ï pena de prisión ï Derecho Penal es también una concepción derivada de la exegética convencional, previamente

18 FERRAJOLI, Luigi, Derecho y razón. Teoría del garantismo penal, Trota, página 767.

${ }^{19}$ Así lo acusa BACIGALUPO SAGUESSE, Silvina, "La crisis de la filosofía del sujeto individual y el problema del sujeto de Derecho Penal", CPC, número 67, 1999, página 16. Señala la autora que "la elección de una determinada idea de sujeto condicional los conceptos y las soluciones dogmáticas de la teoría del delito y en especial los de la acción y la culpabilidad; por lo tanto, la negación de la responsabilidad penal de las personas jurídicas sobre la base de la incapacidad de acción y de culpabilidad, en el sentido de la teoría del delito actual, adolece de una cierta circularidad". Se trata de distinguir lo "natural y lo construido", sin olvidar que también "el delito, la pena y el delincuente" son construcciones sociales, por ende, la responsabilidad penal de las personas jurídicas debe tratarse en sede valorativa o normativa que surge de la necesidad, y no de la legitimación, vid. BUSTOS RAMÍREZ, Juan, "La responsabilidad penal de las personas jurídicas", en MORENO HERNÁNDEZ, Moisés (Coord.), Globalización e internacionalización del Derecho Penal. Implicaciones político-criminales y dogmáticas, CEPOLCRIM, México, 2003, página 334.

20 Ib ídem, p. 27, "en suma: el sujeto no es una cuestión obvia, sino que requiere una determinación conceptual que depende del punto de partida hermenéutico y pre jurídico sin el cual no es posible ninguna construcción dogmática. Por tanto, el concepto de sujeto es una construcción hermenéutica. Por lo tanto, el concepto de sujeto es una construcción hermenéutica que aparece como una preconcepto de toda elaboración dogmático-jurídica". Así también TIEDEMANN, Karl, "Exigencias fundamentales de la Parte General y propuesta legislativa para un Derecho Penal europeo", Revista Penal, número 3, 1999, "Las contradicciones posibles con el principio de culpabilidad son susceptibles de solución a través del reconocimiento de la imputación o de una culpabilidad propia de la empresa. De este modo, la introducción de una responsabilidad penal propia de la empresa constituye en la actualidad más una decisión valorativa que de lógica constructiva”, página 89. 
elaborada para ser punto de partida y de ninguna manera un principio incólume e inmutable. Por lo tanto, podrían ser las personas colectivas sujetos de Derecho Penal si, de acuerdo a un paralelismo funcional, cumplen con determinadas condiciones que hasta hoy habían cumplido las físicas, como lo pueden ser, el que sean sujetos de derechos y obligaciones, esto es, centros de imputación de normas a los que se les puede dirigir un reproche ${ }^{21}$ (algo así como ñpoder haberse conducido de forma diferente a la conducta delictuosaớ2), y por otro lado, el dejar de considerar como pena por antonomasia a la de prisión o privativa de libertad. Se trataría, entonces, de normativizar (también) a la concepción de ñpersonaòcomo sujeto de Derecho Penal. En palabras de Heine mo se trata de un desarrollo antropomórfico ulterior del principio de culpabilidad personas, sino de una nueva fundamentación originaria, vinculada con la organización, del principio sistémico de culpabilidad. No se trata de fundamentar de manera novedosa dicha r̃semejanzaò sino del cumplimiento de una función análoga; el objeto no es un comportamiento defectuoso previsible, sino los desarrollos sistémicos defectuosos. Por todo ello, también se recomienda una separación conceptual con respecto al Derecho Penal individual, lo cual se logrará de la mejor forma mediante una r̃segunda víaळ̄²3

21 TIEDEMANN, Karl, "Responsabilidad penal de las personas jurídicas", en Anuario de Derecho Penal, Universidad de Friburgo, 1996. Señala con acierto que la retribución es posible si se admite que las personas colectivas son destinatarias de normas y que se les puede formular reproches. La finalidad preventiva es compatible con la responsabilidad de las personas jurídicas. Mientras que la pena en abstracto puede intimidarles a "los miembros de la sociedad. Estos estarán intimidados por la condena criminal y reforzará así en ellos su mentalidad de obediencia a las normas jurídicas (prevención llamada general). .. la condena penal de la empresa pone en evidencia que la norma jurídica violada se dirige a la empresa y que la violación merece una reprobación social... la empresa condenada sería intimidada para no reincidir...", página 118.

22 SILVA SÁNCHEZ, Jesús-María, "La responsabilidad penal de las personas jurídicas y las consecuencias accesorias del art. 129 del Código Penal", en Derecho Penal Económico, Consejo General del Poder Judicial, Manuales de formación continua, Madrid, 2001, página 337.

23 HEINE, Gunter, "Modelos de responsabilidad jurídico-penal originaria de la empresa", en GÓMEZ-JARA, Carlos (Ed.), Modelos de autorresponsabilidad penal empresarial, propuestas globales contemporáneas, Thomson Aranzadi, Navarra, 2006, página 49. 
Con esta perspectiva consideramos que es accesible al sistema de Derecho Penal la construcción de ñpersonaơ ${ }^{4}$ desde una perspectiva normativa (incluso, es normativa desde la perspectiva más ontologicista ${ }^{25}$ ) de modo diferente a la tradicional. Por tanto, persona podría no identificarse con individuo humano, sino que podría tener otras características cuyo concepto general podría incluir a las personas jurídicas.

Siguiendo esta línea, también pudiésemos construir algún concepto de acción o conducta y de culpabilidad diferente al tradicional, cuyas características esenciales pudieran ser compartidas por la persona jurídica (organización empresarial) ${ }^{26}$. No es posible desconocer

${ }^{24}$ JAKOBS, G., Sociedad, norma y persona en una teoría de un Derecho Penal funcional, Civitas, Madrid, 1996, p. 50, "ser persona significa tener que representar un papel. Persona es la máscara, es decir, precisamente no es la expresión de la subjetividad"; el mismo, Sobre la normativización de la dogmática jurídico-penal, Civitas, Madrid, 2003, página 21, "'persona' es algo distinto de un ser humano, un individuo humano; éste es el resultado de procesos naturales, aquélla un producto social (de lo contrario nunca podría haber habido esclavos, y no podrían existir las personas jurídicas"; el mismo, Dogmática de Derecho Penal y la configuración normativa de la sociedad, Civitas, Madrid, 2004, página 51, “... personas son destinatarios de derechos y deberes... es persona quien es capaz jurídicamente".

25 Es así, puesto que las construcciones metodológicas más ontologicistas admiten grados importantes de normativización en las categorías jurídico penales, que afectan de alguna u otra manera el concepto de persona, V.gr. la normativización de la autoría mediata o coautoría, Vid. WELZEL, H., Derecho Penal alemán, traducción BUSTOS RAMÍREZ, J., y YAÑEZ PÉREZ, S., Editorial Jurídica de Chile, Santiago, 1993, página 122 y 129.

26 Por ello no podemos estar de acuerdo con LUZÓN PEÑA, Diego Manuel, por caer en el razonamiento circular ya apuntado: "Ciertamente puede argumentarse con la no culpabilidad de la persona jurídica, ya que aquella se basa en la responsabilidad por una determinada capacidad de decisión personal o individual, mientras que en la corporación las decisiones las toman realmente determinados individuos. Y también puede argumentarse con la inadecuación de las penas para las personas jurídicas, no sólo por la incapacidad de éstas para sufrir las penas más abundantes, las privativas de libertad ...., sino sobre todo porque la aplicación de penas a las personas colectivas se opone a los principios de culpabilidad y personalidad o responsabilidad personal y no se ajusta -o al menos no se ajusta bien- a los fines de la pena: ni la prevención general intimidadora, pues los susceptibles de intimidación como potenciales delincuentes serían las personas individuales y no las personas jurídicas como tales; ni a la prevención general de integración social o-si se admite- a la retribución, ya que ambas presuponen la justa respuesta y reafirmación del Derecho frente al culpable de un injusto, y la pena afectaría a la persona jurídica, que no lo es, e indirectamente también a derechos de socios no culpables de la 
que la culpabilidad, como un juicio de reproche a la persona física por no haber actuado de una forma diferente (adecuando su conducta a la norma penal), se fundamenta en la autodeterminación de la misma, y lo que ello implica, esto es, su libre albedrío, es susceptible de ponerse en duda. Decía Cerezo Mir que ña crisis del principio de culpabilidad radica en la imposibilidad o dificultad de probar si un determinado delincuente podía en el caso concreto obrar de otro modo, es decir, conforme a las exigencias del ordenamiento jurídicoo ${ }^{27}$, y valiéndose de las conclusiones de Welzel y Engisch, a los que cita, señala como algo cierto que r̃de acuerdo con nuestro punto de partida tenemos que dejar sin respuesta la pregunta si el autor de acuerdo con su naturaleza, tal como se manifestaba en la situación concreta, hubiera podido hacer uso de una mayor fuerza de voluntad o de una mayor diligenciaơ ${ }^{2}$.

Ya tomamos de lo anterior una provisional conclusión al respecto: si no exigimos en el Derecho Penal de las personas físicas la demostración concreta y real del libre albedrío del individuo en el caso concreto, tampoco lo exigiremos en lo que hace a la persona jurídica ${ }^{29}$. Es entonces posible construir la culpabilidad para la persona jurídica sobre la base, aunque no exclusivamente sobre ella, de la prevención general y de la prevención especial de la pena. En efecto, en sus Fundamentos Jakobs aseguraba la posibilidad de criminalizar a las organizaciones empresariales o personas colectivas, al señalar ñpero no cabe fundamentar que en la determinación del sujeto el sistema que ha de formarse deba estar compuesto siempre de los ingredientes de una persona física (mente y cuerpo) y no de los de una persona jurídica (estatutos y órganos). Más bien los estatutos y los órganos de una

decisión ilícita; ni tampoco estrictamente a la prevención especial, ya que como veremos, en la persona jurídica no hay peligrosidad criminal en sentido estricto", en Curso de Derecho Penal, Universitas, Valencia, 1995, página 290.

27 CEREZO MIR, José, “Culpabilidad y pena”, Anuario de Derecho Penal y Ciencias Penales, Tomo XXXIII, fascículo II, mayo-agosto, 1980, p. 347.

${ }^{28}$ Ib ídem, p. 348.

${ }^{29}$ GÓMEZ-JARA, Carlos, La culpabilidad penal de la empresa, Barcelona, Marcial Pons, 2005, página 85, donde señala "Exigir la prueba de que la empresa pudo actuar de otro modo en un momento concreto sería pedir lo que ni siquiera se puede demostrar con respecto al ser humano". 
persona jurídica se pueden definir también como sistema, en el cual lo interno ï paralelamente a la situación en la persona física- no interesa, pero sí interesa el output. Las actuaciones de los órganos con arreglo a sus estatutos se convierten en acciones propias de la persona jurídica ${ }^{30}$, y en relación con la culpabilidad precisaba que resulta imposible renunciar a la comprobación de la culpabilidad de la persona jurídica, y que es posible encontrar supuestos de indisponibilidad de sus acciones que habrán de disculparse, de forma tal que en la persona física como en la jurídica ré tanto para la acción como para la culpabilidad son idénticas las formas dogmáticas (y no sólo los nombres) $0^{31}$.

Se trata de entender que si la norma penal se dirige a todas las personas que la pueden infringir y con ello, violar la prohibición o el mandato y afectar bienes jurídicos materiales específicos, entonces no debería existir ningún obstáculo para que el Derecho Penal responda y reafirme el mandato normativo a través de la pena. En el quehacer diario de la empresa, en donde se le ha dado libertad total para conseguir sus fines (económicos, sobre todo), no significa que las personas jurídicas ñpuedan acceder a tal fin de cualquier manera, sino sólo correctamente, es decir, cumpliendo con las reglas pertinentes. Por tal motivo, si en las actividades corporativas se producen desde la empresa conductas disfuncionales para el sistema económico que infringen el ordenamiento penal, tendrá que reaccionarse frente a aquellas infracciones y afirmarse, de esta manera, su carácter incorrecto é en este sentido, el Derecho no podrá reafirmar adecuadamente la vigencia de la expectativa defraudada por la empresa si se dirige a sujetos distintos a la empresa, que es quien realmente actúa en el sistema económico y de quien ha surgido,

\footnotetext{
30 JAKOBS, Günther, Derecho Penal, parte general. Fundamentos y teoría de la imputación, Op. Cit., página 183.

31 Ib Ídem, página 184.
} 
independientemente de su formación interna, la conducta defraudadoraò $^{32}$

Por otro lado (por lo que hace a la prevención especial positiva), las consecuencias jurídicas del delito harían más que bien al ámbito organizacional de la persona jurídica, puesto que renunciando por lógica a la pena privativa de libertad (no sobra decirlo), la multa, la intervención juridicial, la prohibición de realizar determinadas actividades económicas, o de acceder a subvenciones, entre otras, significarían candados y garantizarían a niveles muy aceptables que una empresa no delinquiría más. De hecho, la prevención especial puede lucir todo su esplendor cuando las penas son aplicadas a la persona jurídica, a diferencia de la trágica experiencia del penitenciario en el mundo civilizado (de las personas físicas) ${ }^{33}$.

No obstante, no creemos que sea posible construir un fundamento de la culpabilidad de la persona jurídica solamente en la prevención general y especial, como alguna vez lo propuso Gimbernat ${ }^{34}$ para la persona física, o aceptar a la culpabilidad solamente como límite pero no como fundamento de la pena ${ }^{35}$.

La libertad que el ordenamiento jurídico le ha dado a la empresa para organizarse como mejor le parezca para conseguir sus fines y cumplir con sus objetivos debería ser, en la misma medida que lo es para el individuo, el fundamento de la culpabilidad de la persona física. Junto con la libertad de auto organizarse, de configurarse y de auto desarrollarse, que el derecho le reconoce a la persona jurídica, también le adscribe derechos fundamentales que son reconocidos a todos los individuos según la Constitución española, como el derecho a la

32 GARCÍA CAVERO, Percy, La responsabilidad penal del administrador del hecho de la empresa: Criterios de imputación, Bosch Editor, Barcelona, 1999, página 65 y 67. 33 VARIOS, La experiencia del penitenciarismo contemporáneo, Comisión Nacional de Derechos Humanos, México, 1995, pássim.

34 GIMBERNAT Ordeig, Enrique, “¿Tiene futuro la dogmática jurídico penal?”, en Estudios de Derecho Penal, Tecnos, Madrid, 1996, p. 495 y sigs.

${ }^{35}$ ROXÍn, Claus, "La culpabilidad como criterio limitativo de la pena", en Revista de Ciencias Penales", enero-abril de 1973, p. 16 y sigs. 
inviolabilidad del domicilio ${ }^{36}$, a la libertad de expresión ${ }^{37}$, a la libertad sindical $^{38}$, derecho a la igualdad ${ }^{39}$, o el derecho al honor ${ }^{40}$, y a las personas jurídicas de derecho público se les ha reconocido además derecho a la tutela judicial efectiva, a la libertad de expresión y a la autonomía universitaria ${ }^{41}$. Que la persona jurídica no goza de todos los derechos fundamentales que tiene el individuo, ni lo hace de la misma manera con los que si tiene, es una cuestión que alimenta nuestra posición, como lo veremos en la segunda parte de este trabajo.

La libertad de auto organización y la titularidad de derechos fundamentales deberían de asignarle, por contrapartida, una responsabilidad a la persona jurídica diferente de aquella que tienen sus miembros que la componen. La libertad de la persona jurídica solo tendría lugar en un marco de responsabilidad porque sólo así se reafirmaría dicha libertad. Como dice Carbonell Mateu "las personas jurídicas tienen reconocido su estatuto de sujetos de derecho, tienen derechos subjetivos y deberes, generan responsabilidad y tal responsabilidad solo puede ser afirmada tras el correspondiente reproche jurídico; esto es, tras la también correspondiente

\footnotetext{
36 STC $137 / 1985$ y $64 / 1998$.

37 STC $52 / 1995$.

38 ATC $240 / 1982$ y STC $141 / 1985$.

39 STC 99/1983, 20/1985, 26/1985, 39/1989.

40 STC 135/1995, Sala 2a , 29.9.1995 y 183/1995. Dichas sentencias son el corolario a una marcada tendencia jurisprudencial anterior que afirmaba el carácter personalísimo del derecho al honor; aunque el concepto de honor es el que recoge el Diccionario de la Real Academia de la Lengua, es decir, como buena reputación "la cual como la fama y aún la honra, consisten en la opinión que las gentes tienen de una persona, buena o positiva, si no van acompañadas de adjetivo alguno". Cfr. VIDAL MARÍN, Tomás, "Derecho al honor, personas jurídicas y tribunal constitucional”, en In Dret, 1/2007, Barcelona, 2007, página 11. De la misma manera, BUSTOS RAMÍREZ, Juan, "La responsabilidad penal...", Op. Cit., página 333.

41 BACIGALUPO SAGUESSE, Silvina, "Los derechos fundamentales de las personas jurídicas", Revista del Poder Judicial, número 53, CGPJ, 1999, p. 86.
} 
comprobación de la existencia de la obligatoriedad personal, derivada de su capacidad, de su competencia"42.

Finalmente, confiamos en que generar un sistema diferente pero paralelo al de la persona física sería la mejor solución para enfrentar la problemática de la responsabilidad penal de la persona jurídica. Ya se han expuesto algunas tesis que proponen una teoría jurídica del delito omnicomprensiva tanto para la persona jurídica como la física ${ }^{43}$, sin embargo, estimamos que ello podría, forzando la alineación de dos sistemas de Derecho Penal diferentes, dar lugar a una confrontación, o, peor aún, con el sometimiento del sistema de las personas físicas al de las jurídicas y la consiguiente relajación de garantías en aquel. En efecto, dentro de las críticas modernas más importantes en contra de la imposibilidad de generar un sistema de responsabilidad penal de las personas jurídicas ${ }^{44}$ tenemos la advertencia del peligro que implica puesto que r̃determinadas relajaciones en las garantías que necesariamente comportará el régimen de imputación para las personas jurídicas (dolo, v.gr.) se contagiarán al régimen de las personas físicasơ ${ }^{45}$ además de que r̃debilitará la prevención general positivaòpues la pena ñe debilitado su valor comunicativo de fijar las bases estructurales de la organización socialö.

No desoímos las advertencias, sin embargo, y a reserva de dedicarnos con más extensión a ellas, y solo para efectos de este

42 CARBONELl MATEU, Juan Carlos, "Responsabilidad penal de las personas jurídicas: Reflexiones en torno a su "dogmática" y al sistema de la reforma de $2010 ", C P C$, número 101, 2010, separata, página 24.

${ }^{43}$ Como lo es la tesis de GÓMEZ-JARA, La culpabilidad penal de la empresa, Marcial Pons, Madrid, 2005, página 54.

44 CANCIO MELIÁ, Manuel, ¿Responsabilidad penal de las personas jurídicas? Algunas consideraciones sobre el significado político criminal del establecimiento de responsabilidad penal de la empresa", en Nuevas tendencias en política criminal. Una auditoría al CP español de 1995, REUS, 2006, página 13 y siguientes.

45 Ib Ídem, página 14. De la misma manera, VELAZQUEZ V., Fernando, "La responsabilidad de las personas jurídicas", en MORENO HERNÁNDEZ, Moisés (Coord.), Globalización e internacionalización del Derecho Penal. Implicaciones político-criminales y dogmáticas, CEPOLCRIM, México, 2003, página 350.

46 Ib Ídem, página 15. 
subcapítulo, señalamos que la creación de una teoría jurídica del delito diferente al de las personas físicas daría lugar a superar las mismas, puesto que las alejaría en su contenido y permitiría que lo que se ha construido hasta hoy para las personas físicas quede incólume e impasible. Un sistema paralelo, sin comunicación necesaria y sin contaminación para el sistema ya construido, sería la mejor opción en este nuevo reto de la dogmática jurídico penal. 


\section{CAPTIULO II}

\section{TRES DIMENSIONES DE LOS MODELOS DE RESPONSABILIDAD PENAL DE LAS PERSONAS JURÍDICAS}

La doctrina ha echado en falta motivaciones o explicaciones en el preámbulo de la LO 5/2010, de 23 de junio, que señalaran con más o menos precisión las razones o motivos que tuvo el legislador para decidir la determinada forma o manera de regulación de la responsabilidad de las personas jurídicas. Ello hubiese dado un orientación sobre el derrotero político criminal que fue pensado para generar el texto final, que pudo constituir un buen principio de interpretación del mismo, para iniciar a darle contenido, alcances, límites y escotes; sin embargo, no fue así: el legislador eludió una justificación detenida, con base empírica y consideraciones valorativas detalladas ${ }^{47}$.

La alusión a los compromisos internacionales de España con la Unión Europea, que fue tal vez lo único en que fue fundamentada la reforma en este tópico, no nos dice en realidad nada. Ante esa orfandad de justificación político criminal (que hubiese sido en principio bien recibida) sí que tendríamos necesidad de construir una base sobre

\footnotetext{
47 SILVA SÁNCHEZ, Jesús-María, "La reforma del CP: una aproximación desde el contexto", en Diario La Ley, Número 7464, de 9 de septiembre de 2010, Capítulo II, subcapítulo 2 .
} 
razones materiales y formales sobre la responsabilidad de las personas jurídicas, pues serían de gran utilidad para interpretar el nuevo texto legal y perfilarlo hacia parámetros ya definidos, que constituyan fundamentos y límites del sistema. A esos parámetros les llamamos dimensiones de la responsabilidad penal de las personas jurídicas.

Las dimensiones o parámetros funcionarían como el marco sobre el que deben de moverse las construcciones de los modelos de responsabilidad penal de los colectivos (y las interpretaciones construidas y que se construyan sobre la reforma legal), pues pretenden ser construidos de afirmaciones más o menos obvias o más o menos incontrovertibles por la discusión doctrinal. Por ello, tendrían una doble ventaja: serían afirmaciones de principios materiales (político criminales) y formales (constitucionales ï de legitimación constitucional, y de dogmática jurídico penal), así como de aplicación práctica, por un lado, y por otro, estarían clasificadas, priorizadas, y en general funcionarían en conjunto.

Las clasificamos en tres: dimensión político criminal, de legitimación constitucional y dogmática jurídica y dimensión de aplicación práctica. En realidad podrían reconducirse a dos (dimensión político criminal y de legitimación constitucional y dogmática jurídica), no obstante, por la importancia que pretendemos comunicar tiene la dimensión de aplicación práctica dentro de los modelos modernos de responsabilidad de los colectivos, la separamos de la dimensión político criminal. Teniendo las necesidades político criminales para criminalizar a los entes una función más bien de insumo, la dimensión de aplicación práctica, que tiene vocación de servir de producto, debe estar separada de la anterior.

Entendemos por dimensión político criminal aquella fenomenología relativa a la criminalidad de empresa y que fue (y es) objeto de atención de prácticamente todo el sector doctrinal que la estudió. Me refiero a aquellas situaciones de injusticia porque no alcanzaba el Derecho Penal a las personas jurídicas por la vigencia del 
principio societas delinquere non potest. Como lo veremos, haremos un breve análisis de las necesidades, argumentadas por la doctrina, de criminalizar a los colectivos, no tanto en el sentido del sí de esa responsabilidad, sino en el del cómo; en otras palabras, para saber cuáles eran los conjuntos de casos que no se cubrían (debiéndose cubrir) con el Derecho Penal por la irresponsabilidad de las personas jurídicas. Ya debemos estar viendo las ventajas de esta sistematización: un modelo de responsabilidad específico, o el sistema construido por sectores doctrinales que interpretan el nuevo texto legal, aspirará a responder a esas exigencias.

De este mismo género de comentarios adolece la dimensión de aplicación práctica. Vale decir que a diferencia de las necesidades político criminales, esta dimensión no fue (pues nunca pudo ser) suficientemente analizada sino hasta la elaboración de un texto específico que fuese de aplicación inmediata, y ese no pudo ser otro sino el de la LO 5/2010. Ciertamente hubo algunas propuestas de textos específicos de lege ferenda que fueron expuestos ${ }^{48}$, pero precisamente por ello, por ser de lege ferenda, nunca fueron motivo de ejercicios hipotéticos de aplicación específica. Por ello, hasta estos momentos es que tenemos en el texto legal un punto común (o mejor, relò punto común) de análisis a partir del cual deberíamos ensayar su aplicación, evidenciar sus ventajas y desventajas prácticas, y descubrir sus posibilidades de error u sus correcciones.

La dimensión de legitimación constitucional y dogmático jurídico penal es, sin duda alguna, la más complicada. Tendría la función de sistematizar los límites u obstáculos que ha expuesto la labor doctrinal de muchos años al principio societas delinquere non potest, enmarcando así, con los principios ético políticos más importantes que

\footnotetext{
48 Bastan por ahora, aquellos propuestos por NIETO MARTíN, Adán, La responsabilidad penal de las personas jurídicas, un modelo legislativo, Iustel, 2008, página 322 a 342, y HEINE, Günter, "Modelos de responsabilidad jurídico-penal originaria de la empresa", en GOMEZ-JARA DIEZ, Carlos (Ed.), Modelos de autorresponsabilidad penal empresarial, propuestas globales contemporáneas, Navarra, Aranzadi 2006, página 65.
} 
tenemos en España (los derechos o principios constitucionales), los campos o sectores que nadie está dispuesto a invadir, o los que nadie está dispuesto a dejar de observar. Más que un fundamento, en esta parte los expondremos como límites.

\section{DIMENSIÓN POLÍTICO CRIMINAL}

\subsection{Necesidades político criminales de responsabilizar penalmente a las personas jurídicas}

Durante el desarrollo de la discusión doctrinal española sobre la conveniencia o no de criminalizar a los entes colectivos, hasta los más recalcitrantes negadores de responsabilidad penal de personas jurídicas no desautorizaban la ingente necesidad de que las instituciones públicas (específicamente, las del Derecho Penal) fueran más efectivas en contra de los aumentos de riesgos no permitidos que generaban las empresas. Incluso, abandonando una ñerdaderaò responsabilidad penal, afirmaban medidas penales en contra de ellas ${ }^{49}$. Es decir, aun negando la posibilidad de construir una acción o culpabilidad, destacaban la imperiosa necesidad de actuar, no solo con el Derecho Administrativo, contra los ilícitos producidos en el seno de la persona jurídica ${ }^{50}$.

${ }^{49}$ MIR PUIG, Santiago, "Sobre la responsabilidad penal de las personas jurídicas", en Estudios penales en recuerdo del profesor Ruíz Antón, en DE TOLEDO UBIETO, GUARDIEL SIERRA Y CORTES BECHIARELLI (Eds.), Valencia, Tirant lo blanch, 2004, página 749 y sigs.; el mismo, "Una tercera vía en materia de responsabilidad penal de las personas jurídicas", Revista Electrónica de Ciencia Penal y Criminología, 06-01 (2004), 2004, página 4 y 13 y sigs.; SILVA SÁNCHEZ, J.M., "La responsabilidad penal de las personas jurídicas y las consecuencias accesorias del art. 129 del CP", Derecho Penal económico, AA.VV., Madrid, Consejo General del Poder Judicial, 2001, 347 y sigs.; LUZÓN PEÑA, Diego-Manuel, "Las consecuencias accesorias como tercera vía de las sanciones penales", en DE TOLEDO UBIETO, GUARDIEL SIERRA Y CORTES BECHIARELLI (Eds.), Valencia, Tirant lo blanch, 2004, página 546.

50 LOZANO, Blanca, "La responsabilidad de la persona jurídica en el ámbito sancionador administrativo (a propósito de la STC 246/1991, de 19 de diciembre)", en Revista de Administración Pública, Número 129, 1992, página 234. 
Podría decirse, sin temor a equivocarnos, que los problemas relativos a la creciente importancia de las empresas o personas jurídicas en sociedades post capitalistas actuales, los niveles económicos o financieros que manejan, así como su gran capacidad de generar nuevas tecnologías en todos los campos, es el primer gran elemento a tomar en cuenta. De otro lado, al interior de la empresa, la manera en que funcionan, genera otras tantas dificultades de persecución criminal. En líneas abajo tratamos de clasificar y sintetizar las necesidades político criminales más socorridas en la doctrina.

\subsubsection{La persona individual como óelô sujeto ódañinoô.}

Según Schünemann el poder punitivo del Estado en Europa surgió en la Edad Media por la prohibición del derecho de autodefensa del individuo y estaba dirigido contra el hombre r̃dañino $0^{51}$, es decir, de aquellos grupos sociales marginales o subculturas que no querían o no podían adaptarse al sistema estatal de dominio de distribución de bienes. De ahí, obtiene que esa sea la razón por la cual la marginalidad y la miseria han constituido el más visible objeto de persecución de lo que llamamos iDerecho Penalơ ${ }^{52}$.

Cierto, a partir de ese momento, en donde el propietario de los poderes del Estado (generalmente el Rey) incluyó como sus enemigos no solo a aquellos otros propietarios de otros tantos poderes (otros reyes) que ponían en peligro su subsistencia, sino también a quienes en una ñínea horizontalòofendían los derechos subjetivos de otros: súbdito contra súbdito, fue que surgió el poder punitivo del Estado. El bien jurídico de la r̃ealezaò que luego fue sustituido por el r̃Estadoò ya no era el único al que proteger, pues los derechos de otros miembros de la comunidad, diferentes al Rey y a sus cercanos, también fueron objeto

\footnotetext{
51 SCHÜNEMANN, Bernd, "La punibilidad de las personas jurídicas desde la perspectiva comparada", en Hacia un Derecho Penal Económico Europeo, Jornadas en honor del Prof. Karl Tiedemann, BOE, Madrid, 1995, página 568.

52 Ib Ídem, página 568.
} 
de persecución a través de algo muy parecido a un derecho represor. No obstante, en el fondo la razón de la represión fue la misma: la subsistencia de su poder, de su estirpe, de las ñnstitucionesò

La criminología positivista de las postrimerías del siglo XIX, al adjudicar en las clases sociales bajas (incluso, al generar un estereotipo del delincuente nato) la naturaleza de la criminalidad ${ }^{53}$, vino a sellar (esperamos que no para siempre) la ideología de la defensa penal ${ }^{54}$. Entre otras funciones, dicha ideología legitimaba ese Derecho Penal que se dirige exclusivamente contra la clase social más débil, asegurando la brecha clasista existente. La metodología utilizada por la criminología positivista, que estudiaba al delincuente de la cárcel predefiniéndolo como rélò delincuente, hizo de una consecuencia una causa; puesto que sobre la representación de las clases sociales bajas en los ejércitos que inundan las cárceles y el sistema de represión oficial fue tomado como una muestra de que la pobreza, la marginación, la no integración a la cultura ñ́nicaòde la sociedad, eran causas de la delincuencia ${ }^{55}$.

Según las estadísticas oficiales del delito, el delito es rẽl delito comúnò fundamentalmente el robo, homicidio, violación, etcétera, generalmente realizado en la calle, por sujetos extraños a la víctima y que presentan unos indicadores de peligrosidad muy altos. No obstante, fue mérito del labbelling aproach y de la Criminología Crítica mostrarse

53 GARÓFALO, Rafael, Criminología, Editorial Ángel, México, 1998, capítulos I y II. 54 BARATTA, Alesandro, Criminología Crítica y Crítica del Derecho Penal, Editorial Siglo XXI, México, 1993, páginas 34 y siguientes. Ahí explica que tanto la escuela clásica del Derecho Penal, representada por Feuerbach, Carrara, Rossi, Romagnosi, Bentham, y la escuela positivista del Derecho Penal representada fundamentalmente por Rafael Garófalo (quien era el jurista, en cambio Lombroso era Antropólogo y Ferri Sociólogo), solo en apariencia eran contrarios, pues tenían en común un denominador de importancia supina: la ideología de la defensa social. Ésta legitimaba las funciones del Derecho Penal adscribiéndole las que no eran y escondiendo funciones que realmente cumplía, como lo es, la permanencia del status quo en el que solamente la delincuencia "de a pie" era perseguida y aquella otra, la delincuencia de la clase alta -cuello blanco- era sub perseguida.

55 Ib Ídem, página 67 y siguientes, y PITCH, Tarman, Teoría de la desviación social, Nueva Imagen, México, 1980, página 101 y siguientes. 
escépticas ante ello y cuestionaron todo lo que se había r̃̃onstruidoò alrededor de la ideología social. Cohen resalta en un decálogo aquello en lo que estaban en desacuerdo ${ }^{56}$, entre lo que debemos de destacar aquello del rõdelito comúnà Los escépticos responden de tres formas:

En primer lugar, negación de la definición de delito. Lo que la gente llama delito es en realidad formas culturales diversas de actividades definidas. En segundo lugar, la negación de la importancia del mismo. Si miramos las estadísticas observaremos el resto de las causas de mortalidad diferentes a los delitos son cuantitativamente mucho más importantes que la de los homicidios. Lo que sucede es que se crea un pánico moral, y por, tanto se hace una construcción de la realidad como si el delito común fuese "el" delito, como si la delincuencia fuese "él" problema; y en tercer lugar, el delito callejero es pura bagatela ${ }^{57}$.

Fue descubierto que la definición y asignación de las normas están macrosociológicamente determinada por los desniveles socioestructurales en el poder, esto es, las instancias institucionalizadas oficiales y sociales tienen de un modo especial la posibilidad de definición y asignación el status de la desviación a las clases sociales débiles; mientras que los procesos de asignación de normas por las instancias oficiales son selectivos y actúan de un modo general y reducen el espacio de comportamiento de los individuos etiquetados: Reducen comportamientos conformistas; por la carencia o estrechez 0 reducción de comportamientos conformistas es buscada una salida hacia lo definido como desviado: el etiquetamiento conduce a un comportamiento desviado secundario; y, en fin, por la asignación del desvío y por la práctica de estos modos de comportamiento, se desarrollan autodefiniciones desviadas que conducen a una identidad

\footnotetext{
56 Citado y analizado por LARRAURI, Elena, La herencia de la criminología Crítica, siglo XXI, Madrid, 2000, páginas 73 y siguientes.

$57 \mathrm{Ib}$ Ídem, páginas 80 y siguientes.
} 
de la persona, que percibe el rol desviado asignado como algo conforme con su propia personalidad ${ }^{58}$.

Habíamos dicho que también la escuela clásica del Derecho Penal compartía en un denominador común con la otrora escuela positivista, la ideología de la defensa social. Entre nosotros, Zugaldía señala a una de las expresiones del iluminismo alemán, del que abreva aquella, como un obstáculo para desprender de la ñpersona individualò su calidad de rélòdelincuente: el principio de intervención mínima ${ }^{59}$. En suma, se alza como una necesidad imperiosa, el reconocimiento jurídico de que existe un ente más temible que la persona individual rólañinaò que tiene más poder y capacidad de dañosidad social, es la persona jurídica; la sociología jurídico penal lo tiene suficientemente reconocido.

\subsubsection{La importancia de la persona jurídica en el tráfico social: el nuevo y más grave sujeto activo de Derecho Penal}

Existen dos principios fundamentales en Derecho Penal que tienen todo que ver con nuestro tema: el del carácter fragmentario del Derecho Penal y el de igualdad. Ambos son reconocidos por la totalidad de la doctrina penal en España ${ }^{60}$. Se traducen, el segundo

\footnotetext{
58 BARATTA, Alesandro, Op. Cit., página 156.

59 ZUGALDÍA ESPINAR, José Miguel, La responsabilidad criminal de los entes colectivos (personas jurídicas y entes sin personalidad) y de sus directivos $y$ representantes. Análisis de los arts. 31 bis y 129 del CP, Granada, 2012, Inédito, página 8. Señala que "el tan renombrado principio de intervención mínima no puede seguir utilizándose más como coartada para configurar al Derecho Penal de una forma clásica y obsoleta (al modo del "buen y antiguo Derecho Penal liberal") porque ello supone orientarlo a la reproducción sistemática de relaciones de dominio injustas y a vincularlo casi exclusivamente a la delincuencia de los sectores sociales extraídos de la marginación y la pobreza (lower class crime) haciendo así "del Código Civil el Código de los ricos y del CP el Código de los pobres"...". Así también, VELÁZQUEZ V., Fernando, "La responsabilidad penal...", Op. Cit., página 346 y sigs.

60 Vid por todos, MIR PUIG, S., Derecho Penal, parte general, Reppertor, Barcelona, 1999, p. 89; ZUGALDÍA, Espinar, José Miguel, y otros, Derecho Penal, parte general, Op. Cit., P. 206 y sigs.
} 
como una consecuencia del principio de intervención mínima, y el primero, como un principio general del derecho estatuido en las Constituciones (art. 1 de la Constitución Española), en que solamente las conductas de un mayor contenido de dañosidad social, pero todas ellas, serán prohibidas a través de normas penales, esto es, con la respuesta más contundente y terrible del Estado.

Esto es, si vinculamos ambos principios nos permitiría asegurar su violación o incumplimiento si el Derecho Penal conmina con pena de prisión a determinadas conductas que vulneran precisos bienes jurídicos (por ejemplo, el robo ï delito de robo- de una cantidad mínima de dinero) y en cambio solo es regulada con sanciones administrativas aquellas conductas generadas por personas jurídicas que conmueven los cimientos económicos de una nación. Esto es lo que Zugaldía llamaba, criticándolo, rel mundo al revésớ ${ }^{61}$, porque mientras los Manuales de Derecho Penal nos enseñan que el criterio para gravar o graduar las conductas como más o menos dañosas, e incluirlas o excluirlas del Derecho Penal, es precisamente su contenido de dañosidad social, en la realidad cotidiana de la vida, el criterio para determinar lo anterior es más bien personal: si el autor es una persona física, se le sigue un proceso penal, ante un Juez penal, que puede imponerle una sentencia penal, de incluso años de prisión, aunque sean delitos de bagatela, en cambio una persona jurídica puede causar un

61 "Bases para una teoría de la imputación de las personas jurídicas", CPC, 2001, p. 538 "En teoría... el carácter fragmentario del Derecho Penal determina que cuando la dañosidad social del hecho es alta o elevada, el Estado reaccione contra su autor a través del Derecho Penal; por el contrario, cuando la dañosidad social del hecho es de menor entidad, el Estado reaccionaría contra su autor a través del Derecho Administrativo... Pero en la práctica las cosas funcionan de manera completamente distinta... Cuando el autor de la infracción es una persona jurídica el Estado reacciona frente a ella utilizando exclusivamente el Derecho Administrativo sancionador, y ello aunque se trate de hechos de extraordinaria gravedad... Se imponen sanciones administrativas por hechos graves como pueden ser, por ejemplo, causar un daño efectivo a las salud de los consumidores, adulterar los bienes de consumo, engarce a colaborar con las autoridades sanitarias, abrir clandestinamente centros sanitarios, ejecutar obras en zonas de servicios públicos, alterar las cotizaciones en los mercados de valores, causar daños en obras hidráulicas públicas, recoger datos personales de manera engañosa, realizar actividades de blanqueo de capitales, realizar actos limitativos de la libre empresa...". 
daño a la salud de los consumidores o poner en peligro la vida de la ciudadanía por un producto defectuoso puesto en el mercado, o por contaminar ríos o cauces subterráneos de agua, sólo se le impone una multa por parte de la Administración ${ }^{62}$.

La cuestión no es nimia: Si la legitimidad del Derecho Penal tiene su piedra angular en la igualdad, esto es, en la aplicación con conciencia de la diferenciación jurídica de las diferencias ${ }^{63}$, y con ello, debe sancionar sólo a las conductas con contenido de dañosidad social más alto a los bienes jurídicos que más interesan, pero también a todas las conductas de esas características, entonces se doblegaría seriamente su legitimidad si descubrimos y demostramos que el Derecho Penal es selectivo y discriminador, en razón del tipo de persona en Derecho Penal: o persona física o persona jurídica. No es, por tanto, el criterio personal (persona física o persona jurídica) lo que debe imperar, si se quiere disminuir los límites, hasta lo irreductible, de ilegitimidad del Derecho Penal.

Solamente esos argumentos jurídicos podrían legitimar, per se, la reforma y a la fundamentación de un sistema de imputación penal de personas jurídicas, si es que se aceptara que ellas son las que más generan riesgos intolerables para la sociedad (lo que enseguida, también pretendemos fundamentar). Pero hay otra razón, una de pura cepa político criminal (que por lo demás, la exposición de motivos no se fundamenta ni se basa en este esquema ${ }^{64}$ ), y que es que no se realiza

62 Así, aunque con matices, vid. MAPELLI CAFFARENA, Borja, "Las consecuencias accesorias en el nuevo Código Penal", en $R P$, Número 1, Praxis, Enero de 1998, página 44 y sigs., y ZAMORA JIMENEZ, Arturo, "Tendencias legislativas sobre la responsabilidad penal de las personas jurídicas", en MORENO HERNÁNDEZ, Moisés (Coord.), Globalización e internacionalización del Derecho Penal. Implicaciones político-criminales y dogmáticas, CEPOLCRIM, México, 2003, página 358.

63 FERRAJOLI, Luigi, Derechos y garantías, la justicia del más débil, Op. Cit., p. 45.

${ }^{64}$ En el punto VII del preámbulo se señala solamente que "Son numerosos los instrumentos jurídicos internacionales que demandan una respuesta criminal clara para las personas jurídicas, sobre todo en aquellas figuras delictivas donde la posible intervención de las mismas se hace más evidente (corrupción en el sector privado, en las transformaciones comerciales internacionales, pornografía 
adecuadamente la prevención general con la sola amenaza o conminación a los individuos que están dentro de la organización empresarial. Debemos considerar que las normas penales se dirigen también contra las personas jurídicas y las pueden controlar para prevenir la criminalidad. ¿Cómo podemos prevenir la criminalidad dentro de una organización empresarial si las normas penales no se dirigen contra los procedimientos, filosofía o políticas de la empresa, contra las normas o máximas ahí institucionalizadas, contra los procesos defectuosos o el inadecuado control (que, por lo demás, la persona jurídica es libre de autonormarse y autorregularse)? Si dirigimos la norma penal y la sanción exclusivamente contra la persona física a la que consideramos autor y dejamos incólume a la organización empresarial, estaríamos garantizando que siempre habrá otro înombre de pajaòpara pagar la siguiente o futura infracción a la ley penal.

Lo anterior se vuelve más evidente si comprendemos a cabalidad la sustancia de una organización empresarial, su naturaleza, sus peligros, y en general, las razones por las que las consideramos un sistema que puede generar per se conductas tendientes al rompimiento de la ley.

La configuración, los alcances y los pronósticos de un sistema de justicia penal están orientados siempre al servicio y utilidad de una determinada sociedad. Un modo de ser de una sociedad (cultura, valores, bienes, compromisos y futuro) da la pauta de configuración de un determinado sistema de Derecho Penal. Es pues, siempre, la sociedad y sus necesidades las que permiten configurar y dar rumbo a su propio sistema de justicia penal. Flaco favor harían quienes se encargan de crear y dar los perfiles al Derecho Penal si no atendieran al reclamo social, a la fenomenología de un tiempo y un lugar, a la sociología criminal.

y prostitución infantil, trata de seres humanos, blanqueo de capitales, inmigración ilegal, ataques a sistemas informáticos...)" 
Esto es así porque simplemente el Derecho Penal es, en términos sociológicos, un instrumento de control social, un subsistema dentro de la política criminal.

Así las cosas debemos de partir de la fenomenología criminal en nuestros días para entender la reforma comentada: hoy por hoy las conductas ilícitas con mayor contenido de dañosidad social son cometidas, en un porcentaje muy importante, por personas jurídicas, esto es, bajo su nombre, bajo su amparo, bajo sus posibilidades económicas y desde luego, bajo la sombra enorme de la ineficacia del propio sistema de justicia penal.

Debemos concienciarnos del ambiente económico mundial y las irregularidades (por decir lo menos) que vivimos gracias a una fenomenología económica que ya rebasó por mucho a los ordenamientos jurídicos de los países y a su propia soberanía, dentro de una economía desterritorializadaớ,

Se afirma que el viejo binomio de Nación y Economía se ha roto. Contra la concepción de que a un Estado le bastaba cuidar físicamente sus fronteras para cuidar su economía y la de sus habitantes, que el Derecho u orden jurídico que tenía le bastaba para resolver sus problemas internos, y de que el Estado era promotor de su propia economía y que poseía instrumentos que constitucionalizaban su intervención en la propia economía, tenemos que ré este marco aún permanece normativizado en nuestra y en las demás constituciones de nuestro entorno y sin embargo, en el contexto de la mundialización de la economía, ese marco jurídico político de gobierno público estatal del sistema económico puede ser considerado parte de la historia sin que expresamente haya sido derogadoé ò ${ }^{66}$

65 MERCADO PACHECO, Pedro, "La forma de gobierno de una economía desterritorializada", en Transformaciones del derecho en la mundialización, Consejo General del Poder Judicial, Madrid, 1999, p. 125 y sigs.

66 Ib ídem, p. 126 y 127. 
Con todo esto asistimos a un mercado de bienes y servicios mundializado y por eso mismo con una desregulación y liberalización de las barreras protectoras nacionales, a un mercado de capitales que provoca, precisamente por la mundialización, una financiarización del sistema económico, de primacía de la economía financiera sobre la real, y a un mercado del trabajo que por su mundialización provoca la libre movilidad -libertad de contratación y despido- y una reglamentación estricta y represiva de los flujos de trabajadores inmigrantes de procedencia extranjera. $\mathrm{Y}$ a la postre, ha provocado un r̃derecho sin Estadoò puesto que existe la creación no política del derecho o la generación de instrumentos normativos no estatales (contratos como el leasing, perfomance bond, factoring, joint venture, franchisingë ) que en muchas ocasiones se convierten en factor de producción de la riqueza como la multipropiedad, por un lado, y por el otro, la privatización de la justicia, al sostener un modelo dualista de administración de justicia ñuna justicia a medida o a la carta para los detentadores de los poderes económicos y una justicia de masas para las consumidores ordinarios, la Justicia de los negocios y la justicia ordinaria o de lo cotidianoo ${ }^{\not 7}$.

Y lo más importante para los efectos de nuestro trabajo: hay una ruptura del vínculo Estado-empresa. En efecto, antes la fábrica (fordista, por antonomasia) estaba en un lugar visible del conflicto y del compromiso entre capital y trabajo, tenía unión con un territorio y a una nación, y por tanto a la regulación tradicional. Hoy, la empresa trasnacional desborda el marco de los Estados nacionales: porque la propiedad del capital de la empresa no es sino mundial y no tan sólo nacional, porque la competitividad de una empresa no depende ya de las condiciones de una nación, sino del mundo, y porque la toma de decisiones se efectúa sobre una base mundial: r̂Hoy no es ya el Estado el que decide cómo tasar y gravar fiscalmente la riqueza, sino que es la riqueza la que elige dónde debe ser tasada (é ) La liberalización de los mercados y la libre movilidad de la empresa trasnacional posibilitan a 
las distintas empresas trasnacionales hacer shopping entre las distintas legislaciones laborales y fiscales que siguen siendo nacionalesò ${ }^{68}$

Se observa entonces la gran importancia que ha adquirido la empresa, la sociedad, esto es, la persona jurídica en el desarrollo de la economía mundial, pero también en la generación de pobreza, de marginación, de muertes y de guerras.

La doctrina, por las razones de política criminal que vamos a conocer, reclamaba la reforma para criminalizar a las personas jurídicas.

En principio, podemos decir que existen estudios muy serios que afirman que en este mundo globalizado la empresa o asociación ha tenido una fuerte proyección como generadora de criminalidad, sobre todo, de criminalidad económica y por responsabilidad por el producto. Así lo dice Hans Achenbach ${ }^{69}$ EEl estudio de los delitos económicos cometidos en todo el territorio federal, que se lleva a cabo desde 1974 hasta 1985, por el Departamento de Criminología del Max-PlanckInstitut für internatonales und ausländisches Strafrecht de Freiburg in Breisgau, por encargo del Ministerio de Justicia, ha llegado a la conclusión de que en la República Federal Alemana más del $80 \%$ de

68 Ib ídem, p. 138 y 139. Así también, BAIGÚN, David, La responsabilidad penal de las personas jurídicas, De palma, Buenos Aires, 2000, página 4, pues señala que "en los Estados Unidos, ya en 1966, entre el 75\% y el 80\% de todas las actividades de manufactura, minería, transporte, obras públicas y comercio estaban en manos de un millar de grandes corporaciones, mientras que el porcentaje restante se dividía entre millones de pequeñas y medianas empresas, y que algunas de las gigantes -entre ellas, la General Motors Corporation, registraba ingresos brutos a los de todas las naciones del mundo con excepción de los Estados Unidos, Francia, Gran Bretaña y Rusia”.

${ }^{69}$ ACHENBACH, Hans, "Sanciones con las que se puede castigar a las empresas y a las personas que actúan en su nombre en el Derecho Penal”, Fundamentos de un sistema europeo de Derecho Penal, libro homenaje a Claus Roxin, Bosch, Barcelona, 1995. Baigún sigue diciendo que "en los comienzos de 1990, 37.000 firmas trasnacionales, con 170.000 filiales, encerraban en sus tentáculos la economía internacional; entre ellas, un círculo reducido de 200 monopolizaba el dominio del poder. En la esfera del PIB mundial, el 17\% registrado en 1960 saltaron al $24 \%$ en 1980 y a más del 30\% en 1995. Las actividades de las 200 hegemónicas cubren en su irradiación planetaria todos los sectores (primarios, secundarios y terciarios), agrícolas, producción manufacturera, servicios financieros", en BAIGÚN, David, La responsabilidad penal de las personas jurídicas, O. cit., página 8. 
los delitos económicos conocidos se habrían cometido en relación con una actividad del principal inculpado dentro de una empresaò $Y$ en este mismo sentido ya nos mostraba Bacigalupo $^{70}$ sobre las recomendaciones del Comité de Ministros de la Unión Europea, en efecto, da noticia de que el 28 de octubre de 1988 en su 420th reunión se llegó al acuerdo de hacer una recomendación: de que los Estados miembros pudieran modificar sus legislaciones para efecto de reconocer responsabilidad penal de las personas jurídicas, y tuvieron como fundamento: 1. El creciente número de infracciones penales cometidas en el ejercicio de las actividades de las empresas que ocasionan un perjuicio considerable tanto a los particulares como a la sociedad. 2. la dificultad que existe respecto de la identificación de las personas físicas responsables de las infracciones, teniendo en cuenta la estructura compleja de las empresas; 3 . El reconocimiento de que existe una peligrosidad propia de la persona jurídica que puede subsistir incluso después de hacer inocuos a sus órganos o representantes.

El Corpus luris de la Unión Europea, en el marco del Tercer Pilar del Tratado de 1992, respecto de la Cooperación de asuntos de Justicia e Interior (CAJI) prevé la responsabilidad penal directa de las personas jurídicas para la protección de los intereses financieros de la Unión Europea ${ }^{71}$.

Incluso, los autores que se mostraban, antes de la reforma, más acérrimos al cambio a la responsabilidad penal de las personas jurídicas, como Bernardo del Rosal Blasco e Ignacio Pérez Valero ${ }^{72}$ aseguraban que r̃a necesidad de la evolución del Derecho Penal, en

70 BACIGALUPO, Silvina, La responsabilidad penal de las personas jurídicas, Op. cit., p. 143.

71 El Corpus Iuris, traducido por Nicolás García Rivas de la versión Italiana, aparece publicado en $R P$, núm. 1, 1998. En su art. 14 establece: "1. Serán asimismo responsables de los delitos previstos en los art. 1 a 8 las empresas que posean personalidad jurídica, así como aquellas que posean la cualidad de sujetos de derecho y sean titulares de un patrimonio autónomo, cuando el delito se realice por un órgano, representante o cualquier persona que actúe en nombre de la entidad o que tenga poder de decisión, de hecho o de derecho"

72 Op. cit., p. 27. 
este sentido, parece indiscutible y, de hecho, ante nuevos fenómenos de criminalidad de la empresa que tienen lugar en el ámbito del medio ambiente, en el de la criminalidad económica, en los de responsabilidad por el producto o en el ámbito del transporte, lo que se muestran contrarios a la superación del dogma societas delinquere non potest buscan nuevos y más eficaces mecanismos de respuesta, diferentes a los del Derecho Penal tradicional y que logren superar las limitaciones que éste imponeò Hasta los penalistas más ontologicistas, como HansJoachim Hirsch ${ }^{73}$ fundamentaban ya fuertemente la necesidad político criminal de las personas jurídicas.

Un planteamiento muy interesante, que refleja perfectamente la razón del tropiezo de la actual dogmática jurídico penal para no hacer responder penalmente a las empresas, lo da Günter Heine ${ }^{74}$, pues nos dice r̃llos temas actuales que no cubre el Derecho Penal tradicional)é son la criminalidad económica, el lavado de dinero, la responsabilidad por productos defectuosos, la protección penal del medio ambiente. Estos ámbitos están básicamente impregnados de modelos de conducta colectiva, siendo las empresas económicas, en tanto subsistemas característicos de la sociedad industrial moderna, los agentes del desarrollo socialé ò

En conclusión: existe actualmente una necesidad de política criminal (incluso reconocida por quienes están en contra de la responsabilidad penal de las personas jurídicas, como ya lo vimos) que exigía hacer responder a las personas jurídicas penalmente, como entes autónomos e independientes, y no ya tanto a sus miembros, pero siempre independientemente de ellos.

\footnotetext{
73 "La cuestión de la responsabilidad penal de las asociaciones de personas", $A D P C P, 1993$, p. 1099 pássim.

74 HEINE, Gunter, "La responsabilidad penal de las empresas: evolución internacional y consecuencias nacionales", en HURTADO POZO, DEL ROSAL y SIMMONS (Coords.) La responsabilidad criminal de las personas jurídicas: una perspectiva comparada, Tirant lo blanch, Valencia, 2001, página 51.
} 


\subsubsection{Irresponsabilidad individual organizada e irresponsabilidad estructural organizada.}

Por otro lado, quienes estimaban como suficiente, para la prevención general en este tipo de delitos que son cometidos en el seno de las organizaciones empresariales, la punición de las personas miembros de la empresa, tendrían que enfrentarse y superar problemas de dificultad de pruebas y obtención de la verdad en el caso de buscar la responsabilidad individual.

Es muy común y frecuente que dentro de la empresa exista una conformación de procedimientos, jerarquías, líneas de mandos, superposición de funciones o lagunas de las mismas, órdenes encontradas o contrarias, entre otras cosas, que impidan, cuando se genera un riesgo insoportable que se realiza en un resultado típico, conocer a o a las personas físicas que lo realizaron, precisamente por la confusión generada ya en la organización; o bien puede suceder que una vez realizado el delito, la organización empresarial, para evitar sanciones administrativas a ella o además penales para sus miembros, impida a los investigadores la obtención de la información cierta, esto es, burle a las instancias de investigación aprovechándose de su constitución compleja (organización compleja). A lo primero se le denomina irresponsabilidad individual de carácter estructural y a lo segundo irresponsabilidad individual organizada ${ }^{75}$.

75 Quien ha generado esos conceptos es HEINE, Vid. HEINE, Günter, "Modelos de responsabilidad jurídico-penal originaria de la empresa", Op cit., p. 26 y 27; el mismo, "La responsabilidad penal de las empresas: evolución internacional y consecuencias nacionales", en GOMEZ-JARA DIEZ, Carlos (Ed.), La responsabilidad criminal de las personas jurídicas: una perspectiva comparada, tiran lo blanch, 1996, p. 52, refiere “... una gran empresa moderna adquiere, finalmente, la capacidad de actuar mediante la coordinación de diversas tareas más o menos autónomas, relativas a las secciones empresariales y a las divisiones administrativas. En consecuencia, el fraccionamiento en el seno de la organización puede conducir hacia una "irresponsabilidad individual de carácter estructural". A esto se agregan los mecanismos prácticos de encubrimiento al interior de la 
En efecto, parece ser algo insuperable que la propia complejidad de una empresa genere estos dos tipos de obstáculos. $Y$ es que quienes afirmaban la responsabilidad penal individual de las personas físicas como exclusiva respuesta del Derecho Penal no toman en cuenta la fenomenología de la complejidad de toda organización empresarial: existe una extraordinaria descentralización de las funciones de decisión, posesión de la información y la operatividad ${ }^{76}$, que fragmenta a la empresa, y que impide que una sola persona, o en todo caso, varias personas actuando en común, sea o sean quienes, de forma clara y precisa, cometieron en realidad el delito. Si a ello le sumamos que cada día se tiende, en un concepto de administración moderno, al aplanamiento de organigramas, a la generación de equipos inteligentes y autónomos en las empresas, a la segmentación en varios departamentos especializados en la misma, es más, a la competencia de todos esos departamentos especializados, para lograr la optimización en los procesos de producción o de servicios, entonces la complejidad de la organización empresarial de la que tanto hablamos se vuelve más evidente, y por tanto, se diluye sustancialmente la responsabilidad penal de los individuos (por la minimización de la competencia en la totalidad del proceso de producción o de servicios en el plano de la extensión, y en cambio, la maximización de competencia en el pequeño segmento del proceso que le corresponde, en el plano de la intensión), lo que hace muy difícil resolver dicha problemática con las categorías de la teoría jurídica del delito que manejamos (para las personas físicas), por un lado, y una vez cometido el riesgo no permitido en algún resultado típico, se hace realmente difícil adquirir las

empresa. Existen muchas posibilidades de encubrir, inducir al error y generar vacíos que pueden a menudo hacer ineficaz cualquier indagación a causa de al estructura de la empresa ("irresponsabilidad individual organizada"). Así también FEIJOO SÁNCHEZ, Bernardo, “¿Culpabilidad y punición de personas jurídicas?”, en MONTEALEGRE Lynett, Eduardo, (Coord.), El funcionalismo en Derecho Penal: Libro Homenaje al Prof. Gunther Jakobs, Universidad Externado Colombia, Colombia, 2003, página 376 y 377; DE VICENTE Martínez, Rosario, "Persona jurídica y consecuencias accesorias", en $R d P P$, número 8, 2002, páginas 111 y 112. 76 HEINE, G., "La responsabilidad penal de las empresas...", Op. Cit., p. 51. Así también, SILVA SÁNCHEZ, J. M., "La responsabilidad penal de las personas jurídicas...”, Op. Cit., página 313 y sigs. 
pruebas para demostrar el mismo así como la participación de las personas en el delito, por las naturales (o explicables) maniobras de encubrimiento.

Haciendo a un lado lo anterior, no podemos dejar de considerar como una realidad el hecho de que las personas jurídicas, cuando tienen un nivel elevado de complejidad interna en cuanto a su organización no son, ni por mucho, la simple suma de las voluntades de sus miembros ${ }^{77}$. Son personas autónomas, independientes y diferentes a sus miembros, su decisión no es el producto del acuerdo de su consejo directivo, ni sus procesos y procedimientos son el resultado de años de intervenciones de desarrollo organizacional de sus operadores $^{78}$; las personas jurídicas, en un concepto sociológico (sistémico, en forma precisa), tienen vida propia $^{79}$.

\footnotetext{
77 HIRSCH reconoce que en el lenguaje común y en la vida cotidiana hablar de personas jurídicas o de empresas tiene un significado diferente que hablar del conjunto de personas que la integran como sus miembros. Dice que "pero hoy existe claridad acerca de que las asociaciones de personas son formas de organización humana que constituye sujetos autónomos, en la realidad de la vida social, con independencia de la variación de sus miembros".

78 Coinciden DANNECKER, Gerhard, "Reflexiones sobre la responsabilidad penal de las personas jurídicas", $R P$, núm. 7, 2001 p. 45, "las empresas son sujetos reales, sociales y autónomos. Actúan en el tráfico económico como titulares de valores patrimoniales, persiguen fines propios, tienen una propia "corporate identidy" o "corporate culture" y son capaces de motivación"; DE DOELDER, H., "La punibilidad de las personas jurídicas en Holanda", en VV.AA., Jornadas en Honor del Profesor Klaus Tiedemann, Hacia un Derecho Penal económico europeo, BOE, Universidad Autónoma de Madrid, Madrid, 1995, 'p. 498, "La persona jurídica se ha hecho una realidad, y consiguientemente es también una realidad que las personas jurídicas pueden cometer delitos"

${ }^{79}$ Cfr. GARCIA C., Percy, La responsabilidad penal del administrador de hecho de la empresa: Criterios de imputación, Op. Cit., p. 62 a 65, entiende que "Un concepto sistémico de la empresa parte de que no existe una definición a priori del fenómeno empresarial... La empresa es sencillamente analizada como un sistema social organizado cuyas acciones (Output) pertenecen al sistema económico y que contribuye al desarrollo funcional de éste como una de las posibilidades de solución funcionalmente equivalentes... La empresa se constituye en el sistema económico como agente operativo. ... A pesar de que la empresa constituye por sí misma un sistema social diferenciado, ella continúa participando, como unidad, en el sistema económico contribuyendo a su desarrollo funcional: crear mecanismos sociales de equilibrio entre la explotación racional de los recursos y las necesidades actuales de los mismos"
} 
Por esa razón, también debe ser diferente su responsabilidad y las sanciones que de índole penal se le impongan. Confundir la persona y la culpabilidad de la organización empresarial con la persona y culpabilidad de sus miembros, es impunidad, y ello acarrearía el decaimiento del sentimiento de seguridad y certidumbre en la norma penal: la norma vería una excepción en su cumplimiento, cuando el delito es cometido por una persona jurídica.

Los peligros de los que hablamos supra son especialmente visibles en aquellos campos de desarrollo y producción de las organizaciones empresariales que se refieren a la tecnología y al medio ambiente. El sistema de numerus clausus puede ser una buena técnica para que no se disparen los procesos penales en su contra.

\subsubsection{Insuficiencia preventiva de otras sanciones (derecho administrativo y derecho civil).}

Dentro de la discusión de la necesidad político criminal de responsabilizar penalmente a las empresas, esto es, de considerarlas sujetos de Derecho Penal e imponerles sanciones penales en base a su culpabilidad, se plantearon las tesis que, negando dicha necesidad, no niegan en cambio la diversa de controlarlas por algún otro medio, pues reconocen que a través de las personas jurídicas se cometen múltiples delitos y que en ese sentido tienen una peligrosidad muy importante para la supervivencia de los bienes jurídicos de las personas que viven en sociedad.

El argumento toral para negar la criminalización de las organizaciones empresariales es de carácter dogmático: no tienen ni siquiera capacidad de acción, o, los que admiten que si la tienen, niegan la capacidad de culpabilidad.

La incapacidad de acción alegada deviene del argumento de que la persona jurídica es sólo una ficción, un ente imaginado, 
construido por el Derecho, ciertamente un centro de imputación de derechos y obligaciones, pero en todo caso solamente eso, y por ello, es inimaginable que algo que en verdad no existe, por sí misma, produzca acciones o incrementos de riesgos no permitidos. Esta posición asegura que las reputadas acciones de la empresa son en realidad acciones de las personas físicas que ostentan la representación de dicho ente imaginado y construido, que no es posible explicar las rancciones de la empresaòde forma diferente: al principio y al final, son sólo las acciones de sus miembros las únicas que existen en el mundo real. Por tanto, considerar que esas acciones son de la persona jurídica es violentar los principios del Derecho Penal de autor y de intrascendencia del Derecho Penal.

Quienes apuntan a la incapacidad de culpabilidad, admiten que las acciones de las personas físicas, miembros o representantes de la persona jurídica, son en realidad rexpresiónòde las acciones de ésta, esto es, sus acciones sólo pueden ser las que hace a través de sus miembros, y no puede ser de otra forma, porque así está constituida la misma, y en este sentido, en ninguna forma se violaría los principios intrascendencia del Derecho Penal ni del Derecho Penal de autor. Pero no sucedería lo mismo con la culpabilidad: ésta es personalísima porque a través de ella se realiza un reproche ético individual al autor del delito; y esto sólo puede enderezarse en contra de la persona física (miembro o representante) de la persona jurídica. La culpabilidad se fundamenta en la conciencia, en el saberse libre ${ }^{80}$, eso es lo que permite fundamentar la competencia para contribuir a la formación de la norma, pero también la de desautorizarla con expresión de sentido; y es precisamente lo que le falta a la persona jurídica pues no tiene el

${ }^{80}$ JAKOBS, Günther, “¿Puniblidad de las personas jurídicas?”, en Montealegre Lynett, Eduardo, (coord.), El funcionalismo en Derecho Penal: Libro Homenaje al Prof. Gunther Jakobs, Universidad Externado Colombia, Colombia, 2003, p. 336, pues dice culpabilidad es falta imputable de fidelidad a la norma. El autor toma posición frente a la norma, la desautoriza, es decir, es un acto con significado comunicativo. "Únicamente una persona a quien se le adscribe una conciencia propia competente en el plano comunicativo puede comportarse de forma culpable...”, p. 338. 
suficiente equipamiento para producirse contra la norma en el plano comunicativo ${ }^{81}$.

Pues bien, quienes niegan la capacidad de culpabilidad de la persona jurídica tendrían que fundamentar adecuadamente su capacidad de acción, y eso, en principio, parece una contradicción, pues no es entendible que si la acción de la persona jurídica puede ser la de las físicas que actúan para ella o en su seno, esto es, que éstas sean expresión de la acción de aquella, no parece que existan argumentos en materia de culpabilidad no sea así. Pero lo que nos interesa en todo caso, es que tendrían que fundamentar o bien medidas de carácter civil o bien sanciones administrativas (que por cierto, también exigen para su imposición, la demostración de la culpabilidad).

Independientemente de las construcciones dogmáticas y sus fundamentos teóricos de los modelos que se han propuesto al respecto, lo que aquí interesa por el momento es si la respuesta del Derecho Civil o la del Derecho Administrativo sancionador serían lo suficientemente expresivas en la comunicación como para poder generar la suficiente intensidad simbólica de su desaprobación, y con ello, conseguir la prevención que se requiere. Nosotros consideramos que no es posible, y por tanto, sólo el Derecho Penal tendría el carácter simbólico suficiente que desaprueba la violación de la norma y vuelve al equilibrio al ordenamiento jurídico.

La respuesta del Derecho Civil ante los actos ilícitos de las personas jurídicas tiene varios inconvenientes. Por un lado, la acción solamente la puede enderezar las personas afectadas, las que para tomar esa decisión deberían tomar en cuenta los costos económicos que ello implica, por otro lado, y en virtud de que se trataría de derechos dispositivos, siempre estaría sujeta la pretensión de los demandantes a las solicitudes de convenio de la empresa, que en la mayoría de los caso es difícil rechazar, y por último, la sentencia

81 Ib Ídem, p. 342. 
eventual que se pueda pronunciar tendría la calidad indemnizatoria, y nunca sancionatoria por un acto prohibido por la ley, lo que al final tendríamos un resultado sin pizca alguna de desaprobación en el plano comunicativo del acto ilegal de la persona jurídica. Ésta jugaría, como ya lo hace, al juego de las posibilidades: cuántos de todos los afectados la demandaría, y cuántos de estos rechazaría un trato conveniente o en su defecto cuántos le ganaría en un juicio civil, y en todo caso, prevendría asegurando sus pérdidas con alguna compañía aseguradora que le cubra de ello. Todo lo anterior garantiza al resto de la sociedad que la empresa seguirá haciendo y generando riesgos no permitidos y violando el bien jurídico penal que es la norma penal.

La vía de la sanción administrativa también tiene sus inconvenientes. El primero y más importante es que también el Derecho administrativo sancionador exige, para la imposición de sanciones administrativas, la culpabilidad de la persona jurídica ${ }^{82}$.

Esto nos exige traer a colación un tema muchas veces tratado: la diferencia cuantitativa o cualitativa entre el Derecho Administrativo sancionador y el Derecho Penal, por un lado, y en segundo lugar, la diferencia, si es que existe, entre la culpabilidad administrativa y culpabilidad penal, y en su caso, las mismas garantías para la parte imputada.

82 En España la Ley 30/1992 de 30 noviembre de Régimen Jurídico de las Administraciones Públicas y del Procedimiento Administrativo Común, señala en su art. 130: "sólo podrán ser sancionados por hechos constitutivos de infracción administrativa las personas físicas y jurídicas que resulten responsables". En Derecho Comunitario Europeo establecen una situación similar los artículos 85 y 86 del Tratado de la Comunidad Europea, y su Reglamento 17/1962 de 6 de febrero, en su art.15 y 16. El Tribunal Constitucional se ha pronunciado al respecto, en la STC 246/1991 de 19 de diciembre, F.J. 2o. "esta construcción diferente de la imputabilidad de la autoría a la persona jurídica nace de la propia naturaleza de ficción jurídica a la que corresponden estos sujetos. Falta en ellos el elemento volitivo en sentido estricto, pero no la capacidad de infringir las normas a las que están sometidos. Capacidad de infracción y, por ende, reprochabilidad directa que deriva del bien jurídico protegido por la norma que se infringe y de la necesidad de que dicha protección sea realmente eficaz". 
Se pretende distinguirlos atendiendo a que el Derecho Penal protege bienes jurídicos mientras que el Derecho administrativo simplemente pretende el cumplimiento de normas. No obstante, vemos cómo existen normas muy similares entre ambas ramas del derecho que prohíben la misma conducta con el mismo resultado, y en otras ocasiones, lo único que cambia es la intensidad del resultado ${ }^{83}$. Esto ha llevado a una parte de la doctrina a afirmar que entre la materia penal y administrativa sólo existe una solución caprichosa de continuidad del ius puniendi: lo que previene las normas administrativas, y cuya violación es reclamada ante la vía administrativa, ante la autoridad administrativa, entonces es Derecho Administrativo, por contra, lo que es previsto en el CP o en las leyes especiales, reclamado en la vía penal ante el Juez Penal, entonces es Derecho Penal ${ }^{84}$. La diferencia sólo es cuantitativa.

La otra cuestión, relativa a si la culpabilidad del Derecho Administrativo es la misma que se exige en el Derecho Penal, y por ende, si las garantías sustantivas y adjetivas, son las mismas en uno y otro ámbito, también representa una discusión que todavía no puede terminar de forma pacífica. El Tribunal Supremo ha establecido ${ }^{85}$ que en la aplicación de las sanciones administrativas deben imperar las formas del ámbito penal, esto es, se debe exigir también en ese ámbito la culpabilidad de la persona jurídica y su imposición debe estar

${ }^{83}$ Cfr. ZUGALDÍA ESPINAR, José Miguel, La responsabilidad penal de empresas, fundaciones y asociaciones, Op. Cit., p. 107.

84 CARMONA RUANO, Miguel, "La responsabilidad penal de las personas jurídicas”, en BAJO FERNÁNDEZ, M. (Dir.), Empresa y Derecho Penal (II), Consejo General del Poder Judicial, Madrid, 1999, p. 287, "Serán penas, aquellas sanciones que impone un órgano judicial tras un proceso penal, y entre ellas adquiere una significación destacada la privación de libertad. Por el contrario, serán sanciones administrativas aquellas otras que impone un órgano de la administración, tras seguir un procedimiento administrativo, sin que entre ellas pueda encontrarse (art. 25.3 CE) ni directa ni indirectamente la privación de libertad..."

$85 \mathrm{El} \mathrm{TS}$ (4aㅡ sala) decía (16-07-83 y 8-2-95 y 16-3-98) que no se podía imputar a la empresa el hecho de su empleado si había instalado medidas de seguridad; pero la Sala $5^{\text {a }}(10-2,16-3,7-4$ y 8-7 de 1988) resolvió que se producía culpa "in eligendo" o "in vigilando" de la empresa que le hacía responsable de los actos de sus empleados. Luego esta cuestión es zanjada por la STC 246/1991 de 19 de diciembre que dice que la culpa de la persona jurídica "se ha debe aplicar necesariamente de forma distinta a como se hace respecto de las personas físicas". 
rodeada de las mismas garantías. Esto había llevado a alguna parte de la doctrina a afirmar que al Derecho Administrativo sancionador se habría de trasladar todas las garantías del Derecho Penal, pues aquel, en la aplicación de las sanciones, era una especie de subclase de este.

Nosotros consideramos que tanto el Derecho Administrativo sancionador y el Derecho Penal son expresión del mismo ius puniendi, no tanto que aquel esté subvencionado por éste ${ }^{86}$. Esta opinión parece sustentada por el propio Tribunal Constitucional en posteriores resoluciones ${ }^{87}$. Pero también es verdad que difícilmente se puede sostener que la culpabilidad exigida por la sanción administrativa es diferente a la que reclama la pena. La construcción de una culpabilidad de la persona jurídica en el Derecho Administrativo sancionador fue, antes de la reforma, uno de los argumentos más fuertes en contra del principio societas delinquere non potest.

No obstante que la culpabilidad de la organización empresarial pueda ser construida para la imposición de la sanción administrativa, lo que interesa ahora es respondernos a la cuestión de si es lo suficientemente efectiva la sanción administrativa para combatir a la criminalidad de empresa. Estamos convencidos de que no es así.

La actuación de la Administración para la persecución y sanción de los actos ilícitos administrativos siempre se orienta por criterios de oportunidad y conveniencia, no tanto por el de justicia (retribución) y preventivo (general y especial), por lo que la norma difícilmente resultaría integralmente restablecida en aquellos casos en que la Administración decidiera no exigir responsabilidad a la persona jurídica. También la sanción administrativa misma no tiene per se el suficiente carácter de desaprobación con sentido. En efecto, en la construcción normativa sólo las penales poseen, en tanto constituyen la respuesta

\footnotetext{
${ }^{86}$ Cfr. GUARDIOLA LAGO, María de Jesús, Responsabilidad penal de las personas jurídicas y alcance del art. 129 CP, Valencia, Tirant lo blanch, 2004, p. 95.

87 Ha resuelto que no es posible trasladar "en bloque" las garantías del Derecho Penal al administrativo sancionador.
} 
más importante de desaprobación contra las formas de conducta más intolerables, la intensidad expresiva suficiente para desautorizarlas y así, impedir la desprogramación de que la norma sigue siendo vigente y el criterio a seguir.

Por lo tanto, consideramos que difícilmente puede el Derecho Civil o el Derecho Administrativo ser la última respuesta del Estado frente a esas formas de conducta de la persona jurídica $u$ organizaciones empresariales. No proclamamos su exclusión sin más ni más del control sobre las conductas ilícitas de las personas jurídicas, pues esos ámbitos de control social también deben estar presentes en la lucha contra la criminalidad económica provocada por las empresas, y su presencia es muy importante para librar la batalla, pero son insuficientes si no están acompañadas con la más importante herramienta de control social que la sociedad moderna tiene: el Derecho Penal ${ }^{88}$.

\subsection{Hacia un sistema eficiente de responsabilidad penal de} personas jurídicas.

Según lo referido en párrafos anteriores, la responsabilidad penal de las personas jurídicas se alzó en España como un reclamo de necesidades político criminales, al ver y verificar que las características del Derecho Penal individual no rálcanzabanò a cubrir espacios de ingente peligro para bienes jurídicos individuales y colectivos, por lo que se imponía como algo necesario el řsíòa la responsabilidad penal de los entes colectivos. Sin embargo, después del risíòhabrá que ver si de las necesidades político criminales podremos obtener algún r̃cómoò Nosotros creemos que sí.

88 A conclusión similar, según entendemos, llega LOZANO, Blanca, Op. Cit. Página $230 \mathrm{y}$ sigs. 
Podemos afirmar que la formulación de las respuestas a esas necesidades podría ser de la siguiente forma:

1.- Es necesario un sistema o modelo de responsabilidad en el que se haga reprochable a todo ente colectivo de cierta envergadura, de cierto tamaño, de cierta complejidad. Una empresa cuya gran actividad económica genere riesgos a los bienes jurídicos individuales y colectivos.

En efecto, las necesidades político criminales que fueron expuestas por la gran totalidad de la doctrina española y extranjera se dirigían en contra de las grandes empresas, los consorcios, las grandes fábricas o las que tienen un poder económico o incluso político de gran tamaño. Las que son capaces de conmover la economía nacional, de definir cambios bursátiles, de distribuir productos defectuosos en masa, de hacer los grandes fraudes al erario público, en fin, de aquellos grandes peligros que hacen ver, cuando los comparamos con ellos, una bagatela a los delito r̃de a pieò Se dirigía contra las grandes empresas que podían modificar, con la producción masiva de productos, las condiciones medioambientales del globo terráqueo, aquellas tan complejas en su interior que hacía imposible saber y conocer al autor físico o individual de los hechos criminosos (irresponsabilidad estructural organizada), o que era tan importante y prestigiada que podía producir en sus miembros, por esa necesidad de pertenencia que tenemos los humanos, una actitud de grupo -que bien podía ser criminal (irresponsabilidad individual organizada), o aquella capaz de planear el futuro mediato o remoto como para comprar seguros contra las multas derivadas de infracciones administrativas, o incluso, comprar a T̃ombres de pajaò

Uno de los principales escollos que fue enunciado por Heine ${ }^{89}$ (y que fue repetido por gran parte de la doctrina española) para exigir la responsabilidad criminal de las personas jurídicas, era la

89 HEINE, Gunter, "La responsabilidad penal de las empresas: evolución y consecuencias nacionales", Op. Cit., página 51 y siguientes. 
descentralización de las funciones de decisión, información y operación, de las empresas modernas en la era del lean management o del top quality, que hacía a la empresa adquirir r̃capacidad de actuar mediante la coordinación de diversas tareas más o menos autómatas, relativas a las secciones empresariales y divisiones administrativas $0^{\circ 0}$, lo que, por supuesto, no puede suceder en una empresa pequeña. Por su parte Zuñiga expresamente focaliza la necesidad ahí donde el grupo es grande, complejo, donde se hace indispensable la división del trabajo, la delimitación de competencias, definición de roles y delegación de autoridad, ren estos casos, cuando la organización se independiza de sus miembros, cuando se despersonaliza y se institucionaliza, es cuando podemos de hablar de organizaciones complejas. $Y$ es en estos casos cuando la responsabilidad individual propia del Derecho Penal va a plantear problemas para su determinacióné $0^{91}$ y se crea la actitud criminal de grupo. También se planteó el problema de las sociedades (empresas) globalizadas o trasnacionales, la organización de la criminalidad y la empresa red y la producción de nuevas tecnologías.

Contra esas ñpersonas jurídicasò se alzaban las necesidades político criminales de la doctrina. Si hoy se pretende, al amparo de una interpretación literal y cómoda de la ley, dirigir las instituciones del Derecho Penal contra las pequeñas empresas o contra personas jurídicas unipersonales o prácticamente de poca envergadura, se estaría traicionando la palabra doctrinal.

Si no construimos un sistema penal exclusivo para personas jurídicas con cierto grado de complejidad, entonces las instituciones estatales no perseguirán más a las grandes empresas, creadoras de los verdaderos grandes peligros a los bienes jurídicos individuales y colectivos, y se focalizarán a la persecución criminal contra exclusivamente personas jurídicas pequeñas, unipersonales, sin complejidad, como tal parece que ya está sucediendo. Cierto, con el fin

\footnotetext{
90 Ib Ídem, p. 51 y 52.

91 ZUÑIGA, Laura, Bases para un modelo de imputación de responsabilidad penal a las personas jurídicas, Thomson Aranzadi, Navarra, 2003, páginas 67 a 69.
} 
de rellenar sus estadísticas oficiales, que con seguridad le serán exigidas por la sociedad civil, y teniendo el cuidado de colocar el rubro de medición m̃úmero de personas jurídicas procesadas y sentenciadasò sin mencionar la importancia de esa entidad colectiva, será de la satisfacción general encontrar la gran aplicación del art. 31 bis CP; mientras que las grandes compañías, aquellas que son las que generan los grandes riesgos, precisamente por su importancia económica y su influencia política, además de su complejidad (es más fácil procesar a una sociedad unipersonal que a otra de envergadura internacional) seguirán gozando de la inmunidad de la que se dolía la doctrina.

2. Es necesario un sistema o modelo de responsabilidad criminal de personas jurídicas que supere la irresponsabilidad estructural organizada, por tanto, que en la menor medida posible dependa de la responsabilidad individual de la persona física, o de la prueba de esa responsabilidad.

No desconocemos que son las personas físicas de las empresas las que hacen o dejan de hacer, y por tanto, son ellas las que generan los aumentos en los riesgos a los bienes jurídicos. Una o algunas personas físicas, con nombres y apellidos, con cargos y funciones específicas en la empresa, en un lugar, un día y a determinada hora, y bajo determinadas circunstancias. No obstante ello, si la identificación de la persona física (¿quién fue?) era ya una dificultad inmensa en las referencias doctrinales que exigían un sistema de responsabilidad penal de personas jurídicas, ya debemos de estimar más difícil afirmar y comprobar si la persona física actúo dolosa o imprudentemente o si cometió el delito de forma culpable (¿cómo lo hizo?), dentro del ámbito organizativo complejo de una persona jurídica.

Que la descentralización en las funciones de decisión, información y operación dentro de un ente colectivo, así como la descomposición de competencias y departamentos administrativos, por decir lo menos, provocaban la imposibilidad de imputación objetiva y 
subjetiva del delito cometido a una o algunas de esas personas físicas, precisamente porque en ninguna o ningunas de ellas se reunía, in totum, las exigencias del sistema de responsabilidad penal individual, es o fue uno de los principales motivos de los estudios doctrinales para exigir una responsabilidad penal propia, autónoma e independiente de la persona jurídica. Esas exigencias deben ser valederas hoy en día, y disminuir, a límites irreductibles, la importancia o significado del r̃soporte humanoo ${ }^{92}$ para la imputación de responsabilidad penal a la persona jurídica.

En otras palabras: el delito de la persona física debería de ser un simple detonador para el injusto de la persona física, pero nunca su razón de ser o su fundamento. Si así se concibe poco a poco, tal vez, se irá prescindiendo de la identificación del individuo humano, de su dolo o imprudencia o de su culpabilidad. Solamente así la irresponsabilidad estructural organizada se irá desterrando.

Por lo demás, lo que fue una exigencia de política criminal (la superación de la irresponsabilidad estructural organizada) se levanta hoy como otra razón más para pretender como único ámbito de aplicación de la responsabilidad penal de las personas jurídicas aquel donde éstas son complejas, donde encontramos un esquema organizativo grande, descentralizado, niveles de competencia y división de departamentos administrativos, lo que no sucede en sociedades 0 empresas de menor calado.

3. Alineado con lo anterior, es necesario un sistema o modelo de responsabilidad que supere la irresponsabilidad individual organizada, por lo que ese modelo deberá ser propio de la persona jurídica.

Tiedemann hablaba de un rambiente o clima que facilita e incita a los autores físicos (o materiales) a cometer delitos en beneficio de la

92 CARBONELL MATEU, Juan Carlos, Op. Cit., página 14 y 15. 
agrupaciónò que se crea en la agrupación ${ }^{93}$, Schünemann lo llamó ractitud criminal colectiva ${ }^{94}$, y entre nosotros, Silva invoca a Ehrhardt para llamar al mismo fenómeno ñnstitucionalización de la irresponsabilidadơ ${ }^{95}$. Lo cierto es que la pertenencia social a un grupo de personas, en la medida en que adquieren cierta complejidad, autonomía (que se auto regula, se da a sí mismo normas) y autosuficiencia, produce en el miembro (individuo humano) un apego o adquisición de esas normas y valores. Por supuesto que esos valores y normas pueden ser de contenido virtuoso, pero también criminal.

La r̃ rriminalidad de grupoòtiene importancia en dos momentos diferentes: antes y en la comisión del delito, por un lado, y por otro, en forma posterior a su comisión.

Hasta la comisión del delito por parte del o las personas físicas miembros de la empresa, la actitud criminal es producida, generada 0 provocada por la pertenencia misma a la agrupación, puesto que el miembro se solidariza con los valores, principios o incluso visión de la vida del propio grupo, pues tiene el ánimo y deseo de seguir perteneciendo a la agrupación y subir el escalafón que la pirámide grupal le representa. Desde luego que cuando ese grupo es una persona jurídica, los valores, principios, metas, así como los medios o instrumentos institucionalizados para llegar a esos medios, son los

93 TIEDEMANN, Klaus, "Responsabilidad penal de las personas jurídicas", en Anuario de Derecho Penal, Universidad de Friburgo, página 2.

94 SCHÜNEMANN, Bernd, "La punibilidad de las personas jurídicas desde la perspectiva europea", Op. Cit., página 571, "es decir, el espíritu de grupo establecido en una colectividad de personas y, por tanto, también en una empresa económica, por una pluralidad de procesos de aprendizaje, en cuanto fuente de una conducta uniforme lesiva de bienes jurídicos por parte de los miembros del grupo que, como lo ha demostrado la investigación criminológica, están dispuestos en el marco del espíritu de grupo a realizar sin más lesiones de bienes jurídicos a las que no se dejarían arrastrar nunca en su esfera privada". Así también ZIÑIGA, Op. Cit., página 69, MIR PUIG, Santiago, "Una tercera vía en materia de responsabilidad penal de las personas jurídicas", Op. Cit., página 13, donde acepta y admite esa realidad sociológica.

95 SILVA SÁNCHEZ, Jesús-María, "La responsabilidad penal de las personas jurídicas y las consecuencias accesorias del art. 129 del CP", en Derecho Penal Económico, Consejo General del Poder Judicial, Manuales de Formación Continua, Madrid, 2001, página 315. 
propuestos por la propia persona jurídica, los emanados de su escalafón, de su sistema de competencias, de su radio de operatividad de cada una de ellas, así los originados en sus sistemas de movilidad, de promoción, de premios y estímulos positivos y negativos, de perfiles iniciales o ideales, y la manera en que es interpretada toda esa normativa por los operadores de ese r̃sistema normativoò

Así, si una persona jurídica o empresa busca beneficiarse en todos sus ámbitos, a costa de cualquier cosa, y por lo tanto, se promocione a sus miembros que traigan a la empresa esos beneficios sin importarle cómo los obtuvo, entonces seguramente la organización empresarial generará un sistema propicio para la actitud criminal de grupo.

Los estímulos positivos (premios, recompensas, asensos en el escalafón, o acercamientos al staff del círculo de poder) a los miembros que buscan beneficios o ventajas a la empresa a cualquier costa, así como los estímulos negativos (castigos, descensos, la llamada prohibición de coalición o la distancia social) a aquellos que se nieguen a hacerlo o hacerlo solo cumpliendo el ordenamiento jurídico, serían algunos de los elementos que alentarían a esa subcultura muy cerca de ser criminal.

Lo mismo habría qué decirse cuando, una vez cometido el delito, la persona jurídica y sus miembros tienen obligación de descubrir y dar la noticia del crimen hasta la información mayúscula a la autoridad que investigue el delito. La creación de incentivos para que cualquier miembro denuncie algún ilícito de la empresa (y la promesa de la protección de ese miembro), la transparencia (y por tanto el buen control) de sus operaciones financieras, contables, laborales, así como de las actividades de riesgo, el otorgamiento de información detallada y oportuna a las autoridades, marcará también esa rãctitud criminal de grupoòque será verificada en forma posterior a los hechos investigados. 
De ahí que más que (o junto con) la búsqueda de las responsabilidades penales individuales, serán elementos como los que hemos reseñado los que evidencien la propia y auténtica responsabilidad de la persona jurídica; pues se parte de que aquellas son producto de ésta (actitud criminal de grupo).

4. Debe ser un sistema que proporcione equilibrio y distribuya equitativamente las responsabilidades penales, evitando los cabezas de turco u hombres de paja.

Ha sido exigencia perpetua de la doctrina la responsabilidad penal de las personas jurídicas propia y originaria en razón, decían, que no es poco común que al buscar a un responsable que haya cometido el delito las autoridades que lo investigaban encontraban a personas operarias de la empresa, alejadas de los socios o de la dirección de las mismas, o en el peor de los casos, a directivos que se sacrificaban voluntaria o involuntariamente (a través de tratos con la empresa, esto es, a cambio de una contraprestación) ${ }^{96}$. Por tanto, es de supino interés un sistema que amén de buscar responsabilidades penales a los individuos, también implique a la persona jurídica propia por sus propios hechos y culpabilidad.

De esa forma tendríamos una ventaja adicional: los socios y administradores tomarían en serio los programas de cumplimiento ${ }^{97}$ de los que hablaremos líneas abajo.

5. Se exige un modelo que sea auténticamente penal, con sanciones penales, por el efecto simbólico de la pena; sin excluir otras barreras de otras ramas del derecho.

96 Por todos, NIETO MARTíN, Adán, La responsabilidad penal de las personas jurídicas, página 38 y nota 59. Señala que un estudio de 1.500 casos "relativos a reclamaciones contra grandes empresas, pertenecientes al Fortune 500, puso de relieve que sólo en el $1.5 \%$ de los casos estuvieron implicados directivos pertenecientes a las escalas más altas" de la empresa, lo que permite afirmar que ciertos modelos de responsabilidad penal crean una localización de la responsabilidad individual en los niveles más bajos dentro de la estructura jerárquica empresarial.

97 Ib Ídem, página 37. 
Ya hemos concluido que el Derecho Civil y el Derecho Administrativo poseen características específicas que de ninguna manera superarían a las que puede ofrecer el Derecho Penal. Destaca, entre otras, el carácter simbólico de la pena impuesta, después de un proceso penal, a la que cualquier empresa de cierta complejidad y envergadura económica tendría necesidad de no padecer.

6. Es necesario un sistema que sea capaz de regular precisamente la organización de la empresa, para evitar que sea defectuosa.

Este aspecto, más que una necesidad de política criminal tiene un sentido de conveniencia de método. Su origen es que hemos caído en la cuenta de que las empresas grandes tienen una organización interna enormemente compleja, por un lado, y por otro, son pioneras en el manejo de nuevas e innovadoras tecnologías que generan, día a día, nuevos e imprevisibles riesgos a diferentes bienes jurídicos, y la velocidad con la que se presentan nuevas tecnologías es tan vertiginosa que es imposible que las leyes de nuestros países regulen todos los peligros que eso genera. Su razón de ser es precisamente esa imposibilidad de ese control de nuevos riesgos, bajo la supervisión estatal de organizaciones complejas, que las instituciones del Derecho Penal adolecen. Merced a que no pueden controlarlas de forma directa, deben de buscar una forma diferente de garantizar la protección de los bienes jurídicos desde otras técnicas de control hasta ahora inexistentes en el sistema penal: se trata de la autorregulación regulada.

Este tópico, sin ser una dimensión específica, sí es en cambio un método de garantización o protección penal de bienes jurídicos propio de un sistema de responsabilidad penal de las personas jurídicas, y por ello, preferimos desarrollarlo en otro apartado. 


\section{DIMENSIÓN LEGITIMADORA O JURÍDICO PENAL.}

\subsection{Obstáculos dogmáticos penales para la} responsabilidad penal de las personas jurídicas.

En 1980 publicó Zugaldía ${ }^{98}$ un artículo que abordaba el tema en el que por primera vez, después de muchos años, no se había tocado en España: se trataba de poner en la mesa de debate que no obstante que la dogmática jurídico penal española entendía que sólo las personas físicas eran sujetos activos del Derecho Penal, y no así las personas jurídicas, en la realidad social los actos de verdadero contenido de dañosidad social los generaban las personas jurídicas. Ahí, se ponía en evidencia a un Derecho Penal rebasado: Ĩ a falta de congruencia de ambos conceptos es hoy evidente, sobre todo, porque las ciencias jurídicas han quedado en sus concepciones visiblemente estancadas dentro del aparato conceptual de la dogmática de las teorías absolutas, mientras las ciencias sociales han avanzado en un proceso de progresiva racionalización $0^{99}$. Desde ese momento puso en la conciencia de la Ciencia del Derecho Penal que el Derecho Penal y la dogmática penal deben ser el vehículo (y no el obstáculo) para la prevención del delito (independientemente de quienes fuesen sus autores), y proponía que se determinara en qué delitos y bajo qué condiciones debían imponerse sanciones penales a las personas jurídicas y que, para hacerlo posible, se revisaran los conceptos tradicionales de acción (como comportamiento humano), culpabilidad (como juicio de orden tanto biológico como psicológico) y pena (como castigo retributivo de la culpabilidad $)^{100}$.

Bajo la potestad del CP de 1931 (inmediato anterior del reformado de 1944, y del totalmente nuevo de 1995), solo se

\footnotetext{
98 ZUGALDÍA Espinar, J.M., "Conveniencia político criminal e imposibilidad dogmática de revisar la fórmula tradicional societas delinquere non potest", CPC, núm. 12, 1980, p. 67 pássim.

99 Ib idem, p. 69.

100 Ib idem, p. 86 a 89.
} 
escribieron pocos artículos más al respecto ${ }^{101}$, y todos, de una u otra forma, identificaban claras necesidades de imponer algunas consecuencias de carácter penal a las personas jurídicas. Pero también todos veían un obstáculo de apariencia insuperable, como lo era la dogmática jurídico penal del individuo humano.

Al día de hoy, prácticamente hay consenso en la doctrina de generar un sistema de responsabilidad penal para las personas jurídicas diferente y específico al de la persona individual, que tenga la virtud de respetar los derechos fundamentales y los principios básicos de la Ciencia del Derecho Penal: principio de acción propia de la persona jurídica, principio de culpabilidad propia de la persona jurídica y de personalidad de la pena exclusiva a la persona jurídica. Así expresados, queremos incluir en dichos principios la prohibición de una responsabilidad objetiva, de exigencia de dolo y culpa, y en general, el principio de responder más que por actos o hechos propios y no ajenos, y del non bis in ídem.

\subsubsection{Modelos dogmáticos elaborados a la medida de óelô} sujeto individual ódañinoô. Breve reseña.

El estudio del Derecho Penal en su carácter científico moderno (dogmática jurídico penal) desde Von Liszt hasta nuestros días ha significado un importante avance en la construcción de nuestras democracias. Ello, en virtud de las ventajas propias, sobre todo de seguridad jurídica, del pensamiento sistemático de las que habla

101 BARBERO SANTOS, Marino, “¿Responsabilidad de las personas jurídicas?”, en Revista de Derecho Mercantil, Madrid, 1957; el mismo, “¿Responsabilidad penal de la empresa?", en $A P, 1987-1$, páginas de 1081 a 1098, con reimpresión en ARROYO Z., L., Estudios de Derecho Penal Económico, Editorial Universidad de Castilla La Mancha, 1994; MUÑOZ CONDE, Francisco, "La responsabilidad de los órganos de las personas jurídicas en el ámbito de las insolvencias punibles", CPC, Número 3, 1977, páginas 157 y sigs.; RODRÍGUEZ RAMOS, Luis, "Medidas de seguridad aplicables a las personas jurídicas en el proyecto del Código Penal", en La Ley, Revista Jurídica Española, Número 1, Madrid, 1980, páginas de 1004 a 1007. 
Roxin ${ }^{102}$ permiten preferirlo de uno problemático, a la manera de Gimbernat Ordeig: la dogmática penal t̂hace posible, por consiguiente, al señalar límites y definir conceptos, una aplicación segura y calculable del Derecho Penal, hace posible sustraerle a la irracionalidad, a la arbitrariedad y a la improvisación. Cuanto menos desarrollada esté una dogmática, más imprevisible será la decisión de los tribunales, más dependerán del azar y de factores incontrolables la condena y la absolución..$^{03}$ Entendemos que esto podría ser visto también con el término de r̃ rontrolabilidadò

Sin embargo, detrás de esas enormes ventajas que reconocemos indudablemente, se encuentran una serie de áreas de oportunidad que hoy en día se ven como desventajas, y me refiero fundamentalmente a dos: Olvido de la justicia al caso concreto y la obtención de soluciones político criminalmente no legitimables ${ }^{104}$. Esto, en razón de que con el pretexto del respeto a los principios de culpabilidad y del carácter fragmentario del Derecho Penal se dejan sin criminalización sustantiva 0 en su caso procesal, aquellos comportamientos de verdadero contenido de dañosidad social, ocasionado por, entre otros fenómenos, personas jurídicas que no pueden ser incriminadas por otro principio (el de personalidad de las penas, que finalmente es el de culpabilidad), y que permiten considerar, en la comparación, al delito róle a pieòcomo una bagatela. ${ }^{105}$ De esto

102 ROXIN, Claus, Derecho Penal, parte general, Op. Cit., p. 207 y sigs., donde dice que esas ventajas son: Facilitar el examen del caso, el orden del sistema como presupuesto de una aplicación uniforme y diferenciada del Derecho, simplificación y mejor manejabilidad del Derecho, el contexto sistemático como guía para la elaboración y desarrollo del Derecho.

${ }^{103}$ En ¿Tiene un futuro la dogmática jurídico penal?, Op. Cit., p. 158.

104 Ib idem, p. 210 y 213.

105 BARATTA, A., Criminología Crítica y Crítica al Derecho Penal, Siglo XXI, México, 1993, p. 185, dice: "El sistema de valores que en ellos (los contenidos y no contenidos del CP) se expresa refleja sobre todo el universo moral propio de una cultura burguesa-individualista que destaca al máximo la protección del patrimonio privado y que se dirige prioritariamente a tocar las formas de desviación típicas de los grupos socialmente más débiles y marginados. Baste pensar en la enorme proporción de los delitos contra el patrimonio en la tase de la criminalidad, según resulta de la estadística judicial. (...) En cuanto a los "no contenidos" se comienza por fin a buscar la raíz del llamado "carácter 
se trata: que la dogmática penal actual ha sido diseñada pensando en la criminalización de ciertos delitos y dejando, expresamente, otros delitos de mayor dañosidad social en razón, entre otros, del principio societas deliquere non potest.

Por ello, presentaré en breve la evolución que ha tenido el Derecho Penal y la forma en que ha sido pensado y para qué ha sido pensado; dicha exposición que haremos coincide, en gran medida, con lo que Pérez Alonso denomina, no sin razón, ñas revoluciones científicas del Derecho Penalờ ${ }^{106}$. De cualquier forma, los sistemas de Derecho Penal ñpiensanò solamente en la persona física como el prototipo de imputación de Derecho Penal.

fragmentario" del Derecho Penal (que los juristas a menudo consideran como un dato de su naturaleza) no sólo en la pretendida inidoneidad técnica de ciertas materias frente al control a través del Derecho Penal (o en la tautológica suposición de las significación penal de ciertas materias y no de otras), sino más bien en una ley tendencial que lleva a preservar de la criminalización primaria las acciones antisociales que efectúan quienes pertenecen a las clase sociales hegemónicas, o que son más funcionales a las exigencias del proceso de acumulación capitalista". Así también SCHÜNEMANN, Bernd, "Del Derecho Penal de la clase baja al Derecho Penal de la clase alta. ¿Un cambio de paradigma como exigencia moral?", Temas actuales y permanentes del Derecho Penal después del milenio, Tecnos, Madrid, 2002, p. 49 y sigs.: "La protección de la propiedad privada de cosas muebles contra el robo ha sido, por eso, el punto central del Derecho Penal clásico y, hasta hoy, la razón de que los miembros de la clase baja, caracterizados en primera línea por su falta de bienes y, en todo caso, por sus bajos ingresos, suministren a la justicia penal práctica la clientela preferente, o, menos eufemísticamente formulado, de que tanto en la estadística criminal como también en los establecimientos penitenciarios estén considerablemente representados (... En Alemania) entonces llegamos de sobra a más de un 80 por 100 en delitos típicos de estratos bajos y delitos de subcultura, teniendo en cuenta que el porcentaje numérico de la clase baja en la población total es de aproximadamente un 22 por $100 \ldots$ para aclarar por qué no comparto completamente el entusiasmo de Fráncfort por el Derecho Penal clásico, cuya realidad social se reconoce en sus resultados".

106 PEREZ ALONSO, Esteban Juan, "Las revoluciones científicas del Derecho Penal: evolución y estado actual de la dogmática jurídico penal", en Estudios penales en memoria del Profesor José Manuel Valle Muñiz, Aranzadi, Navarra, 2001, páginas 593 y siguientes. En ese estudio el autor afirma que el Derecho Penal vendrá legitimado por tres conceptos que funcionan y se interrelacionan entre sí: pena, máximas garantías y mínima intervención, lo que le permite deducir una concepción personal del injusto y una culpabilidad entendida como motivación; y entonces llega al desarrollo y análisis de la teoría de sistemas de Niklas Luhmann y su aterrizaje en el Derecho Penal por Jakobs. Según entendemos, concluye: no más normativismo, es menester regresar a los valores de la Ilustración. 
En 1882 Franz von Liszt publica su Tratado de Derecho Penal alemán y con ello propone una sistematización del estudio del Derecho Penal basado en la legislación, esto es, propone el método de la dogmática jurídico penal ${ }^{107}$. Precisamente con ese afán de sistematización realiza y desarrolla las categorías del delito concibiéndolo como el acto culpable contrario a derecho ${ }^{108}$, esto es, la suma de una acción, de la culpabilidad y de la contrariedad al derecho o antijuridicidad; y como formas de aparición del delito la tentativa, la participación y la pluralidad de delitos ${ }^{109}$.

Dos cosas son las que nos interesan en Liszt: en primer lugar la r̃onstrucciónò de su sistemática atendiendo a relò sujeto de Derecho Penal como persona física, y en segundo lugar, su idea del fin del Derecho Penal y de la pena hacia el aspecto político criminal ${ }^{110}$.

Cuando Liszt define lo que es el ranctoòcomo base de castigo lo ve como el movimiento corporal voluntario ${ }^{111}$ y lo mismo sucede al explicar el contenido de la culpabilidad ${ }^{112}$.

Y por otro lado, la idea del fin de la pena en Derecho Penal también es una construcción que se hizo pensando en el sujeto de Derecho Penal como la persona física. Dice en La idea del fin en el Derecho Penal: ñ́nicamente la pena necesaria es la pena justa. La pena es, para nosotros, un medio dirigido a un fin. (é ) La pena es coaccióné como coacción la pena tiene doble naturaleza: a) Motivación

107 LISZT, Franz von, Tratado de Derecho Penal, tomo I, trad. Por Luis Jiménez de Asúa de la 18ª. Ed. Alemana, Reus, Madrid, 1999, p. 6 y ss.

108 Ib Ídem, t. II, p. 256.

109 Ídem, p. 258.

110 PEREZ ALONSO, Op. Cit., página 596.

111 Ídem, t. II p. 304 y ss. Así también en La Idea del Fin en el Derecho Penal (1882), trad. Carlos Pérez del Valle, Nota introductoria de José Miguel Zugaldía Espinar, Comares, Granada 1995, cuando habla del principio de la determinación de la medida y de la pena como protección de bienes jurídicos orientada al fin, p. 68 y 80 .

112 De la que afirma está compuesta por dolo y culpa. Del dolo dice que es la "representación del resultado que acompaña a la manifestación de voluntad", t. II, p. 409 y 410. 
o coacción indirecta, mediata, psicológicaé , b) Fuerza o coacción directa, inmediata y mecánicaờ ${ }^{13}$.

Sería posible señalar, contra nuestra tesis, que Liszt se pronunció expresamente por la punibilidad de las personas jurídicas ${ }^{114}$, sin embargo, con las bases de las categorías que expuso no se explica cómo sería eso posible ${ }^{115}$. Creo que su posición en lo fundamental está bien definida: No punibilidad de las personas jurídicas.

A esta formulación arribó en los años 20’s la sistemática propuesta por Edmund Mezger que aunque tiene una concepción más acabada del delito, se queda en las caracterizaciones que resaltamos de Liszt.

El sistema causalista que llevó hasta sus máximas consecuencias Mezger se caracterizó por separar lo objetivo de lo subjetivo no dentro, sino fuera de las distintas categorías del delito: Un injusto objetivo y una culpabilidad subjetiva ${ }^{116}$, una acción a la que le fue escindida su parte subjetiva y fue entendida en el más puro estilo naturalista, un tipo penal (Tatbechtant) que no le interesaba el aspecto subjetivo, sino sólo en determinados casos (contradictoriamente), una antijuridicidad también objetiva, y una culpabilidad (teoría compleja normativa) que se afirmaba principalmente en conceptos subjetivos, como lo eran el dolo (malo) y la culpa. Además, también consideró a la

113 LISZT, F. von, La Idea del Fin en el Derecho Penal, Programa de la Universidad de Marburgo, (1882), Op. cit., p. 78 y ss.

114 BACIGALUPO, Silvina, Op. cit., p. 70, quien cita a Liszt cuando afirmaba que sería aconsejable y deseable y jurídicamente posible el reconocimiento de la responsabilidad penal de las personas jurídicas: "Quien puede concluir contratos, también puede concluir contratos ilícitos o usurarios o incumplir contratos de abastecimientos concluidos".

115 De hecho, es claramente imposible, puesto que la obra de Von Liszt es la culminación del arribo del positivismo a las Ciencias Penales, en absoluto empírico y naturalista. Cfr. PÉREZ ALONSO, Op. Cit., página 597.

116 MEZGER, E., Derecho Penal, parte general, trad. Ricardo C. Núñez, Cárdenas Editor y Distribuidor, México, 1990, p. 75 y ss. 
tentativa del delito, la participación criminal y al concurso de normas como formas anómalas de aparición del delito ${ }^{117}$.

Respecto del fin y justificación de la pena señala que el fin de la pena r̃ consiste en la prevención del delitoé La prevención del delito se puede realizar por dos caminos, o sea, actuando sobre la colectividad, esto es, la comunidad jurídica, o actuando sobre el individuo que tiende a delinquir o comete o ha cometido un delitoò ${ }^{118}$. Sin embargo, aunque Mezger pone el acento en la rãctuación pedagógica-social sobre la colectividadòcomo fin de la pena, sigue desarrollando su teoría en base al modelo de delito contra la vida, la propiedad y la libertad individuales, y entendiendo al destinatario de Derecho Penal a la persona física, por excelencia. ${ }^{119}$

Welzel representa un cambio completo de paradigma en las bases filosóficas de entender el sistema de Derecho Penal ${ }^{120}$. Pretende alejarse de concepciones m̃ormativasò para despegar de concepciones r̃ntologicistasò que no sólo vinculen al Juez sino también al legislador, esto es, como somos así debemos ser.

De esa forma afirma una distinción objetiva-subjetiva pero dentro de las categorías del delito, de acuerdo a como se presentan en la realidad: la concepción de una acción objetiva-subjetiva, dándole mayor importancia al aspecto subjetivo, que es, según él, lo que nos diferencia de las formas de proceder de otro tipo de seres, esto es, si desde el punto de vista ontológico el dato determinante para la conducta del hombre es la finalidad que imprime a sus actos, entonces

117 Ídem, p. 85 y ss.; 131 y ss.; 189 y ss.; 275 y ss.; 297 y ss.; y 325 y ss.

118 Ídem, p. 370 .

119 Ídem, p. 371. Así, se dice que la parte objetiva del delito la consideró una norma de valoración y la subjetiva una norma de motivación. Cfr. PÉREZ ALONSO, $O p$. Cit., página 598.

120 Vid. WELZEL, H., Derecho Penal alemán, Op. Cit., pássim; el mismo, La teoría de la acción finalista, FONTAN BALESTRA, Carlos (Comp.), FRIKER, Eduardo (Trad.), Depalma, Buenos Aires, 1951; el mismo, Estudios de Derecho Penal, ABOSO, Gustavo Eduardo y LÖW, Tea,(Trads.), Editorial B de F, editado en Buenos Aires, 2002; el mismo, El nuevo sistema de Derecho Penal, una introducción a la doctrina de la acción finalista, CEREZO Mir, José (Trad.), Editorial B de F, editado en Buenos Aires, 2001. 
así también deberá serlo para el Derecho Penal, de manera tal que pone mayor énfasis en el desvalor de acción que en el de resultado ${ }^{121}$. De esa forma tiene una concepción de prevención general de la pena: r̃El Derecho Penal lleva a efecto esta protección de bienes jurídicos de siguiente modo: mandando o prohibiendo acciones configuradas de determinada manera. Detrás de sus prohibiciones o mandatos se hallan los elementales deberes ético sociales (valores de acto), cuya vigencia asegura conminando con pena su lesiónờ ${ }^{22}$.

Con ese aparato vertebral le asigna a la acción un aspecto subjetivo y otro objetivo, importándole, como ya hemos dicho, más el subjetivo $^{123}$, al tipo penal un contenido similar ${ }^{124}$ (y por ello se le criticó una doble ubicación sistemática del tipo penal), y dentro del tipo penal subjetivo ubicó el dolo (natural) ${ }^{125}$ y la culpa ${ }^{126}$, las causas de justificación con elementos objetivos y subjetivos también ${ }^{127}$, y la culpabilidad con elementos puramente objetivos ${ }^{128}$. Por su parte, los aspectos de tentativa, concurso de delitos y participación de personas en el delito los consideró como problemas del tipo penal ${ }^{129}$, no ya como formas de aparición del delito.

Por todo ello, podemos afirmar con Silvina Bacigalupo que Welzel estima que rEEl punto de partida debe ser tomado a partir de una

121 WELZEL, H., Derecho Penal alemán, Op. cit., p. 2, al decir: "La misión central del Derecho Penal reside, pues, en asegurar la vigencia inquebrantable de estos valores de acto, mediante la conminación penal y el castigo de la inobservancia de los valores fundamentales del actuar jurídico manifestada efectivamente".

122 Ídem, p. 5.

123 Ídem, p. 39 y ss. Así también El nuevo sistema de Derecho Penal..., Op. cit., p 41 a 47.

124 Derecho Penal alemán, Op. cit., p. 57. Así también El nuevo sistema de Derecho Penal..., Op. cit., p. 97 y ss.

125 Derecho Penal alemán, Op. cit., p. 92: "Por eso, la conciencia de la antijuridicidad de la acción no pertenece al dolo de tipo, sino que es un momento de la culpabilidad, de la reprochabilidad".

126 Ídem, p. 77 y ss.

127 Ídem, p. 96.

128 Ídem, p. 166 y ss. Aunque establece que los presupuestos esenciales de la culpabilidad son la imputabilidad y el libre albedrío, en El nuevo sistema ..., Op. cit., p. 134 y ss.

129 Ídem, p. 221 y ss. y 118 y ss., respectivamente. 
antropología filosófica con base para la comprensión de la composición espiritual del hombre y, en última instancia, para comprender la relación existente entre la personalidad y la culpabilidadò ${ }^{130}$

En 1973 apareció publicado un texto que tuvo el mismo poder de cambio que el Programa de Marburgo de Liszt ${ }^{131}$, realizado por Claus Roxin. Se trata de Política criminal y sistema de Derecho Penal en donde el Profesor de la Universidad de Munich expone el método con el que se debe empezar a trabajar del Derecho Penal ${ }^{132}$.

En la nueva concepción de Roxin se le da la importancia a la prevención general (necesidad de pena) principalmente en la categoría del injusto ${ }^{133}$, y la prevención especial (merecimiento de pena) principalmente en la categoría de la responsabilidad ${ }^{134}$. De esa forma funcionaliza las categorías del Derecho Penal del siguiente modo: (la acción en su concepto personal tiene una base ontológica, pero suficiente para ser un supra concepto que de cabida de arranque a los demás elementos del delito ${ }^{135}$ ) El tipo penal es un elemento sistemático, es un elemento de prevención general, pero además es un elemento de garantía frente a las intervenciones del Estado ${ }^{136}$; dentro del tipo penal, la imputación al tipo objetivo tiene el momento del riesgo permitido, y con ello su natural vinculación hacia valoraciones sociales ${ }^{137}$; en lo que atañe a las causas de justificación, se resuelven entendiéndolas como

\footnotetext{
130 Op. cit., p. 108.

131 MUÑOZ Conde, F., "Introducción" al texto de CLAUS ROXIN, La evolución de la política criminal, el Derecho Penal y el Proceso penal, Op. cit., p. 12.

132 Para la obra de Claus Roxin, vid., Derecho Penal, parte general, Fundamentos, op. Cit.; Autoría y dominio del hecho en Derecho Penal, trad. Joaquín Cuello Contreras y José Luis Serrano González de Murillo, Marcial Pons, Barcelona, 1998; Teoría del tipo penal, tipos abiertos y elementos del deber jurídico, trad. Enrique Bacigalupo, Depalma, 1979; La evolución de la política criminal, el Derecho Penal y el Proceso penal, trad. Carmen Gómez Rivero y María del Carmen García Cantizano, tirant lo blanch, Valencia, 2000.

133 ROXIN, Derecho Penal, parte general, Fundamentos, Op. cit., p. 95 y ss.

$134 \mathrm{Ib}$ Ídem, Roxin no habla de culpabilidad, sino de responsabilidad penal, como una categoría dentro de la cual se encuentra la culpabilidad.

135 Ib Íem, p. 252 y ss.

$136 \mathrm{Ib}$ Ídem, p. 277 y ss.

137 Ib ídem, 365.
} 
solución de conflicto de intereses ${ }^{138}$; y en la responsabilidad como un elemento de prevención general y especial ${ }^{139}$; además en lo que toca a las condiciones objetivas de punibilidad y las causas de exclusión las resuelve con vinculaciones a prioridades de finalidades extrapenales.

Como se observa, Claus Roxin genera un sistema de Derecho Penal pensando en la persona física: un concepto de acción como expresión de la personalidad ${ }^{140}$, un concepto de culpabilidad pensando en condiciones mentales y psíquicas ${ }^{141}$, y en base a las consecuencias del delito con una función de una prevención especial (con prioridad sobre la prevención general). ${ }^{142}$ Con ello, excluye casi por completo la cuestión de la criminalización de la persona jurídico colectiva.

La relación de la política criminal con el Derecho Penal en Roxin, constituye una funcionalización de las categorías del delito y de la pena, que en Jakobs significó una funcionalización de la norma a las categorías sociales. Desmontó las categorías de la teoría jurídica del delito y les dio un contenido (si se puede decir que les dio un contenido) eminentemente social, en extremo normativo. A partir de sus fundamentos sería admisible la edificación de la responsabilidad penal de las personas jurídicas, no obstante, fue él mismo quien negó esa posibilidad $^{143}$.

\footnotetext{
138 Ib ídem, p. 569 y ss; 608 y ss; 682 y ss. y 724; y 734.

139 Ib ídem, p. 791.

$140 \mathrm{Ib}$ Ídem, p. 252, señala “... acción como manifestación de la personalidad, lo que significa lo siguiente: en primer lugar es acción todo lo que se puede atribuir a un ser humano como centro anímico-espiritual de acción, y eso falta en caso de efectos que parten únicamente de la esfera corporal ("somática") del hombre, o del "ámbito material vital del animal del ser".

${ }^{141} \mathrm{Ib}$ Ídem, p. 807, señala "... hay que afirmar la culpabilidad de un sujeto cuando el mismo estaba disponible en el momento del hecho para la llamada de la norma según su estado mental y anímico, cuando (aún) le eran psíquicamente asequibles "posibilidades de decisión por una conducta orientada conforme a la norma", cuando la posibilidad psíquica de control que existe en el adulto sano en la mayoría de las situaciones existía en el caso concreto".

142 Ib ídem, p. 97, señala "...en ello tiene preferencia la prevención especial hasta un grado que a continuación habrá que determinarse".

143 JAKOBS, Gunter, “¿Punibilidad de las personas jurídicas?”, Op. Cit.
} 
Creo entonces que la doctrina tradicional se ha asegurado de realizar toda su dogmática bajo los esquemas de los delitos también tradicionales. Que en las escuelas de derecho también se enseñan en base a delitos r̃ romunesơ ${ }^{144}$, que todo ello ha contribuido a que se sigan repitiendo los esquemas de Derecho Penal que critica Alessandro Baratta. Por ello, todavía no nos convence que la Teoría de Sistemas de Luhmann y el desarrollo que de ella Jakobs ha hecho en el campo del Derecho Penal, sea solamente una impronta que dejará una huella $^{145}$. Los postulados filosóficos estructurales-funcionalistas han alimentado las concepciones más modernas de responsabilidad penal de las personas jurídicas, y seguramente en el futuro, serán punto de referencia en ese tópico.

\subsubsection{Obstáculos de imputación objetiva y de imputación} subjetiva.

La incapacidad de acción de la persona jurídica, en la medida en que rácciónòes capacidad exclusiva del ser humano (obrar humano voluntario que modifica el mundo exterior o ejercicio de acción final humana), que fuera defendida por prácticamente la mayoría de la doctrina en España ${ }^{146}$ para negar, no solo de lege lata sino también de lege ferenda, la responsabilidad penal de las personas jurídicas, es un

144 MUÑOZ Conde, F., "La responsabilidad por el producto en Derecho español”, en HASSEMER, La responsabilidad por el producto, Op. cit., p. 51, señala que: "Cuando todavía los problemas de la causalidad se exponen en los Manuales de Derecho Penal de la mano de casos como el de Juan envía a Pedro por el bosque a coger setas un día de tormenta con la esperanza de que caiga un rayo y lo mate, lo que efectivamente sucede; casos como el de Contengan o el de la colza plantean unas dificultades y una complejidad hasta entonces inimaginadas".

145 PEREZ ALONSO, Esteban Juan, Op. Cit., página 612.

146 BAJO FERNÁNDEZ, Miguel, Derecho Penal económico aplicado a la actividad empresarial, Civitas, Madrid, 1978, página 110 a 115; el mismo, Manual de Derecho Penal (parte especial: delitos patrimoniales y económicos), CERA, Madrid, 1993, páginas 573 y sigs.; GRACIA MARTÍN, Luis, Tratado de las consecuencias del delito, Tirant lo blanch, Valencia, 2006, página536 y sigs.; el mismo, "La cuestión de la responsabilidad penal de las propias personas jurídicas", en AP, XXXIX, 1993, página 585 a 590; PEREZ MANZANO, Mercedes, "La responsabilidad penal de las personas jurídicas", $A P, 1995-1$, página 19 y 20, y 27. 
argumento ya superado que pertenece al pasado. Ya afirmábamos que si restringíamos el concepto de acción a uno de contenido antropológico llegaríamos a un callejón sin salida. No obstante, el núcleo duro de esas disertaciones tiene todavía vigencia: es inadmisible que a una persona se le impute el injusto realizado por otra persona.

A propósito de la problemática de la incapacidad de las personas jurídicas de actuar, y en medio de una crítica a la teoría vicarial de responsabilidad, para Feijoo es posible comparar esta problemática con otras materialmente similares r̃como la del representante de un menor que actúa en nombre de éste y realiza un delito en provecho de dicho menor. No parece que nadie esté dispuesto a imputar al menor el hecho injusto y culpable realizado por el representante ¿Porqué con las personas jurídicas la solución tiene que ser distinta? ¿Qué es lo que diferencia un supuesto del otro? En otro sentido, hay una regla de verificación de legitimidad bastante útil que deberían tener en cuenta ciertos partidarios de la culpabilidad de las pronas jurídicas: siempre que se afirme que una empresa debería responder penalmente se debería decir lo mismo de un empresario individual cuya empresa esté dirigida 0 administrada por otra personaờ ${ }^{47}$.

El tema entonces, en este epígrafe, debe ser planteado no tanto como la incapacidad de acción de las personas jurídicas, sino de la elaboración de un injusto (objetivo y subjetivo) propio y autónomo de las personas jurídicas, e independiente del de las personas individuales.

Ahora bien, debemos alejarnos ya de un concepto de acción de contenido eminentemente naturalístico y admitir criterios normativos que tengan relación con la valoración con sentido social. Más que la acción penalmente relevante, habría que considerar el daño o dañosidad social evitable (suceso evitable que lesiona o pone en peligro

147 FEIJOO SÁNCHEZ, Bernardo, “Culpabilidad y punición de personas jurídicas?”, Op. Cit., página 353. 
bienes jurídicos importantes) ${ }^{148}$, que mejor se relaciona con los fines de protección de bienes jurídicos. De ahí, que si la norma penal es una norma de valoración y de motivación a la vez, y contiene un desvalor de acción y un desvalor de resultado, importa entonces el destinatario de la norma (a quien se pretende prohibir u ordenar, y a quién se pretende motivar) más que la voluntariedad del sujeto ${ }^{149}$. Desde esta perspectiva es posible cumplir con un injusto propio de la persona jurídica.

La imputación subjetiva (la exigencia de dolo o culpa en la comisión del delito) debe estar presente en el sistema de responsabilidad de la persona jurídica. El art. 5o $\mathrm{CP}$ es vigente y aplicable a las personas jurídicas y no debe de ninguna manera olvidarse o disculparse. Es, no obstante, el apartado que más ha suscitado controversia en la doctrina cuando se plantea un dolo o una imprudencia propia y exclusiva de la persona jurídica, diferente al dolo o culpa de la persona física.

En conclusión, es necesario exigir: un resultado lesivo de bienes jurídicos que pueda ser revitadoò por la propia persona jurídica, así como un dolo o imprudencia también propios de la persona jurídica. Nadie podría consentir imputar simple y sencillamente lo de una persona física a la jurídica para cumplir con estos requisitos.

Ciertamente que el injusto (objetivo y subjetivo) de la persona jurídica deberá ser buscado en una línea paralela a la de la persona física, lo que significa que no serán los mismos contenidos los que se hallarán en, por ejemplo, el dolo de la persona jurídica respecto del dolo de la física. Esta discusión se encuentra clásicamente en el tema de la culpabilidad, si esta se entiende en su concepción también clásica: no hay imputación sin dolo o culpa; sin embargo, por cuestión de método habremos de colocar el apartado en este lugar, como imputación subjetiva. El límite deberá ser encontrado, de cualquier forma, en la prohibición de la responsabilidad objetiva, esto es, de responder por un

148 ZUÑIGA, Laura, Op. Cit., página 228.

149 Ib Ídem, página 229. 
resultado de cualquier forma (proscripción de la responsabilidad por el resultado ${ }^{150}$ ).

Ahora bien, el contenido del dolo tiene que ser construido desde una base normativa, no tanto psicológica. Hoy en día, como ya lo hemos señalado, ni en el Derecho Penal de las personas físicas se exige la comprobación del libre albedrío o de la libertad en la ejecución de una conducta criminosa; las concepciones más modernas del dolo han dejado de lado la voluntad como pivote del mismo. Se construye desde la base de un conocimiento del peligro concreto para los bienes jurídicos, en la medida r̃que se tiene conciencia de que el resultado puede ser una consecuencia inmediata de la accióno ${ }^{51}$.

Que el dolo y la imprudencia en el sistema de responsabilidad penal de las personas jurídicas deben ser distintos que los de las físicas, lo debemos de dar por descontado ${ }^{152}$. Una tierra fértil para su construcción podría ser la organización empresarial de la persona jurídica.

\subsubsection{Obstáculos de culpabilidad.}

Dejando el estudio del límite dogmático y exigencia constitucional del dolo y la imprudencia para ser responsable de un delito en el apartado anterior (imputación subjetiva), mencionaremos que también la culpabilidad de la persona jurídica debe ser exigida,

150 MUÑOZ CONDE, Francisco, Derecho Penal, parte general, Tirant lo blanch, Valencia, 2010, página 93, "solo en este último sentido es unánimemente aceptado el principio de culpabilidad, los otros dos son objeto de viva discusión", refiriéndose a la culpabilidad como fundamento de la pena y como elemento de medición de la pena.

151 ZUÑIGA, Laura, Op. Cit., página 238.

152 El Tribunal Constitucional lo dejó claro en su Sentencia 246/1991 de 19 de diciembre, aunque no señaló de qué forma habría de ser construido. Vid. análisis completo de esa Sentencia en LOZANO, Blanca, Op. Cit., página 211 y pássim; así como BAJO FERNÁNDEZ, Miguel, "Hacia un nuevo Derecho Penal: el de las personas jurídicas", en IGLESIAS PARADA (Coord.), Estudios en homenaje al Profesor Aurelio Menéndez, Tomo IV, Civitas, Madrid, 1996, página 5096 a 5101. 
aunque con contenido distinto al de la persona física. Debe ser la culpabilidad de la persona jurídica, no una que tome de prestada de la persona física.

Si la culpabilidad la entendemos, no tanto como un reproche de carácter moral o ético ${ }^{153}$, sino como libertad individual y como elemento de medición de la pena ${ }^{154}$, entonces podría cumplirse con las exigencias de una culpabilidad propia y autónoma de la persona jurídica a través del concepto de organización empresarial.

\subsubsection{Obstáculos de personalidad de las penas.}

Las consecuencias jurídicas derivadas del injusto y de la culpabilidad también debieran calar exclusivamente en la persona jurídica, precisamente porque lo que se le reprocha es su injusto y su culpabilidad. No deberá existir empacho en admitir que ningún obstáculo representa el que la multa (por ejemplo) que se imponga a la persona jurídica en realidad se carga a los socios que la conforman, incluso a los que son ñnocentesò del crimen perseguido, o que la disolución de la persona jurídica como consecuencia de su delito afecte a los trabajadores que para ella laboran, cuando éstos no tienen por qué cargar con esa vicisitud. Estos argumentos que iniciaron en algún tiempo la discusión sobre la irresponsabilidad penal de las personas jurídicas deberían estar superados ${ }^{155}$.

153 ORTS BERENGUER, Enrique/GONZÁLEZ CUSSAC, José L., Compendio de Derecho Penal. Parte General, Tirant lo blanch, Valencia, 2010, página 184, donde hacen descansar consistir la culpabilidad, en su conceptuación material, en la ética preventiva, en la actitud interna desaprobada o la libertad individual.

${ }^{154}$ Cfr. MUÑOZ CONDE, Francisco, Derecho penal. Parte General, Op. Cit., página 92, y QUINTERO OLIVARES, Gonzalo, Parte General de Derecho Penal, Thomson Reuters, Pamplona, 2010, página 76.

155 Ya desde BARBERO se decía que también los miembros inocentes de la familia (los hijos) sufren la merma económica que supone el encarcelamiento del criminal, o que el socio inocente puede repetir contra la sociedad para resarcirse del perjuicio sufrido, finalizando por encontrar útil el castigo a la sociedad porque produce la consecuencia de que los miembros de la misma, para evitar ser 
En este epígrafe deberemos llamar la atención más bien sobre dos cuestiones diferentes pero que se relacionan entre sí: la proscripción del principio non bis in ídem y la proporcionalidad de las penas.

El primer tópico se refiere a la problemática que surge cuando de un mismo hecho (el hecho de la persona física, típico y antijurídico) se pretenda el castigo a dos personas diferentes, como lo es, la propia persona física y la persona jurídica; y en el caso que la persona física sea socio de la empresa, recibiría doble pena por su parte, por el hecho delictivo que como persona física cometió, y por las consecuencias a la persona jurídica en la que tiene depositado parte de su patrimonio. Es una derivación del principio de culpabilidad o de la necesidad de responder por el hecho propio y no por el ajeno.

En otros subsitemas jurídicos (Derecho Civil o Administrativo) que prevén sanciones a las personas jurídicas no existe esa doble consecuencia como sanción tanto para las físicas como para las jurídicas. O responde una, o responde la otra, pero no ambas. ĩEn otros ordenamientos la persona física no es tenida en cuenta como sujeto de imputación sino sólo come medio, instrumento o elemento de la persona jurídica. En el derecho privado siempre se ha aceptado la responsabilidad colectiva bajo el siguiente axioma: quod Universitas debet, singuli non debent. Si se quiere tomar en serio la entidad, identidad, consciencia o personalidad colectivaé el Derecho Penal

alcanzados por la condena del ente moral, harán presión sobre los dirigentes para obligarles a actuar en conformidad a la Ley, en "¿Responsabilidad de las personas jurídicas?, Op. Cit., página 1089; y hoy se ha formulado un segundo argumento: que la merma patrimonial por el pago de multa es un peligro más de entre otros muchos peligros derivados del riesgo económico de la asociación, "no existe razón alguna para que los accionistas deban soportar el riesgo procedente de todos los sectores de la actividad empresarial, salvo el proveniente de actividades delictivas de sus empleados", Vid. NIETO GARCÍA, Adán, La responsabilidad penal de las personas jurídicas, Op. Cit., página 109. 
debe prescindir de la responsabilidad individual en el ámbito de la criminalidad de empresas y personas jurídicasờ ${ }^{156}$.

El sistema de responsabilidad de personas jurídicas deberá de respetar esta exigencia constitucional: no a la imposición de penas a dos personas diferentes por la comisión de un solo hecho. Por supuesto que para afirmar la violación al non bis in ídem es menester tener en cuenta la trilogía que compone el principio, esto es, hecho, sujeto y fundamento ${ }^{157}$, por lo que es menester preguntarnos si el hecho es en realidad el mismo. Aquí es donde se tendrían respuestas diferentes dependiendo del modelo de responsabilidad penal que se construya, pues uno vicarial en el que se traslade simplemente el hecho de la persona física a la jurídica seguramente no pasará el tamiz de la inconstitucionalidad, pero mientras nos alejemos de la dependencia del hecho de la persona física se tendrá mayor margen de maniobra para respetar ese principio. Dicho sea de paso, este es un argumento jurídico para afirmar que solamente las personas jurídicas con cierto tamaño y nivel de complejidad podrían ser sujetos de responsabilidad penal, y por contra, sería muy criticable que a una empresa unipersonal o realmente muy pequeña, donde el hecho punible lo haya cometido el socio mayoritario y a la vez administrador de la misma, se le imponga también una consecuencia derivada del mismo delito.

El otro tema es el relativo a la proporcionalidad de las penas. La problemática la encontramos bajo el siguiente planteamiento: Ya hemos dicho que solamente aquellas personas jurídicas de cierto tamaño y complejidad pueden tener capacidad de organización, y por tanto, capacidad de organización defectuosa como para poder crear un ñnjusto organizativoò que se les pueda reprochar; sin embargo, de cierto parámetro hacia arriba, habría de todas formas enormes diferencias de tamaño y de grados de complejidad, de ahí que esas

\footnotetext{
156 FEIJÓO SÁNCHEZ, Bernardo, “¿Culpabilidad y punición de personas jurídicas?”, Op. Cit., página 356.

157 NIETO MARTÍN, Adán, La responsabilidad penal de las personas jurídicas, Op. Cit., página 111 y 112 .
} 
diferencias de tamaño y complejidad podrían hacer diferencia a la hora de imponer sanciones a la persona física y a la jurídica, esto es, para aplicar una mayor sanción a una de ellas y menor sanción a otra, en otras palabras, r̃modularòla sanción entre la física y la jurídica. El único factor determinante para m̃modularò la sanción de la física y la jurídica debería ser el tamaño y complejidad (el grado de autorreferencialidad o el nivel de sistema autopoiético, en palabras de Gómez Jara ${ }^{158}$ ), pues las sanciones a aquellas personas jurídicas con complejidad o autorreferencialidad plenas y completas no tendrían por qué ser moduladas o equilibradas con la pena o sanción a la persona física (ambos responderían, en medida total, de su propio hecho y de su propia culpabilidad), mientras que las personas jurídicas que no traspasen ese límite mínimo de complejidad y tamaño, no recibirían sanción penal alguna ${ }^{159}$.

En consecuencia, un sistema adecuado debería prever este mecanismo de modulación de sanciones en los casos indicados.

\subsection{Hacia un sistema garantista de responsabilidad penal de las personas jurídicas.}

Corolario a lo anterior, y con miras a sintetizar lo previamente analizado, se impone construir un modelo de responsabilidad penal de las personas jurídicas que:

1.- Haga responder a la persona jurídica por un hecho propio (a nivel de injusto objetivo), y nunca por un hecho ajeno.

2.- Exija un dolo o imprudencia propios de la persona jurídica, y no se le impute o atribuya el dolo o imprudencia de otra persona.

158 GÓMEZ-JARA DÍEZ, Carlos, Culpabilidad penal dela empresa, Op. Cit., página 241 y sigs.

159 Entendemos que en este mismo sentido, NIETO MARTÍn, Op. Cit., página 113 y 114. 
3.- Reclame una culpabilidad propia de la persona jurídica.

4.- Sería un sub sistema paralelo al sub sistema de las personas individuales, que no se vea afectado en ninguna medida.

5.- Solamente las personas jurídicas de cierto tamaño y complejidad serán sujetos responsables, para respetar el principio non bis in ídem.

6.- El concepto alrededor del cual es posible construir un sistema adecuado de responsabilidad penal de personas jurídicas es la autorregulación regulada como fin de la pena, el de organización defectuosa o inadecuada como injusto penal, y de libertad organizativa como culpabilidad.

\section{DIMENSIÓN PRÁCTICA O DE APLICACIÓN.}

Las necesidades político criminales que exigieron un sistema positivo de responsabilidad de las personas jurídicas deben ponerse a prueba una vez que se pueda tener un modelo específico de referencia que sea punto común de partida para ensayar los problemas de aplicación que puede tener. Digamos que las necesidades político criminales son enunciadas como problemas en lo general que se encuentran y que no son resueltos con el sistema de responsabilidad individual, mientras que el ejercicio práctico de poner a prueba un modelo específico pone a prueba en lo particular si se cumplieron esas razones de política criminal. De ahí la utilidad de este epígrafe.

Expondremos las características de aplicación práctica de lo que imaginamos es un modelo idóneo de responsabilidad colectiva, atendiendo a las exigencias de las dimensiones anteriores, esto es, de un modelo o sistema conveniente y legitimable. Comenzaremos exponiendo las ventajas de aplicación práctica en aquellos modelos que crean un injusto (objetivo y subjetivo) y una culpabilidad propios y 
específicos de las personas jurídicas, y a renglón seguido, las ventajas de aplicación de su consecuencia, es decir, de la separación de las responsabilidades de la persona física de la persona jurídica, para efectos del cumplimiento del fin de la pena y del derecho penal; luego lo relativo a la posible fundamentación del injusto y de la culpabilidad de la persona jurídica en la organización empresarial (autorregulación regulada).

\subsection{Injusto objetivo y subjetivo y culpabilidad propios de la} persona jurídica.

\subsubsection{No necesidad (o menor necesidad) del injusto y culpabilidad de la persona física.}

Dos de los aspectos más sentidos e importantes que se han expuesto en la aplicación diaria de la justicia penal son los que se ha enunciado como la irresponsabilidad individual organizada e irresponsabilidad estructural organizada. De hecho, estos argumentos fueron los que iniciaron a calar en la doctrina escéptica de un sistema de responsabilidad de la persona jurídica.

La descentralización de las funciones de decisión, información y operación en una empresa o asociación de cierto grado de complejidad y tamaño, daba lugar a que la justicia penal dejar en la impunidad hechos de un enorme grado de dañosidad social, pues no existía ninguna persona física que reuniera en ella todas las exigencias de imputación para ser merecedor de una sanción penal. El Derecho Penal individual se arrodillaba frente a la organización empresarial por no comprenderla 0 no interesarse en ella. Incluso, los sistemas de responsabilidad penal de personas jurídicas que exigieran la ubicación e identificación de un responsable físico, en el que se reunieran los elementos de imputación penal (o pluralidad de personas físicas que juntas reunieran esos elementos), tenían y tienen la misma 
problemática: imposible imputar a la persona jurídica el delito de la física, precisamente porque no existe ninguna persona física que haya cometido un delito.

De esa manera, un sistema de responsabilidad criminal de la persona jurídica que no necesite en ningún caso y desde ninguna perspectiva a la persona física, superará este problema alejándose de la impunidad criticada.

Para efecto de evitar este problema, habría que exigir del sistema o modelo de responsabilidad desde un injusto objetivo y subjetivo propio de la persona jurídica, no solamente la culpabilidad. Si se imputa solamente el injusto de la física a la jurídica y a ésta se le exige su propia culpabilidad, amén de desajustar las categorías jurídico penales de imputación de la persona jurídica, daría lugar a al mismo imperio de impunidad que originaron y dieron lugar a la criminalización de la persona jurídica.

Por otro lado, y por lo que hace a la irresponsabilidad individual organizada, es menester considerar que en aquellas empresas 0 colectivos con cierto grado de complejidad, compuesta por un grupo de personas de tamaño importante, con una mínima organización, con jerarquías, reglas, procesos o procedimientos, con escalafón, y por tanto, con valores, principios, metas y medios o instrumentos institucionalizados, se genera un ánimo de pertenencia a dicho grupo por parte de sus miembros, que están dispuestos a alcanzar esos valores, principios, metas y objetivos para subir en el escalafón de esa subcultura, pero cuando esos principios y objetivos son disfuncionales (el beneficio de la empresa a toda costa, sin importar las reglas y normas externas a esa empresa, las normas del orden jurídico) entonces se genera una ráctitud criminal de grupoò que da lugar a delitos sistemáticos o a elevar el contenido de injusto, cada vez más, de los delitos que se cometen ahí. En estos casos, el Derecho Penal individual serviría de muy poco pues no focaliza el problema real y es sobre explotado sin ser útil a la solución del problema. 
En cambio, cuando la legislación vigente permite la persecución inmediata de la persona jurídica, sin importarle y sin requerir a la persona física, entonces el sistema se vuelve útil, oportuno y deja de lado el lastre de encontrar a la persona física. Esto por lo que hace a la irresponsabilidad individual organizada antes o durante la comisión del delito, sin embargo, la exclusiva relevancia del injusto y culpabilidad propios de la persona jurídica también cala en forma posterior a la comisión del delito.

Si la razctitud criminal de grupoò funcionaba como una ŕsolidaridad criminalò una vez que se iniciaban las investigaciones del caso por parte de la autoridad estatal, escondiendo o destruyendo las pruebas, haciendo un plan de desinformación a la autoridad, generando una barrera para el conocimiento de la verdad, y en fin, logrando desubicar al o a las personas físicas responsables frente a los ojos de la autoridad, entonces con un sistema de responsabilidad que solo le importe el injusto y culpabilidad de la persona jurídica, no necesitando la de la persona física, la r̃solidaridadòpost delito no deberá significar un problema práctico e infranqueable. Podría generar el efecto contrario: que para salvar la indemnidad de la persona jurídica se muestren las pruebas y se facilite toda la información que se hace necesaria para procesar a los responsables.

\subsubsection{Equilibrio en las cargas probatorias del órgano} acusador.

Bajo un esquema en que la responsabilidad de la persona física se le imputaba, trasladaba o trasfería a la persona jurídica, era insoportable que siempre y en todos los casos la persona jurídica sería condenada por el delito (Identification theory o respondant superior) o que una vez demostrando el órgano acusador el injusto objetivo y subjetivo de la persona física, era la persona jurídica la que debía 
demostrar su inculpabilidad (propia de aquellas teorías del thecho de conexión).

En efecto, amparados de la ratio cognoscendi de la tipicidad que permite presumir la antijuridicidad y la culpabilidad, quienes sostenían y sostienen que el hecho delictivo (a nivel de imputación objetiva y subjetiva) de la persona física habrá de simplemente imputársele a la jurídica, afirman que una vez demostrado el delito de la persona física (que es a la vez el injusto de la persona jurídica) la antijuridicidad y la culpabilidad (el juicio de desvalor en lo particular y juicio de desvalor personal) de la persona jurídica será presumido; y en todo caso, será la persona jurídica la que deberá probar que no es así. Frente a la ventaja práctica de f̂acilidad de procesamientoò de las personas jurídicas, esas posiciones tienen la desventaja de que en la aplicación práctica será sobre explotada la responsabilidad penal del colectivo, hasta límites jamás deseados.

Si en cambio, un sistema análogo y paralelo al de la persona física se construye para la jurídica, entonces ninguna duda cabrá que se deberá demostrar un injusto y una culpabilidad propia de la persona jurídica, que evitará procesamientos sobre abundantes con costes para el sistema jurídico, el sistema judicial y desde luego para las empresas. $Y$ es que, visto desde otro ángulo, el delito de una persona física dentro de una empresa no debe dar lugar jamás a presumir su culpabilidad.

\subsection{Separación de responsabilidades de la persona física y} la jurídica.

\subsubsection{Problemática de disparidad de procedimientos} (persona física y jurídica).

Si el sistema construido para la persona jurídica depende de la comisión del delito de la persona física, entonces existen varios problemas prácticos en apariencia intolerables. 
Si no se logra la identificación y ubicación de la persona física, pues será imposible el procesamiento de la jurídica. Sin embargo, si existen suficientes elementos como para ubicar e identificar a la persona física, e imputarle el delito, el problema estribaría de diferentes maneras: por un lado, si la persona física no es sometida a proceso (huye o muere, por ejemplo) sería un sinsentido que la persona jurídica tuviera que echar mano de su defensa exclusivamente arguyendo estar bien organizada (esto es, a nivel de culpabilidad), dejando de lado el hecho de si la persona física cometió o no el hecho delictivo. Sin embargo, si la defensa de la jurídica es la negación del hecho delictivo de la física, parece ser que difícilmente podría formular su defensa cuando la persona física no está presente, y en su caso, es a ella a quien le corresponde este rubro.

Por otro lado, de qué manera se condenaría a la persona jurídica por un delito cometido por la persona física, cuando dicho delito no ha sido juzgado por un Juez Penal que declare demostrado dicho delito. Incluso, si a la persona jurídica se le condena por un delito, y tiempo después se procesa a la física y se le declara no responsable (o responsable del delito de forma imprudente, cuando el delito imputado a la persona jurídica fue fallado como doloso), qué sustento tendría la condena anterior.

Un sistema ideal sería aquel que separase por completo ambas responsabilidades.

\subsubsection{Problemas de intereses opuestos.}

Cuando dos personas (físicas o jurídicas) enfrentan una acusación penal dentro de un proceso penal siempre existirá la posibilidad de oposición de intereses procesales, lo que no excluye a un sistema de injusto y culpabilidad propia de la persona jurídica y sin necesidad de la física. Sin embargo, cuando el delito (injusto y/o culpabilidad) de una de ellas (en este caso, la persona física) es a su 
vez el delito (injusto y/o culpabilidad) de la otra (la persona jurídica) pues la problemática aumenta exponencialmente.

Ambas partes acusadas intentarán desplazar la responsabilidad a la otra, y en su caso, la persona jurídica, con el poder económico que puede tener, intentará ubicar a un r̃cabeza de turcoòo r̃chivo expiatorioò involuntario o voluntario, para deshacerse de la acusación. A ello se suman las vendettas o pactos de los acusados con la acusación, lo que toma gran importancia en aquellos sistemas procesales que acogen el principio de oportunidad de la acusación, puesto que dependerá de a cuál de ambos acusados quiere perjudicar más el órgano acusador para pactar con su contrario.

Un sistema de responsabilidad penal propio y exclusivo de las personas jurídicas permitirá separar ambas acusaciones, disminuir a límites irreductibles la posibilidad de los juegos procesales perversos, y hacer responder a cada uno por su propio hecho y por su propia culpabilidad.

\subsubsection{Problemática de obtención y legitimación de pruebas.}

Dentro de los efectos perversos que exponencia un modelo diferente al de la propia responsabilidad de las personas jurídicas, se encuentra el de la obtención y legitimación de las pruebas en el proceso penal. No es un efecto exclusivo de esos modelos, pero sí es exponenciado a límites insostenibles.

Como producto de la oposición real y verdadera de intereses entre los acusados (persona física y persona jurídica) y atendiendo a la intención mutua de incriminarse y, en su lugar, deshacerse de la acusación en contra, las pruebas que estén en poder de una de ellas en contra de la otra puede llegar a ser moneda de cambio de gran valor. $Y$ en la medida en que la responsabilidad penal de uno de los acusados dependa de la otra, ese valor aumentará. Si, en cambio, la persecución 
penal se dirige contra las dos por igual, porque cada uno de los acusados (persona física y persona jurídica) cometió un injusto y una culpabilidad diferente, entonces no se verían compensadas la imputación de una con la imputación de otra, y viceversa.

Lo que nos puede dar un modelo o sistema ideal son procesos penales dirigidos a demostrar hechos $u$ objetos de prueba diferentes, y por lo tanto, las pruebas en contra de uno de los acusados podrían ser diferentes de las pruebas en contra de otro. Ello se produce con la separación de las responsabilidades penales. 


\section{CAPITULO III}

\section{EVOLUCIÓN DOGMÁTICA Y LEGISLATIVA DEL SOCIETAS DELINQUIERE NON POTEST}

Estimamos muy importante realizar un estudio específico del desarrollo y estado actual de la dogmático jurídico penal española así como de la evolución legislativa hasta este momento. Es claro que si la pretensión de las ideas plasmadas en el presente trabajo es incluirse en el debate científico, deberá referirse a un momento y a un lugar específicos. No podemos, por tanto, agregar algo a lo que ya se ha dicho si no dejamos claro qué es eso que ya se ha dicho o ya se ha hecho.

Es en España (lo digo convencido) donde se producen los conocimientos de la ciencia jurídico penal de donde abrevan, en forma directa, muchos de los teóricos ïe incluso legisladoreslatinoamericanos. Por ello, debe ser bien recibida una exposición de esa evolución.

1. EL PRINCIPIO SOCIETAS DELINQUERE NON POTEST O SOCIETAS NEMO PATITUR 
Se trata de una alocución latina de origen romana, más derivada del derecho civil en el que trascendieron los romanos, y pretende establecer, a nivel de principio, el estatuto casi ontológico de que las personas jurídicas no pueden delinquir. Sin embargo, que las personas colectivas puedan cometer delitos ha sido una cuestión de la visión sobre el concepto de sujeto de Derecho Penal, sobre la acción y la culpabilidad que cada sociedad ha ido variando en la historia ${ }^{160}$, y de hecho, en tiempos anteriores al lluminismo europeo del siglo XVIII y principios del XIX, y a los principios de Derecho Penal que de ese gran movimiento emanaron, se admitía sin ningún miramiento la criminalización de los colectivos ${ }^{161}$. Ya Saldaña reportaba cómo en la escuela italiana se admitía la responsabilidad criminal desde Alberto de Gandino (m. 1290) a Julio Claro (m. 1575) y por casi todos los glosadores italianos de la baja Edad Media y del Renacimiento ${ }^{162}$. Bartolo di Sossaferrato (m. 1357) afirmaba una capacidad propia e impropia de delinquir de las asociaciones; delinquen propiamente por omisión, y por comisión en actividades propias de su giro o competencia, e impropiamente son capaces de delinquir por graves infracciones a través de sus órganos o miembros ${ }^{163}$. Empero, después de ahí, y siguiendo a Becaria se consolidó la concepción de la exclusiva responsabilidad penal personal o individual que ha llegado hasta

160 BARBERO SANTOS, Marino, “¿Responsabilidad penal de la empresa?, Op. Cit., página 1081, "Según las épocas y los países ha imperado tanto el principio "societas delinquere non potest" como su contrario "societas delinquere potest". La aceptación o repulsa de uno y otro principio ha dependido de condicionamientos históricos complejos".

161 Así BACIGALUPO SAGUESSE, Silvina, "La crisis de la filosofía del sujeto individual y el problema del sujeto del Derecho Penal", en Cuadernos de Política Criminal, Número 67, 1999, p. 16, al señalar que a si bien la idea de la ficción se inició con los canonistas por el interés de no excomulgar a las universitas (colectivos) al negarles una realidad, los posglosadores sí reconocieron en cierta medida la responsabilidad de éstas (Bartolo de Sexaferrato).

162 SALDAÑA Y GARCÍA-RUBIO, Quintiliano, Capacidad criminal de las personas sociales (doctrina y legislación), Reus, Madrid, 1927, página 42.

163 Ib Ídem, página 43. 
nuestros días ${ }^{164}$, pues la ley francesa de 2-7 de marzo de 1791 suprimió las r̃corporationsơ ${ }^{65}$.

La idea fundamental que consolidó la negación de la responsabilidad penal de las personas jurídicas se inició con la obra de Savigny en la época más liberal. Desde una perspectiva individualista señalaba que las personas colectivas no tenían sustancia o configuración propia, que estaban en realidad compuestas de personas individuales que eran las que en realidad tomaban las decisiones y ejecutaban las órdenes, y eran las que, en todo caso, cometían las conductas delictuosas; por tanto, las sociedades o asociaciones eran solamente unas ficciones, sin existencia real, que fueron creadas por el derecho para fines específicos, para ser instrumentalizadas y por esas razones veía un contrasentido imponerles alguna pena ${ }^{166}$.

Ese es el momento, tal vez, al que se han aferrado las concepciones posteriores que niegan la responsabilidad colectiva hasta nuestros días.

Contra la tesis de Savigny, aseguraba Saldaña, se alza gran parte de la doctrina civil y penal alemana, por ello le hace decir que la r̃doctrina de la responsabilidad corporativa es de pura cepa germánica. Se haya establecida en las antiguas leyes alemanas manteniéndose en las modernasơ ${ }^{67}$. Y no le faltaba razón, pues desde el gran civilista Otto Gierke hasta Franz Von Lizst, pasando por Dahm y Hafter, han configurado criterios que admiten esa clase de responsabilidad.

\footnotetext{
164 MIR PUIG, Santiago, Derecho Penal, parte general, Reppertor, Barcelona, 1998, página 171, "Mas la negación de la responsabilidad penal de las personas jurídicas encontró su fundamento decisivo en los principios político criminales que caracterizaron al Derecho Penal liberal, entre los cuales no podía sino contar el principio de personalidad de las penas".

165 MARINO BARBERO, Santos, Op. Cit., página 1082.

166 BACIGALUPO, La responsabilidad penal de las personas jurídicas, Bosch, Barcelona, 1998; así también "La crisis de la filosofía del sujeto individual...", Op. Cit., página 17.

167 SALDAÑA, Op. Cit., página 21.
} 
El libro de Gierke (Das Deutsche Genossenschaftsrecht) es considerado la fuente más importante de toda teoría de la responsabilidad corporativa y social del siglo XIX y principios del posterior ${ }^{168}$. En su teoría organicista Gierke se opone a Savigny y refuta diciendo que una asociación o colectivo constituye una realidad social innegable que tienen personalidad real, cuyas acciones son imposibles de ser explicadas desde la perspectiva individual. Bacigalupo hace cita de él: ñoda construcción sistemática del Derecho, la forma y el contenido de los más importantes conceptos jurídicos y la decisión de numerosas preguntas puntuales dependen en la práctica de la concepción o de la construcción de la personalidad de la asociación (é ) Por lo tanto, el Derecho se debe adaptar a la doble naturaleza del hombre, que puede ser un todo o parte de otro todo, y se debe dividir en dos grandes categorías: el Derecho individual y el Derecho social $(\text { Sozialrecht })^{169}$. Esta tesis es celebrada por Liszt, a la que llama ña doctrina justaòo r̃ roncepción justaờ ${ }^{70}$, pues veía como aconsejable que se castigue a las personas jurídicas ${ }^{171}$ y agregaba que ré es recomendable la aceptación de la doctrina (de Gierke) pues, por una parte el acto, detrás del cual se encuentra, no uno o varios individuos, sino una corporación, alcanza una significación distinta y más elevada y por otra parte, es contrario tanto a la justicia como a la política criminal, dejar impune al culpable y cargar exclusivamente la responsabilidad sobre un órgano de voluntad ajenaơ ${ }^{72}$. Al señalar que las capacidades de las corporaciones en materia penal no son tan distintas a las que tiene en materia civil o mercantil, aseguraba que ré cualquier sociedad puede contratar; puede también celebrar contratos dolorosos o

\footnotetext{
$168 \mathrm{Ib}$ Ídem, página 23.

169 BACIGALUPO, S., "La crisis de la filosofía del sujeto individual...", Op. Cit., p. 18.

170 LISZT, Franz Von, Op. Cit., página, 299.

${ }^{171}$ Ib Ídem, página 299, al decir que "La capacidad (de las personas jurídicas) no se extiende al terreno de los actos punibles... sin embargo, se debe afirmar que el reconocimiento de la responsabilidad penal de las sociedades, hasta donde llegue su capacidad civil, y la punición de tales entidades, en cuanto son sujetos independientes de bienes jurídicos, se presentan no solo como posible, sino, así mismo, como convenientes".

172 Ib Ídem, página 300.
} 
leoninos, o no cumplir los contratos celebrados, de los que se derivan las obligaciones de daré ờ73.

También a principios del siglo pasado Binder y Hafter se decantaban por una tesis similar. El primero llamaba la atención de los pre conceptos de la teoría del delito, y en forma específica, del pre concepto de sujeto de Derecho Penal, pues es concebido como algo con un contenido ya dado y por ello afirmaba los errores de origen de la doctrina ${ }^{174}$, mientras que Ernesto Hafter realiza su doctrina netamente sobre la culpabilidad y punibilidad de las asociaciones ré llegando en progresivas amplificaciones de la tesis a sostener la creación de un Derecho Penal asociacionista (Verbandsstrafrescht) ${ }^{475}$. Y finalmente, el propio Mezger admitía (aunque el desarrollo de sus tesis no lo permitía, como lo hemos señalado) la responsabilidad de las corporaciones r̃El autor del hecho punible es una corporación solamente en casos excepcionalesé no se puede enviar a la cárcel a la sociedad como tal; pero se puede concebir, y es posible, la imposición de penas pecuniarias también contra la sociedad, en su condición de talé ờ76. De hecho, desde su perspectiva, y aunque reconocía una discusión viva y vigente en el nivel doctrinario e incluso en el legislativo, da cuenta de que en la Ordenanza del Reich de 13 de diciembre de 1919, art. 393, se preveía ré se admiten las penas pecuniarias contra personas jurídicas y sociedades sin que sea necesaria la demostración de la culpabilidad de una persona física, en las actividades realizadas por aquellas, hayan sido cometidos fraudes fiscalesờ ${ }^{77}$.

Esos son los orígenes y desarrollo del principio.

\footnotetext{
173 Ib ídem, página 300.

174 BACIGALUPO, S., “La crisis de la filosofía del sujeto individual...”, Op. Cit., página 19.

175 SALDAÑA, Q, Op. Cit., página 26.

176 MEZGER, Edmund, Op. Cit., p. 95.

177 Ib Ídem, página 96.
} 


\section{LEGISLACIÓN PENAL Y DOCTRINA ESPAÑOLA} ANTERIOR A LA LO 10/1995, DE 23 DE NOVIEMBRE.

Poniendo foco a las reformas al CP español que operó la Ley Orgánica 5/2010 de 22 de junio, Del Rosal Blasco señala que ĩsin ninguna duda, la novedad más importante que introduce en nuestra legislación penal vigenteé es la regulación de un sistema de atribución de responsabilidad penal para las personas jurídicas. Es más, desde la época de la Codificación penal, a comienzos del siglo XIX, es probablemente la reforma más importantes que ha sufrido nuestra legislación penalờ ${ }^{78}$. En gran medida no es del todo correcta dicha afirmación, puesto que la responsabilidad criminal de las personas jurídicas fue inaugurada desde hace más de un siglo en España.

En efecto, la Constitución española de $1^{\circ}$ de junio de 1869 señalaba en su art. 19 lo siguiente $\tilde{A}$ toda asociación, cuyos miembros delinquieren por los medios que la misma se les proporcione, podrá imponérsele la pena de disolución. La autoridad gubernamental podrá suspender la asociación que delinca, sometiendo incontinenti los reos al juez competente. Toda asociación cuyo objeto o cuyos medios comprometan la seguridad del Estado podría ser disuelta por una leyò A reserva de que se quiera entender el texto constitucional como una responsabilidad administrativa (lo que estimamos resulta poco probable), lo cierto es que de uno u otro modo se preveía una responsabilidad dentro del ius puniendi del Estado concibiendo consecuencias jurídicas incluso como la ñpena de muerteò de la sociedad que es la disolución. Ni duda cabe que aquí se inició en la

\footnotetext{
178 DEL ROSAL BLASCO, Bernardo, "La delimitación típica de los llamados hechos de conexión en el nuevo art. 31 bis, número 1, del CP", Cuadernos de Política Criminal, número 103, Dykinson, 2011, página 41. En el mismo sentido BACIGALUPO SAGUESSE, Silvina, "Los criterios de imputación de la responsabilidad penal de los entes colectivos y de sus órganos de gobierno (arts. 31 bis y 129 CP)", en Diario La Ley, número 7541, de 5 de enero de 2011.
} 
legislación española la admisión de una responsabilidad penal de las personas jurídicas.

Sin embargo, en ese momento era la doctrina española la que no tenía desarrolladas tesis que dieran vida a la previsión legal; los primeros dos tercios del siglo XIX nada se escribió sobre ese tópico ${ }^{179}$. Fue hasta finales del siglo XIX donde la doctrina desarrolla esos criterios con Luis Silvela, quien después de negar la capacidad criminal a las asociaciones(en una primera fase de su evolución intelectual) ${ }^{180}$ realiza el Proyecto del CP de 1884 en cuyo art. 25 imprimió ños que delinquieren estando constituidos en una entidad o personalidad jurídica, o formen parte de una sociedad o empresa de cualquier clase, si los delitos son ejecutados por los medios que la misma les proporcione, en términos que el delito resulte cometido a nombre y bajo el amparo de la representación socialò y en el preámbulo de dicho Proyecto Silvela señalaba que cuando las asociaciones que se constituyen lícitamente pueden ser utilizadas, así como sus medios sociales, por los socios para delinquir pueden ser vistas como propiamente las delincuentes, ré de tal suerte que para la conciencia pública, fácil siempre en dar verdadera forma personal a todo suceso, sea la sociedad, la empresa o la colectividad la que delinqued ${ }^{81}$. Saldaña calificó el proyecto de Silvela como rêl más perfecto y científicoò y reporta que la repercusión que tuvo en el extranjero fue muy importante, pero en España no fue bien apreciado ${ }^{182}$.

\footnotetext{
179 SALDAÑA, Op. Cit., página 51 y 52, dice "Pese al reconocido influjo del Derecho canónico, sobra la evolución científica de nuestro Derecho, no hayamos doctrina de capacidad social criminal en los penalistas de la "Escuela española". Siguen al derecho romano afirmando su adhesión constante a la doctrina clásica de exclusiva capacidad individual criminal".

$180 \mathrm{Ib}$ Ídem, página 54, donde considera, en una primera etapa, a un Silvela doctrinario y desinteresado de la realidad que distingue y se opone a la criminalidad de los corporativos (1874); luego como comentarista se observa la transición; hasta que en 1884 cambia totalmente su concepción.

$181 \mathrm{Ib}$ Ídem, página 55.

182 Ib Ídem, página 56, la Comisión parlamentaria de 1885 suprimió ese texto por miedo a que se dañase a la libertad de imprenta.
} 
Posterior al Proyecto Silvela aparecieron el Proyecto Villaverde, de 1891, el art. 22 del Proyecto Piniés de 1912 y el Proyecto Saldaña de 1927, que mantienen y desarrollan la disposición de Silvela ${ }^{183}$, por supuesto, influidos por el contenido de las tesis de éste.

Un título similar se imprimió en el CP Español de 8 de septiembre de $1928^{184}$, en su art. 44 , que estuvo en vigor hasta abril de 1931: óla responsabilidad penal por los delitos o faltas es individual. Pero cuando algún miembro o representante de una persona jurídica, o de una sociedad, corporación o empresa de cualquiera clase, con excepción de las instituciones del Estado, cometa un delito con los medios que para tal objeto las mismas entidades le proporcionen, de modo que resulte cometido a nombre o bajo el amparo de la representación social o en beneficio de ella, el juez podrá, en los casos exclusivamente especificados por la ley, decretar en la sentencia la suspensión de la agrupación o su disolución, cuando lo estime necesario para la seguridad públicaô Aparentemente el contenido de este art. se debió en mucho al II Congreso Internacional de Derecho Penal de Bucarest de $1926^{185}$. Pero el contenido en los términos

183 ZUGALDÍA, E., J.M., “Conveniencia político...”, Op. Cit., p. 72.

184 El Proyecto Saldaña de 1927 (que a la postre dio lugar al CP de 1928), fue modificado en su versión original. Sobre esto, el autor relata que "La ponencia original, que hice por encargo de la Comisión general de Codificación, dividía la materia en dos artículos: el 70 (nuevo) donde se definía, como grado en la "extensión de la responsabilidad criminal", la "Asociación" y el 71 que establecía el concepto legislativo de "Responsabilidad social". Luego fueron refundidos en uno: el art. 53... Empero, la Comisión tachó el atrevimiento, volviendo al texto contradictorio de Silvela y de 1912 (ahora art. 44).

185 Así, CARRANCÁ Y TRUJILlO, Raúl, Derecho Penal mexicano, Porrúa, México, 1988, p. 266, "El II Congreso Internacional de Derecho Penal de Bucarest de 1926 votó por la responsabilidad penal de las personas jurídicas aceptando la teoría de Mestre. Sus conclusiones fueron "Comprobando el crecimiento continuo y la importancia de las personas morales y reconociendo que ellas representan una fuerza social considerable en la vida moderna; considerando que el orden legal de toda sociedad puede ser gravemente perturbado cuando las actividades de las personas jurídicas constituyan una violación de la Ley Penal, resuelve: 1. Que deben establecerse en el Derecho Penal interno medidas eficaces de defensa social contra las personas jurídicas cuando se trate de infracciones perpetradas con el propósito de satisfacer el interés colectivo de dichas personas o con recursos proporcionados por ellas y que envuelvan también su responsabilidad. 2 . Que la aplicación de las medidas de defensa social a las personas jurídicas no debe excluir la responsabilidad penal individual, que por la misma infracción se 
apuntados de ese CP sólo fue vigente durante poco más de 2 años, de ahí, que la doctrina española no había visto ningún desarrollo de este tema en lo sucesivo.

Adicional a lo anterior, el CP de 1944, resalta Rodríguez Mourullo $^{186}$, ya preveía la disolución de asociaciones en cuyo domicilio se encontraren armas, explosivos, en su art. 265, mismo precepto que pervivió al CP de 1973. Además, los arts. 344 bis, b), 344 ter, 347 bis, 174 del CP de 1944 y sus correlativos del de 1973 preveían sanciones a las personas jurídicas que ré fueron aceptadas sin que la doctrina ni la jurisprudencia le prestasen atención o se planteasen las posibles dificultades de inserción en el sistema dogmático en el que se basa tradicionalmente el CP españolơ ${ }^{87}$. El art. 132 del Proyecto de CP de 1980 (de Mir Puig y Luzón Peña ${ }^{188}$ ) se preveían medidas de seguridad para las asociaciones, empresas, sociedades a causa de los delitos de sus directivos, mandatarios o miembros cometieran en el ejercicio de las actividades sociales o aprovechando la organización de tales entes $^{189}$; mientras que el art. 138.1 del Anteproyecto de 1983 añadía la exigencia r̃cuando pueda deducirse fundada y objetivamente que seguirían utilizadas para la comisión de delitos, con lo que parecía partir del criterio doctrinalmente conocido como de la ñpeligrosidad objetiva⿳⺈⿴囗十 90 .

exija a las personas físicas que tomen parte en la administración o en la dirección de los intereses de la persona jurídica, o que hayan cometido la infracción valiéndose de los medios proporcionados por la misma persona jurídica. Esta responsabilidad individual podrá ser, según los casos, agravada o reducida".

186 RODRÍGUEZ MOURULLO, Gonzalo, "Hacia la responsabilidad penal de las personas jurídicas en el CP español", (versión española de la colaboración del Libro Homenaje a Tiedemann, München, 2008), en Estudios de Derecho Penal económico, Thomson Reuters, Civitas, Navarra, 2009, página 258 y 259.

187 Ib Ídem, página 259.

188 Así referido por RODRÍGUEZ RAMOS, Luis, "Medidas de seguridad aplicables a las personas jurídicas en el proyecto del CP", Op. Cit., página 1010.

189 Con lo que no deja satisfecho a ninguno de los bandos de doctrinarios españoles que exigían la previsión de la responsabilidad penal de las personas jurídicas, porque para unos no se justificaban dichas medidas de seguridad, y para otros, esas mismas medidas se quedaban cortas, según opinión de Rodríguez Ramos, Ib Ídem, página 1013.

190 RODRÍGUEZ MOURULLO, G., “Hacia la responsabilidad...”, Op. Cit., página 256. 
Cuando Zugaldía escribió el visionario artículo sobre la conveniencia político criminal de responsabilidad a las personas jurídicas en 1980, sólo recibió pocas adhesiones a su visionario concepto del cambio de paradigmas ${ }^{191}$, y en cambio, más detracciones ${ }^{192}$ que pronto, a fuerza de las tendencias legislativas, pero sobre todo, del desarrollo de la dogmática jurídico penal, se convirtieron a favor de la tesis de Zugaldía ${ }^{193}$. Contrario a la tendencia inicial que negaba, incluso de lege ferenda, la responsabilidad penal de las personas jurídicas, lo que hizo el autor fue desarrollar mejor su postura, que consideró cristalizada con el art. 129 del CP de noviembre de $1995^{194}$, y mejor aún, fue tal vez, el primer Catedrático de Derecho

191 Fundamentalmente, RODRIGUEZ RAMOS, L., "Medidas de seguridad aplicables a las personas jurídicas en el proyecto de CP", Op. Cit., página 1004, donde die que la ley y la doctrina española se han "adherido a la irresponsabilidad penal de las personas jurídicas" (excepción hecha del Proyecto de Derecho Penal de 1927, el Proyecto Saldaña (Quintiliano), que la aceptaba), sin embargo, sigue diciendo, esto no es absoluto o de radical vigencia, pues hay delitos (vigentes) en donde se impone alguna consecuencia jurídica a las personas jurídicas.

192 Por todos, BAJO FERNÁNDEZ, Miguel, "De nuevo sobre la responsabilidad criminal de las personas jurídicas", $A D P C P, 1981$, p. 375 pássim.

193 BAJO Fernández, Miguel, "La responsabilidad penal de las personas jurídicas en el derecho administrativo español", Responsabilidad penal de las empresas y sus órganos y responsabilidad por el producto, Bosch, Madrid, 1996, p. 31, donde atempera su posición y aunque considera imposible fundamentar la responsabilidad penal de las personas jurídicas en la culpabilidad, admite las sanciones sólo en "la necesidad preventiva derivada del hecho" y eso es preferible “... que prostituir el principio de culpabilidad, que referido a las personas jurídicas, sería culpabilidad por el hecho de otro, por más que otros autores (Tiedemann, Jakobs, Brender, Zugaldía) pretendan salvar la situación". Sin embargo, en "Prólogo" a GÓMEZ-JARA, Carlos, La culpabilidad penal de la empresa, Marcial Pons, Barcelona, 2005, p. 9 y 10, admite implícitamente una posición contraria a la inicial, "Entiendo, sin embargo, que el pensamiento jurídico y las legislaciones caminan -parece que inexorablemente- por la senda de hacer responder penalmente a las corporaciones, no sólo el Derecho Penal estadounidense..., sino también el propio continental como se deduce del CP francés o de las Directivas europeas". Así también BAJO F., M., "La responsabilidad penal colectiva", en VIEIRA M., F. J., (dir.), Nuevas posiciones de la dogmática jurídica penal, CDJ VII-2006, Madrid, 2006, p. 84 y 85, "La elaboración de una teoría de la imputación subjetiva o culpabilidad de las personas jurídicas tiene tierra de abono suficiente".

194 ZUGALDIA Espinar, J. Miguel, “Capacidad de acción y capacidad de culpabilidad de las personas jurídicas", CPC, No. 53, 1994, 613 pássim; el mismo, "Una vez más sobre el tema de las responsabilidad criminal de las personas jurídicas (doce años después)", Hacia un Derecho Penal económico europeo (en Jornadas en Honor del Profesor Klaus Tiedemann, VV. AA.), Madrid, BOE, Universidad Autónoma de Madrid, 1995, 723 a 727; el mismo, "Las penas previstas en el art. 129 del CP para 
Penal en España que agrega un capítulo a su Manual de Derecho Penal destinado exclusivamente a la teoría jurídica de la responsabilidad penal de la persona jurídica ${ }^{195}$.

\section{LA LO 10/1995, DE 23 DE NOVIEMBRE, DE CREACIÓN DEL NUEVO CP ESPAÑOL.}

El CP de 1995 significó la renovación (con nuevos bríos) del debate doctrinal sobre la responsabilidad penal de las personas jurídicas. La razón fue el contenido del art. 129 y luego, la LO 15/2003 de 25 de noviembre, de reforma al CP, que dio lugar a un nuevo art. 31.2 .

El art. 129 del CP de ese momento se ubicaba en el título VI, de ñas consecuencias accesoriasò y establecía:

ó1. El Juez o Tribunal, en los supuestos previstos en este Código, y previa audiencia de los titulares o de sus representantes legales, podrá imponer, motivadamente, las siguientes consecuencias: a) Clausura de la empresa, sus locales o establecimientos, con carácter temporal o definitivo. La clausura temporal no podrá exceder de cinco años. b) Disolución de la sociedad, asociación o

las personas jurídicas (consideraciones teóricas y consecuencias prácticas)", Cuadernos del Poder Judicial, núm. 46, 1997, 327 y ss.; el mismo, "Art. 129", Comentarios al CP, en COBO DEL ROSAL, Manuel, Tomo IV, Madrid, Edersa, 2000, 1049 a 1061; el mismo, "Bases para una teoría de la imputación de la persona jurídica", CPC, 2001, 329 y ss.; el mismo, "Vigencia del principio societas delinquere potest en el moderno Derecho Penal", La responsabilidad criminal de las personas jurídicas: una perspectiva comparada, Tirant lo blanch, 2001; el mismo, "La responsabilidad criminal de las personas jurídicas en el Derecho Penal español", El nuevo Derecho Penal español: estudios penales en memoria del Profesor José Manuel Valle Muñíz, Navarra, Aranzadi, 2001, 885 y ss.

195 ZUGALDIA Espinar, J. Miguel, "La responsabilidad criminal de las personas jurídicas", Derecho Penal, Parte General, en Zugaldía (Dir.) y Pérez Alonso (Coord.), Tirant lo blanch, Valencia, 2004, 941 y sigs. 
fundación. c) Suspensión de las actividades de la sociedad, empresa, fundación o asociación por un plazo que no podrá exceder de cinco años. d) Prohibición de realizar en el futuro actividades, operaciones mercantiles $o$ negocios de la clase de aquéllos en cuyo ejercicio se haya cometido, favorecido o encubierto el delito. Esta prohibición podrá tener carácter temporal o definitivo. Si tuviere carácter temporal, el plazo de prohibición no podrá exceder de cinco años. e) La intervención de la empresa para salvaguardar los derechos de los trabajadores o de los acreedores por el tiempo necesario y sin que exceda de un plazo máximo de cinco años. 2. La clausura temporal prevista en el sub apartado a) y la suspensión señalada en el sub apartado c) del apartado anterior, podrán ser acordadas por el Juez Instructor también durante la tramitación de la causa. 3. Las consecuencias accesorias previstas en este art. estarán orientadas a prevenir la continuidad en la actividad delictiva y los efectos de la mismaò

Desde la vigencia de esta norma, se ha producido una gran cantidad de art.s en revistas e incluso monografías en España que trataron de zanjar, fundamentalmente, la cuestión de si lo que estaba previsto en el 129 eran verdaderas penas del Derecho Penal, o se trataba de medidas de seguridad, 0 incluso de consecuencias administrativas o civiles impuestas por un juez en sede penal, $u$ otro tipo de consecuencias accesorias (tercera vía). Hubo quienes estimaron que la naturaleza jurídica de dichas consecuencias accesorias era de ñercera modalidad de sanciones penales peculiares; o híbridas o inclasificables; otros defendieron que se trataban de circunstancias accesorias de la sentencia condenatoria, bajo una perspectiva procesal; también hubo quien las consideró consecuencias accesorias especiales; o que no eran sanciones sino simples consecuencias 
jurídicas preventivas-reafirmativas desprovistas de la naturaleza de sanción ${ }^{196}$, y otros más con algunos diversos matices.

Los pocos autores ${ }^{197}$ (cuyo número cada vez fue creciendo) estimaban que las consecuencias accesorias eran verdaderas penas, y por tanto, consideraron que el principio societas delinquere non potest había sido desterrado en el ordenamiento jurídico español ${ }^{198}$. Al realizar una interpretación armónica del texto penal decantaban su criterio hacia ese rumbo, porque, decían, al no ser ni instrumentos reparatorios civiles (porque no tienen a reequilibrar patrimonios), ni ser sanciones administrativas (porque las impone la justicia penal, en un proceso penal, previstas en el CP, y orientadas a los fines de la pena), ni consecuencias jurídicas preventivas-reafirmativas desprovistas de sanción (porque su imposición está rodeadas de garantías constitucionales), ni sanciones a la persona física de privarla del instrumento peligroso, en consecuencia ñpor exclusión, las

196 Así lo reporta ZUGALDÍA ESPINAR, en "Una vez más sobre el tema de la responsabilidad criminal de las personas jurídicas (doce años después), en Hacia un Derecho Penal europeo económico. Jornadas de honor del Profesor Klaus Tiedemann, BOE, Madrid, 1995, páginas 222 y 223.

197 Esto es, admiten que sea posible que la dogmática jurídico penal pueda rendir para generar un Derecho Penal (de culpabilidad) de las personas jurídicas, Vid. BACIGALUPO S., S., La responsabilidad penal de las personas jurídicas, Bosch, 1998; BUSTOS RAMÍREZ J. y HORMAZÁBAL MALAREE, H., Lecciones de Derecho Penal, Parte General, tomo I, Madrid, Trotta, 1997; CARMONA Ruano, Miguel, "La responsabilidad penal de las personas jurídicas", Empresa y Derecho Penal (II), Bajo Fernández, M. (Dir.), Madrid, Consejo General del Poder Judicial, 1999; GOMEZ-Jara Díez, Carlos, Autoorganización empresarial y autorresponsabilidad empresarial: hacia una verdadera responsabilidad penal de las personas jurídicas, Revista Electrónica de Ciencia Penal y Criminología 08-05, 2006; GUARDIOLA Lago, Ma. de Jesús, Responsabilidad penal de las personas jurídicas y alcance del art. 129 del CP, Valencia, Tirant lo Blanch, 2004, MUÑOZ Conde, Francisco, y GARCÍA ARÁN, M., Derecho Penal, parte general, Tirant lo Blanch, Valencia, 2002, RODRIGUEZ Ramos, L., Nuevos aspectos dogmáticos y procesales del principio societas delinquere potest, La responsabilidad criminal de las personas jurídicas: una perspectiva comparada, Tirant lo Blanch, 2001; ZUGALDIA Espinar, J. Miguel, Derecho Penal, Parte General, en Zugaldía (dir) y Pérez Alonso (coord.), Valencia, Aranzadi, 2004; ZUÑIGA Rodríguez, Laura Elena, Bases para un modelo de imputación de responsabilidad a las personas jurídicas, Aranzadi, Navarra, 2003.

${ }^{198}$ Cfr., por todos, RODRÍGUEZ RAMOS, Luis, "Nuevos aspectos dogmáticos...", Op. Cit., página 173, "en aras de una justicia material, se ha impuesto consecuencias jurídicas realmente aflictivas que suponen una limitación de sus derechos patrimoniales o de otra índole a las personas jurídicas, y esto, sólo porque no se acepta que se ha superado el principio societas delinquere non potest...". 
consecuencias accesorias del art. 129 del CP deben merecer la consideración de sanciones penalesỡ ${ }^{99}$.

En otras concepciones no se les negaba el carácter punitivo a dichas consecuencias jurídicas ${ }^{200}$, pero se les asignaba el carácter de medidas de seguridad ya que ré las medidas de seguridad no requieren el presupuesto de culpabilidad, tampoco precisan ninguno de los demás presupuestos subjetivos que son propios de la pena (ni la acción final, ni dolo, ni imprudencia)é Basta con que la situación de ausencia de imputación subjetiva (en cualquiera de sus niveles) existente en el momento de la realización del hecho lesivo de la norma de valoración jurídico penal sea atribuible el factor que constituye precisamente la razón de la imposición de las medidas de seguridad (estructura organizada supraindividualơ ${ }^{201}$. $Y$ en otras, que negaban la capacidad de acción, de culpabilidad y de ser sujetos pasivos de la pena, a las personas jurídicas, se les estimó como una tercera vía de consecuencias del delito que se asemejan a su aplicación a las penas por la peligrosidad objetiva de la empresa ${ }^{202}$, que tienen naturaleza no punitiva, sino puramente preventiva; que se exige un hecho de conexión de la persona física que sea antijurídico por lo menos; que no se exige

199 ZUGALDÍA ESPINAR, "Una vez más sobre el tema de la responsabilidad penal...", Op. Cit., p. 226 y 227.

200 SILVA SÁNCHEZ, Jesús María, Delitos contra el medio ambiente, Valencia, 1999, página 143, "En mi opinión, la imposición de las consecuencias accesorias requiere de la constatación de una participación de la estructura de la empresa (al menos por una organización defectuosa) en la propia realización del hecho (...) En el caso de las consecuencias accesorias imponibles a las empresas, resulta difícil negar, salvo incurriendo en un abierto fraude de etiquetas, su naturaleza punitiva..."

201 SILVA SÁNCHEZ, Jesús María, "La responsabilidad penal de las personas jurídicas y las consecuencias accesorias del art. 129 del CP”, Op. Cit., p. 345.

202 MIR PUIG, Santiago, "Una tercera vía en materia de responsabilidad penal de las personas jurídicas", Op. Cit., página 13, señala "El sistema empresarial, como todo sistema autopoyético en el sentido de los sistemas de Luhmann, tiende a su propio interés... cuando hechos delictivos cometidos dentro de una empresa aparecen como manifestación de una actitud criminal colectiva, es necesario tomar medidas que neutralicen su peligrosidad" 
que la persona física sea identificado ni se pruebe su autoría y que su aplicación lleve todas las garantías del debido proceso penal ${ }^{203}$.

Nos parece que ese debate tuvo su inicio y su final en un simple fraude de etiquetas, es decir, simplemente nominal, y por esas limitaciones de la discusión, inútil. En realidad, la mayoría de la doctrina convergía en que independientemente del nombre que se le quisiera dar a las consecuencias del art. 129 del CP, lo importante era, tal vez, que se le reconocieran y respetaran a la persona jurídica todos los derechos procesales que tenían las personas físicas procesadas.

En ese momento nosotros consideramos ${ }^{204}$ que una buena parte de la doctrina española, de alguna u otra forma, no admitía esa responsabilidad penal de las personas jurídicas, por incapacidad de culpabilidad $^{205}$. Si consideráramos nuestros puntos de partida

${ }^{203} \mathrm{Ib}$ Ídem, página 6 y siguientes.

${ }^{204}$ GONZÁLEZ SIERRA, Pablo, La responsabilidad penal de las personas jurídicas, Tesis para obtener el grado de Maestro en Ciencias jurídico penales, Universidad de Guanajuato, México, p. 83 y siguientes.

205 BARBERO SANTOS, M, “¿Responsabilidad penal de la empresa?”, Op. Cit., p. 25 y sigs.; BOLDOVA PASAMAR, Carmen, y ALASTUEY DOBÓN, Carmen, "Las consecuencias accesorias", Tratado de las consecuencias jurídicas del delito, Valencia, Tirant lo blanch, 2006, p. 533 a 577; CANCIO Meliá, Manuel, “¿Responsabilidad penal de las personas jurídicas? Algunas consideraciones sobre el significado político criminal del establecimiento de responsabilidad criminal de empresa", Op. Cit.; CEREZO Mir, José, Curso de Derecho Penal español: Parte General, II, La teoria jurídica del delito, Op. Cit., p. 65 a 71; DE LA FUENTE Honrubia, Las consecuencias accesorias del art. 129 del CP, 2004, 79 y sigs.; DE VICENTE MARTÍNEZ, R., "Persona jurídica y consecuencias accesorias", RDPP, N. 8, 2002, 94 y sigs.; FEIJÓo Sánchez, Bernardo José, “¿Culpabilidad y punición de personas jurídicas?", Op. Cit., pagina 351 a 384; FEIJóo Sánchez, Bernardo José, Sanciones para empresas por delitos contra el medio ambiente, Madrid, Civitas, 2002, pássim; FERNÁNDEZ Teruelo, Javier Gustavo, "Las consecuencias accesorias del art. 129", El nuevo Derecho Penal español: estudios penales en memoria del Profesor José Manuel Valle Muñíz, Navarra, Aranzadi, 2001, 273 y sigs.; GARCIA ARAN, Mercedes, "Algunas consideraciones sobre la responsabilidad penal de las personas jurídicas", El Nuevo CP: presupuestos y fundamentos: Libro homenaje al Profesor don Angel Torío López, (en CEREZO MIR, José, et al, Ed.), Granada, Comares, 1999, página 332; GRACIA Martín, Luis, "La cuestión de la responsabilidad penal de las propias personas jurídicas", Responsabilidad penal de las empresas y sus órganos y responsabilidad por el producto (en MIR PUIG, S., y LUZÓN PEÑA, D.M, coords.), Bosch, 1996; GRACIA Martín, Luis, Op. Cit.; LANDROVE DÍAZ, Gerardo, Las consecuencias jurídicas del delito, Madrid, Tecnos, 2005; LUZÓN Peña, D. M., "Las consecuencias accesorias como tercera vía de las sanciones penales”, Op. Cit., páginas 545 a 551; MIR Puig, Santiago, Op. Cit.; MIR 
metodológicos en aquellos en los que se basa la doctrina negadora de la responsabilidad de las personas jurídicas, esto es, en un cierto grado de ontologicismo, por lo menos como determinante o suficiente para la caracterización de las categorías dogmático penales, entonces la discusión se acabaría ya mismo. Como lo dice uno de los representantes de dicha corriente: r̃La acción es r̃ejercicio de actividad finalistaò esto es, ejercicio de una actividad dominada por la voluntad con dirección a un resultado determinado, y la omisión es la no realización de una acción cuando se tiene posibilidad concreta de realizarla. Al carecer la persona jurídica de una voluntad en sentido del Derecho Penal, debe negarse a aquélla la capacidad para ser sujeto activo del delito por incapacidad de acción ${ }^{206}$.

Pero una crítica general a estas posiciones doctrinales es que conciben a la acción y a la culpabilidad como categorías dadas, prejurídicas, ónticas: ya le han dado un contenido a la acción y a la culpabilidad, y con ese contenido que (de forma, tal vez caprichosa) le han dado, ciertamente es imposible concebir a la acción y culpabilidad de las personas jurídicas. Si partiéramos de esas perspectivas, de esos puntos de vista iniciales, entonces nada habría que añadir ni nada qué agregar. Es cierto: las personas jurídicas no pueden cometer delitos (aunque haya acuerdo general que ellas son las que pueden generar riesgos de envergadura inimaginable). Pero no es así, la discusión debería reabrirse y dársele otro sentido si nuestros conceptos de acción y culpabilidad, de persona y pena, tienen un contenido distinto, un contenido de índole sociológico.

Puig, Santiago, "Una tercera vía en materia de responsabilidad penal de las personas jurídicas", Op. Cit.; SILVA Sánchez, J.M., "La responsablidad penal de las personas jurídicas y las consecuencias accesorias del art. 129 del CP", Op. Cit., páginas 307 y sigs.; SILVA Sánchez, Jesús-María, "Responsabilidad penal de las empresas y de sus órganos en Derecho español", Fundamentos de un sistema europeo del Derecho Penal, Bosch, 1995.

206 GRACIA Martín, Luis, El actuar en lugar de otro en Derecho Penal. Teoría General (Tomo I), Op. Cit., página 9 y sigs. 
En forma posterior, mediante la Ley Orgánica 15/2003 de 25 de noviembre se reforma, entre otros, el art. 31 del CP para añadírsele el apartado $2^{\circ}$ que rezaba de este modo:

\begin{abstract}
2. En estos supuestos, si se impusiere en sentencia una pena de multa al autor del delito, será responsable del pago de la misma de manera directa y solidaria la persona jurídica en cuyo nombre o por cuya cuenta actuó. También este art. provocó la discusión airada de la doctrina española.
\end{abstract}

Para quienes habían interpretado las consecuencias accesorias del 129 como verdaderas penas, no fue raro ver en este texto de ley una clase de responsabilidad penal de las personas jurídicas. La llamaron responsabilidad penal indirecta ${ }^{207}$ y otros, la mayoría, la consideraron cualquier cosa, menos una pena genuina ${ }^{208}$. Ese art. fue derogado cuando entró en vigor la Ley Orgánica 5/2010 de 22 de junio, sin que durante el tiempo de vigencia de ambos arts. (129 y 31.2) el Tribunal Supremo se haya pronunciado en alguna sentencia para sentar orientaciones judiciales ${ }^{209}$.

Luego se dio inicio al movimiento de reforma del CP que dio lugar a la ley orgánica publicada el 23 de junio de 2010. Se inicia con el Anteproyecto de modificación parcial del CP vigente en ese momento,

207 ZUGALDÍA ESPINAR, José Miguel, "Bases para una teoría de la imputación de la persona jurídica”, Op. Cit., página 547.

208 Cfr. Por todos, SILVA SÁNCHEZ, Jesús María y ORTIZ DE URBINA GIMENO, Íñigo, "El art. 31.2 del CP", InDret, revista electrónica, 2/2006, página 39, dicen “... los autores nos inclinamos por la segunda posibilidad, esto es, por considerar que estamos ante el aseguramiento de una deuda de Derecho público que trae causa de una sanción..."

209 ZUGALDÍA ESPINAR, José Miguel, "Teoría de la imputación a las personas jurídicas", en ZUGALDÍA E., J. M. (Dir.), Fundamentos de Derecho Penal, parte general, Tirant lo blanch, Valencia, 2010, página 587. Señala que solamente algunos juzgados mostraron el desconcierto general de dichos textos de ley en algunas sentencias anecdóticas, como por ejemplo, el Juzgado de Tafalla que condenó al Ayuntamiento de Peralta como autor de la falta del art. 636 del CP por ser el propietario de un ciclomotor que circulaba sin seguro. 
aprobado por el Consejo de Ministros del 13 de julio de 2006. Lo relevante, para los efectos que nos ocupan, fue la propuesta de derogación del art. 31.2, la modificación de los diversos 33 (se creó el 33.7), 53 (para agregar el 53.5), el 66 (para agregarse el 66.3) y el art. 129, así como la creación del 31 bis. Por la importancia que tuvo, sobre todo, porque casi supervivió por completo hasta la reforma y porque de su texto se cogió la discusión doctrinal, reproducimos el art. 31 bis propuesto.

1. En los supuestos previstos en este Código, las personas jurídicas serán penalmente responsables de los delitos cometidos, por cuenta y en provecho de las mismas, por las personas físicas que tengan en ellas un poder de dirección fundado en la atribución de su representación o en su autoridad, bien para tomar decisiones en su nombre, bien para controlar el funcionamiento de la sociedad.

En los mismos supuestos, las personas jurídicas serán también penalmente responsables de los delitos cometidos, en el ejercicio de actividades sociales y por cuenta y en provecho de las mismas, por quienes, estando sometidos a la autoridad de las personas físicas mencionadas en el párrafo anterior, han podido realizar los hechos por no haberse ejercido sobre ellos el debido control atendidas las concretas circunstancias del caso.

2. La responsabilidad penal de las personas jurídicas no excluirá la de las personas físicas a que se refiere el apartado anterior, ni la de éstas excluirá la responsabilidad penal de aquéllas. Cuando como consecuencia de los mismos hechos se impusiere a ambas la pena de multa, los jueces o tribunales modularán las respectivas cuantías, de modo que la suma resultante no sea desproporcionada en relación con la gravedad de aquéllos. 
3. La concurrencia, en las personas que materialmente hayan realizado los hechos o en las que los hubiesen hecho posibles por no haber ejercido el debido control, de circunstancias eximentes de la responsabilidad penal o de circunstancias que la atenúen o agraven no excluirá ni modificará la responsabilidad penal de las personas jurídicas, sin perjuicio de lo que se dispone en el apartado siguiente:

4. Serán circunstancias atenuantes de la responsabilidad penal de las personas jurídicas haber realizado, con posterioridad a la comisión del delito y a través de sus representantes legales, las siguientes actividades:

a) Haber procedido antes de conocer que el procedimiento judicial se dirige contra ella, a confesar la infracción a las autoridades.

b) Haber colaborado en la investigación del hecho aportando pruebas, en cualquier momento del proceso, que fueran nuevas $y$ decisivas para declarar su responsabilidad.

c) Haber reparado o disminuido sus efectos en cualquier momento del procedimiento y con anterioridad a la celebración del acto del juicio oral el daño ocasionado por el delito.

d) Haber establecido, antes del comienzo del juicio oral, medidas eficaces para prevenir y descubrir los delitos que en el futuro pudieran cometerse con los medios o bajo la cobertura de la persona jurídica.

5. Las disposiciones relativas a la responsabilidad penal de las personas jurídicas se aplicarán a las asociaciones, las fundaciones y las sociedades. 
Como se observa, parecía ser que los autores del anteproyecto pretendían, sin cortapisas ni miramientos, la derogación del principio societas delinquere non potest, y por tanto, la posibilidad legal de su criminalización. Así lo vieron los comentaristas de ese momento, quienes en lugar de preguntarse si era posible o no, o si era adecuado o no, la responsabilidad criminal de las corporaciones, se dedicaron a proponer sistemas de atribución de esa responsabilidad ${ }^{210}$. Según la exposición de motivos de dicho anteproyecto, en materia de la responsabilidad penal de las personas jurídicas, se trató de sincronizar el sistema respectivo con rél máximo respeto a las garantías acumuladas por el Derecho Penal de la culpabilidadò explicando en seguida que se trata de un sistema de numerus clausus, una responsabilidad penal directa y autónoma de la de la persona física, y con un conjunto considerable de sanciones. Los anteproyectos y el proyecto de reforma posteriores, prácticamente no sufrieron grandes cambios con respecto al de 2006, y de hecho, el texto final de 2010 tampoco lo hizo.

\section{LA IMPORTANCIA DE LOS COMPROMISOS INTERNACIONALES DE ESPAÑA QUE PROPICIARON LA REFORMA.}

El legislador del 2010 motivó la reforma en la necesidad de que el ordenamiento jurídico está r̃sometido a un proceso constante de revisiónò y que junto a un marco jurídico de respeto a los derechos fundamentales debe proponerse ñn paralelo avance en materia de

210 GÓMEZ-JARA, Carlos, Fundamentos modernos de la responsabilidad penal de las personas jurídicas, B de F, 2010, pássim; NIETO MARTÍN, Adán, La responsabilidad penal de las personas jurídicas, un modelo legislativo, Iustel, 2008, pássim; ZUGALDÍA ESPINAR, José Miguel, La responsabilidad penal de empresas, fundaciones y asociaciones, Tirant lo blanch, Valencia, 2008, pássim. 
libertad y de seguridad, pilares indisolublemente unidos del concepto mismo de Estado de Derechoò En un solo punto expresó las razones sobre el sí a la responsabilidad penal de las personas jurídicas (que son también razones generales para el resto de los temas de la reforma): obligaciones internacionales que España tiene contraídas en el ámbito de la unión europea; la necesidad de corregir rälgunas carencias o desviacionesà y el surgimiento de m̃uevas cuestionesòque la realidad social exige ser abordadas.

La doctrina ha considerado que el único motivo que tuvo a consideración el legislador fue precisamente el tratar de cumplir la normativa europea ${ }^{211}$; lo que no es falso, pues ciertamente la cita y fundamento de la generalidad de los puntos de reforma es precisamente la legislación internacional, concretamente Directivas de Consejo y Decisiones Marco. Concretamente se señala que î́Se regula de manera pormenorizada la responsabilidad penal de las personas jurídicas. Son numerosos los instrumentos jurídicos internacionales que demanda una respuesta penal clara para las personas jurídicas, sobre todo en aquellas figuras delictivas donde la posible intervención de las mismas se hace más evidente (corrupción en el sector privado, en las transacciones comerciales internacionales, pornografía y prostitución infantil, trata de seres humanos, blanqueo de capitales, inmigración ilegal, ataques a sistemas informáticosé )ò

En consecuencia, pensamos que es menester conocer $y$ comprender el contenido de esos compromisos con la Unión Europea que ha tenido España para acceder a los alcances y los límites de la reforma de 2010, y de paso, conoceremos el origen, contenido y alcances de la legislación en otros países pertenecientes a la zona euro, ya que es lógico que tanto este país como los otros de la comunidad tiendan a la homogenización o alineamiento de sus textos legales y de sus decisiones judiciales.

\footnotetext{
211 Por todos, QUINTERO OLIVARES, Gonzalo, “Art. 31 bis", en Comentarios al CP español, Thomson Reuters, Aranzadi, Navarra, 2011, p. 367, y
} 
La Decisión Marco 2002/475/JAI del Consejo, de 13 de junio de 2002, sobre la lucha contra el terrorismo señala en sus art.s $7^{\circ}$ y $8^{\circ}$ los lineamientos generales de la responsabilidad penal de las personas jurídicas y de las sanciones que se deben imponer. Por su importancia consideramos que es menester traer su texto a este lugar.

Art. 7.- Responsabilidad de las personas jurídicas.

1. Todos los Estados miembros adoptarán las medidas necesarias para que las personas jurídicas puedan ser consideradas responsables de los delitos mencionados en los art.s 1 a 4, cuando dichos delitos sean cometidos por cuenta de éstas por cualquier persona, actuando a título particular o como parte de un órgano de la persona jurídica, que ostente un cargo directivo en el seno de dicha persona jurídica basado en:

a) un poder de representación de dicha persona jurídica;

b) una autoridad para tomar decisiones en nombre de dicha persona jurídica;

c) una autoridad para ejercer un control en el seno de dicha persona jurídica.

2. Sin perjuicio de los casos previstos en el apartado 1, todos los Estados miembros adoptarán las medidas necesarias para que las personas jurídicas puedan ser consideradas responsables cuando la falta de vigilancia $o$ control por parte de una de las personas a que se refiere el apartado 1 haya hecho posible que una persona sometida a su autoridad cometa uno de los delitos mencionados en los art.s 1 a 4 por cuenta de una persona jurídica. 
3. La responsabilidad de las personas jurídicas en virtud de los apartados 1 y 2 se entenderá sin perjuicio de la incoación de acciones penales contra las personas físicas que sean autores, incitadores o cómplices de alguno de los delitos a los que se refieren los art.s 1 a 4.

Como se observa, y a reserva de un análisis más profundo, la Decisión Marco exige una responsabilidad de las personas jurídicas por la comisión de delitos, pero no exige precisamente una penal o solamente administrativa, lo que ha dado lugar a algunos comentaristas a señalar que ninguno de estos compromisos europeos exigía, en definitiva, la creación de una responsabilidad de carácter penal o criminal de las personas jurídicas ${ }^{212}$, lo que no es del todo exacto, como veremos párrafos adelante. Salvo algunos matices, algunos de ellos más o menos importantes, el resto de las decisiones marco y directivas europeas tienen el mismo texto que el transcrito. Lo que debemos de tener por descontado es que en un primer acercamiento, las características generales del sistema de responsabilidad serían:

El sujeto pasivo de la responsabilidad es llamado ñpersona jurídicaò

La responsabilidad es detonada siempre por el actuar (el r̃delitod̆ de una persona física.

Es un sistema de doble vía: a) el hecho de referencia puede ser el delito de una persona física que, actuando como particular o como parte de un órgano directivo basado en poder de representación, de

\footnotetext{
212 Por todos, GÓMEZ JARA Diez, Carlos, y otros, Responsabilidad penal de las personas jurídicas, Aspectos sustantivos y procesales, La Ley, Madrid, 2011, página 19, nota 1: "No obstante, ello no debe malinterpretarse puesto que no existe obligación alguna derivada de los instrumentos europeos (mucho menos de los internacionales) de establecer una genuina responsabilidad de la persona jurídica; dicho de otra manera, con la anterior regulación a la reforma de 2010 se cumplía igualmente con los compromisos internacionales".
} 
tomar decisiones en su nombre o de ejercer control en el seno de ella; o, b) puede ser el delito de una persona sometida a la autoridad de los anteriores, y que lo haya cometido gracias a la falta de vigilancia o control de los mismos.

El delito de la persona física debe ser cometido ñpor cuentaò en beneficioòo renn provechoòde la persona jurídica.

Se trata de una responsabilidad autónoma y diferente de la responsabilidad de la persona física.

La normativa europea de la decisión marco apuntada exige la responsabilidad penal de las ñpersonas jurídicasò adoptando un término amplio y puramente formal, dejando de lado las denominaciones como rempresaò r̃̃orporaciónò rãsociaciónò o f̂uundaciónò De hecho, casi todas las decisiones marco o directivas señalan en sus r̃definicionesò qué debe entenderse por ñpersona jurídicaòy todas ellas coinciden en ré toda entidad a la cual el derecho vigente reconoce este estatuto, salvo los Estados y otros organismos públicos que ejercen prerrogativas estatales y las organizaciones internacionales de derecho públicoà Esto debe ser tomado en cuenta cuando interpretemos nuestro texto legal.

También exige que esa responsabilidad sea detonada por los r̃delitosò cometidos por r̃cualquier personaò La regulación europea, en todas las decisiones marco y directivas, no duda en atribuir la responsabilidad por un hecho de una persona física, constituyendo así la única puerta de entrada de criminalización de la jurídica. No obstante, cuando señala r̃ cualquierò persona, no se refiere a toda persona en general, sino que en seguida define los criterios de las personas físicas que originan esa responsabilidad, decantándose, primeramente, por un sistema del alter ego: solamente las personas que tengan u ostenten un cargo directivo (individual o en órgano colegiado) dentro de la persona jurídica derivado o basado en ciertos poderes o autoridades, como lo pueden ser, de representación de la persona jurídica, de tomar decisiones dentro de la persona jurídica y de control (material o de 
facto) en el seno de la persona jurídica. De hecho, el texto del Anteproyecto de reforma de 2006 del CP tenía más bien ese tenor ré por las personas físicas que tengan en ellas un poder de dirección fundado en la atribución de su representación o en su autoridad, bien para tomar decisiones en su nombre, bien para controlar el funcionamiento de la sociedadò Aunque enseguida extienda el origen de su responsabilidad a cualesquiera otras personas que dependan (r̃sometidas a su autoridadò de los antes referidos.

Desde luego, esos r̃delitosò que son realizados por la persona física debe serlo ñpor cuentaò de la persona jurídica, pues de esa manera podría tener sentido la responsabilidad empresarial.

El primer párrafo del art. $7^{\circ}$ la decisión marco 2002/475/JAl del Consejo, de 13 de junio de 2002, sobre la lucha contra el terrorismo ya citado, fue prácticamente el mismo que el diverso 4ํㅜ de la decisión marco 2002/629/JAI del Consejo, de 19 de julio de 2002, relativa a la lucha contra la trata de seres humanos, con la única diferencia que en ésta los delitos de la persona física deben ser cometidos ren su provechoò y no ya ñpor cuentaò de la persona jurídica. Cosa exactamente idéntica sucede con las Decisiones Marco 2003/568/JAI del Consejo, de 22 de julio de 2003, relativa a la lucha contra la corrupción en el sector privado, la 2004/757/JAI del Consejo, de 25 de octubre de 2004, relativa al establecimiento de disposiciones mínimas de los elementos constitutivos de delitos y las penas aplicables en el ámbito del tráfico ilícito de drogas, la 2004/68/JAl del Consejo, de 22 de diciembre de 2004, relativa a la lucha contra la explotación sexual de niños y la pornografía infantil, la 2005/667/JAI del Consejo de 12 de julio de 2005, destinada a reforzar el marco penal para la represión de la contaminación procedente de buques, y la Directiva 2005/60/CE del Parlamento Europeo y del Consejo, de 26 de octubre de 2005, relativa a la prevención de la utilización del sistema financiero para el blanqueo de capitales y para la financiación del terrorismo. Otra diferencia de todas las anteriores, pero en relación con la Decisión marco 
2005/222/JAI del Consejo de 24 de febrero de 2005 relativa a los ataques contra sistemas de información es que en ésta no se utilizan los términos ñpor su cuentaò o ren su provechoò sino de delitos r̃cometidos en su beneficioò

En ז̃su provechoò o en r̂su beneficioò o ñpor cuentaò de la persona jurídica, son expresiones, quizá equivalentes, que permiten dar sentido a que lo hecho por las personas físicas, generen u originen racionalmente la responsabilidad penal de las jurídicas.

Lo mismo sucede en la segunda vía, la que origina el delito de r̃ualquier personaò sometida a vigilancia de los directivos o representantes de la persona jurídica, por la falta de control de éstos. En efecto, todas las decisiones marco literalmente coinciden en que el delito de la persona física haya sido gracias a ña falta de vigilancia o de controlò a excepción de la Directiva 2008/99/CE del Parlamento europeo y del Consejo de 19 de noviembre de 2008 relativa a la protección del medio ambiente mediante el Derecho Penal que se las arregla con la expresión ráusencia de supervisión o de controlò Ese delito debe ser también realizado ñpor cuentaò o ren provechoò o ren beneficioò de la persona jurídica. Solo llama la atención que en la Decisión Marco 2002/629/JAl del Consejo, de 19 de julio de 2002, relativa a la lucha contra la trata de seres humanos, prevea un texto diferente señalando que el delito de la persona física sea ré en provecho de dicha persona jurídica o de una persona que se encuentre bajo su autoridadò

El catálogo de sanciones o penas se reproduce en todas las decisiones marco y en las directivas. El art. $8^{0}$ de la Decisión Marco 2002/475/JAI del Consejo, de 13 de junio de 2002, sobre la lucha contra el terrorismo, que hemos elegido como ejemplar, previene:

Art. 8. Sanciones a las personas jurídicas 
Todos los Estados miembros adoptarán las medidas necesarias para que toda persona jurídica a la que se haya declarado responsable con arreglo al art. 7 sea sancionada con penas efectivas, proporcionadas $y$ disuasorias, que incluirán multas de carácter penal o administrativo $y$, en su caso, otras sanciones, en particular:

a) medidas de exclusión del disfrute de ventajas o ayudas públicas;

b) medidas de prohibición temporal o permanente del desempeño de actividades comerciales;

c) sometimiento a vigilancia judicial;

d) medida judicial de liquidación;

e) cierre temporal o permanente del establecimiento que se haya utilizado para cometer el delito.

Estas consecuencias jurídicas de la responsabilidad de las personas jurídicas se repiten, en nomen e incluso en orden, en casi todos los instrumentos europeos. Una inicial aproximación nos indica que los compromisos europeos exigen sanciones refectivas, proporcionadas y disuasoriasò y priman a la multa (penal o administrativa), sin dejar a un lado la llamada ñpena de muerteò de la persona jurídica como lo es la liquidación judicial, o la intervención y prohibición de actividades económicas específicas o de obtención de ventajas o ayudas públicas. Por lo demás, solo detectamos en el art. $6^{\circ}$ de 2005/667/JAl del Consejo de 12 de julio de 2005, destinada a reforzar el marco penal para la represión de la contaminación procedente de buques, la exigencia a los países miembros de cuotas 
mínimas de multas que se deberán imponer como sanción a las personas jurídicas.

Hemos señalado supra que no consideramos pacífica la afirmación de que la normativa europea no obligue a España a responsabilizar, con penas del Derecho Penal, a las personas jurídicas. Ciertamente la mayor parte de las decisiones marco establecen que las personas jurídicas responderán de las ñnfraccionesòque previamente definieron en art.s anteriores cada una de ellas, e incluso, exigen sanciones de carácter penal o administrativo, que pueden alinearse perfectamente con las que hemos transcrito. No obstante, llama la atención la Directiva 2008/99/CE del Parlamento europeo y del Consejo de 19 de noviembre de 2008 relativa a la protección del medio ambiente mediante el Derecho Penal. En efecto, esta directiva, cuyo nombre incluye la protección del medio ambiente r̃a través del Derecho Penalò (y no del administrativo), explica en su considerando tercero que ré los sistemas de sanciones existentes no son suficientes para lograr el total cumplimiento de la legislación para la protección del medio ambiente. Este cumplimiento puede y debe reforzarse mediante la aplicación de sanciones penales que pongan de manifiesto una desaprobación social de naturaleza cualitativamente diferente a la de las sanciones administrativas o un mecanismo de compensación conforme al Derecho civilò En el $10^{\circ}$ se lee ñ La presente Directiva obliga a los Estados miembros a prever sanciones penales en su legislación nacional por las infracciones graves de las disposiciones del Derecho comunitario sobre protección del medio ambienteò En seguida, ya en su art. 3ํㅜ, que intitula como r̃delitosò establece que r̃os Estados miembros se asegurarán de que las siguientes conductas sean constitutivas de delito, cuando sean ilícitas y se cometan dolosamente $\mathrm{o}$, al menos, por imprudencia graveé ò dejando a un lado el nombre de infracciones, como se hace en otras directivas o decisiones marco.

En el inciso d) del art. $2^{\circ}$ define el concepto de ñpersonas jurídicasò (en los términos de otras directivas y decisiones marco) y en 
el art. 6º de la îResponsabilidad de las personas jurídicasò previene que ños Estados miembros se asegurarán de que las personas jurídicas pueden ser consideradas responsables por los delitos a los que se hace referencia en los art.s 3 y 4 é ò por lo que se echa en falta la infracción, que era el término utilizado en otros instrumentos. Finalmente, la fecha límite de transposición según el art. 8o fue el día 26 de diciembre de 2010, con lo que casi coincide con la fecha de la entrada en vigor de la LO 5/2010.

Salvo la mención expresa de r̃esponsabilidad penal de las personas jurídicasò que se echa en falta en el articulado de la Directiva, que no dejaría dudas sobre el compromiso adquirido por España, estimamos que tal Directiva sí obliga a los países miembros de la Unión Europea a penalmente responsabilizar a las personas jurídicas. 


\title{
CAPITULO IV
}

\section{MODELOS DE RESPONSABILIDAD PENAL DE LAS PERSONAS JURÍDICAS}

\begin{abstract}
Pretendemos mostrar los modelos o sistemas de responsabilidad penal de las personas jurídicas partiendo del más antiguo, pero también el más sencillo, el que fue utilizado en Estados Unidos de Norteamérica y que a nivel Federal se sigue utilizando. Es un modelo de responsabilidad por atribución o vicarial del respondant superior o identification theory, para luego separarnos poco a poco de dicho modelo y emigrar hasta modelos de responsabilidad originaria de la persona jurídica. El criterio que utilizamos para determinar la cercanía del respondant superior es: a) la identificación del injusto objetivo y subjetivo y la culpabilidad de la persona física con el injusto objetivo y subjetivo y la culpabilidad de la persona jurídica, por lo que a medida que no se exijan esos elementos de identificación y que el injusto y la culpabilidad de la persona jurídica sean propios, estaremos trasladándonos a modelos de responsabilidad originaria; y b) La independencia de culpabilidad de la persona jurídica, y por ende, la existencia de causas de exclusión de culpabilidad específicas para la persona jurídica. Incluiremos dentro de este capítulo aquellos modelos
\end{abstract}


que son construidos para thacer responderòmediante el Derecho Penal a las personas jurídicas $u$ organizaciones empresariales.

Los modelos que analizamos en este apartado, no son modelos simplemente teóricos, esto es, ahistóricos, sino que tienen una referencia del derecho positivo, por lo que estimamos adecuado relacionar el modelo con algunas legislaciones extranjeras, específicamente, Francia, Alemania y Holanda.

No queremos dejar de estudiar y analizar algunos modelos $\sin$ culpabilidad de la empresa, que se basan o fundamentan en la peligrosidad de la persona jurídica, pero que podrían tener una extraordinaria funcionalidad en nuestra realidad jurídica española en la actualidad. Por su importancia, y para no solucionar la línea de continuidad de los modelos con culpabilidad, los analizaremos inmediatamente.

\section{MODELOS DE RESPONSABILIDAD PENAL DE LAS PERSONAS JURÍDICAS SIN CULPABILIDAD.}

Los intentos más importantes que han sido publicados en Alemania para justificar las consecuencias jurídico penales a las personas jurídicas han sido del profesor Bernd Schünemann ${ }^{213}$, mientras que en España quien ha sostenido esta posición con mayor vehemencia en un principio, aunque en forma posterior ha decaído de

\footnotetext{
213 Vid. SCHÜNEMANN. Bernd, "La punibilidad de las personas jurídicas desde la perspectiva europea", Op. Cit., páginas 565 a 600, el mismo, "La responsabilidad penal de las empresas y sus órganos directivos en la unión europea", en BAJO F. (Dir.), BACIGALUPO y GOMEZ (Coords.), Constitución europea y Derecho Penal económico, Madrid. Centro de Estudios Ramón Areces, 2006, páginas 143 y siguientes; el mismo, "Responsabilidad penal en el marco de la empresa. Dificultades relativas a la individualización de la imputación", ADPCP, 2002.
} 
su posición para considerarlas de otra forma lo fue Bajo Fernández ${ }^{214}$ quien se suma simplemente a Schünemann, y por otro lado, con una fundamentación abundante y contundente, encontramos a Silva Sánchez ${ }^{215}$, Mir Puig y Feijóo Sánchez (en sus trabajos anteriores a la LO 5/2010).

En el intento de construir Schüneman una culpabilidad para los entes colectivos le parece irrenunciable analizar la cuestión desde puntos de vista de necesidades político criminales, legitimación material (constitucional) y de dogmática jurídico penal y procesal penal ${ }^{216}$. Concluye que sí son necesarias las medidas penales contra las personas jurídicas, incluso si consideráramos la optimización del Derecho Penal individual (al que considera ineficaz), sobre todo, por la

${ }^{214}$ BAJO Fernández, Miguel, "La responsabilidad penal de las personas jurídicas en el derecho administrativo español", Op. Cit., página 31, donde atempera su posición y aunque considera imposible fundamentar la responsabilidad penal de las personas jurídicas en la culpabilidad, admite las sanciones sólo en "la necesidad preventiva derivada del hecho" y eso es preferible "... que prostituir el principio de culpabilidad, que referido a las personas jurídicas, sería culpabilidad por el hecho de otro, por más que otros autores (Tiedemann, Jakobs, Brender, Zugaldía) pretendan salvar la situación". Sin embargo, en "Prólogo" a GÓMEZJARA, Carlos, La culpabilidad penal de la empresa, Marcial Pons, Barcelona, 2005, p. 9 y 10, admite implícitamente una posición contraria a la inicial, "Entiendo, sin embargo, que el pensamiento jurídico y las legislaciones caminan -parece que inexorablemente- por la senda de hacer responder penalmente a las corporaciones, no sólo el Derecho penal estadounidense, sino también el propio continental como se deduce del Código penal francés o de las Directivas europeas". Así también BAJO F., M., "La responsabilidad penal colectiva", Op. Cit., páginas 84 y 85, "la elaboración de una teoría de la imputación subjetiva o culpabilidad de las personas jurídicas tiene tierra de abono suficiente..."

215 SILVA Sánchez, Jesús-María, y ORTIZ de U. Gimeno, Iñigo, "El art. 31.2 del CP, ¿Responsabilidad penal de las personas jurídicas o mero aseguramiento del pago de la pena de multa?", Op. Cit., páginas 343 y siguientes; el mismo, "Criterios de asignación de responsabilidad en estructuras jerárquicas", Empresa y delito en el nuevo CP (Cuadernos de Derecho Judicial), CGPJ, Madrid, 1997, p. 11 a 58; el mismo, "Art. 31", Comentarios al CP, tomo III, en COBO DEL ROSAL, (Dir.) , 2000, p. 369 a 414 ; el mismo, Delitos contra el medio ambiente, Valencia, 1999; el mismo, "La aplicación judicial de las consecuencias accesorias para las empresas" InDret 2/2006, www. indret.com, 2006; el mismo, "La responsabilidad penal de las personas jurídicas y las consecuencias accesorias del art. 129 del CP”, Op. Cit., p. 307 y siguientes; el mismo, "Responsabilidad penal de las empresas y de sus órganos en Derecho español", en SILVA S. (Ed.), Fundamentos de un sistema europeo del Derecho Penal, Libro Homenaje a Claus Roxin, Bosch, 1995.

216 Vid. SCHÜNEMANN, B., "La punibilidad de las personas jurídicas desde la perspectiva europea”, Op. Cit., p. 566 y 577. 
creciente existencia de modelos colectivos de comportamiento para la explicación de acciones lesivas de bienes jurídicos y por el amplio debilitamiento del Derecho Penal individual para combatir la criminalidad de modelos colectivos de comportamiento ${ }^{217}$.

En cuanto a la legitimación material lo estima insuperable: no es posible construir un modelo de responsabilidad penal para los entes colectivos basado en la culpabilidad puesto que se comprometería r̃el principio de culpabilidad contenido en el principio del Estado de Derecho, como de lesión del principio de proporcionalidad, a causa de la inidoneidad de la sanción a la empresa para la protección del bien jurídicoơ ${ }^{18}$. Asegura que ello es así, puesto que la empresa, por más que le busquemos, no puede tener una culpabilidad propia, ya que al principio y al final, toda referencia a su acción y culpabilidad es una referencia a la acción o culpabilidad de sus miembros o representantes ${ }^{219}$.

Critica, por otro lado, los intentos de construir un concepto de culpabilidad jurídica o social ${ }^{220}$, a los que considera un rengendro dogmático, que no soluciona problemas, sino que los encubreơ ${ }^{21}$. Entiende que la culpabilidad no puede ser simplemente social y no moral, puesto que, citando a Hirsch, r̃quien no puede algo en realidad, tampoco lo puede en sentido jurídicoơ ${ }^{22}$. Sin embargo, no hay que claudicar en la intención de controlar la criminalidad de empresa a

\footnotetext{
217 Ib Ídem, p. 567 y 568.

218 Ib Ídem, p. 582.

219 Ib Ídem, p. 584, señala además que aquellos intentos de justificar la culpabilidad propia de la persona jurídica fueron iniciados en 1966 por una decisión del Tribunal Federal Constitucional alemán (Vid. p. 585) cuando declaró lícita una imputación de culpabilidad en el ámbito de las personas jurídicas mediante la culpabilidad de las "personas que actúan responsablemente para ella" (BVefGE 20, p. 323 y ss., y 335 y ss.)

220 Op. Cit., p. 586, esto es, aquellos conceptos en donde la culpabilidad ya no implica la capacidad individual de actuar de otro modo, sino que únicamente se manifestar en un juicio genérico de que la persona implicada no habría satisfecho las exigencias sociales a ella impuesta. Esto es, una culpabilidad sin referente individual, sino medida a través de un baremo social.

221 Ib Ídem, p. 587.

222 Ib Ídem, en relación con la nota 57.
} 
través del Derecho Penal, pero no sería a través de consecuencias basadas en la culpabilidad, sino en la necesidad de protección del bien jurídico y en la peligrosidad en el manejo organizativo de la empresa que generaría ya una ractitud criminal de grupoơ ${ }^{23}$.

Su tesis se traduciría de la siguiente forma: r̃si una persona natural realiza, en el marco de una empresa, una acción conminada con una pena o una multa administrativa, que debiera redundar en beneficio de la empresa, y si faltaran o fueran incompletas las medidas de dirección o de vigilancia necesarias para evitar tales hechos, entonces se podría aislar mediante estos dos supuestos la actitud criminal de la entidad, difícilmente constatable en sentido estricto; es decir, se podría distinguirla por sus presupuestos y sus frutos. $\check{\sigma}^{24} \quad Y$ esta responsabilidad podría ser disparada incluso por cualquier subordinado (no sólo por directivos, como exige Tiedemann), y por ello bastaría con un fallo objetivo de las medidas necesarias de dirección y vigilancia.

Además de Bajo, en España, Silva Sánchez ${ }^{225}$ asegura que debemos de hacer un Derecho Penal ñparaleloò de las personas jurídicas ré siempre que se tuviera claro que el modelo de atribución de responsabilidad penal a las personas jurídicas no es idéntico al de la

223 Ib Ídem, p. 590 y 591. Estas consideraciones las había realizado por primera vez Schünemann en "Cuestiones básicas de la dogmática jurídico penal y de la política criminal acerca de la criminalidad de empresa", ADPCP, (Trad. Bruckner y Lascurain), 1988, p. 533 y 547. Este estudio es un resumen de un trabajo publicado bajo el título Strafrechtsdogmatische und kriminalpolitische Grundfragen der Unternehmenskriminalität, en Wistra, Zeitschrift für Wirtschaft, Steuer, Strafrecht, año 1, fascículo 2, 15 de marzo de 1982, página 41 a 50, que realizó en 1979. A diferencia de la primera publicación, en la publicada en 2002 abandona su tesis de que el estado de necesidad se limitaría a “... que no se lograra la constatación de un autor individual del delito de empresa, por lo que hoy quiero abandonar la limitación, propuesta por mí en 1979, de la denominada multa a entidades colectivas anónimas... Pues con su aplicación y punición de un autor individual no se puede acabar propiamente con el efecto criminógeno, analizado por mí de forma detallada ya en 1979, de una actitud criminal de la asociación...", p. 590.

224 "La punibilidad de las personas jurídicas desde la perspectiva europea", $O p$. Cit., p. 590.

225 Vid. "La responsabilidad penal de las personas jurídicas y las consecuencias accesorias del art. 129 del CP", en AA.VV., Derecho Penal económico, Madrid, Consejo General del Poder Judicial, 2001, p. 307 y sigs. 
responsabilidad criminal individual|ّ̋26. Luego de asegurar la necesidad político criminal de las consecuencias a la empresa (basadas en irresponsabilidad organizada; dificultades probatorias de identificación de la persona individual y insuficiencia preventiva cuando si se identifique y castigue; insuficiencia preventiva de alternativas no penales $^{227}$; por la imposibilidad de articular satisfactoriamente la acumulación de procedimientos penal y administrativo, y la inidoneidad del procedimiento administrativo sancionador para abordar asuntos de delincuencia organizada), entra a analizar los diferentes modelos de responsabilidad penal de las personas jurídicas (de atribución y directa y originaria $)^{228}$.

Una vez que critica las construcciones de los modelos basados en la culpabilidad de la empresa, se decanta, abiertamente, no por sanciones penales a la empresa, sino por medidas de seguridad ${ }^{229}$, las cuales entiende que las puede legitimar a través de considerar que la norma que previene la consecuencia jurídica a la persona moral no es de determinación, sino de valoración, esto es, como expectativas de conducta institucionalizada.

El hecho de la persona jurídica y su antijuridicidad objetiva la fundamenta en un ñnjusto de sistemaà ñas personas jurídicas pueden ir configurando con el tiempo, y sin que ello sea atribuible a nadie en

\footnotetext{
226 Ib Ídem, p. 312.

227 Ib Ídem, página 319, por el significado simbólico del Derecho Penal “... el hecho de que las consecuencias jurídico penales se hayan asociado tradicionalmente a los hechos con un significado ético social más grave y se impongan por un órgano independiente, y en un proceso rodeado de las máximas garantías, atribuye a dichas consecuencias una fuerza expresiva de la que carecen las sanciones extrapenales".

228 Ib Ídem, p. 329 y sigs.

${ }^{229} \mathrm{Ib}$ Ídem, p. 345, pues dice que las del $129 \mathrm{CP}$ son medidas de seguridad. "las medidas de seguridad no requieren el presupuesto de culpabilidad, tampoco precisan ninguno de los demás presupuestos subjetivos que son propios de la penal (ni acción final, ni dolo, ni imprudencia)... Basta con que la situación de ausencia de imputación subjetiva (en cualquiera de sus niveles) existente en el momento de la realización del hecho lesivo de la norma de valoración jurídico penal sea atribuible al factor que constituye precisamente la razón de la imposición de las medidas de seguridad (estructura organizada supra individual)".
} 
particular, una realidad objetivamente favorecedora de la comisión de delitos por parte de sus integrantes (organizándose de determinada manera o generando una actitud criminal de grupo). Y así mismo puede afirmarse que ese restado de cosasòpuede ser penalmente antijurídico, en tanto que lesivo de normas penales de valoración. Ahora bien, lo cierto es que esto no tiene nada que ver con un injusto personal, ni siquiera con la antijuridicidad objetiva de un hecho concreto. El injusto de la persona jurídica se hallaría, más bien, en una conducción de la vida jurídicamente desaprobada. Como ha expresado Lampe, la empresa potencialmente criminal da lugar a un injusto de sistema (Systemunrecht), ya por su filosofía criminógena, ya por su deficiente estructura de organización: esto constituye un estado de injusto. Desde luego, esto no constituye un hecho antijurídico suficiente para soportar una culpabilidad por el hecho que diera lugar a la imposición de una pena. Pero me parece que sí constituye la base fáctica suficiente para imponer, sin vulnerar el principio del hecho, consecuencias jurídico penales a las personas jurídicasò 230

Cuando analiza las consecuencias accesorias del desaparecido art. $129 \mathrm{CP}$ (que el CP de 1995 inauguró), abiertamente se pronuncia, no a favor de penas, ni medidas de seguridad cuyo destinatario sea la persona física, ni consecuencias jurídico-administrativas no sancionatorias que se imponen en el proceso penal por razones de economía procesal, sino verdaderas medidas de seguridad dirigidas contra la persona jurídica ${ }^{231}$. Posiciones similares las encontramos en $\mathrm{Mir}^{232}$, quien también se adhiere abierta, aunque parece que parcialmente, a Schünemann ${ }^{233}$.

${ }^{230} \mathrm{Ib}$ Ídem, p. 340.

231 Ib Ídem, supra nota 138.

232 MIR PUIG, Santiago, "Una tercera vía en materia de responsabilidad penal de las personas jurídicas”, Op. Cit., pássim.

233 Ib Ídem, página 13, "coincido, pues, en parte, con Schüneman cuando cree necesaria y legítima la intervención del Derecho Penal frente a personas jurídicas y empresas por razón de la especial peligrosidad que tiene una empresa cuando existe en ella una 'actitud criminal de grupo'... También comparto su opinión de que de tales medidas no pueden basarse en la culpabilidad porque "a una entidad 


\section{EL MODELO DE LA RESPONSABILIDAD VICARIAL}

\subsection{La identification theory o respondant agent}

La tradición anglosajona, más práctica que preocupada por responder a un complejo sistema de garantías sustanciales, ha admitido desde hace más de un siglo, la responsabilidad penal de las personas jurídicas, lo que constituye uno de los aspectos que más la alejaban con la romano germánica influenciada por el iluminismo alemán del siglo XIX.

Desde 1897 se imponen penas a las empresas en los Estados Unidos de Norteamérica. Es en el caso Coleman vs. Mills donde se por primera vez se trata a la empresa como penalmente responsable de las acciones de sus empleados ré Existen ciertos trabajadores o empleados de la empresa que pueden considerarse la mente y la voluntad directriz de la empresa, el verdadero ego y centro de la personalidad de la empresa ${ }^{234}$. A pesar de ese precedente, los Tribunales tenían ciertas dificultades para justificar el procesamiento penal a las empresas, por lo que se reconoce que con el caso New York Central and Houdson river Railroad vs EUA de 1909 y el Tratado de Derecho Penal de Bishop titulado El nuevo Derecho Penal se inaugura claramente en el derecho estadounidense la criminalización de las empresas ${ }^{235}$. Bishop señalaba en 1901 que ñoda vez que la empresa actúa a través de sus empleados y representantes, sus propósitos, motivos e intenciones son de la empresa en la misma

colectiva siempre se la hace responsable por la culpa de otra persona". El fundamento de la imposición de medidas sobre personas jurídicas y empresas ha de ser, como en todas las medidas de seguridad, su peligrosidad".

${ }^{234}$ Cfr. LAUFER, W. S., "La culpabilidad empresarial y los límites de derecho", en GÓMEZ-JARA, C., (ed.) Modelos de autorresponsabilidad penal empresarial, propuestas globales contemporáneas, Navarra, Aranzadi, 2006, p. 72.

$235 \mathrm{Ib}$ Ídem, p. 75. 
medida en la que lo son los hechos que realizan. Si la esencia invisible e intangible de la corporación puede nivelar montañas, rellenar valles, poner vías del tren y hacer que anden los vagones de tren sobre éstas, puede intentar hacerlo e incluso actuar en consecuencia de manera virtuosa como viciosa ${ }^{36}$, y la sentencia de ese caso cita frecuentemente a Bishop. Por tanto, el origen y nacimiento de la responsabilidad penal de las organizaciones empresariales se encuentra en la práctica judicial ${ }^{237}$, y se justificó por su necesidad político criminal ante el auge y crecimiento de la economía principalmente en el seno de las organizaciones empresariales. ${ }^{238}$

Antes de esta sentencia importante lo que existía como consecuencia de delitos para las personas jurídicas eran aquellas derivadas simplemente de responsabilidad objetiva y de stricti liability, ren los primeros casos de responsabilidad penal empresarial no existía imputación jurídico-penal ni subjetiva ni personal de ningún tipo, sino que se trataba en definitiva, de meras infracciones objetivasó ${ }^{239}$

Desde inicio el modelo adoptado por la práctica judicial norteamericana ha sido la vicarious liability o responsabilidad penal vicaria, también llamado modelo vicarial de responsabilidad penal. Consiste en un m̃modelo de imputación mediante el cual se atribuyen a

236 Citado por $I b$ Ídem, p. 75.

237 Como decía MULLER "Entre estas malas hierbas (del campo de la jurisprudencia) se encuentra la responsabilidad penal empresarial. Nadie la cultivó, nadie la justificó, nadie la plantó. Simplemente creció”, citado por GÓMEZJARA DIEZ, CARLOS, La responsabilidad penal de las empresas en los EE. UU., Editorial Universitaria Ramón Areces, Madrid, 2006, p. 31, especialmente nota 75. 238 ABOSO, G.E., y ABRALDES, S.F., Responsabilidad de las personas jurídicas en el Derecho Penal, BdF, Buenos Aires, página 179, citando a Celia Wells y su obra Corporations and Criminal Responsability: “... el emprendedor individual estaba siendo reemplazado por acuerdos de negocios más complejos y, en términos de su actividad, el desarrollo de los ferrocarriles transformó el panorama, la economía y la movilidad. Las empresas empezaron a causar daños y lesiones a la propiedad y a las personas. Los acusadores descubrieron que no tenía sentido perseguir al individuo. Así surgió que lo más sencillo para la parte perjudicada era lo más seguro para la empresa imputada por un daño: el tratar a la corporación como si fuera un actor individual."

239 GÓMEZ-JARA, La responsabilidad penal de las empresas en EE. UU., Op. Cit., p. 44. 
la corporación el actus reus y la mens rea de su agenteé ${ }^{240}$. Los Tribunales comenzaron a considerar que las empresas son penalmente responsables de las conductas de sus empleados, siempre que éstos actúen en el marco de sus competencias y con la intención de beneficiar a la empresa. Esto también se identifica con la teoría del superior que responde (respondeat superior) que r̃ ronsidera que las empresas son los representados y los directivos, supervisores y empleados los representantesé las intenciones de los representantes simplemente se imputan o atribuyen al representadoé Ningún Tribunal (en Estados Unidos de Norteamérica) se ha alejado tanto de la regla del respondeat superiorò ${ }^{241}$

En efecto, la práctica judicial norteamericana ha generado un sistema sencillo y simple de responsabilidad empresarial: el acto y la intención del empleado, bajo ciertas condiciones, se consideran también el acto y la intención de la empresa. Esta simpleza de la solución es su principal triunfo, pero también lo que le significa la razón de la mayúscula crítica para la perspectiva de la tradición romano germánica. Algo tan ñplásticoò tan eminentemente fácil, trae como consecuencia una aplicación sencilla y por lo tanto, esperadamente constante (lo que así es), pero existe un enorme escrúpulo: no hay una fundamentación suficiente para justificar la misma.

Se estima que los Tribunales adoptaron ese modelo por dos razones fundamentales. Por un lado, por motivos de conveniencia judicial y utilidad, y en segundo lugar, por la acogida de dos presunciones, una, que se logra un compromiso justo a la hora de ubicar el riesgo y las pérdidas, y otra, que la teoría del respondeat superior induce a las agrupaciones para que hagan efectiva la responsabilidad individual. ${ }^{242}$ A pesar de ello, como lo hemos dicho, la doctrina (de la tradición romano germánica y también estadounidense) ha criticado este modelo, puesto que la culpabilidad empresarial r̃carece

\footnotetext{
$240 \mathrm{Ib}$ Ídem, p. 45.

${ }^{241}$ LAUFER, W. S., Op. Cit., p. 71.

242 Ib Ídem, p. 72.
} 
de sentido cuando se basa en las acciones de un empleado delincuente que, dentro los límites de su competencia, actúa para beneficiar a la empresa pese a infringir así la política empresarial de carácter expreso, las regulaciones administrativas o el Derecho Penalò ${ }^{243}$

El fundamento de la pena para las personas jurídicas es, en principio, motivo de discusión en la doctrina norteamericana actualmente. El tema resulta relevante porque depende de la fundamentación de la pena la forma en que se construirá el modelo de responsabilidad penal. Hasta la fecha parece ser dominante el criterio de la disuasión: la pena se debe imponer a la organización empresarial en tanto es necesaria para disuadir a las demás empresas para que no favorezcan, con una cultura empresarial defectuosa o proclive a la infracción de las normas, esto es, se identifica con lo que en nuestra tradición llamamos prevención general negativa. El promotor de esta tesis es Khanna, a quien parte de la doctrina le recrimina excluir a la retribución como fundamento y medida de la pena a la persona jurídica, con lo que podría caer en el castigo a inocentes si solamente la necesidad social así lo exige ${ }^{244}$. Khanna sostiene que r̃siempre que sus empleados hayan cometido un delito, la empresa puede ser hecha responsable aunque no exista prueba alguna de su propia culpabilidadé por lo tanto justifica el establecimiento de la responsabilidad penal sobre la base del valor social del establecimiento de la responsabilidad y con independencia de la retribución del autorò $^{245}$

243 Ib Ídem, p. 73. Así también LAUFER, W. S., y STRUDLER, A., "Intencionalidad corporativa, retribución y variantes de la responsabilidad vicaria", en GÓMEZJARA, C., (ed.) Modelos de autorresponsabilidad penal empresarial, propuestas globales contemporáneas, Navarra, Aranzadi, 2006, p. 211: "Una notable debilidad de la responsabilidad vicaria se observa claramente cuando los tribunales consideran que existe culpabilidad pese a que: (a) la acción del empleado tiene poca, si acaso alguna, relación con las acciones de la entidad; (b) el agente actúa sin tener en consideración los diligentes esfuerzos empresariales para prevenir el daño".

${ }^{244}$ LAUFER y STRUDLER, Op. cit., p. 201.

$245 \mathrm{Ib}$ Ídem, p. 202. Vid. bibliografía sobre la doctrina que estima que la retribución no debe ser el fundamento de la pena a la persona jurídica, Ídem, nota 36. 
Por el contrario, otros más estiman que la retribución constituye la perspectiva normal del castigo e implica esencialmente la expresión de un reproche, una condena moral, r̃sólo la condena penal implica expresar una censura moral y una condena moralò ${ }^{246}$ Esta fundamentación tiene la ventaja de su propia eficacia pues se ha demostrado que las normas de derecho tienen un nivel más elevado de cumplimentación si se considera que son justas más que si se temen a las consecuencias de su desobediencia. Además, tiene la ventaja de dar elementos concretos de justificación que se resumen en la diligencia empresarial. En otras palabras, fundamentar la responsabilidad en la retribución facilita encontrar medios de justificación o eximentes que dependen o están en manos de las personas jurídicas: ellas pueden crear su propio rumbo y destino.

Precisamente por todo lo anterior se dice que el modelo vicarial está en crisis, y la doctrina de ese país ha ido elaborando otros modelos de responsabilidad penal que son muy importantes para el desarrollo de este trabajo.

\subsection{Relajamiento de la Identify theory o respondant}

\section{superior}

Específicamente en Estados Unidos de Norteamérica las críticas al sistema vicarial extremo se enderezan porque en muchos de los casos en que se aplica no toma en cuenta las condiciones de vida de la empresa, y por lo tanto, el concepto de justicia, que dirige y justifica el sistema penal, se ve comprometido: r̃allí donde la empresa ha realizado esfuerzos diligentes para cumplir con el Derecho, y no hay indicios de que el management empresarial ha comulgado con las prácticas ilegales, la imposición de una pena a la empresa por la acción aislada de un empleado subordinado plantea importantes cuestiones de

246 Ib Ídem, p. 204. 
justiciaò ${ }^{247}$ Nosotros (los de tradición romano germánica) reprocharíamos esa sencillez, su falta de fundamentación dogmática, y por supuesto, le impondríamos aquellas otras críticas que se han generado para los modelos de responsabilidad por rãtribución.

Algunos Tribunales han seguido la tesis de la róliligencia empresarialò y han absuelto a empresas cuando se demuestra que realizaron una conducta adecuada a derecho. En el caso United Status ex rel Porter vs. Kroger Grocery and Baking Company de 1947 se reconoció lo anterior, esto es, que no debía condenarse a la empresa cuando las acciones delictivas de un empleado subordinado fueran realizadas sin el conocimiento de la empresa y en contra de sus instrucciones específicas, y es que ra medida que las dimensiones de un negocio crecen, y se imposibilidad la supervisión personal, también las dificultades crecieron en correspondencia con ello. Con toda seguridad, un cumplimiento del $100 \%$ no puede esperarse en ningún caso, de hecho, resulta imposible ${ }^{48}$. Mirando las fechas de varios precedentes se entiende que se diga que la progresión hacia algo diferente del modelo vicarial de responsabilidad nace casi al mismo tiempo que nació ella. A la fecha se considera que cada vez más la tendencia es hacia el alejamiento de la teoría vicarial y hacia una verdadera y genuina responsabilidad empresarial. ${ }^{249}$

Estas nuevas tendencias están representadas por el CP Modelo de 1962 y por las Directrices para imponer sentencias a organizaciones (organizacional sentencing guidelines). El primero acoge la teoría del órgano (solamente un directivo o representante, por lo menos con su conocimiento y autorización de la acción de un subordinado, puede detonar la responsabilidad de la empresa), y las segundas se acercan a una culpabilidad empresarial.

247 LAUFER, W. S., y STRUDLER, A., Op. cit., p. 211.

$248 \mathrm{Ib}$ Ídem, p. 216, en relación con nota 77.

${ }^{249} \mathrm{Ib}$ Ídem, p. 219 y 220. 
Las Directrices constituyen un cambio de paradigma en la manera de conceptualizar la culpabilidad empresarial ${ }^{250}$. En 1984 el Congreso estadounidense dicto la Ley para la reforma de la imposición de sentencias, creándose con ello la Comisión Sentenciadora (Sentencing Comisión). Esta tuvo la misión de originar fórmulas generales para establecer parámetros controlables y previsibles al imponer la sentencia, ante el contexto de la disparidad de criterios a la hora de establecer la misma. El producto fueron las Directrices ya comentadas, que significaron un cambio de paradigma por el abandono del enfoque basado en la teoría de las sanciones óptimas, propia del análisis económico del derecho ${ }^{251}$.

Las Directrices para dictar Sentencias contra Organizaciones Condenadas (DSOC) constituyen un cambio de paradigma porque a diferencia de la concepción vicaria, el nuevo enfoque obliga, mediante ley escrita, a los Tribunales a considerar una genuina responsabilidad empresarial, no prestada de las personas físicas, sino propia, derivada de los atributos de la organización ${ }^{252}$. Sus lineamientos generales son: se restringe al marco jurídico federal (delitos federales graves y menos graves: fraude, robo, defraudación tributaria, infracciones contra la competencia, blanqueo de capitales, extorsión y cohecho; no rige en infracciones en materia ambiental, alimenticia y farmacológica); son aplicables a toda organización, incluyendo pequeñas empresas (lo que ha generado cierta polémica); tienen el objetivo de que las organizaciones prevengan, detecten e informen de las infracciones de la ley; y previenen como sanciones básicamente la obligación de

250 GÓMEZ-JARA, La responsabilidad empresarial en EE. UU., Op. Cit., p. 64.

251 Ib Ídem, p. 64.

252 LAUFER y STRUDLER, Op. Cit., p. 224. Así también ZUÑIGA R., L., Bases..., Op. Cit., p. 128, pues señala que las Directrices constituyen un giro copernicano de las técnicas de control de los comportamientos criminosos de la empresa, y genera incentivos a las empresas que se organizan de acuerdo al aseguramiento del respeto a la ley. 
resarcir el daño causado por la infracción, la supervisión judicial, y la multa pecuniaria ${ }^{253}$.

De ahí que en la doctrina se hayan desarrollado diferentes tipos de modelos de culpabilidad empresarial genuina y directa ${ }^{254}$ :

1. Culpabilidad empresarial proactiva.

2. Culpabilidad empresarial reactiva.

3. Ethos empresarial.

4. Políticas empresariales.

La primera se centra en las políticas, procedimientos y prácticas de la empresa, y confirma la culpabilidad cuando se demuestra que los anteriores fueron insuficientes para asegurar el comportamiento adecuado a la ley de sus miembros, o incluso, fue importante para la promoción del delito. Esto es, rel ejercicio proactivo de la diligencia debida (esto es, la prudencia y atención que deben poner los empleados de la empresa en circunstancias similares) constituyen el test decisivo de (este modelo de culpabilidad) ${ }^{255}$.

El segundo modelo ubica los puntos críticos a medir y ponderar en momentos posteriores a la comisión de la infracción: si la empresa ha reaccionado frente al hecho delictivo de forma adecuada, esto es, ha denunciado el hecho ante las autoridades de forma espontánea, investigando y dando todo lo que le pidan los investigadores oficiales, además, si realizaron, después del hecho, las medidas de carácter preventivo y correctivo que exige el caso.

El tercer modelo mira hacia el ethos organizativo o personalidad organizativa. Si las políticas, misión, visión, valores, lo que realmente se premia y valoriza dentro de la organización, favorece o promueve la

253 Vid, GÓMEZ-JARA, La responsabilidad penal de las empresas en EE. UU., Op. Cit., p. 68 a 72. Para encontrar las DSOC en castellano, vid. Ib Ídem, p. 114 a 163, en la Adenda, que reproduce el capítulo 8 de las mismas.

${ }^{254}$ Cfr. Principalmente con LAUFER Y STRUDLER, Op. Cit., p 74 y sigs.; y GÓMEZJARA, C., La responsabilidad penal de las empresas en EE. UU., p. 83 y sigs. 255 LAUFER y STRUDLER, Op. Cit., p. 76. 
infracción de la ley, entonces es evidente su culpabilidad de la empresa: rél ethos organizativo se puede descifrar de la jerarquía empresarial, los objetivos y las políticas empresariales, los esfuerzos por cumplir con los códigos éticos y las regulaciones jurídicas, así como las indemnizaciones a los empleadosò ${ }^{256}$

Por último, la tesis de la culpabilidad empresarial como políticas empresariales sostiene que la acción y la intención corporativa pueden localizarse en opciones e intenciones que se comunican a los miembros de la empresa a través precisamente de las políticas empresariales.

Las desventajas de estas construcciones teóricas consisten en que desempatan o no analizan los dos por separado y a la vez, los conceptos de Derecho Penal exigidos para cualquier infracción criminal: el actio rea y el mens rea. Por otro lado, valoran la culpabilidad anterior o posterior, y reflejan la existencia de responsabilidad más que de culpabilidad. ${ }^{257}$ Por eso, hay otras propuestas diferentes, como lo es, la culpabilidad constructiva.

Esta tesis (la culpabilidad constructiva) exige que, para que haya infracción criminal, es necesario una acción ilegal (actio rea) y un estado mental corporativo (mens rea). La primera se encuentra en la llamada rácción primariaò que es una autorizada por la entidad, cuyo carácter lo adquiere toda acción que razonablemente se puede decir que son acciones de la empresa en virtud de su tamaño, complejidad, formalidad, funcionalidad, procesos y estructuras de tomas de decisión. Por lo que hace al estado mental, que puede ser intención, conocimiento, imprudencia y negligencia, de la empresa a través de sus órganos. ${ }^{258}$

Podemos concluir que en el sistema anglosajón de los Estados Unidos de Norteamérica existe de manera inveterada la práctica judicial

\footnotetext{
256 LAUFER Y STRUDLER, Op. Cit., p. 77.

257 Ib Ídem, p. 79 y sigs.

258 Ib Ídem, p. 84 a 91.
} 
y legislativa (en ese orden) de criminalizar a las personas jurídicas. Las necesidades político criminales, y sobre todo, la realidad social que exponían a las empresas como generadoras de riesgos inaceptables o intolerables, derivó en el reconocimiento judicial de su capacidad de acción y culpabilidad, y por tanto, de penas. El modelo que ha regido en la práctica judicial estadounidense ha sido y es un modelo p̃por atribuciónò esto es, la acción y la culpabilidad de la persona física miembro de la empresa es, también y a la vez, la acción y culpabilidad de la empresa. Las Sentencing Guidlines son reglas para graduar sanciones ya impuestas, no para decidir si la empresa es culpable o no lo es; pero precisamente porque afectan a la graduación de la pena, es claro que se vinculan fuertemente con la culpabilidad, y han sido de gran utilidad para que los países de nuestra tradición puedan abrevar de esas perspectivas y construir una verdadera culpabilidad de la persona jurídica.

\subsection{El caso francés}

Antes de 1994 en Francia prevalecía la criminalización exclusivamente para las personas físicas o individuales. Sin embargo, con la aprobación del nuevo CP hoy en día se admite abierta y expresamente la responsabilidad penal de las personas jurídicas. ${ }^{259}$

${ }^{259}$ El art. 121-2 del nuevo CP Francés, reza así: "Las personas jurídicas, con exclusión del Estado, son responsables penalmente, conforme a lo dispuesto por los art.s 121-4 a 121-7 y en los casos previstos por la ley o el reglamento, de las infracciones cometidas por cuenta suya, por sus órganos o representantes"

"Sin embargo, las colectividades territoriales o sus agrupaciones sólo serán penalmente responsables por las infracciones cometidas en el ejercicio de actividades susceptibles de ser objeto de conciertos de delegación de servicio público"

"Sin perjuicio de lo dispuesto por el párrafo cuarto del art. 121-3, la responsabilidad penal de las personas jurídicas no excluye la de las personas físicas autores o cómplices de los mismos hechos". 
Antes de esa importante reforma existían algunas normas, con carácter de ley, que la doctrina cita insistentemente ${ }^{260}$, pero que finalmente fueron insuficientes para estimar que el principio societas delinquere non potest fuere considerado abrogado. Más recientemente, y en un país donde la responsabilidad individual (o la prohibición de la trascendencia de las penas) lo identifica como nación (por haberse gestado y culminado las ideas de la llustración) y donde los Tribunales permanecían reacios a aplicar sanciones a las empresas, incluso las multas, que consideraban multas personales, se estableció en al Código del Trabajo la responsabilidad solidaria de la empresa para el caso de muerte o lesiones de los trabajadores y la Ordenanza de 1986 relativa a la regulación de precios y competencia. La Comisión de reforma del $\mathrm{CP}$ incluyó en sus discusiones más importantes lo relativo a la ciriminalización de las empresas, y en 1992 aprobó el Noveau Code Penal, vigente a partir de 1994, que significó el parte aguas que implica el verdadero cambio de paradigma. ${ }^{261}$

Los comentaristas franceses en habla hispana ${ }^{262}$ señalan varios aspectos que aquí trataremos de verificar. Por un lado el

\footnotetext{
260 Ordenanzas de 5 de mayo de 1945 relativa a la represión de los hechos de colaboración realizados por las empresas de prensa durante el último conflicto mundial, admitía la posibilidad de perseguir penalmente, a título de autor o cómplice, a cada sociedad, asociación o sindicato, de derecho o hecho, órganos de dirección o administración, etc.; la segunda ordenanza de 30 de mayo de 1945 reprimía infracciones de cambios, instituía procedimiento penal a la persona jurídica cuando algunos de sus administradores o directores actuaran por cuenta o en nombre de ella; y la tercera, de 30 de junio de 1945, sobre infracciones a la legislación económica, contemplaba la posibilidad de pronunciar interdicción del ejercicio de la profesión a una persona jurídica de derecho privado cuando el delito se hubiese cometido por su cuenta. Cfr. ABOSO, G.E., ABRALDES, S.F., Responsabilidad de las personas jurídicas en el Derecho Penal, BdF, Buenos Aires, 2000, p. 129 y 130.

261 ZUÑ̃GA R., L., Bases..., Op. cit., p. 110.

262 Ib Ídem; además, PRADEL, J., La responsabilidad penal de las personas jurídicas en el Derecho francés: algunas cuestiones, $R d D P C$, núm. 04, 1999, 661 a 677; el mismo, "Derecho Penal económico francés: algunos aspectos actuales", Revista del Poder Judicial, núm.49, 1988, 361 a 372; el mismo, "La responsabilidad penal de las personas jurídicas en el Derecho Penal francés: algunas cuestiones", $A D P$, Universidad de Friburgo; el mismo, "La responsabilidad penal de la persona jurídica", La responsabilidad criminal de las personas jurídicas: una perspectiva comparada, Tirant lo blanch, Valencia, 2001; BACIGALUPO, S., La responsabilidad..., Op. cit.; ZUÑIGA R., L., Bases para un modelo..., Op. cit.
} 
cuestionamiento de quién (qué persona jurídica) puede ser responsable penalmente; por otro, cuáles son los requisitos de imputación penal para la persona jurídica (desde qué significa que sus representantes cometan infracción ñpor cuenta suyaò hasta el dolo o la culpa); además, qué significa aquello que la responsabilidad penal de la jurídica es independiente de la de la física (si estamos hablando de una responsabilidad por atribución o por hecho de conexión), y por último, la sanciones.

En primer lugar, sólo las personas jurídicas con personalidad jurídica reconocida, de derecho privado, puede ser sujeto activo de delito en Francia. De ahí, que la legislación excluya en principio a cualquier otra agrupación de personas de facto ${ }^{263} \mathrm{o}$ en formación (la formación de una persona jurídica puede durar varios meses) ${ }^{264}$, que no tenga personalidad reconocida por el derecho, y por otro lado, a las personas jurídicas de derecho público ${ }^{265}$.

Por lo que hace a las agrupaciones de facto, es controvertida aquella cuestión que se refiere a aquellas asociaciones que han sido liquidadas o disueltas y fusionadas, esto es, si ellas tendrían responsabilidad penal. La solución correcta apunta a que si es posible siempre y cuando la infracción se cometa durante la vida de la persona jurídica; problema diferente plantea lo dispuesto por el art. 133-I del CP francés que previene que ré la disolución de la persona jurídicaé impide o paraliza la ejecución de la pena. Sin embargo, puede procederse al cobro de la multa y de los gastos de justicia, así como a la ejecución de la confiscacióné después de la disolución de la persona

263 Lo que dejaría fuera de responsabilidad a agrupaciones de personas importantes en la vida económica diaria en la actualidad, por ejemplo, Holdings, multinacionales, etc., Vid. ZUÑIGA, Op. Cit. p. 112.

${ }^{264}$ Sólo puede tener responsabilidad una persona jurídica en formación cuando los delitos se cometan antes de que adquiera el reconocimiento jurídico, si confirma dichos actos. Cfr. PRADEL, "La responsabilidad penal de la persona jurídica", Op. Cit., p. 142.

265 Se dice que el Estado no puede "castigarse así mismo", Cfr. PRADEL, Op. Cit., p. 141. Aunque existe una excepción prevista en el segundo párrafo del 121-2 del CP Francés. 
jurídica hasta el cierre de las operaciones de liquidaciónò puesto que solamente se refiere a la ejecución de la pena, esto es, una vez que haya sido declarada en sentencia la responsabilidad de la persona jurídica.

Lo relativo a que sólo las personas de derecho privado pueden ser criminalizadas, puede enfrentarse con el principio de igualdad. Parece injustificable que una persona pueda ser criminalizada o no dependiendo de las funciones para las que fue creada así como su origen: si es privada, puede ser criminalizada, si es pública, es inmune a criminalización. La injustificabilidad radica en que la potencialidad de dañosidad social no radica en su carácter ni en las funciones que ejerce, sino en el incremento de riesgo al ámbito de organización de otra persona expresando con ello una desautorización a las normas jurídicas, cuando la persona tenía las condiciones de adecuar su conducta a la norma, esto es, depende de su propia conformación y decisión. Sin embargo, se prefirió esta fórmula (la inmunidad de las personas jurídicas públicas) puesto que de lo contrario quien pagaría la pena sería en realidad cada uno de los ciudadanos de un Estado.

Más controvertidos aún son los presupuestos de imputación penal de la persona jurídica: qué clase de infracciones puede dar lugar a su responsabilidad, qué clase de personas físicas pueden detonarla, que significa actuar ñpor cuenta suyaò y cómo se justificaría y se construiría el dolo o la culpa de la persona jurídica. Las respuestas las ha dado tanto la doctrina como la jurisprudencia francesa.

Es importante señalar que la legislación francesa eligió el sistema de numerus clausus para la criminalización de la persona jurídica, tanto en materia de delitos como de contravenciones. Podrá ser condenada por los delitos de genocidio, homicidio y heridas involuntarias, tráfico de estupefacientes, blanqueo de dinero, puesta en peligro de muerte, discriminaciones, proxenetismo, atentado a la vida privada, hurto, extorsión, chantaje, estafa, malversaciones, receptación, daños, traición, espionaje, atentado, complot, participación en un 
movimiento insurreccional, corrupción, tráfico de influencia, usurpación de funciones o de título, falsificación de documentos y moneda, terrorismo; así como por contravenciones como atentados involuntarios a la integridad personal, difusión de mensajes indecentes, amenazas de destrucción que entrañan un daño ligero, atentados contra la moneda, utilización de pesos y medidas diferentes. De esta forma la legislación excluye varios campos o ámbitos de delitos que pueden considerarse como aquellos que preferentemente comete la persona jurídica, como por ejemplo, infracciones al derecho tributario y aduanero, al derecho de sociedades mercantiles, derecho del consumidor, la mayor parte del derecho laboral, entre otros. ${ }^{266}$

Por lo que hace a las personas físicas que desatan o detonan la responsabilidad penal de las personas jurídicas, la ley es muy clara al referirse solamente a los rórganos y representantesò De esta forma, el modelo francés ha seguido, por un lado, la responsabilidad indirecta o por atribución, y, por otro lado, la teoría del órgano.

La teoría del órgano establece que de todas las personas que pueden ractuaròen el seno de la persona jurídica, solamente serán los órganos o representantes los que vinculen a ésta, en cuanto a su responsabilidad penal. No la vincularán, por tanto, aquellos subalternos que no tengan dentro del escalafón la importancia suficiente de decisión o representación. Solamente lo harán los administradores, directores 0 representantes de la misma, los que con su actuación expresen lo que la agrupación pretenda expresar.

Esto deja algunos cuestionamientos que han sido resueltos: El administrador de hecho (el que no ha sido reconocido jurídicamente por la sociedad como su representante) no puede detonar la responsabilidad penal de la persona jurídica ${ }^{267}$; además, la

\footnotetext{
266 PADREL, Op. Cit. p. 145.

${ }^{267} \mathrm{Ib}$ Ídem, p. 154 y 155. Con crítica de ZÚÑIGA, Op. Cit., p. 114, por excesivo formalismo, dejando a un lado conductas realmente dañosas de personas con dominio en la organización pero sin un nombramiento oficial.
} 
extralimitación en las facultades por parte del administrador si podría acarrear responsabilidad para la persona jurídica siempre y cuando actuara en su beneficio financiero; y aquellas causas de inculpabilidad del órgano o representante no generarían responsabilidad penal a la jurídica. ${ }^{268}$

Entonces, qué significa actuar por r̃cuenta suyaò (de la organización empresarial). El concepto es vago y puede dar lugar a dudas en su aplicación práctica, es muy amplio y parece que no está, y difícilmente estará, definido. ${ }^{269}$ Sin embargo, podemos señalar algunas coincidencias. En principio, parece que no es controvertido en la doctrina la definición de aquello que no vincula a la persona jurídica: los actos de la física que sean en perjuicio de la jurídica, o a favor de algunos pocos miembros de la misma, o a favor de la comunidad, esto es, de los intereses del Estado. ${ }^{270}$ Tampoco es controvertido el hecho de que por lo menos son dos los casos en que es fácil admitir tal vinculación: el primero, el más simple y evidente, es la de la búsqueda de una ventaja financiera, el segundo, es actuar dentro de las atribuciones expresas de la empresa (inclusive por culpa in vigilando o in eligiendo).

El dolo y la culpa de la persona física también se atribuyen a la persona jurídica, aunque tienen ya la interpretación de tribunales que exigen un dolo propio de la persona jurídica ${ }^{271}$. Sin embargo la doctrina

\footnotetext{
268 PRADEL, Op. Cit., p. 155.

269 ZUÑIGA R., Op. Cit. p. 116.

270 Ib Ídem, p. 159; ABOSO Y ABRALDES, Op. Cit., p. 160; BACIGALUPO, S., "La responsabilidad penal de las personas jurídicas", Op. Cit., p. 151.

${ }^{271}$ La doctrina reporta que existen los dos criterios para resolver el problema del dolo y la culpa: el directo y el indirecto. Por el segundo se decantan, por ejemplo, una decisión del Tribunal correccional de Verdu, de 12 de julio de 1995; pero por el primero, citan tres decisiones, una del Tribunal de París de 3 de noviembre de 1995, el Tribunal de Versalles de 18 de diciembre de 1995, y el de Lyon de 9 de octubre de 1997, donde campea el criterio de que el dolo o la culpa de la persona jurídica es diferente del de la persona física. Vid. PRADEL, Op. Cit., p. 148. En esta última sentencia es posible leer que "la responsabilidad penal de la persona jurídica exige que se determine en su contra el conjunto de elementos constitutivos de la infracción perseguida, el elemento material por una parte, el elemento intencional por otra, que consisten en una omisión deliberada o en la
} 
considera como algo incontrovertido la tesis del órgano, esto es, que la persona jurídica no puede querer o no querer algo, sino que son sus órganos o representantes quienes lo hacen.

Por último, el sistema de sanciones no es muy rico, sin embargo existen las suficientes para considerarlo adecuado. La principal es la multa, que además de todo parece la más indicada para ser aplicada a las personas jurídicas, y ha sido reconocido por el Consejo Constitucional como legítima: m̃o existe ningún principio de valor constitucional que se oponga a que una pena de multa pueda ser pronunciada a la vista de una persona moralò ${ }^{272}$

Según el art. 132-24 del CP francés establece que el juez debe pronunciar la pena de multa r̃eniendo en cuenta igualmente los recursos y el cargo del autor de la infracciónò mientras que el diverso 131-38 permite que la multa puede fijarse hasta el quíntuple del monto aplicable a la persona física. Ante este panorama, y teniendo en cuenta que la multa debe perseguir un fin suficientemente disuasorio, se imponen dos límites deseados en la condena dineraria: que no sea demasiado elevada como para frenar la actividad económica de la organización empresarial y terminar su función de facto; y por el otro, que no sea tan mínima como para que deje de ser disuasoria. Con todo, se debe de tomar en cuenta que el límite mínimo no debe identificarse con el beneficio obtenido con el delito, puesto que si así fuera, simplemente la empresa la prevería de forma tal que ya se incluiría en los egresos anuales o hasta la asegure (ante una compañía aseguradora) y se integre a sus gastos normales.

realización de actos imputables a su órganos pero distintos de aquellos que podrían ser reprochados a las personas físicas que hayan participado en la comisión de la infracción. Cualquier otra solución conduciría en la práctica a erigir una responsabilidad penal de las personas jurídicas por los hechos de los dirigentes que actúan por su cuenta", Vid. GÓMEZ-JARA DIEZ, Carlos, "El nuevo art. 31.2 del CP: Cuestiones de lege lata y de lege ferenda", en GÓMEZ-JARA DIEZ, Carlos (Editor), Modelos de autorresponsabilidad penal empresarial. Propuestas globales contemporáneas, Thompson Aranzadi, Navarra, 2006, página 269, nota 60 .

272 ABOSO Y ABRALDES, Op. Cit., p. 166. 
Otras sanciones como la disolución, la colocación de la persona jurídica bajo vigilancia judicial, la prohibición de ejercer directa o indirectamente una $\mathrm{o}$ varias actividades profesionales $\mathrm{o}$ sociales, $\mathrm{O}$ sanciones patrimoniales diferentes a la multa, forman un universo que es bienvenido y que puede ser utilizado para el buen combate a la delincuencia económico empresarial.

\section{MODELO DEL HECHO DE REFERENCIA O HECHO DE CONEXIÓN SIN CULPABILIDAD PROPIA DE LA PERSONA JURÍDICA}

Las características fundamentales de estos modelos, tal vez serían las siguientes:

a. Un hecho de conexión. Esto es, que la persona jurídica se le considerará responsable por los hechos o actos de alguna persona física que sea órgano o representante. Es el elemento que determina el quién desata la responsabilidad penal de la persona jurídica.

b. El actuar dentro del r̃senoò o en el m̃marcoò de la empresa. Este elemento es el que determina cuándo y en qué términos se debe de dar el hecho de conexión para dar vida a la responsabilidad penal de la empresa.

c. El actuar r̃en beneficioòo ren provechoòde la entidad colectiva. Este aspecto tiende a distinguir cuándo la persona jurídica es víctima y no tanto victimaria del delito.

d. También puede desatar la responsabilidad cualquier persona empleada de la empresa, siempre y cuando reúna los requisitos anteriores (a excepción del inciso a.) y lo haga por ausencia de control de algún directivo o gerente del inciso a.

Esta aclaración resulta importante, puesto que los problemas a los que se enfrenta este tipo de modelos de responsabilidad penal son 
diferentes a los que enfrentarían aquellos otros modelos que llamaremos de $\tilde{\text { rresponsabilidad originariaơ }}{ }^{73}$.

Una cantidad importante de legislaciones, como tendremos oportunidad de verlo, construyen, expresamente, la imputación de las consecuencias jurídicas por la comisión del delito a la persona jurídica a partir de la acción y culpabilidad de la persona física. El hecho antijurídico y culpable de la persona física es el t̃necho de conexiónòa través del cual se le imputa la acción y la culpabilidad a la organización empresarial. Lo que hacen los modelos que justifican esta concepción es, más que legitimar la pena o las consecuencias jurídico penales por esta vía, establecer qué personas dentro de la persona jurídica y bajo qué condiciones, se desencadenaría la responsabilidad de ésta.

A diferencia de la identification theory o respondant agent, que exige que solamente los administradores o socios o gerentes de la empresa (controlling officers) pueden desatar la responsabilidad penal de la persona jurídica, cuando en ellos se encuentran los elementos objetivos y subjetivos del delito así como la culpabilidad, sino que se abren dos vías, ambas con ciertas exigencias: Por un lado, los administradores pero siempre y cuando lo hagan en el r̃contexto socialò (es decir, en ejercicio de sus competencias) y en beneficio, en provecho o en favor de la persona jurídica; por otro, cualquier empleado que en las mismas condiciones logré cometer el delito por la falta de control de los administradores. Ya no se entiende al administrador o representante de la empresa como el alter ego de ella (así simplemente), sino que se

273 Esta misma distinción, pero referida como Heterrorresponsabilidad y Autorresponsabilidad de la persona jurídica, la hace también GÓMEZ-JARA, Vid. GOMEZ-Jara Díez, Carlos, "El modelo constructivista de autorresponsabilidad penal empresarial”, en Carlos Gómez-Jara Díez (ed.), Modelos de autorresponsabilidad penal empresarial, propuestas globales contemporáneas, Navarra, Aranzadi, 2006; el mismo, "El nuevo art. 31.2 del CP: cuestiones de lege lata y de lege ferenda", en Carlos Gómez-Jara Díez (ed.), Modelos de autorresponsabilidad penal empresarial, propuestas globales contemporáneas, Navarra, Aranzadi, 2006; el mismo, La culpabilidad penal de la empresa, Barcelona, Marcial Pons, 2005, pássim; el mismo, "Autoorganización empresarial y autorresponsabilidad empresarial: hacia una verdadera responsabilidad penal de las personas jurídicas", RECPC, número 8, 2005, pássim. 
exige que lo haga bajo ciertas condiciones. Ya no es solo el administrador o gerente de la empresa, sino otros empleados, pero porque los administradores no ejercieron el debido control sobre ellos.

En el primer caso, la persona jurídica recibe el injusto de su administrador, del que ella es responsable; en el segundo caso, la persona jurídica recibe un injusto diferente de su administrador (tal vez un injusto imprudente de omisión de cuidado sobre el delito de otra persona ï el empleado), pero no el injusto del empleado. La lógica del modelo es que las penas más graves a la empresa se dan cuando el delito lo cometen los dirigentes, y penas más leves cuando el delito lo cometen los empleados por falta del control del administrador.

Este modelo es el que Nieto llama versión intermedia del agente de la responsabilidad vicaria ${ }^{274}$, y que es propio de los modelos de la Unión Europea y de las Decisiones Marco.

La otra característica del modelo es que no contempla ningún elemento que pueda generarse a favor de la defensa de la persona jurídica. Esto es, no vale la organización adecuada de la persona jurídica, ni su voluntad fiel al derecho ni las políticas internas de cumplimiento del orden jurídico. La culpabilidad del agente también se le transfiere a la persona jurídica.

\subsection{El caso alemán}

En Alemania el principio societas delinquere non potest sigue estando, hoy en día, vigente. El CP alemán no previene algún dispositivo o artículo que especialmente amplié la responsabilidad penal para las personas jurídicas, de suerte tal que se ha interpretado en la doctrina, de forma casi unánime, que las organizaciones empresariales

${ }^{274}$ NIETO MARTÍN, Adán, La responsabilidad penal..., Op. Cit., página 94 y 95. 
no delinquen ${ }^{275}$, y es más, consideran que a nivel constitucional existe el pronunciamiento del principio de culpabilidad (y que constriñe a aplicar el Derecho Penal únicamente a las personas físicas) y que ha reconocido el Tribunal Constitucional ${ }^{276}$.

En Alemania es donde más han desarrollado, quizás, los sistemas de la Ciencia del Derecho Penal y en especial, de la dogmática jurídico penal, hasta límites insospechados, que le han llevado a ser un referente a nivel internacional, en aquellos países que siguen su tradición (como España, por supuesto), y ha desarrollado todas las categorías de Derecho Penal sustantivo en base a la persona física o humana. La persona humana es el centro en cuyo derredor giran las concepciones dogmáticas y desarrollos sistemáticos más avanzados hoy en día.

No debe confundirse nuestras afirmaciones anteriores (esto es, la impunibilidad de la persona jurídica, por la no previsión en el CP o leyes especiales penales) con el contenido del art. 14 del CP que establece la hoy en día muy conocida figura del rãactuar en nombre de otroơ ${ }^{77}$. Ahí se señala que también será castigado con pena aquella persona representante de una persona jurídica que cometa el hecho delictivo pero sin tener las cualidades exigidas por el tipo penal. Es unánime en la doctrina ${ }^{278}$ que dicha figura jurídica no implica la responsabilidad penal de las personas jurídicas, de forma tal que el

275 JESCHECK, T.W., Tratado, Op. Cit., p- 243 a 246; STRATENWERTH, G., Derecho Penal, Parte General I, el hecho punible, Civitas, Navarra, 2005; ROXIN, Derecho Penal, parte general, Op. Cit., p. 259 y 260; WELZEL, Vid. nota 27 y sigs. De otra opinión, JAKOBS, Derecho Penal, Op. Cit. p. 184, aunque en forma posterior abandona su inicial postura, Vid. el mismo, “¿Puniblidad de las personas jurídicas?", Op. Cit., p. 328, nota 7.

276 BVefGE 20, 323.

277 Este art. fue introducido en Alemania a finales de los años setentas, y fue el modelo que siguió el CP español en las importantes reformas de 1983 que lo prevenía en su art. 15 bis. Después, con la derogación de ese Código y la generación del nuevo, en noviembre de 1995, dicha figura de "la actuación en lugar de otro" está prevista en el art. 31. Vid. por todos GRACIA M., L., El actuar en lugar de otro en Derecho Penal, Teoría general, Editorial Universidad de Zaragoza, Zaragoza, 1985.

278 Por todos, Ib Ídem. 
principio societas delinquere non potest no se deroga por dicho artículo., sino más bien se trata de casos de extensión de punibilidad para aquellas personas físicas que realizan de forma personal la conducta delictiva, sin poseer las cualidades personales exigidas por los tipos penales especiales, que sólo las posee la persona representada (física o jurídica). Así se llenaba un ñacíoòen el sistema de justicia penal que en su momento dio lugar a impunidad.

Sin embargo, los esfuerzos que se han realizado para controlar a través del ius puniendi a la criminalidad de empresa han sido a través del Derecho Administrativo. En efecto, la Ley de Contravenciones o OWiG (Derecho Administrativo Sancionador) en su parágrafo 30 sí establece la punición de las personas jurídicas con una sanción pecuniaria hasta de un millón de Euros, cuando alguien, como órgano legítimo de representación de una ñpersona jurídica o como miembro del mismo, como director de una asociación sin capacidad jurídica o como miembro de su dirección, como socio que ostenta la representación legítima o como procurador que ocupa una posición directiva de un ente de esta naturaleza, haya cometido un delito o una infracción administrativa mediante la lesión de los deberes de la entidad o habiendo o debiendo haber conseguido un enriquecimiento de éstaò 279. Este parágrafo fue reformado en 1986 para quedar tal como está, no obstante, antes de dicha reforma preveía solamente una responsabilidad subsidiaria para la empresa, y así está ya acorde con la Segunda Ley contra la delincuencia económica.

El parágrafo 130 de OWiG también establece para la persona jurídica algo así como un deber de vigilancia sobre las conductas de sus subordinados, es decir, para que no cometan delitos, cuya infracción sería el fundamento de la responsabilidad de la organización empresarial. De la redacción de dicho artículo se han generado todas las construcciones dogmáticas sobre la responsabilidad penal de las personas jurídicas en Alemania, considerando que si bien el CP no

279 JESCHECK, Op. Cit., p. 244. 
prevé ninguna consecuencia para la empresa, el Derecho administrativo sancionador es expresión del mismo ius puniendi del Estado, que también exige culpabilidad en ella.

No obstante, debemos decir que los modelos de criminalización de las personas jurídicas más desarrollados o de cuyos fundamentos se puede construir un mejor modelo para la criminalización de las personas jurídicas son, principalmente, originados en Alemania. Desde Jakobs (por su tesis de la prevención general positiva y la teoría de los sistemas autopoiéticos) ${ }^{280}$, Tiedemann (quien fue quien inició una tesis inteligente y con necesidad de completarse, muy convincente, que se le ha dado por llamarle teoría de la responsabilidad penal por defecto en la organización) ${ }^{281}$, Dannecker (con su tesis de la culpabilidad ética social, y la responsabilidad por el carácter criminógeno de la empresa) ${ }^{282}$, hasta Heine (con su tesis de la culpabilidad por la conducción de la empresa) ${ }^{283}$, todos ellos reconocen que en Alemania

${ }^{280}$ Derecho Penal. Fundamentos...Op. Cit., p. 184.

281 TIEDEMANN, K., "El Derecho Penal económico en la comunidad europea", Estudios de Derecho Penal Económico, Castilla la Mancha, Universidad Castilla la Mancha, 1994, 235 a 254; el mismo, "Presente y futuro del Derecho Penal económico", en V.V. A.A. Jornadas en Honor del Profesor Klaus Tiedemann, Hacia un Derecho Penal económico europeo, Madrid, BOE, Universidad Autónoma de Madrid, 1995, 29 a 44; el mismo, "Exigencias fundamentales de la Parte General y propuesta legislativa para un Derecho Penal europeo", $R P$, número 3, 1999, 76 a 86; el mismo, "Presente y futuro del Derecho Penal económico", V.V. A.A., Homenaje al Profesor Dr. Gonzálo Rodríguez Mourillo, Civitas, Madrid, 2005, 1029 a 1037; el mismo, "El concepto de derecho económico, de Derecho Penal económico y de delito económico", $C P C$, número 28, 1986, 65 y sigs.; el mismo, "Responsabilidad penal de las personas jurídicas", Anuario de Derecho Penal, Universidad de Friburgo, 1996, el mismo, "Responsabilidad penal de personas jurídicas, otras agrupaciones y empresas en derecho comparado", La reforma de la justicia penal: Estudios en homenaje al Prof. Karl Tiedemann, Publicaciones de la Universitat Jaume I, 1997, p. 12 y sigs.

282 DANNECKER, Gerhard, "Sanciones y principios de la parte general del derecho de la competencia en las comunidades europeas", en V.V. A.A. Jornadas en Honor del Profesor Klaus Tiedemann, Hacia un Derecho Penal económico europeo, Madrid, BOE, Universidad Autónoma de Madrid, 1995, 545 a 564; DANNECKER, Gerhard, "Reflexiones sobre la responsabilidad penal de las personas jurídicas", Revista Penal, núm. 7, 2001.

283 HEINE, Günter, "Modelos de responsabilidad jurídico-penal originaria de la empresa", en Carlos Gómez-Jara Díez (ed.) Modelos de autorresponsabilidad penal empresarial, propuestas globales contemporáneas, Navarra, Aranzadi, 2006; el mismo, "La responsabilidad colectiva: una tarea pendiente a la luz de la evolución penal europea", en Carlos Gómez-Jara Díez (ed.) Modelos de autorresponsabilidad 
las personas jurídicas no pueden delinquir (penalmente). Pero los modelos que construyen o son de lege lata para la operatividad del parágrafo 130 de OWiG, o de lege ferenda para su posible aplicación en un futuro $\mathrm{CP}$ que se reforme y acepte abiertamente dicha responsabilidad penal; hecha excepción de Jakobs, quien como ya lo comentamos ha concluido la incapacidad de la empresa a cometer delitos por su imposibilidad de desautorizar las normas y de comunicar por tanto, el rompimiento de la vigencia de las mismas ${ }^{284}$.

\subsection{El caso holandés}

En Holanda la responsabilidad penal de las personas jurídicas es una práctica que aparece, por lo menos, desde $1951^{285}$. Por lo tanto, podemos encontrar un rico y nutrido bagaje de respuestas en este tema en ese país que puede enseñarnos, en primer lugar, que sí es posible practicar una dogmática diferente a la que venimos practicando en los países de un Derecho Penal de tradición romano germánica, sin perjuicio de los principios liberales de nuestra ciencia, y además, de los aspectos, gruesos hasta los más finos, de la forma en que se practica la atribución de esa responsabilidad.

Desde 1870 se admite la responsabilidad penal de las personas jurídicas en Holanda en Derecho Penal fiscal y aduanero. Sin embargo, se admite que fue hasta 1950, en que entró en vigor la WED (Wet op de

penal empresarial, propuestas globales contemporáneas, Navarra, Aranzadi, 2006; el mismo, "La responsabilidad penal de las empresas: evolución internacional y consecuencias nacionales", La responsabilidad criminal de las personas jurídicas: una perspectiva comparada, Tirant lo blanch, Valencia, 2001; el mismo, "La responsabilidad penal de las empresas: evolución internacional y consecuencias nacionales", Anuario de Derecho Penal, Universidad de Friburgo, 1996.

284 “¿Punibilidad de las personas jurídicas?”, Op. Cit.

285 VERVAELE, J. A. E., "La responsabilidad penal de y en el seno de la persona jurídica en Holanda. Matrimonio entre pragmatismo y dogmática jurídica", en Revista de Derecho Penal y Criminología, Núm. 1, 2a época, Enero, 1998, p. 153; DE DOELDER, H., "La punibilidad de las personas jurídicas en Holanda", en V.V. A.A., Jornadas en Honor del Profesor Klaus Tiedemann, Hacia un Derecho Penal económico europeo, Madrid, BOE, Universidad Autónoma de Madrid, 1995, página 497. 
Economische Delicten) orientada a sanción de delitos económicos, en que se rompe el adagio societas delinquere non potest. Es una ley marco a la que se han añadido más de 100 leyes en el ámbito socioeconómico. $^{286}$ En 1965 se reforma el 50 $0^{\text {a }}$ del CP donde se establece la subsistencia de la pena tanto para la persona jurídica como para la física, esto es, de forma independiente. ${ }^{287}$ Pero no fue sino hasta 1976 que aparece por fin la responsabilidad penal de la persona jurídica con el art.. 51 del CP actual, que dice:

ñi. Las infracciones pueden cometerse por personas físicas y jurídicas. 2. Si una infracción se comete por una persona jurídica, las acciones judiciales pueden dirigirse y las penas y medidas previstas por la ley pueden pronunciarse, en tanto en cuanto estén involucradas en esta materia: 1. contra la persona jurídica, si no 2. contra los que hayan dado la orden, así como contra los que hayan dirigido efectivamente el comportamiento ilícito, si no 3. Contra las personas citadas en los números 1 y 2 conjuntamente 3. Para la aplicación de lo que aquí

\footnotetext{
286 VERVAELE, Op. Cit., p. 154. En su art. 15 señalaba: «1. Si se comete un delito económico por o en el nombre de una persona jurídica, de una sociedad, de cualquier otra asociación de personas o de una fundación, se emprenderán las acciones judiciales y se impondrán las penas y medidas, bien contra las personas jurídicas, la sociedad, la asociación o la fundación, bien contra los que han dado la orden o han dirigido efectivamente el acto ilícito o la omisión, bien contra ambos. 2. Un delito económico se comete por o en el nombre de una persona jurídica, una sociedad, una asociación de personas o una fundación, entre otros supuestos, cuando se comete por personas que, sea en razón de un servicio remunerado, sea por otras razones, actúan en la esfera de la persona jurídica, la sociedad, la asociación o la fundación, independientemente del hecho de que estas personas hayan cometido individualmente cada una un delito económico o que integren conjuntamente los elementos del delito. 3. Si las acciones judiciales se dirigen contra una persona jurídica, una sociedad, una asociación de personas o una fundación, éstas estarán representadas en el curso de las acciones por el administrador $y$, si hay varios, por uno de ellos. El representante puede comparecer mediante abogado. El tribunal puede ordenar la comparecencia personal de un administrador determinado; puede entonces extender un auto de comparecencia. 4. Si las acciones judiciales se dirigen contra una persona jurídica, una sociedad, una asociación de personas o una fundación, se aplicará el art. 538, apartado $2^{\circ}$, del Código procesal penal. »

287 «Por disposición legal, como consecuencia de una infracción, cometida por o en nombre de una persona jurídica, una sociedad, cualquier otra asociación de personas o una..., puede establecerse una pena contra los administradores, miembros del consejo de administración o comisarios, así como contra los que han dado la orden o han dirigido efectivamente el acto ilícito o la omisión»
} 
precede, la persona jurídica se sitúa en igualdad de condiciones que la sociedad que no tenga personalidad jurídica, la asociación o la fundación.ò

En este contexto podemos obtener ya varias conclusiones iniciales: La responsabilidad penal de la persona jurídica en Holanda es por vía de rãtribuciónòo por el t̂necho de otroò que en el caso sería, de una persona física relacionada con la organización empresarial; y que la responsabilidad penal de la persona física es independiente de la de la persona jurídica.

El primer aspecto nos lleva a preguntarnos cómo se genera en Holanda el hecho de conexión, esto es, quién o qué persona física detona la responsabilidad de la jurídica, y cuáles son los criterios de imputación. No es, en principio, la simple teoría del órgano, la que determina la vinculación entre las dos personas, sino que se exige algo más: que la persona física actúe en el contexto de la persona jurídica. Esto significa que la actuación de la física debe ser vista o entendida como la propia actuación de la jurídica, esto es, que una sea expresión real de la otra. ${ }^{288}$ De aquí se obtiene una derivación, consecuencia que se aleja de la teoría del órgano: no sólo es el órgano o representante de la organización empresarial el que puede desatar la responsabilidad de la jurídica, sino también cualquier otro subalterno, es más, cualquier persona que sea ajena a la jurídica, siempre y cuando actúe en el contexto de la misma y le reporte beneficio económico, así como que la persona jurídica lo acepte. ${ }^{289}$

${ }^{288}$ Cfr. DE DOELDER, Op. Cit., p. 498, pues dice que la persona jurídica puede obrar no sólo a través de sus órganos oficiales, sino se exige ya sólo "... si la acción en el contexto social ha de calificarse como una acción de la persona jurídica. Este criterio del contexto social es la doctrina actual en materia penal en Holanda". Así también BACIGALUPO, S., La responsabilidad penal de la persona jurídica, Op. Cit., p. 323.

${ }^{289}$ Cfr. VERVAELE, Op. Cit., p. 166 y 167, al señalar que el acto de la persona física se imputará a la jurídica si “... el comportamiento real de la persona física concuerda con la función social que cumple la persona jurídica en cuestión... (esto es, según el Hoge Raad, Tribunal Supremo) La persona jurídica debe tener un cierto poder sobre la persona en cuestión y, además, debe haber aceptado el 
Lo mismo sucede en materia de imputación subjetiva, esto es, en la construcción del dolo o la culpa. Se considera que a la empresa se le imputa el dolo o culpa de la persona física, pero ella también tiene una intención o culpa independiente: ré la cualidad de autor de una persona jurídica exige dos condiciones acumulativas, a saber, que la persona jurídica a) podía actuar con un comportamiento para prohibir 0 regular una determinada conducta, y b) que aceptó el comportamiento punible o al menos toleró un comportamiento análogo en el pasado. La aceptación no significa que la persona jurídica hubiera aceptado ella misma explícitamente el acto, sino que resulte que el acto ilícito deba ejecutarse en el marco de la política de empresa de la persona jurídicaé ${ }^{290}$.

En materia administrativa la Ley Mulder $^{291}$ no establece en ningún precepto, de forma expresa, la admisión de que la empresa puede cometer delitos, sin embargo, en la doctrina y en la práctica judicial es aceptado que tanto las personas jurídicas como las físicas pueden ser autoras de las infracciones administrativas y que se les puede condenar con las sanciones típicas de las mismas. ${ }^{292}$

\section{MODELOS POR HECHO DE CONEXIÓN Y CULPABILIDAD PROPIA DE LA PERSONA JURÍDICA}

comportamiento en cuestión. Un simple empleado puede por tanto ocasionar esta responsabilidad, e incluso alguien que no trabaja formalmente bajo las órdenes de la persona jurídica pero que opera sobre el plano material como tal...".

$290 \mathrm{Ib}$ Ídem, p. 170.

291 Así llamada porque el creador de la Wet Administratiefrectelike Handharving Verkeersvoorschrifen fue Mulder, Vid. BACIGALUPO, S., Op. Cit., p. 325.

292 VERVAELE, Op. Cit.,, p. 171, "En lo que concierne a las contravenciones, existe un deber general de cuidado que se aplica en este sentido de que la organización realice su poder potencial dirigido a evitar que se produzcan infracciones, por medio de una política de instrucciones, procedimientos y medidas que tiendan a prevenir o mejorar las situaciones que pudieran ser peligrosas. Se debe, sin embargo, haberlas podido prevenir, sin lo cual hablaríamos de una responsabilidad por riesgos (strict liability). Una total ausencia de culpa es, sin embargo, rara..... Lo que significa en cierto modo una responsabilidad penal directa basada sobre la autoría directa de la persona jurídica. 


\subsection{Culpabilidad por defecto de organización}

Dentro del ámbito de Derecho Penal económico existe preponderantemente el Derecho Penal de la empresa, y por lo tanto, de las formas o maneras en que la empresa puede responder penalmente por hechos suyos y no tanto las personas físicas que las conforman. Desde hace tres décadas el profesor Tiedemann ${ }^{293}$, de la Universidad de Friburgo en Brisgovia, Alemania, había llamado la atención de la necesidad de la criminalización de las personas jurídicas dentro del Derecho Penal económico en la pujante y cada vez más compleja Comunidad Europea ${ }^{294}$.

La tesis desarrollada por Tiedemann se ha llamado culpabilidad de la organización, y con ella pretende desarrollar categorías dogmáticas, principalmente acción y culpabilidad, propias de las personas jurídicas.

293 La obra del profesor KARL TIEDEMANN respecto al tema en estudio en el habla hispana, se traducen los siguientes artículos y monografías: TIEDEMANN, K., "Estado actual y tendencias de la ciencia jurídico-penal y de la criminología en la República Federal Alemana", CPC, núm. 14, 1981, 265 y sigs.; el mismo, "El concepto de derecho económico, de Derecho Penal económico y de delito económico", CPC, Num. 28, 1986, 65 y ss.; el mismo, "El Derecho Penal económico en la comunidad europea", Estudios de Derecho Penal Económico, Editorial Universidad Castilla la Mancha, Castilla la Mancha, 1994, 235 a 254; el mismo, "Presente y futuro del Derecho Penal económico", en VV. AA., Hacia un Derecho Penal económico europeo, Jornadas en Honor del Profesor Klaus Tiedemann, BOE y Universidad Autónoma de Madrid, Madrid, 1995, 29 a 44; el mismo, "Responsabilidad penal de las personas jurídicas", $A D P$, Universidad de Friburgo, 1996; el mismo, "Responsabilidad penal de personas jurídicas, otras agrupaciones y empresas en derecho comparado", en VV. AA., La reforma de la justicia penal: Estudios en homenaje al Prof. Karl Tiedemann, Castelló de la Plana, Publicaciones de la Universitat Jaume I, Madrid, 1997; el mismo, "Exigencias fundamentales de la Parte General y propuesta legislativa para un Derecho Penal europeo", $R P$, número 3, enero 1999, 76 a 86; y el mismo, "Presente y futuro del Derecho Penal europeo", Homenaje al Profesor Dr. Gonzalo Rodríguez Mourullo, Civitas, Madrid, 2005, 1029 a 1037.

294 TIEDEMANN, K., "Presente y futuro del Derecho Penal económico", Op. Cit., p. 35, "Yo aventuro el pronóstico de que el futuro pertenece al Derecho Penal (sancionador) de la empresa ¡Nada tiene tanta fuerza como una idea cuyo tiempo ha llegado (Víctor Hugo)". Diez años antes, en 1986, ya hacía comprender la criminalización de las personas jurídicas en los temas urgentes a tratar por el Derecho Penal económico, vid., el mismo, "El concepto de derecho económico, de Derecho Penal económico y de delito económico", Op. Cit., p. 73. 
Tiedemann parte de que ha sido un craso error el pretender construir las categorías de responsabilidad penal de las personas jurídicas atendiendo a los conceptos de la responsabilidad de la persona individual o física. Considera que es adecuado establecer todo un sistema de responsabilidad penal de las personas jurídicas a parte 0 paralelo al de las individuales, pero que por tanto, no debe de simplemente extrapolarse los conceptos, sino que es necesario partir del principio. ${ }^{295}$

Lo que hace es realizar un análisis del parágrafo o art. 30 OWiG a través o con motivo de la segunda ley contra la delincuencia económica alemana de 1986 que introdujo la multa como sanción aplicable a una empresa suprimiendo la hasta entonces vigente calificación de r̃consecuencias necesariasò Precisamente de ahí interpretó que si una ley penal establecía una prohibición no a una persona individual o física sino expresamente a una persona jurídica, entonces, por ser esa persona jurídica destinatario de la misma, tendría capacidad de acción. Dice que si el legislador dirige normas a las personas jurídicas es porque ellas también pueden producir los efectos exigidos por la norma, es decir, pueden producir acciones y omisiones. Contundentemente señala que ré existen en derecho económico y social normas jurídicas que se dirigen únicamente a las empresas, y no a los individuos. Citamos el ejemplo del derecho de la competenciaé Las acciones de las personas físicas actuando para la empresa deben, pues, ser considerados como de la empresaò 296

Es algo así como decía von Liszt r̃quien puede concluir contratos, también puede concluir contratos ilícitos o usurarios 0 incumplir los contratos de abastecimiento concluidosé ò ${ }^{297}$ Desde luego no importa que la acción en el mundo real sea cometida por una

295 TIEDEMANN, K., "La responsabilidad penal de las personas jurídicas, otras agrupaciones y empresas en derecho comparado", Op. Cit., p. 36. Con referencias en BACIGALUPO Saggese, Op. cit., p. 169; y GRACIA Martín, Luis, Op. cit., p. 59.

296 TIEDEMANN, K., "La responsabilidad penal de las personas jurídicas, otras agrupaciones y empresas en derecho comparado", Op. Cit., p. 36.

297 Ib Ídem, p. 36. 
persona individual o física o un conjunto de ellas, ya que la prohibición no está siendo referida a ellas, sino a aquella otra independiente de quienes la forman, esto es, la persona jurídica.

Tampoco tiene ningún problema en afirmar o fundamentar la autoría de la persona jurídica. En su contra se esgrime que para realizar el tipo penal que contiene la prohibición de la norma, la persona jurídica tendría que hacerlo siempre a través de otras personas, esto es, las físicas que la componen, y ello sería incorrecto porque la persona jurídica estaría respondiendo por la conducta ajena, esto es, por la acción de otro. Sin embargo, Tiedemann asegura que ya el Derecho Penal reconoce ciertos criterios de imputación al autor o para señalar que alguien es autor en aquellos casos en que una persona no realiza por sí misma la conducta típica y no obstante ello se considera que es ŕsuò hecho. Habla de que esos casos son los de coautoría y autoría mediata: en los mismos una persona que participa en el f̂hechoòy no realiza por sí misma la conducta descrita en el tipo penal, se le atribuye la misma como si fuera su propia obra. Precisamente por esas razones es que la empresa o asociación, al responder por la conducta que aparentemente no realiza ella sino sus órganos, no responde por una acción ajena o de otro, sino por la propia. ${ }^{298}$

En suma: si hay algún tipo penal que prohíba una conducta, no a un sujeto físico, sino a una persona moral, entonces ello será suficiente para darle capacidad de acción, y es irrelevante que las físicas que la conforman sean quienes realicen en el mundo factual de los hechos, ya que el Derecho son solamente normas de atribución (autoría) lo que determina ese aspecto ${ }^{299}$.

298 Ib Ídem, p. 37 y 38, concretamente señala “... no es, o no totalmente, la acción física la que cuenta, sino que es la violación de las medidas y expectativas normativas la que importa para imputar un resultado nocivo a un autor (persona física o moral) ... La acción de una empresa, también es acción en la realidad jurídica".

${ }^{299} \mathrm{Ib}$ Ídem, p. 38, "Admitir la idea de que una agrupación puede ser autora de una infracción (de competencia, de derecho fiscal, etc.) no significa nada más que recoger en el derecho el juicio que la realidad social porta sobre estas entidades". 
El aspecto más difícil es el de la culpabilidad. Comienza considerando que en el Derecho administrativo sancionador también se conoce el concepto de culpabilidad como un presupuesto de la sanción, pero que los requisitos y contenidos están disminuidos. Pues bien, construyendo algo disminuido en cuanto a contenidos, pero siempre comprendiendo que no debe nunca equipararse el carácter ético de la culpabilidad de las personas individuales o físicas, señala que es posible entender la culpabilidad de las personas jurídicas como r̃ulpabilidad por defecto en la organizaciónò o simplemente r̃ ulpabilidad de organizaciónò que, precisamente por lo que estamos diciendo, tiene un contenido de carácter social y normativo y no ético. ${ }^{300}$

Dice que los hechos individuales (hechos de contacto) tienen que ser contemplados como hechos de agrupación en razón de que y en tanto que la agrupación, a través de sus órganos o representantes, ha omitido la adopción de medidas de precaución que son exigibles para garantizar un desarrollo ordenado y no delictivo de la actividad relativa al tráfico de empresa. ${ }^{301}$ Es decir, la persona jurídica es responsable por los hechos delictuosos realizados por las personas físicas que componen sus órganos (hecho de conexión) por razón de que ésta y sus órganos no han tomado las suficientes medidas y precauciones de cuidado que son necesarias para garantizar un negocio ordenado y no delictivo. ${ }^{302}$ Es responsabilidad por un error en la organización.

\footnotetext{
$300 \mathrm{Ib}$ Ídem, p. 41: "la organización correcta de la persona jurídica es el deber de ella misma, no únicamente de las personas físicas... esta culpabilidad no está exenta de la huella ética o moral, incluso aún cuando la coloración moral toma un contenido particularmente distinto".

301 TIEDEMANN, K., Op. Cit. p. 39 y 40: "Nosotros hemos sostenido un punto de vista similar para el derecho de las Ordunungswdrigkeiten alemanas que partiría de un principio de falta (y de culpa) de la organización como legitimación de la responsabilidad de la agrupación, permitiendo así la imputación de la culpa individual de los dirigentes a la empresa...". Abundando sobre el tema: BACIGALUPO Saggese, Op. cit., p. 171, donde cita a TIEDEMANN, en su art. en NJW, 1988. Así también GRACIA, Op. cit., p. 62, donde cita a TIEDEMANN, en su art. en NJW, 1988, 302 BACIGALUPO, Op. cit., p. 171.
} 
No se trata de solo un error humano de una acción, sino de todo un estado de cosas, de una responsabilidad por la forma de ser de la organización: defectuosa.

De ahí que Tiedemann diga que el momento de la culpabilidad no es exactamente aquel en que se comete el delito, sino uno anterior: el momento en que la persona jurídica debió realizar todo aquello que estaba en sus manos para una organización adecuada, correcta y sin defectos. De tal suerte que si el hecho típico se realiza fue precisamente en virtud de la mala organización, la ausencia de controles, la falta de inducción de los operarios, el descuido del rumbo de la misma. Precisamente aquí es donde señala que esta forma de razonar no es nueva en Derecho Penal ya que la compara con el actio libera in causa en la que el autor del delito (en aquellos clásicos casos de la persona individual o física ingesta alguna droga o sustancia que le va a hacer perder la conciencia para no comprender el carácter ilícito de su conducta o para no poder conducirse de acuerdo con esa comprensión) no es al momento de la comisión del mismo capaz de ser culpable: en estos casos no es punible porque en la realización de la conducta típica no sea culpable, sino porque en el momento en que voluntariamente ingresó a su cuerpo sustancias espirituosas lo hizo mientras tenía la plena conciencia de que podía suceder lo que hizo.

En España desarrollaron tesis de este tenor Zugaldía 303 principalmente, así como Silvina Bacigalupo ${ }^{304}$ y Laura Zuñiga Rodríguez ${ }^{305}$.

303 Vid. ZUGALDIA Espinar, J. Miguel, "Capacidad de acción y capacidad de culpabilidad de las personas jurídicas”, CPC, No. 53, 1994, 613 pássim; el mismo, "Una vez más sobre el tema de las responsabilidad criminal de las personas jurídicas (doce años después)", Hacia un derecho penal económico europeo (en Jornadas en Honor del Profesor Klaus Tiedemann, VV. AA.), Madrid, BOE, Universidad Autónoma de Madrid, 1995, 723 a 727; el mismo, "Las penas previstas en el artículo 129 del Código Penal para las personas jurídicas (consideraciones teóricas y consecuencias prácticas)", Cuadernos del Poder Judicial, núm. 46, 1997, 327 y ss.; el mismo, "Artículo 129", Comentarios al Código Penal, en COBO DEL ROSAL, Manuel, Tomo IV, Madrid, Edersa, 2000, 1049 a 1061; el mismo, "Bases para una teoría de la imputación de la persona jurídica", 
Zugaldía asegura que el punto de partido fundamental es la afirmación de que las personas jurídicas son capaces de realizar acciones y actuar de forma culpable. $Y$ ello porque, como ré no es posible considerar que existe un único concepto válido de acción (como comportamiento humano voluntario) y un único concepto de culpabilidad (como juicio de base biosicológica). Tales concepciones son posibles pero no excluyen ni otros conceptos distintos de acción y de culpabilidado ${ }^{306}$. En forma específica, asegura que la persona jurídica es culpable cuando ré en su seno, estatutariamente, y en su beneficio, con posibilidad de conocer la ilicitud del hecho, se adoptan o ejecutan acuerdos delictivos o se ejecutan acciones delictivas que no son impedidas por los órganos sociales competenteso $0^{307}$. Como criterios objetivos de imputación estima que la persona física debe actuar en el seno de la jurídica y dentro de su marco estatutario, la acción de la física ha de aparecer en el contexto social como de la jurídica. Los criterios de la imputación subjetiva serían que la física debe actuar en nombre e interés de la jurídica, si la física actúa con dolo y la jurídica con imprudencia, será castigada por imprudencia. No se impondrá pena

CPC, 2001, 329 y ss.; el mismo, "Vigencia del principio societas delinquere potest en el moderno Derecho penal", La responsabilidad criminal de las personas jurídicas: una perspectiva comparada, Tirant lo blanch, 2001, p. ; el mismo, "La responsabilidad criminal de las personas jurídicas en el derecho penal español", El nuevo Derecho penal español: estudios penales en memoria del Profesor José Manuel Valle Muñíz, Navarra, Aranzadi, 2001, 885 y sigs. Recientemente, CUADRADO RUÍZ, Ma. de los Ángeles, "La responsabilidad penal de las personas jurídicas. Un paso hacia adelante... ¿un paso hacia atrás?”, en Revista Jurídica de Castilla y León, número 12, abril de 2007, página 135 y sigs.

304 Vid. BACIGALUPO Saggese, Silvina, La responsabilidad penal de las personas jurídicas, Bosch, Barcelona, 1998; la misma, "Responsabilidad penal de las personas jurídicas", Curso de Derecho penal económico, en Bacigalupo, E. (dir.), $2^{\text {a }}$ edición, Marcial Pons, 2006, p. 81 pássim; la misma, "La crisis de la filosofía del sujeto individual y el problema del sujeto de Derecho penal", CPC, núm. 67, 1999, p. 11 pássim; la misma, "Los derechos fundamentales de las personas jurídicas", Revista del Poder Judicial, núm. 53, 1999, CGPJ, 1999, 49 pássim; la misma, "Las sanciones del Código penal aplicables a las personas jurídicas en los delitos contra el medio ambiente", en Jorge Barreiro, Agustín (dir.), Estudios sobre la protección penal del medio ambiente en el ordenamiento jurídico español, Comares, Granada, 2005, 151 pássim.

305 Vid. ZUÑIGA RODRÍGUEZ, Laura, Bases para un modelo de imputación de responsabilidad penal a las personas jurídicas, Aranzadi, Navarra, 2003, p. 67

306 ZUGALDÍA, "Vigencia del principio societas delinquere non potest...", p. 259.

307 ZUGALDÍA, “Bases para una teoría de la imputación...”, Op. Cit., p. 551. 
si -por el principio de culpabilidad- la jurídica no ha omitido la adopción alguna de las medidas de precaución previstas para garantizar el desarrollo legal de la actividad de empresa, el órgano no ha sido elegido por la jurídica sino impuesto por un tercero, no hay dolo o culpa de la jurídica en la realización del hecho ${ }^{308}$.

Por otro lado, es la profesora Bacigalupo Saguesse ${ }^{309}$ quien al reformular la concepción de ñpersonaò en Derecho Penal haciendo tambalear su conceptuación biosicológica, y siguiendo a Jakobs, afirma que ré habría que afirmar la existencia de culpabilidad y, por lo tanto, la necesidad de imponer una pena cuando así lo exija el restablecimiento de la vigencia de la normaé habrá que comprobar en cada caso la existencia de injusto, de autor competente, de motivación del autoré $\mathrm{o}^{30}$, identificando la culpabilidad por defecto de la organización. En el nivel del injusto objetivo y subjetivo vuelve al thecho de conexiónòde la persona física, que circunscribe a los representantes de la misma: né se puede sostener que la acción del representante se puede imponer, en principio, a las personas jurídicas $0^{311}$.

Zuñiga $^{312}$ abraza de manera expresa el concepto de culpabilidad por defecto de la organización de Tiedemann

\subsection{El caso italiano}

El decreto legislativo $231 / 2001$ de 8 de junio significó una reforma de gran calado en materia de responsabilidad criminal de las personas jurídicas, pues se consideró que con él se derogó el principio societas delinquere non potest $t^{313}$.

\footnotetext{
308 ZUGALDÍA, “Vigencia del principio ...”, p. 257 y 258.

309 BACIGALUPO, S., La responsabilidad penal de las personas jurídicas, Op. Cit.

$310 \mathrm{Ib}$ Ídem, p. 399.

311 Ib Ídem, p. 381.

312 Op. Cit., 141.

313 Italia era uno de los países con más resistencia a admitir una responsabilidad penal que no fuere la de la persona física, Cfr. NIETO MARTíN, Adán, La
} 
La doctrina nacional dominante había concluido que la legislación italiana (Constitución General y codificación penal) permanecían indemnes ante los embates al principio ya referido, y por tanto, en ese país no existía la responsabilidad penal de las personas jurídicas ${ }^{314}$. Cierto, la Constitución General italiana establece en el art. 27,1 que ña responsabilidad penal es personalò y ese texto ha sido interpretado en el sentido de que solamente es la persona física, la persona en el carácter bioantropológico, la que puede ser capaz de ser autora de delitos en Derecho Penal ${ }^{315}$. Es decir, se interpretaba como principio a nivel constitucional el principio de la irresponsabilidad penal de las organizaciones empresariales.

Lo anterior había sido repetidamente sostenido por los Tribunales italianos, es más, la Corte Constitucional Italiana hubo refrendado esta postura en las sentencias pronunciadas en 1988 y 1989316. Eso no obstaba para que la doctrina, también mayoritaria, reconociera que existían necesidades político criminales que orillaban a poner en la mesa del debate el tema planteado ${ }^{317}$. Ya Bricola ${ }^{318}$

responsabilidad penal de las personas jurídicas: Un modelo legislativo, Iustel, Madrid, 2008, p. 194.

314 En nuestro idioma podemos encontrar las siguientes referencias en relación al tema en Italia, antes de la reforma de 2001: PALIERO, C. E., "Problemas y perspectivas de la responsabilidad penal de la persona jurídica en el derecho italiano", La responsabilidad criminal de las personas jurídicas: una perspectiva comparada, Tirant lo blanch, 2001; el mismo, "La sanción administrativa como medida en la lucha contra la criminalidad económica", en V.V. A.A., Jornadas en Honor del Profesor Klaus Tiedemann, Hacia un Derecho Penal económico europeo, Madrid, BOE, Universidad Autónoma de Madrid, 1995, 469 a 491; MILITELLO, Vicenzo, "La responsabilidad jurídico-penal de la empresa y de sus órganos en Italia", en V.V. A.A., Libro Homenaje a Claus Roxin, Fundamentos de un sistema europeo del Derecho Penal, Bosch, Madrid, 1995, p. 409 a 424.

315 Esta interpretación constitucional se estimó muy influenciada con la teoría de Savigny de que las personas jurídicas son simples entes ficticios, creados por el Derecho, que no pueden tener jamás una conciencia, una voluntad y no se les puede reprochar nada en el sentido psíquico. Vid. MILITELLO, Vicenzo, Op. Cit., p. 414.

316 Números 364/1988, 1085/1988 y 487/1989. La primera interpreta el principio nullum poena sine culpa.

317 Por todos, vid. PALIERO, Op. Cit., p. 111. Señala tres razones político criminales: El incremento vertiginoso de la criminalidad de cuello blanco, la complejidad del modelo post capitalista y post moderno de la industria y las finanzas, y en Italia, como en el mundo, la crecientes actividades de la criminalidad organizada, 
denunciaba el costo (político y económico) que representaba dejar incólume el principio de irresponsabilidad de las personas morales; mientras que Paliero aseguraba ĩEvocar, en política criminal, el principio societas delinquere non potest resulta hoy en día más surrealista que irrealo ${ }^{319}$.

El ámbito que se consideraba que podría tener una fuente de disposiciones para criminalizar a la persona jurídica era el administrativo. Italia trasladó el modelo de sanción administrativa alemana, las Ordungswidrigkeit o OWiG (ya analizada, supra), mediante la Ley No. 689 de 1981, que es un modelo parapenal y que admite ciertas consecuencias para la persona jurídica. En ella se establecen los principios dogmáticos que han regido tradicionalmente en el Derecho Penal clásico, como el de legalidad, imputabilidad, culpabilidad, dolo o culpa, justificantes o eximentes de culpabilidad, entre otras. No obstante, la legislación administrativa sancionadora había renunciado a fijar de manera general una responsabilidad directa de la persona jurídica: le configura una obligación solidaria (con derecho de reversión contra la persona física, art. 6, inciso 4, de la Ley 681/81) y se limita al ente a ser una simple garantía de pago de la sanción pecuniaria.

Luego, se abrió un nuevo panorama donde en la legislación administrativa penal especial parece ser que se admitía aunque tímidamente su criminalización: se trataba de los sectores de la concurrencia (anti trust), telecomunicaciones y mercado inmobiliario. Sus características comunes son que están insertas en el Derecho Penal administrativo, no están regidas por la solidaridad que previene el

desarrolladas en el ámbito de la delincuencia mafiosa y de la criminalidad económica.

318 BRICOLLA, F., "Il costo del principio "societas delinquere non potest" nell'attuale dimensione del fenómeno societario", Revista Italiana de Derecho Penal, 1970, citado por ZUÑIGA R., L., Op. Cit., p. 119. Lo que impide una adecuada eficacia contra la criminalidad económica, sobre todo en un país que se distingue por la proliferación de delincuencia organizada y mafias, que utilizan a las empresas para cometer delitos.

319 Ib Ídem, p. 112. 
art. 6, inciso 4, de la Ley 689/1981 (ya analizada), y que la competencia para perseguir y aplicar las sanciones corresponde a las autoridades administrativas especiales creadas ex professo para ello ${ }^{320}$.

El decreto legislativo No. 231 de 8 de junio de 2001 llama a la materia que rige ha responsabilidad administrativa del enteò que generó inicialmente algunas breves consideraciones consistentes en que no se abría el paso a la responsabilidad penal, sino que se trataba únicamente de responsabilidad administrativa y que nada había cambiado. Sin embargo, inmediatamente también la doctrina dominante concluyó que no se debería caer en un fraude de etiquetas, y que si la nueva ley preveía sanciones graves a las personas jurídicas por la comisión de hechos delictivos, en un proceso penal y frente a un juez penal, en donde gozaban de todas las garantías constitucionales de un proceso penal, entonces no debía caber duda de que se trataba de responsabilidad auténtica criminal para las personas jurídicas ${ }^{321}$. En la propia exposición de motivos de la ley se puede leer que la pretensión del legislador al llamarle responsabilidad administrativa tuvo como fin salvar el prurito constitucional del art. 27.1 (que exige que la responsabilidad penal sea personal) y acercarse más a una de clase cuasi penal o tertium genus ${ }^{322}$.

De forma inicial, y merced a que su aparición se debía a los compromisos internacionales italianos, particularmente las relativas a la corrupción, solo era posible encontrar responsabilidad penal para ese tipo de conductas. No obstante, el catálogo de conductas delictivas se fue ampliando para abarcar aspectos en los que las empresas pueden tener mayor influencia y posibilidad de cometer delitos; y de esta manera la Ley No. 146 de 16 de marzo de 2006 incorporó los delitos societarios de carácter internacional o trasnacional, pues en su art. 10

\footnotetext{
320 Ib Ídem, p. 129.

321 CARNEVALI RODRÍGUEZ, Raúl, "La criminalidad organizada. Una aproximación al Derecho Penal italiano, en particular la responsabilidad de las personas jurídicas y la confiscación", en Revista Ius et Praxis, año 16, No. 2, 2010, Universidad de Talca, Chile, página 297.

322 ZUÑ̃IGA RODRÍGUEZ, Laura, Op. Cit., p. 123.
} 
señala que habrá responsabilidad administrativa del ente por los delitos del art. 3 (de la misma Ley, los relativos a los delitos trasnacionales), en los casos de los art.s 416, 416 bis del CP italiano, del art. 291 quarter del decreto ley No. 43 de 23 de enero de 1973 y del art. 74 del decreto ley 309 de 9 de octubre de 1990; y en forma posterior se introdujeron delitos relativos a la criminalidad organizada ï art. 24 ter del Decreto legislativo No. 231- mediante la Ley No. 94 de 15 de julio de 2009 conocida como il ópacchettoô sicurezza. Al día de hoy se comprenden delitos contra la administración pública, societarios, abusos de mercado, homicidio o lesiones culposas en materia laboral, delitos con finalidad terrorista o de subversión, prácticas de mutilación de órganos genitales femeninos, esclavitud, prostitución de menores o pornografía infantil ${ }^{323}$.

Los criterios de imputación los podemos encontrar en los arts. 5, 6 y 7 de dicho Decreto Legislativo. Muy brevemente señalaremos las características generales de ese sistema.

1.- Se aplicación se dirige a todo renteò con personalidad jurídica propia reconocida (con lo que en principio se opta por un criterio formal, dejando de lado descripciones materiales o casuísticas); pero también se aplica a las sociedades y asociaciones privadas de personalidad jurídica (art. 1).

2.- No se aplica al Estado, ni a las personas jurídicas o entes públicos territoriales ni aquellas que realizan funciones de relevancia constitucional (art. 1.3).

3.- Es de doble vía, porque dos son las clases de hechos que pueden disparar la responsabilidad criminal: por un lado, los r̃delitosò cometidos por sus representantes, administradores o directivos o unidades organizativas dotadas de autonomía financiera o funcional, así como las personas que ejercitan de facto la gestión y control de los mismos (art. 5.1, a)); y por otro lado, por los r̃delitosò de personas

323 CARNEVALI RODRÍGUEZ, Raúl, Op. Cit., p. 297. 
sometidas a la vigilancia o dirección de uno de los sujetos anteriores $(\operatorname{art} .5 .1, b))$.

4.- Las personas anteriores (los raggentesò) deben cometer el delito en r̃su interés o en su ventajaò de la persona jurídica. De tal manera que el ente no responde si el agente cometió el delito en interés exclusivo propio o de tercera persona.

5.- La distinción del agente que comete el delito tiene relevancia práctica muy importante, puesto que conforme al art. 6, si el mismo es cometido por personas que se encuentren en posición apicale, esto es, del art. 5.1,a), entonces se generará una especie de presunción iuris tantum $^{324}$ en tanto que en todos los casos quedará bajo la carga de la empresa imputada el demostrar que mantenía una organización adecuada, amén de que el propio art. 6 establece pautas muy específicas que será necesario acreditar para que la persona jurídica se desembarace de la responsabilidad, que, de hecho, son más exigentes que las que establece en el caso de los sujetos bajo la vigilancia de los directivos. Esto se entiende en razón de que si quien comete el delito es precisamente la persona encargada de dirigir al ente, de señalarle el rumbo y sus políticas, de permear en él el respeto al orden jurídico, no mucho se tendría que decir a su favor cuando se trata de acreditar un funcionamiento organizativo adecuado.

Así, deberá demostrar que el órgano ha adoptado y eficientemente actuado, previo a la comisión del delito, modelos de organización idóneas a fin de prevenir el delito de la especie que se ha verificado (inciso a), del número 1 del art. 6); que se ha confiado el poder de vigilar el funcionamiento y observancia de las normas a un organismo del ente dotado de autonomía y poder de iniciativa y control

\footnotetext{
324 CARNEVALI RODRÍGUEZ, Raúl, Op. Cit., p. 300, pues señala que la carga de la prueba de que no existe en el ente un defecto de organización recae en el ente, esto es, "... probar que aun cuando el modelo de organización era eficaz como mecanismo de control, la persona jurídica no tenía la capacidad de impedir la comisión de delitos por parte de los sujetos en posición jerárquica superior", y ZUÑIGA, Laura, Op. Cit., p. 124.
} 
$(6,1, b))$; que el agente cometió el delito eludiendo fraudulentamente el modelo de organización y de gestión $(6.1, c))$; y no ha habido omisión o insuficiente vigilancia del órgano de vigilancia de la letra b) (6.1.d)).

En la exposición de motivos se hace hincapié en el interés de prevenir la comisión de los delitos y del compromiso que habrán de tener aquellas personas que estén en posición, dentro de la empresa, de desarrollar su deber de vigilancia y control dentro de la misma. Coincidimos con quienes observan en esta legislación su vocación eminentemente preventiva a través de la autorregulación regulada ${ }^{325}, y$ más, a diferencia del modelo español y norteamericano, en ninguna parte del texto de la ley italiana se observa algún criterio para desmedrar la culpabilidad de la persona jurídica que tenga lugar en forma posterior al delito, hecha excepción del pago de la reparación del daño y a la adopción del modelo organizativo adecuado antes del juicio oral, como lo señalan el art. 12, apartado 2, inciso a) y b).

Si quien comete el delito es el agente de la letra b), apartado 1, del art. 5, entonces la persona jurídica si el delito fue posible gracias a la inobservancia de las obligaciones de dirección y de vigilancia (1), y se excluirá su responsabilidad si antes de la comisión del delito tenía adoptado un modelo de organización, gestión y control idóneo para prevenir delitos de la misma especia (2), el modelo prevé, en relación con la naturaleza y el tamaño de la organización así como el tipo de actividades llevadas a cabo, medidas apropiadas para asegurar la realización de la actividad dentro de la ley y para descubrir rápidamente y eliminar situaciones de riesgo (3), y la efectiva actuación del modelo requiere de una a) verificación periódica y la posible modificación de los mismos cuando son descubiertos violaciones graves de la normativa, y b) de un sistema disciplinario idóneo para sancionar el incumplimiento de las medidas indicadas en el modelo.

325 NIETO MARTÍN, Adán, "Responsabilidad social, gobierno corporativo y autorregulación: sus influencias en el Derecho Penal de la empresa", en Política Criminal, No. 5, 2008, A3-5, p. 15, al decir que el Decreto Legislativo 231 de 2001 “... ha consagrado a los modelos de organización como el epicentro de su sistema de responsabilidad (Art. 6)". 
6.- Las sanciones, que la ley insiste en llamar administrativas, están previstas en el art. 9 y son: a) la sanción pecuniaria; b) las sanciones interdictivas; c) la confiscación; y d) la publicación de la sentencia.

La sanción pecuniaria se regula en los siguientes 10 y 11 , y se calcula a través del sistema de cuotas, y con el fin de aplicarlas la ley establece criterios que hace consistir en la gravedad del hecho, el grado de responsabilidad del ente y la actividad desarrollada para eliminar 0 atenuar las consecuencias del hecho o para prevenir la reiteración; con la posibilidad de reducción final, como ya lo hemos comentado, que son los casos previstos en el art. 12. Las interdictivas (art. 13) pueden ser la interdicción en el ejercicio de la actividad, la suspensión o revocación de autorizaciones, licencias o concesiones, prohibición de contratar con la Administración pública; y pueden ser temporales o definitivas. La confiscación es equivalente al del precio o provecho del delito, siempre que se establezca en la sentencia de condena (art. 19); y la publicación de sentencia, según el art. 18, puede ser dispuesta por el juez cuando aplica una sanción interdictiva, y será a expensas de la persona jurídica condenada.

7.- Tiene un sistema de numerus clausus que incluye los delitos a los que ya hemos hecho alusión, previene los supuestos de responsabilidad patrimonial en casos de fusión y transformación, la aplicación de la ley para entes extranjeros, regula el proceso penal y la ejecución de la sentencia, entre otros aspectos.

\section{MODELOS DE INJUSTO Y CULPABILIDAD PROPIOS DE LA PERSONA JURÍDICA}

A diferencia de los modelos anteriores, los modelos que trataremos limitan al máximo la importancia del factor humano para la configuración de la responsabilidad penal colectiva. No solo estamos 
hablando de una configuración de la culpabilidad empresarial (que suponía una atribución o imputación del injusto objetivo y subjetivo de la persona física al injusto de la persona jurídica), sino de la creación de un ñnjustoòpropio de la persona jurídica. Son elaboraciones doctrinales que ni siquiera necesitan el sustrato humano como elemento que desata la responsabilidad penal.

Son tres. Uno corresponde a Dannecker, otro a la ñpropuesta desarrollada, compleja y matizadaò de Heine ${ }^{326}$ y la otra a Gómez Jara $^{327}$. Además brevemente referiremos el caso inglés del Manslaugther y el Código Penal australiano, que al parecer receptan modelos de responsabilidad penal de los colectivos de ese tenor.

\subsection{Culpabilidad ético social}

El profesor Gerhard Dannecker, Catedrático de la Universidad de Bayreut, Alemania, ha aportado importantes ideas en torno a la integración de modelos de responsabilidad penal de las organizaciones empresariales. El aspecto principal de su tesis, tal vez lo que más y mejor desarrolla, es la categoría de la culpabilidad específica para empresas.

Inicia admitiendo que hay una actual ñesistencia de una tendencia generalizada (ley y doctrina) al reconocimiento o a la introducción de la responsabilidad penal de las personas jurídicasò ${ }^{328}$ Sin embargo, el Derecho Penal debe enfrentar los cambios económicos y medioambientales: las estructuras complejas de las organizaciones, por división de trabajo y que reúnen gran capacidad de poder, y que

\footnotetext{
${ }^{326}$ Así la concibe FEIJOO, en “¿Culpabilidad y punición de personas jurídicas?”, Op. Cit., página 369.

327 Calificado por NIETO como el "intento doctrinal más serio existente en la doctrina española y probablemente europea de explicar la responsabilidad penal de las personas jurídicas", en La responsabilidad penal de las personas jurídicas. Un modelo legislativo, Op. Cit., página 142.

328 DANNECKER, G., "Reflexiones sobre la responsabilidad penal de las personas jurídicas, $R P$, núm. 7, 2001, p. 40.
} 
cometen en ñprimer lugar delitos económicos y contra el medio ambiente $0^{329}$ que provocan difuminación de la responsabilidad penal individual, lo que impone la necesidad de regresar y pensar que es adecuada la criminalización de las personas jurídicas. En Alemania el parágrafo 30 de la Ley de Contravenciones (OWIG) impone penas pecuniarias a las personas jurídicas para compensar con sanciones las ventajas obtenidas por personas jurídicas a través de la infracción. Por tanto, para lograr idoneidad de sanción para eliminar ventajas obtenidas con el delito; para lograr proporcionalidad y adecuada sanción; para eliminar oportunidades que favorecen el encubrimiento de responsabilidades y comportamientos incorrectos; superar irresponsabilidad individual y estructural; necesidad de estabilizar la norma; sólo las penas resaltan un efecto preventivo (carácter simbólico del Derecho Penal); el Derecho administrativo no despliega el resultado de prevención general. ${ }^{330}$ Pero, es ¿el Derecho Penal es idóneo para sancionar a las personas jurídicas? Dannecker considera, sin dudarlo, que sí. ${ }^{331}$

Ahora bien, de qué forma lo hacemos, es lo que trataremos de explicar según las ideas de este autor.

En principio, Dannecker estima que el Derecho Penal individual debe quedarse incólume, que no debemos tocarlo, y en su lugar, debemos generar un sistema paralelo de Derecho Penal. Los conceptos del Derecho Penal de la persona individual deben ser similares al de la persona colectiva, utilizando el método analógico. Con esto se daría un cambio de paradigma: del concepto de castigo del injusto personal y decisiones personalísimas partiendo de la libertad individual a la función de control del Derecho Penal para restablecer la paz pública y jurídica. Señala ré se hace preciso conciliar el Derecho Penal de la empresa con las categorías fundamentales penales si no se quiere degradar el

\footnotetext{
$329 \mathrm{Ib}$ Ídem, p. 41.

$330 \mathrm{Ib}$ Ídem, p. 42.

331 Ib Ídem, p. 43.
} 
Derecho Penal contra las personas jurídicas convirtiéndolo en un mero instrumento arbitrario de control socialé ${ }^{332}$.

Afirma, por otro lado, que las empresas $u$ organizaciones empresariales son personas reales, que pueden generar acciones reales con una culpabilidad real, y por tanto, pueden ser, al igual que las personas físicas, sujetos de Derecho Penal. De lo que se trata, dice, es de desarrollar una concepción racional de la regulación penal sobre empresas partiendo de que los peligros no sólo provienen del titular sino del sistema social empresarial ${ }^{333}$ : ré . Las empresas son sujetos reales, sociales y autónomos. Actúan en el tráfico económico como titulares de valores patrimoniales, persiguen fines propios, tienen una propia r̃ corporate identidyò o r̃ motivaciónò ${ }^{334}$

Además, como ya lo han señalado otros autores (como Tiedemann y Hirsch), la empresa es destinataria de las normas jurídico penales. Es difícil, realmente difícil, poner en duda esta afirmación: la empresa tienen un deber originario en el marco de su actividad empresarial de no lesionar ningún bien jurídico ${ }^{335}$. Esta obligación puede ser cumplida por miembros de los órganos y por los trabajadores. Señala que ñas normas penales colectivas deben dirigirse a éstas obligaciones empresariales originarias que se distinguen en cuanto a su contenido de los deberes empresariales a nivel interno de cada trabajador en particularo ${ }^{36}$. Por lo que hace a la acción rél comportamiento de una persona jurídica representa el comportamiento de un sistema que puede ser entendido como un sistema con propio sentido y que posibilita y requiere una valoración penalò $^{337}$ La imputación a la empresa se basa en la acusación de un resultado antijurídico derivado del hecho de la persona física que actúe

\footnotetext{
332 Ib Ídem, p. 44.

$333 \mathrm{Ib}$ Ídem, p. 48.

334 Ib Ídem, p. 45.

$335 \mathrm{Ib}$ Ídem, p. 46.

336 Ib Ídem, p. 46.

337 Ib Ídem, p. 47.
} 
para la empresa y/o por la deficiencia del sistema (organización defectuosa o ética empresarial viciada).

El aspecto más espinoso y al que le dedica mayor esfuerzo y profundidad es a la culpabilidad empresarial. Aquí propone un cambio de paradigma, apoyándose en un concepto diferente de culpabilidad: ré deriva de su responsabilidad para sus prestaciones colectivas defectuosas que son debidas a carencias en la estructura organizativa o en la ética empresarialé y consiste en no haber creado las condiciones necesarias para la realización del injustoò ${ }^{338}$ Lo que tiene ventaja de encontrar causas de inculpabilidad si ha configurado correctamente su estructura organizativa. En forma específica, el reproche a la empresa lo ve de la siguiente forma: $\tilde{E}$ En estos términos (biosicológicos) no puede plantearse un reproche personal contra una persona jurídica. Dado que la ética de las corporaciones, tal como se ha manifestado no es individual sino exclusivamente social, desde este punto de vista puede efectuarse un reproche al sistema por su incorrección, pues como asociación que aspira racionalmente a alcanzar un fin determinado, puede someter sus fines a exigencias éticas y organizarse conforme a las mismas. Cuando esta responsabilidad y las obligaciones que de ella se desprenden no se cumplen, el comportamiento del grupo puede desaprobarse ético socialmente y este reproche puede expresarse mediante una pena configurada exclusivamente desde un punto de vista ético social. Dado que el contenido de la pena es determinado por el Derecho, su contenido depende del mismo. De este modo, cuando el legislador decide sancionar a las personas jurídicas, configura una sanción carente de reproche ético individual y que contiene exclusivamente una censura ético social, derivada de una deficiente filosofía individual o de una estructura organizativa incorrecta. Esta pena desaprueba que la empresa no haya añadido a sus fines exigencias éticas y que no las haya reflejado en su organizacióné ò ${ }^{339}$

$338 \mathrm{Ib}$ Ídem, p. 47.

$339 \mathrm{Ib}$ Ídem, p. 48. 
La pena y su función no contendería con una aplicación adecuada de la persona jurídica, siempre y cuando se conciba al Derecho Penal en su función de restablecimiento controlado de la paz jurídica dañada y su aseguramiento en el futuro, y si es así, no caben dudas sobre la capacidad de aplicación de los fines de la pena a las personas jurídicas pues las personas jurídicas son sistemas dotados de sentido, al igual que sus operaciones internas y externas. Los fines de la pena, en consecuencia, pueden ser alcanzados. La capacidad de aplicación de los fines de la pena a una empresa puede afirmarse particularmente atendiendo a la prevención general, ya que los efectos que se deducen para otras personas jurídicas son comparables con los ejercidos frente a otras personas particulares a través de la imposición a éstos de una pena de multa. Lo mismo se debe decir de los fines preventivos especiales, pues aquellas consecuencias relativas a la intervención judicial, puede afirmar la utilidad de la misma; es más, tampoco genera demasiados problemas la idea de retribución respecto de las personas jurídicas puesto que se las considera como destinatarias que pueden vulnerar la norma de comportamiento de una manera responsable, lo que implica que puedan ser destinatarias de la censura social ligada a la sanción. ${ }^{340}$

El fundamento de la responsabilidad de las personas jurídicas ré no radica en la infracción en sí, sino en la omisión de las premisas necesarias para un comportamiento conforma a la norma. Esta circunstancia debe tenerse presente tanto en la imputación del injusto como de la culpabilidadò ${ }^{341}$

Trata de resolver otros aspectos relevantes en el tema, como lo es, el relativo a la materia de los delitos que pueden cometer las personas jurídicas, cualquier delito puede ser cometido por ellas, lo determinante es si la lesión del bien jurídico es imputable como delito a la persona jurídica, así se debe renunciar ya al sistema francés, que

\footnotetext{
340 Ib Ídem, p. 49.

341 Ib Ídem, p. 49.
} 
establece un sistema de numerus clausus. En materia de cuál es la forma jurídica de la empresa que debe ser tomada en cuenta para ser sujeto de Derecho Penal ŕsolo los colectivos jurídicamente autónomos que constituyen una persona jurídica o al menos muestran una forma de organización cercana a ser una persona jurídicaé Un sistema debe ser únicamente destinatario de normas y sanciones cuando adopta una forma institucionalò ${ }^{342}$

Los principios de imputación son los siguientes:

a. Lesión punible imputable a la empresa: a través del principio de causalidad, desatada por cualquier persona dentro de la empresa sin importar su posición; pero ré debe haber actuado autorizadamente, es decir, dentro de su competenciaé Para determinar si la lesión del bien jurídico se ha producido en el marco de la organización y del reparto de deberes o bien respecto de la garantía de una filosofía empresarial debida se puede partir del ámbito de responsabilidad de la persona natural, de una eventual posición de garante para el impedimento de la lesión del bien jurídico y de los deberes de vigilancia e inspección que le competené ò ${ }^{343}$

b. Antijuridicidad. ña conexión de la antijuridicidad sólo existirá cuando se puede averiguar respecto del hecho concreto que la lesión del bien jurídico se posibilitó a través de una deficiente estructura organizativa o de una filosofía de la empresa no correspondiente a los requisitos ético sociales ${ }^{344}$, por lo tanto, siempre se exigirá un hecho de conexión concreto.

c. Dolo e imprudencia. No se refieren a la lesión del bien jurídico, sino al conocimiento de la posibilidad del defecto en la organización interna (dolo) o la posibilidad de conocer y que era

342 Ib Ídem, p. 50.

343 Ib Ídem, p. 51.

${ }^{344} \mathrm{Ib}$ Ídem, p. 51. 
evitable (imprudencia) por parte de una persona miembro de la empresa.

d. Delito o sanción administrativa. Se plantea la cuestión de cómo podrá distinguirse cuándo una infracción será delito, y por tanto castigado por el Derecho Penal, o cuándo será una simple infracción administrativa, y por tanto será una simple sanción de ese mismo carácter. Elige un criterio del órgano, pues será delito de la empresa r̃uando un directivo ha actuado antijurídica y culpablemente en relación con las obligaciones de organización y aseguramiento de los fines éticos reconocidos que competen a la empresa ${ }^{345}$ ísi el dolo o imprudencia sólo pueden predicarse en relación con una persona que no pertenece al cuadro directivo, aunque exista dolo o imprudencia empresarial, la sanción a imponer deberá tener carácter administrativoé La sanción administrativa será subsidiaria respecto del delitoò $^{346}$

La responsabilidad de la empresa e individuo pueden coexistir por la diferente obligación original de cada uno de ellos, desde luego.

\subsection{Culpabilidad por la conducción inadecuada de la} empresa

Heine ha escrito sobre este tema ${ }^{347}$ de manera amplia y con mucha intensidad, concluyente.

\footnotetext{
$345 \mathrm{Ib}$ Ídem, p. 52.

$346 \mathrm{Ib}$ Ídem, p. 53.

${ }^{347}$ La obra en habla hispana de este autor respecto al tema planteado la podemos referir a: HEINE, Günter, "Modelos de responsabilidad jurídico-penal originaria de la empresa", Modelos de autorresponsabilidad penal empresarial, propuestas globales contemporáneas, en GÓMEZ-JARA Díez (ed.); Navarra, Aranzadi, 2006; el mismo, "La responsabilidad colectiva: una tarea pendiente a la luz de la evolución penal europea", Modelos de autorresponsabilidad penal empresarial, propuestas globales contemporáneas, en GÓMEZ-JARA Díez (ed.), Navarra, Aranzadi, 2006; el mismo, "La responsabilidad penal de las empresas: evolución internacional y consecuencias nacionales", La responsabilidad criminal de las personas jurídicas:
} 
Parte de que hoy en día el Derecho Penal ya no puede responder con el control retrospectivo de las conductas dañosas, sino que debe preferir el control de las disfunciones sociales provocadas por los subsistemas sociales, para responder a los nuevos ámbitos de la política criminal: delincuencia económica, lavado de dinero, narcotráfico, medio ambiente, los que están, todos, impregnados de modelos de conducta colectiva y no tanto individual, y en ese sentido el tema tiene importancia, porque las empresas son agentes de desarrollo económico. Señala ña exigencia de la política criminal moderna consiste más y más en el control de procesos sociales defectuososé se trata de incrementar la autorresponsabilidad de las empresas y de limitar la actividad de supervisión estatal a una suerte de 'control de los controles internos de las empresas' ò ${ }^{348}$

Asegura que mientras se considere por parte del Derecho Penal que las actividades operativas, la posesión de la información y las de poder de decisión, son concentradas en un solo sujeto, en lugar de estimar que se encuentran dispersas en nuevos modelos de organización como son las empresas, difícilmente se pueden superar lo que llama ñrresponsabilidad individual de carácter estructuralò (pérdida de la capacidad de obrar por descomposición de funciones operativas y estratégicas) y la ñrresponsabilidad individual organizadaò (investigaciones judiciales plagadas de errores o de ineficacias). ${ }^{349}$

Que los modelos básicos de responsabilidad penal de las personas jurídicas, como lo son el de identificación de la responsabilidad penal del órgano con la empresa misma (que simplemente traslada la responsabilidad de la persona física que ostenta la titularidad del órgano de la empresa a la empresa misma), la

una perspectiva comparada, Tirant lo blanch, 2001, (también aparecido en) "La responsabilidad penal de las empresas: evolución internacional y consecuencias nacionales" Anuario de Derecho Penal, Universidad de Friburgo, 1996.

348 "Modelos de responsabilidad jurídico-penal originaria de la empresa", Op. Cit., p. 30.

349 HEINE, "La responsabilidad penal de las empresas: evolución internacional y consecuencias nacionales", Op. Cit., p. 51 y 52. 
organización deficiente de la corporación (que le asegura responsabilidad a la empresa por haber generado un hecho delictuoso derivado de un defecto en la organización, esto es, haber faltado al deber de vigilancia y no establecer las cautelas y cuidados Tiedemann), y por último, el principio de causalidad (es hacer responsable a la empresa por el simple hecho de haber incumplido alguna de las reglas técnicas que el Estado establece en el comercio o en la utilización de tecnología o aparatos peligrosos -Schünemann), favorecen de hecho a una ampliación de la punibilidad de la persona física o a la punibilidad de la persona jurídica por caso fortuito, es totalmente cierto; y todo ello en razón de que se trata siempre de equiparar las categorías del delito de contenido netamente natural o lógico objetivo y ético o moral con las categorías sociales que deben corresponder a la sociedad: ${ }^{350}$ ña equiparación de la responsabilidad individual y colectiva, por parte de los partidarios de la responsabilidad penal de las personas jurídicas, conduce necesariamente, sea a una exigencia excesiva de los particulares, sea a una equivocada dirección de las empresas con una cierta laxitud o cualquier adaptación pragmáticaò $^{351}$

Por ello se afirma por un sistema separado o ñparaleloò de responsabilidad de las personas jurídicas al de las individuales, encontrando incluso ventajas en ello, pues îEn un sistema independiente, se atenúan los problemasò ${ }^{352}$ Que la categoría de la culpabilidad sería exclusivamente normativa, no importa, puesto que ré es finalmente sistemática, cuyos requisitos se deciden normativamente en función a fundamentos socialmente consensuales (concepto de culpabilidad normativa) y cuyo contenido conceptual ya se orienta, en el Derecho Penal individual, de acuerdo a funciones específicasò ${ }^{353}$

\footnotetext{
350 Ib ídem, p. 57 a 60.

351 Ib ídem, p. 64.

352 Ib ídem, p. 64. Así también lo considera BAIGÚN, David, La responsabilidad penal..., Op. Cit., página 28 y 29.

353 Ib ídem, p. 67.
} 
¿Cómo se debe conceptualizar la culpabilidad de la persona jurídica? Como culpabilidad por la conducción de la empresa. Se trata de reconocer la función de la rólimensión temporalà ña mayor parte de los casos que el Derecho Penal debe tratar con el resultado de un desarrollo deficiente de la empresa no atribuible a decisiones individuales, sino a una deficiencia duradera en la previsión de los riesgos e explotación (é ) es más bien de un estado de hecho culpable, que se podría caracterizar, de manera análoga al concepto de đ́ulpabilidad por conducta de vidâि ${ }^{354}$

Ya en materia de una dogmática propuesta específica para las personas jurídicas, Heine señala que tanto la imputación objetiva al resultado como el aspecto de la culpabilidad dependen del giro de la empresa. Pone el ejemplo de una empresa que desarrolla procedimientos empresariales de explotación basados en la tecnología ${ }^{355}$, las categorías dogmáticas serían las siguientes:

1. En principio, y en el sentido de una consideración general, la empresa debería ser considerada como garante de control puesto que los deberes de evitar los peligros de la explotación pueden ricamente ser controlados mediante una administración de los riesgos por parte de la empresa, y no tanto de medidas estatales. ${ }^{356}$

2. Como criterios rectores de imputación, tenemos a una condición necesaria: administración incorrecta del riesgo.

3. Una condición suficiente: materialización del peligro típico de la empresa. Este aspecto sería considerado como una condición objetiva de punibilidad. Que, por cierto, ya no se concibe como una acción particular dominada por la voluntad de una persona, sino como el resultado de la acumulación de procesos empresariales de unos mandos medios que han surgido con el tiempoò ${ }^{357}$

\footnotetext{
${ }^{354}$ Ib ídem, p. 68.

355 Ib ídem, p. 69.

356 Ib ídem, p. 69.

357 HEINE, "Modelos de responsabilidad jurídico-penal originaria de la empresa", Op. Cit., p. 53.
} 
4. Y como criterio de relación entre b. y c. : teoría del aumento del riesgo propio de las organizaciones. No se trata de una causalidad estricta, puesto que no se trata de una coordinación de sucesos puntuales entre la administración incorrecta del riesgo y la materialización del peligro típico de la empresa, sino del dominio de situaciones de riesgo que no parecen ser concretamente previsibles.

5. La autoría se entendería como dominio funcional sistemático de la organización que reemplaza al dominio funcional del hecho individual. Por ello se considera a la materialización del peligro típico de la empresa como condición objetiva de punibilidad, ya que los resultados riesgosos típicos generados por una empresa son producto, de un comportamiento dominado por la voluntad de un autor, sino que es percibido como consecuencia de procesos acumulativos de una administración deficiente generada durante largo tiempo. Dice que rel dominio de la organización es defectuoso cuando la empresa desperdicia la oportunidad de adoptar un remedio a tiempo que sea más adecuado al riesgo; cuando, en situaciones de crisis, no anticipa lo suficiente la planificación y la inversión perjudicando los programas de cuidado ofrecidos. Se exigen, por ejemplo, medidas organizativas horizontales que persiguen conseguir una defensa estratégicamente operativa frente a las fuentes del riesgo técnico, o una adaptación estructural dentro de la empresa a una minimización de riesgos generalé $\sigma^{358}$

6. Dolo, culpa y conciencia de ilicitud. Es más fácil imputar a la empresa el dolo que a una persona individual, que tampoco actualmente se fija con criterios del conocimiento real del autor, sino de carácter social. rimientras que en el caso de un autor individual la presunción de la existencia del conocimiento jurídico relacionado a la multitud de reglas relativas de seguridad existentes se hace cada vez

\footnotetext{
358 HEINE, "Modelos de responsabilidad jurídico-penal originaria de la empresa", op. Cit., p. 51. Así, dice, no se "precisan grandes esfuerzos de carácter difuso como hasta ahora pretende la jurisprudencia del Derecho Penal individual-, sino un cuidado empresarial orientado a los estándares del sector y que, de esta forma, toma en cuenta el estado actual de la ciencia y la técnica para el área de negocio en concreto".
} 
más ficticia, la imputación correspondiente a las empresas es cada vez más real, a condición que se pueda imputar, igualmente, a la empresa autora en su conjunto el conocimiento poseído por sus secciones legal y de seguridadò ${ }^{359}$

7. Culpabilidad por la conducción de la empresa. En tanto forma de responsabilidad específica de la empresa obliga al juez a justificar que ha considerado la ñndividualidadòde la empresa. ${ }^{360}$

8. Sanciones. En materia de sanciones propone como eje central aquellas que apunten a asegurar en el futuro una regulación adecuada del riesgo, como las auditorías así como intervenciones judiciales que aseguren el control del riesgo desde afuera. ${ }^{361}$

Con todo este esquema, bien planteado y bien estructurado, Heine está en disposición de ensayar y proponer una muestra de lo que bien podría ser de lege ferdenda un tipo penal que integre adecuadamente la responsabilidad penal de las organizaciones empresariales. ${ }^{362}$

359 HEINE, "La responsabilidad penal de las empresas: evolución y consecuencias nacionales", Op. Cit., p. 70.

360 Ib ídem, p. 71.

361 HEINE, "Modelos de responsabilidad jurídico-penal originaria de la empresa", Op. Cit., p. 55.

$362 \S 1$ Responsabilidad penal de la empresa

(1) La empresa que descuide los riesgos típicos de la actividad empresarial al infringir:

1.- el deber de asegurar, mediante las medidas organizativas y restructuraciones dentro de la empresa, fuentes empresariales de peligro a largo plazo,

2.- el deber de mantener el nivel de seguridad en caso de delegación de competencias empresariales,

3.- el deber de supervisar y controlar los riesgos empresariales, será sancionada con una pena empresarial cuando se produzca un incidente empresarial considerable.

Se produce un incidente empresarial relevante en el caso de:

1.- muertes o lesiones corporales graves de una parte de la población,

2.- peligros para la comunidad, especialmente los incendios o las explosiones que pongan en peligro a la comunidad (o considerables daños de las cosas en numerosos edificios),

3.- daños medioambientales graves que sólo podrán ser eliminados con dificultades desproporcionadas o al cabo de un periodo largo de tiempo.

(2) Las penas empresariales son: 


\subsection{La culpabilidad constructiva}

Frente a los modelos anteriores, que Gómez-Jara reconoce r̃de avanzadaò por estimar que se acercan mucho a un concepto de responsabilidad propia de la persona jurídica, propone este autor un nuevo modelo, que abreva de los anteriores, pero que trata de aplicar todas las consecuencias extremas de la teoría de la prevención general positiva y del constructivismo. ${ }^{363}$ En la Introducción de su inicial monografía ${ }^{364}$ el autor ya nos deja ver su perfil metodológico: Se pregunta ¿la sociedad deberá cambiar su propio auto entendimiento, considerando ahora si a las personas jurídicas, a quienes las hace fuera de su mundo r̃̃omo si no existieranờ?, luego asegura que son una realidad las personas jurídicas, y si el Derecho Penal tiene la misión de

(el catálogo de penas, clasificado conforme a la necesidad preventiva y a la medida del desencadenante de la responsabilidad, limitación de la producción sólo bajo presupuestos estrictos, descritos de manera explícita).

363 Respecto de la obra de GÓMEZ-JARA en relación con la responsabilidad penal de las personas jurídicas, vid. GOMEZ-Jara Díez, Carlos, La culpabilidad penal de la empresa, Barcelona, Marcial Pons, 2005; el mismo, La responsabilidad penal de las empresas en los EE. UU., Editorial Universitaria Ramón Areces, Madrid, 2006; el mismo, "El modelo constructivista de autorresponsabilidad penal empresarial", en Gómez-Jara Díez (ed.), Modelos de autorresponsabilidad penal empresarial, propuestas globales contemporáneas, Navarra, Aranzadi, 2006; el mismo, "El nuevo art. 31.2 del CP: cuestiones de lege lata y de lege ferenda", en Gómez-Jara Díez (ed.) Modelos de autorresponsabilidad penal empresarial, propuestas globales contemporáneas, Navarra, Aranzadi, 2006;; el mismo, "Autoorganización empresarial y autorresponsabilidad empresarial: hacia una verdadera responsabilidad penal de las personas juridicas", en RECPC, número 8, 2006; el mismo, “¿Imputabilidad de las personas jurídicas?”, Homenaje al Profesor Dr. Gonzalo Rodríguez Mourullo, Civitas, Madrid, 2005, 425 a 446; el mismo, "Teoría de sistemas, ciudadanía corporativa y responsabilidad penal de las empresas", en BAJO Fernández, (dir.); BACIGALUPO y GÓMEZ-JARA (Coords.), Constitución europea y Derecho Penal económico, Madrid, Centro de Estudios Ramón Areces, 2006, 158 y sigs.; el mismo, "Constitución Europea y Derecho Penal: ¿Hacia un Derecho Penal federal europeo?”, en VV.AA., Derecho Penal y política trasnacional, Barcelona, Atelier, 2005; el mismo, " ¿Responsabilidad penal de los directivos de empresa en virtud de su dominio de la organización? Algunas consideraciones críticas", en CPC, número 88, 2006, 119 a 152; el mismo, Fundamentos modernos de la responsabilidad penal de las personas jurídicas. Bases teóricas, regulación internacional y nueva legislación española, Montevideo/Buenos Aires, 2010; el mismo, "La responsabilidad penal de las personas jurídicas en la reforma del Código Penal”, en Diario La Ley, Número 7534, 23 de diciembre de 2010; el mismo, Responsabilidad penal de las personas jurídicas. Aspectos procesales y sustantivos, La Ley, Madrid, 2011.

364 Tesis doctoral leída en 2004 en la Universidad Autónoma de Madrid. 
garantizar la identidad de la sociedad ¿estará preparado para asumir su mutación al de la identidad de la actual sociedad? Se impone el reto de generar un nuevo paradigma ayudados de las teorías sociales: r̂si, en el análisis de la sociedad moderna, se parte de la perspectiva que brinda la teoría de los sistemas sociales autopoiéticos, puede fundamentarse materialmente un concepto de culpabilidad empresarial con auténtico sentido jurídico-penal. ${ }^{365}$ El cambio de paradigma consiste en que partiendo del concepto de r̃sistemas sociales autopoiéticosò se puede fundar la culpabilidad empresarial (con función equivalente a la culpabilidad individual).

Asegura que es necesario salir del círculo hermenéutico en el que se encuentra la dogmática jurídico penal: supone introducir un sujeto que no se cumple con los p̃preconocimientosòbásicos sobre los que se construyó la teoría jurídica del delito ${ }^{366}$. Por tanto, hay que hacer un cambio de raíz, un cambio de paradigma hacia la teoría de los sistemas sociales autopoiéticos, que es un arsenal completo de notable complejidad y precisión, que considera al Derecho, a la empresa y al individuo como sistemas sociales autopoiéticos ${ }^{367}$.

El sistema jurídico está constituido de comunicaciones jurídicas que permiten la reproducción del sistema, no tiene acceso al interior del sistema organizativo ni psíquico, sólo construye una imagen de ambos, a la que le atribuye comunicaciones jurídicas, en el caso del Derecho Penal, comunicaciones jurídico penales ${ }^{368}$.

r̃En lo referente al sistema organizativo, dicho sistema está compuesto por decisiones y, por tanto, su autopoiesis consiste en la reproducción continua de decisiones. De nuevo, dicha autorreferencialidad cierra al sistema frente a su entorno tanto humano como social, constituyendo una determinada imagen de ambos dentro

\footnotetext{
${ }^{365}$ La culpabilidad penal de la empresa, Op. Cit., p. 31

366 Ib Ídem, p. 199.

$367 \mathrm{Ib}$ Ídem, p. 200.

368 Ib Ídem, p. 203.
} 
del sistema. Precisamente gracias a la construcción de sus propias realidades sociales, los sistemas organizativos desarrollan una capacidad epistemológica ï denominada en la literatura teóricoorganizativa especializada, como r̃conocimiento organizativoò y de aprendizaje ïsc. rapprendizaje organizativo-. Más aún, dichas capacidades están estrechamente vinculadas con un cierto ñumbralòde complejidad, a partir del cual la organización empresarial se constituye a sí misma y adquiere una capacidad autoorganizativa y de autorreflexión que le independiza de su entorno. En definitiva, adquiere la autonomía necesaria para auto administrarse. Una de las características de dicha auto administración consiste en la creación de una determinada cultura empresarial que adquiere una determinada vigencia en el ámbito organizativo empresarialo ${ }^{369}$.

Pues bien, para comenzar delimita el objeto de investigación: ¿Persona jurídica o empresa? Mejor organización empresarial: ré lo determinante a estos efectos es la existencia de una autopoiesis organizativa con base en la cual se alcanza en el seno de la organización empresarial un nivel de reflexión tal, que ésta se constituye en un sistema autopoiéticos de orden superior, emergiendo así el verdadero actor corporativo. Expresado con otras palabras, se precisa en todo caso la existencia de una organización empresarial con una determinada complejidad interna. Por lo tanto, el Derecho Penal empresarial es fundamentalmente un Derecho Penal de organizaciones

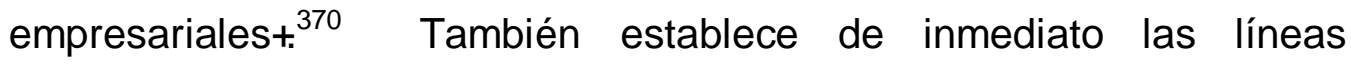
metodológicas de su análisis. En efecto, GOMEZ no parte del holismo, sino de la ré teoría de sistemas en general y el constructivismo operativo como paradigma filosófico en particular ${ }^{371}$; señala que ña clave para entender la forma de proceder de esta teoría es que la interdisciplinariedad se busca de la mano de la abstracción conceptual, no del razonamiento analógico. La abstracción conceptual es la única

\footnotetext{
$369 \mathrm{Ib}$ Ídem, p. 204

370 Ib Ídem, p. 46.

371 Ib Ídem, p. 50
} 
forma de mantener la riqueza teórica para campos muy heterogéneosé $\sigma^{372}$. Contra la dicotomía todo/parte o sistema/elemento, la teoría de sistemas dice sistema/entorno fälcanzando nuevas posibilidades de análisisò

Se pronuncia, así mismo, por un modelo de responsabilidad penal de las personas jurídicas de autorresponsabilidad penal, no de responsabilidad vicaria o por rãtribuciónò sino propio de los actos y singularidad de la persona jurídica en especial. Rechaza el modelo de T̃erecho Penal marginalò de BAJO FERNÁNDEZ, y prefiere el que propone por el peso específico de las empresas en la sociedad actual, y porque sólo dando un concepto autónomo a la culpabilidad de la empresa se puede lograr rél restablecimiento completo de la vigencia de la normaơ 373 .

Del modelo constructivista ï corriente epistemológica de la teoría de los sistemas autopoiéticos-, del que se fundamenta para producir su modelo, exige las características siguientes:

1. Autorreferencialidad de los sistemas: que se reproduzcan a sí mismos a partir de sus propios productos (persona física, jurídica y Derecho) $)^{374}$.

2. Unidad de la teoría: aplica tanto a personas físicas como a jurídicas. IMPOSIBLE elegirlo para personas jurídicas y no para personas físicas $^{375}$.

3. Idéntica capacidad autopoiética (psíquica y social) ${ }^{376}$.

A la tesis constructivista le añade la tesis de la ciudadanía empresarial (ciudadano fiel al derecho) que es una corriente fundamentalmente norteamericana expresada en las Directrices para

\footnotetext{
372 Ib Ídem, p. 50, nota 71.

373 Ib Ídem, p. 54.

${ }^{374}$ Ib Ídem, p. 242, así también, en GÓMEZ-JARA, "El modelo constructivista de autorresponsabilidad penal empresarial", Op. Cit., p. 100 y 101.

${ }^{375}$ La culpabilidad penal de la empresa, Op. Cit., p. 220.

376 "El modelo constructivista de autorresponsabilidad penal empresarial", $O p$. Cit., p. 103.
} 
dictar Sentencias contra Organizaciones Condenadas (DSOC), que tienen a su vez las siguientes características:

A. Vertiente formal: Empresa que tiene el deber de institucionalizar una cultura empresarial de fidelidad al Derecho: Exige referentes teóricos (Teoría del Good Corporate Citizen) y Referentes prácticos (Directrices EUA para imponer sentencias) ${ }^{377}$.

B. Vertiente Material: Dimensión de la ciudadanía. La empresa que participan en asuntos públicos, en dos cuestiones ${ }^{378}$ :

i. Status adquirido por empresas como miembros activos de la sociedad, que refleja sus derechos y obligaciones ${ }^{379}$.

ii. Legitimación de sanciones penales por el hecho de que el sujeto ha participado en la producción y vigencia de normas: Si la empresa participa en la producción r̃̃omún de sentidoòentonces puede cuestionar legítimamente esa norma y si la puede cuestionar, entonces tiene capacidad de culpabilidad ${ }^{380}$.

Con los contenidos anteriores GOMEZ JARA considera poder generar elementos conceptuales funcionalmente similares a los que el día de hoy han sido propuestos para las personas físicas, esto es, acción o conducta, imputación objetiva, imputabilidad y culpabilidad. Por un lado la acción y la capacidad de acción empresarial la fundamenta en la r̃competencia empresarialò (que había sido llamada ñominio de la organización sistémico funcionalò por Heine, o por Lampe îPersona social productora de injustoò o por Botke ñorganización de contactos socialesò o por Jakobs ñámbitos de organización de los que dimana riesgo superior al permitidod̀ GOMEZ

377 La culpabilidad penal de la empresa, p. 248 a 257, y en "El modelo constructivista de autorresponsabilidad penal empresarial", Op. Cit., p. 105 a 107. 378 La culpabilidad penal de la empresa, p. GÓMEZ-JARA, "El modelo constructivista de autorresponsabilidad penal empresarial”, Op. Cit., p. 108 a 110. ${ }^{379}$ La culpabilidad penal de la empresa, p. 262 y sigs.

380 La culpabilidad penal de la empresa, p. 286 a 289. 
JARA lo llama ñorganización interna complejaò que define como capacidad de autoorganización, autoconducción y autodeterminación ${ }^{381}$.

Por otro lado, la imputabilidad empresarial, que estima como capacidad de culpabilidad y que en las personas físicas había sido hasta hoy considerado como capacidad de conocer el carácter antijurídico de su hecho y de conducirse de acuerdo con esa comprensión, en las personas jurídicas serían también el mismo concepto con contenido funcionalmente similar. La imputabilidad estaría fundamentada en la conciencia y comunicación: Igual autorreferencialidad, recursividad y reflexión, por un lado, y por otro, el sistema organizativo: Sistemas que pueden mostrar indicios racionales de autorreferencialidad suficiente, lo que se plasma en sistemas autopoiéticos de orden superior ${ }^{382}$. Para explicar lo anterior, cita a Teubner ña organización sale de su minoría de edad en el momento en que se produce una vinculación hipercíclica entre los caracteres autorreferenciales del sistema organizativo: una doble autorreferencialidad ${ }^{383}$

Pero de qué forma sabemos cuándo la organización sale de su minoría de edad y se produce esos niveles de autorreferencialidad suficiente. Nos lo explica considerando cuatro ámbitos ${ }^{384}$ :

1. Límite del sistema: Condición de miembro.

2. Estructura del sistema: Programas de decisión.

3. Elementos del sistema: las Decisiones.

4. Identidad del sistema: Identidad corporativa.

381 La culpabilidad penal de la empresa, p. 242 a 245, y en "El modelo constructivista de autorresponsabilidad penal empresarial", Op. Cit., p. 112 a 116. 382 En "El modelo constructivista de autorresponsabilidad penal empresarial", Op. Cit., p. 117 y 118.

383 "El modelo constructivista de autorresponsabilidad penal empresarial", $O p$. Cit., p. 119.

384 "El modelo constructivista de autorresponsabilidad penal empresarial", $O p$. Cit., p.119 y 129. 
Si la empresa tiene una r̃omplejidad interna suficienteò entonces será considerada persona en Derecho Penal.

En materia la culpabilidad (empresarial) también genera un equivalente funcional ${ }^{385}$ a través de tres elementos que debemos afirmar en la organización empresarial suficientemente compleja:

1. Fidelidad al Derecho ${ }^{386}$ : Como el Estado no puede controlar todos los riesgos de la modernidad, se genera cierta libertad empresarial: autorregulación. Se aspira a lo mucho a un control reflexivo. Si es así, por lo menos se impone a la organización la obligación de institucionalizar una cultura empresarial de fidelidad al derecho; si no es así, quiebra el rol de ciudadano fiel al Derecho.

2. Sinalagma básico del Derecho Penal| ${ }^{387}$ : Libertad de autoorganización (empresarial) versus Responsabilidad por consecuencias. Aquí radica la legitimación de la responsabilidad e imposición de sanciones.

3. Capacidad de poder cuestionar la vigencia de las normas ${ }^{388}$ : Es la dimensión material de la culpabilidad: es la posibilidad de participar en la producción común de sentido ré la empresa es competente para intervenir en asuntos públicosé ò Es la función de participar en democracia, no votando, sino debatiendo.

Por último, trata de identificar la función de la pena en la organización empresarial. Dice que la pena ya no es una pena de prisión ni de sufrimiento. Pena (fin) es la prevención general positiva (r̃etribución comunicativą). r̃ Su función es contribuir al restablecimiento comunicativo de la norma, derivándose como prestación el reforzar la

385 "El modelo constructivista de autorresponsabilidad penal empresarial", $O p$. Cit., p. 123.

386 La culpabilidad penal de la empresa, p. 248, y en "El modelo constructivista de autorresponsabilidad penal empresarial", Op. Cit., p. 124.

387 La culpabilidad penal de la empresa, p. 274 y sigs., y en "El modelo constructivista de autorresponsabilidad penal empresarial", Op. Cit., p. 126.

388 La culpabilidad penal de la empresa, p. 286 y sigs., y en "El modelo constructivista de autorresponsabilidad penal empresarial”, Op. Cit., p. 127. 
fidelidad al Derechoo ${ }^{389}$. La prestación diferencial es la siguiente: Persona individual: autorresponsabilidad de la persona (libre albedrío); Empresa: Estimulación y refuerzo de la autorresponsabilidad empresarial, para la cultura empresarial de fidelidad al Derecho.

Por último, propone un Derecho Penal de doble vía, esto es, penas y medidas de seguridad contra las empresas, para ser verdaderamente eficaces contra la delincuencia económica ${ }^{390}$.

De forma esquemática, lo siguiente sería una visión de un modelo de responsabilidad penal de las personas físicas comparado con las personas jurídicas, puesto que, como se ha dicho, también pretende que su modelo sea funcionalmente similar al de las físicas ${ }^{391}$ :

A. HECHO O ACCIÓN: Configuración de un ámbito empresarial ï organizativo determinado ${ }^{392}$.

B. INJUSTO: Organización empresarial (defectuoso o inexistente) ${ }^{393}$.

C. DOLO: Conocimiento organizativo de riesgo empresarial ${ }^{394}$.

D. CULPABILIDAD: cultura empresarial de incumplimiento al Derecho.

Por último, estima que su modelo tiene las siguientes ventajas: Superación de la irresponsabilidad individual organizada y estructural; Introducción de causas de justificación o exclusión; Tratamiento de

389 "El modelo constructivista de autorresponsabilidad penal empresarial", $O p$. Cit., p. 130. Asegura que ya desde SILVELA, respecto del CP Español de 1884 justificaba la sanción a la persona jurídica de la siguiente forma "el orden jurídico no se restablece con el solo castigo de los autores individuales", vid. La culpabilidad penal de la empresa, p. 297.

390 "El modelo constructivista de autorresponsabilidad penal empresarial", $O p$. Cit., p. 133.

${ }^{391}$ Ib ídem, Op. Cit., p. 134.

392 Ib ídem, Op. Cit., p. 135.

393 Ib ídem, Op. Cit., p. 137,

394 Ib ídem, Op. Cit., p. 139. 
sociedades pantalla y levantamiento del velo; Catálogo amplio de sanciones (doble vía).

\subsection{El Manslaugther act inglés de 2007}

Las legislaciones de algunos países no han sido ajenas a las necesidades de política criminal, especialmente a los resultados de impunidad derivados de modelos o sistemas de responsabilidad penal de personas jurídicas que exigen la identificación o ubicación de la persona física para trasladar o imputar su acción y su dolo a la empresa. En los casos en que era imposible que una persona o un grupo de personas físicas de una empresa (los officers controlling en el sistema de la identify theory o respondant superior) reunieran en ellas los elementos del delito (actus reus y mens rea), y por tanto, imposible la verificación de su responsabilidad penal, entonces la responsabilidad penal de la persona jurídica también se desdibujaba, creando una insatisfacción generalizada por la impunidad que el modelo o sistema había generado.

Comúnmente se asocia la Manslaugther act 2007 con un caso del hundimiento de un barco de pasajeros ${ }^{395}$. El Herald of Free Enterprise era barco-coche y ferry de pasajeros propiedad de la empresa inglesa Townsend Thoresen. Tenía una ruta para operar en Dover-Calais en el Canal Inglés. El ferry se hundió en la noche del 6 de marzo de 1987, momentos después de salir del puerto belga de Zeebrugge, muriendo a 193 pasajeros y tripulación, siendo el desastre más mortífero marítimo involucrado un buque británico en tiempos de paz desde el hundimiento de la Lolaire en 1919.

La revisión judicial de la investigación oficial convenció al director de la Fiscalía para presentar cargos por homicidio contra la

395 NIETO MARTÍN, Adán, La responsabilidad penal de las personas jurídicas, Op. Cit., página 128. 
empresa $P$ \& $O$ European Ferries y siete empleados, pero el juez dictaminó que no había ninguna evidencia de que un miembro lo suficientemente alto en la gestión de la compañía que pudiera decirse que fue imprudente. Una posterior apelación confirmó la decisión. Dado que los acusados sólo eran operadores medianos de la corporación, significaba que era imposible identificar a un controlador de la mente de la empresa para encontrarla personalmente responsable de homicidio. Se demostró entonces que en el Derecho Inglés los esfuerzos para condenar a las personas en las grandes entidades corporativas tienden a fallar porque la estructura de gestión es más difusa y se hace más difícil hacer esa identificación (la demostración de todas las categorías del delito ï act rea y mens rea- en una sola persona de la alta dirección).

Con ello, y algunos casos más de accidentes mortales en trasportes públicos se puso r̃de manifiesto la ineficacia de la teoría de la identificación. Los tribunales ingleses fueron incapaces de establecer la culpabilidad individual en senior manager a partir de la cual derivar la responsabilidad empresarial $0^{396}$.

Visto el fracaso de la identify theory en los casos anteriores una comisión de expertos realizó un informe (Law Commission Report $\mathrm{n}$. 237 de 1996) ${ }^{397}$, que crea un nuevo delito, como lo es, el Corporate homicide, lo que dio origen al Manslaugther Acto del año 2000. Se trata de ñna propuesta que encarna fielmente lo que se quiere expresar bajo el modelo de culpabilidad de empresa. Lo decisivo para la imputación de la muerte es el defecto o fallo de organización (managent failure), cuya concreción se dirige además a lo que cabe exigir a una empresa en circunstancias semejantes $0^{398}$.

Rezaba de la siguiente manera:

\footnotetext{
396 Ib Ídem, página 128.

397 Ib Ídem, página 128.

398 Ib Ídem, página 129.
} 
(1) Una corporación es responsable por homicidio de la corporación cuando:

a. Un fallo en la dirección es la causa o una de las causas de la muerte,

b. Y dicho fallo puede considerarse una actuación que no cumple con el estándar que razonablemente puede exigírsele a una corporación en semejantes circunstancias.

(2) A los efectos de la sección anterior,

a. Existe fallo de dirección cuando su actividad se ejecuta y organiza sin garantizar la salud y la seguridad de las personas empleadas o relacionadas con dicha actividad.

b. El falo puede considerarse la causa de la muerte aunque su causa inmediata se encuentre en la acción o en la omisión de una persona física.

Merced a que se consideraba indeterminado ese baremo del restándar que razonablemente pueda exigírseleò a la persona jurídica, fue reformulada mediante una nueva legislación que entró en vigor a partir de abril de 2008 por la propuesta de reforma en la Cámara de los Comunes el 20 de julio de 2006 para crear nuevos delitos de thomicidio empresarial, en Inglaterra y Gales, y el homicidio corporativo, en Escociaò por la referencia a la ñiolación del cuidado debidoò relacionado con ley de negligencia o ley de salud y seguridad.

El Corporate manslauhter and Corporate homicide act 2007 es la ley vigente, y en lo que nos concierne, reza de la siguiente manera:

1. El delito.

(1) Una organización a la que se aplica esta sección es culpable de un delito si la forma en que sus actividades se gestionan y organizan:

(a) causa la muerte de una persona, $y$.

(b) equivale a una violación grave de un deber de cuidado 
relevante por la organización a la persona fallecida.

(2) Las organizaciones a las que se aplica esta sección son.
(a) una empresa;
(b) un departamento u otro órgano de la Lista 1;
(c) un cuerpo o fuerza de policía;
(d) una asociación o un sindicato o asociación de empleadores, que es un empleador.

(3) Una organización es culpable de un delito bajo esta sección sólo si la forma en que sus actividades son gestionadas u organizadas por la alta dirección es un elemento sustancial en la infracción mencionada en el inciso (1). .

(4) A los efectos de esta ley.

(a) "el deber de cuidado relevante " tiene el significado dado por el artículo 2, en relación con los artículos 3 a 7; (b) el incumplimiento de un deber de cuidado por una organización es un "grave" incumplimiento si la conducta que supuestamente equivalen a una violación de ese deber está muy por debajo de lo que razonablemente se puede esperar de la organización en las circunstancias;

(c) "alta dirección", en relación con una organización, significa que las personas que desempeñan un papel importante en.

(i) la toma de decisiones acerca de cómo la totalidad o una parte sustancial de sus actividades han de ser administrados $u$ organizados, 0 .

(ii) la gestión actual o la organización de la totalidad o una parte sustancial de esas actividades. .

(5) El delito previsto en esta sección se llama.

(a) homicidio empresarial, en la medida en que es un delito tipificado en la legislación de Inglaterra y Gales o Irlanda del Norte,.

(b) homicidio corporativo, en la medida en que constituye un delito bajo la ley de Escocia.

(6) Una organización que es culpable de homicidio sin premeditación u homicidio corporativo empresarial es responsable en caso de condena de acusación a una multa.

(7) El delito de homicidio corporativo es perseguible sólo en el Alto Tribunal de Justicia. 
Como es fácil observar, el r̃sustrato humanoòno aparece como exigencia para la calificación de responsable a la persona jurídica, y basta que su organización sea defectuosa para que sea posible su condena penal con una multa. El único factor importante y determinante para la responsabilidad penal de la persona jurídica es su organización defectuosa.

De hecho, en el artículo $8^{\circ}$ de la nueva ley, se destaca lo que el jurado debe tomar en cuenta. Ahí podemos darnos cuenta de que la ley ordena a los miembros del jurado observar y justipreciar, para r̃decidir si hubo una grave violación de esta obligaciónòde cuidado por parte de la empresa, la r̂si la evidencia demuestra que la organización no cumplió con la legislación de salud y seguridad que se relaciona con la presunta infracción, y si es así: (a) que tan grave fue la falla; (b) que tanto nivel de riesgo de muerte planteabaò

En el art. $\left.8^{\circ}, 3\right)$, a), ordena al jurado r̃ que la evidencia muestra que hubo actitudes, políticas, sistemas o prácticas aceptadas dentro de la organización que probablemente han alentado cualquier falla, como se menciona en el inciso (2), o que ha producido la tolerancia de la mismaò

Originalmente, el proyecto de ley exigía que el defecto o fracaso de su organización haya sido logrado por sus rãltos directivosò como para causar la muerte de una persona, se abandonó en el Comité Permanente, de manera tal que solo se castiga esa especie de ráumento de riesgoò a la vida o salud de las personas por la organización defectuosa ${ }^{399}$.

\footnotetext{
${ }^{399}$ Lo que le permite a Heine señalar que "Por supuesto, lo que está claro es que, desde el punto de vista judicial, debe establecerse que el hecho desencadenante ha procedido de la empresa. Sin embargo, ¿resulta también necesario probar que exista certeza suficiente de que la lesión del bien jurídico se habría evitado mediante una organización sin fallo alguno? En lugar de esta conocida quasicausalidad, la manslaughter act del año $2000 \ldots$ defiende una suerte de teoría de elevación del riesgo específicamente empresarial. El decisivo contenido disvalioso se traslada fundamentalmente al management defectuosos de la organización", Op. Cit., página 185.
} 
Por último, conviene destacar algo que ya debe considerarse como lógico y consecuencia de la sistematización propia del r̃ofefecto de organizaciónòcomo pivote de la responsabilidad penal de las personas jurídicas: es imposible la participación de personas físicas en este nuevo delito. El art. 18을 impide expresamente la responsabilidad individual al señalar que (̂̃1) Una persona individual no puede ser culpable de inducción, de complicidad, de asesoramiento o procuración de la comisión de un delito de homicidio empresarialò

Decimos que es lógico con la sistemática de esta nueva forma de entender la responsabilidad penal empresarial porque el fundamento y el contenido del act rea y mens rea (el injusto y la culpabilidad) en las personas jurídicas son totalmente distintos de la persona física. Esto no solo porque la ley inglesa significa la creación de un específico homicidio imprudente, por lo que la norma se dirige específicamente a las personas jurídicas, y los actos dolosos o imprudentes de homicidio de las personas físicas tienen regulación en el Código Penal ${ }^{400}$, sino porque parece por lo menos inadecuado a un criterio de organización deficiente sea posible hacer partícipe un criterio de rejercicio final de acciónòo de rexpresión de la personalidadò

\subsection{EI CP australiano}

Australia sigue el sistema jurídico anglosajón, por lo que no es de extrañar que una gran parte de su legislación vaya a tono con la teoría de la identificación o del superior responsable. El CP de 1995 (creado por Act No. 12, 1995) vigente desde 2001, y con algunas reformas en 2007, mediante Act No. 177, previene en su Capítulo 2º, parte $2^{\mathrm{a}}$., división $12^{\mathrm{a}}$, la responsabilidad penal de las personas jurídicas

\footnotetext{
400 NIETO MARTíN, Adán, Op. Cit., página 130 "lo que tipifica la Law Commission es un delito imprudente cometido por una persona jurídica. Si lo que se quiere imputar es un homicidio, por ejemplo, a título de reckless no hay otro camino que acudir a la teoría de la identificación. El corporate manslaughter es una respuesta de la Parte Especial a un problema de la Parte General".
} 
(corporate criminal responsability) señalando, en principio (arts. 12.1 y 12.2), que ese CP se aplicará r̃ las personas jurídicas de la misma manera como se aplica a los individuos. Se aplica así con las modificaciones que se establecen en la presente parte, y con esas otras modificaciones que resulten necesarias por el hecho de que la responsabilidad penal se impone a las personas jurídicas en lugar de individuosò

Luego señala que lo que conocemos como el thecho de referenciaòo thecho de conexiónò (physical elements, esto es, el hecho físico realizado para cometer el delito) realizado por la persona física deberá ser atribuido a la persona jurídica. Lo mismo sucede con los elementos no físicos, es decir, los elementos que se conocen como ñntención, conocimiento o negligencia (o imprudencia) Q̀ rõlebe ser atribuido a una persona jurídica que expresamente, tácitamente o implícitamente autorizó o permitió la comisión del delitoò (12.3(2)(a) y (b)), siempre y cuando se pueda demostrar que el Consejo Directivo de la entidad r̃a) intencionalmente, a sabiendas o imprudentemente llevó a cabo el acto correspondiente expresamente, tácitamente o implícitamente, o autorizó o permitió la comisión del delito, o; (b) demostrando que un alto agente directivo de la persona jurídica intencionalmente, a sabiendas o imprudentemente participó en la conducta relevante, o expresamente, tácitamente o implícitamente autorizó o permitió la comisión del delitoò

Esta primera parte del CP australiano no deben llamarnos la atención, pues marida perfectamente con una responsabilidad vicarial que, como ya hemos dicho, tiene desventajas político criminales, dogmáticas 0 de legitimación y en la práctica diaria. Lo que debe ser materia de reflexión y análisis es lo que enseguida está previsto.

Señala el art. 12.3(2)(c) y (d) que a la persona jurídica será responsable del delito: 
(c) probando que existía una cultura corporativa dentro de la corporación que dirige, fomenta, tolera o lleva al nocumplimiento de la disposición pertinente, o

(d) que demuestre que la persona jurídica no puede crear y mantener una cultura corporativa que requería cumplimiento con la disposición pertinente.

Como se puede observar, el CP australiano crea vía de responsabilidad dolosa en la comisión del delito. Es decir, amén de exigirle por la vía del 12.3(2)(a) y (b)), es posible exigirle y demostrarle por esta otra vía: la creación de una cultura corporativa que dirige, fomenta, tolera o lleva al no cumplimiento del orden jurídico (acción) o la no creación o mantención de una cultura corporativa que requería cumplimiento con la disposición pertinente (omisión).

Creemos que sería adecuado interpretar estas previsiones legales considerando que el CP exige un thecho de referenciaò o T̂echo de conexiónòen cualquier caso (desde el inciso a) hasta el d)), no obstante, mientras en los supuestos (a) y (b) ese hecho de la persona física fundamenta el injusto de la persona jurídica (ejercitando así la teoría de la identificación o respondant superior que ya hemos analizado), en los supuestos (c) y (d) solamente representa un hecho que dispara o desata la responsabilidad penal de la persona jurídica, pero no la fundamenta.

De hecho, el 12.3(3) señala una causa de no responsabilidad que es exclusivamente aplicable en los casos del 12.3(2), es decir, del directivo que individualmente actuó con intención, a sabiendas o imprudencialmente. Solo evitará la responsabilidad criminal si la persona jurídica demuestra que en este caso:

(3) El párrafo (2) (b) no se aplican si la persona jurídica prueba que ejerció debida diligencia para prevenir la conducta, o la autorización o permiso. 
Esto es, la indentification theory en su expresión extrema (sin posibilidad de exceptuar o disculpar en ningún caso a la persona jurídica) solo se aplica en los casos en que el Consejo de Administración haya acordado o decidido la realización del delito (authorised or permitted the commission of the offense) ${ }^{401}$. Pero si solamente fue un administrador (high managerial agente) entonces es posible disculpar la comisión del delito de dicho administrador con la demostración de una debida diligencia (due diligence) para evitar dicho delito. Esta parte la identificamos con aquellas previsiones en las directivas y decisiones marco europeas relativas a la responsabilidad penal de las personas jurídicas que tienen que ver con la romisión de cuidado y vigilanciaò por parte de los altos directivos a sus empleados cuando éstos cometen delitos en favor, en beneficio o por cuenta de la empresa.

Pero la situación cambia si la razón por la cual la empresa es responsable se ubica en el art. 12.3(2)(c) y (d). En este caso el CP no exige que algún directivo o empleado haya experimentado intención, conocimiento o imprudencia, sino que es la intención, conocimiento o imprudencia de la propia persona jurídica la que permite fundamentar su propia responsabilidad. Esto significa nada menos que ña culpabilidad de empresa, concretada en la idea de cultura corporativa, $y$, por tanto, de un modelo de imputación absolutamente despersonalizado ${ }^{402}$. No es ya el dolo o imprudencia que se encuentra en el ñnecho de referenciaòo el m̂necho de conexiónò de la persona física (alto directivo o empleado mal vigilado) la que se imputa simplemente a la persona jurídica, sino el dolo y la culpa de la propia persona jurídica.

La vía por la que se exige responsabilidad penal originaria a la empresa se perfila o se especifica en el art. 12.3(4)(a) y (b), de la siguiente forma:

401 Lo que Nieto Martín llama "núcleo de verdad de la teoría de la identificación", Op. Cit., página 96.

402 Ib Ídem, página 131. 
(4) Los factores relevantes para la aplicación del párrafo

(2) (c) o (d) incluyen:

(a) si la autorización para cometer un delito del mismo o similar clase había sido dada por un alto agente directivo de la entidad corporativa, $y$

(b) si el empleado, agente o funcionario de la persona jurídica que cometió la ofensa creyó por motivos razonables, o tuvo una expectativa razonable de que un alto agente directivo de la entidad corporativa pudo haber autorizado o permitido la comisión del delito.

Son criterios de prueba para demostrar los fundamentos de la propia responsabilidad: Una cultura corporativa que dirige, fomenta, tolera o permite la violación de la ley penal, o la omisión de la cultura corporativa necesaria para evitar violaciones a la ley penal. De tal forma que pueden ser considerados, pero no son necesarios para fundamentar esa responsabilidad.

En el 12.3(6) el CP explica qué es lo que entiende por cultura corporativa: ña actitud, la política, el estado, conducta o práctica existente dentro de la empresa en general o en la parte de la persona jurídica en la que las actividades pertinentes se llevan a caboò

Por último, parece que en el art. 12.4(3) el CP australiano se previenen disposiciones relativas a la imprudencia de la persona jurídica en la comisión del delito. Según Nieto ña conducta negligente, de no constatarse un autor individual, puede predicarse de la propia empresa, sin necesidad de localizar la imprudencia en un concreto empleado: 'la culpabilidad es atribuible a la organización cuando la conducta de la empresa aparece como imprudente en su conjunto $\mathrm{o}^{403}$. Señala el art. en cuestión que:

(3) La negligencia puede evidenciarse por el hecho de que la conducta prohibida era atribuible sustancialmente a:

403 Op. Cit., página 132. 
(a) la falta de gestión empresarial de control o supervisión de la conducta de uno o más de sus empleados, agentes o funcionarios, 0

(b) falta de sistemas adecuados para transmitir información relevante a personajes relevantes de la entidad corporativa.

Interesa el CP australiano porque en él se concreta, tal vez, sistemas o modelos de imputación de responsabilidad penal para las personas jurídicas que no requieren del sustrato humano, de la identificación y ubicación de la persona física responsable, que se dirige exclusivamente o casi exclusivamente a su propia fíorma de actuaròo ñorma de seròde la empresa, acercándose a lo que desde un principio la doctrina en España exigía: un sistema de responsabilidad penal genuino y originario de las personas jurídicas. 
SEGUNDA PARTE:

TEORÍA JURÍDICA DEL DELITO DE LAS PERSONAS JURÍDICAS A PARTIR DE LA LO 5/2010 


\section{CAPITULO V}

\section{CONSTRUCCIONES TEÓRICAS A PARTIR DE LA LO 5/2010, DE 23 DE JUNIO}

\section{INTRODUCCIÓN}

La LO 5/2010, de 23 de junio, que introduce la responsabilidad penal de las personas jurídicas, ha traído una gran vaharada de interpretaciones distintas e incluso encontradas por parte de la doctrina española. Luego de que se ha dado un modelo legislativo que era tan esperado, ahora era necesario interpretarlo de acuerdo a un modelo doctrinal para poder obtener las directrices e interpretaciones que el caso ameritaba.

Es importante que el texto legal sea maridado con un modelo de responsabilidad penal de personas jurídicas porque de esa manera tendría una posibilidad de éxito en su aplicación, ya que pasaría a ser un modelo sólido, y por ello, pleno, íntegro, sin contradicciones internas ni externas (por tanto, alineado a los principios constitucionales que informan nuestro Derecho Penal). Como decía el Consejo General del Poder Judicial en su informe del año 2006 al Anteproyecto de Reforma 
del Código Penal rêl fundamento dogmático de la imputación subjetiva de las personas jurídicas no ha de verse como mero ejercicio de discusión académica, en la que vienen vertiendo ríos de tinta la literatura jurídica europea, incluida la española con importantes aportaciones. La conclusión que se obtenga resultará trascendental para la configuración del conjunto del sistema penalò

Huelga decir que desde el Anteproyecto de 2006 de reforma al Código Penal, se proponía una reforma a ese tópico, y hasta antes de la Ley Orgánica que reformaba el Código Penal ya había propuestas de interpretación doctrinales que contribuyeron hondamente al esclarecimiento anticipado de la cuestión que estamos tratando ${ }^{404}$.

La doctrina se ha centrado, fundamentalmente, en dos posiciones: por un lado, quienes ven en el art. 31 bis CP un modelo de heterorresponsabilidad ${ }^{405}$, atribución, adhesión o alter ego o respondant superior, por otro, un grupo interpreta que estamos frente a un verdadero modelo de autorresponsabilidad penal de las personas jurídicas, es decir, un modelo de responsabilidad originaria del ente colectivo. Dentro de este último grupo destacan quienes afirman que el T̃echo de conexiónò (que es la conducta típica y antijurídica de la persona física, que actúa en nombre y por cuenta de la jurídica) se traspasa a la persona jurídica constituyendo de ese modo su ñnjusto

404 Para mencionar solo algunas, NIETO MARTÍN, Adán, La responsabilidad penal de las personas jurídicas, Op. Cit.; GÓMEZ-JARA DIEZ, Carlos, Fundamentos..., Op. Cit.; y ZUGALDÍA ESPINAR, José Miguel, La responsabilidad penal de empresas, fundaciones y asociaciones, Op. Cit., pássim; CUADRADO RUIZ, Ma. de los Ángeles, "La responsabilidad penal...", Op. Cit., pássim.

405 Por todos, DIEZ RIPOLLÉS, José Luis, "La responsabilidad penal de las personas jurídicas. Regulación española", en InDret, Número 1/2012, Barcelona, enero 2012, que señala "la reforma penal española de 2010 ha optado por el sistema de imputación societaria basado en el modelo de transferencia de responsabilidad. A su tenor, se imputa a la persona jurídica el hecho injusto cometido por sus representantes, administradores o empleados, esto es, el tipo objetivo y subjetivo, la antijuridicidad y la graduación del injusto genérico en ellos concurrentes. En todo caso, es preciso que ese hecho lo hayan realizado en nombre o por cuenta de la persona jurídica, y en su provecho. Como iremos viendo al analizar las interpretaciones alternativas, resulta difícil negar tal conclusión dada la estructura del art. 31 bis", página 13 y pássim. 
personalö ${ }^{406}$ mientras que la culpabilidad la hacen descansar en el r̃defecto de la organizaciónơ ${ }^{407}$; mientras que otros más aseguran que el r̃defecto de la organizaciónò es en realidad el injusto personal de la persona jurídica y la cultura empresarial fiel al derecho constituiría su culpabilidad $^{408}$. Desde luego, existen otras voces con razones de mucho peso que miran en la redacción legal actual una responsabilidad penal de los entes pero no a través de penas que exigen culpabilidad, sino, a

406 Por todos, ZUGALDÍA ESPINAR, José Miguel, La responsabilidad criminal de los entes colectivos (personas jurídicas y entes sin personalidad) y de sus directivos $y$ representantes. Análisis de los arts. 31 bis y 129 del Código Penal, 40, "el modelo del hecho de referencia o del "hecho de conexión" considera que la acción típica de la persona jurídica se integra por la realización, por una persona física, de la vertiente objetiva y subjetiva de un tipo penal en el que se admita la responsabilidad criminal de las personas jurídicas, siempre y cuando el hecho se lleve a cabo en unas condiciones tales que permitan afirmar que es, al mismo tiempo, una acción propia de la persona jurídica y expresión de su específico obrar corporativo (v.gr. que se lleve a cabo por una persona competente de la empresa, que se infrinjan deberes que le competen como miembro de la misma, que se actúe en el giro de la empresa, que se lleve a cabo en beneficio de la empresa)" (las cursivas y comillas son del texto original).

407 Ib Ídem, página 40, "la culpabilidad de la persona jurídica -siguiendo el punto de vista de Tiedemann, dominante en esta materia- consistiría en una culpabilidad por defecto de organización. Esta construcción, en una combinación armoniosa de la prevención general, tanto en la forma de disuasión frente a la colectividad, como en la forma del reforzamiento de la conciencia jurídica, considera que el objeto de la imputación es el hecho típico de conexión o de referencia de la persona física y que la persona jurídica sería culpable siempre que haya omitido tomar las medidas de cuidado necesarias para garantizar un desarrollo ordenado y no delictivo de la actividad de empresa (se trataría de la infracción del deber de evitar que la actividad de empresa se concrete en la realización de hechos delictivos)".

408 Por todos, DE LA CUESTA ARZAMENDI, José Luis, "Responsabilidad penal de las personas jurídicas en el derecho español", en Revista electrónica de la Asociación Internacional de Derecho Penal (ReAIDP), 2012, página 15, señala "en efecto, a nuestro parecer y como ya se ha indicado, resulta dogmáticamente muy razonable, y coherente con la realidad de la "criminalidad de la empresa", construir no tanto la culpabilidad cuanto el núcleo del injusto específico de la persona jurídica sobre la infracción por parte de ésta de su deber de evitación de delitos en el marco de las actividades sociales realizadas por su cuenta y provecho; un deber de garantía "del cumplimiento de la legalidad y de la adecuación de la organización a lo prescrito por el Derecho", que se presenta como de carácter "colectivo", dirigido "a todos los entes dotados de personalidad jurídica", y que no por el hecho de que sólo resulte mencionado de manera expresa en el párrafo segundo del art. 31 bis 1, deja de ser legalmente exigible respecto de los hechos de sus administradores o representantes contemplados en el párrafo primero, habida cuenta de la delimitación legal de su actuar y de la reconducción del mismo al giro propio de la entidad, esto es, al "ámbito que la persona jurídica podría y debería haber controlado", por ser el desplegado "al amparo de su nombre y/o con la ayuda de sus recursos". 
lo sumo, de medidas de seguridad que tratan de controlar la peligrosidad de ciertas personas jurídicas ${ }^{409}$. Todo lo anterior con muchos matices y matices que imprimen de forma personal los autores que han dedicado muchas líneas a este tema y que veremos en las páginas siguientes.

La intención de este capítulo es mostrar la evolución doctrinal a partir del texto legal de la LO 5/2010, de 23 de junio, sus intentos de interpretación y de la adquisición de un modelo específico. Pero al mismo tiempo, el análisis y la crítica de las posiciones desde el punto de vista de las dimensiones o directrices que hemos remarcado en la primera parte de este trabajo de investigación. Esto es, si, bajo las reglas marcadas por los distintos modelos o sistemas de responsabilidad penal de las personas jurídicas que han surgido en el debate doctrinal, es posible que superen las necesidades político criminales en virtud de las cuales se alegaba la necesidad de la derogación del principio societas delinquere non potest, si no contradicen los principios constitucionales y los derechos fundamentales de las personas procesadas, y si son practicables (o más practicables que otras) desde el punto de vista del ejercicio diario de su aplicación.

Por ello, primero daremos cuenta de aquellas posiciones que se soliviantan contra una culpabilidad penal de la persona jurídica (2), considerando más bien un modelo de responsabilidad por peligrosidad, para luego ver aquellos modelos que afirman la heterorresponsabilidad penal o de atribución integral (3), enseguida los de autorresponsabilidad penal que se fundan en un t̃echo de conexiónò de la persona física

${ }^{409}$ ROBLES PLANAS, Ricardo, "Pena y persona jurídica: crítica del artículo 31 bis CP”, en Diario La Ley, Número 7705, 29 de septiembre de 2011., página 6, quien señala "es claro que la persona jurídica no participa en el delito finalmente cometido por la persona física por el mero hecho de estar «desorganizada». Por consiguiente, la responsabilidad no puede surgir con arreglo al sistema de imputación de la Parte General, sino, en su caso, creando «un injusto de desorganización» específico, cuyo merecimiento de pena habría de fundamentarse no en una relación de imputación entre la «desorganización» y el delito final, sino en una suerte de injusto de peligro". 
como injusto de la jurídica (4), y luego aquellos que estiman un injusto personal (objetivo y subjetivo) así como una culpabilidad propios de la persona jurídica ï en los que el Thecho de conexiónò es solo un presupuesto de la responsabilidad (5). Siguiendo con una exposición sintética de otras respuestas doctrinales difícilmente reconducibles a las anteriores, o por lo menos, con rasgos específicos dignos de comentar (6). En el capítulo II, tomaremos posición respecto de todas las anteriores, exponiendo nuestras consideraciones respecto del modelo que sigue el art. 31 bis CP.

Intencionalmente hemos omitido el análisis de quienes lamentan, no tanto la forma del texto legal que introduce la responsabilidad penal de los entes colectivos, sino que se haya introducido ese sistema de responsabilidad penal ${ }^{410}$. La discusión no es, según lo creemos, si debe o no responsabilizarse a las asociaciones, sino de qué manera aplicamos el sistema que hoy en está vigente en el CP español, tras la reforma operada por la LO 5/2010, de 23 de junio.

\section{EL ART. 31 BIS CP COMO RESPONSABILIDAD PENAL SIN CULPABILIDAD DE LAS PERSONAS JURÍDICAS.}

410 CARRETERO SÁNCHEZ, Adolfo, "Aspectos sustantivos y procesales de la responsabilidad penal de las personas jurídicas", en Diario La Ley, Número 7786, 30 de enero de 2012, página 5, señala "en nuestra modesta opinión, por muy adecuado que parezca el «dolo organizativo», la responsabilidad penal de las personas jurídicas sigue residiendo en la de las personas físicas que la integran, que son las que cometen la culpa in vigilando o la comisión por omisión, máxime cuando no puede incluso aplicarse la responsabilidad personal subsidiaria del art. $53 \mathrm{CP}$ en caso de impago de multa a las personas jurídicas. Creemos sinceramente que la regulación de la responsabilidad penal de las personas jurídicas es una vuelta atrás a sistemas superados de responsabilidad colectiva e incluso tiene un tufo de Derecho penal de autor, como dice FEIJOO SÁNCHEZ. Desde el punto de vista de la política criminal, dudamos de la eficacia de las sanciones pecuniarias en las grandes empresas, y nos parece excesiva y perjudicial para los trabajadores y los acreedores la disolución de la empresa, que viene a ser la muerte empresarial". 
A pesar del contenido del nuevo art. 31 bis CP, es decir, de la claridad con que está expuesta la responsabilidad de carácter penal por la comisión de ciertos delitos, de las consecuencias jurídicas de carácter penal, de la lateralidad del art. 129 CP de imposición de otras r̃ consecuencias accesoriasò en caso de la comisión de hechos por agrupaciones sin personalidad jurídica, y en general, de la expresa mención del legislador en su exposición de motivos de la reforma de que se introducía por primera vez la responsabilidad penal de las personas jurídicas, algunos autores ${ }^{411}$ han expresado su escepticismo a tal conclusión.

Las razones expuestas por quienes así lo estiman no son, a nuestro entender, de menor importancia o interés. En realidad analizan a fondo las varias interpretaciones que se han hecho del nuevo texto legal para concluir que es imposible considerar que el art. 31 bis CP haya venido a inaugurar un sistema de verdadera responsabilidad penal para las personas jurídicas, principalmente por objeciones dogmáticas y de legitimación constitucional, razón por la cual propone una interpretación lateral.

2.1. El art. 31 bis CP como un modelo de responsabilidad objetiva del riesgo.

Se trataría de una norma para t̃acer responder con el patrimonio social tras la comisión de un hecho delictivo por parte de los administradores o bien de otros subordinados sobre los que los

\footnotetext{
${ }^{411}$ Nos referimos fundamentalmente a ROBLES PLANAS, Ricardo, "¿Delitos de las personas jurídicas?", InDret, 2/2006; el mismo, "El hecho propio de las personas jurídicas y el informe del Consejo General del Poder Judicial al Anteproyecto de Reforma del código penal de 2008", InDret, Número 2/2009; el mismo, "Crítica del artículo 31 bis CP”, en Diario la Ley, No. 7705, Año XXXII, Editorial La Ley, 29 de septiembre de 2011; y DEL ROSAL BLASCO, Bernardo, "Responsabilidad penal de empresas y códigos de buena conducta corporativa", en Diario La Ley, Número 7670, 11 de julio de 2011, pássim, especialmente los últimos dos párrafos de su trabajo de investigación.
} 
primeros no han ejercido el debido controlo ${ }^{412}$. No se trataría en forma precisa de una responsabilidad de carácter civil, que ya se encuentra establecida en el art. 1903 CC español (aunque algo parecido), sino que aparece como r̃ consecuencia relevante el comiso de las ganancias obtenidas y los costes de prevención de tales enriquecimientos injustos $0^{413}$ que tiene que soportar la persona jurídica y sus titulares. No es, desde luego un r̃eprocheò por el delito, sino la ñegitimación del Estado para actuar sobre la empresa que se enriquece injustamente ${ }^{414}$, para exigirle a los titulares de la empresa que mantengan el estado de cosas caracterizado por la obtención lícita de ganancias ${ }^{415}$.

La finalidad de un sistema así es la de ñncentivar para que en el ámbito de la persona jurídica no se introduzcan ganancias provenientes de hechos delictivos y, en esa medida, combatir la perpetuación del estado de injusto producido por la comisión del hechoo ${ }^{416}$. Así, el modelo del art. 31 bis CP obedece a la estructura de responsabilidad objetiva por el riesgo.

Atendiendo a lo anterior, la responsabilidad de la persona jurídica no tendría un fundamento de manera alguna penal. El adverbio ñpenalmenteò del art. 31 bis CP no estaría ñeferido al fundamento o naturaleza de la responsabilidad, sino al contexto en el que ésta se deriva. El fundamento y naturaleza de esa responsabilidad de la persona jurídica, es por el contrario, ajeno al Derecho Penalơ ${ }^{417}$. Parece ser que el fundamento en el que piensa el autor es más bien de carácter público pero de raigambre civil, esto es, derivado del estado de injusto en beneficio económico de la organización, a la persona jurídica le debe corresponder r̃osde el punto de vista de una justa distribución, los costes de prevención, y en su caso, de eliminación de tales situaciones jurídicamente indeseadas estrechamente vinculadas con

\footnotetext{
412 “Crítica al art. 31 bis CP”, Op. Cit., página 15.

$413 \mathrm{Ib}$ Ídem, página 15.

${ }^{414} \mathrm{Ib}$ Ídem.

$415 \mathrm{Ib}$ Ídem.

416 Ib Ídem.

417 Ib Ídem, página 17.
} 
esa finalidad de obtención de beneficiosơ ${ }^{418}$, como una medida disuasoria de Derecho público o multa coercitiva, a la manera de Gracia Martín ${ }^{419}$.

Con el fundamento anterior, los alcances y consecuencias del texto del art. 31 bis CP tiene ya sentido y legitimación: la responsabilidad de la persona jurídica tiene doble vía consistente en el hecho delictivo del administrador de hecho y de derecho y del representante legal, por un lado, y en el delito del subordinado que está sometido a la autoridad de los anteriores y que lo haya cometido por no haberse ejercido el debido control atendiendo a las circunstancias del caso. Si el delito, en ambos casos, fue cometido en m̃ombre o por cuenta y en su provechoò de la persona jurídica, en el primer caso, o, además, en rẽl ejercicio de las actividades socialesò en el segundo, entonces el modelo r̃̃e trasferencia o de atribuciónò expresamente adquirido por nuestra legislación, generaría rãutomáticamenteơ ${ }^{420}$ la responsabilidad del ente.

La persona jurídica ñesponde automática y objetivamente por todo hecho delictivo que hayan llevadoò a cabo las personas ya señaladas en las condiciones apuntadas. ${ }^{421}$ La responsabilidad por rel hecho ajenoò o la responsabilidad objetiva, propugnadas por el nuevo texto legal, no serían criticables ni serían ilegítimas porque no estaríamos hablando de responsabilidad penal, sino simplemente de contenido público de raigambre civil. Lo mismo habría de decir del dolo y la imprudencia, que no serían propias de la persona jurídica, sino de la persona física, que en un ejercicio de atribución, se le imputaría a aquella ${ }^{422}$.

\footnotetext{
418 Ib Ídem, página 11.

419 GRACIA MARTÍN, Luis, "La cuestión de la responsabilidad penal de las propias personas jurídicas", Op. Cit., página 72.

${ }^{420}$ ROBLES PLANAS, Ricardo, "Pena y persona jurídica: crítica al art. 31 bis CP", Op. Cit., página 12.

421 Ib Ídem, página 12.

422 Ib Ídem, página 12.
} 
Y por último, la finalidad de un sistema así, como el propuesto, tendría la distribución de costes y la incentivación a la implantación de programas de control y organización para que no se cometan delitos (compliance programs), como r̃cargasòo ñncumbenciasơ ${ }^{423}$, de manera tal que no se impondrían como obligaciones, pero si poseen esos programas de cumplimiento entonces tendrían ventajas a la hora de desactivar su propia responsabilidad.

Para arribar a esta conclusión el autor desautorizó la pretensión de asignarle la categoría de penal al art. 31 bis CP por las razones siguientes:

1. El T̃echo propioò de la persona jurídica no existe ${ }^{424}$. El supuesto thecho propioò de la persona jurídica en realidad son los hechos objetivos y físicos de las personas físicas que actúan para ella. Y esto, tanto a partir del modelo de atribución o vicarial hasta el modelo llamado de autorresponsabilidad.

2. El modelo de atribución o trasferencia, que trata de construir la responsabilidad de la persona jurídica exclusivamente a partir de la trasferencia o imputación de la responsabilidad de la persona física que actúa como órgano (ño que realiza el órgano se le imputa a la persona jurídica ${ }^{425}$ ), no solo no integra en realidad un hecho propio de la persona jurídica, sino que conculca el principio de proscripción de responsabilidad por hechos ajenos, y en ese sentido, el de proscripción de responsabilidad objetiva en materia penal ${ }^{426}$.

423 ROBLES PLANAS, Ricardo, "El 'hecho propio' de las personas jurídicas y el Informe del Consejo General del Poder Judicial al Anteproyecto de Reforma de Código Penal de 2008”, Op. Cit., página 10.

${ }^{424}$ Ib Ídem, página 9. Dice "por un lado, no existe tal «hecho propio» porque la persona jurídica carece de culpabilidad al margen de la culpabilidad de las personas físicas: no puede expresarse en acciones que conformen hechos $\mathrm{y}$, por tanto, no puede reprochársele ni acción ni hecho alguno.

${ }^{425}$ ROBLES PLANAS, Ricardo, “¿Delitos de personas jurídicas?”, Op. Cit., página 5.

426 ROBLES PLANAS, Ricardo, "El 'hecho propio' de las personas jurídicas y el Informe del Consejo General del Poder Judicial al Anteproyecto de Reforma de Código Penal de 2008", Op. Cit., página 9, cuando señala que "El modelo del «hecho propio» de la persona jurídica resulta ser una forma de responsabilidad por la 
3. Al voltear a los sistemas de autorresponsabilidad, donde el defecto de organización podría constituir el injusto personal de la persona jurídica, habría que concluir que ese título no es suficiente para imputar a la persona jurídica el delito que cometió la persona física ${ }^{427}$. Es imposible legitimar la sanción a una entidad por la no colaboración con el Estado ren las labores de prevenciónơ ${ }^{428}$. El ñnjusto de sistemaò no es ñu injusto penal en relación con la conducta delictiva de la persona física, pues no ñe alcanzanòlas reglas de la imputación típicas del delito producidoơ ${ }^{429}$. Lo que recuerda lo dicho por Schünemann ños actos de organización incorrectos no infringen en todo caso la norma cuya infracción describe el correspondiente tipo penal, así que al responsabilizar penalmente a la persona jurídica en realidad se subsume en la norma penal supuestamente infringida una acción lesiva referida a otra norma ${ }^{430}$.

En todo caso, este sistema peca de la misma forma que el vicarial, puesto que quien no r̃rganizaò adecuadamente a la empresa no es la persona jurídica misma, sino los administradores y directores, y no parece adecuado propugnar por un delito del administrador por m̃o colaboraròcon la prevención del delito ${ }^{431}$.

transferencia o atribución y, por consiguiente, de responsabilidad por hechos ajenos y puramente objetiva".

427 Ib Ídem, página 9.

428 Ib Ídem, página 9. También en el mismo, “Delitos de las personas jurídicas?”, Op. Cit., página 7, "menor atención ha merecido la cuestión de si las infracciones de deberes de organización que pueden cometer las personas jurídicas ingresan en el programa normativo de protección jurídico penal. Sea cual sea la perspectiva que se adopte, lo cierto es que con las reglas de definición de la tipicidad de las conductas (reglas de imputación) no es posible afirmar que la infracción de deberes organizativos constituyen comportamientos directamente típicos del delito que se produzca. En todo caso, tales infracciones pueden llegar a calificarse, desde el punto de vista estructural, como omisiones del deber de cuidado que facilitan (o implican el peligro de facilitar) la comisión de delitos (por parte de personas físicas)."

$429 \mathrm{Ib}$ Ídem, página 16.

430 SCHÜNEMANN, Bernd, "Responsabilidad penal en el marco de la empresa. Dificultades relativas a la individualización de la imputación", en Anuario de Derecho Penal y Ciencias Penales, Vol. LV, 2002, página 29.

431 ROBLES PLANAS, Ricardo, "El 'hecho propio' de las personas jurídicas y el Informe del Consejo General del Poder Judicial al Anteproyecto de Reforma de Código Penal de 2008", Op. Cit., página 7. 
4. Contra la pretensión de hacer un ñnjusto de desorganización de sistema específicoò ya en la parte general ï como parece que está hecho con el 31 bis CP-, ya en la parte especial, constituyendo así a la persona jurídica (o a sus administradores) en una especie de garantes del colectivo consistente en provocar o no impedir el sistema de injusto, el autor opone la falta de legitimación: r̃en tanto en cuanto no pueda establecerse una relación de participación típica entre los garantes y el concreto delito, el ñnjustoò de aquellos no será injusto penalmente típicoơ ${ }^{432}$.

Graves dificultades de legitimación material por ser un delito de peligro abstracto y la demasiada facilidad en la atribución de responsabilidad penal por la simple infracción de deberes formales ${ }^{433}$.

5. La culpabilidad propia de la persona jurídica debería tener las mismas críticas que las que se hicieron al injusto personal, pues no es la persona jurídica la que debe responder de algo que no está en sus manos evitar. En el modelo vicarial, la atribución de hechos ajenos y la responsabilidad objetiva obstruirían todo intento de legitimar una pena derivada de ello, y lo mismo ocurriría en cualquier modelo (mal llamado) de autorresponsabilidad porque ren realidad, el modelo de culpabilidad propia de la persona jurídica no es más que una variante refinada del modelo de la transferencia o de la atribuciónơ ${ }^{434}$.

6. En cuanto a la adopción de los sistemas de prevención de delitos (compliance programs), que no es más que trasladar a las empresas los costes de la prevención y detección de delitos que le incumben al Estado, el autor critica su falta de referencia al delito (no se castigaría el comportamiento relacionado con el delito, sino más bien con algo previo al delito y más abstracto, como lo es, la no adopción de

\footnotetext{
432 , "¿Delitos de las personas jurídicas?", Op. Cit., página 16.

433 ROBLES PLANAS, Ricardo, "El 'hecho propio' de las personas jurídicas y el Informe del Consejo General del Poder Judicial al Anteproyecto de Reforma de Código Penal de 2008", Op. Cit., página 7.

$434 \mathrm{Ib}$ Ídem, página 5.
} 
esos programas de cumplimiento ${ }^{435}$ ) y su falta de legitimidad (ño parece posible legitimar hoy por hoy un nuevo tipo penal que castigue a directivos y administradores por no r̃ colaborarò con el Estado en el sentido expresado ${ }^{436}$ ).

¿Qué queda entonces? Propone lo ya antes dicho, es decir, estructurar la responsabilidad de la persona jurídica, pero no basada en la culpabilidad y sí anclada en principios jurídicos extrapenales, de carácter público pero con finalidades civiles de repartir los costos del delito. Esta forma de intervención es legítima a pesar de un sistema de transferencia del injusto y la culpabilidad de la persona física a la persona jurídica, incluyendo su dolo o la imprudencia. La creación y gestión de los programas de cumplimiento (compliance programs) y su efecto r̃exculpanteò se explica desde una perspectiva de que son incentivos rá la adopción de mecanismos de prevención a la vez que desincentiva que en el patrimonio social se integren ganancias provenientes del delito ${ }^{437}$. No son obligaciones, sino cargas o incumbencias de la persona jurídica, que cuando son desplegados por la persona jurídica le pueden beneficiar en la medida ren que se haya reaccionado inmediatamente a la comisión del delito evitandoòque las ganancias económicas del delito se lleguen a confundir con el patrimonio de la persona jurídica ${ }^{438}$.

La posición anterior recuerda aquella de Silva Sánchez que desde mucho tiempo atrás abogaba por un sistema de responsabilidad de las personas jurídicas, si bien penal, sí sin culpabilidad, ya que la capacidad de ellas de ir configurando a través del tiempo un estado de injusto favorecedora de la comisión de delitos por parte de sus integrantes, daría lugar a la suficiente ñbase fácticaò para imponer consecuencias jurídicas sin vulnerar el principio del hecho ${ }^{439}$, así como

\footnotetext{
435 Ib Ídem, página 7.

436 Ib Ídem, página 8.

$437 \mathrm{Ib}$ Ídem, página 11.

$438 \mathrm{Ib}$ Ídem, página 11.

439 SILVA SÁNCHEZ, Jesús-María, "La responsabilidad penal de las personas jurídicas y las consecuencias accesorias del art. 129 del CP”, Op. Cit., página 340.
} 
a Mir Puig quien sigue estimando adecuado un sistema de peligrosidad, no de culpabilidad, para las personas jurídicas ${ }^{440}$, y las importantes contribuciones que hizo hacia este horizonte Feijóo ${ }^{441}$. De la misma forma, Fernández Teruelo hace apología de un sistema de ese talante ${ }^{442}$.

\section{EL ART. 31 BIS CP COMO HETERO RESPONSABILIDAD} PENAL DE LAS PERSONAS JURÍDICAS

\subsection{Exposición general de la tesis: injusto y culpabilidad de las personas jurídicas}

A prima facie el art. 31 bis CP puede ser sugerente de un sistema de atribución simple y sencillo, desde el injusto personal hasta la culpabilidad de la persona física hacia la persona jurídica.

No es para menos, la literalidad del 31 bis. 1 CP así lo hace parecer:

440 MIR PUIG, Santiago, Derecho Penal. Parte General, Reppertor, 9a edición, Barcelona, 2011, al criticar la reforma de la LO 5/2010 y la tensión que provoca sobre los principios de culpabilidad y personalidad de las penas, señala "todo ello no es obstáculo para que la peligrosidad que entrañan algunas personas jurídicas pueda explicar que sobre ellas recaigan medidas de seguridad o consecuencias accesorias. Del mismo modo, puesto que no cabe dudar que una persona jurídica puede causar a terceros daños susceptibles de ser evaluados o reparados económicamente, también debe afirmarse la conveniencia de que quepa determinar reglas de responsabilidad civil derivada del delito que obliguen a la persona jurídica a reparar el daño causado", página 211.

441 FEIJÓO SÁNCHEZ, Bernardo, Sanciones para empresas por delitos contra el medio ambiente, Civitas, Madrid, 2002, especialmente 34 y pássim, 137 y pássim; el mismo, “¿Culpabilidad y punición de personas jurídicas?”, en MONTEALEGRE LYNETT, Eduardo (Coord.), El funcionalismo en Derecho Penal, Universidad Externado de Colombia, Colombia, 2003, pássim.

442 FERNÁNDEZ TERUELO, Javier Gustavo, "El nuevo modelo de responsabilidad penal de las personas jurídicas introducido por la LO 5/2010", en Lex Nova http://www.reformapenal.es/2010/11/23/algunas-consideraciones-criticassobre-el-nuevo-modelo-de-responsabilidad-penal-de-las-personas-juridicas-i/, última visita 3-12-12. 
1. En los supuestos previstos en este Código, las personas jurídicas serán penalmente responsables de los delitos cometidos en nombre o por cuenta de las mismas, $y$ en su provecho, por sus representantes legales $y$ administradores de hecho o de derecho.

En los mismos supuestos, las personas jurídicas serán también penalmente responsables de los delitos cometidos, en el ejercicio de actividades sociales y por cuenta y en provecho de las mismas, por quienes, estando sometidos a la autoridad de las personas físicas mencionadas en el párrafo anterior, han podido realizar los hechos por no haberse ejercido sobre ellos el debido control atendidas las concretas circunstancias del caso.

Como se observa, el $1^{\circ}$ y $2^{\circ}$ párrafos hacen depender la responsabilidad penal de la persona jurídica in totum del delito (de la responsabilidad) de la persona física, en uno y otro caso ${ }^{443}$. De tal manera que puede parecer claro y evidente que el delito de los administradores o de los empleados, simplemente se le transfiere ${ }^{444}$. Se

443 Así SOLÉ RAMÓN, Ana María, "La responsabilidad penal de las personas jurídicas. Hacía una nueva regulación de la persona jurídica como sujeto activo del Derecho Penal y Procesal Penal", en Revista General de Derecho Penal, Número 13/2010, http://www.iustel.com/v2/revistas/detalle_revista.asp?numero=13 \&id=8, última visita 9-01-12, página 21, "la reforma opta por un sistema de imputación y culpabilidad de conductas a la persona jurídica consistente en vincularlo a la comisión del mismo... ello implica una suerte de transferencia de la culpabilidad del directivo a la persona jurídica"; y CARDONA TORRES, Juan, "La responsabilidad penal de las personas jurídicas", en Diario La Ley, Número 7699, 21 septiembre de 2011, p. 2. De la misma manera, pero crítico por haber acogido este sistema vicarial RODRIGUEZ MOURULLO, Gonzalo, "La responsabilidad penal de las personas jurídicas y los principios básicos del sistema", en Abogados, septiembre 2010, página 38.

${ }_{444}$ Así, DIEZ RIPOLLÉS, José Luis, "La responsabilidad penal de las personas jurídicas. Regulación española”, en InDret, Número 1/2012, Barcelona, 2012, www.indret.com, última visita 9-02-12, página 13, cuando señala que "la reforma penal española de 2010 ha optado por el sistema de imputación societaria basado en el modelo de transferencia de responsabilidad. A su tenor, se imputa a la persona jurídica el hecho injusto cometido por sus representantes, 
piensa que se trasfiere la acción o conducta y su resultado, las modalidades de la conducta, el dolo o la imprudencia, la comisión activa u omisiva, la tentativa y la consumación, la autoría o la participación en el delito ${ }^{445}$. De hecho, como dice el Informe del Consejo General del Poder Judicial al Anteproyecto de Ley Orgánica por la que se modifica la Ley Orgánica 5/1995, de 23 de noviembre, del Código Penal, aprobado el 18 de febrero de 2009, que tanto en el $1^{\circ}$ párrafo como en el $2^{\circ}$ del art. 31 bis CP propuesto (que fue prácticamente el mismo que finalmente es el vigente) el legislador optó por un modelo de responsabilidad vicarial, ñas personas jurídicas son responsables porque se les atribuye el actus reus y la mens rea de quien es su agenteò $^{446}$

Esta perspectiva también es propiedad de la Fiscalía General del Estado, que en su Circular 1/2011 relativa a la responsabilidad penal de las personas jurídicas conforme a la reforma del Código Penal efectuada por Ley Orgánica número 5/2010, en donde comunica el resultado del análisis y su posición de interpretación final con el texto de la reforma, que indudablemente la ley incorpora un sistema de heterorresponsabilidad, de responsabilidad de las personas jurídicas de naturaleza indirecta o subsiguiente ${ }^{447}$, o abiertamente, un modelo vicarial $^{448}$. Expresamente señala que r̃dado que, como hemos visto, la persona jurídica puede devenir responsable de la infracción penal consecuencia del substratum del individuo que la comete, la tipicidad, los criterios de imputación objetiva y subjetiva, el dolo o la imprudencia,

administradores o empleados, esto es, el tipo objetivo y subjetivo, la antijuricidad y la graduación del injusto genérico en ellos concurrentes. En todo caso, es preciso que ese hecho lo hayan realizado en nombre o por cuenta de la persona jurídica, y en su provecho. Como iremos viendo al analizar las interpretaciones alternativas, resulta difícil negar tal conclusión dada la estructura del art. 31 bis".

445 RODRIGUEZ MOURULLO, Gonzalo, Op. Cit., página 38 "la consecuencia que se deriva de la vigente definición del artículo 10 es que la responsabilidad penal de la persona jurídica que introduce la Reforma es una responsabilidad penal sin delito y que la pena que se impone a la persona jurídica es una pena sin dolo o imprudencia, que contraviene, por ello, la contundente garantía consagrada en el artículo 5 del CP"

446 Página 12.

447 Circular 1/2011, página 30.

$448 \mathrm{Ib}$ Ídem, página 38. 
así como todos los demás elementos de la infracción concurrentes o no, sea cual fuere la concepción dogmática del delito que se prefiera, deben residenciarse en las personas físicas, de modo que en presencia de una infracción penal cometida por un sujeto individual, la corporación solo resultará comprometida si la infracción se produce en las específicas circunstancias y por quienes establece el legisladorô ${ }^{49}$.

Que las eximentes o circunstancias modificativas de la responsabilidad penal no se transfieran de la persona física a la jurídica, según lo dispone el art. 31 bis 3 CP no sería una muestra de la conclusión contraria a la arribada, pues también se debe valorar que la persona jurídica no tiene en realidad exculpantes o eximentes propias que hayan de valorarse ${ }^{450}$. En efecto, las eximentes de responsabilidad del art. 31 bis. 4 CP no son referentes a la propia culpabilidad de la persona jurídica, puesto que se refieren a eventos posteriores a la comisión del delito, y por tanto atinan más bien a la necesidad de pena, y ratienden, por tanto, a una menor necesidad del juicio de responsabilidad trasferido, ligada a razones de eficacia, efectividad o eficiencia, según los casoso ${ }^{451}$, aunque también reconocen que la culpabilidad es propia de la persona jurídica, sin embargo, no le dan ningún contenido ${ }^{452}$. Efectivamente, Diez Ripollés, en su caso, es

${ }^{449} \mathrm{Ib}$ Ídem, página 33.

450 DIEZ RIPOLLÉS, Op. Cit., página 6, "en todo caso, la culpabilidad se imputa estrictamente a partir del hecho injusto transferido por la persona jurídica, sin que estén previstas eximentes, atenuantes o agravantes de la persona jurídica, y estando vedada la aplicación de las susceptibles de concurrir en las personas físicas transferentes. Es, por tanto, un juicio desvalorativo de carácter general, que reprocha a la sociedad el concreto comportamiento antijurídico realizado en su seno a su cuenta y provecho, sin que puedan tomarse en cuenta elementos fácticos concurrentes en ella que pudieran matizar o excluir ese reproche en el caso concreto".

${ }^{451} \mathrm{Ib}$ Ídem, página 25. Así también la Circular 1/2011, página 38.

452 DIEZ RIPOLLÉS, José Luis, Op. Cit., página 16 "Y ello por más que el hecho ajeno imputado a la sociedad es solo el comportamiento injusto de las personas físicas competentes, y que personas física y jurídica responden autónomamente de su respectiva culpabilidad, punibilidad, merecimiento y necesidad de pena. En suma, nuestro legislador no ha querido o no ha sido capaz de configurar en la ley penal un injusto específico propio de la persona jurídica. Lo que reconduce la cuestión a la admisibilidad social y constitucional de atribuir a la persona jurídica responsabilidad por hechos cometidos por personas físicas por cuenta y en 
silente y hace mutis de la segunda categoría dogmático penal, como lo es, la culpabilidad. No le merece ningún comentario. No obstante, podemos concluir que dicho autor entiende que aún y cuando la culpabilidad es ñpropiaò de la persona jurídica, esa culpabilidad no será el r̃̃lefecto de organizaciónò cosa diferente en el caso de la Fiscalía General del Estado, que va más allá, y ningún contenido propio le da a la culpabilidad de la persona jurídica ${ }^{453}$.

El r̃defecto de organizaciónò de la persona jurídica no figura ni tiene efecto alguno ni en el injusto típico ni en la culpabilidad, es un elemento ajeno y extraño al sistema de responsabilidad del art. 31 bis CP. Así parecen indicarlo quienes comparten esta perspectiva, cuando señalan, como en el caso de Diez Ripollés, que no comparten la interpretación doctrinal de quienes ven en el $2^{\circ}$ párrafo del art. 31 bis. 1 CP un defecto de organización como fundamento de la responsabilidad penal del ente, en el sentido de que la ley exige a los administradores de hecho o de derecho o a los representantes legales un deber de control de los subordinados para que no cometan ningún delito. r̃a sociedad no responde por el injusto propio derivado del control indebido de sus representantes o administradores a sus subordinados, sino por el delito cometido por éstos: De ahí que sea irrelevante que la ausencia de control sea dolosa o imprudente, o que la implantación, previa al delito, de un plan de cumplimiento carezca de consecuenciaso ${ }^{454}$. Así también la Fiscalía General del Estado, quien insiste en atribuir responsabilidad penal a la persona jurídica aún y cuando exista un programa de cumplimiento: r̃su formalización no aporta ni su

provecho de ella. Como decimos, la culpabilidad y la punibilidad son las propias de la persona jurídica".

453 Así también lo entiende el Informe del CGPJ al Anteproyecto de 2009, sin embargo, sí reclama una corrección al propuesto para que el "defecto de organización" sea la base y objeto del injusto penal de la persona jurídica, puesto que si no es así, si se queda así el proyecto, caeríamos en una responsabilidad objetiva de la persona jurídica.

454 Ib Ídem, página 24 (las cursivas son mías). 
inexistencia resta la capacidad potencial de incurrir en responsabilidad penalö ${ }^{455}$

Al analizar las atenuantes del 31 bis $4 \mathrm{CP}$, dejan muy claro que el ordenamiento no va m̃ás allá de atribuir un efecto atenuatorio a conductas societarias equiparables a programas de cumplimiento siempre que se realicen tras la comisión del delito y para prevenir o detectar nuevos delitos en el futuroo ${ }^{456}$, por lo que ningún efecto tendría un compliance guide si se gestionara y desarrollara con anterioridad a la comisión del delito ${ }^{457}$.

Es claro, y así lo admiten quienes defienden esta construcción a partir de la nueva legislación penal, que un modelo interpretativo de ese tenor podría llegar a infringir los principios más caros de lo que se conoce como el Derecho Penal liberal, como lo son los relativos a la proscripción de responder por el hecho ajeno y la responsabilidad objetiva ${ }^{458}$. Si la persona jurídica es responsable penalmente por un hecho que no fue cometido por ella misma, sino por una persona diferente, quien no actúo como mero instrumento ni tampoco entre su hecho y la actuación de la persona jurídica existe una suerte de participación en el delito, entonces resulta claro que no puede eventualmente evitar el resultado dañoso que es significado por el delito, de ahí que responda de forma objetiva sin posibilidad de evitación.

No obstante, dicen, la cuestión de la legitimidad de un sistema así, de su corrección constitucional, está fuera de discusión, pues no

455 Circular 1/2011, página 39.

$456 \mathrm{Ib}$ Ídem, página 28.

${ }^{457}$ Circular 1/2011, página 38.

458 DIEZ RIPOLLÉS, José Luis, Op. Cit., página 5, "Este modelo infringe el principio de responsabilidad por un hecho propio, elemento constitutivo del principio de imputación personal, en su vertiente cuantitativa. Se hace responder a la persona jurídica por un hecho delictivo ajeno, propio de sus representantes o empleados: el mismo injusto cometido por estos es el que se imputa asimismo a la persona jurídica. Por lo demás, el injusto de los representantes o empleados es un injusto propio de ellos, pues tales representantes o empleados no se consideran meros instrumentos materiales de ejecución de un injusto en realidad propio de la persona jurídica, lo que llevaría a tener que declararlos irresponsables". 
existe ni responsabilidad objetiva ni se responde por hecho ajeno, ni se infringe el non bis in ídem, rel modelo vicarial diseñado por el legislador español parece difícilmente objetable desde el punto de vista constitucionalo $^{459}$. Otros, más cautos, admiten que ello sería un tema a debatir, pero mientras tanto no cabe una interpretación que se aparte del modelo de atribución ${ }^{460}$.

Señalan que ñimitar la cuestión a un problema de interpretación constitucional supone adoptar una postura reduccionista en exceso. Solo una oposición manifiesta de nuestra constitución a la atribución de cualquier tipo de responsabilidad por el hecho ajeno supondría un freno temporalmente insalvable al debate sobre este asunto. Pero, en cualquier caso, la cuestión decisiva reside en si nuestro sistema de creencias admite responsabilizar a la persona jurídica por hechos realizados por otras personas por cuenta y en provecho de ella. Y mi impresión es que nuestra sociedad está dispuesta, dada la trascendencia social de las actividades de los entes colectivos, a aceptar tal responsabilidad societaria. Si esto es así, se trata de encontrar el modo socialmente más convincente de estructurar esa responsabilidado ${ }^{461}$.

\subsection{Causas eximentes de responsabilidad de la persona} jurídica

A tono con lo expuesto, la tesis que propugna la identificación total (en injusto personal y en culpabilidad) del delito de la persona física y de la persona jurídica, no observan ninguna clase de posibilidad

459 Circular 1/2011, página 38.

460 DIEZ RIPOLLÉS, José Luis, Op. Cit., página 6, "El asunto se suele plantear en términos estrictamente constitucionales: Un sector doctrinal estima que nuestra constitución avala que las personas jurídicas no deberían gozar de las mismas garantías que las personas físicas, al carecer aquellas de determinados atributos de estas, singularmente la dignidad personal; eso permitiría afirmar la no vigencia respecto a ellas de principios como el de responsabilidad por el hecho propio o el de imputación subjetiva".

$461 \mathrm{Ib}$ Ídem, página 6. 
de alegar alguna causa ñpropiaò de la persona jurídica para evitar su responsabilidad penal. A nivel del tipo penal, de la antijuridicidad y de la culpabilidad, todas las causas para evitar su propia responsabilidad dependen también de las causas de evitación de la responsabilidad penal de la persona física. Si se quisiera alegar atipicidad, justificación o inculpabilidad, se obliga a probar o demostrar los hechos de otra persona.

Cabría también demostrar que la persona física no actuó por cuenta o a nombre ni en ejercicio de las actividades sociales de la empresa, o que lo hizo pero no en provecho del ente corporativo, ciertamente. No obstante, esta posibilidad de evitación de su responsabilidad también implica demostrar hechos ajenos, hechos propios de la persona física.

\subsection{Ventajas del sistema de responsabilidad penal de la persona jurídica por el hecho ajeno}

Debemos concluir que la ventaja que tendrían estas posturas, amén de su simpleza y fácil manejo ${ }^{462}$, es que se apegarían de forma acrítica al texto simple del art. 31 bis CP. Los intentos de ñntroducir atipicidad, eximentes 0 atenuantes en tales casos, pecan de voluntarismo ${ }^{463}$, y toda interpretación diferente no es más que forzar, ilegalmente, el texto de la ley. El legislador, dicen, no ha querido o no ha sido capaz de r̃ ronfigurar en la ley penal un injusto específico de la persona jurídicaơ ${ }^{4}$.

No vemos ninguna ventaja adicional a la anterior.

\footnotetext{
462 Puesto que utilizarían la teoría del delito de la persona física que ya está hecha, y simplemente trasladarían el resultado de las conclusiones del análisis ("la persona física cometió un delito tal, como autor o cómplice, y en grado de tentativa, en nombre y por cuenta y en provecho de la persona jurídica"), y enseguida pronunciarían la responsabilidad de la persona jurídica.

463 DIEZ RIPOLLÉS, José Luis, Op. Cit., página 22, nota 84.

$464 \mathrm{Ib}$ Ídem, página 16.
} 


\section{CONSTRUCCIONES CON INJUSTO POR EL HECHO DE} CONEXIÓN Y CULPABILIDAD POR DEFECTO DE LA
ORGANIZACIÓN.

4.1. Exposición general de las tesis: el injusto personal de la persona jurídica

Una gran parte de la doctrina se ha decantado por la interpretación de que el art. 31 bis CP recoge en realidad un modelo en donde la persona jurídica tiene una culpabilidad propia y autónoma de la persona física, aunque el injusto personal, bajo ciertas exigencias normativas, si le sea transferido. De ahí que el injusto típico de la persona jurídica sea a la vez el injusto personal del de la persona física ${ }^{465}$. A este sistema algunos le llaman con tendencia a la heterorresponsabilidad ${ }^{466}$, otros entre la heterorresponsabilidad y autorresponsabilidad ${ }^{467}$ y hay quien dice que es un modelo puro $y$

\footnotetext{
465 Por todos, ZUGALDÍA ESPINAR, José Miguel, La responsabilidad criminal de los entes colectivos (personas jurídicas y entes sin personalidad) y de sus directivos y representantes. Análisis de los arts. 31 bis y 129 del Código Penal, página 40.

466 RODRÍGUEZ MOURULLO, Gonzalo, "Hacia la responsabilidad penal de las personas jurídicas en el Código penal español", en Estudios de Derecho penal económico, Thomson Reuters, Civitas, Navarra, 2009, página 277, ahí critica al modelo de atribución llamado vicarial (que fue acogido por el proyecto de 2008 de reforma del $\mathrm{CP}$ ) en virtud de que, dice, constituye una "responsabilidad penal por el hecho de otro", además de que da lugar a una responsabilidad penal sin dolo o culpa y sin acción u omisión, pues "... contienen esencialmente un inexcusable sustrato psicológico", y todo ello, hace que choque con el principio constitucional de personalidad de la sanción o pena como, por el contrario, exige su respeto la STC 219/1998 de 22 de noviembre, amén de que vulnera el principio "non bis in ídem". El autor encuentra un contrasentido en el texto del Proyecto y Anteproyecto, pues por un lado acogen un modelo de atribución de "sistema vicarial" y luego independizan las responsabilidades (31 bis.3).

467 Que es prácticamente la mayoría de los autores que ubicamos en este epígrafe, BACIGALUPO S., Silvina, "Los criterios de imputación de la responsabilidad penal de los entes colectivos y de sus órganos de gobierno (arts. 31 bis y $129 \mathrm{CP}$ ), en Diario La Ley, Número 7541, de 5 de enero de 2011, página 5, "el Código Penal ha optado por establecer, tanto en el art. 31 bis como en el art. 129 CP un sistema de atribución de responsabilidad a las personas jurídicas por el hecho delictivo cometido por una persona física dentro de la estructura empresarial", aunque
} 
auténtico de autorresponsabilidad penal de las personas jurídicas ${ }^{468}$. No sería inadecuado llamar en términos generales a estas posturas como m̃mixtasò en tanto que se encuentran en tránsito hacia una autorresponsabilidad, pero dependiendo de la acción de la persona física, como lo dice Carbonell Mateu ren definitiva, la Reforma parece adoptar un camino intermedio entre la responsabilidad directa de las personas jurídicas por hecho propio ï que es el modelo defendido en este trabajo- y el de traslación de responsabilidad derivada del hecho cometido por personas físicas como consecuencia del rólefecto de organizacióno ${ }^{469}$.

Como sea, estas interpretaciones parten del mismo punto que el anterior: el texto expreso y literal de la ley específicamente contenido en los párrafos $1^{\circ}$ y $2^{\circ}$ del art. 31 bis $\mathrm{CP}$, pues ahí es donde se prevé la responsabilidad penal para la persona jurídica a partir, y solo a partir, de un referente objetivo, visible, tangible, como lo es, el hecho (acción y omisión) de la persona física que actúa por su cuenta y en su nombre y en su provecho. Es decir:

después señala que la culpabilidad de las personas jurídicas es propia y se identifica por el defecto de organización, al decir, "en mi opinión, la existencia de un déficit o defecto de organización debe ser el presupuesto de punibilidad de las personas jurídicas. Por tanto, el modelo de imputación debe basarse sobre la existencia de un hecho de conexión y sobre la idea de la culpabilidad por defecto de organización", página 6 (cursivas en el original). También CUDRADO RUIZ, Ma. de los Ángeles, "La responsabilidad penal de las personas jurídicas. Un paso adelante... ¿Un paso hacia atrás?”, Op. Cit., página 135 y sigs.; DÍAZ GÓMEZ, Andrés, "La responsabilidad criminal de las personas jurídicas en el Derecho Español", http://www.newsmatic.eol.com.ar/usr/721/6159/la responsabilidad criminal de-las personas jur dicas en el derecho espa ol.pdf página 53; GALÁN MUÑOZ, Alfonso, "La responsabilidad penal de la persona jurídica tras la reforma de la LO 5/2010: entre la Hetero- y la Autorresponsabilidad", en Revista General de Derecho Penal, número 16, 2011, página 16 y pássim; GOMEZ TOMILLO, Manuel, Introducción a la responsabilidad penal de las personas jurídicas en el sistema español, Lex Nova, Valladolid, 2010, página 66 y 67; GOMEZ MARÍN, V., "Artículo 31 bis", en MIR PUIG, S. y CORCOY BIDASOLO, M. (Dirs.) Comentarios al Código Penal. Reforma LO 5/2010, Tiran lo Blanch, Valencia, 2011, página 131.

468 ZUGALDÍA ESPINAR, José Miguel, La responsabilidad criminal de los entes colectivos (personas jurídicas y entes sin personalidad) y de sus directivos $y$ representantes. Análisis de los arts. 31 bis y 129 del Código Penal, página 40.

469 CARBONELL MATEU, Juan Carlos, "Responsabilidad penal de las personas jurídias: reflexiones en torno a su "dogmática" y al sistema de la reforma de 2010", en CPC, número 101, 2010, página 31 (de la separata). 
1. Injusto personal de la persona jurídica: el injusto de la persona física.

2. Culpabilidad de la persona jurídica: Defecto de organización.

Para esta parte de la doctrina la acción de la persona física se transfiere a la jurídica sin problemas de legitimación: por un lado, así está establecido en forma expresa en el texto legal, y por otro lado, no parece existir problemas constitucionales.

Ciertamente, es muy claro el texto reformado al señalar que la persona jurídica será responsable de los r̃delitosò de la persona física, del administrador de hecho o de derecho o de su representante legal, o en su caso, de los empleados que dependan de ellos, siempre y cuando exista una falta de control debido atentas las circunstancias del caso. Si ese núcleo o universo de personas comete el delito, y lo hace, además, en nombre, por cuenta y en provecho de la persona jurídica (o en ejercicio de las actividades sociales de la empresa) el ente responderá.

A partir de aquí encontramos dos vías de justificación o legitimación del sistema señalado: por un lado, defienden la acción de la persona física r̃̃omo siò fuera propia de la persona jurídica, bajo ciertas condiciones normativas, y por lo tanto, no se conculcaría el principio que prohíbe la responsabilidad objetiva y el de responder del hecho ajeno; y por otro, aseguran que la persona jurídica, no obstante de ser una verdadera persona de derecho penal, no tiene todos los derechos constitucionales ni en la misma medida le deben ser adscritos aquellos que sí tiene, de manera tal que su acción o conducta debería poder ser consideradas como m̃o propiasò sin violentar los anteriores principios ni el de personalidad de las penas, amén de que el fin de la pena es la autorregulación regulada.

Los primeros señalan que ña construcción parte de considerar a la persona física y a la persona jurídica como sistemas que actúan conjuntamente, aunque pueden ser responsabilizados independientementeò Se trataría, partiendo del hecho de una persona 
física que realiza un tipo penal (lesionando o poniendo en peligro un bien jurídico), de establecer los criterios normativos de imputación que permiten considerar a la persona jurídica como autora culpable del hecho e imponerle la pena prevista por la leyé pero no es la responsabilidad de éstas la que hace responsable a la persona jurídicaé no se trata de transferir lo que ha hecho una persona (la persona física) a otra que no lo ha hecho (la persona jurídica)é se trata de determinar bajo qué condiciones normativas se puede atribuir directamente el hecho a la persona jurídica como propio, como su autoría ${ }^{470}$. Enseguida se evidencian los criterios normativos de imputación: una acción de la persona física que debe ser vista como de la jurídica por aparecer en rél contexto socialò por lo tanto, debe vulnerar deberes y obligaciones de la persona jurídica en el ejercicio de las actividades sociales de la empresa (giro de la empresa), que sea hecho por un grupo cerrado de personas (directivos o empleados bajo la supervisión de aquellos) y que se haya actuado por cuenta, en nombre y en provecho de la persona jurídica ${ }^{471}$; y lo mismo sucedería con la vertiente subjetiva pues ña regla debe ser, por consiguiente, que la persona jurídica responderá dolosamente o imprudentemente según el conocimiento (dolo) o desconocimiento evitable (imprudencia) de quien realiza el hecho de referencia ${ }^{472}$. El profesor Zugaldía llama al anterior modelo de autorresponsabilidad penal de la persona jurídica por el ñecho de conexiónò

La segunda opción, avalada por otros autores ${ }^{473}$, aún y cuando admiten que el injusto personal (tipicidad y antijuridicidad) de la persona

470 ZUGALDÍA ESPINAR, José Miguel, La responsabilidad criminal de los entes..., Op. Cit., página 40 .

471 ZUGALDÍA ESPINAR, José Miguel, La responsabilidad penal de empresas, fundaciones y asociaciones, Op. Cit., página 216.

472 Ib Ídem, página 223; y el mismo, La responsabilidad criminal de los entes colectivos... Op. Cit., página 53.

473 DÍAZ GÓMEZ, Andrés, Op. Cit., página 51, "Aparece así la posibilidad de un modelo a caballo entre la responsabilidad vicaria y la de culpabilidad de la empresa, de un sistema mixto que parte de la heterorresponsabilidad y se encamina a la autorresponsabilidad"; en el mismo sentido MARTíNEZ PARDO, Vicente, "La responsabilidad penal de las personas jurídicas", en Revista 
jurídica se identifica con el injusto personal de la persona física (con las exigencias normativas adicionales expuestas en el propio art. 31 bis CP: que sean administradores de hecho o derecho, representantes legales o bien cualquier empleado bajo el control de aquellos, por cuenta y en nombre, los primeros o en ejercicio de actividades sociales, los segundos, y todos en provecho de la persona jurídica), aseguran que la traslación, imputación, trasferencia o conexión del injusto de una persona a otra no irrumpe ningún principio constitucional o legal o derecho de la persona jurídica (como podría ser el de culpabilidad, el de personalidad de las personas, el de interdicción de responder por el hecho ajeno, o el de proscripción de responsabilidad objetiva) por dos razones fundamentales: Porque las personas jurídicas, aún y cuando poseen prácticamente todos los derechos constitucionales y procesales que también tienen las personas físicas, el propio ordenamiento debe decidir en qué medida deben gozar aquellas esos derechos, y por tanto, nada impide que sean sometidas a regímenes de responsabilidad más estrictos que las físicas en función de obtener fines públicos ${ }^{474}$, es más, el propio Tribunal Constitucional ha admitido que si bien las personas jurídicas tienen derechos fundamentales, también es cierto que la protección constituye un efecto reflejo del derecho fundamental del que son titulares las personas físicas que la integran ${ }^{475}$.

En conclusión, dice Nieto Martín, r̃el modelo vicarial es constitucionalmente inobjetable siempre y cuando posibilite utilizar al órgano judicial encargado de determinar la pena utilizar el principio de cuenta y por supuesto se respeten los derechos de defensa. Ambos requisitos son necesarios por lo demás, sea cual sea el modelo de imputación elegido. En estos momentos no existen argumentos constitucionales suficientes que hagan preferible un modelo basado en

internauta de práctica jurídica, Número 26, 2011, página 69. Con matices GOMEZ TOMILLO, Op. Cit., páginas 66 y 107, pássim.

474 NIETO MARTÍN, Adán, La responsabilidad penal de las personas jurídicas. Un modelo legislativo, Op. Cit., página 105.

475 Ib Ídem, página 106. 
la propia culpabilidad de la empresa 0 en su defecto de organizaciónơ ${ }^{476}$.

A partir de aquí dirigen sus esfuerzos a la interpretación y la delimitación del art. 31 bis.1 en su primer y segundo párrafo, para concluir que si a la persona física (directivo o dependiente) se le comprueba el hecho delictivo con cualquier clase de autoría y en cualquier etapa punible del delito, si lo hizo por cuenta y en nombre y en provecho de la persona jurídica, entonces la persona jurídica tendrá que responder de ese delito. $Y$ también desarrollan una teoría jurídica del delito de la persona jurídica basada en el hecho de la persona física en el nivel del injusto personal, por lo que pueden hablar de imputación objetiva de resultado, dolo e imprudencia, tentativa del delito, participación de personas en el delito; en donde, en todos los casos, el poseedor del dolo o la imprudencia, o el iter crimimins, o el cómplice o instigador y el autor del delito, es siempre una persona física ${ }^{477}$.

\subsection{La culpabilidad de la persona jurídica}

La diferencia, con las anteriores posiciones doctrinales, la hace la prédica de la ñpropiaò autónoma e independiente culpabilidad de la persona jurídica.

En efecto, esta parte de la doctrina se apoya en los puntos 2 y 3 del artículo 31 bis CP, que señalan:

476 Ib Ídem, página 120. A esto se suman simplemente CLEMENTE CASAS, Israel, y ÁLVAREZ FEIJOO, Manuel, “¿Sirve de algo un programa de compliance penal? ¿y qué forma de le doy? (Responsabilidad penal de la persona jurídica en la LO 5/2010: incertidumbres y llamado por la seguridad jurídica)", en Actualidad jurídica Uría Menéndez, 28-2011, http://www.uria.com/documentos/publicaciones/2903/documento/articuloUM.pdf?id=2974,última visita 10-02-12 al afirmar que "los seres humanos y las entidades jurídicas son realidades muy distintas... el principio de culpabilidad no puede proyectar sobre estas las mismas garantías que sobre las personas de carne y hueso", página 32.

477 GOMEZ TOMILLO, Manuel, Op. Cit., página 45 y sigs., 95 y sigs., 149 y sigs. y 173 y sigs.; y ZUGALDÍA ESPINAR, José Miguel, Fundamentos.., Op. Cit., página 582; el mismo, La responsabilidad penal de empresas, fundaciones y asociaciones, Op. Cit., página 271 y sigs. 
2. La responsabilidad penal de las personas jurídicas será exigible siempre que se constate la comisión de un delito que haya tenido que cometerse por quien ostente los cargos o funciones aludidas en el apartado anterior, aun cuando la concreta persona física responsable no haya sido individualizada o no haya sido posible dirigir el procedimiento contra ella. Cuando como consecuencia de los mismos hechos se impusiere a ambas la pena de multa, los Jueces o Tribunales modularán las respectivas cuantías, de modo que la suma resultante no sea desproporcionada en relación con la gravedad de aquéllos.

3. La concurrencia, en las personas que materialmente hayan realizado los hechos o en las que los hubiesen hecho posibles por no haber ejercido el debido control, de circunstancias que afecten a la culpabilidad del acusado o agraven su responsabilidad, o el hecho de que dichas personas hayan fallecido o se hubieren sustraído a la acción de la justicia, no excluirá ni modificará la responsabilidad penal de las personas jurídicas, sin perjuicio de lo que se dispone en el apartado siguiente.

De la simple lectura de los dos puntos anteriores se puede observar que expresamente la ley decreta que la responsabilidad penal de las personas jurídicas no depende en ninguna medida ni de la ñdentificaciónòo ñndividualizaciónòni del procesamiento de la persona física: la responsabilidad penal de la persona jurídica es independiente, autónoma y, en ese sentido, es ñpropiaòde la persona física.

Más abona a esa perspectiva el hecho de que las circunstancias que rafecten su culpabilidad del acusado o agraven su responsabilidadò no se comuniquen a la persona jurídica, manteniéndose así, al parecer, diferenciados y no confundidos los 
elementos de la culpabilidad de ambas personas. Si a ello le agregamos que ni siquiera en el caso del fallecimiento (y por tanto, la imposibilidad de obtener una sentencia de condena contra de ella) de la persona física o su carácter de ab judice, podrá detener enjuiciar y culpar a la persona jurídica, pues entonces parece ser que es bien recibida la conclusión de una culpabilidad propia de ésta.

Es más, el hecho de que la persona jurídica tenga exclusivamente para ella, ciertas circunstancias atenuantes de su responsabilidad, como lo señala el 31 bis $4 \mathrm{CP}$, adosa a su responsabilidad propia.

Así expuesto, parece ser que en la opinión de esta parte de la doctrina el modelo que ha elegido el legislador para responsabilizar a las personas jurídicas es intermedio, entre el vicarial y el de autorresponsabilidad, por el hecho de exigir un injusto personal de la persona física y una, aparentemente, culpabilidad propia de la jurídica.

Ahora bien, ¿cuál es el contenido de la culpabilidad propia de la persona jurídica? Aunque con matices, podríamos afirmar que este grupo de autores le da un contenido conocido como r̃defecto de la organizaciónò

Zugaldía ha entendido su contenido como ña imputación del hecho ilícito como culpabilidad se produce cuando el mismo se lleva a cabo como consecuencia de haberse omitido la adopción de alguna de las medidas de precaución y de control (defecto de la organización) que eran exigibles para garantizar el desarrollo legal (y no delictivo) de la actividad de empresa. Se trata de que nadie ha prestado la debida y razonable diligencia conforme a las circunstancias del caso, para aplicar las medidas técnicas, organizativas y personales fundamentales para impedir los hechoso ${ }^{478}$, lo que tiene íntima relación con ños protocolos

478 Vid. La responsabilidad penal de empresas, fundaciones y asociaciones, Op. Cit., página 350. En el mismo sentido BACIGALUPO, Enrique, "Responsabilidad penal y administrativa de las personas jurídicas y programas de "compliance" (A 
de minimización de riesgos delictivos y a los códigos de ética y conducta empresariales (responsabilidad social corporativa) $0^{479}$.

Es muy claro que el texto de la reforma no tiene incluido, en ninguna parte, que la culpabilidad de la persona jurídica tenga ese contenido. Es verdad, basta con leer los artículos 31 bis, 33.7, 52, 53, 66 bis, 129 y $130 \mathrm{CP}$, y cualquiera de los delitos en que expresamente está prevista la responsabilidad de las personas jurídicas, para darse cuenta que están ayunos de conceptos como ródefecto de la organizaciónò r̃culpabilidad empresarialò r̃ultura corporativaò m̃nala conducción de la empresaò p̃programas de complianceòo ñprogramas de cumplimientoò No existe pues, nada expresado en el texto legal, que en principio autorice a exigir un r̃defecto organizativoò a la persona jurídica para dar por cumplida la categoría jurídica de su culpabilidad. Si esto es así, deberían tener un asidero para dar cabida y función a la culpabilidad propia de la persona jurídica. Este lo encuentran en el r̃centro del orden político y jurídico de un Estado social y democrático (arts. 1, 9, 24 y 25 CE) ò como lo son los principios de personalidad de la responsabilidad penal (en el sentido de no responder por hechos ajenos), principio de responsabilidad por el hecho (frente al derecho de autor), principio de dolo o culpa (derivado del artículo 5 y $10 \mathrm{CP}$ ), principio de imputación personal, entre otros ${ }^{480}$.

propósito del Proyecto de reformas del Código Penal de 2009)", en Diario La Ley, Número 7442, 9 de julio de 2010, página 4; BACIGALUPO SAGUESSE, Silvina, "Los criterios de imputación...", Op. Cit., página 6; GOMEZ TOMILLO, Manuel, Op. Cit., página 105; MARTÍNEZ PARDO, Vicente José, "La responsabilidad penal de las personas jurídicas", Op. Cit., página 71 y 72; ZUÑIGA RODRÍGUEZ, Laura, Bases para un modelo de imputación de responsabilidad penal a las personas jurídicas, $O p$. Cit., página 241.

479 Vid. Fundamentos..., Op. Cit., página 590. Así mismo en La responsabilidad criminal de los entes colectivos (personas jurídicas y entes sin personalidad), Op. Cit., página 54 y 55.

480 RODRÍGUEZ RAMOS, Luis, RODRÍGUEZ RAMOS, Luis, "La culpabilidad en los delitos cometidos por la persona jurídica. El "delito de sospecha blindado" y la responsabilidad objetiva "impura" en la Circular 1/2010 de la FGE", en Diario La Ley, Número 7694, Sección Doctrinaria, 14 de septiembre 2011, Año XXXII, Editorial La Ley, 14037/2011, página 7 y 8. 
La necesidad de interpretar el art. 31 bis CP como un sistema de responsabilidad penal no objetiva ni del hecho de otro, sino una interpretación acorde a la Constitución y respetuosa de los derechos fundamentales del sujeto imputado, la persona jurídica, abre la puerta para alinear algunas prevenciones de la reforma que darían lugar a una interpretación en donde cabría el r̃defecto de organizaciónòcomo eje de la culpabilidad de la persona jurídica.

A esta solución llegan, quienes defienden esta posición, por dos vías diferentes, aunque no excluyentes: por un lado, se apoyan en la prevención contenida del inciso d), del punto 4, del art. 31 bis CP (la cuarta atenuante de responsabilidad de las personas jurídicas), y otros se apoyan en el $2^{\circ}$ párrafo del punto 1 del art. 31 bis CP (ñpor no haberse ejercido sobre ellos el debido control atendidas las circunstancias del casoò ${ }^{481}$

Una persona jurídica que tuviera y mantuviera adecuados programas de cumplimiento de la legalidad en su organización, volcados hacia su giro empresarial y hacia, sobre todo, los peligros o riesgos a los bienes jurídicos que su actividad genera, con procedimientos, políticas y cultura de cumplimiento de esos programas, anteriores a la comisión del evento delictivo, entonces la atenuante del 31 bis 4.d CP se convertiría en una excluyente de la culpabilidad de la persona jurídica ${ }^{482}$, a pesar de que la persona física haya satisfecho el injusto personal y su propia culpabilidad, lo haya hecho por cuenta, en nombre y en provecho del ente colectivo ${ }^{483}$.

Esto se logra a través de una interpretación in bonam partem porque r̃aunque el legislador sólo los haya previsto como atenuante el establecimiento de los programas de compliance cuando éstos se

481 ZUGALDÍA ESPINAR, José Miguel, La responsabilidad criminal de los entes colectivos (personas jurídicas y entes sin personalidad), Op. Cit., página 55.

482 Sobre los compliance programs y el artículo 31 bis.1.d) vid. BACIGALUPO, Enrique, Compliance y Derecho Penal, Thomson Reuters, Pamplona, 2011.

483 Ib Ídem, página 55 y sigs.; así mismo NIETO MARTíN, Adán, "La responsabilidad penal de las personas jurídicas tras la LO 5/2010", en Revista Xurídica Gallega, número 63, 2009, página 69 y 70. 
establezcan en la organización empresarial con posterioridad al descubrimiento del hecho delictivo, éstos deberían ser tenidos especialmente en cuenta cuando fueran establecidos con anterioridad a la comisión del hecho para determinar la culpabilidad de las personas jurídicas: la culpabilidad por defecto de organización se debe excluir necesariamente cuando ex ante el programa de compliance $y / o$ un adecuado código de buen gobierno corporativo permita demostrar que en el seno de la organización de la persona jurídica se ha cumplido con el deber de cuidado y exigido para la evitación de riesgos penales y, por lo tanto, no haya infracción de deber, ni defecto de organización de la persona jurídicaơ ${ }^{484}$.

A la misma solución (la culpabilidad de la persona jurídica es su r̃defecto de organizaciónò) arriban quienes centran su atención en el $2^{\circ}$ párrafo del 31 bis.1 CP. A diferencia del $1^{\circ}$ párrafo, en éste la responsabilidad penal de la persona jurídica tendrá lugar si los dependientes, operarios o empleados (r̃quien estando sometido a la autoridad de las personas físicas mencionadas en el párrafo anteriorò cometen del delito ñpor no haberse ejercido sobre ellos el debido controlò Es r̃́lebido controlò el que permite maridar la culpabilidad del ente corporativo con el r̃defecto de organizaciónò

Incluso ven en este párrafo el hilo conductor del que se deriva el defecto de organización, ya que rel CP art. 31 bis declara que las entidades están jurídicamente obligadas a ejercer sobre las personas que actúan a su servicio un control para evitar que en el ejercicio de las actividades cometan delitos en su provecho. Esta declaración general, que hasta el momento con mucho sólo existía de modo tácito, es una de las piezas fundamentales del nuevo sistema. Este es el verdadero

\footnotetext{
484 BACIGALUPO S., Silvina, "Los criterios de imputación de la responsabilidad penal...", Op. Cit., página 8. De la misma forma DOPICO GÓMEZ-ALLER, Jacobo, "Capítulo I. Responsabilidad de las personas Jurídicas", en ORTIZ DE URBINA GIMENO (Coord.), Memento Experto Reforma Penal, Ediciones Francis Lefebvre, 2010, página 34; GOMEZ MARÍN, V., "Artículo 31 bis", en MIR PUIG, S. y CORCOY BIDASOlO, M. (Dirs.) Comentarios al Código Penal. Reforma LO 5/2010, Tiran lo Blanch, Valencia, 2011, página 136.
} 
criterio de imputación de responsabilidad a la persona jurídica: el incumplimiento, imputable a ésta, del debido control sobre el trabajadorơ ${ }^{485}$, lo que se trata de una imputación a la persona jurídica por defecto de organización ${ }^{486}$.

Pues bien, una vez que establecen el fundamento del defecto de organización en el $2^{\circ}$ párrafo del 31 bis. $1 \mathrm{CP}$, lo trasladan simplemente a la primera vía de responsabilidad, el $1^{\circ}$ párrafo, señalando, no sin razón, que la distinción del 1으 y $2^{\circ}$ párrafo en el 31 bis.1 CP es innecesaria, no solo porque no se le da un tratamiento diferente en materia de sanción ni de imputación, sino que la ley no p̃arece entender que la ausencia del debido control sólo sería un requisito para el caso de delitos cometidos por personas que hayan actuado a las órdenes de los administradores y sin poderes de representación, pues en el segundo párrafo se omite mencionar a los que hayan actuado r̃en nombreòde la persona jurídica, es decir, en su representación. Dicho de otra manera, parecería que el déficit de organización habría sido establecido como presupuesto de la punibilidad de las personas jurídicas sólo para el caso de la infracción de deberes de vigilancia de los administradores sobre sus subordinados. Si esto fuera así, en la hipótesis de la responsabilidad de los administradores se habría renunciado al déficit de organización como presupuesto de la punibilidad de la persona jurídica y como elemento legitimador de la mismao ${ }^{487}$; por lo que puede concluirse que también en el primer caso (31 bis.1 primer párrafo) se debe entender que la ley exige, además de lo que textualmente exige, un defecto de organización de la persona jurídica.

Adicionalmente a ello, se exponen razones de índole político criminal (porque conduce a mejores resultados prácticos), razones de interpretación sistemática (en relación con el 31 bis.1.d) CP), que

\footnotetext{
485 DOPICO GÓMEZ-ALLER, Jacobo, Op. Cit., página 20.

486 Ib Ídem, página 13.

487 BACIGALUPO, Enrique, Op. Cit., página 4.
} 
permiten afirmar que, en general, el defecto de organización permea en definitiva la culpabilidad de la persona jurídica ${ }^{488}$.

\subsection{Causas que eximen la responsabilidad penal de la persona jurídica}

¿De qué manera podría evitar la persona jurídica ser declarada culpable de un delito?

Bajo estas construcciones teóricas estimamos que la respuesta tendría dos variantes, dependiendo de la categoría del delito que quisiera evitar.

Si pretendiera evitar que se le imputara el injusto personal (esto es, una conducta típica y antijurídica) solamente tendría que probar que la persona física (administrador o representante o empleado mal controlado) no cometió el delito, o que lo hizo pero no bajo las circunstancias exigidas que lo relacionen con ella (por cuenta o en nombre y en provecho de la persona jurídica, o en ejercicio de sus actividades sociales), pero nada más. Es decir, alega la atipicidad y/o juridicidad del hecho de otro (la persona física) o alega que la persona física no lo hizo por cuenta, en su nombre, en ejercicio de actividades sociales y en provecho), lo que es también, probar o demostrar las circunstancias del hecho de otra persona. La persona jurídica no tendría ninguna posibilidad más de evitar la atribución o imputación del injusto personal.

No olvidamos que también podría alegar, en el caso del $2^{\circ}$ párrafo del 31 bis $1 \mathrm{CP}$, que no existió un indebido control sobre su empleado, lo que nos llevaría a demostrar que no existió defecto de

488 NIETO MARTÍN, Adán, “'La responsabilidad penal de las personas jurídicas tras la LO 5/2010", Op. Cit., página 8. En el mismo sentido, de integrar ambas vías de justificar la culpabilidad de la empresa con el defecto de organización, vid. ZUGALDÍA ESPINAR, José Miguel, La responsabilidad criminal de los entes colectivos", Op. Cit., página 55. 
organización, como lo veremos en seguida. Esta es la misma solución que las tesis que expusimos supra (capítulo V.3) que es propia de aquellas tesis conocidas como vicariales.

En el nivel de la culpabilidad sería diferente. La persona jurídica, a diferencia de la construcción teórica anterior, podría alegar y demostrar que el hecho delictivo de la persona física (que también es el r̃suyoòpor la atribución que se le ha hecho) ocurrió sin que existiera en ella ningún defecto de organización, atendiendo a una interpretación extensiva y en favor del reo del inciso d) del punto 4 del art. 31 bis CP. Es claro que, habiendo sido ubicado el r̃defecto de organizaciónòen la culpabilidad, en el proceso penal la parte acusadora debe demostrar la conducta típica, mientras que la persona jurídica debería demostrar lo excepcional: que no es culpable. Es decir, que a cargo de la persona jurídica debe colocarse la prueba de que está bien organizada y que no tiene defecto de organización, por lo cual el r̃defecto de organizaciónò debe presumirse bajo una presunción iuris tantum ${ }^{489}$.

Gómez Tomillo ha expuesto de forma abierta y expresa esta cuestión que de cualquier forma cabe asumirse como consecuencia necesaria de esta construcción teórica (y de quienes la siguen), al señalar que ráceptado que cabe acreditar una organización cuidadosa, desde nuestra perspectiva debe mantenerse que, como todas las cuestiones atinentes a la culpabilidad, la carga de la prueba de la concurrencia de circunstancias que la excluyen recae sobre la misma persona jurídica infractora ${ }^{490}$. De esta forma, la empresa podría evitar la imputación de su culpabilidad demostrando ella que el defecto de organización es ausente.

Por tanto, si en el seno de una persona jurídica, un administrador o representante legal comete un delito por cuenta y en su nombre y en su provecho, la persona jurídica será reo de dicho delito, a menos que demuestre que no tiene defecto de organización.

489 GOMEZ TOMILLO, Manuel, Op. Cit., página 82.

490 Ib Ídem, página 133. 


\subsection{Ventajas del sistema de responsabilidad penal de la}

persona jurídica por el óhecho de conexiónô.

Estimamos que una visión de conjunto de las posiciones doctrinales aquí expuestas (es decir, las que fundamentan la culpabilidad de la persona jurídica en el defecto de organización, pero toman el thecho de conexiónò de la persona física como el injusto, también, de la jurídica), darían ciertas ventajas desde puntos de vista de legitimación constitucional y político criminales.

En principio, tendría la ventaja de las construcciones anteriores (que imputan a la jurídica el injusto y la culpabilidad de la persona física) en cuanto constituyen una interpretación rá la letraò de la ley, merced a que se sirven del delito de la persona física para construir el injusto personal de la persona jurídica. Tal y como es expuesto en el 31 bis.1 CP, párrafos $1^{\circ}$ y $2^{\circ}$, efectivamente es necesario el delito de ciertas personas físicas, que lo ejecuten bajo ciertas circunstancias que los relacionen con la empresa, y entonces será también el delito de la empresa. Como la ley no exige, según la letra del texto legal, ningún otro requisito, entonces parecería que con ello se cumpliría lo suficiente para atribuir a la persona jurídica el delito.

Adicional a esta ventaja debemos tomar en cuenta el manejo de la culpabilidad, ya no atribuida desde la persona física, sino separada y propia de la persona jurídica, que es lo que la distingue de la primera construcción teórica. En efecto, desde la perspectiva de legitimación material la culpabilidad propia de la persona jurídica permitiría enfrentar los argumentos (en ese nivel: culpabilidad) de quienes acusan y se duelen por la violación del principio que prohíbe responder por el hecho ajeno, pues ya no es la culpabilidad de la persona física la que fundamenta y, por tanto, se traslada simplemente a la persona jurídica, 
sino una propia de la persona jurídica ${ }^{491}$. De esa forma, es posible separar las causas de inculpabilidad e independizarlas, de manera que la persona jurídica tendría causas de justificación que permitirían excluirla de responsabilidad penal no obstante que a la persona física se le condene por el delito. Si esto es así, entonces la persona jurídica cuidaría al extremo, si es que le interesa no ser criminalizada, de planes o programas de cumplimiento al derecho que la organicen y la gestionen para reducir a límites irreductibles su responsabilidad penal.

La autorregulación regulada, como una nueva estrategia de control por parte del Estado, sería también bien recibida en este sistema o construcción, y los fines de un sistema de responsabilidad penal de personas jurídicas podrían cumplirse con empresas que reducen sus riesgos típicos a extremos permitidos.

\section{CONSTRUCCIONES CON INJUSTO Y CULPABILIDAD PROPIOS DE LA PERSONA JURÍDICA}

El art. 31 bis CP también ha sido visto e interpretado por una gran parte de la doctrina como la expresión de un sistema verdadero de autorresponsabilidad penal de la persona jurídica desde el nivel injusto personal hasta la culpabilidad de la propia empresa. Se alejan, en la medida que la letra de la ley les permite, de todo lo que huela a sistema vicarial, a responsabilidad por el hecho ajeno y a responsabilidad objetiva.

Para hacerlo, y sin desconocer que es necesario un hecho de una persona física, se abrazan de aquellas partes de la ley que se los permiten. Es de buen recibo lo previsto en el 31 bis.1, segundo párrafo (f̂aberse ejercido sobre ellos el debido control), el 31 bis. 2

491 ZUGALDÍA ESPINAR, José Miguel, La responsabilidad criminal de los entes colectivos, Op. Cit., página 42, al señalar que una de las ventajas es "en el ámbito constitucional (ya que la responsabilidad criminal de las personas jurídicas no es una responsabilidad objetiva por el hecho ajeno)". 
(independencia de la responsabilidad penal de la persona física y de la jurídica), el 31 bis.3 (la independencia de las atenuantes entre las personas responsables), y por supuesto el 31 bis $4 . d$ (relativo a la atenuante de r̃organización adecuadaò que puede llegar a ser excluyente de responsabilidad penal).

Pero la interpretación letrística de la ley es insuficiente para armar el sistema de responsabilidad de las personas jurídicas, es necesario además adecuarlo al contexto más amplio de la legitimidad constitucional que exige que una persona solamente será responsable de los delitos que ella cometa. Ĩa persona jurídica no puede ser penada por conductas que no les son imputables a ella, es decir, que no están bajo su capacidad de dirección. En este sentido, no es posible reprochar a la persona jurídica las infracciones de las personas físicas a su servicio (lo cual sería hacerle responder por actos ajenos), sino solo sus propias infraccionesơ ${ }^{492}$, y es que estamos hablando de personas que son sujetos de imputación, no de r̃consecuencias accesoriasò sino de ñpenas gravesò (como dice la ley), por lo que thay que exigir materialmente, más allá de los requisitos formales del art. 31 bis CP para adecuar la responsabilidad pena de las personas jurídicas a las exigencias del principio de legalidad, un injusto y una culpabilidad propios de la persona jurídica ${ }^{493}$.

492 DOPICO GÓMEZ-ALLER, Jacobo, "Capítulo 1. Responsabilidad de personas jurídicas", Op. Cit., página 18.

493 FEIJOO SÁNCHEZ, Bernardo, "La responsabilidad penal de las personas jurídicas", Op. Cit., página 84. En el mismo sentido DE LA CUESTA ARZAMENDI, José Luis, "Responsabilidad penal de las personas jurídicas en el derecho español", en Revista electrónica de la Asociación Internacional de Derecho Penal, Op. Cit., página 1, al señalar "desde el prisma constitucional y de los principios penales fundamentales toda responsabilidad penal debe erigirse sobre un hecho injusto (y culpable) propio, por lo que los esfuerzos doctrinales dirigidos a la búsqueda de una adecuada fundamentación en esta línea se encuentran plenamente justificados"; GARCÍA ARÁN, Mercedes, "Artículo 31", en CORDOBA RODA, Juan/GARCÍA ARÁN, Mercedes (Dirs.), Comentarios al código penal. Parte general. Madrid, Marcial Pons, 2010, páginas 394 a 397; y URRAZA ABAD. "La responsabilidad criminal de las personas jurídicas: una propuesta de interpretación del nuevo art. 31 bis", en Res Pública, Portal Jurídico Vasco, consultado en http://rpublica.org/contenidos/704-la-responsabilidad-criminalde-las-personas-juridicas, última visita 12-01-12, asegura "A nuestro entender, una lectura respetuosa con las más elementales estructuras garantistas jurídico- 
Por lo tanto, y para dejar claro desde un principio el sistema propuesto por esta parte de la doctrina, el esquema es de la siguiente forma.

1. Injusto personal $=$ Defecto de la organización

2. Culpabilidad = Cultura empresarial de incumplimiento de la legalidad

Debemos dejar claro que este esquema debe tomarse con cautela, puesto que no existe un bloque de la doctrina que lo defiende tal y como lo presentamos, sino que entre los diferentes autores hay muchos matices, desarrollos diferentes, e incluso hay quienes asumen esa asignación de conceptos pero no los desarrollan. No obstante, para efectos de señalar las diferencias que queremos resaltar con el anterior modelo, se puede tomar el esquema como un perfil suficiente que individualiza a los defensores de esta perspectiva ${ }^{494}$.

5.1. El injusto personal de la persona jurídica: el defecto de organización.

penales haría inevitable exigir la concurrencia en la persona jurídica de un plus de desvalor, individualmente atribuible a la propia estructura societaria, que permita ir más allá del mero reproche jurídico realizable a su representante legal. Dejando al margen cuestiones relativas al necesario respeto al principio penal de culpabilidad, la participación en el hecho, -presupuesto inevitable del reproche de antijuridicidad material implícito en todo delito-, exige acreditar una participación activa o por omisión de la propia estructura societaria"; ZÚÑIGA RODRÍGUEZ, Laura, "El sistema de sanciones penales aplicables a las personas jurídicas", en BERDUGO GÓMEZ DE LA TORRE, Ignacio (Coord.), Lecciones y Materiales para el estudio del Derecho Peal, Tomo I, Iustel, Madrid, 2010, página 316 , se decanta por afirmar que el modelo legislativo es de responsabilidad propia de la persona jurídica y bajo ese esquema se solucionan los obstáculos de legitimación.

${ }^{494}$ El modelo paradigmático lo habría dado ya GOMEZ-JARA DIEZ, Carlos, $L a$ culpabilidad penal de la empresa, Op. Cit., página 248 y sigs., además, y en la línea de interpretar el art. 31 bis CP, el mismo, "La responsabilidad penal de las personas jurídicas en la reforma del Código Penal", en Diario La Ley, Número 7534, de 23 de diciembre de 2010, página 6 y 7, y el mismo, Responsabilidad penal de las personas jurídicas, Op. Cit., página 39 y sigs. 
El llamado T̃echo de conexiónò de la persona física (administrador de hecho o derecho, representante legal o empleados mal controlados) del que habla el art. 31 bis. 1 CP es un requisito necesario, imprescindible, pues así lo exige la ley y es imposible no pensar en él. La persona jurídica responde entonces, de forma inicial, por el delito de dichas personas físicas. Sin embargo, el thecho de conexiónòno es, ni debe ser, el fundamento de la responsabilidad penal de la persona jurídica, ni tampoco es, ni debe ser, el injusto personal mismo de la persona jurídica. Si así lo fuera, como lo hemos dicho, vulneraríamos los principios constitucionales más caros de la propia persona jurídica enjuiciada: r̃dichas actuaciones de las personas físicas, ŕsoloò constituyen un presupuesto de la responsabilidad penal de las personas jurídicas pero no pueden considerarse su fundamento ï al menos no, si se considera que la persona jurídica es responsable por su hecho propio y no por el hecho ajeno de la persona física ${ }^{495}$.

No debemos olvidar que el sistema de organización proclamado por esta parte de la doctrina pretende dejar intocado el sistema de responsabilidad de las personas físicas ${ }^{496}$, y se quedaría en su lugar con todo lo que se ha ganado en su favor, principalmente las limitaciones al ius puniendi y los avances a la controlabilidad de las decisiones en los casos concretos, r̃siempre que se tuviera claro que el modelo de atribución de responsabilidad penal a las personas jurídicas no es idéntico al de la responsabilidad criminal individual. De modo que habría que establecer que la teoría del delito en sentido amplio contiene

495 GOMEZ-JARA DIEZ, Carlos, Responsabilidad penal de la persona jurídica, Op. Cit., página 66; así también, el mismo, "La responsabilidad penal de las personas jurídicas en la reforma del Código Penal”, Op. Cit., página 6; DE LA CUESTA ARZAMENDI, José Luis, $O p$. Cit., página 15; MARTíNEZ PRADO, Vicente José, $O p$. Cit., página 6.

496 Incluso en el caso de GOMEZ-JARA, puesto que para él, el sistema de responsabilidad penal de las personas jurídicas y el de las personas físicas, se basan en los mismos fundamentos y se desarrollan bajo la misma metodología, de forma tal que también para este autor el sistema de las personas físicas quedaría incólume. Es claro que los contenidos de las categorías penales serían diferentes, pero habría una analogía funcional, Responsabilidad penal de las personas jurídicas, Op. Cit., página 38. 
dos sistemas de imputación: el de las personas físicas y el de las personas jurídicasơ ${ }^{497}$.

Así las cosas el injusto personal de la persona jurídica es el r̃defecto de organizaciónơ ${ }^{498}$.

Tiene sustento en la libertad de organización y en el uso legítimo de esa libertad ${ }^{499}$. Zuñiga Rodríguez considera el injusto de organización como ñuna dañosidad social evitableơoc, mientras que Zugaldía lo concibe como ña comprobación de que la persona jurídica ha omitido ñde forma contraria al deber la adopción de alguna de las medidas de precaución y control que eran exigibles para garantizar el desarrollo legal (y no delictivo) de la actividad de la empresaớc1, y Gómez Jara-Diez la estima como ñuna defectuosa configuración de su ámbito de organización que supera el riesgo permitido, o un defecto de organización que supera el riesgo permitidoơ ${ }^{502}$.

A partir de aquí surgen dudas de qué es lo que se debe entender por r̃defecto de organizaciónò es decir, en qué consiste, cuáles son sus contenidos, sus límites y alcances, y sobre todo, en qué casos se puede decir que una persona jurídica está bien organizada y en qué otros se puede afirmar que adolece del defecto organizativo ${ }^{503}$,

497 SILVA SÁNCHEZ, Jesús María, "La reforma del Código Penal: una aproximación desde el contexto", Op. Cit., página 4.

498 GARCÍA ARÁN, Mercedes, "Artículo 31", Op. Cit., página 395, que dice "el defecto de organización (se sitúa) en el ámbito del injusto, no en el de la culpabilidad strictu sensu". En el mismo sentido, GOMEZ-JARA DIEZ, Carlos, Responsabilidad penal, Op. Cit., página 40 y sigs., y 73 u sigs.; el mismo "La responsabilidad penal de las personas jurídicas...”, Op. Cit., página 5 y 6; DOPICO GÓMEZ-ALLER, Jacobo, Op. Cit., página 18; FEIJOO SÁNCHEZ, Bernardo, Op. Cit., página 89, lo llama "defecto organizativo".

499 FEIJOO SÁNCHEZ, Bernardo, "La responsabilidad penal...”, Op. Cit., página 104, por lo que solamente así se puede hablar "de la lesión de la juridicidad (antijuridicidad) como presupuesto material de la culpabilidad de la persona jurídica".

500 En Bases para un modelo de imputación de responsabilidad penal de las personas jurídicas, Op. Cit., página 237.

501 En La responsabilidad criminal de los entes colectivos..., Op. Cit., página 54.

502 En Responsabilidad penal de las personas jurídicas, Op. Cit., página 77.

503 NIETO MARTÍN, Adán, La responsabilidad penal de las personas jurídicas..., Op. Cit., página 149. 
son preguntas no siempre fáciles de contestar ${ }^{504}$. Debemos tener en cuenta, por lo menos, que en un sistema preventivo, la contraparte de un defecto de organización, debe estar encaminado a la evitación razonable de los riesgos derivados de la actividad empresarial ${ }^{505}$, aunque nadie podrá exigir jamás el desarrollo de programas de cumplimiento que garanticen la evitación total y definitiva de riesgos, a lo mucho, una disminución razonable de los riesgos delictivos o lesivos que se desprendan de la actividad empresarial ${ }^{506}$.

Consideramos que un defecto organizativo debe referirse a la manera en que está configurada una empresa desde puntos de vista organizacionales, es decir, deben tomarse en cuenta la misión, visión y valores de la empresa, la forma de llevarlos a cabo y la manera en que los permean al personal, así como las políticas internas en general pero sobre todo, aquellas relativas a la consecución de sus fines y provechos económicos o de mercado, los sistemas de escalafón o de carrera interna de la empresa, los perfiles iniciales e ideales de los puestos (lo que implica también, los sistemas de contratación o elección de los solicitantes de ingreso y de ascenso en la empresa), lo relativo a modelos de premios y castigos, de comunicación interinstitucional (interna y hacia el exterior), de vigilancia y revisión o auditorías inductivas y correctivas, y en la misma medida que todo lo anterior, los procedimientos, la normativa interna para llevar a cabo todas y cada una de las acciones o actividades operativas de la empresa.

504 CLEMENTE CASAS, “¿Sirve de algo un programa de compliance penal?...”, Op. Cit., página 38, señala que es difícil tener seguro cuáles deben ser los contenidos de los programas de prevención para evitar la declaración judicial eventual de organización defectuosa en una empresa, por lo que consideran que hay un vacío normativo.

505 NIETO MARTÍN, Adán, La responsabilidad penal de las personas jurídicas..., Op. Cit., página 146.

506 Ib Ídem, página 148. Así mismo, GOMEZ-JARA DIEZ, Responsabilidad penal de las personas jurídicas, Op. Cit., página 93 y 94, dice "debe producirse un análisis ex ante de las medidas -y no ex post- de tal forma que deben reputarse eficaces aquellas medidas que razonablemente hubieran debido prevenir o detectar la comisión de un delito". 
Por otro lado, el defecto organizativo debe tener una relación con el resultado lesivo de tal manera que aquel pueda considerarse como su antecedente normativo, esto es, entre el defecto organizativo y el resultado lesivo debe existir una relación normativa de imputación, en donde se estime que la lesión o puesta en peligro tuvo lugar en el riesgo no permitido creado por la persona jurídica, esto es, por el defecto organizativo ${ }^{507}$. Esta es una diferencia muy importante con la construcción teórica expuesta en el epígrafe anterior, ya que si el defecto de organización se encuentra en la culpabilidad (y no en el injusto personal) entonces no se exigirá una relación causal con el resultado, mucho menos, acreditada ésta, una relación normativa. En el mismo hilo explicativo debemos de tener en cuenta otra gran diferencia: la parte acusadora debería de demostrar no solamente que la persona física cometió un delito, que es administrador o representante o empleado mal controlado, y que lo hizo por cuenta, en nombre o en ejercicio de la actividad social, y en provecho, sino que es además necesario acreditar positivamente el defecto organizativo de la persona jurídica y que dicho defecto de organización produjo un riesgo no permitido al bien jurídico y que dicho riesgo se ha realizado en el resultado típico concreto.

\subsection{La culpabilidad propia de la persona jurídica}

Una vez identificado el injusto objetivo y subjetivo de la persona jurídica, resta saber en qué consiste su culpabilidad.

El defecto de organización, por ser algo objetivo no podía ser parte de la culpabilidad, r̃uedando pendiente de aclaración la cuestión de en qué casos y porqué la persona jurídica puede ser estimada culpable del defecto de organización que se produce en su seno. La búsqueda de la culpabilidad de una persona jurídica debería partir

507 GOMEZ-JARA DIEZ, Responsabilidad penal de las personas jurídicas, Op. Cit., página 77. 
entonces, hipotéticamente, de la constatación de algo así como un p̃oder organizarse de otro modoo ${ }^{508}$.

Sin entrar en cuestiones doctrinales sobre el fin y funciones de la culpabilidad, lo cierto es que se han construido conceptos de culpabilidad ajenos a reproches de carácter moral o ético moralizante propio de la persona individual para dar un contenido a la culpabilidad empresarial. La han llamado r̃ultura empresarial de incumplimiento de legalidad $0^{509}$ o f́alta de ética empresarialơ ${ }^{510}$. Se trata de buscar algo diferente al defecto de organización pero que tenga relación con él, se trata de buscar algo que pueda ser permanente en la organización, algo así como parte de r̃su personalidadơ ${ }^{511}$, y que sea análoga a la capacidad de poner en entredicho el contenido de las normas, su fuerza, sus alcances y su cumplimiento, algo del interior de la persona jurídica que sea capaz de manifestar una desaprobación de la norma jurídico penal.

Por lo anterior habrá culpabilidad cuando el defecto de la organización que produjo el resultado lesivo a los bienes jurídicos se debió a esa cultura empresarial de incumplimiento de la legalidad, de esa disposición rempresarial individualòde despreciar la norma jurídica, de expresar que la norma no vale para ella, y eso lo encontraremos en

508 SILVA SÁNCHEZ, Jesús-María, "La reforma del Código Penal: una aproximación desde el contexto", Op. Cit., página 15.

${ }^{509}$ GOMEZ-JARA DIEZ, Carlos, Responsabilidad penal de las personas jurídicas, Op. Cit., página 82.

510 FEIJÓO SÁNCHEZ, Bernardo, "La responsabilidad penal de las personas...", $O p$. Cit., página 83, aunque hace una diferencia con Gómez Jara, quien "ha definido en este sentido la culpabilidad de las personas jurídicas como que el hecho debe reflejar una "cultura empresarial de incumplimiento de la legalidad"... nuestro sistema parece exigir más a las personas jurídicas que no tener una cultura empresarial de incumplimiento de la legalidad. Se exige más bien como prestación positiva adoptar una cultura de cumplimiento de la legalidad". En el mismo sentido que Feijoo Sánchez, DE LA CUESTA ARZAMENDI, José Luis, Op. Cit., página 9, pues le resulta "más razonable fundamentar la culpabilidad de la persona jurídica en "su disposición jurídica en el momento del hecho", como recuerda Feijoo Sánchez, no de la cultura empresarial de incumplimiento de la legalidad, sino de la falta de (o carencias que presenta en la entidad) esa "cultura de cumplimiento de la legalidad" que le es legal e individualmente exigible".

511 FEIJÓO SÁNCHEZ, Bernardo, Op. Cit., página 107. 
el m̃motoròde las personas jurídicas que son las personas físicas que la dirigen, r̃es decir, lo que denominamos rãctitudò rólisposiciónò r̃̃ulturaò o réticaò de la persona jurídica es un estado de cosas al que se ha llegado debido al management o la gestión de una persona física o de una serie de personas físicas a lo largo del tiempoo ${ }^{512}$, y para ello tienen una gran importancia los códigos de ética o los códigos de conducta 0 de clima interno ${ }^{513}$.

En la concepción de algunos autores, como en el caso de Gómez Jara-Diez, la culpabilidad está integrada, como en la culpabilidad individual, de por lo menos el elemento consistente de la capacidad de culpabilidad, que es la imputabilidad, es decir, que ciertas personas jurídicas, a pesar de ser personas jurídicas en el tenor del 31 bis $1 \mathrm{CP}$, no serían sujetos de Derecho Penal simplemente porque no tienen ña mayoría de edadò para estar sujetas a este régimen de personas jurídicas rádultasò por lo tanto, no habría penas para ellas, aunque sí otro tipo de consecuencias jurídico penales si ha lugar para ello.

A tono con el concepto r̃ ronstructivistaò de la culpabilidad de empresa que ya hemos expuesto, Gómez Jara-Diez piensa que solamente las personas jurídicas que tienen la suficiente autorreferencialidad y complejidad interna suficiente pueden ser ŕsujetos de derecho penalò pues solamente ellas tienen la capacidad de expresar con sentido î́su reprobación a las normas jurídicasò de tal manera que una persona jurídica pequeña o insuficientemente compleja no podría generar una expresión con sentido lo suficientemente comunicativa $^{514}$. En el Derecho Penal español, ese aspecto de la inimputabilidad, lo ve reflejado en el artículo $130.2 \mathrm{CP}$ que expresamente previene:

512 Ib Ídem, página 108.

513 Ib Ídem, página 109.

514 GOMEZ-JARA DIEZ, Carlos, La culpabilidad penal de la empresa, Op. Cit., página 117 y sigs. 
2. La transformación, fusión, absorción o escisión de una persona jurídica no extingue su responsabilidad penal, que se trasladará a la entidad o entidades en que se transforme, quede fusionada o absorbida y se extenderá a la entidad o entidades que resulten de la escisión. El Juez o Tribunal podrá moderar el traslado de la pena a la persona jurídica en función de la proporción que la persona jurídica originariamente responsable del delito guarde con ella.

No extingue la responsabilidad penal la disolución encubierta o meramente aparente de la persona jurídica. Se considerará en todo caso que existe disolución encubierta o meramente aparente de la persona jurídica cuando se continúe su actividad económica y se mantenga la identidad sustancial de clientes, proveedores $y$ empleados, o de la parte más relevante de todos ellos.

$\mathrm{Si}$ el texto legal reformado exige que solamente las personas jurídicas sean sujetos de Derecho Penal, no debe entenderse que está reclamando un requisito meramente formal (formalizarse en persona jurídica e inscribirse adecuadamente), porque una interpretación sistemática del CP daría lugar a explicarnos qué es lo que hace la redacción que acabamos de transcribir. La explicación es que el CP ha optado inicialmente por un criterio formal (persona jurídica) pero luego, para completar ese criterio, exige también un criterio material (la autorreferencialidad y complejidad suficiente) como es el que la persona jurídica mantenga algo que le da individualidad: su actividad económica y se mantenga la identidad sustancial de clientes, proveedores y empleados, o de la parte más relevante de todos ellos.

En palabras de Gómez-Jara Diez: rãdemás de ese primer filtro de inimputabilidad basado en la personalidad jurídica, lo cierto es que una lectura completa de texto legal arroja como resultado un (segundo) filtro a la hora de determinar qué entidades están sujetas a la regulación 
del art. 31bis; o expresado de otra manera, la personalidad jurídica es condición necesaria pero no suficiente. La legislación española establece un ulterior criterio organizativo-material que aparece expresamente reflejado en al menos una circunstancia: si se extingue la personalidad jurídica, pero continúa "su actividad económica y se mantenga la identidad sustancial de clientes, proveedores y empleados, o de la parte más relevante de todos ellos" (art. 130.2. CP) la responsabilidad penal sigue vigente. Adicionalmente, la regulación española cuenta con algunas previsiones que, si bien no pueden considerarse como establecedoras de un criterio claro de imputabilidad, sin duda avanzan en la línea expuesta. Así, se podrá acordar tanto la disolución de la persona jurídica como la imposición de medidas interdictivas cuando ésta «se utilice instrumentalmente para la comisión de ilícitos penales» (art. 66 bis 2), supuesto especialmente previsto para las sociedades pantalla y/o instrumentales. En sentido similar, incluso en el caso de que se trate de las entidades públicas consignadas en el art. 31 bis 5 , formalmente, si las mismas son consideradas instrumentos materialmente $\partial$ esto es: una forma jurídica para evitar una eventual responsabilidad penalð, los órganos judiciales podrán establecer su responsabilidad penalo ${ }^{15}$.

Parece ser que, a despecho de la posición anterior, la doctrina mayoritaria se decanta por considerar solamente el criterio formal para delimitar a los entes colectivos sujetos de Derecho Penal ${ }^{516}$, y desatender la ingeniosa elaboración de que solo ciertas personas jurídicas con cierto grado de complejidad interna y autorreferencialidad

515 En "La responsabilidad penal de las personas jurídicas en la reforma del Código Penal”, Op. Cit., página 3, y en Responsabilidad penal..., Op. Cit., página 55 y 56.

516 Por todos, FEIJOO SÁNCHEZ, Bernardo, Op. Cit., página 73, quien estima que la interpretación que hace Gómez Jara-Diez es contra legem y que acaba diluyendo una decisión político criminal del legislador indubitablemente plasmada en la reforma, "de una norma para un problema muy específico de sortear fraudes de ley como cierre del sistema, que acaba siendo el único supuesto en el que se permite imponer de forma absolutamente excepcional una pena a una organización empresarial sin personalidad jurídica, no se puede crear una categoría". 
serían los destinatarios de la norma penal. Incluso quienes frente a un modelo ideal habían sugerido la inimputabilidad de ciertas personas jurídicas $^{517}$, con el estudio y análisis del derecho positivo vigente en España (31 bis CP) lo han descartado ${ }^{518}$.

Finalmente, como en el modelo anterior, la ausencia de culpabilidad habrá de ser demostrada por la defensa de la persona jurídica, ya que al tener demostrado el injusto empresarial que es el defecto organizativo, la cultura de cumplimiento a la legalidad es un concepto excepcional que no debe estar a cargo de la acusación ${ }^{519}$.

\subsection{Causas que eximen la responsabilidad penal de la persona jurídica}

Debe dividirse en tres la solución a este epígrafe. Es posible, en primer lugar, que la persona jurídica demuestre que contra la tesis de la acusación es inexistente el llamado T̃hecho de conexiónò(que, como se dejó planteado, es solamente un elemento r̃detonadorò 0 un p̃presupuesto ${ }^{520}$, e incluso hay quienes lo toman como una r̃condición objetiva de punibilidadơ ${ }^{21}$, pero no será nunca el fundamento de la pena a la persona jurídica). Demostrando entonces que es inexistente, o que es incompleto (por ejemplo, la persona física actuó no por cuenta o no

\footnotetext{
517 NIETO MARTíN, Adán, La responsabilidad penal de las personas jurídicas. Un modelo legislativo. Op. Cit., página 169, construyó un sistema de responsabilidad de los entes en el que excluía de respuesta con sanciones penales a aquellas personas jurídicas pequeñas (por no haber desarrollado una complejidad suficiente, pues si no es así, "solamente existe una agregación de personas, donde los actos e intenciones de la colectividad son reconducibles a sus miembros"), las personas jurídicas ilícitas y las personas jurídicas "pantalla".

518 NIETO MARTÍN, Adán, "La responsabilidad penal...", Op. Cit., página 12: “La opción del CP ha sido clara solo las personas jurídicas tienen responsabilidad penal, al resto de organizaciones sin personalidad jurídica ("empresas, organizaciones, grupos o cualquier otra clase de entidades o agrupaciones") les es de aplicación el nuevo art. 129".

519 FEIJÓO SÁNCHEZ, Bernardo, Op. Cit., página 106.

$520 \mathrm{Ib}$ Ídem, página 90.

${ }^{521}$ NIETO MARTÍN, Adán, “La responsabilidad penal...”, Op. Cit., página 11.
} 
en nombre, o no en beneficio) entonces la persona jurídica podrá evitar su responsabilidad penal.

En segundo lugar, podrá demostrar que a pesar de que existió ese t̂necho de conexiónòde la persona física con significación de delito, no se le deberá tomar en cuenta a la persona jurídica porque el defecto de organización es inexistente. Esto podrá alcanzarse si demuestra que, contrario a la tesis de la acusación, que está organizada de manera tal que cumple con los estándares exigidos para el cumplimiento de la ley, tal y como lo expusimos en el epígrafe anterior. La imputación subjetiva podrá ser evitada si no es demostrado el dolo empresarial si es que el tipo penal exige el mismo para la configuración del delito. Ya sea desde la vía del segundo párrafo del 31 bis.1 CP (ñpor no haberse ejercido sobre ellos el debido control atendidas las concretas circunstancias del casod o ya sea por la del inciso d) del 31 bis.4 CP (la atenuante relativa a la implementación de r̃medidas eficaces para prevenir y descubrir los delitos que en el futuro pudieran cometerse con los medios o bajo la cobertura de la persona jurídicaò), o ambas, si la persona jurídica tiene establecidos programas de cumplimiento de la legalidad eficaces y adecuados a los riesgos generales y específicos producidos por su actividad empresarial especial con anterioridad a los hechos, entonces es legalmente posible que no tuviera responsabilidad penal ${ }^{522}$.

Por último, debería acreditar el defecto organizativo no ocurrió debido al déficit de la cultura empresarial contraria al derecho, sino que a pesar de su modo de ser fiel al ordenamiento jurídico el defecto organizativo ocurrió y dio lugar al delito de la persona física. Son relevantes los códigos éticos o códigos de conducta internos de la empresa, siempre y cuando además de estar institucionalizados tengan

522 Así, DOPICO GÓMEZ ALLER, “ Responsabilidad de personas jurídicas”, Op. Cit., página 18, y MATA BARRANCO, Norberto J. de la, "La responsabilidad penal de las sociedades mercatiles", Op. Cit., página 4, al decir "es obligado aceptar que cuando éstas ya existen y simplemente no han tenido éxito puntual en el caso concreto por la elusión de las mismas por parte del concreto autor del delito, la exenión de responsabilidad por ausencia de tipicidad es obligada". 
eficacia y no sean solamente una máscara o signifique un simple aditamento cosmético.

\section{OTRAS POSICIONES DOCTRINALES}

Como anticipamos, es menester exponer otras posiciones que se han elaborado en la doctrina a partir del nuevo art. 31 bis CP. Exponemos tres que con difícilmente podríamos reconducir de forma automática a cualquiera de las posiciones anteriores o en su caso tiene aspectos particulares muy específicos que vale la pena comentarlas de manera separada. Se trata de una fundamentación de los párrafos primero y segundo del art. 31 bis.1 CP a través de la comisión por omisión imprudente que realiza Rodríguez Ramos (a), o de la estimación de que el art. 31 bis CP constituye, de la misma manera que lo hace el art. $12 \mathrm{CP}$, una especie de numerus clausus imprudente pero específico para las personas jurídicas, de Galán Muñoz (b), para terminar con la perspectiva de Nieto Martín (c).

\subsection{La comisión por omisión imprudente como título de} imputación a la persona jurídica

En dos artículos ${ }^{523}$ el profesor Rodríguez Ramos edifica una interpretación muy especial del art. 31 bis CP. Definitivamente considera que la conducta en la que se hace consistir el delito de la persona jurídica deberá de ser, única y exclusivamente, el de comisión por omisión imprudente.

\footnotetext{
523 “Cómo puede delinquir una persona jurídica en un sistema penal antropocéntrico? (la participación en el delito de otro por omisión imprudente: pautas para su prevención)", en Diario La ley, Número 7651, de 3 de febrero de 2011; y "El "delito de sospecha blindado" y la responsabilidad objetiva "impura" en la Circular 1/2010 de la FGE", en Diario La Ley, Número 7694, de 14 de septiembre de 2011.
} 
Es así ya que a pesar de que la persona jurídica es rãlgo distinto de cada una de las personas físicas que forman parte de la mismao ${ }^{24}$, siempre será considerada desde una perspectiva antropomórfica, y por tanto, se debe concluir que carece de capacidad de acción ${ }^{525}$, pero en cambio, si tiene capacidad de omisión que tiene una maturaleza ideal, hipotética, pues consiste en un no hacer, en la nada, en algo inexistente ${ }^{56}$, razón por la cual estima que el único título en virtud del cual se puede imputar una conducta específica a la persona jurídica es la comisión por omisión ${ }^{527}$.

De hecho, así se desprende con claridad del segundo párrafo del art. 31 bis CP (ñpor no haberse ejercido sobre ellos el debido controlò, pues al no haber controlado los hechos por los responsables de la organización, ña no evitación del resultado por parte de esta entidad en posición de garante es lo que fundamenta la imputación objetiva de esta conducta de comisión por omisión $0^{528}$, mientras que en el primer párrafo, aunque no es tan evidente, la ñmposibilidad de derivar una responsabilidad penal de una conducta ajenaé exige encontrar ese fundamento implícito que, en cualquier caso, tendrá que consistir en un m̃o hacerò coetáneo 0 anterior al hecho delictivo protagonizado por el administradorơ ${ }^{529}$.

Por lo que hace a la imputación subjetiva, afirma la exclusiva viabilidad de la imprudencia, porque ñpor mucho que se fuerce el modelo antropomórfico de la responsabilidad penal de las personas jurídicas, no es posible concebir su comportamiento omisivo doloso, es decir, con consentimiento previo o coetáneo de los hechos y con voluntad o aceptación de que se realiceno $\sigma^{30}$, y en relación con la cualidad de su participación en el delito, niega que la persona jurídica

\footnotetext{
524 “Cómo puede delinquir...”, Op. Cit. Página 5.

525 Ib Ídem, página 7.

526 Ib Ídem, página 7.

527 Ib Ídem, página 6.

$528 \mathrm{Ib}$ Ídem, página 6.

${ }^{529} \mathrm{Ib}$ Ídem, página 6.

530 Ib Ídem, página 8.
} 
pueda ser autora material (art. 28, primer párrafo, primer inciso) pues ese papel lo tienen los administradores de hecho o derecho 0 representantes legales o dependientes, ni autora mediata r̃al carecer en sí misma de capacidad de ideación y resolución para delinquirò ni inductora, por lo que solamente cabría considerarla r̃cooperadora necesariaòen el delito de la persona física ${ }^{531}$.

Por ello, aunque califica de r̃autorresponsabilidadò el sistema del art. 31 bis CP m̃o deja de ser al mismo tiempo una Theterorresponsabilidadò sin embargo, se deberán respetar los principios penales, r̃sustantivos y procesales (arts. 24 y 25 CE y concordantes) $0^{532}$, así como la interdicción de la responsabilidad objetiva $^{533}$.

6.2. El art. 31 bis CP como numerus clausus de delito imprudente propio de las personas jurídicas

Parten de evidenciar la contradicción entre aquellas posiciones doctrinales que defienden la heterorresponsabilidad penal en la interpretación del art. 31 bis CP y de los que defienden la autorresponsabilidad penal, con las implicaciones y razonamientos que ya hemos tenido ocasión de verificar nosotros mismos. Pretende que es posible conciliar estas posiciones en una sola en la que se superen las objeciones o críticas de ambas posturas.

Por lo tanto, estima que el fundamento de la responsabilidad penal de las personas jurídicas en la reforma a nuestro $\mathrm{CP}$, común a los dos niveles de imputación del art. 31 bis $1 \mathrm{CP}$, es ña infracción del deber colectivo de control de riesgos que el citado precepto dirigiría a

\footnotetext{
531 Ib Ídem, página 11.

532 Ib Ídem, página 10, así como en "El delito de sospecha blindado...", op cit., página 8 y sigs.

533 Ib Ídem, página 8, así como en "El delito de sospecha blindado...", Op cit., página 9 y sigs.
} 
todos los entes dotados de personalidad jurídica5034. Es un deber de supervisión o control que compele a vigilar lo que se efectúa al amparo del ejercicio de su propia actividad empresarial ${ }^{535}$ que está muy claro en el segundo párrafo del mencionado dispositivo, pero también aplicable al primero (delitos de los administradores o representante legal) porque en este caso las personas jurídicas solo r̃esponderían de los delitos que cometan los administradores o representantes actuando ren nombreôo ópor cuentaôy óen provechoôde dichas entidadesơ ${ }^{536}$, lo que indica que no es el cargo lo que se prioriza, sino el ámbito en que cometieron el delito (en ejercicio de actividades sociales). Lo que obliga la ley es garantizar la no comisión de delitos bajo ciertas condiciones.

A diferencia de otros criterios de interpretación (de heterorresponsabilidad), señala que la norma jurídica no se dirige a las personas físicas sino en todo caso a las personas jurídicas, es un m̃mandato de control de los recursos tato personales, como materiales e inmateriales que conforman la propia persona jurídica $0^{537}$, esto es, una norma de determinación y no solamente una norma de valoración, que les obligaría a organizarse y actuar de forma coordinada ${ }^{538}$.

El segundo aspecto interesante es la consideración del art. 31 bis CP como una especie de numerus clausus de la imprudencia para la persona jurídica, pues dicho artículo r̃contempla y describe una modalidad específica y muy delimitada de comportamientos imprudentes colectivos, lo que determina que si bien todos los elementos delimitadores de dicha conductas aparezcan generalmente contemplados en el referido precepto, también obliga a que su posible sanción tenga que aparecer expresamente contemplada en aquellos delitos en los que resulte viable ${ }^{539}$, con lo que consigue que el sistema

\footnotetext{
534 GALÁN MUÑOZ, Alfonso, Op. Cit., página 29.

$535 \mathrm{Ib}$ Ídem, página 28.

536 Ib Ídem, Página 28.

537 Ib Ídem, Página 30.

538 Ib Ídem, Página 32.

539 Ib Ídem, Página 36.
} 
adquiera unos niveles de coherencia interna desconocidas hasta el momento ${ }^{540}$.

\subsection{Doble fundamentación del art. $\mathbf{3 1}$ bis CP y confusión de la culpabilidad con peligrosidad.}

La de Nieto Martín es una de las visiones que más ha contribuido al esclarecimiento de la responsabilidad penal de las personas jurídicas. Amén de sumar (y sumar mucho) al debate y que en principio podríamos considerarlo como valedor de las construcciones interpretativas de la autorresponsabilidad a partir del art. 31 bis CP, podemos contarle aspectos novedosos e interesantes que por su importancia vale la pena comentar.

Nieto abraza la tesis del defecto de organización como fundamento del injusto penal propio de las personas jurídicas en los dos párrafos del art. 31 bis CP (por delitos de los administradores y representantes legales y por los delitos de los empleados mal controlados), sin embargo, mientras en el 20 párrafo lo estima evidente, en el $1^{\circ}$ párrafo lo de un tratamiento más bien propio de un injusto personal derivado del delito de la persona física (injusto de la persona jurídica es el injusto de la persona física). Estimamos que, atendiendo a su consideración del m̃úcleo de verdad de la teoría de la identificaciónò ve en el primer párrafo un sistema de heterorresponsabilidad penal a la manera que el vicarial de forma que el delito de la persona física (administrador o representante legal) es el fundamento del injusto personal de la persona jurídica, quien puede evitar su responsabilidad si demuestra en contra de la ñpresunción iuris tantumò que estuvo bien organizada ${ }^{541}$ : ñConforme a cuanto acaba de decirse el art. 31 bis 1 primer párrafo debe leerse como una presunción de responsabilidad de

\footnotetext{
$540 \mathrm{Ib}$ Ídem.

${ }^{541}$ Cuando analiza este mismo texto en la legislación italiana, expresamente habla de dos subsistemas diferenciados, vid. NIETO MARTÍN, Adán, La responsabilidad penal ..., Op. Cit., página 198.
} 
la empresa cuando el hecho haya sido cometido por los administradoresé se trata de una presunción refutable en la que la persona jurídica debe tener oportunidad de demostrar que contaba con una organización eficaz para la prevención y detección de hechos delictivos y la condena puede hacerse sólo a partir de la prueba de oficio de este elementoo ${ }^{542}$.

A tono con lo que había señalado anteriormente ${ }^{543}$, Nieto se decanta en considerar que la relación que existe entre el delito cometido por la persona física y el delito de la persona jurídica es la misma que existe en los casos de una r̃ condición objetiva de punibilidadà El delito cometido por la persona natural constituye una condición objetiva de punibilidad a partir de la cual debe investigarse el verdadero fundamento de la responsabilidad del ente, el defecto de organización, con independencia de si se ha plasmado o no en la comisión de un concreto delito ${ }^{54}$.

En el dolo y la culpa del injusto personal de la persona jurídica (defecto de organización) no encuentra ninguna diferencia como tales, sino en cuanto a la gravedad del defecto de organización ${ }^{545}$, es decir, rel pretendido tipo subjetivo no es, por tanto, sino la intensidad de la relación entre el defecto de organización y el comportamiento del autor. No es posible hablar por ello de un tipo objetivo y otro subjetivo de la empresa. Lo que los partidarios del tipo subjetivo empresarial llaman dolo o negligencia, aquí se denomina un defecto de organización más o menos grave ${ }^{546}$.

Finalmente, apuesta por un defecto de organización al que llama r̃déficit organizativo permanente ${ }^{547}$ que tiene en cuenta ña

\footnotetext{
542 NIETO MARTÍN, Adán, “La responsabilidad penal...”, Op. Cit., página 10.

543 NIETO MARTÍN, Adán, La responsabilidad penal..., Op. Cit., página 152.

${ }^{544}$ NIETO MARTÍN, Adán, “La responsabilidad penal... “, página 11.

545 NIETO MARTÍN, Adán, La responsabilidad penal ..., Op. Cit., página 160.

546 Ib Ídem.

547 Ib Ídem, Página 150.
} 
personalidad o el carácter de la persona jurídica ${ }^{548}$, esto es, con el tipo de autor (por lo que el derecho penal de las personas jurídicas es un derecho penal de autor); y por ello importa tanto el déficit organizativo anterior al delito como el post delictual. De forma tal, y atentos a los arts. 31 bis 4, d), y 66 bis CP, la culpabilidad y la peligrosidad delictivas (y la dualidad entre penas y medidas de seguridad), ren el caso de las personas jurídicas ambos conceptos de fundenơ ${ }^{549}$.

548 NIETO MARTÍN, “La responsabilidad penal...”, Op. Cit., página 13.

${ }^{549} \mathrm{Ib}$ Ídem, Página 14. 


\section{CAPITULO VI}

\section{EL MODELO DE RESPONSABILIDAD PENAL DEL ART. 31 BIS CP: TOMA DE POSICIÓN}

La manera que ha sido implementado el sistema de responsabilidad penal de las personas jurídicas por parte del legislador de 2010 en España, no responde con claridad a contestar la cuestión sobre cuál ha sido el modelo que ha elegido. Por un lado, tienen razón aquellos que ven en el art. 31 bis CP un sistema vicarial de responsabilidad al exigir hechos de personas físicas que, a través de ellos, se hace responsable a la persona jurídica de esos delitos. Sin embargo, difícilmente se podría explicar que el 31 bis.2 CP declare una independencia y autonomía de ambas responsabilidades, mientras que el 31 bis.3 CP impide la comunicación de ciertas circunstancias, y que el 31 bis.4 CP establezca circunstancias de atenuación propias y exclusivas de las personas jurídicas y diferentes de las de la persona física.

El pragmatismo con el que ha actuado el legislador pone frente a la doctrina española el gran reto de crear y desarrollar interpretaciones que siendo respetuosas de los principios penales puedan también darle mayor alcance a la política criminal 
manifiestamente expresada a través del texto reformado en 2010, esto es, haciéndola más eficaz y eficiente.

La razón por la que es tan importante conocer el modelo de responsabilidad penal es sencillamente la de la coherencia interna y externa del sistema y de las explicaciones dadas y las respuestas a los problemas prácticos diarios. No es solamente un ejercicio del arte por el arte, sino que es imposible interpretar y desarrollar una institución o figura del Derecho Penal sin antes saber y tener claro en dónde estamos, de dónde venimos y hacia dónde partimos en materia dogmático jurídico penal y de derechos constitucionales, por un lado, y por lo que hace a la coherencia interna, es necesario desarrollar interpretaciones adecuadas para que funcione como un todo, sin lagunas y sin contradicciones, para colmar al sistema de sentido, de fluidez y funcionalidad. El hecho de que la responsabilidad penal de las personas jurídicas sea un tema de impronta anglosajona, no quiere decir que un pragmatismo veleidoso reinará en su aplicación con el aval de la doctrina española.

Ciertamente que las respuestas doctrinales para resolver la cuestión planteada en el art. 31 bis CP han sido muchas y muy variadas como lo hemos visto; todas ellas aportan criterios inobjetables y desventajas de carácter político criminal, legislativa y doctrinal, empero podemos pensar en un sistema operativo que sea m̃ás útil, práctico, razonable jurídica y funcionalmente que otro ${ }^{550}$. Lo que se pretende, entonces, es exactamente lo que decía el profesor Gimbernat de que el jurista r̃que quiere ocuparse de un tema de Derecho Penal precisa, en primer lugar, ver dónde están los problemas. Después, para solucionarlos o intentar solucionarlos, ha de averiguar cuáles son las respuestas que se han dado a tales problemas, y al final tomar posición y fundamentarlaơ ${ }^{551}$.

\footnotetext{
550 MORILlas CUEVA, Lorenzo, Derecho Penal. Parte General. Addenda a la obra, Tomo II, Volumen I, Dikinson, 2008, página 9.

551 GIMBERNAT ORDEIG, Enrique, Concepto y método de la ciencia del Derecho Penal, Tecnos, Madrid, página 119.
} 


\section{EL MODELO DE RESPONSABILIDAD PENAL SEGUIDO POR EL LEGISLADOR ESPAÑOL DE 2010}

1.1. El art. 31 bis CP no expresa un sistema de autorresponsabilidad penal radical

En los sistemas de autorresponsabilidad penal de las personas jurídicas, digamos, extremos o radicales, el factor humano tiene una importancia marginal tanto desde el punto de vista de la construcción dogmática como desde el de política criminal ${ }^{552}$. No se trata solamente que el injusto personal así como la culpabilidad penal de la empresa sean propios de la persona jurídica, sino que la acción u omisión de la persona humana simplemente pueda resultar ajena al sistema mismo.

En efecto, la lesión o puesta en peligro al bien jurídico estaría satisfecha con una materialización del peligro típico en la empresa que estaría relacionado con la rãcciónòpropia de la persona jurídica a través de una administración incorrecta del riesgo (defecto de organización, si se quiere llamar), y la relación entre estos dos conceptos se resolvería bajo el criterio de imputación objetiva (específicamente, aumento del riesgo propio de las organizaciones), bajo una autoría de dominio funcional sistemático de la organización ${ }^{553}$. Un sistema de este talante no es solamente ideal y ahistórico, sino que tiene un reflejo en la realidad bajo las concepciones del Manslaugther acto inglés de 2007 y el CP Australiano de 2001.

Un sistema así tendría todas las ventajas político criminales que desarrollamos en el capítulo II, como directriz o dimensión de la responsabilidad penal de las personas jurídicas, es decir, entre otras, las siguientes:

552 Vid. supra, capítulo IV.5.

$553 \mathrm{Ib}$ Ídem. 
En principio podría cambiarse (o mejor dicho, evolucionar) la perspectiva hacia esquemas que la indagación sociológica nos ha puesto al descubierto sobre la idea del ŕsujeto dañinoò del Derecho Penal, pues ya no sería más la persona humana rẽlò (único) sujeto capaz de lesionar o poner en peligro bienes jurídicos individuales y colectivos, a través, principalmente, de acciones violentas que son propias de ciertas clases sociales, como lo tenía por sentado la criminología positivista desde las postrimerías del siglo XIX y cuyos postulados siguen siendo, al día de hoy, vigentes y funcionales en nuestro sistema social. Estamos hablando de esa queja de la que se dolía la doctrina desde antes de la entrada en vigor del CP de 1995 en el que se daba prisión a una persona individual por un delito de bagatela y solo se imponía una pequeña multa a una persona jurídica que podía conmover las estructuras económicas de toda una sociedad. Estamos hablando de ese r̃mundo al revésòque animó, inicialmente, a la doctrina española a reclamar la revisión del aforismo societas delinquere non potest.

Un sistema de autorresponsabilidad así podría reivindicar aquellas afirmaciones de la sociología que postulaban a las sociedades o empresas como rálgo distintoò de sus integrantes, como algo o alguien que era destinatario de normas jurídicas y que podía infringirlas de la misma manera que las infringen los individuos, por lo que la igualdad proclamada por la Constitución podría ser cumplida: ya no importaba ser persona individual o jurídica, bastaba con infringir la norma penal y la magnitud del daño causado para ser sujeto de sanciones.

En la línea que estamos hablando sería posible hablar del destierro de la irresponsabilidad individual organizada e irresponsabilidad estructural organizada. Estos términos, acuñados por lo menos desde 1982 por Schünemann ${ }^{554}$ y fueron utilizados y desarrollados por toda la doctrina española que se dedicó a estudiar el

554 Vid. nota 223, supra. 
tema. La ractitud criminal de grupoò y la descentralización de las funciones que se originan y funcionan, respectivamente, dentro de la empresa, podrían ser evitados en toda su extensión si la persona jurídica, y no los individuos, eran perseguidos criminalmente, aunque mientras que para superar la actitud criminal de grupo es indiferente la identificación de la persona física infractora de la norma penal en un caso específico (pues es posible identificar los valores y principios de una subcultura como puede ser la empresa sin necesidad incluso de que se cometa algún delito) en el caso de la descentralización de funciones si es necesario exigir la m̃o identificación de la persona individual que cometió el delitoò o por lo menos idear un sistema de responsabilidad penal al que le fuera indiferente por no depender de dicha identificación.

$\mathrm{Si}$, como lo vimos en el modelo legislativo ideal creado por Heine ${ }^{555}$ o en los casos inglés o australiano, la acción u omisión de la persona individual simplemente es irrelevante, entonces la irresponsabilidad estructural organizada tiene posibilidades de dejar de ser un problema en la imputación colectiva.

También entrarían en juego el equilibrio y la distribución equitativa de las responsabilidades penales al tener como autónoma e independiente la responsabilidad penal de la persona jurídica, de forma tal que, al no ser subsidiaria de la de la persona física, se reduciría hasta un mínimo razonable la tendencia de otros sistemas que deslizan la responsabilidad penal hacia las personas físicas operarias de más bajo nivel en una empresa (cabezas de turco involuntarias) o incluso a estas mismas personas o a directivos que han negociado con la persona jurídica su calidad de chivo expiatorio para exculparla mediante una buena compensación. La responsabilidad penal evita ser moneda de cambio.

555 Vid. supra, capítulo IV.5. 
No obstante, esta virtud no es solo de sistemas de autorresponsabilidad penal de personas jurídicas, pues basta con que exista y existiendo no sea subsidiaria, para que se verifique en los hechos. En igual situación queda la necesidad de un sistema que anime a la autorregulación de la empresa, a lo que volveremos más adelante.

Esas ventajas y virtudes de un sistema completo de autorresponsabilidad penal vendrían aparejadas con la legitimación que da un sistema que respeta los derechos fundamentales de la persona jurídica así como los principios del Derecho Penal, puesto que la empresa respondería por hechos propios y no por hechos ajenos, así como por su propia culpabilidad, y junto con ello, la interdicción del bis in ídem.

Sin embargo, el texto del art. 31 bis CP hace inviable interpretarlo como un sistema verdadero, total y completo de autorresponsabilidad empresarial, ya que exige, para responsabilidad a la persona jurídica, ños delitos cometidosé por sus representantes legales y administradores de hecho o de derechoò o ños delitos cometidosé por quienes estando sometidos a la autoridadò de los anteriores, lo que invalida cualquier interpretación que quiera adecuarse al texto legal a afirmar lo contrario. De hecho no conocemos ninguna posición doctrinal que afirme tal cosa.

Sea el delito de la persona física (representante legal o administrador de hecho o de derecho, y el empleado mal controlado) el injusto de la persona jurídica (que se le trasfiere bajo ciertas condiciones normativas), un presupuesto de la responsabilidad de la persona jurídica o una condición objetiva de punibilidad, lo cierto es que es necesario e imprescindible, y sin él es imposible imputar a la persona jurídica responsabilidad alguna. El delito de la persona individual es la única puerta posible para su responsabilidad.

Que el delito de la persona física sea imprescindible para responsabilizar a la jurídica, entonces ya debemos de dejar a un lado la 
aspiración político criminal de superar o evitar la irresponsabilidad penal en aquellos casos en que era imposible encontrar a la persona individual responsable, o en aquellos otros en los que, por la descentralización de las funciones de decisión, información y operación, sea imposible adscribir a una persona específica o conjunto de personas específicas, la responsabilidad por no cumplirse en ninguna de ellas los elementos propios de la teoría del delito. Nuestra conclusión se vuelve diáfana cuando encontramos que en aquellos casos de un vertido contaminante, por ejemplo del art. $327 \mathrm{CP}$, se requiera la demostración del dolo de una persona, pero si no sabemos qué persona o conjunto de personas fueron exactamente las que realizaron el vertido, o conociéndolas es imposible que a una sola de ellas se pueda adscribir el dolo, entonces no podríamos decir que dicha persona cometió una conducta típica y antijurídica por lo menos, razón por la cual es imposible tener por satisfecho el hecho de referencia que exige el art. 31 bis CP.

Podría ser correcto decir, junto con la opinión doctrinal mayoritaria, que estamos frente a un sistema en camino hacia la autorresponsabilidad penal de las personas jurídicas.

1.2. El art. 31 bis CP como un sistema en camino hacia la autorresponsabilidad penal de las personas jurídicas

Parece ser que la doctrina absolutamente dominante en España (prácticamente no conocemos postura alguna que postule o esté a favor de un modelo de heterorresponsabilidad penal como modelo ideal) se decanta por un sistema de autorresponsabilidad penal de las personas jurídicas. Ya desde un punto de vista de lege ferenda como desde una perspectiva de la interpretación del derecho positivo actual, es clara la intención o el deseo de tener un modelo que supere las necesidades político criminales que se reclamaban al exigir la derogación del principio societas delinquere non potest y que además respete los 
derechos fundamentales de las personas jurídicas y los obstáculos de la dogmática jurídico penal.

Las tesis interpretativas del art. 31 bis CP que se han producido hasta la fecha ${ }^{556}$ tienen tendencias, así lo observamos, de alejamiento de sistemas vicariales 0 de heterorresponsabilidad y ubicarse en modelos más modernos, tanto por su eficacia y por su corrección dogmática. Quienes interpretan el texto de la reforma como un sistema de heterorresponsabilidad dejan ver un cierto dejo de resignación ante la letra estricta de la ley. Ante la llegada de la responsabilidad penal de las personas jurídicas no queda más remedio que sacar del texto todo lo que da de sí para que pueda ser rentendibleò bajo los conceptos dogmáticos de injusto personal (objetivo y subjetivo) propios y culpabilidad propios, por lo menos análogos a los del sistema de responsabilidad penal de las personas individuales, y alejarse lo más que sea posible de la responsabilidad por el hecho ajeno y por la responsabilidad objetiva. Nosotros también así lo haremos.

Por ello podemos decir que abrazamos, con las matizaciones que haremos posteriormente, el modelo que en el capítulo V.5 (injusto ï objetivo y subjetivo- propio y culpabilidad propia de la persona jurídica).

\subsection{Rechazo de las tesis interpretativas del hecho de conexión de la persona física como injusto de la persona jurídica.}

Aunque constituye una opción que puede funcionar, no creemos que el sistema de responsabilidad del capítulo V.3 (el hecho de conexión de la persona física es el injusto de la persona jurídica) sea el adecuado para interpretar el art. 31 bis $\mathrm{CP}$, por las siguientes razones:

1. Creemos que el argumento de la falta de legitimidad de un sistema así es insuperable.

556 Vid. capítulo V. 
No desconocemos que los valedores de esa posición afirman que no se trata simplemente de imputar el delito de la persona física a la jurídica, sino que, adicionalmente a una conducta típica y antijurídica $^{557}$ de la persona física es menester la concurrencia de determinadas circunstancias o condiciones normativas, como lo son, que esa persona física tenga cierta competencia (administrador de hecho o de derecho o representante legal o alguien sometido a la autoridad de éstos) y que además r̃se infrinjan deberes que le competen como miembro de la misma, que se actúe en el giro de la empresa, que se lleve a cabo un beneficio de la empresao ${ }^{558}$, y que solamente de esa forma la persona jurídica verá colmada su responsabilidad penal. Sin embargo, tampoco desconocemos que no debieran existir condiciones o circunstancias normativas determinadas en el hecho delictivo ajeno para que de esa manera se pueda imputar ese hecho a otra persona, si esta otra persona no realizó conducta alguna para que se le pueda imputar nada.

Lo que nos parece inaceptable es que el hecho delictivo de una persona (el representante legal de la persona jurídica) sea a su vez el hecho delictivo de otra (el representado, la persona jurídica) bajo ciertas circunstancias o condiciones normativas, cuando eso no sucede si el representado es otra persona física. El hecho ajeno más las condiciones normativas nunca debieran ser, bajo ninguna circunstancia, el fundamento del injusto de otro.

Como ya hemos señalado, la construcción interpretativa del art. 31 bis CP debe partir de una r̃elación análogaòcon las categorías de la teoría del delito para las personas individuales, y parece que esta aseveración no es discutida hasta el día de hoy. Si ello es así, el fundamento y concepto del injusto personal en el sistema de las personas jurídicas debería buscarse en el mismo lugar que en el caso del sistema de las personas físicas: en una norma de determinación y

\footnotetext{
557 BACIGALUPO, Silvina, “La responsabilidad penal...", Op. Cit., página 5.

558 ZUGALDÍA ESPINAR, José Miguel, La responsabilidad criminal de los entes colectivos, (2012), Op. Cit., página 40.
} 
no solamente en una norma de valoración. Una norma de determinación debe ser entendida como un mandato o prohibición a una persona que pueda cumplir, esto es, que esté en sus manos evitar o provocar.

Si salimos del círculo vicioso de aquellas teorías que entienden a la acción desde puntos de vista ontologicistas del Derecho Penal y de sus categorías, y nos ubicamos en posturas más próximas a las que se alinean a un sistema normativo o teleológico funcional, aplicable a las personas jurídicas y a las físicas, y entendemos que a nivel del injusto penal lo que importa es la acción penalmente relevante, entonces la dañosidad social evitable es el concepto a tomar en cuenta. De este modo se puede imputar aquel resultado suficientemente relevante con sentido social y que se pudo haber evitado. D̃Desde esta perspectiva, la determinación de lo que es injusto penal, se fundamenta en la dañosidad social del hecho evitable (fines de prevención y protección de bienes jurídicos plasmados en la norma penal) $0^{559}$.

Lo que nos debe importar es que debe estar en las manos del autor la evitación del resultado dañoso si es que ese sujeto es el destinatario de la norma penal. Si no está en sus manos, si no puede evitarlo, entonces no le sería imputable ese resultado dañoso.

Por tanto, si la persona jurídica no puede dominar a la persona física (y nadie le exige que la domine) como para evitar el resultado producto del actuar típico y antijurídico de la persona física, entonces no se le podría imputar a la persona jurídica ese delito. En otras palabras: el hecho de conexión de la persona física no constituye una dañosidad social que la persona jurídica pueda evitar. No es, ni debe ser, en consecuencia, imputable a la persona jurídica.

Decimos que la persona jurídica no domina y nadie le exige que domine a la persona jurídica. Si así fuera, estaríamos hablando de una

559 ZUÑIGA RAMÍREZ, Laura, Bases para un modelo de imputación..., Op. Cit., página 229 
autoría mediata o de una coautoría, en la que también se tendría que justificar un injusto propio de la persona jurídica, y no simplemente imputarle el injusto de la persona física. Tampoco existe alguna suerte de participación en cualquier otro nivel, en el caso que se diga que la jurídica no domina a la física, pero si actúa conjuntamente, porque también en este caso debería existir un injusto propio de la persona jurídica con el que pueda participar en el delito del otro. Ni dominio ni participación en el hecho delictuoso de la persona física, entonces, qué es lo que queda.

Queda justificar que la persona jurídica es un sujeto al que se le destinan normas penales de determinación, que tienen la intención de motivarla a hacer algo o dejar de hacer algo. Pero, teniendo en cuenta que motivar a algo es diferente de ese algo para lo que se quiere motivar, entonces se debe exigir un injusto propio de la persona jurídica.

Por otro lado, también Jakobs critica el hecho de que si fuera así, esto es, que pudiera trasladarse simplemente la culpabilidad del representante, de quien realiza esa prestación al mandatario, entonces habría que decidir a quién se le debe realizar el reproche, si a la persona jurídica o a la física, pero nunca a los dos, pues no puede un solo acto generar dos culpabilidades.

ño que debe serle atribuido a una persona jurídica, debe, en primer lugar, poder serle amortizado al órgano, y cuando el derecho mantiene al órgano en cuanto persona con su culpabilidad, esta culpabilidad no puede serle amortizada y atribuida a la persona jurídica ${ }^{560}$. Continúa diciendo Jakobs que como parece que nadie está dispuesto a dejar sin penalidad a la persona física, esto es, nadie podría renunciar a castigar y en consecuencia a dejar libre de toda respuesta de Derecho penal al autor material, entonces ahí también fracasaría la punibilidad de la persona jurídica.

${ }^{560}$ JAKOBS, G., “¿Punibilidad de las personas jurídicas?, Op. Cit., p. 336. 
Estas consideraciones críticas a las posiciones antes señaladas nos parecen insuperables dentro de un modelo de rãtribuciónò de la responsabilidad de la persona jurídica.

Seamos serios, si a la persona jurídica no se le imputa un hecho propio o el hecho propio que se le imputa es en realidad un hecho ajeno, de otra persona, entonces el sistema sobre ello construido caería de inmediato. El principio que proscribe la responsabilidad por el hecho ajeno provocaría la ilegitimidad de dicho sistema.

Aquí es, a nivel de injusto personal de la persona jurídica, donde debería de entrar el defecto de organización, pero, creemos con Robles Planas, que r̃el haber abrazado acríticamente la culpabilidad por defecto organizativo como hecho propio de la persona jurídica, sin analizar dogmáticamente, por un lado, en qué consiste y en dónde resideò condujo a ñuna importante confusión entre ñnjustoò y r̃ ulpabilidadò de la persona jurídica cuando se afirma que la culpabilidad lo es por r̃defectos organizativosò En realidad, en todo caso, el defecto organizativo pretendería constituir el injusto de la persona jurídicao ${ }^{561}$.

2. Porque no tendría mucho sentido una culpabilidad construida por un defecto organizativo.

Si bien entendemos, y a tono con lo dicho anteriormente, el defecto organizativo aún y cuando tiene la cualidad de ser graduable (mayor defecto organizativo o menor defecto organizativo), no puede ser un baremo para medir el grado de cultura empresarial de incumplimiento al Derecho, que es propio de la culpabilidad empresarial. Parece que la culpabilidad debe tener más bien un contenido de reproche (no ético ni moral, en el caso de las personas jurídicas, sino social), de censura o desaprobación de la conducta, pero

561 ROBLES PLANAS, Ricardo, "Pena y persona jurídica: crítica del artículo 31 bis CP", Op. Cit., página 5. 
finalmente un juicio de reproche ${ }^{562}$, y no hallamos acomodo dentro de este juicio de reproche a un T̃echo objetivoò como es el defecto organizativo.

Abona más a nuestra perspectiva la manera en que han dado sustancia al defecto organizativo algunos autores, que lo asemejan más bien a una especie de ñiolación del deber de vigilanciaòo ñiolación del deber de organizaciónơ ${ }^{563}$ que es propio de los injustos penales imprudentes. Inclusive, a veces el defecto de organización que se atribuye como la culpabilidad misma de la persona jurídica, se traslada, en las argumentaciones de quienes sostienen esta tesis interpretativa, al injusto personal; esto es, hablan de que la culpabilidad en las personas jurídicas es rél reproche que se formula a una persona jurídica porque ha omitido la adopción de las medidas que le son exigibles para garantizar un desarrollo ordenado y no infractor de la actividad relativa al hecho de la empresa ${ }^{564}$. Por lo que creemos que si el reproche es la culpabilidad (valoración del objeto) entonces el defecto de organización es lo reprochado (objeto de valoración).

Sería incompatible, por lo demás, un injusto (hecho de conexión de la persona física) con una culpabilidad por defecto de organización, para una persona (la jurídica).

\footnotetext{
562 GOMEZ TOMILLO, Manuel, Introducción..., Op. Cit., página 105.

563 ZUGALDÍA ESPINAR, José Miguel, La responsabilidad criminal de los entes..., $O p$. Cit., página 40, pues señala "la persona jurídica será culpable siempre que haya omitido tomar las medidas de cuidado necesarias para garantizar un desarrollo ordenado y no delictivo de la actividad de empresa (se trataría de la infracción del deber de evitar que la actividad de empresa se concrete en la realización de hechos delictivos)", también en páginas 54 y sigs.

564 GÓMEZ TOMILLO, Manuel, Introducción a la responsabilidad penal..., Op. Cit., página 105. Así también, DE LA CUESTA ARZAMENDI, José Luis, "Responsabilidad penal...", Op. Cit., página 15, "a nuestro parecer y como ya se ha indicado, resulta dogmáticamente muy razonable y coherente con la realidad de la criminalidad de la empresa, construir no tanto la culpabilidad cuanto el núcleo del injusto específico de la persona jurídica sobre la infracción por parte de ésta de su deber de evitación de delitos en el marco de las actividades sociales".
} 
3. La culpabilidad (defecto de organización) no debería estar relacionado con el hecho de conexión (el hecho de la persona física) en una vinculación de imputación objetiva.

Cierto, solamente en el injusto personal es posible analizarse la relación que guardan el hecho de una persona con su resultado (en los delitos de resultado material) bajo los criterios de la imputación objetiva. De esa forma es posible predicar que determinado hecho del sujeto activo aumentó de forma no insignificante el riesgo al bien jurídico y que el resultado se hizo gracias a ese aumento de riesgo.

La exigencia de la imputación objetiva de resultado se surte, sin duda alguna, entre el hecho de la persona física (hecho de conexión) y su propio resultado (por ejemplo, la realización de emisiones contaminantes en la atmósfera del art. $325 \mathrm{CP}$ ). Pero, siendo el defecto de organización la culpabilidad misma de la persona jurídica (y no su injusto personal) no debería, entonces, exigirse que tal defecto organizativo tuviese una relación de imputación objetiva de resultado ya con el hecho de conexión o ya con el resultado mismo (las emisiones contaminantes del art. $325 \mathrm{CP}$ ). De ahí que siguiendo el criterio de estas tesis se tenga que sostener, según nos parece, que comprobado el hecho de conexión de la persona física (con las circunstancias normativas que ya conocemos: por cuenta, en su nombre, en provecho) a la persona jurídica se le considerará responsable aún y cuando el defecto organizativo nada tuviere que ver con el resultado dañino al medio ambiente.

4. No existirían causas de justificación propias de la persona jurídica.

No decimos que hemos encontrado casos en los que alguna causa de justificación operara en favor de una persona jurídica a pesar de haber cometido un injusto de defecto de organización. De hecho, creemos que es difícil encontrar algún caso práctico. Lo que queremos poner en claro es que con un modelo del hecho de conexión juzgamos 
la antijuridicidad del hecho de la persona física y se la imputamos a la jurídica, sin darle oportunidad teórica e hipotética a ésta de valerse de una causa de justificación propia en su hecho típico propio, lo que parece incorrecto.

La persona jurídica debería tener también derecho a un sistema que le permitiera justificar de forma autónoma e independiente de la antijuridicidad del hecho de la persona física, su propio hecho.

5. Para evitar la prácticamente automatización de la responsabilidad penal de la persona jurídica, por la presunción iuris tantum de su culpabilidad.

Comprobado el injusto objetivo y subjetivo de la persona jurídica (que es el injusto objetivo y subjetivo de la física, más circunstancias normativas) la culpabilidad de la persona jurídica se presumiría como existente (una presunción que admite prueba en contrario) ${ }^{565}$. En opinión de algún autor, esto tiene que ser así pues no es aceptable que al órgano acusador se le imponga la carga de comprobar algo tan complejo como es el defecto organizativo de la persona jurídica, y porque no resulta factible que recaiga sobre la acusación la prueba de un elemento negativo, como es la ausencia de una organización defectuosa ${ }^{566}$.

Desde nuestra perspectiva, eso es dejar sin ningún contenido práctico el sistema de imputación de la persona jurídica: El órgano acusador no tiene que acreditar nada de la persona jurídica, y lo que debe acreditar no es propio de la persona jurídica, sino de la persona física (el hecho de conexión), mientras que la culpabilidad de ella se presume. Asumiendo lo anterior, cobra más sentido y evidencia nuestro argumento número 3 (supra), esto es, que no es necesario acreditar,

\footnotetext{
565 GOMEZ TOMILLO, Manuel, Op. Cit., página 131 y sigs., pues afirma que "puede excluirse la responsabilidad sancionatoria cuando la persona jurídica acredite una correcta organización de cara a la evitación de delitos, o infracciones administrativas".

566 Ib Ídem, página 134.
} 
bajo este sistema interpretativo del art. 31 bis $\mathrm{CP}$, el nexo normativo entre el resultado y el defecto de organización (la imputación objetiva de resultado).

Esta es la parte que hace más evidente la responsabilidad por el hecho ajeno, la responsabilidad objetiva.

Estimamos que una lógica procesal así dejaría a la persona jurídica en una posición desventajosa y desequilibrada en el proceso penal, y sin ningún contenido práctico a la acusación, quien al demostrar los hechos de la persona física (a quien seguramente también acusará) con las mismas pruebas y con los mismos hechos demostrados podrá acusar a la jurídica. Como dice Nieto Martín, m̃o podemos proclamar la culpabilidad propia de la persona jurídica y luego prescindir de ella o presumir su existencia ${ }^{567}$.

Corolario a todo lo anterior es nuestra preferencia a otra opción que puede ser más garantista que la que estamos analizando, sin que esto quiera decir que la que sostenemos sea la única viable y aceptable, sino una opción más que puede parecer razonable. Finalmente, como dice Zugaldía, y dice bien y con razón, r̃desde esta óptica, la opción por algún modelo de teoría jurídica del delito de la persona jurídica (para hacerla responder por su propia acción y por su propia culpabilidad) es, como ocurre en todas las cuestiones dogmáticas últimas, libre (también lo es en el ámbito de la teoría jurídica del delito de las personas físicas, donde es posible encontrar tantas teorías jurídicas del delito diferente como autores) $0^{568}$.

1.4. Rechazo de las tesis que propugnan un modelo de responsabilidad vicarial en el art. 31 bis $\mathrm{CP}$

\footnotetext{
567 Citado por GOMEZ TOMILLO, Manuel, Op. Cit., página 132.

568 ZUGALDÍA ESPINAR, José Miguel, La responsabilidad criminal..., Op. Cit., página 43.
} 
Estas tesis ${ }^{569}$ adolecen de las desventajas que hemos analizado en el apartado inmediato anterior, al que nos remitimos completamente, y además se pueden observar contra ellas otros argumentos adicionales.

1.- Partiendo de una aceptación acrítica del texto legal, debería declararse incongruente y contradictorio con el art. 31 bis. $1 \mathrm{CP}$ lo previsto por el 31 bis. 2,31 bis. 3 y 31 bis. $4 \mathrm{CP}$.

En efecto, bajo un apego irrestricto del texto legal no se explicaría razonablemente que el mismo sistema hace posible exigir responsabilidad penal a la persona jurídica aún y cuando la r̃concreta persona física responsable no haya sido individualizada o no haya sido posible dirigir el procedimiento contra ellaò(31 bis.2 CP). Si el injusto y la culpabilidad de la persona física simplemente se transfieren o imputan a la jurídica debería ser imposible responsabilizar a la jurídica cuando la física no haya sido individualizada o esté ab judice, pues conforme un análisis letrístico del 31 bis $1 \mathrm{CP}$ el fundamento y razón de la responsabilidad de la jurídica es el de la física. Parece que debe tener algo de razón la tesis que separa ambas responsabilidades y las declara autónomas e independientes.

A la misma conclusión deberíamos llegar (responsabilidades independientes y autónomas) si sopesamos los alcances del art. 31 bis $3 \mathrm{CP}$ en cuanto a la no comunicabilidad de las circunstancias que afecten a la culpabilidad del acusado o agraven su responsabilidad a la persona jurídica, ya que permite, sin ninguna duda, palpar dos culpabilidades diferentes. Y si son diferentes, la de la persona física no es la misma que la de la jurídica, y en consecuencia, la persona jurídica tendría una culpabilidad propia que separaría al sistema legal de la tesis vicarial.

Abona a la conclusión anterior si valoramos el 31 bis 4 CP que previene causas específicas de atenuación de responsabilidad penal 
específicas y propias para la persona jurídica, que si no tuviera una culpabilidad propia, difícilmente podrían tener cabida.

2. La ausencia de legitimación constitucional.

Entendemos que la huida de estos criterios doctrinales (y legislativos) tiene su origen en las tesis vicariales de responsabilidad penal. De hecho, creemos que la razón por la que fue tan difícil (por lo menos, parsimoniosa) la aceptación doctrinal de debatir sobre este tema fue la concepción de que el sistema de responsabilidad penal de las personas jurídicas se basaba, por antonomasia y sin posibilidad de alternativas, precisamente en criterios de simple atribución o imputación del hecho de las personas físicas a las jurídicas.

Hemos dicho que el CGPJ ha señalado en su Informe al Anteproyecto de 2009 (que es el fiel reflejo de la reforma de 2010) que estimaba la asunción del sistema vicarial por la forma en que estaba redactado. Sin embargo, también se menciona ese dejo de decepción junto a la aspiración de un cambio en el Anteproyecto para evitar ŕsuscitar problemas de constitucionalidad ${ }^{570}$, y que si no se incluyen las modificaciones que se recomendaban ${ }^{571}$, debería, así me parece, evitarse interpretaciones que se acerquen a una responsabilidad vicarial que emparentan con responsabilidad por el hecho ajeno y responsabilidad objetiva.

En el fondo late en la doctrina un alejamiento al sistema vicarial por saber que un sistema así no tendría legitimad alguna y partiría el sistema de derecho penal y la teoría del delito que tanto trabajo ha costado construir. Dice Rodríguez Mourullo ña consecuencia que se deriva de la vigente definición del artículo 10 es que la responsabilidad penal de la persona jurídica que introduce la Reforma es una

\footnotetext{
570 Página 12.

571 "sería recomendable que éste, más que al defecto de control y a la imputación de este defecto a la conducta de determinadas personas físicas, aludiera expresamente al defecto de organización, que es el criterio de imputación del hecho a la personas jurídicas técnicamente más homologable con el derecho, la doctrina y la jurisprudencia comparados", página 11.
} 
responsabilidad penal sin delito y que la pena que se impone a la persona jurídica es una pena sin dolo o imprudencia, que contraviene, por ello, la contundente garantía consagrada en el artículo 5 del CPờ ${ }^{57}$, por ello ña imputación normativa del comportamiento individual como propio del grupo se reduce a una mera imputación objetiva $0^{573}$, lo que suscribimos totalmente, si y solamente si entendemos que el sistema de responsabilidad del art. 31 bis $\mathrm{CP}$ es vicarial.

No es posible obtener una conclusión diferente: Si ña tipicidad, los criterios de imputación objetiva y subjetiva el dolo o la imprudencia, así como todos los demás elementos de infracción concurrentes o noé deben residenciarse en la persona físicao ${ }^{574}$ para que la persona jurídica sea responsables de ellos, entonces no queda más que declarar la reforma como inconstitucional por infringir los principios de personalidad de la responsabilidad penal, de responsabilidad por el hecho, de dolo y culpa, de imputación personal, en fin, el principio de culpabilidad ${ }^{575}$.

1.5. Rechazo de las tesis del modelo de responsabilidad objetiva del riesgo.

No son menos importantes los argumentos expuestos por quienes sostienen una hipótesis interpretativa del art. 31 bis CP de responsabilidad objetiva, penal pero no de culpabilidad, esto es, de peligrosidad. Más que sus argumentos para la construcción del modelo, son merecedores de comentario los que exponen para desautorizar cualquier modelo de culpabilidad propia de las personas jurídicas, y de éstos, aquellos que esgrimen que: 1. El defecto de organización no podría constituir el injusto personal de la persona jurídica porque no sería ese título suficiente para imputar a la persona jurídica el delito que

\footnotetext{
572 Vid. “La responsabilidad penal...”, Abogados, Op. Cit., página 38 y 39.

573 Ib Ídem, página 40.

574 Circular 1/2011 de la FGE, página 33.

575 Tal como lo dice RODRÍGUEZ RAMOS, Luis, "El "delito de sospecha blindado" y la responsabilidad...", Op. Cit., página 6 y 7.
} 
cometió la persona física, pues el ñnjusto de sistemaòno es ñn injusto penal en relación con la conducta delictiva de la persona física, pues no ñe alcanzanòlas reglas de la imputación típicas del delito producido ${ }^{76}$; $y$, 2. No es adecuada la pretensión de hacer un ñnjusto de desorganización de sistema específicoò constituyendo así a la persona jurídica (o a sus administradores) en una especie de garantes del colectivo consistente en provocar o no impedir el sistema de injusto, pues encuentran graves dificultades de legitimación material por ser un delito de peligro abstracto y la demasiada facilidad en la atribución de responsabilidad penal por la simple infracción de deberes formales ${ }^{577}$.

Entendemos que si una persona física (administrador o representante $\mathrm{o}$ el sujeto mal controlado) comete un delito bajo las exigencias normativas del artículo 31 bis $\mathrm{CP}$, por ejemplo, el delito contra el medio ambiente del art. 325 en relación con el 327 CP (emisión de contaminantes), debemos preguntarnos ¿por qué razón la persona jurídica responderá penalmente de ese delito? ¿Cuál es el título bajo el cual asignaremos responsabilidad penal a la persona jurídica? ¿El defecto de organización (injusto de la persona jurídica) sería suficiente para imputarle el delito de la persona física a la persona jurídica?.

\section{Nosotros pensamos que sí.}

La persona jurídica no responde, ni debe responder, de cualquier delito que realiza la persona física. No es garante de toda conducta que pueda representar peligro para los bienes jurídicos individuales o colectivos que realice una persona física. La persona jurídica no es destinataria de una norma que la obliga a organizarse de tal modo que pueda evitar cualquier clase de conductas delictivas.

\footnotetext{
576 ROBLES PLANAS, Ricardo, "El 'hecho propio' de las personas jurídicas y el Informe del Consejo General del Poder Judicial al Anteproyecto de Reforma de Código Penal de 2008", Op. Cit., Ib Ídem, página 16.

577 Ib Ídem, página 7.
} 
Sin embargo, con la existencia misma de una persona jurídica se originan dimensiones de riesgo y peligro para bienes jurídicos que no existirían si la empresa no hubiese sido creada. La función sociológica de una persona jurídica que entra en juego en ámbitos económicos, tecnológicos, de mercado y de competencia, así como el subsistema que se genera hacia su interior (organización, roles, competencias, procedimientos, políticas, metas y fines) la pueden convertir en una fuente de peligro diferente de la fuente misma que significa un mero agregado de personas físicas. De ahí la vinculación íntima y necesaria entre la organización empresarial y los peligros creados por ella. Peligros nuevos y diferentes creados a raíz de su existencia y de su organización específica, esto es, de tener una organización de una forma y no de otra. Por eso el art. 31 bis CP solo previene responsabilidad penal en los casos en que el delito se cometa en nombre o por cuenta de las mismas y en su provecho, y en el ejercicio de actividades sociales: esto es, solo garante de peligros específicos, los que ella misma crea. Es lo que Zugaldía llama giro de la empresa.

De esa forma, debe concluirse que la empresa si responde, y sí debe responder, cuando se cometan aquellos delitos por ciertas personas que desempeñan roles dentro de la empresa y que se justifican precisamente por la existencia y la operación de la misma empresa, y que no existirían si no existiera dicha empresa o que existiera de una forma organizada diferente de la que realmente está. No son, entonces, las simples personas físicas las responsables de ese resultado de riesgo a los bienes jurídicos (la sustitución de decisores u operarios fungibles sería suficiente para demostrarlo), sino algo más complejo: la organización defectuosa de la persona jurídica.

Ahora bien, no es esa relación íntima y muy cercana entre el riesgo a los bienes jurídicos individuales o colectivos y el injusto de la persona jurídica es lo que ha querido criminalizar el legislador utilizando 
una estrategia de control específica ${ }^{578}$, sino un delito específico que está previsto en el art. 31 bis $\mathrm{CP}$, como lo veremos adelante. Finalmente el legislador es libre para decidir cuándo una conducta es en sí misma generadora del riesgo suficiente como para ser prohibida, y en el caso ha decidido hacerlo bajo un esquema de tipos penales específicos $^{579}$. Tendría razón la crítica si asociáramos el defecto de organización con el peligro al bien jurídico del delito de la parte especial del CP.

A prima facie podría parecer desarticulado o desvinculado un delito (emisión de contaminantes a la atmósfera) con el injusto personal de una persona jurídica (el defecto de organización), pero si no se desconoce la realidad social de la empresa y el carácter estructural del delito ${ }^{580}$, deberá tenerse como necesaria e indispensable esta nueva estrategia y una legitimación y justificación suficiente del sistema mismo.

Por lo demás, no parece que sea consecuente el disminuir la entidad de la persona jurídica a la imposibilidad de su t̂necho propioò (porque en realidad todos son hechos de las personas físicas que actúan dentro y para ella) eliminando la posibilidad de un sistema penal de culpabilidad para ellas, y enseguida promover un sistema de medidas penales por su peligrosidad, admitiendo que puede convertirse en un estado peligroso. La opción alternativa que se introduce ${ }^{581}$ colisiona, en definitiva, con el texto expreso de la ley (art. 31 bis) de que

578 La estrategia ha sido llamada Third Party Strategy (implicación político criminal de la empresa en la evitación de la comisión de conductas delictivas que puedan favorecerle). Vid. Mir Puig, Santiago, Derecho Penal. Parte General, 2011, Op. Cit., página 200.

579 Vid. NIETO MARTÍN, Adán, La responsabilidad penal de las personas jurídicas, Op. Cit., página 45 y sigs. Específicamente señala "la reubicación del riesgo que se consigue a través de la sanción a las personas jurídicas es absolutamente necesaria para que las medidas de autoorganización se lleven a cabo de forma eficiente y con éxito".

580 NIETO MARTÍN, Adán, La responsabilidad penal de las personas jurídicas, Op. Cit., página 38 y sigs.

581 ROBLES PLANAS, Ricardo, "Pena y persona jurídica...", Op. Cit., página 17, apartado III.3) 
la responsabilidad es penal, en la que la absoluta mayoría de la doctrina está conforme ${ }^{582}$.

\section{TOMA DE POSICIÓN}

Como se ha señalado, abrazamos la tesis de que el art. 31 bis CP previene un sistema de responsabilidad penal de las personas jurídicas basado en un injusto propio (defecto de organización) y de una culpabilidad propia (cultura de incumplimiento de la legalidad), y por tanto, el hecho de conexión de la persona física, de la que habla el apartado 1 del art. 31 bis CP es un elemento desencadenante de la responsabilidad penal, un presupuesto de la conducta, una condición objetiva de punibilidad.

Es una posición que se apoya en las prescripciones de los apartados 2, 3 y 4 del art. 31 bis CP, que a despecho de las tesis que promueven la heterorresponsabilidad, tienen elementos que permiten negar que el delito de la persona física sea el fundamento de la responsabilidad penal de las personas jurídicas. Si la responsabilidad penal de éstas es exigible aún y cuando la persona física que cometió el delito no es ubicable ni identificada o aun siéndolo no es posible procesarla, si las circunstancias que afectan la culpabilidad de ésta no excluye ni modifica la de las jurídicas, y si las personas jurídicas tienen atenuantes propias, nos queda claro que la persona jurídica responde por algo propio. Pero no es el hecho de la persona física por lo que responde, pues es posible encontrar su propio injusto. Así, el defecto de organización, más que en la culpabilidad, deberemos buscarlo en el injusto personal y de esa forma evitamos una interpretación que puede generar tensiones con el principio de responsabilidad solo por el hecho propio y aquel que proscribe la responsabilidad objetiva. Esa es la valoración general a esta tesis que es partidaria de reconocer en la persona jurídica la capacidad de realizar un injusto propio (injusto

582 MIR PUIG, Ricardo, Derecho Penal, Op. Cit., página 200 y 210. 
empresarial) y una culpabilidad propia: es más garantistas de los derechos fundamentales de las personas jurídicas ${ }^{583}$. Es así puesto que parece ser que respeta los principios constitucionales de culpabilidad, de interdicción de responder por el hecho ajeno y proscripción de la responsabilidad objetiva.

Efectivamente, si el thecho de conexiónòde los párrafos primero y segundo del art. 31 bis CP es solamente un presupuesto de la responsabilidad penal de la persona jurídica, y a ésta se exige un T̃echo propioòy una r̃culpabilidad propiaò entonces podrían superarse aquellas críticas propias de los sistemas de heterorresponsabilidad penal y los que propugnan el t̃necho de conexiónòde la persona física como fundamento del injusto personal de la persona jurídica.

Por otro lado, solamente desde esta perspectiva podría comenzar a hablarse de superar los problemas de la irresponsabilidad individual organizada e irresponsabilidad estructural organizada. Aunque bien sabemos que al exigir la comprobación de un hecho delictivo por parte de una persona física (aun y cuando no haya sido individualizada o procesada) esas aspiraciones podrían quedar a un lado por ahora.

Una ventaja que también podríamos contar a favor de nuestra perspectiva, es la exigencia de encontrar una relación normativa entre el injusto personal de la empresa (defecto de organización) y la conducta de la persona física (y no solamente una imputación objetiva de resultado entre lo hecho por la persona física y su resultado), lo que debería ser acreditado por la parte acusadora en un procedimiento penal (aún y cuando esa relación normativa sea de raumento objetivo del riesgoò. Estimamos que aún y cuando un defecto de organización

\footnotetext{
583 FEIJÓo SÁNCHEZ, Bernardo, “La responsabilidad penal...”, Op. Cit., página 87, pues dice que ese modelo "resulta más restrictivo en su aplicación que los otros dos, pero si se ha tomado la decisión político-criminal de imponer penas a las personas jurídicas ello exige criterios de imputación y garantías penales equivalentes a las que nuestro ordenamiento viene exigiendo para las penas".
} 
tenga un carácter complejo ${ }^{584}$, sobre todo cuando sean procesadas empresas de gran tamaño, no debe ser esa razón suficiente para crear un sistema donde el elemento más importante de imputación a la persona jurídica sea considerado existente o presente por una presunción iuris tantum, como lo propugnan quienes ven el defecto de organización en la culpabilidad. La ubicación del defecto organizativo en el injusto personal inunda de lógica y coherencia el sistema y permite hacerlo más garantista, mientras que lo contrario vaciaría en gran medida la imputación a la persona jurídica, facilitando hasta extremos insostenibles la acusación en su contra e incluso, invirtiendo la carga de la prueba.

Si lo que gira alrededor del sistema de imputación a la persona jurídica es el defecto de organización, elemento que ha sido llamado el fundamento de la responsabilidad penal de las personas jurídicas, tomémoslo en serio y exijamos que esté presente siempre en una sentencia de condena como un elemento positivo y razonadamente justificado.

Tampoco pensamos que el defecto organizativo sea un elemento negativo: la ausencia de una organización defectuosa ${ }^{585}$. Se trata de hacer punible a las personas jurídicas porque su organización defectuosa provocó un aumento de riesgo de un bien jurídico, y por esa razón habría que demostrar la causa que dio origen a ese incremento de riesgo al bien jurídico.

En forma especial nosotros matizamos las características del sistema de responsabilidad penal de las personas jurídicas que creemos puede desarrollarse a partir del art. 31 bis CP, a partir de las siguientes afirmaciones, que pretendemos desarrollar en los siguientes epígrafes. Partiendo de los rasgos generales expuestos supra, la opción que proponemos tendría los siguientes perfiles:

584 GOMEZ TOMILLO, Manuel, Introducción..., Op. Cit., página 133.

585 Ib Idem, página 134. 
1. El art. 31 bis CP no es una norma penal que atribuye responsabilidad penal a la persona jurídica a partir de la responsabilidad penal de la física (en una lógica de subsidiaridad o solidaridad). Tampoco es una norma más de autoría y participación que multiplica los tipos penales de la parte especial dando a las personas jurídicas la capacidad de cometerlos participando en el delito de otros.

2. El art. 31 bis CP es una norma penal que constituye un delito en sí mismo, un tipo penal específico, un ñnjusto de organización empresarial defectuosaò que se atribuye a determinadas personas jurídicas cuando también concurre el presupuesto de la responsabilidad (condición objetiva de punibilidad) que es la conducta delictiva de la persona física.

3. El tipo penal de ñnjusto de organización empresarial defectuosaò amén de exigir un injusto objetivo específico, también exige un injusto subjetivo específico que no es otro que el de imprudencia. De forma tal que el art. 31 bis CP tiene una función similar al $12 \mathrm{CP}$, es decir, un numerus clausus de imprudencia pero específico para los delitos por los que debe responder la persona jurídica.

4. La imprudencia tiene referencia a la propia organización empresarial defectuosa de la persona jurídica, no a la conducta delictiva de sus miembros (administradores o representantes o los sometidos a la autoridad de éstos) ni a la lesión o puesta en peligro al bien jurídico que haya acaecido por la conducta delictiva de la persona física.

5. La persona jurídica es garante de una organización adecuada, no defectuosa (porque solo sobre ello tiene control), pero de ninguna forma puede ser garante de que las personas físicas no cometan delito (porque no tiene control alguno sobre ellas).

6. La organización empresarial defectuosa (el injusto típico) puede ser evitado con una organización adecuada. Diversos baremos auxilian a ese fin, pero poco, o tal vez nada, tienen 
que ver con este fin los programas de cumplimiento del Derecho (compliance programs), pues estos tienen qué ver más bien con la culpabilidad de la persona jurídica.

7. La culpabilidad de la persona jurídica se concibe como una cultura corporativa de incumplimiento del Derecho. Es decir, que la organización empresarial defectuosa obedezca a una cultura de incumplimiento del Derecho.

8. Los programas de compliance, por tener el contenido y límites que estableceremos, no organizan adecuadamente a la persona jurídica, sino que son expresión y proclama propias de la persona jurídica de que quiere cumplir con el Derecho y que, por tanto, no quiere en ninguna medida un defecto en su organización.

9. Por lo anterior, solamente las personas jurídicas con un nivel de complejidad determinado pueden ser sujetos activos del delito de organización empresarial defectuosa. En las pequeñas o en aquellas sin complejidad bastará el Derecho Penal individual para resolver el conflicto político criminal con suficiencia. 


\section{CAPITULO VII}

\section{EL PRESUPUESTO DE LA RESPONSABILIDAD PENAL DE LAS PERSONAS JURÍDICAS: EL HECHO DE CONEXIÓN}

Este apartado está destinado a analizar y explicar lo que para nosotros es la condición objetiva de punibilidad de la responsabilidad penal de las personas jurídicas, y no su fundamento, esto es, el r̃delitoò de la persona física competente. Es el requisito que ha sido interpretado por otros autores como el fundamento de esa responsabilidad, admitiendo una interpretación demasiado acrítica y apegada a la letra de la ley, y en consecuencia, la adscripción de un modelo de heterorresponsabilidad penal de las personas jurídicas en España.

Iniciaremos con un breve análisis de lo que la ley entiende por delito de la persona física para estar en condiciones de conocer los márgenes y límites de este hecho de conexión y resolver mejor la relación que existe entre el delito de la persona física y el de la persona jurídica. Enseguida será menester analizar las calidades de las personas que deben cometer el delito y que desatan la responsabilidad penal de la persona jurídica: administrador de hecho y de derecho, representante legal y la persona mal controlada por éstos. Luego estudiaremos el hecho de conexión y sus elementos bajo una teoría 
jurídica del delito de la persona física (su conducta, los elementos normativos, el dolo y culpa de la persona física y su culpabilidad, así como las causas de exclusión del delito, atenuantes y agravantes), y finalmente la relación que existe entre este hecho y el injusto personal de la persona jurídica.

\section{EL DELITO DE LA PERSONA FÍSICA}

El art. 31 bis 1, primer párrafo CP previene que la persona jurídica será responsable de los delitos cometidos en nombre o por cuenta de las mismas, y en su provecho, por sus representantes legales y administradores de hecho o de derecho, mientras que en su segundo párrafo establece que serán penalmente responsables de los delitos cometidos en el ejercicio de actividades sociales y por cuenta y en provecho de las mismas, por aquellos que estando sometidos a la autoridad de los primeramente nombrados, hayan realizado los hechos por no haberse ejercido el debido control. Por lo tanto, se hace menester desentrañar el concepto y alcance de delito del que habla la ley.

La cuestión resulta ser si por delito debemos entender el concepto estricto del mismo, es decir, una conducta típica, antijurídica y culpable (y punible).

Que r̃delitoòdel art. 31 bis CP es la conducta típica, antijurídica, culpable y punible, es una perspectiva que podría ser adecuada si consideramos que el art. 52.4 CP, que proporciona los elementos que se deben tomar en cuenta al momento de cuantificar la sanción de la multa a la persona jurídica, y en los casos en los que no es posible imponerla en proporción al beneficio obtenido o facilitado, al perjuicio causado, al valor del objeto, 0 a la cantidad defraudada 0 indebidamente obtenida, obliga al Juez a calcular la multa en base a la pena de la persona física. Debe entonces sustituir la base de cálculo 
que le da el art. 51.3 CP por: a) Multa de dos a cinco años, si el delito cometido por la persona física tiene prevista una pena de prisión de más de cinco años. b) Multa de uno a tres años, si el delito cometido por la persona física tiene prevista una pena de prisión de más de dos años no incluida en el inciso anterior. c) Multa de seis meses a dos años, en el resto de los casos. Lo mismo habría qué decir de lo previsto por el art. 66 bis $2 \mathrm{CP}$, que hace depender el máximo de la duración específica de las penas previstas en las letras c) a g) del apartado 7 del art. $33 \mathrm{CP}$ al máximo de la pena privativa de libertad prevista para el caso de que el delito fuera cometido por persona física.

No obstante, contra la perspectiva anterior podría alegarse que no es necesario que a la persona física se le imponga la pena, pues la ley (art. 52.4 CP) no establece un parangón de la pena impuesta, sino simplemente de los límites específicos de punibilidad que correspondería imponer a la persona física en caso de que fuese imputada por delitos que mereciesen cierta cantidad de pena de prisión, por un lado, y por otro, que el art. 31 bis 2 CP no exige (o mejor, prevé que es innecesario) que la persona física que cometió el delito haya sido concretamente individualizada o no haya sido posible dirigir el procedimiento contra ella. En nuestra opinión, no es la punibilidad el límite que define el delito de la persona física.

Tampoco sería de recibo la tesis que coloca el límite en la culpabilidad de la persona física, merced a que una interpretación armónica y no aislada daría lugar a que no es necesaria esa categoría del delito para satisfacer este primer elemento del art. 31 bis $1 \mathrm{CP}$. El apartado 3 del mismo art. 31 bis CP desvincula las circunstancias que afecten a la culpabilidad del acusado o agraven su responsabilidad, o el hecho de que dichas personas hayan fallecido o se hubieren sustraído de la acción de la justicia a la culpabilidad de la persona jurídica, amén de que en el apartado 4 se mencionan circunstancias atenuantes exclusivas de la responsabilidad penal de las personas jurídicas. En consecuencia, las causas de inculpabilidad contenidas en el art. 20, 1丷, 


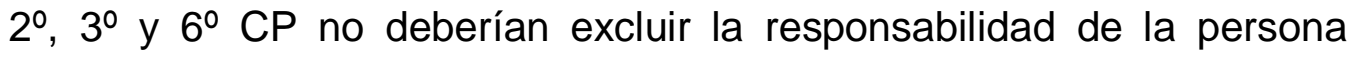
jurídica a pesar de que concurrieren en la persona jurídica (que no sabemos de qué manera pudieran concurrir, por ejemplo, un miedo insuperable o una alteración grave de la conciencia), pero sí la podría excluir alguna causa de justificación ${ }^{586}$ : ñn primer límite a la responsabilidad de la persona jurídica sería, por tanto, que no se pueda constatar que una persona física haya cometido una conducta típica o que, habiendo existido una conducta típica, ésta se encuentre amparado por una causa de justificación ${ }^{587}$.

Aparentemente esta opción sería la que reconoce el $\mathrm{CP}$, sobre todo si tomamos en cuenta que en el Proyecto de enero de 2007 la propuesta legislativa era que la concurrencia, en las personas que materialmente hayan realizado los hechos o en las que los hubiesen hecho posibles por no haber ejercido el debido control, de circunstancias eximentes de la responsabilidad penal 0 de circunstancias que la atenúen o agraven no excluirá ni modificará la responsabilidad penal de las personas jurídicas, pero precisamente el término circunstancias eximentes, que fue criticado ${ }^{588}$, fue cambiado por circunstancias que afecten la culpabilidad. Por lo que puede significar que el legislador siguió un modelo de accesoriedad limitada ${ }^{589}$.

Tenemos, no obstante, otras perspectivas. A partir de la concepción de delito que previene nuestro Código Penal se podría también construir una respuesta a este respecto. Son delitos o faltas las

586 De este pensamiento es BACIGALUPO S., Silvina, "La responsabilidad...", $O p$. Cit., página 6; DÍAZ GÓMEZ, Andrés, "La responsabilidad criminal...", Op. Cit., página 46; FEIJÓo SÁNCHEZ, Bernardo, "La responsabilidad...", Op. Cit., página 91; MUÑOZ CONDE, Francisco, y GARCÍA ARÁN, Mercedes, Derecho Penal. Parte General, Op. Cit., página 632.

${ }^{587}$ FEIJÓO SÁNCHEZ, Bernardo, “La responsabilidad penal...”, Op. Cit., página 91.

${ }^{588}$ Fue criticado por el Informe del Consejo Fiscal de 4 de febrero de 2009 (página 8 y 9), por el Informe del Consejo general del Poder Judicial de noviembre de 2006 (página 22 y 23). Vid. también críticas de MORALES PRATS, Fermín, "La responsabilidad penal de las personas jurídicas", en Estudios de derecho judicial, Número 155, 2009, página 402.

589 MIR PUIG, Santiago, Op. Cit., 2011, página 208, aunque a renglón siguiente señala que también excluyen la responsabilidad penal de la persona jurídica el indulto, la prescripción del delito o de la pena. 
acciones y omisiones dolosas o imprudentes penadas por la Ley, reza el art. $10 \mathrm{CP}$, por lo que bastaría que el delito de la persona física sea solamente una conducta típica (objetiva y subjetiva). De este tenor es el pensamiento de Zugaldía $^{590}$ quien estima que la persona jurídica responderá dolosa o imprudentemente r̃según el conocimiento (dolo) o desconocimiento evitable (imprudencia) de quien realiza el hecho de referenciaò Es más, considera que si el delito a imputar exige necesariamente el dolo (porque no está en el catálogo del art. $12 \mathrm{CP}$ como de comisión posible imprudente) la persona física deberá cometer el delito de forma dolosa para poder considerar que la persona jurídica también cometió dicho delito, de otra forma la persona jurídica deberá quedar impune, r̃on ello se evita tratar a la persona jurídica peor que a la persona físicaơ ${ }^{51}$.

Las posiciones anteriores son aceptables y constituyen opciones de interpretación muy posibles. Sin embargo, la intención es obtener todo el provecho que nos pueda dar una interpretación también conforme a derecho pero que represente ventajas político criminales superiores, para hacer del sistema de responsabilidad penal de personas jurídicas algo más funcional y eficiente.

Lo que pretendemos es disminuir a límites irreductibles la necesidad de la persona física en el sistema con el objetivo de dejarle menor espacio de operación a aquel fenómeno social del que se dolía la doctrina y que fue uno de los más importantes motivos para exigir cambios legales. Me refiero a la irresponsabilidad estructural organizada (Vid. supra, capítulo II.1.1.3.). Ciertamente que en el sistema que eligió el legislador le ha dado una importancia fundamental a la persona física, de hecho, el delito de la persona física (ya como

\footnotetext{
590 ZUGALDÍA ESPINAR, José Miguel, La responsabilidad criminal de los entes..., Op. Cit., página 47 y 53.

591 Ib Ídem, página 53. Entiendo que el autor exige del delito de la persona física la vertiente objetiva y la subjetiva, no obstante que anteriormente había adoptado una tesis de accesoriedad mínima "solo se requiere que el hecho de referencia realice la vertiente objetiva de un tipo penal", Vid. La responsabilidad penal de empresas, fundaciones y asociaciones, Op. Cit., 2008, página 145.
} 
administrador o representante legal, o como persona indebidamente controlada por éstos) es la única puerta de entrada a la responsabilidad penal de la persona jurídica. Por ello, mientras más requiramos de ella y de su t̂echo de conexiónòmenos eficiencia tendremos al momento de llevar a cabo la práctica del sistema.

Como lo hemos señalado, la descentralización de las funciones de decisión, información y operación, la creación de competencias y roles dentro de una empresa, el olvido de la fábrica f̂́rdistaò y la inauguración, desde hace muchos años ya, de desterritorialización de la empresa, el flujo rápido de la información, la creación de tecnologías, entre muchas otras cosas, impide en ocasiones imputar un delito a una o varias personas físicas porque en ninguna de ellas se cumple íntegro el injusto objetivo y subjetivo completo, es decir, a diferencia de lo que ocurre en el delito tradicional, en un esquema empresarial no serían raros los casos en que el dolo o la imprudencia no concurrieran en la persona que cometió el injusto objetivo ${ }^{592}$ (Vid. supra IV.5.4).

Si por delito de la persona física exigimos una conducta típica y antijurídica, o incluso, una conducta típica (incluyendo el injusto subjetivo ï dolo o imprudencia), entonces dotaríamos al sistema de un universo más o menos importante de casos en los que sería imposible incriminar a dicha persona física y por consiguiente, tampoco a la persona jurídica.

592 Esto fue lo que determinó al parlamento inglés a la configuración y puesta en marcha del Manslaugther act 2007, pues la prueba del derecho común para determinar responsabilidades penales en una empresa sólo se planteaba cuando por negligencia grave de una persona que ha llevado a la muerte de otra persona y (en la "doctrina de la identificación") esa persona es una "mente controladora", cuyas acciones e intenciones puede ser atribuida a la empresa (es decir, una persona en control de los asuntos de la compañía en un grado suficiente como para decir que esa empresa piensa y actúa a través de él). Pero a menudo no hay una sola persona que actúa como una "mente controladora", sobre todo en las grandes empresas, y muchos problemas de salud y seguridad se delegan a los gerentes junior que no son "las mentes de control". Esto hizo que absolvieran a la empresa del Herald of Free Enterprise por la muerte de 193 personas el 6 de marzo de 1987, así como que absolvieran a cualquier persona física implicada en tales sucesos. 
La cuestión se sitúa en dos opciones: Un injusto simplemente objetivo o un injusto objetivo y subjetivo.

A tono con lo anterior, Gómez Tomillo ${ }^{593}$ señala que por delito habrá de entenderse ñun hecho objetivamente típicoò Bastará entonces una acción objetivamente típica de la persona física, sin ser necesario que se demuestre el dolo o la imprudencia del mismo, porque sería intrascendente para la responsabilidad penal de las personas jurídicas.

Ahora bien, ¿de qué forma se puede afirmar el dolo o la imprudencia de la persona jurídica, si es intrascendente el dolo o imprudencia de la persona física en la comisión del hecho de conexión? Como lo señalamos, las tesis que identifican el injusto personal de la física con el de la jurídica incluyen el dolo o la imprudencia en esa identificación, de suerte que es de trascendental importancia su demostración, pero esa concepción pugna con su misma conclusión de que ambas responsabilidades son independientes y autónomas, conclusión a la que llegan con la interpretación de los apartados 2 y 3 del art. 31 bis CP.

Nosotros creemos que es posible darle contenido y funcionalidad a dichos apartados ( 2 y 3 del art. 31 bis CP) y llevarlos hasta donde nos permita una interpretación legítima pero lo más eficiente en términos de política criminal. En consecuencia, si ambas responsabilidades son diferentes, autónomas e independientes, el dolo - la imprudencia de la persona jurídica no se identificarán ni dependerán del dolo o imprudencia de la física, de lo que obtenemos que podemos encontrar casos en los que la persona física comete el hecho sin dolo ni imprudencia, pero la persona jurídica puede ser reo de un delito doloso si su organización defectuosa fue dolosa, o viceversa. De esta suerte y de forma inicial nos sumamos a la tesis de Gómez Tomillo. Pero todavía hay un problema más.

593 Op. Cit., página 59. 
Lo que nos impide admitir acríticamente que delito del art. 31 bis CP es una conducta típicamente objetiva es que en el catálogo de delitos por los que debe responder la persona jurídica existen delitos que tienen el fundamento de su punibilidad no solamente en la parte objetiva del injusto, sino también en la parte subjetiva. Se trata de esos delitos o tipos penales incongruentes por exceso subjetivo ${ }^{594}$ o tipos penales con elementos subjetivos especiales ${ }^{595}$, cuya norma penal prohíbe la realización de determinada conducta exterior pero con determinado sentido de la voluntad, de ahí que sin éste (el específico sentido de la voluntad) la conducta podría ser inocua. Pensemos en los delitos de trata de seres humanos del art. 177 bis CP que exige del sujeto activo del delito no solamente captar, transportar, trasladar, acoger, recibir o alojar a la víctima empleando violencia, intimidación, engaño o abuso de su situación de superioridad o de necesidad o vulnerabilidad de la víctima, sino también finalidades específicas (por ejemplo, la imposición de trabajo o servicios forzados, la esclavitud o prácticas similares a la esclavitud o a la servidumbre, explotación sexual o la servidumbre); o en el delito de corrupción en las transacciones comerciales internacionales del art. $445 \mathrm{CP}$ cuya norma, amén de prohibir corromper o intentar corromper a funcionarios públicos extranjeros, exigen también que esa conducta sea con el fin de que actúen o se abstengan de actuar en relación con el ejercicio de funciones públicas.

En estos casos no es suficiente la comprobación de un comportamiento simplemente objetivo de la persona física, y en consecuencia, la conducta de trasladar a un extranjero a este país (alguna compañía de trasporte público de personas vía terrestre) sería inocua (o incluso, necesaria y favorable para la economía del país) si no tiene alguna de esas finalidades específicas que constituyen también la materia de la prohibición de la norma penal. En estos casos debe ser

594 MIR PUIG, Santiago, Derecho Penal. Parte General, 2011, Op. Cit., páginas 236 y 237; y GIL GIL, Alicia, Op. Cit., páginas 183 y 184.

595 BERDUGO GÓMEZ DE LA TORRES, Op. Cit., página 267 y 268; LOPEZ BARJA DE QUIROGA, Op. Cit., páginas 497 y 498. 
exigido de la persona física el injusto penal objetivo y subjetivo para efecto de constituir la condición objetiva de punibilidad que daría lugar a la responsabilidad de la persona jurídica, si se verifica en ella su delito propio.

En cambio, en otros delitos, como por ejemplo el relativo a sustancias que pueden causar estragos del art. $348 \mathrm{CP}$ o el delito contra los recursos naturales y medio ambiente del art. 327 y $328 \mathrm{CP}$, que no exigen elementos subjetivos especiales, podría ser suficiente el injusto objetivo para constituir la condición objetiva de punibilidad que daría lugar a la responsabilidad del ente colectivo.

De esa manera salvamos a límites irreductibles, pero legitimables, el escollo u obstáculo de la irresponsabilidad estructural organizada.

\section{LOS SUJETOS ACTIVOS COMPETENTES}

En los términos del art. 31 bis 1, primer párrafo, CP las personas físicas que desatan y realizan el hecho de conexión son los administradores de hecho y de derecho y los representantes legales, mientras que en el segundo párrafo se les atribuye una importante función en el hecho de conexión pues deben haber sometido bajo su autoridad y no haber ejercido el debido control sobre las personas físicas que cometieron dicho hecho de conexión.

La delimitación de estos conceptos, de forma estricta 0 extensiva y amplia, es de gran importancia porque siendo el hecho de conexión de la persona física la puerta de entrada a la responsabilidad penal de la persona jurídica, y dependiendo de esa interpretación la puerta de entrada rácabará siendo un portón o un ojo de agujaơ ${ }^{596}$.

596 FEIJÓO SÁNCHEZ, Bernardo, “La responsabilidad penal...”, Op. Cit., página 93. 


\subsection{Administrador de hecho y de derecho}

El concepto de administrador de derecho debe venir dado principalmente, aunque no solamente, por la legislación mercanti ${ }^{597}$ merced a que se trata de un término formal. Desde este mismo punto de vista sería aquel que hubiese sido nombrado por la Junta General, y enseguida formalmente aceptado, inscrito y publicado su nombramiento, como en el caso del administrador de una sociedad anónima según el arts. 123 y 125 de la Ley de Sociedades Anónimas $^{598}$. Tendría las funciones de ejecutar las decisiones de la Junta General (o Consejo de Administración), y entre ellas, las decisiones diarias para el correcto funcionamiento de la empresa o sociedad ${ }^{599}$. El concepto no tiene que ser exactamente como ha sido interpretado en los tópicos de los delitos societarios y el actuar en nombre de otro del art. $31 \mathrm{CP}^{600}$, aunque es claro que deberían aprovecharse de lo que se ha desarrollado ahíi ${ }^{601}$.

Se ha suscitado la importante discusión en la doctrina de si es posible que otra persona jurídica, que sea administradora formal de la persona jurídica responsable, pudiese significar un presupuesto de responsabilidad válido tal y como lo es en el caso de la persona física. Quienes dan una respuesta negativa ${ }^{602}$ aseguran que como la ley señala r̃erróneamente, de forma expresa, que los administradores y representantes legales son siempre personas físicasò entonces

597 BACIGALUPO S., Silvina, "La responsabilidad...", Op. Cit., página 5; FEIJóo SÁNCHEZ, Bernardo, "La responsabilidad penal...", Op. Cit., página 93; GOMEZ TOMILLO, Manuel, Introducción..., Op. Cit., página 71; ZUGALDÍA ESPINAR, José Miguel, La responsabilidad criminal de los entes..., Op. Cit., página 45.

598 DEL ROSAL BLASCO, Bernardo, "La delimitación típica de los llamados hechos de conexión...", Op. Cit., página 58.

599 GOMEZ TOMILLO, Manuel, Introducción..., Op. Cit., página 71, y ZUGALDÍA ESPINAR, José Miguel, La responsabilidad criminal de los entes..., Op. Cit., página 45.

600 QUINTERO OLIVARES, Gonzalo, "Artículo 31 bis", en QUINTERO OLIVARES, G. (Dir.), MORALES PRATS, F. (Coord.), Comentarios al Código Penal Español, Thomson Reuters, Navarra, 2011, página 379 y 380.

601 FEIJÓO SÁNCHEZ, Bernardo, “La responsabilidad penal...”, Op. Cit., página 93.

602 GONZÁLEZ-CUELLAR SERRANO, Nicolás, y JUANES PECES, Ángel, "La responsabilidad penal de las personas jurídicas...", Op. Cit., página 8. 
conforme al principio de legalidad penal es imposible imponer sanciones a personas jurídicas por el delito de otra persona jurídica que la administra, desconociendo la ley la lógica ren un mercado dominado por holdings empresarialesơ ${ }^{603}$. Sin embargo, voces autorizadas aseguran que sí es posible porque también en este caso la persona jurídica administradora está compuesta de personas físicas ${ }^{604}$ y la persona jurídica no será administradora hasta que no conste la identidad de la persona física designada para el ejercicio de los deberes de administración, como está previsto en el art. 143, RD 1784/1996, de 19 de julio ${ }^{605}$.

Pensamos que ambas posturas tienen razón si de lo que se trata es considerar que en tal caso no es la persona jurídica administradora la que da lugar al hecho de conexión de los párrafos $1^{\circ} \mathrm{y}$ $2^{\circ}$ del art. 31 bis $1 \mathrm{CP}$, sino la persona física designada por la persona jurídica administradora. Ahora bien, esta persona física designada para administrar a la persona jurídica responsable (que no es la administradora, sino la administrada) podrá ser considerada como administradora de la administrada, y si comete un hecho objetivamente típico por cuenta, en nombre y en provecho de la persona jurídica administrada, entonces dará lugar a la responsabilidad penal de la persona jurídica si ésta comete el injusto propio de administración defectuosa ${ }^{606}$.

Más difícil de delimitar es el administrador de hecho.

Ya la doctrina había admitido una concepción funcional del administrador de hecho como aquel que tiene rel dominio que los sujetos activos ejercen sobre la concreta estructura social en la que el bien jurídico se halla necesitado de protección y el Derecho penal, a

${ }^{603} \mathrm{Ib}$ Ídem.

${ }^{604}$ ZUGALDÍA ESPINAR, José Miguel, La responsabilidad criminal de los entes..., Op. Cit., página 45.

605 BACIGALUPO S., Silvina, “La responsabilidad ...”, Op. Cit., página 6.

606 Entiendo que en el mismo sentido FEIJÓO SÁNCHEZ, Bernardo, "La responsabilidad penal...", Op. Cit., página 97. 
través de semejantes tipos, protege ${ }^{607}$. Es decir, son personas que tienen un real poder de decisión y conducción dentro de la empresa pero que además tienen, con esa capacidad o poder, de lesionar o poner en peligro bienes jurídicos.

El Tribunal Supremo concibe al administrador de hecho a aquella que sin ostentar ñormalmente la condición de administrador de la sociedad, ejerza poderes de decisión de la sociedad y concretando en él los poderes de un administrador de derechoé es la persona que, en realidad manda en la empresa, ejerciendo los actos de administración, de obligación de la empresa, aunque formalmente sean realizadas por otra persona que figura como su administrador $0^{608}$.

Cabe destacar que en estas concepciones cabrían aquellos personajes de la alta dirección que no son administradores generales (como los directores generales o gerentes generales) o aquellos que tienen poder amplio y suficiente (y con regulares y laxos niveles de supervisión de sus superiores) sobre sectores de la empresa, como serían los directores o gerentes de divisiones o regionales, o incluso, directores o gerentes generales de ciertas áreas de una empresa (por ejemplo, de compras y adquisiciones) que se manejan con gran independencia y autonomía de la administración general ${ }^{609}$. El criterio para separar a los subordinados del administrador de derecho (que daría lugar, posiblemente, a la hipótesis del 31 bis 1, 2ํárrafo, CP) es

607 DEL ROSAL BLASCO, Bernardo, "La delimitación típica de los llamados hechos de conexión...", Op. Cit., página 58.

608 STS 59/2007, de 26 de enero, de la Sala de lo Penal.

${ }^{609}$ De la misma manera se pronuncian GOMEZ TOMILLO, Manuel, Introducción..., Op. Cit., página 72 y 73, y ZUGALDÍA ESPINAR, José Miguel, La responsabilidad criminal de los entes..., Op. Cit., página 46. En contra de este criterio DOPICO GÓMEZ-ALLER, Jacobo, "Responsabilidad de las personas jurídicas", Op. Cit., página 17, "deben rechazarse interpretaciones que busquen introducir en el concepto de "administrador de hecho" a mandos intermedios o sujetos con cierta capacidad de decisión autónoma, pero supeditada a la dirección, supervisión o control del administrador de hecho, pues un subordinado del administrador de derecho no es un administrador de hecho... o los que están subordinados al administrador de derecho como los jefes de obra, encargados del servicio, directores de subdivisiones, directores de zona o locales, etc."; FEIJóo SÁNCHEZ, Bernardo, "La responsabilidad penal...", Op. Cit., página 95; y MIR PUIG, Santiago, Derecho Penal. Parte General. Op. Cit., página 205. 
el importante grado de autonomía e independencia con que actúan y resuelven los problemas del sector que tienen a su cargo de forma cotidiana. $Y$ es que no se puede negar que son ellos quienes dirigen y gobiernan, y con su poder de dirección sin suficiente supervisión y capacidad tienen la posibilidad de poner en peligro el bien jurídico. En ese sentido la reciente STS que al restringir el concepto de administrador de hecho, expone criterios definidos para poder considerar a esos m̃mandos mediosò como tales, pues los incluye siempre que su actuación se desenvuelva ren condiciones de autonomía o independencia y de manera duradera en el tiempoơ ${ }^{10}$.

\subsection{Representante legal}

Desde el punto de vista mercantil, se trata de aquella persona física o personas físicas que pueden vincular a la persona jurídica de forma contractual para con terceros, esto es, las personas que ejercen la representación de la persona jurídica en los actos comprendidos en su objeto social, según los arts. 128 y 129 de la Ley de Sociedades Anónimas y 233 y 234 de la Ley de Sociedades de Capital (RD Leg. 1/2010).

Del Rosal Blasco hace una matización al respecto, y señala que la ley se refiere a los representantes voluntarios no orgánicos de los entes corporativos ${ }^{611}$, analizando que no están incluidos los administradores de derecho en este concepto porque expresamente la ley también los señala, no obstante que éstos son representantes legales orgánicos de las sociedades. Por lo que incluye en el concepto de representante legal a los empleados de la persona jurídica que participan de su actividad exterior y que řsin necesidad de un acto de apoderamiento tienen las facultades representativas propias que les

${ }^{610}$ STS 606/2010, de 2de junio. En igual sentido, GOMEZ JARA-DIEZ, Carlos, La responsabilidad penal de las personas jurídicas, Op. Cit., página 70.

611 DEL ROSAL BLASCO, Bernardo, "La delimitación típica de los llamados hechos de conexión...”, Op. Cit., página 63. 
permiten realizar, en nombre y por cuenta de la empresa, actos jurídicos integrantes del giro o tráfico de la mismaơ ${ }^{12}$.

No obstante, creemos que los empleados de la persona jurídica con facultades para obligarla, como por ejemplo, un gerente de sucursal bancaria o directores, no deberían de considerarse representantes legales, Como dice Feijoo ${ }^{613}$ la referencia al r̃epresentante legalòtiene el fin de abarcar a cualquiera que tenga la función de representar o gestionar en favor de la sociedad aún y cuando no reciban el nombre de administradores de derecho ${ }^{614}$, a lo que se abona que en el Anteproyecto de Gobierno enviado a las Cortes se incluía en la redacción a ños empleados con facultades de obligar a dicha persona jurídicaò lo que fue criticado por alguna parte de la doctrina y suprimido finalmente ${ }^{615}$.

\subsection{Los sometidos a la autoridad de los anteriores}

Son las personas físicas que en el ejercicio de actividades sociales y por cuenta y en provecho de las personas jurídicas, y sometidos a la autoridad de los dos anteriores (administradores de hecho y de derecho y representantes legales), cometen el delito por no haberse ejercido sobre ellos el debido control atendidas las circunstancias del caso.

A prima facie podría pensarse que se trata del resto de las personas que laboran para la persona jurídica, es decir, aquellos que no son administradores de hecho o derecho o representantes legales: operarios, trabajadores, mandos medios o inferiores sin autonomía e independencia suficiente, o cualquier persona que no tenga capacidad de decisión dentro de la empresa, sin embargo, esto no es absoluto.

\footnotetext{
612 Ib Ídem, página 64.

613 FEIJÓO SÁNCHEZ, Bernardo, “La responsabilidad penal...”, Op. Cit., página 95.

${ }^{614}$ Así también, GOMEZ TOMILLO, Manuel, Introducción..., Op. Cit., página 77.

615 FEIJOO SÁNCHEZ, Ib Ídem.
} 
En principio, problemas varios podrían surgir ante la cuestión de si los mandos medios con capacidad de decisión y con una autonomía o independencia suficiente son o no administradores de hecho, como lo hemos concluido en párrafos arriba. Lo anterior es así, puesto que si son considerados verdaderos administradores de hecho bastará con que cometan el delito por cuenta o en nombre y en provecho de la persona jurídica, ubicando la hipótesis normativa a aplicar en el primer párrafo del 31 bis $1 \mathrm{CP}$; pero si no es así, y ubicamos la hipótesis normativa en el segundo párrafo, entonces tendríamos que exigir, adicionalmente, que hayan cometido el delito por no haberse ejercido sobre ellos el debido control.

Por otro lado, no queda clara todavía la definición del universo de personas que se encuentran en la expresión por quienes, estando sometidos a la autoridad de las personas físicas mencionadas en el párrafo anterior. Estar sometido a la autoridad de administradores de hecho y derecho o representantes legales da la idea de un sometimiento inmediato, cercano, casi físico, es decir, aquellas personas físicas que se ubican en el escalafón de la persona jurídica inmediatamente a las órdenes de los directivos de la misma. Sin embargo, hay acuerdo en la doctrina de que se trataría de cualquier trabajador de la empresa, que no tenga poder de decisión dentro de ella o de un sector con suficiente autonomía, y basta que tenga un contrato laboral ${ }^{616}$.

Se discute, así mismo, si debe tratarse de toda persona que tenga una relación laboral formal con la persona jurídica o, por el

616 DOPICO GÓMEZ-ALLER, Jacobo, "Responsabilidad de las personas jurídicas”, Op. Cit., página 17; FEIJÓO SÁNCHEZ, Bernardo, "La responsabilidad penal...", Op. Cit., página 100; GOMEZ TOMILlO, Manuel, Introducción..., Op. Cit., página 78; GONZÁLEZ-CUELLAR SERRANO, Nicolás, y JUANES PECES, Ángel, "La responsabilidad penal de las personas jurídicas...", Op. Cit., página 10; ZUGALDÍA ESPINAR, José Miguel, La responsabilidad criminal de los entes..., Op. Cit., página 46. Entiendo que en contra de lo anterior, MIR PUIG, Santiago, Op. Cit., 2011, página 206 y GOMEZ MARÍN, V., "Artículo 31 bis CP", Op. Cit., página 133, que estiman que solamente serán aquellos que operen en el "ámbito de dirección de los representantes legales o los administradores. 
contrario, si deben incluirse en esta categoría cualquier persona que materialmente se encuentre bajo la línea de dirección formal de los administradores y representantes legales, y que pueden no tener contrato laboral con la empresa, incluyendo empleados de otras empresas o simples proveedores externos o quienes tengan contratos de prestación de servicios. Quien piensa que se deben circunscribir a los trabajadores formales centran su razón en el concepto formal de persona jurídica como sujeto activo del delito amén de que las personas subordinadas deben actuar en ejercicio de actividades sociales y por cuenta de la persona jurídica ${ }^{617}$; empero la doctrina mayoritaria, a la que nos sumamos, se decanta por extender el concepto a cualquier persona que se encuentra bajo la influencia o dirección material de los administradores o representantes legales siempre y cuando desarrollen su actividad para y en favor de las actividades de la empresa y en su ámbito de dominio social ${ }^{618}$. Es así porque si hemos generado un concepto de administrador de hecho desde puntos de vista materiales, específicamente penales, con el fin de evitar lagunas de punibilidad, entonces creo que deberíamos hacer lo mismo que este concepto de personas sometidas a la autoridad de los representantes y administradores, r̃de no ser así, las personas jurídicas podrían soslayar toda responsabilidad penal eludiendo la contratación laboral y subcontratando trabajadores ${ }^{619}$, como es el outsourcing.

617 FEIJÓO SÁNCHEZ, Bernardo, “La responsabilidad penal...”, Op. Cit., página 101. 618 Vid. DOPICO GÓMEZ-ALLER, Jacobo, "Responsabilidad de las personas jurídicas", Op. Cit., página 19, dice "ello podría ocurrir en el caso de los autónomos que operan integrados temporalmente en el ámbito de dominio social de la persona jurídica, o en el de subcontratas (donde ha sido objeto de específica regulación sectorial, como ha ocurrido en el sector de la construcción mediante la L 32/2006)". De la misma manera, GOMEZ TOMILLO, Manuel, Introducción..., Op. Cit., página 79 y 80; ZUGALDÍA ESPINAR, José Miguel, La responsabilidad criminal de los entes..., Op. Cit., página 46.

619 DOPICO GÓMEZ-ALLER, Jacobo, "Responsabilidad de las personas jurídicas", Op. Cit., página 20. 


\section{EL INJUSTO DE LA PERSONA FÍSICA}

\subsection{La conducta de la persona física}

El r̃delitoò de los administradores, representantes legales o las personas sometidos a ellos, como ya lo hemos expuesto, será lo que fundamente la materia de la prohibición, generalmente el injusto objetivo, y en los delitos incongruentes por exceso subjetivo, la vertiente subjetiva deberá ser incluida, de la persona física, sin que sea exigible la demostración del dolo o la imprudencia de ella (en el caso de los primeros) en virtud de que esos elementos subjetivos no son necesarios porque de ninguna manera se le transfieren a la persona jurídica. El injusto objetivo tampoco le es transferido a la persona jurídica pues ella será responsable de su propio injusto, pero en cambio si es necesario porque así lo exige el art. 31 bis CP.

La persona física debe de realizar aquellos tipos penales que expresamente están formulados en el CP como susceptibles de ser cometidos por las personas jurídicas, según lo disponen las primeras palabras del art. 31 bis $1 \mathrm{CP}$ ón los supuestos previstos en este Código, las personas jurídicas serán penalmente responsables de los delitos cometidosë por sus representantes legales y administradores de hecho y de derechoô y r̃en los mismos supuestosë ôque previene el segundo párrafo del mismo. Además de las circunstancias normativas específicas que se exigen para que esa conducta sea el presupuesto de la responsabilidad penal de la persona jurídica (en nombre, por cuenta, en ejercicio de las actividades sociales, en provecho), los elementos típicos propios de cada tipo penal deberán ser presupuestos de esa responsabilidad.

Lo primero que habría de verificar será en cuáles supuestos previstos en el CP, que es el numerus clausus que se ha impuesto. 
Todos están de acuerdo que los delitos que pueden ser cometidos por las personas jurídicas son los siguientes:

Tráfico ilegal de órganos humanos (156 bis); trata de seres humanos (177 bis); prostitución y corrupción de menores (189 bis); descubrimiento y revelación de secretos (197); estafa (251 bis); insolvencias punibles (261 bis); daños 288); lavado de dinero (302); delitos contra la hacienda Pública y la Seguridad Social (310bis); delitos contra los derechos de los ciudadanos extranjeros (318 bis); delitos urbanísticos (319); delitos contra los recursos naturales y medio ambiente (327 y 328); delitos relativos a la energía nuclear y las radiaciones ionizantes (343); delitos relativos a las sustancias que pueden causar estragos (348); delitos contra la salud pública (369 bis); falsificación de tarjetas y cheques (399 bis); cohecho (427); tráfico de influencias (430); corrupción de funcionarios públicos extranjeros e internacionales (445) y terrorismo (570 quáter y 576 bis).

En seguida tendríamos que verificar de qué manera puede r̃cometer delitoò el administrador y representante legal para efecto de que ese delito sea el presupuesto de la responsabilidad penal de las personas jurídicas, y en qué supuestos ese delito provendría no del administrador o representante legal, sino de la persona física sometida a la autoridad de aquellos.

\subsubsection{La acción y la omisión de los administradores y} representantes legales, y de los sometidos a su control

Según el art. 31 bis 1, primer párrafo $\mathrm{CP}$ el delito lo deben cometer directamente los administradores de hecho o de derecho o los representantes legales de la persona jurídica. Es claro que dichas personas físicas solamente podrían ser responsables de los delitos en los términos de los arts. $28 \mathrm{CP}$, es decir, como autores directos, autores indirectos o mediatos, coautores, inductores o cómplices. El asunto será 
zanjado en definitiva si la persona que comete el delito por sí es el propio directivo, pues no habría ningún problema en asignarle la calidad de autor inmediato y material del delito cometido.

Sin embargo, no es tan claro cuál sería el título bajo el cual deberá responder el directivo en los casos en que no es él quien realiza de forma personal y directa el hecho delictivo, sino a través de un empleado o de otra persona dentro o fuera de la misma organización empresarial, considerando la complejidad de las empresas grandes y la descentralización de las funciones de información, operación y decisión, a lo que se suman los problemas de imputación en delitos especiales.

Aproximados al problema, iniciaremos por decir que el administrador o representante pueden ser autores o partícipes de los delitos que son el presupuesto de responsabilidad de las personas jurídicas. Sean autores o sean cómplices o inductores, será ese el título del presupuesto de responsabilidad para el ente colectivo. Por ejemplo, si el administrador de derecho de una sociedad anónima es reo del delito a la ordenación del territorio y urbanismo del art. $319 \mathrm{CP}$, como cómplice, por haber facilitado a otra persona, a urbanizar y construir en predios con valor ecológico, y por tanto, no urbanizable, daría lugar al presupuesto de imputación para la responsabilidad penal de esa sociedad anónima (y sería responsable dicha empresa si se demuestran el injusto y culpabilidad propios de la persona jurídica); y en esa medida, la responsabilidad penal de la persona jurídica como responsable del injusto del art. 31 bis $\mathrm{CP}$ en razón de haber aumentado el riesgo de la conducta delictiva de la persona física como cómplice del delito del art. 319 CP, dependería de la existencia y comprobación del injusto (conducta típica y antijurídica) del autor material y de la conducta objetivamente típica de su propio administrador, que es el cómplice.

Por ello se vuelve interesante conocer bajo qué título de participación podría considerarse al administrador o representante legal, y qué criterios habría de aplicarse para resolver el problema. No es de 
nuestro interés desarrollar el tema en toda su extensión ${ }^{620}$, que significaría varias veces el tamaño de este trabajo, sino simplemente hacer una breve introducción al tema con el fin de mostrar la importancia del mismo.

En los casos en que el administrador o representante legal se sirvan de otra persona como simple instrumento, no habría problema en asignarle la categoría de autor mediato o en los términos del art. 28 CP. El problema puede surgir cuando el administrador o representante legal, sin cometer el delito de forma personal y directa, si lo hace a través de otras personas que son instrumentos dolosos e igualmente responsables. Algunos autores, siguiendo la tesis que Schüneman inauguró en 1979 consideran que el expediente debe resolverse con la figura de la coautoría en razón de que el administrador o representante legal tendrían la posición de garante ${ }^{621}$, y por lo tanto ñlega a poseer un control tan intenso sobre el hecho por su contribución activa adicional que sus aportaciones, aisladamente calificables de inducción y participación omisiva, unidas sólo puede abarcarse adecuadamente por la pena de la coautoríaò

Junto a esta propuesta, es considerable aquella otra que estima que debe considerarse la empresa de forma similar a un aparato

620 El desarrollo de este tema se encuentra en importantes monografías y artículos, como MARÍN DE ESPINOZA CEBALLOS, Elena Blanca, Criminalidad de empresa: la responsabilidad penal en las estructuras jerárquicamente organizadas, Valencia, 2002; MUÑOZ CONDE, Francisco, "Problemas de autoría y participación en el derecho penal económico, o ¿cómo imputar a título de autores a las personas que sin realizar acciones ejecutivas, deciden la realización de un delito en el ámbito de la delincuencia económica?", en Revista Penal, Número 9, 2002; NUÑEZ CASTAÑO, E., Responsabilidad penal en la empresa, Valencia, 2000; SCHÜNEMANN, Bernd, "Responsabilidad penal en el marco de la empresa. Dificultades relativas a la individualización de la imputación", en Anuario de Derecho Penal y Ciencias Penales, Vol. LV, 2002; ROXIN, Claus, Autoría y dominio del hecho en Derecho Penal, CUELLO CONTRERAS Y GONZÁLEZ DE MURILLO (Trads.), Marcial Pons, 2000.

621 SCHÜNEMAN, Bernd, "Responsabilidad penal en el marco de la empresa...", $O p$. Cit., página 19, señala que Roxin está de acuerdo con esa interpretación en donde consideró como incorrecta la admisión de la autoría mediata de un órgano directivo de una empresa que está detrás de un órgano de ejecución que actúa de modo completamente delictivo, "en su lugar, considero apropiada la admisión de una coautoría si y porque el principal, por un lado, tiene una posición de garante". 
organizado de poder y por lo tanto resolverse como autoría mediata en los términos que lo ha hecho Roxin ${ }^{622}$, o bajo los auspicios de la coautoría como otro sector de la doctrina española ${ }^{623}$. No obstante, no nos convence la postura en razón de que son esencialmente distintos un apartado organizado de poder y una empresa, sobre todo ante el cuadro legal español que estima responsabilidad penal a aquellos entes colectivos que tengan una actividad lícita (lo que no podría ocurrir cuando consiguen ser inscritas como personas jurídicas). Además, la idea o funcionamiento de la ñerarquía en una organización empresarial no se corresponde con la que está presente, sin embargo, en los apartados organizados de poder, de naturaleza estatal o asimilada, ni los individuos de una estructura empresarial aparecen siempre tan fungibles como sí lo suelen ser en estos últimos, al margen de que, igualmente, las estructuras empresariales no suelen estar diseñadas para actuar al margen del Derecho ni la comisión de delitos es su último objetivoơ ${ }^{64}$.

Finalmente Del Rosal Blasco resuelve el problema a través de lo que llama criterio objetivo-formal r̃debiéndose de interpretar la realización del hecho a partir de una interpretación integral de los preceptos del Código Penalớ ${ }^{25}$ y dando respuestas caso por caso.

Estimamos que la solución debería ser la primera: un caso de coautoría material, y ello en razón de que los administradores serían garantes de la causa del resultado r̃concretamente por el dominio de la vigilancia ejercido con los medios de poder de la agrupación (dirección

${ }^{622}$ Autoría y dominio del hecho en Derecho Penal, Op. Cit., página 267 y sigs.

${ }^{623}$ MARÍN DE ESPINOZA CEBALLOS, Elena Blanca, Criminalidad de empresa: la responsabilidad penal en las estructuras jerárquicamente organizadas, Op. Cit., página 83 y sigs., y ZUGALDÍA ESPINAR, José Miguel, La responsabilidad criminal de los entes..., Op. Cit., página 23.

${ }^{624}$ DEL ROSAL BLASCO, Bernardo, "La delimitación típica de los llamados hechos de conexión...", Op. Cit., página 76. Claro está que si concurren pluralidad de sujetos activos que se estructuran de manera jerárquica y con división de funciones, el aparato funciona de forma automática y con miembros fungibles, y todos ellos tienen conocimiento de que cumplido su rol se pondrá en peligro bienes jurídicos, no tendríamos empacho en admitir esa postura.

$625 \mathrm{Ib}$ Ídem. 
e información) sobre los miembros subordinados de la misma y/o en virtud de la custodia sobre los objetos peligrosos del patrimonio empresarial que son propiedad de la agrupación ${ }^{226}$.

El caso de los delitos especiales, es decir, aquellos que exigen determinadas relaciones, cualidades o condiciones personales en el sujeto activo del mismo, de forma que de no concurrir estaríamos en ausencia del delito por atipicidad, es un tema que vale la pena tratar por su importancia. El art. $31 \mathrm{CP}$ resuelve el problema del ragctuar en lugar de otroò a través de la equivalencia de la conducta del sujeto no cualificado tiene con la del sujeto idóneo que no ha actuado, desde la perspectiva del contenido del injusto. Señala que óel que actúe como administrador de hecho o de derecho de una persona jurídica, o en nombre o representación legal o voluntaria de otro, responderá personalmente, aunque no concurra en él las condiciones, cualidades $o$ relaciones que la correspondiente figura de delito o falta requiera para poder ser sujeto activo del mismo, si tales circunstancias se dan en la entidad o persona en cuyo nombre o representación obreâ

Los problemas, para efectos de nuestra investigación, podrían surgir en los siguientes casos:

1.- El administrador que comete personalmente el delito no tiene las relaciones, cualidades o condiciones personales exigidas por el tipo penal, pero la persona jurídica, de la que es administrador y representante, sí las tiene.

2.- El administrador no tiene las relaciones, cualidades o condiciones personales exigidas por el tipo penal, pero la persona jurídica, de la que es administrador y representante, sí las tiene, pero no es el administrador quien comete el delito, sino una tercera persona por el encargo de aquel.

626 SCHÜNEMANN, Bernd, "Responsabilidad penal en el marco de la empresa. Dificultades relativas a la individualización de la imputación”, Op. Cit., página 30. 
3.- El administrador no tiene las relaciones, cualidades 0 condiciones personales exigidas por el tipo penal, pero la persona jurídica, de la que es administrador y representante, sí las tiene, pero quien comete el delito es una tercera persona subordinada de aquel pero lo hace por su cuenta y sin que se lo haya encargado éste, sino por un ñndebido controlò

En el primer caso, estaríamos hablando del ejemplo del art. 261 CP (insolvencias punibles) en donde el administrador, para efecto de obtener la declaración de insolvencia de la persona jurídica en un procedimiento concursal presentare a sabiendas datos falsos del estado contable. Permítasenos afirmar que estamos frente a un tipo penal que exige una cualificación especial del sujeto activo por tener un deber $u$ obligación especial de proporcionar solamente datos verdaderos y exactos (o por lo menos, no deliberadamente mentirosos) en el procedimiento concursal, y si estamos hablando del concurso de una persona jurídica, será ella quien tiene ese deber jurídico especial y por tanto, esa cualificación especial: solo ella podrá ser sujeto activo. Sin embargo, quien realiza personalmente la conducta delictuosa (presentar datos falsos del estado contable) es, en nuestro caso, el administrador de la misma.

No habrá problema alguno en asumir que, en términos del art. $31 \mathrm{CP}$, el administrador deberá responder como autor material del art. $28 \mathrm{CP}$, y por lo tanto, su actuar objetivamente típico podrá ser presupuesto para la responsabilidad penal de la persona jurídica como autora material y directa del delito del art. 31 bis.

En el segundo caso, un tercero, por ejemplo, quien tiene a cargo la contabilidad de la empresa sin ser su representante legal, es quien presenta directamente ante el tribunal de la causa (del concurso) los documentos probatorios de la insolvencia de la persona jurídica por encargo y orden del administrador de ella. Deberá resolverse en el sentido de que el administrador es penalmente responsable del delito de insolvencia punible del art. 261 CP como autor mediato, siguiendo a 
una buena parte de la doctrina en España que se aparta del concepto de dominio del hecho para resolver los problemas de la autoría y participación ${ }^{627}$, o tendríamos que conformarnos con una imputación en calidad de inductor o cooperador necesario tal y como lo señala el art. $65.3 \mathrm{CP}^{628}$. En cualquier evento la persona jurídica podría ser responsable penalmente por existir el presupuesto de su responsabilidad.

El tercer caso es el que nos interesa. Si alguna persona que se encuentre sometida a la autoridad del administrador, comete un delito en ejercicio de las actividades sociales y por cuenta y en provecho de la persona jurídica, por no haberse ejercido sobre ella el debido control, y ese delito exige relaciones, cualidades o condiciones personales (por ser un delito especial), surgen entonces varias dudas.

a. Si la persona competente ha podido realizar el delito por no haberse ejercido sobre ella el debido control por parte del administrador o representante legal, pero ese indebido control es de tal magnitud que es posible concluir responsabilidad penal para ese administrador (es decir, el administrador cometió el delito que realizó la persona competente por una comisión por omisión al tener una posición de garante) como autor o coautor (por no impedir la comisión del delito del otro), entonces ese nivel de autoría sería el presupuesto de responsabilidad a la persona jurídica, siempre y cuando las cualidades, relaciones o condiciones personales concurriesen en tal administrador. Es decir, el delito especial sería imputable al administrador en el que no concurrieren las cualidades personales en razón de la aplicación del art. $31 \mathrm{CP}$ (por un lado) y en razón de que siendo garante de la no comisión del delito de su subordinado, es responsable del mismo si éste lo

627 Vid. por todos y MIR PUIG, Santiago, Derecho Penal. Parte General. Op. Cit., página 384 y 389 y sigs., para quien ser responsable es tener presencia en el delito, que el delito le pertenezca a él, mejor que a ninguna otra persona interviniente.

${ }^{628}$ Art. 65.3 CP "Cuando en el inductor o en el cooperador necesario no concurran las condiciones, cualidades o relaciones personales que fundamentan la culpabilidad del autor, los jueces o tribunales podrán imponer la pena inferior en grado a la señalada por la ley para la infracción de que se trate" 
cometió por un indebido control, y en consecuencia, la persona jurídica sería responsable también, pues estaríamos en presencia de la hipótesis normativa del art. 31 bis 1, primer párrafo $\mathrm{CP}$ porque es el administrador quien comete el delito, presupuesto de la responsabilidad penal de la persona jurídica.

b. En cambio, si se decidiera que en el caso concreto el indebido control no es de tal magnitud como para que se considere que el administrador o representante legal también cometió delito, el injusto personal se predicaría exclusivamente del empleado (permítaseme llamarlo rempleadoò a la persona competente que da lugar a la responsabilidad penal del ente en la hipótesis del segundo párrafo del art. 31 bis $1 \mathrm{CP}$ ), y si esto es así, y el delito es de aquellos que llamamos especiales y no concurren en el empleado las calidades personales que exige el tipo penal, habría entonces imposibilidad de aplicar el art. 31 CP (el actuar en nombre de otro) porque el empleado no es representante legal ni administrador de hecho o de derecho de la persona jurídica, y, en consecuencia, no será posible predicar la existencia del presupuesto de la responsabilidad de la persona jurídica. Estaríamos en la hipótesis del segundo párrafo del art. 31 bis CP, donde el administrador no es el que comete el delito, $y$ en la imposibilidad de aplicar el art. 31 CP porque es imposible hacer concurrir en el empleado las cualidades personales que exige el injusto.

Para que elijamos, en el caso anterior, la aplicación del primer párrafo, o en su defecto, del segundo párrafo, ambos del art. 31 bis 1 $\mathrm{CP}$, tendríamos que encontrar el criterio diferenciador que parte de la interpretación del por no haberse ejercido sobre ellos el delito control atendidas las circunstancias del caso que reza en el segundo párrafo. ¿En qué casos y bajo qué condiciones la ausencia del debido control sobre el sometido a la autoridad del administrador, es también delito del administrador que tiene la posición de garante, que nos ubicaría en el primer párrafo? ¿Cuándo no constituye delito la ausencia del debido 
control de parte del administrador, sino solo del empleado sometido a su autoridad?

La cuestión no es de ninguna manera nimia, pues en los delitos especiales la respuesta que demos a esas interrogantes puede dar lugar a la no responsabilidad de la persona jurídica.

Entendemos que para una parte de la doctrina que se aparta del criterio del dominio del hecho, tal caso así planteado quedaría impune porque no se surten los requisitos de la autoría, ya que r̃si se quiere mantener en los delitos de omisión la diferencia entre autoría y participación nunca puede considerarse autor directo de comisión por omisión a quien no impide que otro cometa un delitoơ 29 ; con lo que estaría solucionado el problema: en ningún caso el indebido control del administrador o representante de la persona jurídica sobre la persona sometida a su autoridad que comete un delito por cuenta y en nombre de la persona jurídica, por lo que si el empleado comete un delito especial sin tener las cualidades personales exigidas por el tipo penal que en cambio sí tiene la persona jurídica, ésta no tendría responsabilidad criminal por no existir el hecho de referencia, presupuesto de su responsabilidad.

La posición anterior resolvería todo el problema, pues quedaría muy claro el criterio rector bajo el cual distinguimos la aplicación del primer o del segundo párrafos ya señalados en los casos de delitos de omisión, es decir, el administrador o representante no puede ser jamás autor directo de comisión por omisión si su conducta consistió en no impedir que otro cometa el delito. No obstante, si no se es partidario de esa tesis de la autoría y participación (de la pertenencia del delito, que se distingue de la del dominio del hecho) entonces el problema tendría que resolverse de diferente manera.

Desde una posición alternativa se pregunta ¿qué queda para el segundo párrafo entonces?, y bajo un criterio interpretativo por ${ }^{629}$ MIR PUIG, Santiago, Derecho Penal. Parte General. Op. Cit., página 394. 
exclusión, se propone que en los casos en los que el administrador o representante legal no generan responsabilidad penal para ellos por su indebido control sobre quienes están sometidos a su autoridad r̃se delimitan mediante un criterio meramente formal, que entiende violado el deber de control por parte del administrador o del representante cuando éste hubiera conocido los hechos (esto es, el riesgo o la certeza de comisión de un delito por parte del empleado o dependiente) y los hubiera podido remediar, sin necesidad de que las medidas correctoras fueran actos de la propia competenciaò El criterio formal distingue entonces dos clases de medidas correctoras, las de propia competencia del administrador o representante legal, y aquellas otras que no son de su competencia ï seguramente para diferenciar los conceptos en nombre o por cuenta del primer párrafo; y si el administrador o representante hubiesen podido evitar el delito del subordinado utilizando las medidas que sí son de su competencia, habría delito del administrador y ubicaríamos la hipótesis normativa a aplicar en el primer párrafo, pero si las medidas correctoras que se necesitaban aplicar no eran propias de su competencia, entonces hablaremos del segundo párrafo.

Esta cuestión tan importante, que solo hemos planteado sin intención de resolver, deberá ser motivo de atención para la doctrina penal en un futuro inmediato. No obstante, todavía no nos convence la respuesta trazada por Del Rosal Blasco, pues por un lado, de aceptarla no habría posibilidad fáctica de evitar la imputación del delito del subordinado o empleado a la persona jurídica, ya que si correspondía evitar al administrador según su competencia, daría lugar a la imputación por el primer párrafo, y si no era de su competencia, daría lugar a imputación por el segundo párrafo, pero debemos caer en la cuenta de que el administrador solamente tiene dos clases de medidas correctoras: las que son y las que no son de su competencia. Por otro lado, dejaría prácticamente sin aplicación el segundo párrafo del art. 31 bis $1 \mathrm{CP}$, en razón de que en la mayoría de los casos se nos antoja que la infracción del deber de control sea precisamente por motivos de no 
haber aplicado medidas de su propia competencia del administrador o representante, de ahí que se hable del debido control (esto es, algo que le es debido, le es exigido, le es correspondido al administrador o representante).

\subsection{Circunstancias normativas}

\subsubsection{En nombre o por cuenta de la persona jurídica}

El primer párrafo del art. 31 bis $1 \mathrm{CP}$ exige que el delito de la persona física se realice en nombre o por cuenta. Son expresiones alternativas, de forma tal que, si es que son diferentes en contenido y alcances ambas expresiones, bastará con que se actualice una de ellas para que esta circunstancia normativa se tenga por satisfecha.

No obstante, hay quienes ${ }^{630}$ estiman ambos conceptos como sinónimos y les dan el mismo alcance y contenido, esto es, que la persona física haya realizado el delito en el marco de sus funciones empresariales, esto es, en términos de las funciones autorizadas por su propia competencia o funciones delegadas por sus superiores. Lo que excluye la responsabilidad penal de la persona jurídica, limitando la misma a la persona física (por ejemplo, administración desleal ${ }^{631}$ ) es la extralimitación del administrador de los poderes que le fueron encomendados o la extralimitación en las funciones del marco de actuación conferido. Esto es, identifican ñpor cuentaòy renn nombreò en un solo concepto y conducen su interpretación a criterios formales de competencia.

630 BACIGALUPO S., Silvina, “La responsabilidad...”, Op. Cit., página 6; DOPICO GÓMEZ-ALLER, Jacobo, "Responsabilidad de las personas jurídicas", Op. Cit., página 18; FEIJÓo SÁNCHEZ, Bernardo, "La responsabilidad penal...", Op. Cit., página 98; MIR PUIG, Santiago, Op. Cit., 2011, página 205; GOMEZ MARÍN, V., "Artículo 31 bis CP", Op. Cit., página 133; y ZUGALDÍA ESPINAR, José Miguel, La responsabilidad criminal de los entes..., Op. Cit., página 49.

631 BACIGALUPO S., Silvina, "La responsabilidad...", Op. Cit., página 6, y ZUGALDÍA ESPINAR, José Miguel, La responsabilidad criminal de los entes..., Op. Cit., página 49. 
Pero encontramos posturas todavía más exigentes que reducen mucho (a niveles inaceptables, desde nuestro punto de vista, porque reducen a muy pocos casos la responsabilidad penal de la persona jurídica) los conceptos ñpor cuentaò y ren nombreò Considerándolos sinónimos, estiman que deben distinguirse una extralimitación formal y otra material, en donde la primera sería aquella que el administrador actuara fuera de la competencia formal que le ha sido asignada (en los términos de las posturas del párrafo anterior) y la segunda, aquella en que la actuación se ciñera a las atribuciones previamente dadas pero mediante ellas contradice abiertamente criterios de la política empresarial, y concluye que solo sería aceptable hablar de la satisfacción de estos requisitos (rẽn nombre o por cuentaò) cuando ña acción del representante constituya la implementación de una política empresarial ïno siendo necesaria una autorización propia de la empresa ${ }^{632}$. Esta postura, lo decimos de una vez, no nos convence, ya que restringe el ámbito de responsabilidad de las personas jurídicas, y prácticamente solo admite su responsabilidad cuando el administrador actuó alineado y acorde con la f̃orma de seròde la empresa, por lo que cumplió internamente con los deseos del ente para quien trabaja.

Con las posturas anteriores estarían resueltos los casos, parece ser, cuando la persona competente es el administrador de derecho o el representante, pues es quien tiene r̃competenciasò dentro de la empresa, y por tanto r̂funcionesòy r̃delegacionesòespecíficas, es decir, es él quien puede actuar en tanto administrador o representante legal; y por lo tanto, solo de ellos se puede predicar que se extralimitaron en sus funciones o en su competencia. Pero tal parece que la respuesta no debería ser idéntica en el caso del administrador de hecho, del que hemos dicho no tiene una relación formal con la empresa, sino solo material por tener en sus manos el control fáctico de la misma, a veces con un radministrador pantallaò o a veces sin necesidad de él, sino administrando y gestionando directamente hacia el interior de su

632 GOMEZ JARA-DIEZ, Carlos, La responsabilidad penal de las personas jurídicas, Op. Cit., página 68 y 69. 
empresa y logra ser obedecido por el personal en virtud de un código no formalizado en el que se le reconoce a él como el verdadero dueño, o a veces a través de un nombramiento no formalizado todavía. ¿Cómo es posible aplicar un criterio formal (extralimitarse en su competencia y funciones), cuando el administrador de hecho no ostenta una condición formal dentro de la empresa?

Aunque no fueron diferenciados para resolver esta problemática (actuación del administrador de hecho ren nombre o por cuentaò de la persona jurídica) es interesante conocer los criterios que los consideran conceptos diferentes. FEEn nombreò será cuando el sujeto realice su comportamiento rácomodándolo a la política o directivas de la empresa previamente fijadasò y por r̃ cuentaò cuando persigue los intereses r̃de ésta determinados autónomamente en el marco de sus funciones sociales, aun cuando contradiga la política 0 directivas empresarialesơ ${ }^{63}$; en ren nombreò cuando actúa ejerciendo una competencia solo aparente, y ñpor cuentaò cuando supone una actuación dentro de lo que es realmente su ámbito competencial ${ }^{634}$; o r̃en nombreòdebería ser entendido como en el ejercicio de la funciones representativas, y ñpor cuentaòen interés de la sociedad ${ }^{635}$

Consideramos que los dos esfuerzos para distinguir ambos conceptos no logran darles un margen de diferenciación suficiente como para tomarlo en cuenta, pues de cualquier forma es difícil entender en qué casos estamos en una y en qué casos estamos en otra hipótesis, amén de que en el caso de la segunda postura, en realidad también es un criterio meramente formal. Pero no podemos predicar lo mismo de la tercera postura, o mejor dicho, de los elementos que nos da esa tercera visión para desarrollar algo propio para el administrador de hecho.

633 DIEZ RIPOLLÉS, José Luis, "La responsabilidad penal de las personas jurídicas...",Op. Cit., página 21.

634 GOMEZ TOMILLO, Manuel, Introducción..., Op. Cit., página 83.

635 GONZÁLEZ-CUELLAR SERRANO, Nicolás, y JUANES PECES, Ángel, "La responsabilidad penal de las personas jurídicas...", Op. Cit., página 9. 
Estimamos que r̃en nombreò es precisamente un concepto formal, y tiene una relación inmediata con el ámbito de las competencias del administrador de derecho y del representante legal, quienes son las personas que tienen una competencia formal derivada de asignación específica y formal del Órgano General de Administración o de la Junta General. Incluso cuando esa competencia sea expresada de forma general con cláusulas como radministrar la empresaò o r̃generar un ambiente laboral de cordialidadò o ñobtener los mejores estándares de productividadò se puede decir que el administrador de derecho o el representante legal tienen una competencia específica e individualizable. r̂Por cuentaò en cambio, podría tener perfiles más bien materiales. Entendemos que esta circunstancia se satisfaría cuando el administrador de hecho actúa en interés de la empresa o sociedad, en su favor. Si utiliza a un administrador pantalla, se surtirá cuando éste realice el hecho alineado a su competencia formal, pero si el administrador de hecho directamente realiza el hecho de conexión u ordena y gestiona hacia dentro de su empresa, entonces podrá utilizarse este criterio.

Por último, debemos señalar que renn nombreòy y p̃or cuentaò son circunstancias de carácter objetivo y por lo tanto, de ninguna manera pertenecen a la parte subjetiva del injusto penal de la persona física ${ }^{636}$. La cuestión no es baladí porque si se consideran que son elementos subjetivos específicos entonces habrá de entenderse que también se exigirá el dolo en la persona física como substratum mínimo para poder detonar la responsabilidad penal de la jurídica, lo que nosotros ya lo hemos descartado y solo creemos que la legislación exige un comportamiento típicamente objetivo; pero además, porque difícilmente podría configurarse un delito imprudente en aquellos tipos penales donde el art. $12 \mathrm{CP}$ enumera como imprudentes, precisamente.

636 DIEZ RIPOLLÉS, José Luis, "La responsabilidad penal de las personas jurídicas... ", Op. Cit., página 21, que dice que la actuación en nombre y por cuenta de la persona jurídica "son dos elementos subjetivos de tendencia, de carácter alternativo, cuya concurrencia es materialmente compatible con eventuales comportamientos imprudentes expresamente previstos como punibles". 


\subsubsection{En ejercicio de actividades sociales}

Esta circunstancia que se exige en las personas físicas ŕsometidos a la autoridadò de los administradores y representantes legales, según el segundo párrafo del art. 31 bis $1 \mathrm{CP}$, debe entenderse como que la persona competente realiza el hecho de conexión dentro de la actividad que realiza para la empresa, la que tiene formal o materialmente asignada. Como en este caso tratamos a personas diferentes de la alta dirección encontraremos siempre que obedecen manuales de procedimientos, códigos y políticas internas de la empresa o en su caso, obedecen órdenes (generales o específicas) dadas por sus superiores jerárquicos, que en este caso, pueden ser formales 0 materiales. Así, el criterio de interpretación absorbe tanto a las personas que tienen relación laboral con la empresa y a quienes no la tienen, como el caso de los prestadores de servicios que trabajan para la empresa, o empresas subcontratadas u outsourcing.

De lo que se trata es de desvincular a la responsabilidad empresarial en aquellos casos en que el empleado realiza un delito fuera del ámbito de sus actividades que le han sido asignadas por la persona jurídica, esto es, aquellos hechos delictuosos propios de la esfera o ámbito privado del individuo y que la persona jurídica no tiene porqué regular.

\subsubsection{En provecho}

La doctrina mayoritaria está de acuerdo en que esta circunstancia debe ser tratada como la tendencia de la acción a darle o conseguir un beneficio a la persona jurídica. El beneficio puede ser directo, como modo de obtener un beneficio o ventaja empresarial, o 
indirecto, para ahorrar costes o evitar pagos o tomar un camino abreviado $^{637}$.

No se exige que sea inmediato y directo el beneficio que se trata de obtener para la persona jurídica; ni tampoco que sea necesariamente económico ese beneficio o ese ahorro de costes, de forma tal que pueden entrar ventajas no económicas, como lo pueden ser en la comisión del delito de años informáticos, por ejemplo, para evitar la adecuada competencia con otra empresa o borrar lista de clientes y proveedores de otro ente ${ }^{638}$.

Uno de los aspectos más importantes es la ubicación de este elemento. Contra la concepción de considerarlo un elemento subjetivo del tipo penal ${ }^{639}$, la doctrina mayoritaria ${ }^{640}$ lo prefiere ver como una cualidad de la acción que se traduce en la idoneidad de dicha acción para reportar una ventaja a la persona jurídica, y si esto es así, es irrelevante que el resultado (el efectivo provecho) se haya producido 0 se haya conseguido, o incluso se haya obtenido exactamente lo contrario. En esta línea Zugaldía expresa muy buenas razones para preferir el carácter objetivo de esta circunstancia ${ }^{641}$. Es, en definitiva,

637 Vid. DOPICO GÓMEZ-ALLER, Jacobo, "Responsabilidad de las personas jurídicas", Op. Cit., página 18; GOMEZ MARÍN, V., "Artículo 31 bis CP", Op. Cit., página 133; y MIR PUIG, Santiago, Op. Cit., 2011, página 205.

638 BACIGALUPO S., Silvina, "La responsabilidad...", Op. Cit., página 7; y ZUGALDÍA ESPINAR, José Miguel, La responsabilidad criminal de los entes..., Op. Cit., página 51.

639 Vid. GONZÁLEZ-CUELLAR SERRANO, Nicolás, y JUANES PECES, Ángel, "La responsabilidad penal de las personas jurídicas...”, Op. Cit., página 9, incluso, los autores exigen que la persona física tenga el ánimo de proporcionar un beneficio, lo que requiere de un conocimiento o representación del resultado.

640 BACIGALUPO S., Silvina, "La responsabilidad...", Op. Cit., página 6; DIEZ RIPOLLÉS, José Luis, "La responsabilidad penal de las personas jurídicas... ", $O p$. Cit., página 20; MIR PUIG, Santiago, Op. Cit., 2011, página 205; y ZUGALDÍA ESPINAR, José Miguel, La responsabilidad criminal de los entes..., Op. Cit., página 51.

${ }^{641}$ ZUGALDÍA ESPINAR, José Miguel, La responsabilidad criminal de los entes..., Op. Cit., página 50, al señalar que la persona física puede calcular pésimamente el resultado y no obtenerlo, porque se subordinaría la responsabilidad penal a un dato que depende de múltiples variables no siempre controlables por quien realiza la acción, existen acciones delictuosas que no se pueden cifrar en términos económicos, lo que ha sido pensado por el legislador al prevenir una forma distinta de cuantificación de la multa en el art. 52.4 CP. 
una r̃objetiva tendencia de la acción a conseguir el provecho, que conlleva la constatación de la idoneidad ex ante de la conducta para que la persona jurídica obtenga alguna clase de ventaja asociada a aquella, aunque tal beneficio no fuere directo ni inmediatoò o simplemente no se verifique ${ }^{642}$.

3.4. El injusto subjetivo de la persona física (dolo e imprudencia)

El dolo y la imprudencia de la persona física, así como elementos subjetivos especiales, dejarían de ser trascendentes bajo los criterios de interpretación propuestos en este trabajo de investigación. Nuestra perspectiva es que cuando la ley exige delito (en la expresión ñas personas jurídicas serán penalmente responsables de los delitos cometidos en nombre o por cuentaé ò se está refiriendo exclusivamente a una acción objetivamente típica en los delitos congruentes, y en los incongruentes por exceso subjetivo, también a los elementos especiales subjetivos, pues ellos fundamentan la materia de la prohibición. La comisión dolosa e imprudente podrá tener importancia para la responsabilidad individual de la persona física, pero ya no para la jurídica, lo que nos permite eficientizar la responsabilidad penal del ente al disminuir a límites irreductibles la irresponsabilidad estructural organizada.

No podemos hacer depender la responsabilidad de la persona jurídica del injusto subjetivo de la persona física, pues dejaríamos vacío o casi sin contenido los apartados 2 y 3 del art. 31 bis CP que expresan la independencia y autonomía de ambas responsabilidades. Además, si hemos dicho que la persona jurídica comete su propio injusto personal, objetivo y subjetivo, tampoco sería útil el conocimiento o comprobación y constatación del dolo o imprudencia de la persona física porque no se trasfiere a la persona jurídica.

642 Ib Ídem. 
Por lo demás, propugnamos porque un delito imprudente de la persona física pueda ser castigado en la persona jurídica, como lo veremos infra; lo cual cambia sustancialmente la respuesta respecto de quienes atribuyen a la jurídica el dolo o la imprudencia de la física, que tendrían que resignarse a la impunidad del ente colectivo a la vista de que el numerus clausus que significa el art. 31 bis CP incluye preponderantemente delitos dolosos.

\subsection{Justificantes, atenuantes, agravantes y excluyentes de} la persona física

La existencia de una causa de justificación de las contenidas en los apartados $4^{\circ}, 5^{\circ}$ y $7^{\circ}$ del art. $20 \mathrm{CP}$, es decir, legítima defensa, estado de necesidad y ejercicio de un derecho y cumplimiento de un deber, en el hecho de la persona física, no deberán de calar en la responsabilidad de la persona jurídica ${ }^{643}$. Así deberá de ser si ambas responsabilidades son independientes y autónomas.

El art. 31 bis $3 \mathrm{CP}$ señala al respecto lo siguiente,

óla concurrencia, en las personas que materialmente hayan realizado los hechos o en las que los hubiesen hecho posibles por no haber ejercido el debido control, de circunstancias que afecten a la culpabilidad del acusado o agraven su responsabilidad, o el hecho de que dichas personas hayan fallecido o se hubieren sustraído a la acción de la justicia, no excluirá ni modificará la

\footnotetext{
${ }^{643}$ Entendemos que es de la misma opinión, ZUGALDÍA ESPINAR, José Miguel, $L a$ responsabilidad criminal de los entes..., Op. Cit., página 54, al hablar de la antijuridicidad del injusto de la persona jurídica, señala que "no estará justificada la acción de la persona jurídica cuando una persona física, actuando en el seno de la una persona jurídica, cometa una estafa a un tercero amparado en un estado de necesidad propio (atender gastos hospitalarios de un hijo gravemente enfermo) en beneficio de la persona jurídica y de sí mismo (ya que parte de lo obtenido con el delito lo piensa desviar del patrimonio social en su provecho)".
} 
responsabilidad penal de las personas jurídicas, sin perjuicio de lo que se dispone en el apartado siguienteâ

No obstante, de esta redacción surgen interpretaciones que, con diferencia a la por nosotros sostenida, restringen aquellos aspectos del delito de la persona física que no deberán transferirse a las personas jurídicas, y por lo tanto, encuentran que sola y exclusivamente no podrán trasladarse las circunstancias que afectan la culpabilidad de la persona física (r̃el acusadoò dice la ley) ni las que agraven su responsabilidad, ni su muerte o su sustracción de la acción de la justicia $^{644}$. De hecho, esa interpretación se puede reforzar si se toma en cuenta que en el Proyecto de ley de 2007 o el Anteproyecto la referencia no era a circunstancias que afectaran la culpabilidad, sino a todas las circunstancias eximentes de la responsabilidad de la persona física (no se trasladarían a la persona jurídica) ${ }^{645}$; por lo que, si el legislador ha dejado solamente las causas que afectan la culpabilidad como las que no se pueden transferir de la física a la jurídica, entonces sí se pueden hacer las demás, en las que se incluyen, las causas de justificación.

Sin embargo, esta opción que es también practicable, dejaría sin sentido y sin utilidad pragmática la independencia y autonomía de ambas responsabilidades penales, hasta el grado de hacer inútil el no identificar o no individualizar a la persona física (como lo señala el apartado 2 del 31 bis (P) si no se puede saber y demostrar fundadamente el dolo o imprudencia y el juicio de desvalor del hecho concreto o particular (el juicio de antijuridicidad). Si la intención es optimizar o volver más eficiente la legislación hasta hacer lo mejor practicable el sistema de responsabilidad penal de las personas

${ }^{644}$ Así BACIGALUPO S., Silvina, “La responsabilidad...", Op. Cit., página 9, pues señala "no puede admitirse -al menos en el modelo de responsabilidad elegido por el legislador basado en la atribución del hecho de la persona física a la persona jurídica- que si el hecho ha quedado justificado para la persona física, no lo pueda estar también para la persona jurídica".

645 FEIJOO SÁNCHEZ, Bernardo, “La responsabilidad penal...”, Op. Cit., página 91. 
jurídicas, se debería aceptar esta interpretación como una opción acreditable.

Además, el apartado 3 del art. 31 bis CP ciertamente establece que las circunstancias que afecten la culpabilidad de la persona física no se trasladarán a la jurídica (óno excluirá ni modificaráô dice literalmente la ley), pero en ningún lado señala que no sea posible excluir de esa traslación también a las causas de justificación. El modelo del sistema de responsabilidad penal de las personas jurídicas que se elija, así como las necesidades de su coherencia interna, darán la pauta de interpretación más correcta.

En otro orden de ideas, se plantea la extensión de lo que debe entenderse por circunstancias que afecten a la culpabilidad del acusado. En una primera aproximación parecería que solamente se refiere a las contenidas en los apartados $3^{\circ}$ del art. $14,1^{\circ}, 2^{\circ}$ y $3^{\circ}=$ del art. $20 \mathrm{CP}$, que se refieren a la capacidad de comprensión del hecho antijurídico y a la capacidad de conducirse de acuerdo con esa comprensión.

Sin embargo, hay quien entiende que el término culpabilidad debería ser considerado en un sentido más amplio, tal y como lo resuelve el art. $65.1 \mathrm{CP}^{646}$, e incluir como circunstancias que sí se podrían trasladar, aquellas como el indulto, la prescripción del delito o de la pena ${ }^{647}$, conclusión, esta última, que sustentan en que si el art. 31 bis $3 \mathrm{CP}$ señala que no se trasladarán las circunstancias de muerte del reo, y ésta se encuentra prevista en el $130.1 \mathrm{CP}$, y en cambio, no se refiere al resto de dichas causas de extinción de responsabilidad,

\footnotetext{
${ }^{646}$ Art. $65.3 \mathrm{CP}$ "Cuando en el inductor o en el cooperador necesario no concurran las condiciones, cualidades o relaciones personales que fundamentan la culpabilidad del autor, los jueces o tribunales podrán imponer la pena inferior en grado a la señalada por la ley para la infracción de que se trate"

647 Vid. MIR PUIG, Santiago, Op. Cit., 2011, página 208, y GOMEZ MARÍN, V., "Artículo 31 bis CP", Op. Cit., página 135.
} 
entonces una interpretación a contrariu sensu, posibilitaría esa posición ${ }^{648}$.

Nosotros estimamos que no es así. Ni las circunstancias que afecten la culpabilidad ni aquellas que extingan la culpabilidad habrán de ser compartidas por la persona jurídica, a menos que concurran en su propia responsabilidad penal. A tono con la posición expuesta líneas arriba, solo es necesario un injusto típicamente objetivo como presupuesto de la responsabilidad del ente corporativo para que se analice su propio injusto y su propia culpabilidad.

Finalmente, las agravantes generales en la responsabilidad penal de la persona jurídica tampoco serán materia de traslación a la persona jurídica, lo que es en cierta medida lógico puesto que los supuestos del art. 22 CP se refieren a aspectos personalísimos de una persona física.

Debemos exponer en este lugar la tesis aportada por Gómez Tomillo respecto de que a pesar de la incomunicabilidad de las circunstancias de culpabilidad y atenuantes y agravantes que puedan estar presentes en la persona física hacia la persona jurídica ordenada por el art. 31 bis $3 \mathrm{CP}$, sí sea posible realizar un ñeflejoò de algunas eximentes $\mathrm{o}$ de eximentes incompletas de la culpabilidad y de atenuantes. Dice que ren suma, la ausencia de culpabilidad de la persona física actuante $u$ omitente puede tener un reflejo en la culpabilidad de la persona jurídicaò ya que del 31 bis $3 \mathrm{CP}$ no se desprende expresamente que r̃deba excluirse cualquier clase de reflejo de la culpabilidad del sujeto realmente actuante $u$ omitente, en la culpabilidad de la organizaciónơ ${ }^{49}$.

No podemos estar de acuerdo con dicha posición. No creemos sostenible afirmar que sea necesario y suficiente un hecho típicamente objetivo para ser el presupuesto de la responsabilidad penal del ente

\footnotetext{
648 Ib Ídem.

${ }^{649}$ GOMEZ TOMILLO, Manuel, Introducción..., Op. Cit., página 144.
} 
corporativo, pues no es necesario nada más pues ambas responsabilidades penales son autónomas y diferentes, y luego afirmar que las causas que eximen la culpabilidad de la persona física podrían tener un reflejo hacia la culpabilidad de la persona jurídica. Sobre todo cuando el apartado 3 del art. 31 bis CP es un eje fundamental para afirmar esa independencia y autonomía de las responsabilidades. Por lo demás, en la doctrina causa mucha extrañeza la parte final del apartado 2 del mismo dispositivo, pues se vuelve incoherente con el resto de las propias disposiciones ${ }^{650}$.

650 Por todos, BACIGALUPO S., Silvina, “La responsabilidad...”, Op. Cit., página 7. 


\section{CAPÍTULO VIII}

\section{LA PERSONA JURÍDICA}

La primera cuestión a tratar es el de conocer cuáles deberán de ser las características generales y especiales, formales y materiales, del sujeto activo del delito en el sistema de responsabilidad penal de los entes colectivos. La ley no señala, como era de esperarse, algún concepto o definición de lo que debe entenderse por persona jurídica.

Dentro de los compromisos internacionales que fueron el origen de la reforma, según lo hemos explicado ${ }^{651}$, las directivas y decisiones marco de la Unión Europea se han referido de manera invariable a la ñpersona jurídicaòcomo sujeto activo del ius puniendi.

Sin embargo, hubo otras alternativas de las cuales echar mano. De acuerdo con el Tratado de la Unión Europea y el art. 107 del proyecto de CP Suizo de 1998, la alusión son rempresasò El Tribunal de Justicia de la Unión Europea es una empresa un r̃conjunto unitario de factores personales, materiales e inmateriales, que se atribuye a un

${ }^{651}$ Vid. supra Capítulo IV, D, página 96. 
sujeto jurídico autónomo, con los cuales persigue a lo largo de tiempo una finalidad económicaơ ${ }^{\$ 2}$, lo que ha sido criticado como estático, y ha sido sustituido por la Comisión Europea por un concepto económico de empresa, que requiere, de cualquier forma, ser enmarcado en límites más exactos por parte de la doctrina ${ }^{653}$.

De hecho, como recuerda Nieto Martín ${ }^{654}$, también en nuestro ámbito está resuelto la definición de qué clase de personas colectivas podrían tener responsabilidad penal adoptando un concepto de ñnidad económicaò como está establecido en la Ley de Defensa de la Competencia, aunque podríamos decir que la delimitación del concepto del sujeto activo del derecho penal en el sistema penal de las personas jurídicas seguirá siendo complejo.

Teniendo a la vista la LO 5/2010, de 23 de junio, creemos que el legislador ha decidido.

\section{LA PERSONALIDAD JURÍDICA COMO CRITERIO} FORMAL

La doctrina mayoritaria acepta y admite que el legislador del 2010 se ha decantado por un concepto puramente formal, e implícitamente ha definido al sujeto activo del delito como personas jurídicas con personalidad jurídica ${ }^{65}$.

652 HEINE, Günter, "Modelos de responsabilidad jurídico-penal originaria...”, $O p$. Cit., página 56.

653 Ib Ídem.

${ }^{654}$ NIETO MARTÍN, Adán, "La responsabilidad penal de las personas jurídicas", $O p$. Cit., página 12.

655 BACIGALUPO S., Silvina, "La responsabilidad...", Op. Cit., página 4; Circular 1/2011 de la Fiscalía General del Estado, página 16; DE LA CUESTA ARZAMENDI, José Luis, "Responsabilidad penal de las personas jurídicas en el derecho español", Op. Cit., página 19; DIEZ RIPOLLÉS, José Luis, "La responsabilidad penal de las personas jurídicas... ", Op. Cit., página 10; DOPICO GÓMEZ-ALLER, Jacobo, "Responsabilidad de las personas jurídicas", Op. Cit., página 14; FEIJOO SÁNCHEZ, Bernardo, "La responsabilidad penal...", Op. Cit., página 71; GONZÁLEZ-CUELLAR SERRANO, Nicolás, y JUANES PECES, Ángel, "La responsabilidad penal de las personas jurídicas...", Op. Cit., página 7; MARTÍNEZ PARDO, Vicente, "La 
Esta propuesta deviene en reconocer que efectivamente la ley no señala qué es lo que debe entenderse por persona jurídica. Sin embargo, una interpretación sistemática de la reforma a la que hemos hecho alusión podría poner firmes y sólidas bases respecto de lo que es el concepto buscado. Así, al tomar en cuenta el art. 129 CP (que antes de 2010 prevenía las consecuencias accesorias para las personas jurídicas), ahora previene consecuencias accesorias a ómpresas, organizaciones, grupos o cualquier otra clase de entidades 0 agrupaciones de personas que, por carecer de personalidad jurídica, no estén comprendidas en el artículo 31 bis de este Código, el Juez o Tribunal podrá imponer motivadamente a dichas empresas, organizaciones, grupos, entidades o agrupaciones una o varias consecuencias accesorias a la pena que corresponda al autor del delito, con el contenido previsto en los apartados c) a g) del artículo 33.7ò podríamos concluir, dice la doctrina mayoritaria, que a contrario sensu, el art. 31 bis CP solamente se aplica a personas jurídicas con personalidad jurídica. Dice Feijóo que ño decisivo es, por consiguiente, que la titularidad de la organización esté reconocida jurídicamente (no bastando sólo con algún tipo de relevancia en el tráfico jurídico) ${ }^{656}$ ò

Por tanto, dejando de lado la enumeración de lo que el art. 297 CP entiende por ŕsociedadesơ 57 para todo el capítulo de delitos societarios, que hace referencia exclusivamente a las sociedades de naturaleza mercantil ${ }^{658}$, debemos entender que las personas jurídicas

responsabilidad penal de las personas jurídicas", Op. Cit., página 73; URRAZA, Jesús, "La responsabilidad criminal de las personas jurídica ...", Op. Cit., página 3; ZUGALDÍA ESPINAR, José Miguel, La responsabilidad criminal de los entes..., $O p$. Cit., página 63. En el mismo sentido, aunque señalando que se trata de un concepto extrapenal, en donde la personalidad jurídica solo es un presupuesto de dicho concepto, vid. GOMEZ MARÍN, V., "Artículo 31 bis CP", Op. Cit., página 131, y MIR PUIG, Santiago, Op. Cit., 2011, página 202.

656 MIR PUIG, Santiago, Op. Cit., 2011, página 72.

657 Art. 297 CP "A los efectos de este Capítulo se entiende por sociedad toda cooperativa, Caja de Ahorros, mutua, entidad financiera o de crédito, fundación, sociedad mercantil o cualquier otra entidad de análoga naturaleza que para el cumplimiento de sus fines participe de modo permanente en el mercado.

658 Así la Circular 1/2011 FGE; GOMEZ MARÍN, V., "Artículo 31 bis CP", Op. Cit., página 131; MIR PUIG, Santiago, Op. Cit., 2011, página 202; y ZUGALDÍA ESPINAR, José Miguel, La responsabilidad criminal de los entes..., Op. Cit., página 63. 
de las que trata el art. 31 bis CP serán aquellas privadas de Derecho civil y mercantil y algunas personas jurídico públicas con personalidad jurídica. Habremos de atender a los arts. 35 del Código Civil ${ }^{659}, 116$ del Código de Comercio ${ }^{660}$, y en cuanto a requisitos constitutivos de las diferentes formas asociativas, a lo previsto por los mismos cuerpos de leyes y al Real Decreto Legislativo 1/2010, de 2 de julio (Ley de Sociedades de Capital). Estas últimas exigirán escritura pública que deberá inscribirse en el Registro Mercantil.

Desde nuestra perspectiva, es cierto que no podemos negar que la personalidad jurídica de los sujetos activos del nuevo sistema es un requisito necesario. La existencia del art. $129 \mathrm{CP}$, que hace una clara diferencia con aquellos entes sin dicha personalidad jurídica, impide negar esta circunstancia. Sin embargo, creemos que bajo una interpretación sistemática en la que se incluya la afirmación del defecto de organización como injusto personal de la persona jurídica y el 130.2 $\mathrm{CP}$ podría darnos los insumos suficientes para considerar que el requisito solamente es necesario, pero no suficiente. Esto lo desarrollaremos infra, en el inciso c) de este subcapítulo.

\section{ENTES COLECTIVOS SIN PERSONALIDAD JURÍDICA} (ART. 129 CP)

Aquellas empresas, sociedades, asociaciones $u$ organizaciones que, siendo entes colectivos, no tengan personalidad jurídica en

659 Art. 35 Cc. "Son personas jurídicas: 1. Las corporaciones, asociaciones y fundaciones de interés

público reconocidas por la Ley. Su personalidad empieza desde el instante mismo en que, con arreglo a derecho, hubiesen quedado válidamente constituidas. 2. Las asociaciones de interés particular, sean civiles, mercantiles o industriales, a las que la Ley conceda personalidad propia, independiente de la de cada uno de los asociados.

660 Art. 116 CC "El contrato de compañía, por el cual dos o más personas se obligan a poner en fondo común bienes, industria o alguna de estas cosas, para obtener lucro, será mercantil, cualquiera que fuese su clase, siempre que se haya constituido con arreglo a las disposiciones de este Código. Una vez constituida la compañía mercantil, tendrá personalidad jurídica en todos sus actos y contratos". 
atención a las leyes civiles, mercantiles y de Derecho público, no tendrán responsabilidad penal en el sentido del art. 31 bis $\mathrm{CP}$, sino que podrán ser criminalizadas por el art. $129 \mathrm{CP}$, pero no tanto por su culpabilidad, sino por su peligrosidad ${ }^{661}$.

El art. 129 CP prevenía, antes de la LO 5/2010, de 23 de junio, lo que solamente pocos llamaban responsabilidad penal de las personas jurídicas, sin embargo, al entrar en vigor el 31 bis $\mathrm{CP}$, no fue aquel derogado sino que recobró sentido al reconocer la ley la existencia de entes corporativos sin personalidad jurídica pero de gran fuerza social y capacidad de delinquir ${ }^{662}$.

Literalmente señala el art. $129 \mathrm{CP}$ :

1. En caso de delitos o faltas cometidos en el seno, con la colaboración, a través o por medio de empresas, organizaciones, grupos o cualquier otra clase de entidades o agrupaciones de personas que, por carecer de personalidad jurídica, no estén comprendidas en el artículo 31 bis de este Código, el Juez o Tribunal podrá imponer motivadamente a dichas empresas, organizaciones, grupos, entidades o agrupaciones una 0 varias consecuencias accesorias a la pena que corresponda al autor del delito, con el contenido previsto en los apartados c) a g) del artículo 33.7. Podrá también acordar la prohibición definitiva de llevar a cabo cualquier actividad, aunque sea lícita.

2. Las consecuencias accesorias a las que se refiere en el apartado anterior sólo podrán aplicarse a las empresas, organizaciones, grupos 0 entidades 0

\footnotetext{
${ }^{661}$ FEIJOO SÁNCHEZ, Bernardo, "La reforma del art. 129 CP", en DIAZ-MAROTO Y VILLAREJO (Dir.), Estudios sobre las reformas del Código Penal operadas por la LO 5/2010, de 22 de junio, y 3/2011, de 28 de enero, Thomson Reuters, página 243 y 244.

662 ZUGALDÍA ESPINAR, José Miguel, La responsabilidad criminal de los entes..., Op. Cit., página 101.
} 
agrupaciones en él mencionados cuando este Código lo prevea expresamente, o cuando se trate de alguno de los delitos o faltas por los que el mismo permite exigir responsabilidad penal a las personas jurídicas.

3. La clausura temporal de los locales o establecimientos, la suspensión de las actividades sociales y la intervención judicial podrán ser acordadas también por el Juez Instructor como medida cautelar durante la instrucción de la causa a los efectos establecidos en este artículo y con los límites señalados en el artículo 33.7.

\subsection{Agrupaciones incluidas en la hipótesis normativa}

El primer aspecto que deberemos de observar es qué clase de rempresas, organizaciones, grupos o cualquier otra clase de entidades o agrupaciones de personasòsin personalidad jurídica podrían entrar en esta hipótesis normativa.

Zugaldía hace una ardua labor de integración y sistematización para responder a la pregunta anterior, en los que incluye a Comités ciudadanos, asociaciones de hecho (como peñas o agrupaciones deportivas que disponen de un fondo común), sociedades irregulares o en formación, las sociedades de hecho (que tienen un vicio de nulidad formal), las comunidades de bienes, así como las que previene el art. 35.4 de la LGT, como lo son, las comunidades de bienes. También las comunidades de propietarios en régimen de propiedad horizontal referidas por la Ley 49/1960, de 21 de julio, comunidad de titulares de montes vecinales en mano común de la Ley 55/1980, de 11 de noviembre, las sociedades civiles sin personalidad jurídica, las herencias yacentes, los fondos de inversión previstos en la Ley 35/2003, de 4 de noviembre, de Instituciones de Inversión Colectiva, las uniones temporales de empresas, conforme la Ley 18/1982, de 26 de 
mayo, los fondos de capital-riesgo, de la Ley 1/1999, de 5 de enero, los fondos de pensiones que se rigen por el Real Decreto Legislativo 1/2002, de 29 de noviembre, los fondos de regulación del mercado hipotecario de la Ley 2/1981, de 25 de marzo, los fondos de titulación hipotecaria previstos en la Ley 19/1992, de 7 de julio, los fondos de titulación de activos referidos en la disposición adicional quinta de la Ley $3 / 1994$, de 14 de abril y los fondos de garantía de inversiones previstos en el artículo 77 de la Ley 24/1988, de 28 de julio, del Mercado de Valores, entre otros ${ }^{663}$.

Finalmente, y a diferencia del art. 31 bis CP que siempre se aplica en casos de comisión de delitos que tienen una consecuencia de pena grave ï como lo señala el art. 33.7 CP, el art. 129 CP se aplica en casos de delitos pero también de faltas, lo que es previsto tanto en el número 1 y número 2 de dicho dispositivo.

\subsection{Naturaleza jurídica de las consecuencias accesorias}

Con anterioridad a la entrada en vigor de la LO 5/2010, de 23 de junio, solamente pocos tratadistas consideraban verdaderas penas a las consecuencias jurídicas del art. $129 \mathrm{CP}^{664}$ (por exclusión, ya que no las consideraban ni siquiera medidas de seguridad). Describían un sistema de responsabilidad directo de la persona jurídica separado del sistema vicarial, acumulativo, de catálogo mínimo de penas. Imputaban a la persona jurídica su injusto objetivo y el subjetivo, y siempre y cuando concurrieran circunstancias normativas que permitiera determinar que estábamos bajo aquellas condiciones en las que se ñpuede atribuir directamente el hecho a la persona jurídicaơ ${ }^{65}$, afirmaban la responsabilidad penal de dicha persona jurídica. Lo

663 ZUGALDÍA ESPINAR, José Miguel, La responsabilidad criminal de los entes..., Op. Cit., página 102.

${ }^{664}$ Principalmente ZUGALDÍA ESPINAR, José Miguel, La responsabilidad penal de empresas, fundaciones y asociaciones, Op. Cit., página 190.

665 Ib Ídem, página 198 y pássim. 
anterior, no obstante, que expresamente el apartado 3 del $129 \mathrm{CP}$ preveía que la imposición de las consecuencias accesorias estaría r̃orientada a prevenir la continuidad en la actividad delictiva y los efectos de la mismaò

Hoy en día, la existencia del propio art. 129 CP en simbiosis con el diverso 31 bis $\mathrm{CP}$ nos permite concluir que mientras éste persigue la criminalidad de sujetos jurídicos con personalidad jurídica que cometen delitos con acción y culpabilidad propios, aquel prevé verdaderas medidas de seguridad que tienen la finalidad de garantizar que agrupaciones peligrosas y sus actividades igualmente peligrosas puedan ser controladas por el ordenamiento jurídico. Estamos pues, frente a medidas interdictivas que tienen el objetivo de prevenir la continuidad de la actividad delictiva ${ }^{666}$.

Esta conclusión se obtiene a pesar, como se indicó, que ha desaparecido una expresa finalidad de tales consecuencias accesorias, porque las consecuencias son exactamente las mismas que las previstas en la anterior redacción.

En efecto, la clausura de la empresa, sus locales o establecimientos, temporal o definitiva, la disolución de la sociedad, la suspensión de actividades, la prohibición de realizar en el futuro actividades $u$ operaciones mercantiles y negocios y la intervención de la empresa para salvaguardar los derechos de los trabajadores, consideradas del inciso c) al g) del art. $33.7 \mathrm{CP}$, coinciden sustancialmente con aquellas previstas en el antiguo $129 \mathrm{CP}$.

Por otro lado, en el art. 66 bis 1,a) CP ordena considerar, para la aplicación de las penas de las letras b) a g) del apartado 7 del art. 33, ŕsu necesidad para prevenir la continuidad de la actividad delictiva o de

666 Así, DE LA CUESTA ARZAMENDI, José Luis, "Responsabilidad penal de las personas jurídicas en el derecho español”, Op. Cit., página 24; FEIJOO SÁNCHEZ, Bernardo, "La reforma del art. 129 CP", Op. Cit., página 244; BERDUGO GÓMEZ DE LA TORRES, Ignacio, y otros, Curso de Derecho Penal. Parte General, Ediciones Experiencia, Barcelona, 2010, página 559; y NIETO MARTÍN, Adán, "La responsabilidad penal de las personas jurídicas”, Op. Cit., página 16. 
sus efectosò y precisamente esas consecuencias son las accesorias para los entes sin personalidad jurídica.

Debemos tomar en cuenta que las consecuencias accesorias no son de aplicación obligatoria. No son raros los delitos que permite imponerlas, por ejemplo, el de manipulación genética del art. 162 CP, cuando rél culpable perteneciere a alguna sociedad, organización o asociación, incluso de carácter transitorio, que se dedicare a la realización de tales actividadesò lo que refleja la intención de controlar la peligrosidad de la organización; que es lo mismo que sucede en el art. $366 \mathrm{CP}$ que permite imponer la clausura del restablecimiento, fábrica, laboratorio o local por tiempo de hasta cinco años, y en los supuestos de extrema gravedad podrá decretarse el cierre definitivo conforme a lo previsto en el artículo 129ò Esa extrema gravedad se refiere, según creemos, al carácter peligroso del ente colectivo sin personalidad jurídica.

Abona a nuestra conclusión, que en la redacción del apartado 1 del $129 \mathrm{CP}$ se establezca que los delitos o las faltas deberán ser cometidos en el seno, con la colaboración, a través o por medio de empresas $u$ organizaciones; términos que posibilitan a concluir la instrumentalización de la organización a la que se ve como algo peligroso. El legislador de 2010 concibió un subsistema diferente del 31 bis CP r̃dotándolo de un sentido y una finalidad diferente. La reforma ha conformado este precepto como una auténtica consecuencia accesoria cuyo fin es acabar con una organización, no dotada de personalidad jurídica, que es peligrosamente objetiva, en cuanto que su única función es la comisión de hechos delictivosớ67.

El carácter de medidas de seguridad de las consecuencias del art. $129 \mathrm{CP}$ no es, sin embargo, algo pacíficamente admitido por la doctrina. Es cierto que antes de la reforma de 2010 solo una parte de la doctrina entendía que las consecuencias accesorias que eran previstas

667 NIETO MARTíN, Adán, “La responsabilidad penal de las personas jurídicas”, $O p$. Cit., página 16. 
en el antiguo $129 \mathrm{CP}$ eran verdaderas penas $^{668}$, pues el resto de la doctrina, tal vez la mayoritaria, afirmaba de ellas otro carácter. Lo que debemos tomar por descontado es que hoy en día parece justificado la diversidad de opiniones por la diferenciación de dos sistemas, dos clases de sujetos destinatarios de la norma y un silencio injustificado en la regulación de las consecuencias accesorias ${ }^{669}$.

Una parte de la doctrina sostiene que al igual que sucede en el art. 31 bis $\mathrm{CP}$, en este caso se prevén verdaderas penas para agrupaciones, empresas, sociedades, grupos o cualquiera otra entidad, ya que en ambos casos, corresponde imponer las consecuencias del art. 33.7 CP (a excepción de la multa y disolución de la persona jurídica, que son los incisos a) y b) del artículo invocado).

En efecto, no existe diferencia en las penas o consecuencias para una agrupación de personas con personalidad jurídica y para otra que carece de ella, a excepción, como ya dijimos, de la multa y de la disolución, propiedad exclusiva de las personas jurídicas formalmente constituidas. Si esto es así, la diferencia en una propiedad o característica formal del sujeto activo del delito (poseer personalidad jurídica) no puede cambiar ni modificar la función y fin de las penas a ellas aplicables. Algunos autores sostienen que ña naturaleza, el contenido y fundamento de las consecuencias accesorias del art. 129 $\mathrm{CP}$ coincide por tanto con el de las penas del art. 33.7 CP que se orientan principalmente a la prevención especial negativa aunque también provocan efectos preventivo generales negativosơ 670 .

668 Vid, primera parte, capítulo IV, letra C. También ZUGALDÍA ESPINAR, José Miguel, La responsabilidad penal de empresas, fundaciones y asociaciones, Op. Cit., página 187 y pássim.

669 Vid. GÓMEZ JARA-DIEZ, Carlos, Responsabilidad penal de las personas jurídicas, $O p$. Cit., página 59, cuando dice que "la confusión que introduce esta regulación es, cuando menos, notable y, de nuevo, no ayuda en nada a la necesaria seguridad jurídica que debe primar en un ámbito tan delicado como es el jurídico-penal".

670 GIL GIL, Alicia, LACRUZ LÓPEZ, Juan Manuel, MELENDO PARDOS, Mariano, y NUÑEZ FERnÁNDEZ, José, Curso de Derecho Penal. Parte General, Dykinson, Madrid, 2011, página 971. Entiendo que en el mismo sentido, vid. LANDECHO VELASCO, Carlos María, y MOLINA BLÁZQUEZ, Concepción, Derecho penal español. Parte General, 8aㅡ ed., Tecnos, Madrid, 2010, página 659. 
Otros autores, en cambio, las consideran solamente ñpenas accesorias a la pena (principal) que corresponda al autor del delitoò por lo que no pueden ser ni ñpenas principales, ni medidas de seguridad ${ }^{671}$.

No podemos concitar con las posturas anteriores. En primer lugar, asignar a las consecuencias del art. 31 bis CP las funciones de prevención especial y general negativa parece maridarse, más bien, con verdaderas medidas de seguridad y no de penas, de ahí que resulte fácil, en seguida, afirmar de las que dimanan del art. $129 \mathrm{CP}$ (que son casi las mismas del 33.7 CP) la misma función.

Sin embargo, no creemos que las consecuencias relativas a la infracción del art. 31 bis tengan, todas ellas, tales funciones (prevención general positiva y especial negativa). Ciertamente que aquellas consecuencias incluidas en los apartados c) a g) del art. 33.7 CP tienen un aroma a prevención especial positiva, y por tanto, al tratamiento de un instrumento peligroso, pero ello se explica porque al también pertenecer al subsistema de responsabilidad penal de personas jurídicas (31 bis CP) se deja claro que dicho subsistema es de doble vía: tanto penas como medidas de seguridad, muy consecuente con el sistema amplio de responsabilidad penal.

Una vez dicho lo que es común en ambos subsistemas, debemos referirnos ahora a aquello que hace diferencia. Es imposible asignar una función de medida de seguridad a la pena de multa. La multa tiene una importancia ingente en el nuevo sistema de responsabilidad penal de las personas jurídicas, puesto que es la única pena que se impone necesariamente si existe responsabilidad del ente colectivo, a diferencia del resto de las consecuencias que ños jueces o tribunales podrán así mismo imponerò (según la expresión marcadamente repetida en cada uno de los tipos penales de la parte especial del (P). Además, los criterios de imposición de la multa siempre serán en proporción al daño causado, el valor del objeto del

671 ZUGALDÍA ESPINAR, José Miguel, La responsabilidad criminal de los entes..., Op. Cit., página 103. 
delito o el beneficio reportado por el mismo (según el art. $52.1 \mathrm{CP}$ ), y será fijada dentro de los límites para cada delito, y en caso de no poderse cuantificar con lo anterior, entonces refiere la imposición de la multa emparejándola con la pena de prisión que le correspondería a la persona física que dio lugar al presupuesto de la responsabilidad penal al ente colectivo.

En consecuencia, no debe haber ni existir duda alguna, la multa tiene una verdadera y real función preventivo general positiva $y$ negativa que la hace diferente de las consecuencias accesorias del art. $129 \mathrm{CP}$, por lo que éstas no pueden ser penas. Como dice Feijoo ña inexistencia de penas pecuniarias demuestra que el art. $129 \mathrm{CP}$ no persigue fines preventivo-generales sino exclusivamente preventivo especiales $\delta^{72}$.

\subsection{Numerus clausus de las consecuencias accesorias}

Otra característica que se debe tener en cuenta al momento de aplicar las consecuencias accesorias es su universo de aplicación. De la redacción del art. 129.2 CP debe destacarse, en lo que nos interesa, que previene ñas consecuencias accesorias a las que se refiere el apartado anterior solo podrán aplicarseë cuando este Código lo prevea expresamenteô además de aquellas hipótesis que previenen responsabilidad para las personas jurídicas. Hemos encontrado que las hipótesis en que aparece esa previsión son las siguientes:

Delito de manipulación genética (del art. 162), alteración de precios de concursos y subastas públicas (art. 262), obstrucción a la actividad inspectora o supervisora (art. 294), delitos contra los derechos de los trabajadores (art. 318), delitos contra la salud pública relativos a productos alimenticios (art. 366), falsificación de moneda (art. 386),

672 FEIJOO SÁNCHEZ, Bernardo, "La reforma del art. 129 CP”, Op. Cit., página 247. 
asociaciones ilícitas (art. 520), y criminalidad organizada y financiación del terrorismo (art. 570 quárter).

\subsection{Consecuencias accesorias que pueden ser impuestas}

El art. 129 remite al 33.7, y solamente incluye aquellas de los apartados c) a g), que son las siguientes:

c) Suspensión de sus actividades por un plazo que no podrá exceder de cinco años.

d) Clausura de sus locales y establecimientos por un plazo que no podrá exceder de cinco años.

e) Prohibición de realizar en el futuro las actividades en cuyo ejercicio se haya cometido, favorecido o encubierto el delito. Esta prohibición podrá ser temporal o definitiva. Si fuere temporal, el plazo no podrá exceder de quince años.

f) Inhabilitación para obtener subvenciones y ayudas públicas, para contratar con el sector público y para gozar de beneficios e incentivos fiscales o de la Seguridad Social, por un plazo que no podrá exceder de quince años.

g) Intervención judicial para salvaguardar los derechos de los trabajadores o de los acreedores por el tiempo que se estime necesario, que no podrá exceder de cinco años.

Por ser la multa una sanción cuya función es de prevención general positiva no se incluye en el listado de consecuencias accesorias, y merced a que la disolución de la persona jurídica, prevista en el inciso b) del 33.7, consiste en la ñpérdida definitiva de su personalidad jurídica, así como la de su capacidad de actuar de cualquier modo en el tráfico jurídico o de llevar a cabo cualquier clase 
de actividad, aunque sea lícitaò tampoco se incluye porque m̃o hay personalidad que disolver ${ }^{73}$.

\section{3. ¿INMUTABILIDAD DE LAS PERSONAS JURÍDICAS? ${ }^{674}$}

La línea que delimita estos conjuntos de personas unidos por un fin común (asociaciones, grupos o sociedades) con los sujetos activos de la responsabilidad de personas jurídicas, es formal por una decisión de voluntarismo legislativo. Que no tengan capacidad de realizar acciones y de actuar culpablemente ${ }^{675}$ no debe ser una característica derivada de su carencia de personalidad jurídica, sino a la unidad económica que en sí mismas pueden significar y a la complejidad que puedan tener. La capacidad de acción y de culpabilidad, desde perspectivas materiales, tiene que encontrarse en algo más que en una decisión legislativa.

Es decir, reconocemos que la personalidad jurídica es un requisito formal necesario para que una agrupación de personas con fin común pueda ser recriminada por los actos de algunos miembros cualificados en los términos del art. 31 bis $\mathrm{CP}$, y que por la misma razón, delitos de idénticas agrupaciones sean solventados por la vía del art. $129 \mathrm{CP}$ en los casos en que carezcan de personalidad jurídica. Sin embargo, la personalidad jurídica es, según entendemos, solamente un requisito necesario, pero no suficiente, para que una persona jurídica sea destinataria de la norma que la obliga a organizarse adecuadamente. De ahí que se discuta si es posible exigir algo más de la sola personalidad jurídica para considerar sujeto de Derecho Penal de personas jurídicas a determinados entes delictivos.

${ }^{673}$ ZUGALDÍA ESPINAR, José Miguel, La responsabilidad criminal de los entes..., Op. Cit., página 103.

${ }^{674} \mathrm{~A}$ este tema ya hemos introducido, vid. supra capítulo V.5.2.

${ }^{675}$ Como lo señala el profesor Zugaldía, Ib Ídem. 
Con anterioridad a la LO 5/2010 algunos autores se habían pronunciado, de lege lata, a la introducción de un requisito necesario para delinear los perfiles de la persona jurídica como nuevo sujeto de Derecho Penal. Gómez Jara-Diez fue tal vez el primero que llamó la atención en la imputabilidad de la persona jurídica como un límite de su propia culpabilidad, señalando que no cualquier empresa $u$ organización colectiva debería ser sujeta a responsabilidad criminal, sino solamente aquellas que se alinearan con el sistema que previamente había configurado ${ }^{676}$, es decir, solamente aquellas organizaciones que tuvieran una autorreferencialidad y complejidad suficiente podrían tener autoconciencia del sistema y por tanto, podrían generar comunicaciones con sentido desaprobando el sistema jurídico a través de acciones propias. Decía r̃que el sistema al que se le atribuye la condición de persona y, por ende, la capacidad de recibir una imputación jurídico penal ï imputabilidad- tiene que haber desarrollado una autorreferencialidad suficiente basada en una determinada complejidad propia para poder ser destinatario de las imputaciones jurídico-penalesơ ${ }^{67}$, con lo que debería excluirse, en el uso práctico del sistema, a sociedades pantalla y en general a sociedades sin complejidad suficiente (pequeñas necesariamente), lo que no impide imponerles algún otro tipo de consecuencia. El límite de esa complejidad deberá ser necesariamente normativo ${ }^{678}$.

Nieto Martín también consideraba razonable el concepto de inimputabilidad de la empresa. Separándose de la fundamentación de Gómez Jara y en línea con Peter French, señalaba que cualquier organización, para ser entes morales, deben tener desarrolladas restructuras propias para la toma e implementación de decisiones empresariales, si no es así, únicamente existe una agregación de personas donde los actos e intenciones de la colectividad son

\footnotetext{
676 Vid. capítulo IV.5.3.

677 GOMEZ JARA-DIEZ, Carlos, La culpabilidad de la empresa, Op. Cit., página 244, cursivas en el original.

${ }^{678} \mathrm{Ib}$ Ídem.
} 
reconducibles a sus miembros $\delta^{69}$, dejando fuera de responsabilidad criminal a las sociedades pequeñas (por respeto al principio non bis in ídem), a las sociedades pantalla y a las empresas criminales.

La cuestión es si este concepto es hoy receptado, o puede ser interpretado, desde la LO 5/2010. Solamente Gómez-Jara contesta afirmativamente ${ }^{680}$. Nosotros nos sumamos a dicha posición por entenderla razonable y respetuosa de derechos fundamentales, aunque no partimos del sistema constructivista de Gómez-Jara.

1. Que el defecto de organización de la empresa sea la piedra de toque para la construcción del sistema de responsabilidad penal a partir del 2010 en España (lo que desde una u otra perspectiva es admitido por la doctrina dominante), exige darle un contenido material y funcional, y no solamente voluntarista y formal. Si nos tomamos en serio esa organización defectuosa es porque admitimos que organización y personas que la conforman no son lo mismo, que la organización, como cosa distinta de sus integrantes, constituye una especie de entramado normativo interno dentro de la persona jurídica (creado, naturalmente, por personas físicas, pero una vez puesto a funcionar, sigue su propia lógica y dinámica independientemente de ellas) que gobierna los procedimientos y procesos para llevar a cabo el producto o el servicio, las relaciones entre sus integrantes, sus competencias y roles, cumplimiento de metas y objetivos y la institucionalización de medios, recursos y herramientas para llegar a ellos, así como la interdicción de otros medios y recursos, materialmente útiles (y potencialmente más eficientes) pero institucionalmente no permitidos.

Solamente se arriba a una verdadera organización cuando se tiene el tamaño y la complejidad suficiente, y solamente así se puede

${ }^{679}$ NIETO MARTíN, Adán, La responsabilidad penal de las personas jurídicas, Op. Cit., página 168.

680 Vid. capítulo IV.5.3. También afirmativamente y comulgando con esta tesis, aunque sin mayor desarrollo, MARTINEZ PARDO, Vicente, Op. Cit., página 74. 
afirmar que determinados actos de personas físicas no son exclusivamente responsabilidad de ellas sino que entra en juego la dinámica y lógica de la organización ï defectuosa- a la que pertenece. Solo cuando es posible separar conceptualmente la acción de la persona física de la organización es dable hacer responsable a la persona jurídica.

Si recordamos las necesidades político criminales que dieron origen a la atención de la doctrina española de abrir el debate sobre la responsabilidad penal de las personas jurídicas, encontraremos un perfil dominante en el ente responsable ${ }^{681}$ : se trataba de empresas de gran tamaño, de enorme complejidad interna, de importancia nacional o internacional, inclusive, y de un ingente potencial de peligro para los bienes jurídicos individuales y colectivos, se hablaba de ese tipo de empresas que pueden generar una razctitud criminal de grupoò y en las que, a la postre, era difícil a veces encontrar a una persona física responsable que fuera propietaria de todas las categorías del delito para imputarle el delito (irresponsabilidad estructural organizada).

No podemos fundamentar el injusto objetivo y subjetivo o la culpabilidad (donde quiera que la ubiquemos) en el defecto de la organización y luego olvidarnos de él y considerar sujetos de Derecho Penal a personas jurídicas unipersonales o sociedades familiares 0 , en fin, que funcione con dos, tres o cinco o diez personas físicas. En estos casos, no es posible predicar defectos organizativos del ente colectivo porque sencillamente su funcionamiento diario obedece a esquemas de control personal y físico, del control de una o dos o tres personas físicas, y por tanto, al talento, capacidad y conocimientos de esa persona física.

2. Ahora bien, vemos como una opción atendible afirmar la inimputabilidad de las personas jurídicas basándonos en el concepto de defecto de organización como piedra angular del sistema de

681 Vid. supra capítulo II.1.1.2. 
responsabilidad penal de las personas jurídicas del art. 31 bis $\mathrm{CP}$, en el apartado 2 in fine del mismo, y en el art. $130.2 \mathrm{CP}^{682}$. Habiendo tratado el defecto de organización que permea la autorresponsabilidad penal de los entes corporativos, queda hacer el manejo de los otros dos fundamentos.

La LO 5/2010 previene responsabilidades separadas, independientes y autónomas de la persona física y la jurídica, pero también señala que ñCuando como consecuencia de los mismos hechos se impusiere a ambas la pena de multa, los jueces o tribunales modularán las respectivas cuantías, de modo que la suma resultante no sea desproporcionada en relación con la gravedad de aquellosô

La invocación más frecuente de este dispositivo por parte de la doctrina es para argumentar a favor de la m̃o tan independiente ni autónomaòresponsabilidad penal de la jurídica con respecto de la física, y por tanto, un elemento que abona a la inclinación de un sistema vicarial $^{683}$. Quienes, en cambio, están a favor de afirmar una autorresponsabilidad penal de las personas jurídicas no pueden explicar suficientemente esta parte del texto legal, y aducen que el legislador pudo haber tenido m̃mala conciencia por acumular responsabilidades y ha introducido el inciso último del artículo 31 bis $26^{684}$, ya que en el fondo ñparece preso de la idea de que está castigando dos veces al mismo sujeto por los mismos hechosòlo que resulta curioso ${ }^{685}$.

682 Vid. GÓMEZ-JARA, Responsabilidad penal..., Op. Cit., páginas 55 a 58.

683 DIEZ RIPOLLÉS, José Luis, "La responsabilidad penal de las personas jurídicas... ", Op. Cit., página 19, al criticar las tesis que afirman la autorresponsabilidad penal de la persona jurídica, señala que "se pasan por alto o desconsideran ciertas previsiones legales adicionales, incompatibles con un modelo de autorresponsabilidad... el art. 31 bis 2- presupone que ambas personas estás sustancialmente respondiendo por el mismo injusto culpable". En similares términos

${ }^{684}$ GOMEZ TOMILlO, Manuel, Introducción a la responsabilidad penal..., Op. Cit., página 171.

685 CARBONELL MATEU, Juan Carlos, "Responsabilidad penal de las personas jurídicas...", Op. Cit., página 30. En el mismo sentido GALÁN MUÑOZ, Alfonso, "La responsabilidad penal...", Op. Cit., página 22, a quien le parece que el legislador da pasos hacia adelante y pasos hacia atrás con este tipo de prevenciones; GOMEZ MARÍN, V., "Artículo 31 bis CP”, Op. Cit., página 134; MIR PUIG, Santiago, Derecho 
Nos sumamos a esta inicial perplejidad de la doctrina: parece contradictorio que por un lado la LO 5/2010 asuma en esta materia una independencia y autonomía de responsabilidades penales (de la física y la jurídica) y por otro, vincule, finalmente, las penas de multas que se aplican a ambas cuando exige al juzgador modularlas y equilibrarlas entre ellas.

Se ha intentado resolver el dilema considerando que el sistema revita situaciones de bis in ídem en casos de pequeñas empresas en las que el capital de la persona jurídica y el de la persona física del administrador coincidan sustancialmente ${ }^{686}$. Empero no convence esa solución (que se queda a medias, aunque coincidimos con el rumbo que toma la misma) porque si aceptamos, como lo hemos hecho, que son dos sujetos de Derecho Penal diferentes, por hechos diferentes y con fundamento jurídico también diferente, no tendría razón la modulación entre ellas de dos penas impuestas. Además, r̃si estuviésemos ante un bis in ídem, es obvio que la previsión de modulación de la cuantía de la multa sería a todas luces insuficiente para evitar los problemas de constitucionalidad que se habrían planteado $0^{687}$, pues no es la consecuencia sino la propia asignación de responsable del delito lo que vulneraría el principio, y en su caso, no sería solamente las penas de multa las únicas dignas de modulación ${ }^{688}$.

¿Cuál podría ser una opción que integre este texto legal al sistema integral de responsabilidad penal de las personas jurídicas? Encontramos aquí el segundo fundamento de la inimputabilidad de las personas jurídicas.

Penal, parte general, Op. Cit., 2011, página 208; ZUGALDÍA ESPINAR, José Miguel, Fundamentos de Derecho Penal, Op. Cit., página 592.

686 GOMEZ MARÍN, V., "Artículo 31 bis CP", Op. Cit., página 134; MIR PUIG, Santiago, Derecho Penal, parte general, Op. Cit., 2011, página 208; ZUGALDÍA ESPINAR, José Miguel, Fundamentos de Derecho Penal, Op. Cit., página 592.

687 CARBONELL MATEU, Juan Carlos, "Responsabilidad penal de las personas jurídicas...", Op. Cit., página 30.

688 NIETO MARTÍN, Adán, “La responsabilidad penal de las personas jurídicas”, $O p$. Cit., página 11. 
Partamos, en principio, con los consensos.

a. La doctrina mayoritaria que admite la autorresponsabilidad del ente colectivo es consciente de que esta figura jurídica (31 bis 2 in fine) tiene la finalidad de evitar castigar a personas jurídicas ñopequeñasò

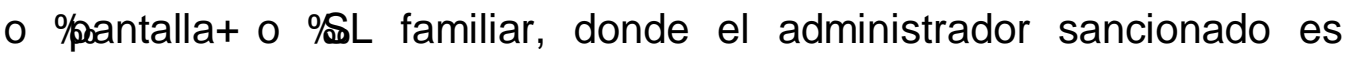
además uno de los tres socios de la empresaớ89.

b. Consecuentemente, es una figura que no tendría razón de ser ni aplicación alguna en personas jurídicas grandes y medianas ${ }^{690}$.

c. Esta figura podría ser explicable en aquellos casos en que la persona jurídica no pueda distinguirse, y en cambio, se confunda, con la o las personas físicas que la componen ${ }^{691}$.

De aquí podemos partir para afirmar que la doctrina mayoritaria que se ha ocupado del tema observa una relación directamente proporcional entre la cuantificación de la multa (pues puede ser modulada) con el tamaño de la persona jurídica. Pero creemos que podemos ir más allá: por las mismas razones, y por las que ya hemos expuesto, esa relación bien puede dar lugar a una no imposición de pena (límite mínimo de importancia de la persona jurídica) o a una nula o inexistente modulación de las penas (límite máximo de importancia, tamaño y complejidad de la persona jurídica), y entre ambos límites, la modulación de prevista en la figura jurídica (31 bis 2 in fine).

Los límites mínimo y máximo que significarían la no imposición de pena de multa o la no modulación de las pena deberá ser establecido en base a criterios normativos. Hace algunos pocos años Nieto Martín hablaba de un límite considerando el número de trabajadores de la empresa (desde 50 trabajadores ${ }^{692}$, según su

\footnotetext{
689 Vid. las cinco citas anteriores.

$690 \mathrm{Ib}$ Ídem.

691 CARBONELL MATEU, Juan Carlos, "Responsabilidad penal de las personas jurídicas...”, Op. Cit., página 30; o con sus respectivos patrimonios.

692 NIETO MARTÍN, Adán, La responsabilidad penal de las personas jurídicas, Op. Cit., página 168.
} 
propuesta de modelo legislativo). Leonard Orland, citado por Nieto, siguiendo la definición de sociedad anónima con capital disperso que se ofrece en los principios de gobierno corporativo del American Law Institute ñpropone restringir la sanción a aquellas sociedades que en la fecha de cierre del registro de socios de su más reciente junta general ordinaria de accionistas, contaran con 500 o más titulares registrados en sus títulos sociales y con cinco millones de dólares o más de activo totalò Hacemos votos para que esto pueda tomarse en sede legislativa, y no tanto caso por caso, que aunque daría lugar, sin duda alguna, a casos de injusticia manifiesta, por otro lado daría seguridad jurídica.

Ahora bien, si el límite mínimo significa imposibilidad de pena y el máximo imposibilidad de modulación (y por tanto, sanción de multa conforme la culpabilidad de cada uno de los responsables ï persona física y persona jurídica), la zona que se ubica entre ambos límites sería de semi imputabilidad o imputabilidad disminuida de la persona jurídica. La figura se equipararía, mutatis mutandi, a la de minoría de edad, pero con los efectos de una modulación de la pena de multa.

Aun así, no deja de causar extrañeza que en lugar de disminuir la pena de multa para la persona jurídica sin referencia a la pena de multa de la persona física, ambas dependan la una de la otra y la ley le provea al Juez o Tribunal de facultades de modulación. En todo caso, la solución deseable hubiese sido que sin referencia compensatoria a otra sanción, se hubiesen manejado esos límites máximo y mínimo con relación directa a su tamaño, complejidad e importancia de la organización.

Para terminar con este segundo fundamento, habría qué decir que no es de ninguna manera extraño esta manera de dar rendimiento a una figura jurídica hacia límites mínimos y máximos, para excluir y para incluir, y entre ellos, para graduar, pues es el mismo criterio que ha utilizado la doctrina dominante que admite la autorresponsabilidad cuando acredita la organización adecuada anterior a la comisión del 
delito no ya como una eximente, sino incluso como una eximente del mismo.

3. El tercer fundamento de la inimputabilidad lo observamos en la previsión que hace el art. $130.2 \mathrm{CP}^{693}$. Nos sumamos a la posición que ve y entiende que si una persona jurídica puede ser procesada y sancionada aun y cuando haya sido transformada, fusionada, absorbida o escindida, y por tanto, extinguida en su singularidad jurídica tal y como era antes de esos actos jurídicos, permanece con la misma identidad para efectos de su responsabilidad criminal. Misma perspectiva impera en el caso de la disolución encubierta o meramente aparente. Corolario a lo anterior es que no es la personalidad jurídica un requisito suficiente, sino solamente necesario, de identidad y definición del sujeto activo del delito de este nuevo sistema.

La aplicación de este artículo debe tener cabida, según lo apreciamos, no solo en la etapa de la imposición de la sanción, sino incluso desde el comienzo de la investigación, pasando por la imputación formal y el proceso penal, la sentencia y desde luego su ejecución. Ciertamente que el primer párrafo in fine del 130.2 CP parece referirse a la etapa de ejecución, cuando ya ha sido declarada responsable la persona jurídica del delito atribuido ( $\tilde{E} E l$ Juez o Tribunal podrá moderar el traslado de la pena a la persona jurídicad̀), pero en realidad solamente soluciona de manera expresa un caso problemático que le pareció importante al legislador, no obstante, con el mismo criterio habrá que resolver aquellos casos de transformación, fusión, absorción o escisión de una persona jurídica cuando haya de iniciarse una investigación o llevar el procedimiento penal haciendo valer los derechos fundamentales de la persona jurídica, lo mismo que en aquellos casos de disolución aparente o encubierta. Recordemos que estamos ubicados en el capítulo I del título VII, relativo a la extinción de la responsabilidad penal.

${ }^{693}$ El planteamiento y las soluciones de la doctrina las hemos planteado vid. supra capítulo V.5.2. 
No es, por tanto, únicamente el criterio formal de personalidad jurídica lo que debe importar en la construcción de la responsabilidad penal, si el límite final de la misma (su extinción) no es tampoco solo la extinción de dicha personalidad jurídica. Si el criterio legal para la identidad de la persona jurídica exige además uno de contenido material, como lo es, la identidad sustancial de clientes, proveedores y empleados, o de la parte más relevante de ellos, ese mismo criterio debe valer para dar inicio a su responsabilidad (así como para extinguirlo): Debe haber un punto de inicio en el que arribe o se incorpore el criterio material de identidad de la persona jurídica, pues el punto final ya lo hemos encontrado, y ese inicio no lo podemos ubicar más que en el momento de la configuración propia de la persona jurídica como sujeto de derecho penal.

Es decir, el límite final (la extinción de la responsabilidad del ente colectivo) lo ubicaremos, a contrario sensu, en el momento en que cambie sustancialmente su personalidad jurídica (transformación, fusión, absorción o escisión) adicionalmente a una disolución real que conlleve, necesariamente, la no continuación de su actividad económica y la no mantención de la identidad sustancial de sus clientes, proveedores y empleados 0 de la parte más relevante de ellos. Disolución formal más disolución material o económica. Si tenemos la primera pero no la segunda o viceversa, permanecerá la responsabilidad penal.

Pensamos, además, que se trata de un criterio sustancial de responsabilidad, porque se traduce en la identidad del sujeto activo del delito, esto es, relativo a los presupuestos materiales del sujeto de derecho. No tiene ni comulga de la misma naturaleza de los otros motivos de extinción de la responsabilidad penal que previene el mismo art. $130 \mathrm{CP}$, como lo son la muerte del reo, el cumplimiento de la condena, la remisión definitiva de la pena, el indulto, el perdón del ofendido, la prescripción del delito, o la prescripción de la pena o de la medida de seguridad. Estos motivos de extinción se explican en razón 
de que después de ocurrido el delito imputable a una persona específica, ocurre un suceso o un evento, que puede ser el simple transcurso del tiempo (ejecutándose o no la pena) o algún hecho o acto de un tercero o suceso de la naturaleza, de tal manera que no sería lógico exigir que fundamentaran la imputación criminal. Pero el del 130.2 CP, precisamente por predicar las consecuencias jurídicas (la no extinción de responsabilidad penal) a pesar de que haya ocurrido un evento jurídico (transformación, fusión o disolución encubierta, etcétera), permite interpretarlo no solo como ñun precepto aislado que pretende, precisamente, aportar soluciones materiales para afrontar un problema muy concreto que presenta la opción formal de partida del art. 31 bisơ $^{694}$, sino como un criterio orientador del sistema general de responsabilidad penal de los entes colectivos que sí permite crear una categoría. Es imposible explicar el sistema integral de responsabilidad penal, y específicamente los requisitos materiales que configuran al sujeto activo de responsabilidad penal de las personas jurídicas, sin contar con dicho precepto; y es imposible afirmar que es suficiente la personalidad jurídica para construir al sujeto de derecho penal, cuando el 130.2 CP contradice esa aserción.

4. Pero todavía tenemos un cuarto argumento, ya no dogmático penal, sino de política criminal, para sostener esta opción interpretativa a la que nos hemos sumado.

La opción que se elija en la aplicación práctica y diaria del sistema de responsabilidad de los entes colectivos por parte de los Jueces y Tribunales reflejará el rendimiento y funcionalidad de aquel sistema imaginado por la doctrina española desde hace varios años. El ñmundo al revésò del que hablaba Zugaldía representó (y debe seguir representando) un ícono de qué es lo que se pretendía con un sistema penal de entes colectivos: las grandes compañías o empresas que

694 FEIJOO SÁNCHEZ, Bernardo, "La responsabilidad penal de las personas jurídicas”, Op. Cit., página 73, quien está a favor del criterio exclusivamente formal para la definición de los sujetos activos del delito en el sistema de responsabilidad criminal de los entes colectivos 
tienen la más grande potencialidad lesiva para un gran número de bienes jurídicos individuales y colectivos no son perseguidos criminalmente por ser personas jurídicas, pero al individuo r̃de a pieò que comete un delito de bagatela se le pueden privar de su libertad. La ráctitud criminal de grupoòy la irresponsabilidad estructural organizada (por la descentralización de las funciones de información, decisión y operación en una empresa de cierto tamaño y complejidad) son otros lugares comunes que ocuparon la razón que justificó la exigencia de ese nuevo sistema.

El sistema de responsabilidad penal de las personas jurídicas nunca fue pensado para hacer frente a los out puts dañosos o lesivos de las pequeñas agrupaciones de personas con personalidad jurídica diferente a sus miembros. Para ello basta y sobra el Derecho Penal tradicional. El nuevo sistema penal de personas jurídicas debe cubrir necesidades político criminales que no satisface ni responde adecuadamente el Derecho Penal de las personas físicas.

Si en la opción interpretativa de la legislación española de responsabilidad penal de personas jurídicas se incluyen a las de pequeño tamaño y sin complejidad, que no tienen r̃organizaciónòy por tanto de ellas no se puede predicar defecto alguno ï porque las decisiones, informaciones y operaciones se pueden imputar a una o dos personas físicas-, se corre el riesgo de sobreexplotar el sistema que con seguridad, en la práctica diaria, se aplicaría única y exclusivamente (o por lo menos, preponderantemente) a las personas jurídicas pequeñas, sin complejidad, identificadas con sus dueños, y en cambio, se dejaría de cubrir aquellos mismos resultados lesivos y dañosos de las grandes empresas. No tiene ningún caso tener dos sistemas de responsabilidad penal cuando uno de ellos (el de las personas físicas) puede seguir cumpliendo las funciones criminógenas reales que finalmente se consiguen con ambos.

Que la posibilidad dogmática penal de aplicación a personas jurídicas pequeñas y sin complejidad puede fracturar en dos al sistema 
(uno contra ellas y otro contra las empresas de cierto tamaño y complejidad y de cierta potencialidad lesiva) sobreexplotando el primero y reduciendo al mínimo el segundo, no es una petición de principio, sino lecciones aprendidas y derivadas del Derecho Penal individual. Baste decir que el primer auto de procesamiento dictado a una persona jurídica ${ }^{695}$ el mismo día en que entró en vigor el estatuto procesal para el sistema de responsabilidad penal de las personas jurídicas, declaró formalmente procesados a seis personas físicas y cinco personas jurídicas ${ }^{696}$, de las que las personas físicas tenían una vinculación muy especial: una de esas personas físicas era ĩsocio únicoò f̂̃undadoròy radministradorò en cuatro de ellas, y los otros aparecían, alternativamente, como socios o administradores, según lo dice la propia resolución ${ }^{697}$.

Abramos un paréntesis en este punto para comentar el auto judicial aludido. Cuando Neira Pena ${ }^{698}$ da cuenta de él y lo analiza, encuentra algunos problemas procesales que tienen su origen en el tópico que nosotros estamos disertando, como lo es, rel presupuesto

695 Auto de procesamiento dictado dentro del Recurso número 19/2011, dictado por el Juzgado Central de Instrucción número 6º, de 11 de octubre de 2011, con número de identificación del Centro de Identificación documental 28079270062011200001.

696 Según la parte dispositiva de la decisión judicial, se dice: "SE DECLARA PROCESADOS por esta causa y sujeta a sus resultas a Carlos Alberto, Juan Alberto, Rebeca, Gabriel @ Largo, Desiderio y Matías, así como de las personas jurídicas TRANSPINELO SL, "INVESTISSEMENT TRANS SPAIN ÁFRICA SA" (ITSA.), "MULTISERVICIOS Y MAQUINARIA O. P.", J y M. C. A "JOYMACA" y GEORMADRID MACHINERY SL como responsables de un DELITO CONTRA LA SALUD PÚBLICA, con la agravante de ser la COCAÍNA de notorísima cantidad..."

697 "Carlos Alberto @ Botines, Administrador y socio único de la empresa GEORMADRID MACHINERY SL. (CIF. B-85619781), reimportadora destinataria de las máquinas que traían la droga a España, y además, apoderado de la empresa INVESTISSEMENT TRANS SPAIN ÁFRICA (ITSA)... TRANSPINELO SLU. (Administrador único Matías), "INVESTISSEMENT TRANS SPAIN ÁFRICA SA" (ITSA.,) (Administradores Vicente e Agustín, y Apoderado Carlos Alberto, @ "Botines"), "MULTISERVICIOS Y MAQUINARIA O. P." (RIF, CIF venezolano, J29893674-6, Presidenta Noelia), J y M. C. A "JOYMACA", (Administrador venezolano: Gerónimo) y GEORMADRID MACHINERY SL (Administrador y socio único Carlos Alberto, @ "Botines") conformaron el entramado societario indicado bajo la cobertura de una operación comercial de reexportación, que no tenía otra finalidad que traer la droga a España".

698 NEIRA PENA, Ana, "Primer auto de procesamiento contra personas jurídicas", en Diario La Ley, Número 7768, de 3 de enero de 2012, pássim. 
procesal de la capacidad para ser parte, del cual depende la posibilidad misma de aplicar el régimen de responsabilidad de las personas jurídicas a un supuesto como el planteado, en el que las entidades mercantiles procesadas no son más que sociedades pantalla, sin una actividad real lícitaợ9, y auxiliándose de los criterios expuestos por la Circular 1/2011 de la FGE resuelve el problema dando, según nosotros, en el clavo: ñnsiste en esa doble vía: por un lado opta por el levantamiento del velo cuando estamos ante una sociedad pantalla y por otro reserva el régimen de responsabilidad penal de las personas jurídicas para cuando realmente existe alteridad entre los sujetos, persona física y persona jurídica, sin ser la última una mera tapadera de las actividades delictivas ideadas por la primeraơo ${ }^{00}$.

En efecto, alteridad, no tanto sociedad pantalla, es la clave de la solución.

Alteridad es la capacidad de desdoblarse, de comunicarse 0 ejercer entendimiento desde la perspectiva de otra persona, esto es, la existencia de dos personas y no ya de una sola. Existe alteridad en una persona jurídica cuando, como lo dijo Peter French, ñas organizaciones sólo pueden ser consideradas entes morales, cuando desarrollan estructuras internas propias para la toma de decisiones empresariales; si no es así, únicamente existe una agregación de personas, donde los actos e intenciones de la colectividad son reconducibles a sus miembrosơo1 ${ }^{01}$ La propia Fiscalía General del Estado abunda al respecto al decir ren los casos en los que se detecte la existencia de sociedades pantalla o de fachada, caracterizadas por la ausencia de verdadera actividad, organización, infraestructura propia, patrimonio etc., utilizadas como herramientas del delito o para dificultar su investigación, nada obsta a recurrir bien a la figura de la simulación contractual, bien a la doctrina del levantamiento del veloò Debemos destacar que la Fiscalía

${ }^{699} \mathrm{Ib}$ Ídem, página 2.

$700 \mathrm{Ib}$ Ídem, página 3 y 4.

701 Citado por NIETO MARTíN, Adán, "La responsabilidad penal de las personas jurídicas", Op. Cit., página 168. 
se separa del criterio formal para incluir uno material: ausencia (o presencia) de verdadera actividad, organización, infraestructura propia, patrimonio etc. Sigue diciendo que ra pesar de que desde el punto de vista estrictamente formal, una empresa pantalla puede gozar de personalidad jurídica y por tanto, ser potencial responsable de conductas delictivas conforme al artículo 31 bis del Código Penal, en los aludidos supuestos de abuso de la forma social, se ajustarán más a la realidad las opciones apuntadas en la medida en que posibilitan la imputación directa de las personas físicas por los delitos cometidos tras el manto de opacidad que otorga la sociedad ficticiaơo2.

Queremos decir que estamos totalmente de acuerdo con la solución anterior a la problemática comentada, pero no así con el fundamento de la misma. Si no se reconoce la categoría jurídico penal de la inimputabilidad de las personas jurídicas derivada de la interpretación de los arts. 31 bis y el defecto de organización como piedra angular del sistema (el 31 bis 3 in fine, y el 130.2 CP), entonces las soluciones a esos casos (como el del primer auto de procesamiento apuntado) no tendrían asidero legal alguno para evitar criminalizar a personas jurídicas pantallas o truchas.

Con esto, cerramos el paréntesis.

Si queremos evitar la sobreexplotación del Derecho Penal de las personas jurídicas y resultados indeseables en la actuación de las instituciones de procuración y administración de justicia, se hace menester afianzar la opción interpretativa que proponemos.

Es cierto que las necesidades de política criminal, como la que hemos expuesto, no pueden por sí solas justificar y legitimar una opción interpretativa de la ley; sin embargo, lo que proponemos no es un criterio contra legem, sino todo lo contrario, derivado de la interpretación armónica y apoyado en ella. Más bien deberíamos replicar diciendo que si todas las personas jurídicas serían sujetos del nuevo subsistema de 
derecho penal, entonces podría reputarse contra legem la opción contraria.

\section{PERSONAS JURÍDICAS EXCLUÍDAS}

Uno de los aspectos de la reforma del 2010 es el relativo a la decisión legislativa de excluir determinadas personas jurídicas. El apartado 5 del art. 31 bis CP establece:

Las disposiciones relativas a la responsabilidad penal de las personas jurídicas no serán aplicables al Estado, a las Administraciones Públicas territoriales e institucionales, a los Organismos Reguladores, las Agencias y Entidades Públicas Empresariales, a los partidos políticos y sindicatos, a las organizaciones internacionales de derecho público, ni a aquellas otras que ejerzan potestades públicas de soberanía, administrativas o cuando se trate de Sociedades mercantiles Estatales o ejecuten políticas públicas o presten servicios de interés económico general.

El ap. 5 del art. 31 bis CP no apareció siempre en las anteriores propuestas de reforma al CP, pues ni en el Anteproyecto de 2006, ni el Proyecto de reforma de 2007, ni el Anteproyecto de 2008 excluían expresamente a los partidos políticos y sindicatos del régimen de responsabilidad penal de las personas jurídicas. De hecho, en el Informe al Anteproyecto de Ley Orgánica que modificaba la diversa 10/1995 realizado por el Consejo General del Poder Judicial aprobado en sesión del 18 de febrero de 2009, se analiza un proyecto de reforma en el que se puede encontrar un ap. 5 que solo decía r̃as disposiciones relativas a la responsabilidad penal de las personas jurídicas se aplicarán a las asociaciones, las fundaciones y las 
sociedadesô excluyendo a ciertas organizaciones pero no expresamente a las que el vigente ha excluido.

Es recomendable tratar de forma diferenciada las diferentes categorías de entidades que se encuentran excluidas de responsabilidad penal, pues no resultan ser homogéneas las razones 0 justificaciones de exclusión que se pueden argüir en cada caso.

\subsection{Estado, Administraciones Públicas territoriales e institucionales y organismos reguladores}

La doctrina mayoritaria ha explicado y justificado la exclusión en el caso del Estado y las Administraciones Públicas y organismos públicos $^{703}$, pareciéndole renteramente razonable ${ }^{04}$, aunque no todos consideran tan claras las razones de política criminal de esta exclusión ${ }^{705}$. Inicialmente ven justificado que las instituciones públicas no sean penalmente responsables por la r̃elevancia constitucional de la funciónòamén de que la r̃multa incidiría negativamente en la capacidad para la correcta prestación de las funciones que tienen encomendadasơo6 ${ }^{06}$, porque es imposible que se les pueda atribuir un defecto de organización r̃dada su total sujeción a la leyỡ ${ }^{07}$. No obstante, esta justificación m̃o puede ocultaré que es concebible también responsabilidad penal en relación con algunas Administraciones (por ejemplo, un Ayuntamiento) partidos y sindicatos. Los Ayuntamientos

703 BACIGALUPO S., Silvina, “La responsabilidad...”, Op. Cit., página 9; GIL GIL, Alicia y otros, Op. Cit., página 1073 y 1074; LANDACHE VELASCO, Op. Cit., página 265; LOPEZ BARJA DE QUIROGA, Op. Cit., página 402; MANZANARES SAMANIEGO, Op. Cit., página 399.

${ }^{704}$ CARBONELL MATEU, Juan Carlos, “Responsabilidad penal...”, Op. Cit., página 30, le parece razonable en "la medida en que no es imaginable que el Estado cometa delitos contra sí mismo y aún menos que se autoaplique pena de clase alguna".

705 BERDUGO GÓMEZ DE LA TORRES, Op. Cit., página 554; y NIETO MARTÍN, Adán, “La responsabilidad penal...", Op. Cit., página 12.

706 MIR PUIG, Santiago, Op. Cit., 2011, página 203, y GOMEZ MARÍN, V., "Artículo 31 bis CP”, Op. Cit., página 131.

707 DE LA CUESTA ARZAMENDI, José Luis, "Responsabilidad penal de las personas jurídicas en el derecho español”, Op. Cit., página 20. 
pueden ser disueltos, al igual que los Consejos y Cabildos Insulares y Diputaciones Provinciales, si su gestión es dañosa para los intereses generalesơo ${ }^{08}$.

Los países que han excluido al Estado y las instituciones de la Administración Pública Estatal han sido la mayoría; entre ellos, podemos citar a Francia, Italia, Suiza, Dinamarca y Portugal, por lo que España se ha unido a la corriente mayoritaria continental. La mayoría de las directivas y decisiones marco, en el derecho penal europeo, expresamente definen al sujeto activo del nuevo sistema represivo que proponen como ñoda persona jurídica conforme al Derecho interno aplicable, a excepción de los Estados u organismos públicos que actúen en el ejercicio de la potestad del Estado y de las organizaciones internacionales públicasơog. En Chile, el art. 2 de la Ley 20.393 limita la responsabilidad penal solamente a las personas privadas y a las empresas del Estado, y en México, la iniciativa de reforma de 14 de abril de 2011 solamente reserva la responsabilidad penal a las personas jurídicas r̃de naturaleza privadaò Como sea, estas decisiones legislativas obedecen, como dice Gómez-Jara, rã la concepción del Estado que impere en un determinado paísò de forma tal que las más liberales, como son las de familia anglosajona (EUA y RU) no ven ningún problema en ñncluir a las entidades estatales entre los destinatarios de la responsabilidad penal de las personas jurídicasơ ${ }^{10}$.

Causa extrañeza que el legislador haya excluido del sistema penal a las personas jurídicas de carácter público, pero sí las incluya en el ius puniendi administrativo, pues ñparece en la actualidad consolidada la doctrina conforme a la cual pueden ser sujetos activos

\footnotetext{
708 QUINTERO OLIVARES, Gonzalo, "Artículo 31 bis", en QUINTERO OLIVARES, Gonzalo (Dir.), MORALES PRATS, Fermín (Coord.), Comentarios al Código Penal Español, Thomson Reuters, Navarra, 2011, página 387.

709 Art. 2 de la Directiva Marco 2008/99/CE del Parlamento Europeo y del Consejo, de 19 de noviembre, relativa a la protección del medio ambiente mediante el Derecho penal.

710 GOMEZ-JARA DIEZ, Carlos, La responsabilidad penal..., Op. Cit., página 53.
} 
de infracciones administrativas personas jurídico públicasơo ${ }^{11}$, como lo muestra la STS de 7 de noviembre de 2007. El argumento de que la sanción a la Administración Pública la pagaba finalmente la ciudadanía es solo ilusión si consideramos que en realidad se p̃produciría un trasvase de fondos de una parte del Estado a otrao ${ }^{12}$.

El Estado español y las Administraciones Públicas territoriales e institucionales son aquellas que se encuentran descritas en la Ley Orgánica 6/1997, de 14 de abril, de Funcionamiento de la Administración General del Estado (LOFAGE).

\subsection{Los organismos reguladores y las Agencias Estatales}

Los organismos reguladores son aquellos expuestos en la Disposición Adicional Sexta de la Ley de la Jurisdicción ContenciosaAdministrativa y en cada una de las leyes reguladoras de los mercados intervenidos donde existen estos organismos ${ }^{713}$, como pueden ser, el Banco de España, Comisión de Mercado de las Telecomunicaciones, Comisión Nacional del Mercado de Valores, Comisión Nacional de Competencia, Comisión Nacional del Sector Postal, Comisión Nacional de Energía, entre otros.

Mientras que las Agencias Estatales están reguladas en la Ley 28/2006 de 18 de junio, de agencias estatales para la mejora de los servicios públicos, y son rentidades de Derecho público, dotadas de personalidad jurídica pública, patrimonio propio y autonomía en su gestión, facultadas para ejercer potestades administrativas, que son creadas por el Gobierno para el cumplimiento de los programas correspondientes a las políticas públicas que desarrolle la Administración General del Estado en el ámbito de sus competenciasò

711 GÓMEZ TOMILLO, Manuel, Introducción a la responsabilidad penal..., Op. Cit., página 42.

$712 \mathrm{Ib}$ Ídem, página 41.

713 ZUGALDÍA ESPINAR, José Miguel, La responsabilidad criminal de los entes..., Op. Cit., página 66. 
atendiendo a la definición del art. 2.1 de la misma Ley. Son ejemplos de Agencias Estatales las que se enumeran en las disposiciones adicionales segunda y tercera: Agencia Estatal Boletín Oficial del Estado, Consejo Superior de Investigaciones Científicas, para el fomento, coordinación, desarrollo y difusión de la investigación científica y tecnológica, de carácter pluridisciplinar, Agencia Estatal Antidopaje de España, Agencia Estatal de Seguridad Aérea, Agencia Estatal de Seguridad del Transporte Terrestre, Agencia Española de Cooperación Internacional para el Desarrollo, Agencia Estatal de Investigación en Biomedicina y Ciencias de la Salud Carlos III, Agencia Estatal de Evaluación, Financiación y Prospectiva de la Investigación Científica y Técnica.

\subsection{Organizaciones internacionales de derecho público}

Se trata de aquellos organismos públicos internacionales que expresamente fueron excluidos de las Decisiones Marco y Directivas de la Unión Europea. El Fondo Monetario Internacional, la Organización Mundial de la Salud, la Organización Internacional del Trabajo, Tribunales Internacionales, serían ejemplos de esta clase de organizaciones, lo mismo que otras entidades como los Estados extranjeros y entidades dependientes de ellos en el plano internacional $^{714}$.

\subsection{Entidades públicas empresariales}

Es el capítulo III del título III de la Ley 6/1997, de 14 de abril, de Organización y Funcionamiento de la Administración General del Estado, el que regula las entidades públicas empresariales. El art. 166.1,a) de la Ley 33/2003, de 3 de noviembre, del Patrimonio de las

714 ZUGALDÍA ESPINAR, José Miguel, La responsabilidad criminal de los entes..., Op. Cit., página 67. 
Administraciones Públicas solamente establece las bases de regulación del patrimonio empresarial de la Administración General del Estado.

El art. 53.1 de la Ley 6/1997 establece qué son las entidades públicas empresariales y las define como ñOrganismos públicos a los que se encomienda la realización de actividades prestacionales, la gestión de servicios o la producción de bienes de interés público susceptibles de contraprestaciónò el apartado 2 previene que r̃se rigen por el Derecho privado, excepto en la formación de la voluntad de sus órganos, en el ejercicio de las potestades administrativas que tengan atribuidas y en los aspectos específicamente regulados para las mismas en esta Lev, en sus estatutos y en la legislaci6n presupuestariaò

Podemos enumerar, entre otras, el Administrador de Infraestructuras Ferroviarias, el Centro para el Desarrollo Tecnológico Industrial y la Fábrica Nacional de Moneda y Timbre.

\subsection{Sociedades mercantiles Estatales que ejecuten} políticas públicas o presenten servicios de interés económico general

Este término es casi exactamente el que utiliza el art. 30.3 de la Ley 33/2003, de 3 de noviembre del Patrimonio de las Administraciones Públicas, para efecto de limitar la ejecución o embargo de bienes que se encuentren afectados al servicio público o sobre valores o títulos representativos de esta clase de sociedades, lo que ha sido interpretado como la razón para excluir estas empresas del ámbito de persecución penal ${ }^{715}$.

Sostenemos, con la doctrina que ha atendido esta problemática, que solamente serán excluidas las sociedades mercantiles estatales en

715 ZUGALDÍA ESPINAR, José Miguel, La responsabilidad criminal de los entes..., Op. Cit., página 68. 
la medida en que ejecuten políticas públicas o presten servicios de interés económico general, pues esta es, y no otra, la razón de su exclusión ${ }^{716}$, aunque ciertamente uno de los problemas estaría en delimitar qué es lo que se entiende por políticas públicas o servicios de interés general ${ }^{717}$. Otra de las cuestiones es si se va a inmunizar totalmente a la sociedad mercantil estatal totalmente de cualquier tipo de actividades que realice, o, en su caso, podrá serle de aplicación el nuevo sistema penal de personas jurídicas nada más en la parte de dicha sociedad que realice actividades de ejecución de políticas públicas o de prestación de servicios de interés económico general. A Feijóo le parece claro que la sociedades mercantiles estatales deberían considerarse como ñpersonas jurídicas como sujetos de imputaciónō̄18, y por tanto, incluirse como sujetos activos del nuevo subsistema de derecho penal; pero matiza la opción al recomendar que la propuesta m̃ás razonable sería optar por penas que no afectaran al sector de interés públicoơ ${ }^{19}$, como la pena de disolución, sino mejor aquellas otras que afectaran solo sectorialmente a la persona jurídica, como la prohibición de ejercer determinadas actividades.

Nosotros entendemos que es preferible ser consecuente con el texto de la ley que indica que las disposiciones de la reforma m̃o serán aplicablesò a este tipo de sociedades. La opción anterior sería contra legem y resolvería el problema de forma muy distinta a la que la ley expresamente ha señalado. La ley ha definido a los sujetos de derecho penal a excluir mediante criterios formales y materiales, pero una vez definidos habríamos de ser consecuentes, y no incluirles pero con penas que no afecten su función. Como dice Zugaldía r̃su exclusión del ámbito de los sujetos penalmente responsables no es por razón de la

\footnotetext{
${ }^{716}$ Así la Circular 1/2010 de la FGE; NIETO MARTÍN, Adán, “La responsabilidad penal...", Op. Cit., página 12; y ZUGALDÍA ESPINAR, José Miguel, La responsabilidad criminal de los entes..., Op. Cit., página 66.

717 NIETO MARTÍN, Adán, "La responsabilidad penal...", Op. Cit., página 12, quien se pregunta "¿La gestión de un parking es un servicio de interés general?, ¿Puede considerarse una política pública la explotación de una mina?".

718 FEIJÓo SÁNCHEZ, Bernardo, “La responsabilidad penal...”, Op. Cit., página 77. ${ }^{719} \mathrm{Ib}$ Ídem.
} 
persona ï no es por r̃seròCorreos o RTVE- sino por razón de su objeto (aunque en el caso concreto la conducta delictiva sea ajena a dichas actividades y se encuentre vinculada a otras actividades que la empresa realice en régimen de libre competencia en el mercado, pues difícilmente la decisión judicial podría no afectar a la consecución de los intereses públicos generales) ${ }^{\not 20}$.

\subsection{Partidos Políticos y Sindicatos}

1. El legislador de 2010 ha podido hacer coincidentes las opiniones de la doctrina dominante en torno al rechazo de la exclusión de los partidos políticos y sindicatos de la responsabilidad penal del sistema del art. 31 bis $\mathrm{CP}^{721}$.

Aun y cuando los partidos políticos respondan electoralmente ante sus electores de sus infracciones y que haya la Ley Orgánica 6/2002, de 27 de junio, de Partidos Políticos que impone verdaderas penas, incluso la disolución o la suspensión judicial, Quintero Olivares se muestra crítico contra dicha exclusión porque m̃o hay razonamiento objetivo que permita sostener que, siempre que se acoja la posibilidad de responsabilidad penal de persona jurídica, sea imposible la comisión de delitos por partidos políticosō ${ }^{22}$; exclusión que se rechaza todavía más por lo que hace a los sindicatos de los que m̃adie recuerda que se

720 ZUGALDÍA ESPINAR, José Miguel, La responsabilidad criminal de los entes..., Op. Cit., página 68.

721 BERDUGO GÓMEZ DE LA TORRES, Op. Cit., página 554; y NIETO MARTíN, Adán, "La responsabilidad penal...", Op. Cit., página 554; DÍAZ GÓMEZ, Andrés, "La responsabilidad criminal de las personas jurídicas", Op. Cit., página 48; DIEZ RIPOLLÉS, José Luis, "La responsabilidad penal...", Op. Cit., página 11; FEIJÓO SÁNCHEZ, Bernardo, "La responsabilidad penal...", Op. Cit., página 77; GOMEZJARA DIEZ, Carlos, La responsabilidad penal...", Op. Cit., página 53; MORILLAS CUEVA, Lorenzo, Op. Cit., página 14; NIETO MARTÍN, Adán, "La responsabilidad penal...", Op. Cit., página 12; QUINTERO OLIVARES, Gonzalo, "Artículo 31 bis", $O p$. Cit., página 387 y 388; y URRAZA, José, “La responsabilidad criminal...", Op. Cit., página 4.

722 QUINTERO OLIVARES, Gonzalo, “Artículo 31 bis”, Op. Cit., página 387. 
haya ni siquiera intentado exigir esa responsabilidadō ${ }^{23}$. No es entendible, entonces esa exclusión, sin embargo es posible percibir un aroma a evitar confrontaciones derivadas de ñpersecuciones políticasơ ${ }^{24}$.

2. No obstante, rechazando la decisión legislativa y con el deber de interpretar la justificación dogmática de esa exclusión, la doctrina se ha pronunciado que se debe porque se ñrata de entidades que forman parte fundamental del sistema político español que, sin duda, dan cauce al ejercicio de derechos fundamentales y libertades públicas; y por ello, deben ser objeto de una especial protección y no pueden ser tratadas como cualquiera otras personas jurídicasơ ${ }^{25}$.

Las funciones constitucionales que pueden cumplir estas organizaciones, a las que se refiere la doctrina mayoritaria en el caso de sindicatos y partidos políticos, se encuentran previstas en el art. 6 CE que señala que ños partidos políticos expresan el pluralismo político, concurren a la formación y manifestación de la voluntad popular y son instrumento fundamental para la participación política. Su creación y el ejercicio de su actividad son libres dentro del respeto a la Constitución y a la ley. Su estructura interna y funcionamiento deberán ser democráticosò y en el art. 7 CE que previene que ños sindicatos de trabajadores y las asociaciones empresariales contribuyen a la defensa y promoción de los intereses económicos y sociales que les son propios. Su creación y el ejercicio de su actividad son libres dentro del respeto a la Constitución y a la ley. Su estructura interna y funcionamiento deberán ser democráticosò

\footnotetext{
723 Ib Ídem, página 388.

${ }^{724}$ GOMEZ-JARA DIEZ, Carlos, “La responsabilidad penal...”, Op. Cit., página 2.

725 DOPICO GÓMEZ-ALLER, Jacobo, Op. Cit., página 15. Aunque también reconoce que la experiencia registra "graves irregularidades en materia electoral y de financiación de los partidos políticos que requieren se adopten medidas sancionadoras más serias" de las que se aplican, exigiendo la adopción de un "régimen híbrido" que permitiera la imposición exclusiva de penas, no así de suspensión o disolución de la persona jurídica.
} 
3. Pese a lo anterior, hay quien dice que no debe admitirse una inmunidad total y absoluta de sindicatos y partidos políticos, sino que debe atenderse a un criterio material para discernir en qué casos una organización puede ejercer las funciones constitucionales que le han sido encomendadas. De ahí que se afirme que, a tono con la doble personalidad del Estado, cuando actúan t̂acia el exteriorò entonces cumplen su fin constitucional y son inmunes al ius puniendi del Estado ${ }^{726}$; en cambio, cuando lo hacen thacia el interiorò podrían ser perfectamente sujetos del nuevo sistema de Derecho Penal ${ }^{727}$, como sucede cuando los partidos políticos o sindicatos hacen ñposible su funcionamiento o financiaciónò cuando contratan a personal administrativo, o a cualquier trabajador operario. Esta opción interpretativa, que permite aplicarles el art. 31 bis CP a esas organizaciones cuando actúan t̃acia el interiorò es una ñnterpretación restrictiva de la excepción que no constituye analogía contra reo, esto es, no supone llevar el tipo más allá de donde lo permite la letra de la leyơ ${ }^{28}$, dicen.

En nuestra opinión no convence esta solución. Debemos de tener en cuenta que el apartado 5 del art. 31 bis CP deja una posición clara y manifiesta de crear inmunidades a cierta clase o categoría de personas jurídicas, precisamente porque cumplen determinadas funciones de importancia capital para el adecuado funcionamiento del Estado. No puede decirse que en ningún caso de los enumerados en el texto de ley las exclusiones (o inmunidades) de las clases o categorías de personas jurídicas se mantengan o se pierdan por las actividades que realicen o puedan realizar. Incluso en el caso (único caso con fundamento de exclusión polémico) de Sociedades mercantiles Estatales, la exclusión (o inmunidad) se adquiere por el hecho de ejercitar políticas públicas o prestar servicios de interés económico

726 ZUGALDÍA ESPINAR, José Miguel, “La ampliación del sujeto del Derecho Penal: entes colectivos susceptibles de ser penados conforme a los artículos 31 bis y 129 del Código Penal", en Libro Homenaje al Profesor Luis Rodríguez Ramos, página 8, y el mismo, La responsabilidad criminal de los entes colectivos...", Op. Cit., página 70. 727 Ib Ídem. 728 Ib Ídem. 
general, y no tanto en la medida (y exclusivamente en los actos que) se ejerciten o presten dichas actividades. La calidad de partido político o sindicato, que es la única variable que interesa a la ley, no se pierde cuando realiza actos administrativos, de financiación o de contratación laboral.

Por ello, creemos una interpretación que incluya a personas jurídicas en la responsabilidad penal cuando están expresamente excluidas es una interpretación contra legem. La asignación de razones de política criminal que fundamenta la exclusión del sujeto en el sistema de Derecho Penal de las personas jurídicas (partidos políticos y sindicatos), intenta generar ciertas bases materiales para resolver problemas de interpretación presentes o futuros, pero no pueden ir contra el texto expreso de la ley. Por lo demás, el caso de los sindicatos y partidos políticos comparte las razones que hemos expuesto para no excluir a ciertas Sociedades mercantiles Estatales: ranunque en el caso concreto la conducta delictiva sea ajena a dichas actividades y se encuentre vinculada a otras actividades que la empresa realice en régimen de libre competencia en el mercado, pues difícilmente la decisión judicial podría no afectar a la consecución de los intereses públicos generalesỡ ${ }^{29}$. Además, sería realmente difícil afirmar que determinado acto, aunque sea de aquellos ejercitados thacia el interiorò de un partido político o sindicato, no tenga relación directa o indirecta con su objeto y funciones legales y constitucionales.

Si la interpretación en cuya contra nos pronunciamos resultare aceptable, nada impediría que igual solución se diera al caso en que el Estado o las Administraciones Públicas territoriales o institucionales (de las que nadie duda su exclusión en ningún caso) pudieran ser también sujetos del nuevo sistema de responsabilidad penal de los entes en los casos en que actuarán en ejercicio de derechos de carácter privado o mercantil, lo que ya debe rechazarse.

${ }^{729}$ ZUGALDÍA ESPINAR, José Miguel, La responsabilidad criminal de los entes..., Op. Cit., página 68. 
Corolario a lo anterior, entendemos que siempre y en todos los casos los partidos políticos y los sindicatos, siendo sujetos expresamente excluidos, deberán así permanecer sin importar la cualidad o características de los actos que realicen o ejerciten.

4. En otro orden de ideas, se plantea el caso del incumplimiento del estado español del orden jurídico de la Unión Europea y, en el caso de que sea afirmativo, los efectos de ese incumplimiento, en lo relativo a la exclusión de responsabilidad criminal de sindicatos y partidos políticos ${ }^{730}$. Valls Prieto ha llamado la atención respecto que la reforma de 2010, al extender la excepción de responsabilidad penal a las personas jurídicas llamadas sindicatos y partidos políticos, está en realidad incumpliendo con las directivas y decisiones marco a las que el Estado español se ha comprometido, basándose en tres premisas: por lo menos una decisión marco y una directiva sí exigía a España la obligación de prevenir una responsabilidad penal, y no tan solo administrativa, para las personas jurídicas; que la concepción de p̃persona jurídicaòen los compromisos europeos incluyen a los partidos políticos y a los sindicatos, pues no puede predicarse de ellos que sean el ŕEstado, u organismos públicos en ejercicio de potestad del Estado u organizaciones internacionales públicasò y que el estado español extendió la excepción de las personas jurídicas inmunes a la responsabilidad criminal, incorrectamente y contra los compromisos de la Unión Europea, a los sindicatos y partidos políticos, lo que permite hablar de un incumplimiento ${ }^{731}$. Es importante analizar esta postura.

En efecto, según el contenido de la mayoría de las decisiones marco y directivas que hemos comentado supra ${ }^{732}$, la persona jurídica, motivo y objeto de la responsabilidad penal de las mismas, era definida como r̃ ualquier entidad que goce de tal régimen jurídico con arreglo al

\footnotetext{
730 VALLS PRIETO, Javier, "Las exenciones de la responsabilidad penal de las personas jurídicas. ¿Son responsables los partidos políticos y sindicatos?”, en Cuadernos de Política Criminal, Segunda Época, II, Número 104, 2011, página 109 y pássim.

731 Ib Ídem, pássim.

732 Vid. Primera parte, Capítulo IV, D.
} 
Derecho nacional aplicable, con la excepción de los Estados u otros organismos públicos en el ejercicio de sus prerrogativas como poderes públicos y de las organizaciones internacionales públicasò de forma tal, que pareciera ser que los compromisos internacionales de España la obligaban a incluir a toda persona jurídica menos el Estados, organismos públicos y organizaciones públicas internacionales. Sin embargo, en forma precisa y específica ni la Decisión Marco 2002/475/JAI de 13 de junio sobre la lucha contra el terrorismo, ni la decisión Marco 2008/919/JAI del Consejo de 28 de noviembre de 2008 por la que se modifica la decisión marco anterior, definen o establecen lo que debe entenderse por ñpersona jurídicaò $\mathrm{Si}$ esto es así, nos parece, en principio, que ninguna falta de compromiso puede alegarse contra España por lo que hace a la reforma de 2010 que incluye, en las excepciones de inmunidades de personas jurídicas, a los sindicatos y partidos políticos, respecto de la normativa europea sobre la lucha contra el terrorismo. El hecho de que otras decisiones marco, que han establecido responsabilidad administrativa o incluso penal para las personas jurídicas, en las que se inspiró el legislador de 2010 según su exposición de motivos, definieron a la ñpersona jurídicaò no es suficiente para afirmar que en este tópico (lucha contra el terrorismo) también deberíamos entender lo mismo.

Que los sindicatos y los partidos políticos no son el ז̃Estado $u$ organismos públicos que actúen en el ejercicio de la potestad del Estadoò que es la excepción que establece el art. 2.d) de la Directiva 2008/99/CE del Parlamento Europeo y del Consejo, de 19 de noviembre de 2008, relativa a la protección del medio ambiente mediante el Derecho penal, es una afirmación admisible, a la que nos sumamos. Sin embargo, todavía creemos que podemos entender el ap. 5 del art. 31 bis CP como respetuoso, y no infractor, de la normativa europea.

Por un lado, el art. 2.d) aludido define a la persona jurídica como ñoda persona jurídica conforme al Derecho interno aplicableò Esta concepción de persona jurídica deja en las manos del derecho 
interno de cada país la configuración del propio concepto, pero obviamente no para entenderlo desde puntos de vista civilistas o mercantilistas (ni partiendo de esas perspectivas), sino penales, es decir, a efecto de comprender el alcance y límites del compromiso con la protección del medio ambiente mediante el Derecho Penal. Tan es así que en la parte inicial del art. 2 se dice r̃a efectos de la presente Directiva, se entenderá:ò Entonces, para efectos de dicha directiva, persona jurídica es lo que el Estado parte entienda lo que es persona jurídica a efectos penales según su derecho interno, y a tono con ello, a partir de 2010 entiende que no entra en dicho concepto los partidos políticos y los sindicatos.

Por otro lado, es posible resolver esta aparente contradicción entre esas dos normas considerando que la ampliación de la excepción que hace el ap. 5 del art. 31 bis CP, extendiendo cuantitativamente las personas jurídicas inmunes a la responsabilidad penal que, en cambio, no contempla inicialmente el art. 2.d) de la Directiva 2008/99/CE del Parlamento Europeo y del Consejo, de 19 de noviembre de 2008, sea legítima y conforme a derecho porque es una excepción pro reo en materia penal. Las decisiones judiciales que Valls cita debemos tomarlas con reserva al ser materia administrativa y, en todo caso, interpreta contra el Estado.

Todavía queda un argumento: es posible afirmar que los partidos políticos y sindicatos no están absolutamente excluidos del Derecho Penal de las personas jurídicas, pues es dable imponerles determinadas sanciones bajo ciertas condiciones extremas, como lo veremos a continuación.

5. Finalmente, se plantea la relación que existe entre el segundo párrafo del art. 31 bis $5 \mathrm{CP}$ con el primero, esto es, en lo que hace a la mención inicial: r̃en estos supuestosò Reza así el dispositivo,

En estos supuestos, los órganos jurisdiccionales podrán efectuar declaración de responsabilidad penal en el 
caso de que aprecien que se trata de una forma jurídica creada por sus promotores, fundadores, administradores $o$ representantes con el propósito de eludir una eventual responsabilidad penal.

Las opciones interpretativas, fijadas por Feijóo, son las siguientes: a) que r̃en estos supuestosòse refiera solamente al último grupo de personas jurídicas enunciadas en el párrafo antecesor, esto es, r̂́Sociedades mercantiles Estatales que ejecuten políticas públicas o presten servicios de interés económico generalà b) se refiere a todos los supuestos del párrafo anterior (incluyendo al íEstado y las Administraciones públicasò entre otros); y, c) solamente se refiera a ñodos los supuestos que quepa en su aplicación, especialmente partidos políticos y sindicatoso ${ }^{333}$.

Creemos que es una opción viable considerar que la ley incluye, en este segundo párrafo del ap. 5 del 31 bis $\mathrm{CP}$, a los partidos políticos y sindicatos y a las Sociedades mercantiles Estatales que ejecuten políticas públicas o presenten servicios de interés económico general, por lo que se podrá efectuar en su contra declaración judicial de responsabilidad penal siempre que hayan sido creados o modificados solamente para eludir una eventual responsabilidad penal ${ }^{734}$.

Esta interpretación es avalada por la parte especial del CP y por la Ley Orgánica 6/2006 de partidos políticos. Cierto, el art. 10.2 a) de ésta previene que la disolución judicial de un partido político podrá tener lugar por decisión judicial cuando ñncurra en supuestos tipificados como asociación ilícita en el Código Penalò mientras que el diverso 10.4 establece que la disolución será resuelta ñpor el Juez competente

\footnotetext{
733 FEIJÓo SÁNCHEZ, Bernardo, “La responsabilidad penal...”, Op. Cit., página 77. ${ }^{734}$ Así también, FEIJÓO SÁNCHEZ, Bernardo, "La responsabilidad penal...", Op. Cit., página 77; MARTÍNEZ GARAY, Lucía, y MIRA BENAVENT, Javier, "La responsabilidad penal de las organizaciones terroristas con personalidad jurídica. Especial referencia al caso de los partidos políticos", en Revista General del Derecho Penal, Numero 14, 2010, página 4. En el mismo sentido, según entiendo, aunque no expresamente, GOMEZ MARÍN, V., Op. Cit., página 132; MIR PUIG, Santiago, Derecho Penal, Op. Cit., página 203.
} 
en el orden jurisdiccional penal, de acuerdo con lo dispuesto en la Ley Orgánica del Poder Judicial, la Ley de Enjuiciamiento Criminal y el Código Penalò De modo que la LOPP devuelve el control de los partidos políticos al $\mathrm{CP}^{735}$, si es que éste se lo remitió a través de la excepción del ap. 5 del art. 31 bis.

Es cierto que el art. 515.2 CP ha sido derogado, y él establecía que eran asociaciones ilícitas las bandas armadas, organizaciones 0 grupos terroristas, empero también es verdad que esto ha sido objeto de regulación autónoma en el nuevo art. $571 \mathrm{CP}^{736}$, por lo que las organizaciones terroristas ( $\mathrm{y}$ un partido político lo puede llegar a $\operatorname{ser}^{737}$ ) deben ser consideradas rásociaciones ilícitasòtodavía, y, aún más, de la mayor perversidad. Por lo tanto, no es absoluta la exclusión de los partidos políticos del sistema de responsabilidad penal de las personas jurídicas, aunque sea por vía del segundo párrafo del ap. 5 del 31 bis, en relación con el 10.2 a) y 10.4 LOPP.

También se debe concluir que sí es posible imponerles a los partidos políticos y sindicatos algunas de las consecuencias penales del art. 33.7 CP, en la medida en que sean, por ejemplo, organizaciones criminales o terroristas. En efecto, el art. 570 quarter $1 \mathrm{CP}$, que dice ños jueces o tribunales, en los supuestos previstos en este Capítulo y en el siguiente, acordarán la disolución de la organización o grupo y, en su caso, cualquier otra de las consecuencias accesorias de los artículos 33. 7 y 129 de este Códigoò Los capítulos a los que se refiere son el VI, relativo a las organizaciones y grupos criminales, y el VII, relativo a las organizaciones y grupos terroristas y de los delitos de terrorismo. Estas previsiones no tendrían sentido si no las referimos al segundo párrafo del ap. 5 del art. 31 bis, que incluye, según interpretamos, a los sindicatos y partidos políticos ${ }^{738}$.

\footnotetext{
735 Vid. MARTÍNEZ GARAY, Lucía, y MIRA BENAVENT, Javier, Op. Cit., página 4. 736 Vid. Ib Ídem.

737 Baste decir, los casos HB-EH-Batasuna, por STS (Sala art. 61 LOPJ) de 27 de marzo de 2003, y ANV y PCTV por STS (Sala art. 61 LOPJ) de 22 de septiembre de 2008.

738 Vid. MARTÍNEZ GARAY y MIRA BENAVENT, Op. Cit., página 7.
} 
Para terminar expresaremos nuestro desacuerdo con quien interpreta que ñn sindicato 0 un partido político constituidos legalmente, pero que acabe convirtiéndose en una organización criminal, quedará exento de responsabilidad penalở ${ }^{39}$, puesto que, dicen, se exige que sea una creación o constitución ad hoc para la evitación de la responsabilidad penal. Es una interpretación válida, sin embargo, también es válida aquella que estima lo contrario, ya que una organización sindical o política existente puede cambiar o trocar con el propósito mismo sin cambiar su forma jurídica, tan es así que no podría tener r̃epresentantesò (que son unos de las personas físicas que deben tener ese propósito) sin antes existir como tal.

739 En este sentido, GOMEZ MARÍN, V., Op. Cit., página 132; MIR PUIG, Santiago, Derecho Penal, Op. Cit., página 203. 


\section{CAPITULO IX}

\section{SISTEMA DE RESPONSABILIDAD PENAL DE LA PERSONA JURÍDICA}

\section{EL INJUSTO OBJETIVO DE LA PERSONA JURÍDICA}

El modelo que ha seguido la LO 5/2010, de 23 de junio, en materia de responsabilidad penal de las personas jurídicas, es el de injusto propio de la persona jurídica como defecto de organización, y culpabilidad propia como ausencia de disposición personal de cumplimiento del Derecho. Las razones expuestas supra justifican nuestra elección en cuanto a la estructura del sistema, resta ahora por configurar con más detalle los contenidos y contornos de los elementos del sistema.

El concepto de r̃defecto de organizaciónò es huidizo y todavía amorfo. Ciertamente que la doctrina mayoritaria (incluyendo a quienes interpretan el nuevo sistema como de peligrosidad de personas jurídicas $^{740}$, y solo descontando a los que lo interpretan de simple y sencilla heterorresponsabilidad ${ }^{741}$ ) se ha decantado en reconocerle presencia en el ordenamiento jurídico vigente, ya como el injusto de la 
persona jurídica ${ }^{742}$, o ya como su culpabilidad ${ }^{743}$, pero creemos que no son en realidad uniformes las tesis que desarrollan su ñdeaò La ñdeaò del r̃defecto de organizaciónòestá todavía pendiente de desarrollar.

En esta parte de nuestra investigación queremos dar algunos prolegómenos para contribuir un poco a darle contenido y contornos al defecto de organización. Por ello, en un primer apartado se impone recordar las tesis de las organizaciones para saber cómo funcionan; en segundo término, debemos reconocer cuáles han sido los conceptos que se le han asignado al defecto de organización, si es que el concepto tiene antecedentes y denominaciones posteriores, que coincidan más o menos con la misma idea. Una relación de la evolución de la ñdea del defecto de organizaciónònos daría aires de frescura para posicionarnos mejor en darle, enseguida, un contenido al mismo. Desde ya lo decimos: creemos que defecto de organización debería de vincularse completamente con el conjunto de normas, escritas y no escritas, generales y sectoriales, horizontales y verticales, que hacen que una persona jurídica de cierta complejidad funcione, y que la individualizan. No son, por tanto, decisiones específicas, aisladas y ajenas del entramado normativo interno empresarial, de determinados órganos de la empresa, sino decisiones que se alinean a la normativa individual de la empresa, a su cultura empresarial.

Seguidamente pretendemos mostrar de forma breve cómo es el funcionamiento de las organizaciones empresariales, y con ello, cómo se alinea a esos modelos de funcionamiento la llamada regulación regulada, como una estrategia específica de la que ha echado mano el ordenamiento jurídico español y que ya está perfectamente asimilado a nivel internacional.

Finalmente propugnamos la opción interpretativa que afirma que el art. 31 bis CP es en realidad un tipo penal específico (organización empresarial defectuosa) y no, en cambio, una norma de

742 Vid. supra Capítulo IV.5.
743 Vid. supra Capítulo IV.4. 
responsabilidad subsidiaria o solidaria, ni tampoco una norma que crea una nueva forma de autoría. Se trata de una norma jurídico penal dirigida a las personas jurídicas complejas que les obliga a organizarse de tal forma que impidan facilitar o animar a las personas físicas que se relacionan con ella a que cometan delitos. El aspecto subjetivo del injusto empresarial estaría referido o relacionado con el objetivo: su propia organización, no con la conducta específica de la persona física o individual ni con la lesión o puesta en peligro del bien jurídico tutelado por el tipo penal cometido por la persona física.

\subsection{Breve reseña de las teorías de la organización}

El sistema de la teoría jurídica del delito está fuertemente vinculado con las explicaciones que la sociología realiza respecto al funcionamiento de la realidad social y de las organizaciones sociales. ¿Cómo funciona realmente la sociedad? ¿Cuáles son los elementos mínimos de la dinámica social? ¿Cómo funciona una organización empresarial? Son las preguntas que intentan contestar las teorías sociales. Desde luego, depende mucho, casi todo, de la explicación social que más convenza, para generar el fundamento y la base de la dogmática jurídico penal.

En los últimos años podemos encontrar varias posturas que explican la forma en que funcionan las organizaciones ${ }^{744}$. En un modelo de explicación burocrático de Max Weber, el dibujo del organigrama de la empresa o diagrama organizativo es real porque refleja lo que verdaderamente es y funciona la empresa u organización, de acuerdo con el cual ña totalidad de las actividades de la empresa estarían protocolizadas y se realizarían a partir de un reparto de tareas y

\footnotetext{
744 Vid. con amplias referencias, NIETO MARTÍN, Adán, La responsabilidad penal de las personas jurídicas: Un modelo legislativo, Op. Cit., página 67 y pássim.
} 
actividades muy exacto, con una clara estructura jerárquica y un sistema de flujos de información que funciona a la perfeccióno ${ }^{45}$.

Por otro lado, bajo un modelo racional, propio del análisis económico del derecho, que también presenta un modelo perfecto, ña empresa es una maquinaria enteramente racional, capaz de general constantemente procesos de producción y organización eficientes, en cuanto que se mueve atendiendo a un fin muy concreto: la búsqueda del beneficio máximoơ ${ }^{46}$. Bajo este contexto la multa correctamente calculada es la idónea, porque la empresa es afectada en sus beneficios que puede conseguir con el delito, se prima la responsabilidad colectiva sobre la individual y se propugna el deslizamiento del Derecho Penal para que regule, de mejor manera, otras parcelas del ordenamiento jurídico como el Derecho Civil, que es más barato a las partes y la sanción es semejante.

Las teorías de la organización de tipo conflictual definen una serie de acciones y reacciones en la empresa que no son, casi en ningún caso, alineadas a favor de los fines de la misma como organización. Ĩa empresa contempla una red en la que se integran diversas unidades de decisión, pequeños centros de poder que compiten con otros y donde los individuos persiguen egoístamente sus propios finesé la acción colectiva no surgiría de seguir una rutina estandarizada preexistente, sino del juego político de los pactos y acuerdos a los que llegan las distintas unidades que componen la empresa donde cada actor persigue sus propios interesesơ ${ }^{47}$.

Mintzberg se opone, en cambio, a describir un único modelo de organización puesto que su estructura es diferente, entre otras cosas, por la influencia de las diferentes factores culturales. Aunque construye cinco diferentes tipos de organizaciones, podríamos decir que aquellas de tamaño pequeño y simple donde el directivo supervisa directa y

\footnotetext{
$745 \mathrm{Ib}$ Ídem, página 68.

$746 \mathrm{Ib}$ Ídem, página 69.

$747 \mathrm{Ib}$ Ídem, página 71.
} 
personalmente y la descentralización de funciones es mínima, la responsabilidad individual es más conveniente. ${ }^{748}$ Pero en las grandes empresas, donde hay división del trabajo, integración de redes de entidades autónomas, independencia funcional entre sus distintas divisiones y la sede central, ño lógico es tomar como centro de imputación la división, y ser consciente que la responsabilidad individual no va a ascender generalmente de la línea media ${ }^{49}$ de la estructura de la empresa.

No podemos dejar de lado, la explicación de Luhmann con su teoría de sistemas que estima la manera en que funciona la sociedad como una dinámica de sistemas autónomos que interactúan entre sí, siendo tanto la sociedad, el derecho y el individuo, simplemente sistemas. Brevemente diremos además que la tesis de Luhmann encuentran antecedente (que no precisamente un contenido similar) en Emilio Durkheim y Talcot Parsons. Durkheim consideraba que por su naturaleza, la sociedad es una realidad distinta a las realidades individuales, todo hecho social tiene como causa otro hecho social y nunca un hecho individual ${ }^{750}$, y que deberíamos realizar el estudio del fenómeno social siendo indiferentes a la ideología profesada. Parsons, por su parte, propone la introducción de un concepto de complejidad distinto al restratificadoò que coincide con la diferenciación institucionalizada de la actividad y que señala en términos definitivos la crisis de las visiones atomísticas fundadas en la reproducción social del sujeto-identidad, y sustituye un concepto de racionalidad basado en el modelo causal-lineal de fin por un concepto de racionalidad fundamentado en la intersección horizontal y la interdependencia funcional entre los diversos subsistemas de acción ${ }^{751}$.

Con estos antecedentes Luhmann crea una teoría social en la que la base de toda relación social es precisamente la comunicación

\footnotetext{
748 Ib Ídem, página 74 y 75.

749 Ib Ídem, página 75.

750 DURKHEIM, E., Las reglas del método sociológico, Premia, México, 1989, p. 84.

751 MARRAMO, G., "El orden desencantado", Anales de la Cátedra Francisco Suárez, número 30, 1990, p. 93.
} 
social, y a través de ella es posible registrar y analizar las experiencias que provengan de ámbitos tan diversos como la vida, la conciencia o la propia comunicación social ${ }^{752}$. Respecto del orden jurídico Luhmann considera que r̃sólo el Derecho puede determinar qué es legal o ilegal, y al decidir esta cuestión deberá referirse a los resultados de sus propias operaciones y las consecuencias que tiene para las futuras operaciones del sistema. En cada una de sus operaciones el Derecho tiene que reproducir su propia capacidad operativa, alcanzando su estabilidad estructural a través de la recursividad y no, como uno pudiera creer, a través de un in put favorable o output desfavorable ${ }^{53}$.

Un sistema, según Luhmann, tiene la función de reducir su complejidad a través de superar la dicotomía sistema y su entorno. Las características del sistema serían autopoiesis (capacidad de autoproducción o autocreación que constituye la fuerza interna que permite que el sistema se mantenga y subsista en el tiempo con independencia de sus concretos componentes, pues la esencia del sistema no son sus elementos sino la forma en que está organizados e interrelacionan entre sí), autorreferencialidad, constructivismo, capacidad de acción colectiva e identidad colectiva y antiindivualismo ${ }^{754}$.

Desde esta perspectiva social, la persona jurídica, precisamente porque produce relaciones sociales valoradas negativamente, tiene la capacidad de autoorganización, esto es, la capacidad de autoorganización es el equivalente funcional de la capacidad de acción. Algunos autores le llaman el dominio de la organización funcional sistémico $^{755}$, otros le llaman capacidad de organización de la capacidad

\footnotetext{
752 LUHMANN, Op. Cit., p. 71.

753 LUHMANN, Op. Cit., p. 73.

754 NIETO MARTíN, Adán, La responsabilidad penal de la persona jurídica, Op. Cit., página 79.

755 Vid supra Capitulo IV.5.2. HEINE aseguraba que por la división de los dominios de la información, operación y decisión en las empresas de alto grado de complejidad y el cambio de la fin del Derecho penal, de protección de bienes jurídicos a control de funciones, era adecuado asegurar que la empresa "actuaba" de forma independiente a las actuaciones de sus miembros. Esto lo llamó dominio
} 
de acción ajena ${ }^{756}$, o la organización de contactos sociales ${ }^{757}$, o simplemente competencia organizativa o capacidad de autoorganización. Cierto, si la organización empresarial es un sistema autopoiético y autorreferencial, como lo es la persona física también, entonces habrá que buscar la clase de operaciones que realiza, y encontraremos que mientras en la persona física son acciones específicas a través de las que comunica y puede desautorizar la vigencia de una norma, en la persona jurídica u organización empresarial es la decisión lo que comunica o tiene capacidad de comunicar esa desautorización de la vigencia de la norma ${ }^{758}$.

Bajo esta perspectiva la misión del ordenamiento jurídico penal es p̃promover una forma de organización que haga más eficaz la relación entre ambos sistemasé el principal objeto de la intervención penal es la autorregulación, a lo que, como ya se ha comprobado, la teoría del derecho reflexivo proporciona un marco teórico adecuadoơ ${ }^{59}$.

Nosotros creemos que estos diferentes criterios explicativos pueden dejarse como expedientes abiertos en el objetivo de fundamentar de mejor manera el sistema de responsabilidad penal de las personas jurídicas. Estimamos que no es posible desinteresarnos de las teorías formales de Weber y las racionales, porque es verdad que reflejan una gran parte de la función y dinámica de las empresas actuales que tienen la intención de desarrollar sus productos y servicios con calidad total y sin errores, prueba de ello son aquellos slogans que se han convertido en lugar común en el ámbito de la administración de

de la organización funcional sistémico mediante la coordinación de diversas tareas situadas en diversos departamentos y en mayor o menor medida independientes.

${ }^{756}$ Es la postura de LAMPE, quien entiende que es la capacidad de desencadenar procesos sociales a través de la organización de las acciones ajenas. Vid. GOMEZ JARA, La culpabilidad penal de la empresa, Op. Cit., p. 233.

${ }^{757}$ Es la postura de BOTTKE, quien define a la acción o comisión desde el punto de vista prejurídico penalmente como toda organización de un contacto social que tiene un organizador.

758 NIETO MARTÍN, Adán, La responsabilidad penal de la persona jurídica, Op. Cit., página 79 .

${ }^{759} \mathrm{Ib}$ Ídem, página 80. 
empresas que dicen si no mido lo que hago, no lo puedo mejorar, o el cambio en procedimientos y tecnología es la base de la calidad total, que se ven reflejados en los esquemas de procedimientos estandarizados o ISO (ISO 9001, ISO 9004, etcétera) de la Organización Internacional de la Estandarización. Hoy por hoy las empresas pretenden estandarizar todo procedimiento en la gestión y en la producción.

Tampoco se puede desatender que ciertamente en toda organización existen límites sociales de cumplimiento de las normas internas de la empresa, provocados por los enfrentamientos de los grupos de poder dentro de ellas. Pero tampoco podemos desechar las explicaciones de la teoría de sistemas que se ha esbozado mejor supra $^{760}$. Las grandes aportaciones no deben tirarse así nada más, sino que pueden aprovecharse al máximo sin necesidad de profesar ciegamente todas sus consecuencias. La autopoiesis es una explicación de ciertas organizaciones que nos convencen sin duda, aunque no resulta de recibo la integridad de esa explicación sociológica, por ser ñna teoría que no deja de levantar críticas y que además tiene un grado de oscuridad considerable ${ }^{761}$, aunque tiene el ñndudable mérito de haber recordado y fortalecido un modelo de autorresponsabilidad 0 de responsabilidad directa de las personas jurídicasơ ${ }^{62}$.

En fin, ña teoría de sistemas al igual que otras que acaban de analizarse deben ser utilizadas y aprovechadas por la política criminal, pero en algún modo elevadas a una suerte de nuevo derecho natural o categoría lógico objetiva a partir de la cual derivar todo el sistemaơ ${ }^{63}$.

\footnotetext{
760 Capítulo IV.5.3.

${ }^{761}$ NIETO MARTÍN, Adán, La responsabilidad penal de las personas jurídicas, $O p$. Cit., página 81.

762 ZUGALDÍA ESPINAR, José Miguel, La responsabilidad criminal de los entes corporativos, Op. Cit., página 42.

763 Ib Ídem.
} 


\subsection{El defecto de organización}

El r̃defecto de organizaciónò nace, con esa denominación, con los trabajos del profesor Tiedemann ${ }^{764}$. No obstante se palpa ya una pregunta obligada ¿qué es el defecto de organización? En esa formulación, y tratando de fundamentarse en categorías sociales o empresariales, Tiedemann vuelca hacia una clara concepción de empresa como garante de evitación de riesgos con medidas de precaución, por lo que es muy difícil concebir su propuesta fuera de la comisión por omisión imprudente. En efecto, ños hechos individuales (hechos de conexión) se consideran delitos de la asociación porque y en tanto que la asociación ï a través de sus órganos o representanteshan omitido tomar las medidas de seguridad necesarias para asegurar un funcionamiento empresarial no delictivo"765. Amén del maridaje con la comisión por omisión imprudente, debemos llamar la atención en dos cosas adicionales en la concepción de Tiedemann: para él son las personas físicas que se ubican en posición apical ï órganos o representantes- las que deben omitir las medidas de seguridad necesarias ${ }^{766}$ para que se entienda que es la persona jurídica la que omite esos deberes de vigilancia, y en segundo lugar, expresamente se ha pronunciado en contra de encontrar causas de inculpabilidad, esto es, que demostrando una organización eficiente en la empresa es imposible que se pueda librar de la sanción. Lo único viable es demostrar la inexistencia del hecho de conexión ${ }^{767}$.

\footnotetext{
764 Vid. supra, Capítulo IV.4.1.

765 TIEDEMANN, K., “La responsabilidad penal...”, Op. Cit., página 11.

$766 \mathrm{Ib}$ Ídem, página 15, expresamente señala "una particular infracción de omisión de organización, de vigilancia y de control debería ser incorporada con el fin de comprender los casos en los que la culpa de personas de alto o medio rango hace posible la infracción cometida por un empleado de rango inferior", que es el caso del segundo párrafo del art. 31 bis 1 CP. No obstante que afirma, por otro lado, que es la propia empresa la que tiene la posición de garante, son las personas físicas -órganos y representantes- los que específicamente ejercen ese control y los que omiten ese control y vigilancia, vid. TIEDEMANN, K., "La responsabilidad penal de las personas jurídicas, otras agrupaciones y empresas en Derecho comparado", Op. Cit., página 39.

${ }^{767}$ Cfr. GOMEZ-JARA DIEZ, Carlos, La culpabilidad penal de la empresa, Op. Cit., página 153.
} 
En esta misma línea encontramos a Dannecker ${ }^{768}$, quien dice que la empresa tiene un deber originario de su actividad empresarial de no lesionar ningún deber jurídico, y esta obligación puede ser cumplida por los miembros de los órganos y por los trabajadores: obligación de no haber creado las condiciones necesarias para la realización del injusto.

Defecto de organización es omisión de medidas empresariales para que sus miembros no cometan delitos. No obstante, hay otra forma de entender al r̃defecto de organizaciónò diferente a la omisión.

En efecto, Busch, de quien abreva Tiedemann según éste mismo reconoce ${ }^{769}$, fundamentó hace casi 80 años la culpabilidad del ente colectivo en algo que es hecho activamente (y no omitido) por la asociación, y que es la creación de una cultura criminógena. Ésta, que puede caber en el concepto más amplio de r̃defecto de organizaciónò (en la medida en que éste no se identifique solamente con omisión de medidas de control y vigilancia para evitar delitos) sería otra cara de la moneda. En efecto, al pretender construir un concepto de culpabilidad para las personas jurídicas, Busch se fundamenta en el fenómeno de que todos los miembros de la asociación than fomentado un determinado espíritu normativo de la asociación (normative Verbandsgeist) $\partial^{70}$, pues la persona jurídica existe realmente ren lo espiritual, en la consecución de fines culturales, en la realización de valoresò Engisch, que comparte el concepto de espíritu normativo de la asociación agrega que la r̃determina materialmente el comportamiento interno y externo de sus miembros y órganos, pero también la asociación está determinada por ese comportamientoò de manera que hay una implicación recíproca ${ }^{771}$, mientras que un discípulo de Tiedemann, Brender, adiciona que la empresa es responsable del delito de su miembro porque aumenta ñas posibilidades de conducción e

\footnotetext{
768 Vid. supra capítulo IV.5.1. con múltiples referencias.

$769 \mathrm{Ib}$ Ídem, página 150.

770 Ib Ídem, página 145

771 Ib Ídem, página 149.
} 
influencia derivados de su propia organizaciónò Ehrhardt, otra de sus discípulas, rancude a la capacidad de la empresa para influir en el comportamiento de sus miembros a través de su cultura corporativa, por lo que si puede motivar a que sus empleados cometan delitos para conseguir fines corporativas, pero cuenta también con la capacidad de fomentar que los empleados tengan un comportamiento respetuoso con la legalidadō ${ }^{72}$.

En la misma línea, Schünemann advierte la importancia de Busch para afirmar el concepto de rãctitud criminal de grupoò (kriminelle Verbandsattitüde) $)^{773}$. En una jerarquía empresarial se crea un respíritu de grupo establecido en una colectividad de personas y, por tanto, también en una económica, por una pluralidad de procesos de aprendizaje, en cuanto fuente de una conducta uniforme lesiva de bienes jurídicos por parte de los miembros del grupo que, como ha demostrado la investigación criminológica, están dispuestos en el marco del espíritu de grupo a realizar sin más lesiones de bienes jurídicos a las que no se dejarían arrastrar nunca en su esfera privadaơ ${ }^{74}$.

Heine arranca un poco diferente, separándose de los dos grupos anteriores. Aunque también ve a la empresa como un garante para la evitación de lesiones o puestas en peligro a bienes jurídicos, se apoya del derecho reflexivo para afirmar que el ordenamiento jurídico penal debe preferir el control de las disfunciones sociales provocadas por los subsistemas sociales para responder a la criminalidad de empresa $^{775}$, quien debe controlar sus propios procesos sociales defectuosos, mediante una administración de riesgos. Como le parece imposible separar la culpabilidad empresarial de la dimensión temporal, habla de culpabilidad por conducción de vida, y el resultado lesivo sería una condición objetiva de punibilidad.

\footnotetext{
772 Ib Ídem, página 168.

773 Vid. supra con todo tipo de referencias capítulo V.3.1.

774 SCHÜNEMANN, Bernd, "La punibilidad de las personas jurídicas desde la perspectiva europea", Op. Cit., página 578 y 579.

775 Vid. supra capítulo V.5.1.
} 
Finalmente Gómez-Jara habla de una r̃defectuosa configuración de su ámbito de organización que supera el riesgo permitidoơ ${ }^{76}$. Una empresa compleja es un sistema autopoiético compuesto por decisiones que se reproducen y auto reproducen, creando una autorreferencialidad, de manera tal que la persona jurídica deja de ser simplemente la conjunción de sus miembros ${ }^{777}$. Su capacidad de acción es su capacidad de organización porque ñas personas jurídicas tienen capacidad de organizar las acciones de las personas físicas o que tiene capacidad para organizar los contactos sociales de las personas físicasơ ${ }^{78}$.

Pues bien, creemos que podemos reconducir la ñdeaò del r̃defecto de organizaciónò (o sus equivalentes: déficit organizativo, competencia organizativa, organización defectuosa, entre otros) que se ha construido en la mayoría de la doctrina, a los siguientes conceptos:

1. Se ha entendido como rãctitud criminal de grupoò (en la medida que un defecto organizativo puede influenciar en el ánimo de la persona física la comisión de delitos).

2. Se ha entendido como omisión de deberes de garantizar un desarrollo ordenado y no infractor.

Sin embargo, en el marco del art. 31 bis CP vigente a partir del 23 de diciembre de 2010, prácticamente toda la doctrina española identifica el defecto de organización solo como el segundo concepto y en los términos también ahí enunciados, es decir, en los términos en que lo concibió Tiedemann hace varios años: la omisión de deberes de garantizar un desarrollo ordenado y no delictivo de la empresa.

Veamos. Bacigalupo Saguesse habla de exclusión de responsabilidad a la persona jurídica el delito se produjo a ñpesar de la existencia de una estructura organizada adecuada y un control

\footnotetext{
776 Cfr. Responsabilidad penal de las personas jurídicas, Op. Cit., página 77.

777 Vid. supra capítulo V.5.2.

778 GÓMEZ-JARA, Responsabilidad penal..., Op. Cit., página 40.
} 
debidoơ ${ }^{79}$; Bacigalupo Zapater encuentra en r̃sistemas de control interno y prevención, así como la infracción de los deberse de supervisión y de controlò presupuestos de la responsabilidad de las personas jurídicas ${ }^{780}$; Gómez Tomillo y Zugaldía reconocen seguir la tesis de Tiedemann y reproducen su concepto de defecto de organización en los mismos términos ${ }^{781}$; Feijóo, al que se suma De la Cuesta $^{782}$, insiste en la organización empresarial defectuosa como un obligación r̃de velar porque las personas físicas no corrompan a otros individuos o cometan cualquier otro delito desde la organización de la que es titularờ3; ${ }^{83}$ Dopico se refiere a un fallo organizativo de la persona jurídica como r̃omisión del cuidado debido en la evitación de delitos en su senoō ${ }^{84}$; Quintero Olivares lo fundamenta en ña ausencia de control exigible a la persona jurídica sobre sus miembrosơo ${ }^{85}$; a Nieto le parece que la persona jurídica será responsable si r̃carece de medidas de organización eficaces para prevenir y detectar delitos como el que ha sido cometidoő ${ }^{86}$; González-Cuellar y Juanes Peces entiende que la persona jurídica es penalmente responsable ñpor un fallo organizativo o a la omisión del control debidoơ ${ }^{87}$; Gómez-Jara, como lo hemos visto, habla de una r̃defectuosa configuración de su ámbito de organización que supera el riesgo permitidoơ ${ }^{88}$; Carbonell Mateu también habla del

\footnotetext{
779 BACIGALUPO S., Silvina, “La responsabilidad ...”, Op. Cit., página 6.

780 BACIGALUPO Z, E., "Responsabilidad penal y administrativa...”, Op. Cit., página 5.

781 GOMEZ TOMILLO, Manuel, Introducción..., Op. Cit., página 105; ZUGALDÍA ESPINAR, José Miguel, La responsabilidad criminal de los entes..., Op. Cit., página 40.

782 DE LA CUESTA ARZAMENDI, José Luis, “Responsabilidad penal de las personas jurídicas en el derecho español”, Op. Cit., página 9.

783 FEIJÓo SÁNCHEZ, Bernardo, "La responsabilidad penal...", Op. Cit., página 88 y 89 , nota 38 .

${ }^{784}$ DOPICO GÓMEZ-ALLER, Jacobo, "Responsabilidad de las personas jurídicas", Op. Cit., página 18.

${ }^{785}$ QUINTERO OLIVARES, Gonzalo, “Artículo 31 bis”, Op. Cit., página 372.

786 NIETO MARTÍN, Adán, "La responsabilidad penal de las personas jurídicas", $O p$. Cit., página 8. Así también BERDUGO GÓMEZ DE LA TORRES, Ignacio, y otros, Curso de Derecho Penal. Parte General, Op. Cit., página 549.

787 GONZÁLEZ-CUELLAR SERRANO, Nicolás, y JUANES PECES, Ángel, "La responsabilidad penal de las personas jurídicas...", Op. Cit., página 10.

788 Cfr. Responsabilidad penal de las personas jurídicas, Op. Cit., página 77.
} 
defecto de organización (aunque con reservas) ${ }^{789}$. No son, en cambio, totalmente claros si abrazan o no la tesis del defecto de organización como el injusto propio de la persona jurídica Mir Puig y Gómez Marín ${ }^{790}$.

Que el hecho o la culpabilidad propia de la persona jurídica, aquello por lo que tiene que responder penalmente, es el rólefecto de organizaciónò es todavía una afirmación que echa en falta cierta concreción. Por lo menos, surgen las siguientes preguntas de importancia capital:

1) El defecto de organización ¿es siempre una omisión de deberes de la persona jurídica?, o ¿puede implicar también una creación de la rãctitud criminal de grupoò?

2) En todo caso, ¿De qué manera, la propia persona jurídica, r̃mite medidas de cuidado necesarias para garantizar un desarrollo ordenado y no delictivoơ?, ¿Es la propia persona jurídica la que directamente r̃omiteò o esa omisión la hace a través de personas físicas?, y en todo caso, ¿dónde encontramos o cómo podemos constatar esas omisiones?, esto es, en ¿decisiones y actos específicos de personas físicas?

3) ¿Cuáles serán los baremos para afirmar que la persona jurídica se aparta de las m̃medidas de cuidado necesariasò?

4) ¿Organización adecuada implica r̃control sobre las personasò para que no cometan delitos? ¿La persona jurídica es garante de lo que otros hacen?

789 CARBONELL MATEU, Juan Carlos, "Responsabilidad penal de las personas jurídicas...", Op. Cit., página 19.

790 MIR PUIG, Santiago, Derecho Penal. Parte General. Op. Cit., página 204; y GOMEZ MARÍN, V., "Artículo 31 bis CP", Op. Cit., página 132. Aunque ambos señalan que si se demuestra que si tuviera en marcha un programa de prevención penal, del que habla el inciso d) del art. 31 bis 4 CP, con anterioridad al delito "la persona jurídica podrá quedar exenta de responsabilidad penal, por acreditar el cumplimiento del debido control". 
Cada una de las interrogantes anteriores tratará de ser contestadas en los siguientes espacios, con el fin de prefigurar mejor el llamado defecto de organización.

\subsection{1.- El defecto de organización como conducta activa y conducta pasiva de la persona jurídica.}

Estimamos que reducir el r̃defecto de la organizaciónò (o fallo organizativo, o déficit de organización) a la omisión de medidas de cuidado para garantizar el desarrollo adecuado y no delictivo, o a la ausencia de control exigible, o la omisión del cuidado debido en la evitación de delitos en su seno, o simplemente a un control defectuoso o inexistente para que no se cometan delitos en el seno de la persona jurídica, es dejar fuera otras modalidades de organización que constituyen r̃defectosò pero que no son realmente omisiones. Nos referimos a lo que ya hemos advertido como creación de la ractitud criminal de grupoò

Esta perspectiva, sin embargo, ha sido prefigurada por una reducida parte de la doctrina española, antes y después de la reforma de 2010, aunque no con el mismo significado que nosotros pretendemos asignar.

Antes de la reforma penal, Laura Zuñiga había advertido esta doble instancia en la fenomenología de la comisión de delitos por parte de la persona jurídica, aunque no coincide en todo con lo que nosotros afirmamos. Señalaba que la conducta organizacional punible podía ser tanto en el supuesto de sujetos individuales que instrumentalizan la organización para la comisión de delitos en beneficio propio, como el supuesto de la realización de un delito en el contexto de una actividad organizacional $^{791}$. El segundo supuesto lo identificaba en los casos de

\footnotetext{
791 ZUÑIGA, Laura, Bases para un modelo de imputación de responsabilidad penal..., Op. Cit., página 230 y 231.
} 
un r̃sistema social independiente de sus miembros, esto es, estamos ante una organización compleja ${ }^{92}$, por lo que estimaba que réste es el verdadero injusto de organizacióno ${ }^{793}$. El primer supuesto, en cambio, lo formuló en aquellos casos r̃de funcionalización de empresas legales por organizaciones criminales cuyos miembros las corrompen: empresas fantasma, empresas tapadera, etc. ̀̀ y encontraba el fundamento de la responsabilidad penal a la persona jurídica en r̃constituir un instrumento peligroso en manos de sujetos criminales, generando una auténtica actitud criminal de grupo. Si hubiera alguna posibilidad de cambiar de mano ese objeto peligroso, la persona jurídica, para lograr la continuidad de la misma en el tráfico jurídico legal, habría que plantear dicha alternativaơ ${ }^{79}$.

Con motivo de la reforma de 2010 hay quien considera que son dos las conductas reprochables a la persona jurídica: por su acción propia y por omisión indebida. Sin embargo, desarrolla la rãcción propiaòde la persona jurídica de manera diferente a lo que nosotros la estimamos, pues en ella ve aquellas acciones de las personas físicas que actúan como rórganos directivos de la empresaò

La acción propia (a diferencia de la omisión) se configurará cuando ña acción penalmente típica protagonizada por el representante legal de la persona jurídica habría estado respaldada (participación activa) por su parte de la propia estructura societaria: la sociedad lo sabía, lo alentaba e hizo lo que tuvo en su mano para promover la ejecución del hecho delictivo mediante la puesta a disposición de su representante legal de los medios materiales e intelectuales necesarios para elloơ ${ }^{95}$. Encontramos enorme coincidencia con aquella perspectiva de Carbonell Mateu de lo que llama T̃echo propio de la persona jurídicaà r̃ ruando se producen hechos constitutivos de delito que sean consecuencia de acuerdos adoptados por sus órganos sociales a los

\footnotetext{
792 Ib Ídem.

793 Ib Ídem, página 232.

794 Ib Ídem, página 231.

795 URRAZA, Jesús, “La responsabilidad penal...”, Op. Cit., página 6 y 7.
} 
que, legal o estatutariamente corresponda la adopción de decisiones ejecutivasơ ${ }^{96}$, y de Feijóo al decir que si la persona física que realiza el hecho delictivo es r̃el órgano colegiado de administración (Consejo de una Sociedad capital) o representación (Patronato de una Fundación)ò entonces r̃epresentará normalmente un defecto organizativoò como injusto de la persona jurídica, ren la medida en la que la actuación del órgano es una actuación de la organización la actuación delictiva del órgano representará normalmente una actuación delictiva de la organizaciónợ ${ }^{79}$.

No obstante, estas perspectivas deben llamar la atención porque no circunscriben el defecto de organización nada más o solamente en una omisión de deberes, de apariencia imprudente. Incluyen una acción, contraparte de la omisión.

A diferencia de las posturas anteriores que describen la rãcción propiaò de la persona jurídica (a diferencia de la omisión), Zuñiga coincide expresamente con nuestra postura de que la conducta activa de la persona jurídica debería de ubicarse en una ractitud criminal de grupoò que produce una influencia en sus miembros para infringir la ley criminal; sin embargo, nos apartamos de su perspectiva en cuanto

796 CARBONELL MATEU, Juan Carlos, “Responsabilidad penal...”, Op. Cit., página 27. Esto lo vuelve a reiterar de una u otra manera: "Una fórmula adecuada habría sido la de declarar que las personas jurídicas (sociedades, fundaciones, empresas) serán penalmente responsables de los hechos constitutivos de delito que sean consecuencia de acuerdos adoptados por sus órganos sociales a los que, legal o estatutariamente corresponda la adopción de decisiones ejecutivas", página 28. De la misma manera MARTÍNEZ-BUJÁN, Carlos, Derecho penal económico y de la empresa. Parte General, Tirant lo blanch, Valencia, 2011, página 524.

797 FEIJÓO SÁNCHEZ, Bernardo, “La responsabilidad penal...", Op. Cit., página 104 y 105. También DE VICENTE MARTÍNEZ, R., "La responsabilidad penal de las personas jurídicas", en DEMETRIO CRESPO, Eduardo (Coord.), Lecciones y materiales para el estudio del Derecho Penal, Tomo II, Iustel, Madrid, 2011, página 56, estima que la acción de las personas jurídicas será por "acuerdos de los órganos de dirección de la empresa", mientras que GÓMEZ RIVERO, Ma. del Carmen, "La responsabilidad penal de las personas jurídicas", en GÓMEZ RIVERO, Ma. del Carmen, (Coord.), Nociones fundamentales de Derecho Penal. Parte General, Tecnos, Madrid, 2010, página 358, se lamenta de que el 31 bis no contenga "ningún precepto que permita la atribución de responsabilidad de las personas jurídicas por los acuerdos de los órganos directivos colegiados que determinen la producción de algún hecho constitutivo de delito". 
vincula este fenómeno en las empresas ñnstrumentalesòo p̃pantallaòde poca o nula complejidad, que son utilizadas, y solamente utilizadas, por sus dueños para cometer delitos haciendo más difícil la prueba de su infracción.

La acción contemplada por los segundos (Carbonell, Feijóo, Urraza y Gómez Rivero o De Vicente), consistente en las decisiones apicales de los dirigentes de la empresa, más que expresar realmente una acción p̃propiaò de la persona jurídica, coinciden con la tesis anglosajona (organicista) del respondant superior que criminaliza a la persona jurídica por los delitos de sus directivos en cuanto son su cerebro, de la que ya hemos tomado distancia y hemos rechazado: para estos casos, si no existe un defecto de organización, debe ser suficiente el Derecho Penal individual o de las personas físicas.

Más bien, junto al defecto de organización como omisión de medidas de organización debidas que garanticen la no comisión de delitos, proclamamos una idea adicional que tiene vínculos con una conducta activa, como lo es, la creación de una actitud criminal de grupo. No nos referimos a aquellas organizaciones criminales que solamente son una pantalla de un entramado de las personas físicas que las dirigen y gobiernan. Nos referimos, coherentes con nuestra perspectiva, también a personas jurídicas de cierto grado de complejidad con funcionamiento lícito, pero con un clima o ambiente organizacional de incumplimiento del derecho que pueda influir en sus miembros y les anime a incumplir o infringir las normas de derecho penal en la medida del giro empresarial. Como lo dice el art. 8.3.a) del Maunslaughter Act 2000 cuando exige al Jurado que juzga el caso que

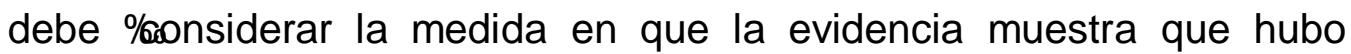
actitudes, políticas, sistemas o prácticas aceptadas dentro de la organización que probablemente han alentado cualquier falla, como se menciona en el inciso (2), o que ha producido la tolerancia de la mismaò 
Si la omisión de medidas organizacionales para evitar delitos es, sin duda alguna, un defecto de organización que puede fundamentar la responsabilidad penal de las personas jurídicas, también lo deben ser las medidas organizacionales defectuosas que produzcan al interior de la empresa comunicaciones que alienten a la infracción de la ley penal, en beneficio de la empresa.

Una omisión de deberes organizativos podría ser, por ejemplo, la ausencia de un protocolo escrito que describa el procedimiento normativo para deshacerse de desechos tóxicos de forma segura y sin causar estragos y sin poner en peligro la vida de personas, o la ausencia de comunicación, capacitación y adiestramiento adecuados a los operarios, o la ausencia de exigencia de la documentación debida del cumplimiento de los protocolos anteriores que impida realizar auditorías inductivas y correctivas; pero una conducta activa de la persona jurídica sería, por ejemplo, la exigencia normativa de que los equipos operarios cumplan con cierto nivel de productividad para deshacerse de determinadas cantidades de desecho tóxico en determinado tiempo (diariamente, o a la semana o al mes) que rebasen su capacidad, bajo la sanción que de no hacerlo no se les pagarán compensaciones o no accederán a determinados beneficios laborales. En este último caso, la persona jurídica genera una política interna de productividad que rebasa el ánimo de una persona física (el operario de la empresa) de cumplir con la norma penal para cumplir, en cambio, con el objetivo de acceder a beneficios laborales. En este caso la organización empresarial alienta y anima de forma positiva a las conductas con tendencias al incumplimiento de la norma penal.

\subsubsection{La estructura formal y material de la persona jurídica} como objeto de imputación penal

Que la persona jurídica r̃omite medidas de cuidado necesarias para garantizar un desarrollo ordenado y no delictivoà como expresión 
de su propio defecto de organización es, como lo hemos visto en los parágrafos anteriores, el fundamento de la responsabilidad penal del ente delictivo según la doctrina mayoritaria. Empero, ¿qué es lo que debe entenderse cuando se dice que la ñpersona jurídica omite medidas de cuidadoò?

Es de suma importancia tomar una postura definida respecto de esta cuestión para poder seguir hablando de una responsabilidad penal p̃propia, autónoma, independienteò de la persona jurídica, esto es, de autorresponsabilidad y no de responsabilidad por el hecho ajeno. $Y$ es que aparentemente, desde algunas concepciones de la doctrina española que dejan ver su postura al respecto, son en realidad otras personas físicas (directivos, representantes o administradores de la persona jurídica) las que deben r̃mitirò esas medidas necesarias que garanticen la evitación de delitos en el seno de la misma.

Esto es, las omisiones del debido control que fundamentan el r̃defecto de organizaciónò de la persona jurídica las residencian en las propias personas físicas.

Si esto es así, entonces aparece una aporía insalvable para los valedores de la rãutorresponsabilidad penal de la persona jurídicaò si la persona jurídica es quien (según la interpretación que hacen de la ley), de forma personal y directa, debe omitir medidas o deberes de cuidado para evitar delitos de las personas físicas que la administren o la representen o por personas que estén bajo el control de éstas (párrafos $1^{\circ}$ y $2^{\circ}$ del 31 bis $1 \mathrm{CP}$ ), sería una contradictio in abjectio que finalmente las medidas y deberes de cuidado sean omitidas por otros administradores o representantes de ella 0 , incluso, en lugar de la propia persona jurídica.

Cierto. Si quienes afirman que el art. 31 bis CP expresa un sistema de autorresponsabilidad penal de las personas jurídicas, porque del texto legal es posible, es más, es necesario para salvar la legitimación constitucional, que la persona jurídica responda por un 
T̃echo propioò y no por el hecho ajeno (de la persona física ï administrador, representante o el sometido a su autoridad), y afirman a la vez que ese thecho propioòes un defecto de organización que no es más que una r̃omisión de deberes organizacionales para evitar delitosò de las personas físicas, entonces esa acción u omisión de deberes no debería realizarla u omitirla otra persona física. Porque si es así, lo único que se haría es radicar el problema en otro momento y sede: la persona jurídica es responsable no por r̃su propio indebido controlò sino por la omisión de cuidado de otra persona física que no impidió el delito de aquella persona física. Sería exactamente la misma cuestión.

Este es el peligro que debemos salvar, y que, por lo menos en apariencia, la doctrina no ha reparado. Más bien, por lo menos así nos parece, esto es precisamente lo que afirma. Veamos.

1. Una parte de la doctrina, como lo hemos visto, se vale del contenido del segundo párrafo del art. 31 bis $1 \mathrm{CP}$ como un elemento fundamentador del r̃defecto de organizaciónò como injusto propio o culpabilidad propia de la persona jurídica ${ }^{798}$. Sin embargo, al identificar al titular del ejercicio del rólebido controlò como a la propia persona jurídica, la confunde, finalmente, con las personas físicas de los administradores y representantes de la persona jurídica. Por lo tanto, parece ser que el defecto de organización, el m̃o haber ejercido el debido controlò pertenece a la persona jurídica (pero a través de las personas físicas de los administradores y representantes legales). En esta línea, se confunde a las personas físicas que deben rejercer el debido controlòcon la propia persona jurídica.

Se dice, por ejemplo, que si la persona jurídica es responsable de los delitos de las personas físicas r̃sometidas a la autoridadòde los administradores de hecho o derecho o representantes, cometidos ñpor no haberse ejercido sobre ellos el debido control atendidas las concretas circunstancias del casoò (2ํㅜ párrafo del 31 bis), es porque la 
persona jurídica está obligada a rejercer sobre las personas que actúan a su servicio un control para evitar que en el ejercicio de las actividades sociales cometan delitos en su provechoo ${ }^{99}$. También que esta es la parte más importante de la segunda vía de imputación pues r̃ecoge una asunción de responsabilidad penal de la empresa por una conducta de los administradores consistente en una omisión del debido controlà y se agrega que r̃en lo que respecta a estos deberes de los administradores y por ende de la persona jurídica de controlar las actuaciones de sus subordinadosò serán importantes los compliance programs $^{800}$.

También se señala que la ley ñparece entender que la ausencia del debido control solo sería un requisito para el caso de delitos cometidos por personas que hayan actuado a las órdenes de los administradores y sin poderes de representación, pues en el segundo párrafo se omite mencionar a los que hayan actuado ren nombreòde la persona jurídicaé si esto fuera así en la hipótesis de la responsabilidad de los administradores se hubiera renunciado al déficit de organización como presupuesto de la punibilidad de la persona jurídica como elemento legitimador de la misma ${ }^{801}$.

Cuando se habla del debido control (art. 31 bis 1, párr. seg.) se dice que ña política corporativa o la llamada organización empresarial resultarán útiles como instrumentos para evaluar el contenido real del mandato de que es titular el gestorò asignando a personas físicas obligaciones propias de la persona jurídica.

Esto es, se reduce la obligación del control debido a personas físicas cuando previamente se hubo afirmado que es una obligación de la persona jurídica.

799 DOPICO GÓMEZ-ALLER, "Responsabilidad de personas jurídicas", Op. Cit., página 20.

800 DÍAZ GÓMEZ, Andrés, “La responsabilidad penal...”, Op. Cit., página 43.

801 BACIGALUPO Z., Enrique, “Responsabilidad penal...”, Op. Cit., página 4. 
2. Por otro lado, hay quienes expresamente conciben el defecto de organización (como injusto propio o culpabilidad propia de la persona jurídica) a cargo de la persona física que la dirigen (y no de la propia persona jurídica). En este supuesto se confunde a la persona jurídica como responsable de su propio defecto de organización, con las personas físicas que tienen carácter directivo dentro de la empresa (y que por ello, deberían responsabilizarse de su buena organización).

Es muy claro, en este sentido, Galán Muñoz, para quien estando a cargo de las personas jurídicas una norma de determinación

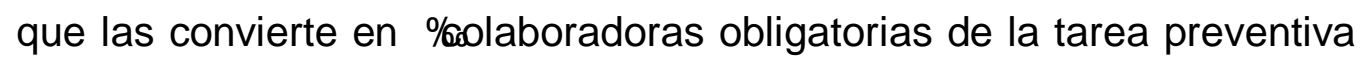
de delitos propia del Derecho Penalò sin embargo estima que la ley róbligará colectivamente a todas las personas físicas que tienen capacidad real de poder intervenir en la dirección de sus actividades a hacer cuanto esté en su mano para evitar que tales actividades pueda amparar y facilitar delitosò es decir, el Derecho Penal crea una norma de determinación r̃ rolectiva que obliga a las personas individuales que la integran y dominan, a controlar no solo lo que ellas hacen, sino también lo que realizan $u$ omiten quienes (co-)dominan con ellas la actividad social ${ }^{802}$.

Lo que pretendemos con lo anterior, es llamar la atención de que cuando hablamos de r̃defecto de organizaciónòcomo r̃algo propioò de la persona jurídica que fundamenta su responsabilidad penal, necesitamos referirlo a la propia persona jurídica, y no ponerlo a cargo de otras personas físicas. Convertiríamos en un fraude de términos si afirmamos la responsabilidad propia, autónoma e independiente de la persona jurídica, respecto del delito de la persona física, y por otro lado, ponemos o referimos sobre las espaldas de otras personas físicas que ellas no hayan organizado adecuadamente a la persona jurídica. Sería incluso cómico el que, por ejemplo en los casos de pequeñas empresas donde hay uno o dos dueños, uno de los cuales es además es el administrador único y representante legal, atribuyéramos a la persona

802 GALÁN MUÑOZ, Alfonso, “La responsabilidad penal...”, Op. Cit., página 32 y 33. 
jurídica el delito del administrador en razón de que el mismo administrador no fue capaz de organizar adecuadamente, y no defectuosamente, a la persona jurídica. Si fuese así, no habría necesidad de tantas vueltas: trabajemos el sistema vicarial más extremo sin ningún remordimiento.

Pues bien, si el defecto de organización no debe estar a cargo de las personas físicas ï administradores o representantes legales de la empresa-, entonces ¿quién debe responder por el defecto de organización? Si es la propia persona jurídica, ¿qué parte de la persona jurídica?, o ¿quién es, si es que existe, esa persona jurídica capaz de omitir las medidas de cuidado para evitar delitos en su seno?

Nosotros lo concebimos como un subsistema social formado fundamentalmente por normas escritas (preferentemente) y no escritas, que rigen el funcionamiento de la empresa hacia el interior (relación de sus miembros, horizontal y vertical, de colaboración o de supra a subordinación, de sanción y de sometimiento, de movimiento escalafonario, de ingreso y éxodo del personal, incluso de adquisición de propiedad ï acciones- de la persona jurídica) y hacia el exterior (en su relación con las autoridades gubernamentales, con la competencia, con el entorno social y de medio ambiente, con sus proveedores o con sus clientes, de imagen y de prestigio). Creo que no habría mejor manera de describirlo que con el término de un sistema autopoiético.

De sobra sabemos que Gómez-Jara ha desarrollado el término en relación con la empresa, y creo que podríamos tomar de recibo una parte importante de sus conclusiones en lo que respecta al poder expresivo y funcional del término. Ya Schüneman había llamado la atención a la utilidad de las investigaciones de Niklas Luhmann y sus discípulos Teubner y Willke sobre la teoría sociológica de los sistemas autopoiéticos que en las empresas tendría este contenido: ñpara el Derecho sería prácticamente imposible influir la conducta del integrante de una empresa económica en el sentido del cumplimiento de la norma por medio de una normación directa porque la empresa constituye un 
sistema que organiza por sí mismo las acciones que en ella se realizan, y cuya autonomía no puede quedar desatendida por un DDerecho regulativoò sino que tiene que ser respetada por un r̃derecho reflexivo $0^{803}$. Heine hace lo propio, como lo hemos advertido, e incluso Mir Puig también se había servido del término ${ }^{804}$.

Nos permitimos, sin embargo, referir ese subsistema o sistema autopoiético que es la empresa o la persona jurídica compleja, al conjunto de normas, a la ñógicaò de la perspectiva interna (desde el punto de vista del miembro de la persona jurídica), al uso de reglas no escritas, que tienen que ver con la adquisición de consecuencias negativas (sanciones) y positivas (premios) por hacer o dejar de hacer determinadas conductas, las reglas o m̃metarreglasòsociológicas que le dan sentido a actuar de determinada forma dentro de la corporación.

Hablamos de la Misión, Visión y Valores de la persona jurídica, que la fundamenta, no tanto en lo jurídico, sino en lo social hacia dentro y hacia el exterior. Pero también del conjunto de políticas generales o especiales, de creación de procedimientos para la gestión de servicios o creación de productos, o la operación de alguna actividad dentro de la empresa, la normativa de ascenso, de ingreso, de sanciones, de revisión y auditorías. De procedimientos o protocolos para pago de proveedores, de compras, de ventas, de competencias de los diferentes departamentos, entre otras cosas. También de la infraestructura (bienes inmuebles, bienes muebles, o bienes de tecnología especial y avanzada) así como el uso de la misma, o la normativa sobre el uso de sistemas de comunicación o uso de la información de la empresa. Incluye los valores y principios explícitos e implícitos que son realmente

803 SCHÜNEMANN, Bernd, "La punibilidad de las personas jurídicas desde la perspectiva europea”, Op. Cit., página 572.

${ }^{804}$ MIR PUIG, Santiago, "Una tercera vía en materia de responsabilidad penal de las personas jurídicas", Op. Cit., página 13, y lo hacía al fundamentar la capacidad de acción de la empresa al señalar que "el sistema empresarial es, como todo sistema, autopoiético, en el sentido de la teoría de los sistemas de Luhmann, y tiene a su propio interés, que en este caso es el de la obtención del máximo beneficio económico posible, a través de sus propias normas, que pueden llevar a sus integrantes a infringir normas legales que por sí solos no infringirían". 
codiciados dentro de la empresa, y las metas y objetivos específicos y generales de la misma. La imagen y el prestigio generan también una actitud de orgullo en aquellas personas físicas que pertenecen al grupo, y que puede influir para que mantengan un determinado ánimo ante problemas específicos.

David Baigún, al hablar de la r̃organizaciónò como un elemento de gran importancia en la responsabilidad penal de las personas jurídicas, decía que la r̃doctrina autorizada considera el orden normativo como uno de los conceptos abarcados por la organización $0^{805}$, y citando la obra de Felipe Fucito, señalaba que se trataba de un subsistema por tener determinadas características ñna colectividad humana de cierta magnitud, un conjunto de fines racionales, un sistema de comunicación institucionalizado, un sistema de poder y un nivel de conflicto interno; el concepto de orden normativo se halla compuesto por reglas formales e informales, que constituyen un sistema de control social interno y que determina el grado de formalización de la organización, así como los restantes aspectos culturales de la normao ${ }^{806}$.

Lo que pretendo es encontrar y abstraer todo aquello que identifique a la persona jurídica, que la individualice y la haga funcionar, así como aquello que haga funcionar a las personas físicas que trabajan dentro o junto con ella, pero que no son las propias personas físicas.

Zúñiga, al referirse a la conducta organizacional, decía que no son r̃ ronductas humanas en el sentido de una persona física, sino que al ser organizacionales comprendeòel ordenamiento jurídico de un país, la estructura organizacional y el objetivo de la organización, esto es ñiene que observarse de acuerdo al medio interno y externo, tanto social como normativo, ya que la persona jurídica es un ente normativo

805 BAIGÚN, David, La responsabilidad penal..., Op. Cit., página 43 y sigs. $806 \mathrm{Ib}$. Ídem, página 44. 
por excelencia807. También lo entiende así, y expresamente lo señala, el Informe al Anteproyecto del Consejo General del Poder Judicial de 18 de febrero de 2009, para quien la imputación del hecho a la persona jurídica r̃se fundamenta, entonces, en una estructura defectuosa 0 reglamentarias internas que dan soporte a conductas o prácticas ilícitas, o sobre mecanismos contables o de otra naturaleza que permiten camuflar los hechos ilícitos, o bien, en suma, sobre procesos organizativos internos que permiten minimizar el riesgo de detección de las infracciones o de que sean sancionadas $8^{808}$.

Ya sabemos que la superestructura de una empresa (su normativa, tal y como la hemos prefigurado) la hacen y la crean personas físicas. No obstante, en nuestra concepción ello no daría lugar a arribar a la misma crítica que hicimos líneas arriba (relativa a que solo retrasamos la aparición de la persona física y su hecho para atribuírselo a la persona jurídica). Lo que salva nuestro punto de vista es, tal vez, que auxiliados de las investigaciones sociológicas al respecto ${ }^{809}$, podemos afirmar que el ente normativo complejo que es la empresa puede llegar a convertirse en un ente diferente de quienes la crearon, regulando el comportamiento de ellos mismos dentro de la empresa, y de esa forma, influir en su conducta futura, ya para crear en ellos una actitud de grupo (que puede generar una tendencia a cometer algún delito) o para tratar de burlar la propia normativa de la organización (defecto de organización).

Por ejemplo, si dentro de una organización empresarial, uno de los socios votó a favor de la decisión que creaba la norma que dictaba

${ }^{807}$ ZUÑIGA, Laura, Bases para un modelo de imputación de responsabilidad penal..., Op. Cit., página 233.

808 Informe, página 10. Sigue diciendo que "la conducta de las personas jurídicas está sometida a procedimientos operativos estandarizados (Standard Operating Procedures), es decir, a procedimientos normalizados de trabajo y de toma de decisiones, y la culpabilidad de la persona jurídica se basa, precisamente, en la existencia de prácticas y procedimientos inadecuados por ser ajenos a los estándares de actuación para prevenir la comisión de delitos".

${ }^{809}$ NIETO MARTÍN, Adán, La responsabilidad penal de las personas jurídicas, $O p$. Cit., páginas 22 y 23, y 38 y pássim; SCHÜNEMANN, Bernd, "Responsabilidad penal en el marco de la empresa...", Op. Cit., página 26 y 27. 
que en lo sucesivo se crearan cuentas bancarias autorizando a tres personas para que conjuntamente (y nunca separadamente) firmaran los cheques de disposición de esa cuenta, si y sólo si había dos firmas de pre autorización de los directores de área, atendiendo a requerimientos de pago de máximo de 10 días hábiles, es claro que ni dicho socio, ni el administrador, ni otro socio o representante legal, podrá hacer lo contrario al dictado de dicha norma reguladora de un procedimiento específico: el socio que ha creado la norma es ahora un súbdito de la misma. Otro ejemplo: si la Junta Directiva de una empresa ha dispuesto una normativa relativa a cargo de cualquier miembro de la misma a denunciar actos de corrupción dentro de la empresa (los llamados whistleblowers ${ }^{810}$ ), asociando el incumplimiento a consecuencias positivas y negativas para el infractor, entonces habrá suficiente motivación e influencia para quienes la integran para hacerlo en caso de que observen algo que merezca la pena denunciar. Dependerá de las otras reglas, las no escritas (las metarreglas), que también son comunicadas de una u otra forma, para que esas reglas se cumplan: si se denuncia, incluso a un alto directivo, y hay consecuencias favorables al denunciante (sin posibilidad de vindictas) y merecidas y justas al infractor, entonces la empresa será un sistema autopoiético que funciona de forma automática a pesar de las personas físicas que las integran. Lo mismo vale para aquellos socios que votaron en contra de la regla o norma (de firma de cheques o de denuncia a infractores), puesto que, súbditos de las normas mercantiles que regulan las sociedades, saben que si fue una decisión tomada en la Junta Directiva por la mayoría exigida por la ley, pasarán también por dichas decisiones.

No son, entonces, decisiones puntuales y específicas ni actos de un directivo o administrador, lo que nos puede reflejar el estado organizativo de una empresa. Por lo menos no la reflejarían si los

810 NIETO MARTÍN, Adán, “Responsabilidad, gobierno corporativo, autorregulación: sus influencias en el derecho penal de la empresa", en Política Criminal, Número 5, A3-5, 2008, página 7. 
consideramos de forma aislada y sin referente alguno. Estimamos que una decisión o un acto específico de una persona de la dirección pueden reflejar el estado de organización de la empresa si el mismo se alinea con las políticas y objetivos generales que previamente ha dictaminado la propia empresa.

Solamente así podemos r̃despersonalizarò el defecto de organización y considerarlo de forma exclusiva como responsabilidad de la persona jurídica, y por ende, predicar, entonces sí, que se trata de r̃algo propioòde la persona jurídica. Solo existiendo normas de todo tipo que regule a la persona jurídica y a los miembros que la componen podemos afirmar (hacia el interior y el exterior) que los miembros ï personas físicas- no son los que tienen ese defecto de organización.

Pero también logramos una coherencia interna del sistema de responsabilidad penal de las personas jurídicas: porque la persona jurídica puede lograr la no imputación del delito del 31 bis CP a través de una organización adecuada, sin contradicciones y sin lagunas, o sin elementos que animen o faciliten la comisión de delitos por parte de las personas físicas. Esta organización adecuada es evidenciada a través de la normativa interna de la empresa, desde las políticas generales y particulares, las reglas de creación de órganos, de sus funciones y competencias, las de protocolos para la realización de algún producto o servicio, de premios y castigos, entre muchas otras, de las que ya hemos hablado.

Los programas de cumplimiento, que no son otra cosa sino la evidencia documentada del cumplimiento (en favor del ordenamiento jurídico) de las normas que gobiernan la empresa, y la evidencia documentada de que las normas que gobiernan la empresa constituyen candados de garantía para la no comisión de delitos por parte de sus miembros, serán también motivo de revisión y análisis para saber si una empresa está bien organizada o por el contrario, si tiene un defecto de organización. 
En efecto, echando una breve mirada a lo que la doctrina llama programas de cumplimiento o compliance programs como la forma de evitar la responsabilidad penal de la persona jurídica, nos daremos cuenta de que no son más que específicas normas y compromisos de la empresa con determinadas formas de organización empresariales que pretenden evitar delitos 0 , si éstos acaecen, descubrirlos y remediar sus resultados. Esas normas y compromisos con una forma de organización son expresadas en documentos que: crean obligaciones para los órganos directivos y operarios de la empresa, crean nuevos órganos de vigilancia y auditoría con competencias específicas ï todas ellas, documentadas a través de normas escritas-, crean procedimientos ï desde luego, expresados en normas documentadas- e incluso crean cultura corporativa que es la expresión de la empresa de ser siempre una cumplidora religiosa de la legalidad en todos los sectores del ordenamiento, pero lo hace a través de normas escritas, programáticas si se quiere, pero finalmente normas escritas.

Lo que queremos destacar es que la manera de que una autoridad judicial perseguidora de los delitos pueda consultar, analizar, concluir y demostrar si determinada empresa tiene o no tiene una organización adecuada (o su lado contrario, un defecto de organización) es indagando en la documentación relativa de la empresa así como las evidencias de su cumplimiento actualizado y permanente; esto es, se revisa la normativa existente y su efectivo cumplimiento en los últimos días, semanas, meses o años. No puede ser de otra forma.

En un caso de vertidos tóxicos de una empresa que puso en peligro la vida de personas que se aprovechaban del agua de un río que fue contaminado, en una empresa ñXòque realiza alrededor de 120 viajes de camiones de 10 toneladas de desecho diariamente en 30 diferentes puntos del país, y que ha comprado los servicios de otra empresa ñyòque recibe esos desechos para reducirlos e inocuizarlos mediante el almacenamiento y tratamiento químico, y cobra por ello 0.70 euros por kilogramo, deberán de tener protocolos de garantía para 
evitar fugas, accidentes en planta o en el traslado, robo de desecho 0 desviación de desecho, por lo menos. Es claro que ninguna empresa que esté mínimamente vinculada a los conceptos de eficiencia, eficacia y calidad colocará, detrás de todo este procedimiento, personas que vigilen a los choferes, almacenistas, receptores, etcétera, porque luego tendría que colocar a personas que vigilen a esos otros vigilantes, pues el costo se elevaría a diez o cien veces más. Lo que hace una empresa así es establecer procedimientos, candados, garantías, generar evidencias, verificación de los puntos estratégicos del proceso, y el uso de tecnología, pues con ello asegura, mejor que de otro modo, la ausencia de daños a bienes jurídicos y mantiene los precios competitivos.

Si esto es así, la autoridad judicial deberá de indagar, si quiere comprobar defecto de organización, si existían protocolos o procedimientos escritos para: 1) cumplir con leyes, reglamentos 0 normas técnicas y del proveedor, para el manejo de los desechos y del equipo que se utiliza para el transporte; 2) deshacerse del vertido tóxico por parte de los operadores, y en su caso, si ese protocolo o procedimiento era documentado y tenía candados que garantizara su cumplimiento, como por ejemplo, verificación de la salida del camión con los desechos (con expresión de día, hora, peso ï considerando la tara del camión-, tipo de desecho, envasado, destino, tiempo estimado al destino, ruta programada, entre otras cosas), la verificación de la llegada del camión con los desechos al destino (con expresión de día, hora, peso, tipo de desecho, envasado, procedencia y la ruta que finalmente siguió), verificación de los cuidados a los trabajadores (vestimenta y equipo especial de protección, equipo de comunicación), verificación de que el envase tuviera sellos de seguridad contra la apertura clandestina, lo mismo que la caja del camión, verificación de un sistema de seguimiento del camión por GPS; 3) realizar auditorías preventivas y correctivas, a través de análisis del procedimiento mismo (ponerlo a prueba), o revisiones al azar de verificadores internos o 
externos; entre otras cosas; y 4) revisar si existe una cultura empresarial de cumplimiento del Derecho, con todo lo que implica.

Si sucede que unos operarios de la empresa ñòo de la ñXò extrajeron clandestinamente unos vertidos y los vendieron 0 los vertieron a vasos de captación hidráulica, entonces la empresa será la primera en detectarlo, y hará dos cosas: creará un procedimiento y protocolo a prueba de la falla como la que detectó, y dará aviso a la autoridad judicial. Si la empresa no lo puede detectar (a pesar de tener un efectivo y óptimo compliance program), entonces se podrá predicar un defecto de organización de la empresa, pero que tal vez no se le puede exigir una organización diferente a la empresa, y no se podrá predicar de ella que actúo culpablemente, a pesar de que los operarios en colusión con sus superiores realizaron un delito contra el medio ambiente por cuenta y en beneficio de la empresa.

Las pruebas testimoniales podrían ser muy útiles, pero resultan ser poco importantes o incluso poco fiables cuando lo que se quiere probar es que un día específico, nada especial para nadie, del que no hay razón para recordar nada, determinados trabajadores se llevaron un camión con desecho tóxico para llevarlo a otra empresa, pero solo entregaron la mitad del mismo, de lo que nadie se enteró hasta seis meses después. Lo que se podría revisar es precisamente la normativa (protocolos, procedimientos y las evidencias de su cumplimiento, las auditorías, las revisiones, el uso de la tecnología, entre otras cosas) porque solo ello es responsabilidad de la persona jurídica.

En conclusión:

a) El defecto de organización es la creación de una actitud criminal de grupo o la omisión de medidas de cuidado para evitar, en la medida de lo posible, de que las personas físicas que trabajan para la persona jurídica, cometan delitos en nombre, por cuenta y en provecho de ella. 
b) Esa r̃rreación de una actitud criminal de grupoòo la r̃omisión de medidas de cuidadoà no deben correr a cargo de otras personas físicas (otros administradores o representantes legales). Deben correr a cargo de la propia persona jurídica.

c) Si el defecto de organización es, al final, a cargo de otras personas físicas, en realidad estaríamos negando a la persona jurídica su propia autonomía e independencia. Negaríamos finalmente una responsabilidad penal ñpropia, autónoma e independienteòde la persona jurídica.

d) Encontramos un defecto de organización propio de la persona jurídica en su propia complejidad, en su normativa interna, su forma de aplicarla, en su ñógica interna de funcionamientoò independiente de las personas físicas que crearon esa normativa.

\subsubsection{El baremo para la recta y adecuada organización de} la persona jurídica

Entiendo que es difícil establecer un recto criterio que deban seguir las empresas para el cumplimiento de su organización adecuada y evitar, en lo que esté a su alcance, que sus funcionarios y empleados cometan delitos en su favor o por su cuenta y en su beneficio. No obstante creo que podríamos encontrar algunos puntos de coincidencia.

Un primer elemento que habría que tomar en cuenta sería el marco legal general y específico. Respecto del primero habría que tomar en cuenta todas aquellas normas legales que tiene que ver con toda persona jurídica o empresa, por ejemplo, el cumplimiento de normas hacendarias y de tributación, de medio ambiente, de prevención de la corrupción, del respeto de los derechos de los trabajadores, así como el respeto a las normas mismas de creación, gestión, desarrollo de las actividades societarias. De forma específica habría que tomar en cuenta el giro y desarrollo de la persona jurídica, pues si se especializa en alguna actividad que tenga prevista su responsabilidad penal, por 
ejemplo, uso de nueva tecnología que pueda afectar el medio ambiente o actividades hospitalarias y servicios médicos en general, habría que asegurarse y mostrarse especialmente cuidadoso con respetar el marco legal y de previsión de delitos en estos ámbitos (delitos contra el medio ambiente o tráfico ilegal de órganos humanos).

Se deberá exigir, de acuerdo al tamaño de la empresa, que tenga departamento administrativo, de desarrollo organizacional, de recursos humanos, un departamento legal, departamento de auditoría, entre otras cosas.

Luego habría que atenderse a las normas oficiales técnicas respecto del uso de los instrumentos, sustancias, o tecnología en general, o los servicios prestados por otras personas o empresas. Las normas del uso de los instrumentos utilizados y que son obtenidos de proveedores diversos tendrán que ser respetadas también.

El marco legal y técnico daría paso a crear el sistema organizacional de la persona jurídica en específico. Este entramado organizacional es realizado por las personas jurídicas en aquellos momentos en que se dan cuenta de que ya no es posible manejar la empresa de forma tradicional, esto es, a través del conocimiento, talento, dirección y revisión de una sola persona o de un conjunto de personas, precisamente por el tamaño de la misma, por su complejidad, o por la creación de campos de especialización o desterritorialización de la empresa. En ese momento el managment se descentraliza de una persona para dar lugar y paso a una managment controlado a través de normas de organización, que pretenden manejar la empresa de forma ranutomáticaò esto es, que se maneje a sí misma, para lo cual se crean departamentos (se departamentaliza), se crean jerarquías, sistemas de información y comunicación internas; se comienzan a medir los resultados de manera objetiva, en atención a diferentes puntos críticos del procedimiento; y sobre todo, se comienza a p̃producirò (a generar productos o servicios) en base a procedimientos estandarizados evitando al máximo el error, optimizando recursos y viendo hacia la 
satisfacción al cliente. En ese momento el managment se limita a crear políticas generales en ciertos tópicos, a revisar las mediciones de la empresa, y a conseguir nuevos mercados. Aquí es cuando nace toda la normativa interna de la empresa, principalmente volcada hacia la optimización de los procedimientos (máximo provecho, costo mínimo).

Sabemos que esto no se hace en unos días, ni siquiera en unas cuantas semanas, sino que se va configurando durante meses, es más, una empresa que crece nunca deja de crear normativa específica interna: desde la Misión, Visión y Valores y la creación de los objetivos generales y particulares de la persona jurídica en general, así como la de los distintos sectores o divisiones que puede tener, la creación de la política empresarial, la cultura empresarial de cumplimiento del derecho, y el desarrollo de los protocolos ISO, y normativas especiales de la empresa.

Por supuesto, se incluyen los programas de cumplimiento o compliance programs que analizaremos por separado.

Estos son elementos mínimos que deberían ser evaluados para concluir si una persona jurídica es o está adecuadamente organizada para la evitación de riesgos y en su caso para el descubrimiento de sus responsables. El análisis y estudio del caso concreto será necesario por no poder desarrollar más aspectos comunes a todos los casos.

\subsubsection{Control sobre la organización o control sobre las} personas

Puede parecer algo lógico que si el art. 31 bis CP atribuye responsabilidad penal a las personas jurídicas por r̃delitos cometidos en su nombre o por cuenta de las mismas y en su provecho por sus representantes legales y administradores de hecho o de derechoò la persona jurídica se convierta en una suerte de garante de las conductas de otras personas. Esto, también aparentemente, se vuelve más 
concluyente si los representantes o administradores (algunos dicen ña propia persona jurídicaò no ejercen el debido control sobre los que están sometidos a su autoridad y cometen delitos en el ejercicio de actividades sociales y por cuenta y en provecho de las personas jurídicas.

En apariencia, si la persona jurídica es responsable del delito que hizo otra persona, entonces es garante de que esa persona no cometa delitos, lo que, formulado así, no deja de reñir con un derecho penal por el hecho propio, para adscribirse en uno de responsabilidad por hecho ajeno. Creemos que así es entendido por parte de la doctrina, pues atribuye a la persona jurídica la obligación de ñmpedir la realización de los hechos (tanto de superiores como de subordinados) $8^{811}$, rode controlar lo que realizan $u$ omiten quienes (co)dominan con ellas la actividad social o lo hacen por delegaciónơ ${ }^{812}$, r̃de evitación de delitos $0^{813}$ o expresamente que la persona jurídica res responsable por los delitos cometidos por personas físicas que actúan en su ámbito para beneficiarla ${ }^{814}$, es más, se habla expresamente de un delito de comisión por omisión o de simple omisión por parte de la empresa al no evitar el delito ${ }^{815}$, incluso, hay quien formula un inicial razonamiento como fundamento de la responsabilidad penal de los entes colectivos al decir r̃el razonamiento que lo inspira es sencillo: las sociedades controlan o tienen el deber de controlar a sus miembros 0 administradores o subordinados $0^{816}$.

811 ZUGALDÍA ESPINAR, José Miguel, La responsabilidad criminal de los entes colectivos, Op. Cit., página 54.

812 GALÁN MUÑOZ, Alfonso, "La responsabilidad penal...", Op. Cit., página 33.

813 DE LA CUESTA ARZAMENDI, José Luis, "La responsabilidad penal...", Op. Cit., página 15.

814 MUÑOZ CONDE, Francisco, Derecho Penal, 2010, Op. Cit., página 630.

815 RODRIGUEZ RAMOS, Luis, “¿Cómo puede delinquir una persona jurídica...”, Op. Cit., página 6.

816 QUINTERO OLIVARES, Gonzalo, "Artículo 31 bis", Op. Cit., página 372. Hay quienes hablan de culpa in vigilando y culpa in eligiendo, vid. MUÑOZ CONDE, Derecho Penal, 2010, Op. Cit., página 630; RODRIGUEZ RAMOS, Luis, “¿Cómo puede delinquir una persona jurídica...”, Op. Cit., página 6; y GÓMEZ RIVERO, Ma. del Carmen, "La responsabilidad penal de las personas jurídicas", en GÓMEZ RIVERO, Ma. del Carmen, (Coord.), Nociones fundamentales de Derecho Penal. Parte General, Tecnos, Madrid, 2010, página 355. Esta última incluso exige que "la 
Aquí es donde surge el problema, ¿Por qué razón la persona jurídica habrá de ser garante de las conductas delictivas de sus administradores, representantes o subordinados? $O$ mejor, ¿real y fácticamente puede la persona jurídica controlar el comportamiento de sus administradores, representantes y subordinados? Parece que nadie, ni siquiera la persona jurídica, puede evitar comportamientos de personas libres, ni siquiera los comportamientos delictuosos; y bajo la premisa de que ño que no es posible, no es Derechoò no deberíamos buscar por ahí el vínculo con el defecto de organización.

Adecuada organización, más que control efectivo sobre las personas que evita que ellas cometan delitos, es un control sobre la organización misma. Es una normativa en la que no haya lagunas o contradicciones que den lugar a aprovechamientos de las personas físicas para cometer delitos (organización defectuosa) o normativa (escrita o no escrita) que dé lugar a una rãctitud criminal de grupoò o que no haya una efectiva aplicación de esa normativa (por lo que hace a la primera) o que funcione realmente de manera defectuosa (por lo que hace a la segunda).

Creemos que ña omisión de medidas de cuidado para garantizar el desarrollo adecuado y no delictivo, o a la ausencia de control exigible, o la omisión del cuidado debido en la evitación de delitos en su seno, o simplemente a un control defectuoso o inexistente para que no se cometan delitos en el seno de la persona jurídicaò no se refieren a r̃controlòo r̃descontrolòsobre las personas físicas mismas. Así parecen tenerlo en cuenta otras posturas, como autores que dicen que ren realidad no se dirige a la persona jurídica la prohibición (o el mandato) de la norma (v.gr. no corromper), sino que se le exige velar, colaborando con el Estado, porque las personas físicas no corrompan a otros individuos o cometan cualquier otro delito desde la organización

falta o carencia de control determine causalmente la actuación delictiva de la concreta persona física, configurando así una especie de responsabilidad por infracción de un deber de la persona física obligada". 
de la que es titularơ 817 , o que el art. 31 bis CP ño exige comprobar que un concreto administrador no ha vigilado correctamente al subordinado que cometió el delito, sino algo substancialmente distinto, que la empresa no ha implementado un conjunto de medidas destinadas a impedir que los empleados de la empresa realizan hechos delictivos o a detectar su comisión, una vez cometidos, atendiendo a las concretas circunstancias de la empresa ${ }^{818}$. Lo mismo podríamos decir del Informe al Anteproyecto del Consejo General del Poder Judicial de 18 de febrero de $2009^{819}$.

La diferencia puede ser sutil, pero es de gran importancia: No es lo mismo estar obligado a controlar a personas para que no cometan delitos (garante sobre la conducta delictiva) que obligado a crear medidas organizativas con el fin de que las personas no cometan delitos (garante sobre la organización de la empresa).

Nuestras afirmaciones tienen coherencia interna porque se relacionan con los compliance programs, que no son más que elementos normativos implementados y desarrollados dentro de la empresa. En efecto, la doctrina mayoritaria está de acuerdo y reconoce que los programas de cumplimiento efectivos deberían ser reconocidos como una forma de evitar la responsabilidad penal de la persona jurídica, si se implementan con anterioridad al hecho delictivo en una empresa, y no solamente circunstancias atenuantes de la responsabilidad penal si se implementan con posterioridad al hecho. Ahora bien, como veremos más adelante, los programas de cumplimiento empatan totalmente con los sistemas de organización empresariales en cuanto gozan de la misma naturaleza: son normas, reglas, obligaciones o deberes de organización dentro de una empresa, que además de ser creados por los órganos directivos de la misma, deben ser implementados, desarrollados, aplicados, ñpuestos en

817 FEIJOO SÁNCHEZ, Bernardo, “La responsabilidad penal...”, Op. Cit., página 88 y 89, las cursivas son mías.

818 NIETO MARTÍN, Adán, “La responsabilidad penal...”, Op. Cit., página 8.

819 Informe, página 10, ya comentado. 
marchaò revisados continuamente con evaluaciones y auditorías, y constituyen un compromiso del mismo valor que la p̃producción o la generación del servicioòque es el giro de la empresa por todos y cada uno de los miembros de la persona jurídica.

De ahí que si los programas de cumplimiento, que son normas que se gestionan y desarrollan dentro de la empresa, pueden y deben generar causas de exculpación a la empresa, entonces es claro que el fundamento de su responsabilidad será también en ese mismo nivel, es decir, normativo o reglamentario de tinte organizativo. No es posible desimputar un delito con implementación de normas (programas de cumplimiento) cuando la imputación consiste en el descontrol sobre personas.

Por lo demás, no encontramos ningún otro caso donde una persona sea responsable de los delitos de otro, por ser r̃garanteò el uno, del comportamiento delictivo del otro. Nos parece que este maridaje (delito de la persona jurídica por ser garante de que otros no delincan) fue lo que provocó tantas desavenencias de la doctrina antes de las reformas de $2010^{820}$.

En conclusión, creemos que la persona jurídica no es responsable de los hechos de otros (las personas físicas de sus administradores, representantes o los sometidos a la autoridad de

820 Se manejó en la doctrina española argumentos muy importantes relativos a afirmar la "responsabilidad penal de la persona jurídica por el hecho ajeno" en cuanto no tiene capacidad de acción, y "se puede comparar la problemática que presenta esta cuestión con otras materialmente similares como la del representante de un menor que actúa en nombre de éste y realiza un delito en provecho de dicho menor. No parece que nadie esté dispuesto a imputar al menor el hecho injusto y culpable realizado por el representante. ¿Porqué con las personas jurídicas la solución tiene que ser distinta? ¿Qué es lo que diferencia un supuesto del otro? En este sentido, hay una regla de verificación de legitimidad bastante útil que debería tener en cuenta ciertos partidarios de la culpabilidad de las personas jurídicas: siempre que se afirme que una empresa debería responder penalmente se debería poder decir lo mismo de un empresario individual cuya empresa esté dirigida o administrada por otra persona", Vid. FEIJÓo SÁNCHEZ, Bernardo, “¿Culpabilidad y punición de personas jurídicas?”, en MONTEALEGRE LYNETT, Eduardo (Coord.), El funcionalismo en Derecho Penal, Universidad Externado de Colombia, Colombia, 2003, página 353. 
éstos), sino que es responsable de su propio defecto de organización. Defecto de organización sería un tipo penal específico de la persona jurídica, que bajo ciertas condiciones externas (el delito de la persona física competente, por su cuenta, en su nombre y en su beneficio, que tendría la categoría de condición objetiva de punibilidad) haría responsable a la persona jurídica.

Que el delito de r̃defecto de organizaciónò no alcanza para formar la suficiente antijuridicidad del injusto de la persona jurídica, y por ello pugna frontalmente con la legitimidad constitucional, sería un argumento atendible, pero entonces debemos reconocer que sería un debate distinto que valdría la pena realizar.

\subsubsection{Un delito específico para la persona jurídica: delito de} organización defectuosa

Todo lo anterior nos lleva a plantear una opción interpretativa que puede tener visos de resolver la problemática de la responsabilidad penal de las personas jurídicas en el Derecho Penal español a partir de la reforma operada por la LO 5/2010, de 23 de junio: el art. 31 bis CP no es una norma que expresa una responsabilidad subsidiaria o solidaria de la persona física, ni es una que establezca una forma específica de participación de personas en el delito, sino un delito específico, un tipo penal especial dentro de la Parte General del CP.

En efecto, debemos plantearnos la clase de norma penal que subyace en el art. 31 bis $\mathrm{CP}$, esto es, ¿Por qué razón la persona jurídica responde penalmente cuando otra persona (física) comete un delito? ¿De qué responde la persona jurídica? ¿Cuál es la relación de la persona jurídica con el delito de la persona física o con el resultado lesivo al bien jurídico? ¿La conducta de la persona jurídica afecta algún bien jurídico? La doctrina dominante en España afirma una responsabilidad penal auténtica y verdadera de las personas jurídicas, 
no obstante con ello no dice de qué manera son responsables, es decir, de qué forma la norma penal los hace responsables. Creo que podemos plantearnos tres respuestas iniciales:

a. La persona jurídica es responsable por el hecho de otra persona (la física), de manera tal que la persona jurídica adquiere, asume o absorbe la responsabilidad de la otra como en una suerte de subsidiaridad o solidaridad;

b) La persona jurídica participa del injusto de otra persona, convirtiéndose así en una suerte de autor mediato o coautor o, incluso, partícipe del delito de la otra persona; $y$,

c) La persona jurídica comete un delito propio, diferente del delito que comete la persona jurídica, aunque relacionado con él, afectando bienes jurídicos diferentes, con conductas diferentes y culpabilidades diferentes.

La primera respuesta hace responsable a la persona jurídica del delito de la persona física, pero por una simple adscripción, una sencilla adhesión de responsabilidad, esto es, haciéndola solidaria de la responsabilidad penal de otra persona. Para esta postura no es que la persona jurídica tenga capacidad de acción o de culpabilidad, sino que por puro voluntarismo legislativo a un ente jurídico se le pone a sus espaldas las consecuencias jurídicas de lo que otros hicieron. De ahí que no se exija una actuación propia de la persona jurídica, ni injusto objetivo ni subjetivo, ni culpabilidad propia.

Pensamos que así es como podrían responder las tesis de las que hablamos supra ${ }^{821}$ y que por ello afirman una heterorresponsabilidad absoluta y total: el injusto objetivo y subjetivo y la culpabilidad de la persona física son también de la jurídica en virtud o mediante un juicio valorativo dado por el art. 31 bis CP y consistente en que la persona física, además de cometer el delito de la parte especial,

821 Capítulo V.3. 
sea administrador, representante o sometido a la autoridad de éstos, y lo haga en nombre, por cuenta y en provecho, r̃disparaòconsecuencias jurídico penales a la persona jurídica. Por ello decimos que bajo esas perspectivas el art. 31 bis es una norma penal que crea consecuencias jurídicas por pura solidaridad, por puro acompañamiento, solamente por hermanamiento con la persona física.

Es más, para estas perspectivas (de heterorresponsabilidad total) la persona jurídica sería tratada peor que la persona física. Es así porque si la persona física comete un comportamiento típico y antijurídico pero de forma inculpable (por ejemplo, un error de prohibición invencible) la persona jurídica de cualquier forma tendría a sus espaldas las consecuencias jurídicas del delito cuya responsabilidad no se puede declarar en contra de la física. Estaríamos bajo un esquema muy similar al de la subsidiaridad (ya ni siquiera de solidaridad).

Las diferencias de esta perspectiva con aquellas otras que atribuyen a la persona jurídica una culpabilidad propia, identificando, sin embargo, el injusto de ésta con el de la persona física, y que revisamos supra $^{822}$ no son muchas. La norma penal del art. 31 bis CP sería, para estas perspectivas, también de atribución, de adhesión, de solidaridad, como así han sido etiquetadas, puesto que es muy difícil considerar que la persona jurídica no responde por el hecho de otro ${ }^{823}$.

\footnotetext{
822 Capítulo V.4.

823 Vid. BACIGALUPO S., Silvina, "Los criterios de imputación de la responsabilidad penal de los entes colectivos y de sus órganos de gobierno (arts. 31 bis y 129 CP)", Op. Cit., página 5, "el Código Penal ha optado por establecer, tanto en el art. 31 bis como en el art. $129 \mathrm{CP}$ un sistema de atribución de responsabilidad a las personas jurídicas por el hecho delictivo cometido por una persona física dentro de la estructura empresarial", aunque después señala que la culpabilidad de las personas jurídicas es propia y se identifica por el defecto de organización, al decir, "en mi opinión, la existencia de un déficit o defecto de organización debe ser el presupuesto de punibilidad de las personas jurídicas. Por tanto, el modelo de imputación debe basarse sobre la existencia de un hecho de conexión y sobre la idea de la culpabilidad por defecto de organización", página 6 (cursivas en el original). También DÍAZ GÓMEZ, Andrés, "La responsabilidad criminal de las personas jurídicas en el Derecho Español”, Op. Cit., página 53; GALÁN MUÑOZ, Alfonso, "La responsabilidad penal de la persona jurídica tras la reforma de la LO
} 
Señalan, por ejemplo, que en el plano de la tipicidad m̃o debe descuidarse que en el caso de la responsabilidad penal de las personas jurídicas no puede decirse en sentido estricto que éstas lleven a cabo una conducta típica, que su conducta sea subsumible en el tipo de la parte especial, toda vez que los tipos están destinados para comportamientos característicos de personas físicas. Más bien debe sostenerse que la responsabilidad se atribuye, se imputa, a las personas jurídicas, en virtud de un juicio fundamentalmente valorativo ${ }^{824}$.

Por otro lado, aquellas otras tesis que afirman un injusto propio (objetivo y subjetivo) y culpabilidad propia de la persona jurídica ${ }^{825}$, al explicar qué es lo que prohíbe la norma penal del art. 31 bis CP y de qué manera lo hace, se ven obligadas a señalar que la persona jurídica participa con la persona física en una relación de coautoría o autoría mediata o una autoría especial, incluso hay quien refiere una r̃oresponsabilidadò pero que en todo caso, la persona jurídica es responsable por coadyuvar o cooperar o participar en el delito de otra persona. Esta misma solución se puede observar en algunos valedores de la postura anterior (del t̂necho de conexiónòy culpabilidad propia de la persona jurídica).

Entre estos últimos, Gómez Tomillo señala que ño injusto característico de las personas jurídicas resulta ser de naturaleza compleja. Deriva de la conjunción, de la sinergia de la actuación de la persona física con las especiales posibilidades estructurales y medios de la persona jurídica efectivamente utilizados e implica necesariamente la lesión o puesta en riesgo de bienes jurídicos. Como veremos infra, se trata de una situación muy próxima, si bien no

5/2010: entre la Hetero- y la Autorresponsabilidad”, Op. Cit., página 16 y pássim; GOMEZ TOMILLO, Manuel, Op. Cit., página 66 y 67; GOMEZ MARÍN, V., Op. Cit., página 131.

824 GÓMEZ TOMILLO, Manuel, Introducción..., Op. Cit., página 159 y 160, las cursivas son mías.

825 Vid. supra Capítulo V.5. 
idéntica, a la característica de la coautoría ${ }^{826}$, enseguida estima que el art. 31 bis CP es ñna causa de ampliación de la tipicidadơ ${ }^{27}$. Lo anterior concita con Gómez Rivero, para quien la responsabilidad penal de la persona jurídica r̃se acerca más a una situación similar a la coautoría $0^{828}$. Zugaldía, por su parte, asegura que el sistema del hecho de conexión ñparte de considerar a la persona física y a la jurídica como sistemas que actúan conjuntamente, aunque puede ser responsabilizados independientemente ${ }^{829}$.

Feijóo, finalmente, estima que solo las personas físicas, con sus conductas humanas, son las que realizan los hechos típicos que exige el art. 31 bis, ñpor muchas vueltas que se le quiera dar sin actuaciones delictivas de parte de personas físicas no hay responsabilidad de personas jurídicasơ ${ }^{830}$, y exige una conducta típica y antijurídica de la persona física ño que se puede denominar una accesoriedad mediaơ ${ }^{81}$. Sigue diciendo que el art. 31 bis tiene la función de r̃determinar cuándo el hecho individual es también un hecho de la persona jurídica, dando lugar a una especie de ñautoría accesoriacé la persona física y la persona jurídica no son coautoras, es decir, cada una no realiza una parte de la organización del hecho ni se puede decir que organicen conjuntamente el hecho, sino que son co-responsableso ${ }^{832}$.

826 GÓMEZ TOMILLO, Manuel, Introducción..., Op. Cit., página 53. De hecho, algún autor coloca en el capítulo 13.IX, "Del autor, los cómplices y la víctima" de su libro de Parte General de Derecho Penal, el estudio del tema de la responsabilidad penal de las personas jurídicas, vid. QUINTERO OLIVARES, Gonzalo, Parte General de Derecho Penal, Op. Cit., página 677. Este autor considera también la tesis de la "accesoriedad intermedia" en la relación de persona física y la persona jurídica, vid. página 687.

827 Ib Ídem, página 53, nota 83.

828 GÓMEZ RIVERO, Ma. del Carmen, "La responsabilidad penal de las personas jurídicas", en GÓMEZ RIVERO, Ma. del Carmen, (Coord.), Nociones fundamentales de Derecho Penal. Parte General, Tecnos, Madrid, 2010.

829 ZUGALDÍA ESPINAR, José Miguel, La responsabilidad penal de empresas, fundaciones y asociaciones, Op. Cit., página 143; el mismo, La responsabilidad criminal de los entes colectivos, Op. Cit., página 40. Las cursivas son mías.

830 FEIJÓO SÁNCHEZ, Bernardo, "La responsabilidad penal...", Op. Cit., página 89. Las cursivas son mías.

831 Ib Ídem, página 90. Las cursivas son mías.

$832 \mathrm{Ib}$ Ídem, página 92. Las cursivas son mías. 
Pues bien, ¿de qué responde penalmente la persona jurídica? Del hecho de otro (bajo determinadas condiciones) o de su participación en el hecho de otro (algo así como coautoría o en co-delincuencia), han sido las respuestas de quienes han tratado este tema. Nosotros creemos que no son correctas estas respuestas, o por lo menos, que es posible construir otra diferente, tan aceptable y admisible como éstas.

La persona jurídica responde de su propio hecho, de su propio injusto, y no del injusto del otro. Esto significa que su responsabilidad ni es solidaria ni subsidiaria del hecho típico y antijurídico de otro, ni que determinando a otro, o dirigiendo su voluntad o actuando conjuntamente con otro, es responsable del delito que éste cometa, porque el art. 31 bis CP no es una norma de subsidiaridad o solidaridad de responsabilidad penal ni de participación de personas en el delito. Se trata de una norma que crea un delito específico, un injusto específico, un delito de r̃organización empresarial defectuosaò

Se trataría de un tipo penal específico. El sujeto activo es siempre común: cualquier persona jurídica con una complejidad suficiente. La conducta ínsita en la norma penal es r̃organizarse de forma defectuosaò La norma penal prohíbe a las personas jurídicas organizarse defectuosamente, ya sea creando una política o ambiente organizacional de incumplimiento del Derecho, o ya sea omitiendo normas o reglas que dificulten a sus miembros cometer delitos, por tanto, la conducta puede cometerse por acción u omisión. Se trataría de un tipo penal de comportamiento o de mera conducta, y de peligro abstracto. El delito de la persona física (injusto objetivo, más el injusto subjetivo en aquellos tipos penales incongruentes por defecto subjetivo) es una condición objetiva de punibilidad. Como lo desarrollaremos en el siguiente epígrafe, solamente puede cometerse de forma imprudente, nivel subjetivo que la doctrina mayoritaria no duda en admitir en la persona jurídica.

A primera vista nuestra posición puede ser considerada con problemas de legitimidad. Cierto, prohibir organizarse defectuosamente 
u ordenar organizarse adecuadamente, así simplemente, podría tener dificultades de alineación con los principios de ultima ratio y de protección de bienes jurídicos mediante el Derecho Penal. Contra esas posibles críticas podríamos alegar dos cosas: 1) la calidad de la persona (persona jurídica y no persona física) y la ausencia de la pena privativa de libertad, podría relajar el ánimo de los críticos; y 2) la supuesta no legitimación de un delito de la persona jurídica no es, en todo caso, una propiedad exclusiva de nuestra posición, sino en general del sistema de responsabilidad de las personas jurídicas.

El punto primero había sido explorado ya, de alguna manera, en este mismo trabajo ${ }^{833}$, pero a propósito de la ausencia o no de legitimidad del modelo o sistema vicarial o respondant superior que considera la responsabilidad penal de la persona jurídica por el hecho de otro. Los mismos argumentos habrán de valer ahora: Porque las personas jurídicas, aún y cuando poseen prácticamente todos los derechos constitucionales y procesales que también tienen las personas físicas, el propio ordenamiento debe decidir en qué medida deben gozar aquellas esos derechos, y por tanto, nada impide que sean sometidas a regímenes de responsabilidad más estrictos que las físicas en función de obtener fines públicos ${ }^{834}$. Es más, el propio Tribunal Constitucional ha admitido que si bien las personas jurídicas tienen derechos fundamentales, también es cierto que la protección constituye un efecto reflejo del derecho fundamental del que son titulares las personas físicas que la integran ${ }^{835}$.

Por otro lado, la vinculación o relación, considerada casi natural u óntica, entre Derecho Penal y la pena privativa de libertad (que es hoy día considerada su consecuencia por antonomasia), hicieron desarrollar en los últimos dos siglos un sistema de derecho penal de excepción, al que se fueron incorporando principios muy entendibles y

\footnotetext{
833 Vid. supra capítulo V.4.1.

834 NIETO MARTÍN, Adán, La responsabilidad penal de las personas jurídicas. Un modelo legislativo, Op. Cit., página 105.

$835 \mathrm{Ib}$ Ídem, página 106.
} 
racionales cuando a lo que se enfrentaba el reo era a la pérdida de su vida o de su libertad. Sin embargo, la necesidad de protección de bienes jurídicos en una sociedad compleja ha provocado a anticipar barreras del Derecho Penal con una tendencia que se ha denominado administrativización del Derecho Penal o segunda velocidad del Derecho Penal. El sistema de responsabilidad penal de las personas jurídicas participa de las características de este fenómeno, pero a diferencia del de las personas físicas, es la multa la pena por antonomasia.

Que todo esto tiene más parecido con un sistema de Derecho Administrador sancionador, es un aserción que tiene algo de cierta pero también de incertidumbre. Recordemos que no es pacífica la afirmación de una diferencia cualitativa de uno y otro, y más bien nos parece que tienen razón quienes afirman que no existe una diferencia de sustancia entre ambos, sino que es el legislador quien dice cuándo estamos ante una infracción penal y una administrativa.

Que, en segundo lugar, m̃o resulta correcto afirmar que la situación de desorganización de la persona jurídica es suficiente para constituir su injusto en relación con el hecho cometido por la persona físicaòes más bien una crítica a quienes ven una relación de solidaridad o participación entre el injusto de la persona jurídica con el de la física. Nuestra posición comparte esta crítica solo en la primera línea de la aserción, pero tiene la ventaja de que no se relaciona en una suerte de responder por otro ni en una lógica de actuación conjunta con la persona física que comete el delito.

Ciertamente, el adjetivo de ilegitimidad de nuestra postura se predica también para las otras tesis y criterios que construyen un sistema de responsabilidad penal a partir del art. 31 bis CP (principalmente). Por tanto, nuestra propuesta no es menos acertada por tener las mismas críticas que la pudieran tachar de ilegitimidad. 
Sin embargo, si encontramos razones para preferirla: Mientras a nuestra postura toca legitimar un injusto de desorganización empresarial como de peligro abstracto y teniendo al delito de la persona física como una condición objetiva de punibilidad, los valedores de la heterorresponsabilidad, los defensores del thecho de referenciaò y culpabilidad por defecto de organización, y quienes proponen el injusto y culpabilidad propias de la persona jurídica, tendrían que justificar, adicionalmente a lo que a nosotros nos corresponde, la responsabilidad por el hecho ajeno y la interdicción de la responsabilidad objetiva (los primeros), y la relación de participación entre el injusto de la persona física y el de la jurídica (los segundos).

En todo caso, la legitimidad del sistema propuesto por nosotros deberá ser debatido. Y no podrá ser un debate completo e íntegro si no se ponen en la mesa las otras posturas para que, bajo el mismo prisma (cuestionamiento de la legitimidad del sistema propuesto), nos acerquemos a soluciones. Creo que al final caeremos en la cuenta de que la perspectiva que se elija no será alguna inmaculada.

No obstante, parece ser que la perspectiva que proponemos daría una dimensión de coherencia y sentido al sistema de responsabilidad penal de las personas jurídicas realmente admisible y adecuada.

Tipo penal del art. 31 bis CP

\begin{tabular}{|l|l|l|}
\hline & Elementos del delito & Causas de exclusión del delito \\
\hline $\begin{array}{l}\text { Injusto objetivo } \\
\text { sujusto } \\
\text { subjetivo }\end{array}$ & Organización defectuosa & Organización adecuada \\
\hline Culpabilidad & $\begin{array}{l}\text { Ausencia de cultura } \\
\text { empresarial de cumplimiento } \\
\text { del derecho }\end{array}$ & $\begin{array}{l}\text { Cultura de cumplimiento del } \\
\text { Derecho con Compliance programs } \\
\text { efectivos. }\end{array}$ \\
\hline $\begin{array}{l}\text { Condición } \\
\text { objetiva de } \\
\text { punibilidad }\end{array}$ & $\begin{array}{l}\text { Injusto de la persona física } \\
\text { (en una relación de } \\
\text { causalidad) }\end{array}$ & $\begin{array}{l}\text { Ausencia del injusto de la persona } \\
\text { física, o de las circunstancias ñor } \\
\text { cuentaò ren nombre ño ren su } \\
\text { provechoò }\end{array}$ \\
\hline
\end{tabular}




\section{EL INJUSTO SUBJETIVO DE LA PERSONA JURÍDICA}

El injusto personal exige, además de la parte objetiva, la comprobación de una vertiente subjetiva del injusto que tiene fundamento en los arts. 5 y 10 del CP, esto es, la demostración del dolo o la culpa en su comisión. Lo que reviste importancia si contamos con que la mayoría de los delitos en los que está prevista la responsabilidad penal de las personas jurídicas prevén una comisión necesariamente dolosa, de manera tal que si se quiere responsabilizar a la persona jurídica es necesario superar ese problema.

En las posturas doctrinales que propugnan la transferencia del injusto de la persona física al injusto de la jurídica no existe ningún problema, puesto que el dolo o la imprudencia de la persona jurídica son el dolo o la imprudencia de la persona física. En nuestra postura, de un injusto personal propio de la persona jurídica diferente del injusto del de la persona física, resulta mucho más difícil y complicado construir el dolo o la imprudencia, que deberán ser acordes a la naturaleza del injusto organizativo.

Aquí debemos también incluir a quienes, estimando un defecto organizativo como el injusto personal de las personas jurídicas, consideran que con el dolo o imprudencia de la persona física en el t̂hecho de conexiónò (el presupuesto de la responsabilidad penal de la persona jurídica) se surte la exigencia constitucional y legal del dolo y la culpa $^{836}$ : NNo creo que ello exija una imputación subjetiva en el sentido de que la pena presupone dolo o imprudencia de la persona física. La referencia no îay penal sin dolo o imprudenciaò del art. $5 \mathrm{CP}$ queda respetada con el dolo o la imprudencia de la persona física. Por ello no hace falta constatar un r̃conocimiento organizativo del riesgo empresarialò

836 FEIJÓO SÁNCHEZ, Bernardo, “La responsabilidad penal...", Op. Cit., página 88, nota 38. 
Excluyendo, pues, las posturas anteriores, hemos encontrado, al respecto de la vertiente subjetiva del dolo o la imprudencia de la persona jurídica, las siguientes posturas:

1.- No existe diferencia entre el dolo y la imprudencia en el injusto de la persona jurídica.

Según esta postura r̃en realidad dolo e imprudencia se convierten en el derecho penal colectivo en metáforas o parábolas mediante las cuales en realidad se intenta describir algo mucho más simple: la gravedad del defecto de autoorganización. El dolo o la imprudencia de la corporación, como muestran los anteriores intentos, no son otra cosa que la falta de mecanismos de prevención, detección, reacción o la existencia de políticas de empresa que inciten o hagan más fáciles la realización de comportamientos ilícitos por parte de personas naturales o en otros casos ï en lo que constituye un derivado de la teoría de la identificación- la tolerancia o aquiescencia por parte de los superioreso837.

Es cierto que el injusto de la persona jurídica, que es un injusto de organización defectuosa, no tenemos tan claramente diferenciado en qué momento la organización tiene conocimiento de su propio defecto o desconocimiento evitable. No obstante, una postura así puede tener como desventaja la aproximación a una responsabilidad objetiva, igual que sucede cuando a alguien se le exige responsabilidad penal simplemente por haber provocado un resultado. Es el caso de la stricty liability offences del derecho anglosajón de las personas jurídicas.

2.- El dolo organizacional como conocimiento acumulado de las personas físicas.

837 NIETO MARTÍN, Adán, La responsabilidad penal de las personas jurídicas..., Op. Cit., página 160. 
Estas posturas dicen partir de conceptos normativos del dolo ${ }^{838}$, y en el caso de las personas jurídicas lo conciben como el r̃conocimiento organizativo del riesgo ${ }^{839}$ que es un conocimiento de la empresa diferente al conocimiento de las personas físicas que integran a la propia persona jurídica. Este dolo organizativo puede descubrirse a partir de indicios objetivos, como podría ser si un grupo de personas físicas conocían el riesgo y esas personas físicas son las decisoras (los administradores) entonces se puede atribuir a la organización ese conocimiento, o también podría ser el collective knowledge doctrine (se imputa a la organización la suma de los conocimientos de sus miembros) $)^{840}$.

Estas posturas hacen referir al dolo o imprudencia al riesgo, esto es, a la posibilidad de afectación de bienes jurídicos individuales o colectivos, y por tanto, conectan el dolo o imprudencia al resultado final mismo: un vertido de sustancias tóxicas que ponga en peligro la vida de personas, por ejemplo. También colocan el conocimiento 0 desconocimiento evitable en la mente o psique de personas físicas, pues ñn indicio que se ha considerado relevante para atribuir ese conocimiento, es si determinadas personas físicas poseían un conocimiento individual de riesgos, así, en caso de que miembros del Consejo de Administración conocieran el riesgo, se infería lógicamente que la persona jurídica también tenía conocimiento organizativo del mismo ${ }^{841}$.

La principal crítica que podemos hacer a estas tesis es que para fundar el dolo o imprudencia vuelven a las personas físicas, cuando en

\footnotetext{
838 Como lo dice HEINE, G., "Modelos de responsabilidad jurídico penal originaria de la empresa", Op. Cit., página 54, al señalar que ni siquiera en el Derecho Penal individual se exige comprobar los conocimientos reales del autor, sino que se adscriben conforme a representaciones sociales.

839 GOMEZ JARA-DIEZ, Responsabilidad penal..., Op. Cit., página 79; también en "El modelo constructivista de autorresponsabilidad penal empresarial", Op. Cit., página 141 y sigs.

$840 \mathrm{Ib}$ Ídem, página 80 , y página 141 y sigs.

841 GÓMEZ-JARA DIEZ. Carlos, Responsabilidad penal de las personas jurídicas, Op. Cit., página 79 y 80.
} 
la parte objetiva ya se había separado de ellas para fundarla, haciendo incompatibles, por diferente fundamento, la parte objetiva y subjetiva de su construcción dogmática. Como dice Nieto r̃si bien fundamenta la culpabilidad de la empresa a partir del constructivismo, y, por tanto, sobre cimientos metodológicos similares a los que utiliza Laufer para construir su mens rea, a la hora de construir el dolo de la empresa abandona el camino del normativismo, para, sobre bases empíricas procedentes de la teoría de la organización, intentar fundamentar con la existencia de un conocimiento por parte de la corporación ï conocimiento organizativo- distinto a la suma de las ñpartículas individuales de conocimientoò y conformado por las r̃elaciones $y$ modelos de vinculación entre estos elementos de conocimientoơ ${ }^{82}$.

3.- Dolo o imprudencia dependiendo del grado del defecto de organización.

Zuñiga Rodríguez cree que no se trata r̃de sumar dolos, ni sumar culpas, sino de observar las actuaciones organizacionales, donde la actuación que denote mayor peligrosidad objetiva del peligro para el bien jurídico dará lugar a la imputación dolosa y la actuación que denote menor peligrosidad objetiva del resultado peligro para el bien jurídico, dará lugar a una imputación culposaơ83.

Tampoco parece admisible estas posturas pues también refieren el dolo o imprudencia a la intensidad del injusto objetivo, lo que

842 NIETO MARTÍN, Adán, La responsabilidad penal de las personas jurídicas, Op. Cit., página 159. También crítico, BAIGÚN, David, La responsabilidad penal..., Op. Cit., página 81 y nota 23, pues llama una ficción el hecho de que algunos tribunales de Estados Unidos de Norteamérica recurran a la teoría de la departamentalización para obtener una respuesta al dolo de la empresa "partiendo de la subdivisión de actividades (departamentos) y extrayendo de cada uno de sus protagonistas el conocimiento vinculado a su actuación, se suman los diferentes conocimientos para asignárselo finalmente a la corporación". Este autor cita la sentencia del caso United States vs. Band of New England, de la Court First Circuit donde sostuvo "que hay que considerar al banco como una institución y que su conocimiento de los hechos es la suma del conocimiento de todos los empleados.

843 ZUÑIGA RODRÍGUEZ, Laura, Bases para un modelo de imputación..., Op. Cit., página 239. 
tendría las mismas críticas que las posturas primeras, esto es, una insoportable cercanía a tesis de imputación objetiva que no son propias del Derecho Penal.

Entendemos que el tema del dolo o la imprudencia de la persona jurídica es el punto más débil de las construcciones teóricas de la responsabilidad penal de las personas jurídicas.

Creemos que podemos contribuir en algo al debate si afirmamos que podríamos construir el aspecto subjetivo del injusto empresarial admitiendo que el art. 31 bis CP, como lo hemos señalado, constituye un tipo penal específico en sí mismo, y no solamente una forma de participación de personas en los tipos penales o delitos de la parte especial (como sucede en el caso de los arts. 28 y 29 CP) o como normas de solución para casos de autoría y participación (como es el caso de los arts. 30 y 31 bis CP); y si esto es así, el tipo penal de r̃defecto de organizaciónò debería tener también una exigencia específica de parte subjetiva que sea propia, referida al defecto de organización mismo (y no al riesgo de afectación de los bienes jurídicos o a la conducta de la persona física que comete el delito de la parte especial), y el rõlelitoòde la persona física sería una condición objetiva de punibilidad.

En primer lugar, y como lo hemos afirmado en otra parte de este trabajo de investigación, creemos que el art. 31 bis CP creó un nuevo tipo penal que podría ser llamado r̃delito de defecto organizativoò Se trata de una norma penal que ordena a todas las personas jurídicas con cierta complejidad y tamaño que se organicen adecuadamente.

El tipo penal de r̃defecto organizativoò también tiene previsto una exigencia subjetiva especial.

Se trataría de una infracción del deber de cuidado o de un desconocimiento evitable referido a su propia desorganización, como no 
puede ser de otro modo, si el injusto objetivo es el defecto de organización.

Por ello, la imprudencia no está referida ni al r̃delitoò de la persona física (estafa, delito fiscal, delito contra ciudadanos extranjeros, etc.) ni al resultado que exigen esos delitos (la afectación en el patrimonio ajeno, la administración pública, el medio ambiente, etc.), porque el delito o el resultado del delito de la persona física solamente es una condición objetiva de punibilidad ${ }^{844}$. Como afirma Dannecker ñun comportamiento doloso o imprudente de la empresa referido al defecto del sistema interno o a la filosofía empresarial incorrectaé el dolo o la imprudencia no se refieren como puede apreciarse a la lesión del bien jurídico. El dolo requiere conocimiento o al menos representación de la posibilidad del defecto del sistema interno ${ }^{845}$. La imprudencia sería el defecto organizativo derivado de una infracción del deber de cuidado.

Ahora bien, es difícil concebir el injusto subjetivo empresarial de una forma psicológica o análoga funcional al de las personas físicas. Tal vez, es imposible concebirlo así por que responden a fundamentos diferentes. Sin embargo, teniendo en cuenta la exigencia del art. 5 y 10 del CP, a la que no podemos renunciar, podríamos construir la vertiente subjetiva ñpropiaòdel injusto empresarial en la imprudencia y solamente en la imprudencia que es simple y sencillamente normativa. Por ello creemos que podemos hablar de que la empresa está defectuosamente organizada porque la empresa misma violó o infringió deberes de cuidado organizativos, y puede ser admitida culpa inconsciente.

Por cierto, la imprudencia de la persona jurídica es muy aceptada en la doctrina penal mayoritaria en España.

\footnotetext{
${ }^{844}$ De la misma forma HEINE, Günter, "La responsabilidad penal de las empresas: evolución y consecuencias nacionales", Op. Cit., página 70.

845 DANNECKER, Gerhard, "Reflexiones sobre la responsabilidad penal de las personas jurídicas”, Op. Cit., página 50 y 51 . No obstante, no se entiende lo que enseguida señala, esto es, que la imprudencia presupone la lesión del bien jurídico era evitable o previsible, lo que ocurre "cuando un miembro de la empresa que ocasiona un defecto que produce una lesión del bien jurídico hubiera podido preverlo y evitarlo mediante una aportación posible y razonable".
} 
Llegando a este punto nos enfrentamos con el problema del numerus clausus del art. $12 \mathrm{CP}$. En efecto, la doctrina mayoritaria ha llamado la atención respecto a que los delitos por los que puede responder la persona jurídica en los términos del art. 31 bis, son delitos que mayoritariamente su injusto subjetivo exige con exclusividad el dolo, en virtud de que no tienen prevista, de forma expresa, la punibilidad de la comisión imprudente.

Ciertamente, el delito de tráfico ilegal de órganos humanos del art. 156 bis, o el de prostitución y corrupción de menores del art. 189 bis, o las insolvencias punibles del 261 bis, o cohecho del 427 o tráfico de influencias del 430, por decir algunos ejemplos, en los que está prevista la responsabilidad penal para las personas jurídicas, no está, en cambio, previsto su castigo para el caso de comisión imprudente. Solamente encontramos que alguna modalidad del delito de blanqueo de capitales (del art. 301.3), y alguna del delito de financiación del terrorismo (del art. 576 bis $2 \mathrm{CP}$ ), pueden ser sancionados cuando se cometan por imprudencia grave.

Por tanto, ¿cómo alinear los delitos por los que puede responder la persona jurídica (que exigen, en su gran mayoría, el dolo) con los delitos que pueden ser castigados al cometerse de forma imprudente, si en realidad no coinciden?

Para los defensores de sistemas de heterorresponsabilidad penal de las personas jurídicas, o incluso, para los defensores del T̃echo de conexiónò y culpabilidad por defecto de organización, que hemos analizado, el problema tendría una solución muy lógica: el dolo o la imprudencia de la persona física (el administrador, representante o el sometido a su autoridad) sería también el título subjetivo de imputación de la persona jurídica, puesto que aquel se le imputa, atribuye o adhiere a ésta. No obstante, ya hemos expuesto las razones por las que nos alejamos de estas posturas. 
El problema realmente lo tienen aquellas opciones interpretativas que estiman que el injusto propio de la persona jurídica es el defecto de organización, porque ellas tienen que construir un dolo o una imprudencia propios de la persona jurídica. En párrafos anteriores hemos relatado algunas propuestas, esto es, r̃onocimiento organizativo del riesgoò collective knowledge doctrine (se imputa a la organización la suma de los conocimientos de sus miembros), y el dolo según el grado objetivo de defecto de organización. Nosotros estimamos, por las razones previamente expuestas, que no es posible admitir las posturas expuestas.

Nuestra postura, en cambio, no construye el aspecto subjetivo del tipo penal en referencia a la conducta delictiva de la persona física ni a la lesión o puesta en peligro del bien jurídico que tutela el delito de la persona física; sino al injusto objetivo: defecto de organización empresarial. Por tanto, si el art. 31 bis CP es en realidad un tipo penal específico ubicado en la parte general del $\mathrm{CP}$, entones tendríamos que construir una vertiente subjetiva propia del mismo tipo penal.

A tono con lo que hemos venido diciendo, debemos considerar que el art. 31 bis CP, amén de prevenir un injusto objetivo específico, propio de un tipo penal especial de rórganización defectuosaò también previene una forma subjetiva específica y propia del injusto empresarial: la imprudencia. Por tanto, el art. 31 bis $\mathrm{CP}$, al prevenir un injusto propio de organización defectuosa, exige también la imprudencia como comisión subjetiva, y en consecuencia, debe considerarse incluido en el catálogo de delitos imprudentes que exige el art. $12 \mathrm{CP}$. En otras palabras: solamente los delitos que establecen en forma expresa la posibilidad de una comisión imprudente, pueden ser sancionados por imprudencia (12 CP), y el art. 31 bis es uno de ellos.

No es que el art. 31 bis CP prevea, en la misma medida que lo hace el art. 12 CP para el sistema penal de las personas individuales, una suerte de numerus clausus de delitos imprudentes para las 
personas jurídicas ${ }^{846}$, lo que pasa es que establece un tipo penal especial, un delito específico, que solamente puede ser cometido de forma imprudente.

\section{PARTICIPACIÓN DE PERSONAS EN EL DELITO DE LA PERSONA JURÍDICA Y TENTATIVA DEL DELITO}

\subsection{Participación de personas en el delito de la persona jurídica}

Es obligado el planteamiento relativo a los problemas de participación en el delito de la persona jurídica, ya sea con otras personas jurídicas o con personas físicas.

Cuando una persona física participa en el delito de la parte especial con otra persona física, se abren las posibilidades tradicionales a las que ha dado respuesta puntual la doctrina española. En principio, a nivel de autoría, puede ser que la persona física sea autora mediata cuando utiliza a otra que le sirve de instrumento, o que sea coautora si es que realizó el hecho delictivo de forma conjunta, si se cumplen las exigencias del criterio del dominio de la voluntad o dominio funcional del hecho, respectivamente. Serían, en ambos casos, autoras (mediatas o coautoras) de un delito cometido por otra persona física. En segundo lugar, si es la persona de adelante la que tiene en sus manos el dominio del hecho de forma exclusiva, la persona de atrás podría ser cómplice o

846 GALÁN MUÑOZ, Alfonso, “La responsabilidad penal...”, Op. Cit., página 36 y nota 71: "Nos encontraríamos por tanto ante una responsabilidad penal colectiva... de naturaleza imprudente", lo que responde al hecho "de que el nuevo art. 31 bis CP haya establecido un sistema de numerus clausus a la hora de fijar los delitos respecto a los que se podría aplicar, ya que ello se corresponde con la opción adoptada por nuestro legislador en el art. $12 \mathrm{CP}$ con respecto al resto de delitos imprudentes. Consideramos, por tanto, que el art. 31 bis CP contempla y describe una modalidad específica y muy delimitada de comportamientos imprudentes colectivos, lo que determina que si bien todos los elementos delimitadores de dicha conductas aparezcan generalmente contemplados en el referido precepto también obliga a que su posible sanción tenga que aparecer expresamente contemplada en aquellos delitos en los que resulte viable". 
inductor del delito de la parte especial que comete aquella, siempre y cuando haya auxiliado dolosamente a otra, o la haya inducido dolosamente, a la comisión dolosa del delito. Empero, a las personas jurídicas ¿se les podrá aplicar los mismos criterios de la participación que se aplican a las personas físicas?

1. Para contestar la cuestión es menester conocer la respuesta de otras opciones interpretativas del art. 31 bis CP.

Quienes avalan la heterorresponsabilidad penal de la persona jurídica, y por tanto, imputan, atribuyen o adhieren a la persona jurídica el injusto objetivo y subjetivo de la persona física (administrador, representante o el sometido a su autoridad) tendrían que considerar responsable a la persona jurídica bajo el mismo título de imputación, es decir, si la persona física cometió el delito como autor directo, o como autor mediato o coautor, o incluso como cómplice o inductor, entonces la persona jurídica será, también, autora directa, mediata, coautora, cómplice o inductora del tipo penal de la parte especial que cometió la persona física. No debería existir ningún problema bajo estos criterios, y la teoría del dominio del hecho no resultaría afectada en ninguna medida puesto que no es en esa sede donde se forma el nudo problemático, sino en un simple sistema de trasferencia de responsabilidad de una persona a otra.

Lo mismo cabría establecer para quienes defienden el sistema del T̂necho de conexiónà el mismo título de imputación de la persona física, será el de la persona jurídica. Si el administrador o representante fue cómplice, en términos del art. 29,b) CP, de un delito de tráfico de influencias del art. 430 realizado por otra persona física, y si lo hizo por cuenta o en nombre y en provecho de la persona jurídica, entonces ésta será también cómplice del delito de tráfico de influencias según el art. $430 \mathrm{CP}^{847}$.

847 Vid. GÓMEZ TOMILLO, Manuel, Introducción..., Op. Cit., página 153 a 178, pues dedica dos capítulos a tratar los problemas de autoría y participación de las personas jurídicas, afirmando no observar ningún inconveniente para ninguno de 
Por nuestra parte, rechazamos esas conclusiones por las razones expuestas líneas arriba ${ }^{848}$ : no podemos admitir que la persona jurídica sea responsable del hecho de otro.

2. Dejando de lado esas vertientes explicativas del problema, debemos entrar a analizar aquellas otras posturas que entienden que la persona jurídica responde penalmente por su propio hecho, es decir, por su propio injusto objetivo y subjetivo y por su propia culpabilidad ${ }^{849}$. Para estas posturas vale preguntarse si la persona jurídica participa en el delito de la persona jurídica, y si es así, cómo participa y cuáles son los criterios de su participación.

Estas opciones interpretativas del art. 31 bis CP se ven obligadas a señalar que la persona jurídica participa con la persona física en una relación de coautoría o autoría mediata o una autoría especial, incluso hay quien refiere una r̃̃o-responsabilidadò pero que en todo caso, la persona jurídica es responsable por coadyuvar o cooperar o participar en el delito de otra persona (esta misma solución se puede observar en algunos valedores de la postura anterior (del f̃echo de conexiónòy culpabilidad propia de la persona jurídica).

Brevemente traemos a colación aquello que sobre el tema señala Gómez Tomillo, quien encuentra una sinergia de la actuación de la persona física con las especiales posibilidades estructurales y medios de la persona jurídica, por lo que afirma que se ñrata de una situación muy próxima, si bien no idéntica, a la característica de la coautoríaơ 850 .

los casos de autoría o participación de una persona jurídica a personas físicas o a otra $\mathrm{u}$ otras personas jurídicas. Dice "Mas bien debe sostenerse que la responsabilidad se atribuye, se imputa, a las personas jurídicas, en virtud de un juicio fundamentalmente valorativo. Desde tal perspectiva, ausente la barrera gramatical que complica la construcción dogmática de la autoría mediata de las personas jurídicas, no parece existir obstáculo alguno para realizar la atribución de responsabilidad en el caso de las personas jurídicas tanto a la persona de atrás como a la de adelante".

848 Capítulo V.3 y V.4.

849 Vid. supra capítulo V.5.

850 GÓMEZ TOMILLO, Manuel, Introducción..., Op. Cit., página 53. De hecho, algún autor coloca en el capítulo 13.IX, "Del autor, los cómplices y la víctima" de su libro de Parte General de Derecho Penal, el estudio del tema de la responsabilidad 
Gómez Rivero observa que la relación entre la actuación de la persona física y la jurídica r̃se acerca más a una situación similar a la coautoría $0^{851}$. Feijóo exige una conducta típica y antijurídica de la persona física ño que se puede denominar una accesoriedad mediaơ ${ }^{852}$, pues ña persona física y la persona jurídica no son coautoras, es decir, cada una no realiza una parte de la organización del hecho ni se puede decir que organicen conjuntamente el hecho, sino que son coresponsablesơ ${ }^{853}$.

De manera expresa Gómez-Jara asegura que entre la acción de la persona física y la jurídica existe una relación de participación ${ }^{854}$, y en relación con la problemática de ña participación de la persona jurídica en el delito de la persona físicaòlo resuelve señalando que ña primera cuestión a determinar es el marco organizativo de la persona jurídica y, a continuación, si la ejecución de la persona física se ha producido en dicho marco organizativo o si, por el contrario, la misma se ha producido al margen de ésteơ ${ }^{855}$, en el primer caso dará lugar a responsabilidad penal de la persona jurídica, en el segundo no será así. Idéntico criterio deberá utilizarse en la participación entre dos o más personas jurídicas, es decir, cuando rél administrador de una persona jurídica es otra persona jurídica o, más aún, en los cuales concurren matriz y filialơ ${ }^{856}$.

penal de las personas jurídicas, vid. QUINTERO OLIVARES, Gonzalo, Parte General de Derecho Penal, Op. Cit., página 677. Este autor considera también la tesis de la "accesoriedad intermedia" en la relación de persona física y la persona jurídica, vid. página 687.

851 GÓMEZ RIVERO, Ma. del Carmen, "La responsabilidad penal de las personas jurídicas", en GÓMEZ RIVERO, Ma. del Carmen, (Coord.), Nociones fundamentales de Derecho Penal. Parte General, Tecnos, Madrid, 2010.

$852 \mathrm{Ib}$ Ídem, página 90. Las cursivas son mías.

853 Ib Ídem, página 92. Las cursivas son mías.

854 "para poder afirmar que una persona jurídica participa en el delito cometido por una persona física, debe constarse un hecho de conexión entre ambas", vid. GÓMEZ-JARA DIEZ, Carlos, Responsabilidad penal de la persona jurídica, 2011, Op. Cit., página 106.

$855 \mathrm{Ib}$ ídem, página 107.

856 Ib Ídem, página 108. 
Desde el punto de vista de estas posturas podemos concluir los siguientes puntos:

a) La persona jurídica nunca podría ser autora material y directa, esto es, no puede cometer de forma personal y directa, con su acción propia (injusto de organización) el delito de la parte especial (corrupción de menores, por ejemplo): siempre será un autor mediato, un coautor o un co-responsable.

b) No concretan ni aclaran cuál es el criterio en virtud del cual el r̃defecto de organizaciónòhace responsable a la persona jurídica por la autoría material y directa de la persona física; y en todo caso, porqué razón ese tal r̃defecto de organizaciónò es un título suficiente para contribuir causal y normativamente al delito de la persona física o a la lesión del bien jurídico tutelado por el delito de la parte especial.

El primer punto es muy importante: este conjunto de teorías niegan la autoría directa, material y personal de la persona jurídica en el delito de la parte especial, pues exigen de una persona física, siempre, esa autoría directa.

Esta relación de las responsabilidades de la persona física y la jurídica, que tendrían que admitir estas opciones interpretativas, nos parece muy forzada porque tensan las reglas de la imputación. En efecto, al pretender hacer responsable a la persona jurídica de los delitos de la parte especial que expresamente prevén su responsabilidad (tráfico ilegal de órganos del 156 bis, por ejemplo), tienen que recurrir necesaria y fatalmente a una norma de participación o a una norma de autoría no directa, en lugar de admitir la forma ordinaria de comisión de delitos, es decir, la autoría material y personal. Nos parece forzada esta postura porque creemos que si alguien puede cometer un delito como coautor o autor mediato, con mayor razón lo podría cometer como autor directo y material (por lo menos, desde un punto de vista normativo, esto es, que jurídicamente nada impida que pueda ser así). ¿Por qué es imposible cometer el delito de forma 
personal y directa, sino única y exclusivamente a través de otra persona?

Al llegar a este punto, las posturas de las que hablamos tendrían que admitir que la norma del art. 31 bis CP es en realidad una norma que crea una forma especial de participación de las personas jurídicas en el delito de la persona física. Esta opción es atendible, sin embargo, no nos convence.

Una opción interpretativa del art. 31 bis de esa naturaleza debería sortear los siguientes obstáculos: a) establecer un criterio en virtud del cual el defecto de organización de la persona jurídica (injusto personal propio de ella) r̃dominaòo ñparticipaòen el delito de la persona física, o hace ver que el delito de la física ñe perteneceò normativamente a la persona jurídica; y junto con ello (lo más importante), b) por qué razón un defecto de organización puede contribuir causal y normativamente a la producción del delito de la persona física.

Heine habla de r̃dominio de la organizaciónòy Gómez-Jara de r̃si la ejecución de la persona física se ha producido en dicho marco organizativoò no obstante, creemos que esas respuestas, amén de ser poco concretas, no responden a la pregunta: cuáles son los elementos de ese dominio de la organización que señalen el límite mínimo para que la persona jurídica sea responsable del delito de la persona física, o qué significa ejecutar el delito en el marco organizativo.

Por otro lado, y en relación con el obstáculo que observamos en la construcción teórica de estas posturas, de por qué razón el r̃defecto de organizaciónò de la persona jurídica contribuye causal y normativamente a la producción del delito de la persona física, o a la lesión o puesta en peligro del bien jurídico, parece irresoluble. Ya Robles Planas concluía que el título del r̃defecto de organizaciónòno es suficiente para imputar a la persona jurídica el delito que cometió la 
persona física ${ }^{857}$. El ñnjusto de sistemaò no es ñun injusto penal en relación con la conducta delictiva de la persona física, pues no ñe alcanzanòlas reglas de la imputación típicas del delito producidoơ ${ }^{858}$. Lo que recuerda lo dicho por Schünemann ños actos de organización incorrectos no infringen en todo caso la norma cuya infracción describe el correspondiente tipo penal, así que al responsabilizar penalmente a la persona jurídica en realidad se subsume en la norma penal supuestamente infringida una acción lesiva referida a otra norma $0^{859}$. Decir que la persona jurídica contribuye con su defecto de organización a la lesión del bien jurídico (que es lo que deben concluir estas tesis) es decir que ese tal defecto de organización tiene capacidad lesiva para los bienes jurídicos tutelados por cada norma penal, y eso es precisamente lo que no creemos.

Nosotros rechazamos, pues, la afirmación de que el art. 31 bis $\mathrm{CP}$ es una norma que prevé una forma especial de participación de las personas jurídicas en el delito de las personas físicas. Amén de las razones expuestas que fundamentan nuestro rechazo, creemos que existe una opción que ofrece explicaciones más admisibles, coherentes, y llena de sentido la interpretación del art. 31 bis: se trata de una norma que prevé un delito en sí mismo, un tipo penal especial propio de las personas jurídicas que consiste simplemente en organizarse adecuadamente.

3. Desde nuestra perspectiva, en materia de participación de personas jurídicas o personas físicas en el delito del art. 31 bis, la problemática debería de cambiar de planteamiento. La cuestión es si puede una persona jurídica participar en la comisión del delito especial del art. 31 bis de otra persona jurídica, como autora mediata o coautora, o participar como cómplice o como inductora; así mismo debemos plantear si una persona física puede participar en el delito del art. 31 bis

${ }^{857}$ Ib Ídem, página 9.

${ }^{858} \mathrm{Ib}$ Ídem, página 16.

859 SCHÜNEMANN, Bernd, "Responsabilidad penal en el marco de la empresa. Dificultades relativas a la individualización de la imputación", en Anuario de Derecho Penal y Ciencias Penales, Vol. LV, 2002, página 29. 
de una persona jurídica, como autora mediata o coautora o como cómplice o partícipe.

Previamente, debemos adelantar que una persona jurídica no puede ser autora directa, autora mediata o coautora de un delito de la parte especial del CP. Por decisión legal, según la construcción que proponemos, la persona jurídica solo puede cometer el delito de organización empresarial defectuosa y ningún otro. El defecto organizativo no es título suficiente para atribuir responsabilidad penal por los delitos que cometieren las personas físicas o por las lesiones a los bienes jurídicos que éstas afectan, es decir, el defecto de organización no es título suficiente para imputar a la persona jurídica el delito cometido por la persona física ${ }^{860}$. Tampoco puede, por las mismas razones, ser inductora o cómplice de ese delito de la parte especial.

Ahora bien, ¿Puede una persona jurídica participar en la comisión del delito del art. 31 bis CP de otra persona jurídica? Nosotros creemos que no.

Partiendo de nuestras propias afirmaciones, es decir, que el delito del art. 31 bis única y exclusivamente puede ser cometido de forma imprudente, ya debemos descontar al dominio del hecho como criterio para resolver la cuestión (igual cosa sucede cuando se trata de participación de personas físicas). Lo mismo deberá decirse de los criterios, nunca bien concretados, del r̃dominio de la organizaciónòdel que hablaba Heine. Tratándose de la imprudencia, decíamos, solamente el criterio normativo de la violación o infracción del deber de cuidado es lo que convierte a una persona jurídica en autora del delito.

En estas condiciones solamente la persona jurídica que infrinja o viole deberes de cuidado específicos de su organización, y esa infracción haya provocado la organización deficiente, será autora del

860 Como lo dice ROBLES PlANAS, Ricardo, “Pena y persona jurídica...”, op. Cit., página 6. 
delito del art. 31 bis CP, si, además, se produce el delito de la persona física que nosotros exigimos como condición objetiva de punibilidad. No es posible, por ello, que una persona jurídica participe en el delito de otra persona jurídica como autora mediata o coautora, pues esas formas de participación exigen el control final del hecho, y por ende, el dolo. Tampoco es posible que una persona jurídica sea cómplice o inductora del delito del art. 31 bis CP de otra persona jurídica, porque la complicidad y la inducción exigen el dolo de la persona de atrás y el dolo de la persona de adelante.

No obstante, es posible que dos personas jurídicas puedan ser autoras de un mismo delito del art. 31 bis CP (en relación con un delito de alguna persona física), pero ambas como autoras materiales y directas por haber violado o infringido deberes de cuidado que provocaron el delito de la persona física. Se trataría como autoras simultáneas o sucedáneas a r̃oda aquella (persona jurídica) que aporta un peligro de causación del resultado sin conocimiento de su producción ${ }^{861}$.

Por otro lado, una persona física tampoco puede ser autora directa, mediata o coautora del delito de defecto de organización empresarial. El principio de legalidad (de tipicidad) lo impide, pues el art. 31 bis CP es una norma penal que se dirige con exclusividad a las personas jurídicas al decir ren los supuestos previstos en este Código, las personas jurídicas serán penalmente responsables deé ò

Queda por resolver si una persona física puede ser cómplice 0 inductora del delito (imprudente) del art. 31 bis CP de la persona jurídica. Nuestra respuesta es en sentido negativo. La participación dolosa en un delito imprudente no es posible, como imposible es la participación imprudente en un delito imprudente ${ }^{862}$, pues la figura del cómplice y del inductor exigen el dolo de la persona de atrás (la

861 ZUGALDÍA ESPINAR, José Miguel, Fundamentos..., Op. Cit., página 427.

862 Ib Ídem, página 428. 
persona física) pero también el dolo de la persona de adelante (la persona jurídica).

El art. 18 del manslaughter act del año 2000, acorde con lo anterior, expresa lo que por lógica se desprende del sistema de responsabilidad penal derivado de un delito especial para la persona jurídica, ñna persona individual no puede ser culpable de inducción, de complicidad, de asesoramiento o procuración de la comisión de un delito de homicidio empresarialò

\subsection{Tentativa del delito del art. 31 bis CP}

Con el fin de ser exhaustos debemos apuntar las diferentes propuestas que se han realizado al respecto, o aquellas otras que es posible colegirse de planteamientos que parten de premisas diferentes a las que nosotros defendemos. Así, las posturas que defienden un sistema vicarial o de heterorresponsabilidad penal derivado del art. 31 bis CP no tendrían ninguna objeción en admitir la tentativa del delito de la persona jurídica. Bien sabemos que para estas posiciones dogmáticas el injusto objetivo y subjetivo de la persona física simplemente se transmite o transfiere a la persona jurídica, haciéndola responder por el hecho ajeno, y por ende, si la persona física realiza actos de ejecución punibles sin llegar a consumar el delito de la parte especial (por ejemplo, el delito urbanístico del art. 319 CP) dicha persona física sería reo de tal ilícito pero a nivel de tentativa del art. 16 $\mathrm{CP}$, y precisamente ese título de imputación será el que tenga la persona jurídica.

Esa solución es de recibo para las posturas del t̂hecho de conexiónò que atribuyen el injusto objetivo y subjetivo de la persona física a la persona jurídica. T̃De la literalidad de los preceptos citados (arts. 15 y $16 \mathrm{CP}$ ) no se desprenden obstáculos jurídico-positivos para 
sancionar el delito meramente intentadoò dice Gómez Tomillo en relación al tema en cuestión ${ }^{863}$, y concluye que m̃o hay duda de que también debe sancionarse a las personas jurídicas por delitos meramente intentados $0^{864}$. De hecho, este autor expresamente señala que el dolo o la imprudencia de la persona física se transmiten a la jurídica, para fundamentar, en el caso, la tentativa del delito ${ }^{865}$.

Zugaldía también señala que rẽl hecho de que para la determinación de la pena el legislador no haya hecho una remisión expresa a la Sección $1^{\text {a }}$ del Capítulo II del Libro I CP no significa que en los delitos de las personas jurídica son quepan las formas imperfectas de ejecución. Lo mismo cabe decir respecto de la autoría (mediata y coautoría) y la participación criminal (inducción y complicidad) $0^{866}$.

Sin embargo, aun y cuando son opciones interpretativas atendibles, a nosotros nos parece que, a tono con los antecedentes que nos hemos planteado, la respuesta debería ser diferente.

La tentativa, desde la perspectiva que manejamos en este trabajo de investigación, solamente tiene una solución. Porque el injusto de organización empresarial defectuosa es imprudente es imposible la tentativa del delito, que en términos del art. $16 \mathrm{CP}$, solo admite la comisión dolosa.

Finalmente, amén de que si hemos dicho que el delito de la persona física es una condición objetiva de punibilidad, y solo por esta vía se desata la responsabilidad penal de la persona jurídica, tampoco será posible hablar de tentativa del delito. En efecto, una condición

\footnotetext{
863 Op. Cit., página 150.

864 Ib Ídem, página 149.

${ }^{865} \mathrm{Ib}$ Ídem, página 150, dice "en el Derecho Penal solo es punible la tentativa de delito doloso. Ciertamente las personas jurídicas por sí mismas no actúan ni dolosa ni imprudentemente. Sin embargo, tampoco ello es inconveniente para imputar a la persona jurídica el delito intentado, si partimos de los postulados aquí defendidos. Concretamente nos referimos al criterio conforme al cual el dolo de la persona física realmente actuante u omitente debe considerarse para fundar la culpabilidad de la persona jurídica, la cual puede presumirse iuris tantum".

${ }^{866}$ ZUGALDÍA ESPINAR, José Miguel, La responsabilidad criminal de los entes..., 2012, Op. Cit., página 87.
} 
objetiva de punibilidad no pertenece ni al injusto ni a la culpabilidad y por tanto no forma parte del iter criminis ${ }^{867}$, son hechos futuros e inciertos independientes de la voluntad del autor que determinan la punición de la conducta típica, son fundamentadoras del castigo y se apoyan en consideraciones político criminales o de necesidad de pena ${ }^{868}$. Por tanto, si no existe un delito de la persona física no habrá, de ningún modo, responsabilidad penal de la persona jurídica.

\section{CULPABILIDAD DE LAS PERSONAS JURÍDICAS}

\subsection{Concepto y límites de la culpabilidad empresarial}

Una vez que haya sido demostrado el injusto de la persona jurídica (tipicidad y antijuridicidad) resta ahora comprobar la culpabilidad, es decir, las condiciones bajo las cuales la persona jurídica debe ser objeto de un reproche jurídico y social por el injusto de organización empresarial que ha cometido, y en consecuencia, sea posible imponer una de las penas establecidas en el art. 33.7 CP.

1. Las categorías jurídico penales que se manejan comúnmente en el Derecho Penal de las personas físicas deben de ser válidas también para el sistema de responsabilidad de las personas jurídicas, como lo hemos visto, es decir, tipicidad, antijuridicidad y culpabilidad. No, en cambio, deberán tener el mismo contenido.

La culpabilidad, como categoría de enlace entre el injusto personal y la pena ${ }^{869}$ en el sistema de las personas físicas, se fundamenta en un juicio de desvalor sobre la individualidad de la

\footnotetext{
${ }^{867}$ MUÑOZ CONDE, Francisco y GARCíA ARÁN, Ma. Mercedes, Derecho Penal. Parte General, 2010, Op. Cit., página 401.

${ }^{868}$ ORTS BERENGUER/GONZÁLEZ CUSSAC, Compendio de Derecho Penal,2010, Op. Cit., página 207.

${ }^{869}$ MUÑOZ CONDE/GARCÍA ARÁN, Derecho Penal. Parte General, 2010, Op. Cit., página 45.
} 
persona que cometió el delito, por ello se dice que la culpabilidad solamente se puede predicar del sujeto que cometió el hecho ilícito, es decir, solo el individuo puede ser culpable ${ }^{870}$.

La culpabilidad tiene su fundamento en la libertad del individuo, es decir, solamente se es culpable cuando se es libre. La pena es el elemento que reconoce la dignidad del infractor, en cuanto que lo trata como un ser libre, y por ello, responsable. Se afirma que es autor culpable quien tha podido actuar de otro modo por haber sido accesible al mandato normativo (porque le podía alcanzar el efecto de llamada de atención de la norma). Dicho de otro modo, culpable es el autor que ha podido comportarse con arreglo a Derecho y no lo ha hecho a pesar de haber sido accesible al mandato normativo ${ }^{871}$.

Los elementos de la culpabilidad, para el caso de las personas físicas, son la capacidad de culpabilidad o imputabilidad y el conocimiento de la antijuridicidad ${ }^{872}$, y están previstas en el CP español en los artículos $20.1^{\circ}, 20.2^{\circ}, 20.3^{\circ}, 20.6^{\circ}$, y 14.3 , aunque de forma inversa, es decir, como causas de inculpabilidad. Se trataría de anomalías o alteraciones psíquicas o intoxicación que le impidan comprender la ilicitud del hecho o actuar conforme a esa comprensión, o alteraciones de percepción que le afecten gravemente la conciencia de la realidad, o el miedo insuperable, y, finalmente, el error de prohibición invencible.

Es aceptada pacíficamente la afirmación que ante la demostración de un hecho ilícito (típico y antijurídico) la culpabilidad del autor debe presumirse, a no ser que haya razones para plantearse la exclusión de la misma, y en su caso, será el reo quien deba demostrar alguna causa que permita considerar ausente su calidad culpable.

\footnotetext{
${ }^{870}$ ZUGALDÍA ESPINAR, José Miguel, Fundamentos..., 2010, Op. Cit., página 329.

${ }^{871}$ lb Ídem, página 329.

872 BERDUGO GÓMEZ DE LA TORRE, Ignacio, Lecciones..., 2010, Op. Cit., página 325 y 347, pássim; y ZUGALDÍA ESPINAR, José Miguel, Fundamentos..., 2010, Op. Cit., página 331 y sigs.
} 
Todo lo que cabe decir de la culpabilidad para el sistema de responsabilidad penal de las personas físicas, tiene cierta cabida para el caso de las personas jurídicas, siempre y cuando realicemos esa analogía funcional para construirla, como veremos a continuación.

2. Es necesario recordar lo que para otras construcciones teóricas que se han elaborado a partir de la LO 5/2010, de 23 de junio, representa la culpabilidad en el sistema de responsabilidad penal de las personas jurídicas.

Para ser congruentes con nuestra exposición es conveniente recordar que quienes consideraran que la reforma operada ha creado un sistema de responsabilidad sin culpabilidad sino de peligrosidad de la persona jurídica y para quienes han creado un sistema de heterorresponsabilidad penal de la persona jurídica, no cabe hablar de culpabilidad penal o de imputación personal del hecho típico y antijurídico a la persona jurídica ${ }^{873}$. Para los primeros, que niegan la libertad de la persona jurídica y su posibilidad de adecuar su conducta a la norma no vale atribuir responsabilidad penal, sino que la persona jurídica deberá ser tratada como un instrumento peligroso en manos de personas físicas. La consecuencia impuesta no es, desde luego, expresión del r̃̃eprocheòpor el delito, sino de la ñegitimación del Estado para actuar sobre la empresa que se enriquece injustamente $88^{874}$, para exigirle a los titulares de la empresa que mantengan el estado de cosas caracterizado por la obtención lícita de ganancias ${ }^{875}$, pues la finalidad de un sistema así es la de ñncentivar para que en el ámbito de la persona jurídica no se introduzcan ganancias provenientes de hechos delictivos y, en esa medida, combatir la perpetuación del estado de injusto producido por la comisión del hechoo ${ }^{876}$. Así, el modelo del art. 31 bis CP obedece a la estructura de responsabilidad objetiva por el riesgo.

873 Vid. supra capítulo V.2 y V.3.

874 ROBLES PLANAS, Ricardo, "Crítica del artículo 31 bis CP", en Diario la Ley, No. 7705, Año XXXII, Editorial La Ley, 29 de septiembre de 2011, op. Cit., página 15.

$875 \mathrm{Ib}$ Ídem.

876 Ib Ídem. 
Ya hemos tomado distancia de este modelo. La segunda postura, aquella que estima el art. 31 bis como de absoluta heterorresponsabilidad para la persona jurídica, no concibe culpabilidad de ésta pues no tiene libertad, dicen, y por tanto capacidad de culpabilidad. La pena se impone por una simple solidaridad 0 subsidiaridad en el delito de la persona física.

En tercer lugar, para quienes consideran una culpabilidad penal de la persona jurídica como el defecto de organización ${ }^{877}$, dicha categoría jurídico penal estaría configurada por una r̃omisión de deberò o ñviolación de cuidadoòal no implementar reglas o normas o medidas para evitar delitos de los miembros de la persona jurídica, lo que nos parece incorrecto. En efecto, no podemos mantener la r̃ culpabilidadòde la persona jurídica como una categoría jurídico penal, pretendiendo hacerla funcionar de forma análoga con la culpabilidad de las personas físicas, y luego renunciar a esa función al inundar esa categoría con un contenido propio de un injusto imprudente. Nos remitimos al discurso que generamos para rechazar estas posturas por las razones expuestas $^{878}$.

3. Desde nuestro punto de vista, la culpabilidad de la persona jurídica tiene también su fundamento en la libertad que les ha otorgado el ordenamiento jurídico a las personas jurídicas (empresas) de organizarse y controlar los riesgos propios de sus actividades. Frente a la libertad que tiene cualquier empresa, existe a su cargo la responsabilidad de organizarse adecuadamente, de crear una organización que disminuya hasta límites irreductibles y razonables las posibilidades de que sus miembros cometan delitos.

Desde luego que la culpabilidad empresarial tiene su fundamento en la libertad de organización que el ordenamiento jurídico le ha otorgado, precisamente como la expresión de esa nueva estrategia de control para este tipo de entes, ña culpabilidad jurídico

877 Vid. supra capítulo V.4.

${ }^{878}$ Vid. supra capítulo VI.1.3. 
penal tiene que ver siempre en última instancia con la libertad de autoorganización como reconocimiento social o intersubjetivo ${ }^{879}$. Por ello se explica que cuando la persona jurídica pone en entredicho su obligación de organizarse adecuadamente para evitar posibles facilidades de cometer el delito de sus miembros, entonces se puede observar una actitud interior de incumplimiento del Derecho. Es, por otro lado, admisible que el título de la desaprobación sea de carácter ético-social, r̃uando el legislador decide sancionar a las personas jurídicas, configura una sanción carente de reproche ético-individual y que contiene exclusivamente una censura ético-social, derivada de una deficiente filosofía individual o de una estructura organizativa incorrectao8 880 .

La culpabilidad, también en el sistema de responsabilidad de las personas jurídicas, debe ser un concepto similar a la m̃o exigibilidad de una conducta conforme a derechoò esto es, a la r̃elaboración dogmática conforma a la cual, de llevarse a cabo el injusto típico en una situación en a la que no cabe exigir al sujeto el comportamiento de la norma, debe quedar exento de responsabilidad penalo ${ }^{881}$.

A tono con la elaboración teórico que hemos mantenido (esto es, dejando el defecto de organización como injusto de la persona jurídica), la culpabilidad empresarial debe construirse en algo así como ñoder organizarse de otra maneraơ 82 , o mo haberse organizado adecuadamente para evitar la comisión de hechos delictivos o detectarlos ${ }^{883}$. Las respuestas que se han dado al respecto por quienes le dan, junto a nosotros, un similar contenido a la culpabilidad han sido de r̃rreación y mantenimiento de una cultura empresarial de

${ }^{879}$ GÓMEZ-JARA DIEZ, Carlos, Responsabilidad penal..., Op. Cit., página 108.

880 DANNECKER, Gerard, "Reflexiones sobre la responsabilidad penal...", Op. Cit., página 48.

881 CÓRDOBA RODA, Juan, en CÓRDOBA RODA Y GARCÍA ARÁN (Dirs.), Comentarios al Código Penal. Parte General, Marcial Pons, Madrid, 2011, página 83. ZUGALDÍA ESPINAR, José Miguel, Fundamentos..., Op. Cit., página 329 y sigs.

882 SILVA SÁNCHEZ, Jesús-María, "La reforma del Código penal: una aproximación desde el contexto", Op. Cit., página 7.

883 NIETO MARTÍN, “La responsabilidad penal...”, página 11. 
incumplimiento de la legalidado ${ }^{84}$ o mo tener una cultura empresarial de incumplimiento de la legalidado8 85 .

Como la culpabilidad se refiere a su defecto organizativo, y éste tiene una dimensión temporal diferente al de las personas físicas, también la culpabilidad se extiende en el tiempo y es posible observar esa r̃ausencia de disposición jurídica mínimaòmediante referencias a su normativa, a la gestión y ejecución de su normativa, a la forma en que se desenvuelve en general la organización, tanto un tiempo más o menos prolongado anterior al delito de la persona física como posterior a él. De ahí que se entienda que las circunstancias atenuantes del punto 4 del art. 31 bis CP estén referidas en etapa post delictiva. No debería causar rechazo esta situación, ni siquiera cuando se admite, como lo hacemos nosotros también, que el defecto de organización y la culpabilidad empresarial se r̃ de la persona jurídica ${ }^{86}$, porque es cosa totalmente diferente del concepto tan denostado en el Derecho Penal individual de r̃derecho penal de autorò o el castigo penal por su f̂́orma de serò o su ñpersonalidadò La diferencia del injusto penal de la persona física con el de la persona jurídica impide referirlos a una dimensión temporal similar, y precisamente por ello no significa que en el caso de la persona jurídica se le castigue por su forma de ser.

Por último, una vez demostrado el injusto de organización empresarial defectuosa de una persona jurídica cabe presumir, tal cual se hace en el Derecho Penal de las personas físicas, la culpabilidad del ente colectivo, y corresponderá a éste demostrar alguna causa de inculpabilidad. Aquí es donde entran en juego los programas de cumplimiento del Derecho, que trataremos en los siguientes epígrafes.

884 GÓMEZ-JARA DIEZ, Carlos, Responsabilidad penal..., Op. Cit., página 82; con amplias referencias, el mismo, Culpabilidad penal de la empresa, Op. Cit., página 201 y sigs.

885 FEIJÓO SÁNCHEZ, Bernardo, “La responsabilidad penal...”, Op. Cit., página 109. 886 Ib Ídem, página 107. 


\subsection{Los compliance programs}

Habremos de analizar los programas de cumplimiento del Derecho o programas éticos en esta parte de nuestra investigación porque aquí corresponde, según nuestra apreciación, y a pesar de que el esquema que ha abrazado la doctrina dominante (que los analiza como contrapartida del r̃defecto de organizaciónòde la persona jurídica) los ubica en el injusto o en la culpabilidad, según la opción del modelo que se siga. Ya sabemos que nosotros consideramos el defecto de organización como el injusto de la persona jurídica, y no tanto como su culpabilidad.

Nosotros tenemos la impresión que los compliance programs son la forma de demostrar una causa de inculpabilidad de la persona jurídica, y no tanto una causa de organización adecuada (concepto contrario al defecto de organización). No obstante, debemos reconocer que resulta difícil desvincular ambos conceptos como equivalentes contrarios.

Pensamos que una organización puede estar defectuosamente organizada, pues en su normativa organizacional (manuales, procedimientos, procesos, flujogramas, competencias, funciones, escalafón, premios y recompensas, y un largo etcétera) y en la implementación y ejecución (mostradas en evidencias de cumplimiento) de la misma, podría tener lagunas o contradicciones, que pudieran ser aprovechadas por las personas físicas que para ellas trabajan para cometer conductas delictivas, o que sirvieran para alentarlas o animarlas para ello. Esto colocaría a la persona jurídica en un defecto de organización que sería un injusto criminal si una persona física comete un delito en los términos del art. 31 bis CP. Hasta aquí tendríamos completo el injusto objetivo de la empresa. Pero no es a lo que se refieren los programas de cumplimiento del Derecho.

La cultura empresarial, la ética empresarial, su fidelidad al derecho, su compromiso o su r̃olisposición personalò con el 
cumplimiento del orden jurídico y con la no producción de lesiones o riesgos a los bienes jurídicos individuales colectivos, se verían reflejados en la creación, gestión, implementación y ejecución de otros elementos organizativos adicionales que más que referirse a su organización diaria para cumplir con su giro específico (producción de bienes o servicios), se refieren al análisis de riesgos, programa ético, compromiso de la Directiva, creación de un delegado de cumplimiento (compliance officer), creación de sistemas para la protección y recompensa a los denunciantes cívicos de conductas ilícitas, colaboración con las autoridades, entre otras cosas. Esos son los compliance programs. Es decir, la contrapartida del defecto de organización es la adecuada organización ${ }^{887}$; la contrapartida de la significación de los programas de cumplimiento (no de su existencia misma) es la culpabilidad de la empresa ${ }^{888}$.

Una empresa de ciertas dimensiones y complejidad que tiene un sistema organizacional determinado, podría estar perfectamente organizada, adecuadamente, sin crear riesgos a bienes jurídicos; y puede ser que no se lo deba a un programa de cumplimiento de Derecho o código de ética; puesto que la inexistencia de éstos no determina la presencia del defecto organizativo. Puede ser que la empresa adolezca de un defecto organizativo que haya tenido relación con un delito de una persona física (en términos del art. 31 bis $\mathrm{CP}$ ), a pesar de poseer un programa de cumplimiento del derecho o código de ética; puesto que la existencia de éstos no eliminan necesariamente la

887 Así, GARCÍA ARÁN, Mercedes, “Artículo 31 bis”, Op. Cit., página 395, pues dice "la omisión de precauciones exigible para asegurar la correcta actuación de la persona jurídica... no permite construir un sistema de causas de exculpación paralelo al de la persona física, puesto que la buena organización -lo contrario del defecto de organización- no puede operar como circunstancia que elimine la culpabilidad por el injusto cometido: si hay defecto de organización, habrá injusto, y frente a él no cabe oponer la buena organización como exculpante, porque partimos de que falta la organización exigible, como concepto objetivo que permite imputar los hechos".

${ }^{888} \mathrm{Ib}$ Ídem, página 396, pues dice "a las personas jurídicas no les es exigible un estado de organización perfecto y desprovisto de fallos; lo que les resulta exigible es la disposición, mantenimiento y aplicación de una organización destinada a evitarlos". 
del defecto organizativo. Es más, el defecto organizativo de una empresa no sería culpable a pesar de no tener ningún programa de cumplimiento o código de ética como tal implementado en la misma, si demuestra que la organización en general (incluyendo la alta dirección y la totalidad de empleados) poseen un sentido de cumplimiento del Derecho suficiente, que rechaza y reprueba la comisión de un delito. En este sentido, la ley chilena no obliga a las empresas a adoptar el programa de cumplimiento ï dice ñpodránà mientras que el decreto legislativo italiano no limita las causas de inculpabilidad a tener un programa de cumplimiento, pues incluye el que la persona física haya cometido el delito burlando o defraudando a la organización. La reforma de 2010 en España, como hemos visto, nada dice al respecto, pues ni siquiera exige expresamente un programa así, por lo que es posible la opción que proponemos.

Estimamos que un programa de cumplimiento del Derecho o un código de ética empresarial, como tendremos oportunidad de verlo infra, constituye la proclamación en voz alta de la persona jurídica de que tiene un interés supino por la no comisión de delitos en su seno ${ }^{889}$. Incide en la organización ya existente de la empresa, para crear garantías o candados de que no será creadora de riesgos a bienes jurídicos a través de conductas de sus miembros; esto es, constituye la puesta en marcha de su decisión de que se puede organizar de otro modo, de un modo acorde al Derecho. Entendemos que en este sentido lo comprende también Feijóo pues señala que la culpabilidad de la persona jurídica tiene su fundamento en la personalidad que es normativa e intersubjetivamente relevante, por lo que rexiste culpabilidad cuando el injusto sólo se puede explicar a partir de una disposición personal de la que se es responsable en exclusiva frente a

${ }^{889}$ Llaman la atención algunas frases de autores que entienden "en todo caso, un Código individualizado de Buen Gobierno Corporativo significa para una empresa su grado de compromiso y su grado de interés por el respeto a la Ley y a la ética empresarial". Aunque parece ser que en definitiva consideran que los programas de cumplimiento del Derecho son contrapartida del defecto de organización, vid. ZUGALDÍA ESPINAR, José Miguel, La responsabilidad criminal de los entes colectivos, Op. Cit., página 60, 
los demásé no existirá culpabilidad cuando el defecto organizativo no obedece a una falta de r̃ultura de cumplimiento de la legalidadò de la propia persona jurídica titular de la organización ${ }^{890}$.

Bien mirado, el contenido tradicional de los códigos éticos empresariales o programas de cumplimiento del Derecho no se dirigen a organizar a la empresa, a establecer competencias, roles, funciones, procedimientos, políticas u objetivos en la producción de bienes y servicios, metas y techos de producción, reducir costes y aumentar beneficios, o contratar o sancionar personal, pues esto está regulado por aquellas normas y ejecutado por los órganos creados por las normas para dicho fin. El compliance program tiene el fin de que esa organización extreme precauciones para ser inocua: análisis de riesgos (específicos del giro de la empresa) de comisión de delitos, creación de una cultura empresarial específica al cumplimiento del Derecho, creación de un compliance officer para vigilar dicha cultura empresarial, vigilancia y auditoría continua respecto de este tópico.

No obstante, en muchas ocasiones la distinción entre normas de organización y normas de compliance no es de ninguna manera diáfana. La discusión futura de la doctrina y la jurisprudencia seguramente dará pautas para su diferenciación más precisa.

Bajo la advertencia anterior analizaremos en este rubro los programas de cumplimiento, sus contenidos y sus límites, una breve referencia a la experiencia extranjera. Iniciaremos, previamente, lo que se ha llamado la autorregulación regulada como una nueva estrategia de control por parte del Estado y la tradición que ya tiene en España.

\subsubsection{La autorregulación regulada}

${ }^{890}$ FEIJÓO SÁNCHEZ, Bernardo, “La responsabilidad penal...”, Op. Cit., página 108. 
Es común la afirmación, y por su evidencia se admite casi sin impugnarla, que las empresas mercantiles persiguen beneficios económicos, y mientras más altos sean éstos, la empresa se considera más exitosa y su modelo organizativo constituirá un paradigma a seguir. Los casos de éxito se estudian en las universidades y en las escuelas de administración, mercado o comercio, con el fin de trasladar las experiencias de éxito a otros giros y así conseguir la prosperidad económica de nuevas empresas, con la consiguiente de sus miembros. El esquema podría ser enunciado así: mayores beneficios económicos, con los menores costes.

No obstante, desde muchas décadas atrás, se ha llegado a la conclusión que el mundo empresarial no es inocuo. Las empresas controlan grandes e importantes parcelas de la vida de las personas, rálimentación, transportes, medio ambiente, salud, ahorro, inversiones y ello sin contar la condición del asalariadoé y muy pronto se experimentó la capacidad de influencia de las corporaciones sobre el poder político, para hacer y deshacer leyes a su medida, a través de turbias relaciones canalizadas por la corrupcióno ${ }^{891}$. Un tanto anecdóticamente, se decía que después de la recesión económica norteamericana de finales de la década de los 20's del siglo pasado las esperanzas del resurgimiento de ese país se pusieron en las generales: General Mills, General Motors y General Electric, lo que expresaba el poder de compañías para levantar un país o hacerlo sucumbir (el caso Enron es también anecdótico), y también expresa la lógica norteamericana de su ordenamiento jurídico.

Un sistema que privilegie la ebullición del beneficio económico sin pensar en las consecuencias, no alternas, sino directas, que puede provocar el mismo, desvela un solo lado del fenómeno. Del otro encontramos la producción de peligros y lesiones a bienes jurídicos

891 NIETO MARTÍN, Adán, "Responsabilidad social, gobierno corporativo y autorregulación: sus influencias en el derecho penal de la empresa", Op. Cit., página 2. 
individuales y colectivos de los que ya hemos hablado supra ${ }^{892}$, es decir, afectación a los propios trabajadores de la empresa, a sindicatos, a sus proveedores, a sus socios, al Estado y la Administración, pero también, a los consumidores, a los clientes, a cualquiera que tiene relación con la compañía, al medio ambiente, la economía nacional o local, y un largo etcétera. Se trata del enfrentamiento de dos lógicas inicialmente contradictorias: por un lado la búsqueda del mayor beneficio para las empresas (con los menores costes, incluso, a pesar de los peligros o lesiones a bienes jurídicos individuales colectivos), y por el otro la guarda y protección de los bienes jurídicos individuales y colectivos.

Hoy en día, ya no se conciben esas posturas como encontradas y en enfrentamiento: el mayor beneficio a los menores costes pero siempre y cuando no haya tensión con los intereses de otros. Se trataría de una r̃cultura empresarial basada en valoresòque se refieren f́básicamente, al fin que justifica una acción y están en la base de una ética normativa empresarial que se expresa en un código de deberes de actuar $o$ de omitir acciones en circunstancias concretas que denominamos reglas de conducta ${ }^{893}$. Esta tensión se expresaría, como lo ha hecho Bacigalupo, 战 Cómo decidir entre competitividad y colaboración? ¿Hasta dónde debemos colaborar con nuestros competidores? ¿Qué limites impone la privacidad al control de personal? ¿Cuáles son nuestras incompatibilidades? $0^{894}$.

En las respuestas a las preguntas se deducen dos posturas 0 ideologías económicas: intervencionismo gubernamental o voluntarismo jurídico contra libertad de mercado y empresarial (con su correspondiente responsabilidad social y ética) ${ }^{895}$. El primero pretende controlar el r̃ comportamiento de las sociedades con la norma jurídica, acompañada de la intervención de la administración a través de

\footnotetext{
${ }^{892}$ Capitulo III.1.1.2.

${ }^{893}$ BACIGALUPO, Enrique, Compliance y Derecho Penal, Op. Cit., página 17.

${ }^{894}$ Ib Ídem, página 18.

895 NIETO MARTÍN, Adán, La responsabilidad penal de las personas jurídicas, Op. Cit., página 218 a 220 .
} 
agencias muy inquisitivas con amplios poderes normativos, de investigación y sanción ${ }^{896}$ y confía en que imponiendo la norma jurídica la empresa adecuará su organización al resultado deseado, y el segundo, desconfiando de la eficacia de la ley, p̃propone, de un lado, incentivar una estrategia de cooperación entre administración, órganos de persecución y empresas, alejada de una posición de choque o constante recelo entre ambos frentes y, de otro, incentivar una cultura ética a través de la promoción de la responsabilidad social de la empresa, la elaboración de programas éticos que finen las pautas de actuación cuando la ley acabaơ

En los años noventa del pasado siglo el debate trasciende entre intervención y autorregulación debido a ñun mundo luhmanianamente más complejo, en el que son ineficientes muchas de las técnicas clásicas de intervención ${ }^{898}$ derivados de la sociedad del riesgo y la globalización que hemos analizado supra ${ }^{899}$, pues el Estado se muestra incapaz de intervenir y regular de forma directa e inmediata ra las complejas organizaciones empresariales, que debido a su tamaño y complejidad interna, no permiten una intervención o regulación externa directaò pues se convierten en verdaderas r̃cajas negrasơ $0^{900}$. El resultado ha sido, hasta hoy, una trasformación de las relaciones entre sociedad y gobierno ${ }^{901}$, en las que éste ha renunciado a intervenir de la misma manera que lo hacía antes, para utilizar una nueva estrategia de intervención, esto es, r̃controlarlas de forma indirecta. Por ejemplo, el

\footnotetext{
896 Ib Ídem, página 219.

$897 \mathrm{Ib}$ Ídem, página 220. El autor identifica el enfrentamiento de las posturas en la política de Roosevelt en medio de la Gran Depresión iniciada con el martes negro en Estados Unidos de Norteamérica, por un lado, y en las políticas del Presidente Ronald Reagan y la primer ministro Margaret Tatcher, apoyados "por la corriente de pensamiento de la escuela de Chicago", vid. también en NIETO MARTíN, Adán, "Responsabilidad social, gobierno corporativo y autorregulación...", Op. Cit., página 3.

898 Ib Ídem, página 3 y 4.

${ }^{899}$ Vid. Capítulo III.1.

900 GOMEZ-JARA DIEZ, Carlos, Responsabilidad penal de las personas jurídicas, Op. Cit., página 28.

901 Así FEIJÓo SÁNCHEZ, Bernardo, "La responsabilidad penal...”, Op. Cit., página 68, y ZUGALDÍA ESPINAR, José Miguel, La responsabilidad criminal de los entes colectivos, Op. Cit., página 61.
} 
Estado ya no está en condiciones de decidir cuál es la mejor técnica posible para controlar riesgos ambientales o los riesgos de los productos alimenticios, delegando esa decisión en las empresas que general los riesgoso $0^{902}$, esto es, en una autorregulación regulada ${ }^{903} \mathrm{o}$ self regulation.

No se trata de una rausencia de Estadoòni de la privatización del control, sino de un control diferente, una ñntervención estatal a distanciao ${ }^{904}$, que proviene del derecho reflexivo de Teubner $^{905}$, y que se traduce en una norma jurídico penal que obliga a la empresa a organizarse adecuadamente, y que si no lo hace y produce alguna lesión o peligro para bienes jurídicos, habrá de ser responsable de ellos.

\subsubsection{Los programas de cumplimiento}

Se les conoce también como ñprogramas de cumplimientoà o p̃ogramas de cumplimiento de la legalidadò o r̃ódigos éticosò o en acepciones en inglés Compliance Programs, o Criminal Compliance, o Corporate Compliance Policy o Compliance guide. Algunas legislaciones le han llamado m̃modelos de organización y gestión para la

\footnotetext{
902 FEIJÓO SÁNCHEZ, Bernardo, “La responsabilidad penal...”, Op. Cit., página 68. 903 Contra esta concepción, equivocadamente, ALONSO GALLO, Jaime, "Los programas de cumplimiento", Op. Cit., página 149, al señalar que "los programas de cumplimiento no pretenden en absoluto suplir la falta de regulación del Estado. Al contrario, precisamente porque hay una regulación estatal enormemente compleja" los programas de cumplimiento tienen sentido, por tanto "no estamos en absoluto ante una forma de autorregulación, sino ante la aplicación de la normativa (no sólo penal, sino regulatoria) del Estado". Nosotros concluimos que nadie ha dicho que el Estado ha abdicado de regular el comportamiento empresarial, sino que lo hace de una forma diferente al clásico y tradicional intervencionismo del siglo anterior, y esa nueva estrategia se llama autorregulación regulada.

904 NIETO MARTÍN, Adán, "Responsabilidad social, gobierno corporativo y autorregulación...", Op. Cit., página 4.

905 Así NIETO MARTÍN, Adán, "Responsabilidad social, gobierno corporativo y autorregulación...”, Op. Cit., página 4, y GOMEZ-JARA DIEZ, Carlos, Responsabilidad penal de las personas jurídicas, Op. Cit., página 28.
} 
prevención de delitosơ ${ }^{906}$, o m̃modelos de organización, administración y supervisión para prevenir delitoso $0^{07}$.

El primer aspecto que debemos de destacar de ellos es que son, esencialmente, normas o reglas o protocolos o procedimientos, y creación de nuevos órganos con nuevas funciones. Esto es, son un conjunto de normas dirigidas a la propia persona jurídica, o a órganos de la misma, que les obliga a hacerse, a dirigirse, a controlarse, a vigilarse, a auditarse, a sí mismas. Esas normas son expresadas en términos lingüísticos (ni duda cabe) y están impresas en documentos validados por la propia persona jurídica. De hecho los códigos de conducta suelen ser hechos públicos en las páginas webb de las empresas $^{908}$.

Este primer aspecto es destacado en la mayoría de las referencias doctrinales sobre el tema. Se dice que son r̃sistemas internos de control que tienen algunas empresas con el fin de evitar incumplimientos normativos serios por parte de sus empleados y directivos 0 , de producirse éstos, detectarlos. Consisten, de forma muy resumida, en una serie de normas de conducta o códigos éticos y unos procedimientos para su aplicación $0^{909}$. Se les suele definir o designar también como p̃protocolos o mecanismos integrados estatutaria, orgánica y jerárquicamente en la sociedad $0^{10}$, o ñprogramas o protocolos específicos a través de los cuales los Gobiernos corporativos establecen el marco y los medios para un comportamiento generalizado

\footnotetext{
906 Art. 6 del Decreto Legislativo 231/2001 Italiano.

907 Art. $3^{\text {o }}$ de la Ley 20.393 que regula la responsabilidad penal de las personas jurídicas en Chile.

908 BACIGALUPO, Enrique, Compliance y Derecho Penal, Thomson Reuters, Pamplona, 2011, página 105. En el caso de las sociedades cotizadas esa obligación está dada por la Ley de Transparencia.

909 ALONSO GALLO, Jaime, "Los programas de cumplimiento", en DIAZ-MAROTO Y VILLAREJO, Julio (Dir.), Estudios sobre las reformas del Código Penal, operadas por las LO 5/2010, de 22 de junio, y 3/2011 de 28 de enero, Thomson Reuters, Madrid, 2011, página 148. Las cursivas son nuestras.

910 ZUGALDÍA ESPINAR, José Miguel, La responsabilidad criminal de los entes colectivos, Op. Cit., página 58.
} 
de la empresa y e la empresa respetuoso con lo establecido por las normas penalesơ ${ }^{11}$.

Pues bien, normas de conducta, códigos éticos, protocolos o programas, son conceptos que describen bien a los Compliance Programs como cuerpos normativos con vocación de ser implementados, aplicados, ejecutados, revisados 0 auditados continuamente en su aplicación, que también crean otros órganos con funciones muy específicas.

El segundo aspecto que debemos destacar de ellos es que tienen su origen en la propia empresa, fundamentalmente en la Alta Dirección. Son las personas físicas en posición apical las que crean u ordenan crear esas normas de conducta o protocolos. Por eso se dice que estamos en presencia de una autorregulación.

El contenido de los mismos no es precisamente libre. Tienen mínimos específicos que podemos deducir del estudio de diferentes parcelas del ordenamiento español, principalmente en materia administrativa, financiera y laboral, así como de las experiencias jurídicas extranjeras (infra 1.3.2.1 y 1.3.2.2). Es claro que el art. 31 bis CP no impone ningún tipo de contenidos a los códigos de ética empresarial, es más, como lo hemos dicho, ni siquiera impone la obligación de tenerlos y crearlos. Pero creo que eso no significa ningún obstáculo para ensayar los rubros que deben tener en materia de responsabilidad penal (infra 1.3.2.3).

Como cuarto punto, los Compliance Programs tienen una finalidad específica, que no es la de organizar a la empresa, sino la de que la organización sea inocua, conociendo bien los riesgos generales y específicos derivados del giro de la empresa, pero introduciendo una r̃cultura empresarial de la legalidadò Para ello existen dos modelos de compliance, unos de contenido ñaicoòque no hacen más que repetir los mandatos o prohibiciones que ya existen en el ordenamiento jurídico 
(administrativo, laboral, financiero, o en nuestro caso penal), por lo que no se agregaría nada más que el simple acercamiento de esas normas a una empresa determinada; otros, en cambio, van más allá, pues tienen un contenido ético, esto es, reflejan ñun vivo debate a tenor del cual la existencia de un clima ético o una cultura empresarial apropiada, que trascienda el mero respecto a la legalidad resulta imprescindible, para evitar comportamientos delictivosé su finalidad es que los trabajadores asuman valores, de modo tal que se instaure en la empresa una cultura de respeto a la legalidad, lo que no puede conseguirse fomentando únicamente el cumplimiento estricto de la legalidad a través de un sistema policial y sancionador internoo ${ }^{912}$.

\subsubsection{Los programas de cumplimiento sectarios en el} derecho español

Al ordenamiento jurídico español no le son raros ni extraños lo que llamamos compliance programs ${ }^{913}$, y aunque no tendrían con exactitud el mismo contenido que exige el art. 31 bis $\mathrm{CP}$, sí comparten objetivos generales de evitación de daños o lesiones o puestas en peligro al personal de la empresa, o evitar la corrupción o el blanqueo de capitales, o la corrupción a nivel del Mercado de Valores, que podrían ser barreras de protección de bienes jurídicos inmediatamente anteriores a las de Derecho Penal.

El ejemplo con gran tradición lo podría tener la Ley 31/1995, de 5 de noviembre, de Prevención de Riesgos Laborales, que establece la obligación básica de la empresa para prevenir, eliminar o minimizar riesgos a los que se ven sometidos la salud y la seguridad de sus trabajadores. En general se puede decir que la empresa está obligada

912 NIETO MARTíN, Adán, La responsabilidad penal de las personas jurídicas, Op. Cit., página 241.

913 Vid. CLEMENTE CASAS, Israel y ÁLVAREZ FEIJÓo, Manuel, Op. Cit., página 43; NIETO MARTÍN, Adán, La responsabilidad penal de las personas jurídicas, Op. Cit., página 216; ZUGALDÍA ESPINAR, José Miguel, Responsabilidad criminal de los entes colectivos, Op. Cit., página 56. 
a: crear un servicio de prevención propio o ajeno y designación de responsables de la prevención y un comité de seguridad y salud; hacer un análisis y evaluar los riesgos por cada puesto específico de trabajo y adopción e implementación de medidas preventivas de seguridad para guardar a los trabajadores de ese riesgo, que sea debidamente comunicado a los empleados con información y formación continua en materia de prevención de riesgos laborales; seguimiento de cumplimiento de las normas creadas con delegados de prevención de los mismos empleados, así como del comité de seguridad y salud y actuación inmediata para remediar los accidentes que sucedan ${ }^{914}$.

Esta ley le da a la empresa una libertad total de organizarse, pero debe seguir, ella misma, normas con contenidos mínimos pero con fines y objetivos explícitos. A diferencia de los compliance programs del art. 31 bis CP, no trata de evitar delitos de sus empleados, sino accidentes de trabajo. Como sea, este es y ha sido el primer elemento que detectamos en derecho español que puede ser la expresión de una autorregulación regulada a través de programas de cumplimiento efectivo.

En materia alimentaria de defensa al consumidor podemos contar con el RD 2207/1995 que crea un Sistema de Análisis de Peligros y Puntos Críticos en materia de seguridad alimentaria, por el que se establecen las normas de higiene de los productos alimenticios, y que fue vigente hasta mayo de 2006. En el art. 3 se previó que ñl. La preparación, fabricación, transformación, envasado, almacenamiento, transporte, distribución, manipulación y venta o suministro de productos alimenticios se realizarán de tal forma que la higiene de los mismos sea preservada durante su transcurso. 2. Las empresas del sector alimentario identificarán cualquier aspecto de su actividad que sea determinante para garantizar la higiene de los alimentos y velarán por que se definan, se pongan en práctica, se cumplan y se actualicen sistemas eficaces de control adecuados, de acuerdo con los siguientes

914 CLEMENTE CASAS, Israel y ÁLVAREZ FEIJóo, Manuel, Op. Cit., página 43. 
principios, en los que se basa el sistema ARCPC (análisis de peligros y puntos de control crítico)à

La Ley 15/1999, de 13 de diciembre, de Protección de Datos de Carácter Personal, también establece, en su art. 32, la posibilidad de formular r̃códigos tipoò que restablezcan las condiciones de organización, régimen de funcionamiento, procedimientos aplicables, normas de seguridad del entorno, programas o equipos, obligaciones de los implicados en el tratamiento y uso de la información personal, así como las garantías, en su ámbito, para el ejercicio de los derechos de las personas con pleno respeto a los principios y disposiciones de la presente Ley y sus normas de desarrolloò que podrán tener reglas operacionales detalladas de cada sistema particular, pero que en todo caso ñendrán el carácter de códigos deontológicos o de buena práctica profesionalò No parece obligar a los titulares de los creadores de ficheros a la creación de estos códigos, no obstante también puede ser un buen ejemplo de la implementación de éstos.

La Ley 44/2002, de 22 de noviembre, de Medidas de Reforma del Sistema Financiero, impone a las sociedades cotizadas la obligación de tener un Comité de Auditoría formado por miembros del Consejo de Administración. La Ley del Mercado de Valores contempla códigos internos de conducta y la obligación de los r̃sujetos que presten servicios de inversiónò de seguir éstos, así como ños códigos de conducta que, en desarrollo de las normas a que se refiere la letra a anterior, apruebe el Gobierno o, con habilitación expresa de éste, el Ministro de Economía y Hacienda, a propuesta de la Comisión Nacional del Mercado de Valoresò (art. 78.1.a) y b). La llamada ñirectiva MiFIDơ ${ }^{15}$ 2004/39/CE del Parlamento Europeo y del Consejo de 21 de abril, obliga a toda empresa de inversión a establecer ñpolíticas y procedimientos adecuados y suficientes para garantizar que la misma, incluidos sus directivos, empleados y agentes vinculados, cumplan las obligaciones que les impone la presente Directiva, así como las normas

${ }_{915}$ ALONSO GALLO, Jaime, Op. Cit., página 133 y 134. 
pertinentes aplicables a las operaciones personales de dichas personasò lo que es transpuesto por la Ley 47/2007, de 19 de diciembre, y el Real Decreto 217/2008, de 15 de febrero.

En materia de blanqueo de capitales, la Directiva 2005/60/CE del Parlamento Europeo y del Consejo de 26 de octubre, relativa a la prevención de la utilización del sistema financiero para el blanqueo de capitales y para la financiación del terrorismo exige, en su art. 34, a los Estados miembros que ñas entidades y personas sujetas a lo dispuesto en la presente Directiva establezcan políticas y procedimientos adecuados y apropiados en materia de diligencia debida con respecto al cliente, información, conservación de documentos, control interno, evaluación de riesgos, gestión de riesgos, garantía del cumplimiento de las disposiciones pertinentes y comunicación con vistas a prevenir e impedir operaciones relacionadas con el blanqueo de capitales o la financiación del terrorismoò El art. 26 a ley 10/2010, de 28 de abril, de prevención de blanqueo de capitales y de la financiación del terrorismo, a los sujetos obligados les impone aprobar por escrito y aplicar ñpolíticas y procedimientos adecuadosò en la misma materia que la Directiva, además, les impone aprobar ñpor escrito y aplicarán una política expresa de admisión de clientes. Dicha política incluirá una descripción de aquellos tipos de clientes que podrían presentar un riesgo superior al riesgo promedio en función de los factores que determine el sujeto obligado de acuerdo con los estándares internacionales aplicables en cada casoò También les obliga a establecer ñu órgano adecuado de control interno responsable de la aplicación de las políticas y procedimientos a que se refiere el apartado 1ò que se r̃eunirá, levantando acta expresa de los acuerdos adoptados, con la periodicidad que se determine en el procedimiento de control internoò y deberá r̃ontar con los recursos materiales, humanos y técnicos necesariosò y operarán r̃con separación funcional del departamento o unidad de auditoría interna del sujeto obligadoò Los sujetos obligados tienen la obligación de rapprobar un manual adecuado de prevención del blanqueo de capitales y de la financiación del 
terrorismo, que se mantendrá actualizado, con información completa sobre las medidas de control interno a que se refieren los apartados anterioresò

Hasta el 2006 la totalidad de las empresas del IBEX y el $70 \%$ de las cotizadas en el Mercado de Valores afirman poseer códigos de conducta ${ }^{916}$, además de que están publicadas en la webb correspondiente de cada una de ellas ${ }^{917}$.

\subsubsection{Las experiencias de otros países}

Como lo hemos señalado, el defecto de organización como culpabilidad de la persona jurídica es un concepto que ha ganado muchos adeptos, y su complemento, los compliance programs han tenido en los últimos años una presencia en la legislación internacional que poco a poco se ha ganado el carácter de tradición. Permítasenos analizar brevemente la ley italiana y la ley chilena, de factura reciente, que son vivos ejemplos de la exigencia explícita y sincera de que lo que el ordenamiento jurídico quiere de las empresas es una autorregulación regulada. Ni qué decir de la norteamericana, de la que hemos tenido ocasión de comentar.

El Decreto Legislativo 231/2001 de 8 de junio, como lo hemos señalado ya, inauguró la nueva responsabilidad penal de las personas jurídicas en Italia, pero además lo hizo con mejor tino que en el caso español. El artículo 60 de dicho decreto previene lo que conocemos como los programas de cumplimiento o compliance programs que, implementados adecuadamente, pueden ser considerados como la moneda opuesta al r̃defecto organizativoò y por lo tanto, a la inculpabilidad de la persona jurídica a pesar de que haya un delito

916 Vid. las referencias que hace del Informe de la subcomisión para potenciar y promover la responsabilidad social de las empresas en el BOCG de 4 de agosto de 2006, que hace NIETO MARTÍN, Adán, La responsabilidad penal de las personas jurídicas, Op. Cit., página 217, nota 440.

917 ALONSO GALLO, Jaime, Op. Cit., página 152. 
cometido por un directivo o representante legal, o de un empleado deficientemente controlado.

El artículo 6을 del Decreto Legislativo reza de la siguiente forma:

Art. 6. La alta dirección y el modelo de organización:

1. Si el delito fue cometido por las personas indicadas en el artículo 5, apartado 1, letra a), el ente no es responsable si prueba que: a) El Consejo de Administración ha adoptado y aplicado efectivamente, antes de la comisión del delito, los modelos de organización y gestión idóneos para prevenir delitos similares a los cometidos; b) la tarea de vigilar la aplicación y observancia de los modelos de la organización fue confiada a un organismo con poderes autónomos de iniciativa y el control; c) las personas han cometido el delito eludiendo fraudulentamente los modelos de organización y gestión; d) no ha habido omisión o falta de supervisión por el organismo mencionado en b).

La persona jurídica no responde, de esa forma, automáticamente por los delitos de sus directivos o de sus empleados mal controlados, sino que tiene un sustrato propio, que puede controlar, y que consiste en la implementación de los programas de cumplimiento. Ciertamente que mientras el artículo $5^{\circ}$ del Decreto Legislativo 231/2001 es, guardadas proporciones, de la misma redacción que el 31 bis CP, puede ser comparado con nuestra legislación y por tanto, interpretando de forma lógica nuestro texto legal podríamos llegar también a la afirmación que el 31 bis CP exige una culpabilidad propia de la persona jurídica consistente en el defecto de organización, como previamente concluimos. 
Lo mismo sucede en el caso chileno. El artículo $3^{\circ}$ de la Ley 20.393 que regula la responsabilidad penal de las personas jurídicas respecto de los delitos previstos en el artículo 27 de la ley №19.913, en el artículo $8^{\circ}$ de la ley №18.314 y en los artículos 250 y 251 bis del Código Penal, establece las reglas de atribución de responsabilidad penal a las personas jurídicas, en la siguiente forma:

Las personas jurídicas serán responsables de los delitos señalados en el artículo $1^{\circ}$ que fueren cometidos directa e inmediatamente en su interés o para su provecho, por sus dueños, controladores, responsables, ejecutivos principales, representantes o quienes realicen actividades de administración y supervisión, siempre que la comisión del delito fuere consecuencia del incumplimiento, por parte de ésta, de los deberes de dirección y supervisión.

Bajo los mismos presupuestos del inciso anterior, serán también responsables las personas jurídicas por los delitos cometidos por personas naturales que estén bajo la dirección o supervisión directa de alguno de los sujetos mencionados en el inciso anterior.

Se considerará que los deberes de dirección y supervisión se han cumplido cuando, con anterioridad a la comisión del delito, la persona jurídica hubiere adoptado e implementado modelos de organización, administración y supervisión para prevenir delitos como el cometido, conforme a lo dispuesto en el artículo siguiente.

En este caso, es evidente y puesto en el primer plano la necesidad del defecto de organización como hecho propio de la persona jurídica, y por ello, insuficiente, aunque necesario, el delito de 
la persona física, sustrato humano del que no ha sido posible desligarse estas legislaciones.

Pero no se quedan ahí, enseguida, cada una de ellas, postula el contenido, las directrices generales y los alcances y consecuencias que deberán tener los modelos o programas de organización o compliance programs, y se hace énfasis en la llamada autorregulación regulada, esa estrategia de control estatal a la que hemos aludido anteriormente.

En el caso de la Ley Chilena va más allá, pues en el art. 4ํㅜㄴ describe el modelo de prevención de los delitos, con los siguientes elementos mínimos:

1. Designación de un encargado de prevención, designado por la máxima autoridad administrativa de la persona jurídica, que por lo menos durará en su cargo hasta tres años, el que podrá prorrogarse por períodos de igual duración. EI encargado de prevención deberá contar con autonomía respecto de la Administración de la Persona Jurídica, de sus dueños, de sus socios, de sus accionistas o de sus controladores. No obstante, podrá ejercer labores de contraloría o auditoría interna.

2. El encargado de prevención deberá contar con los medios y facultades suficientes para el desempeño de sus funciones (recursos y medios materiales necesarios; acceso directo a la Administración de la Persona Jurídica para informarla de las medidas y planes implementados en el cumplimiento de su cometido y para rendir cuenta de su gestión y reportar a lo menos semestralmente)

3. Un sistema de prevención de los delitos, elaborado por el encargado de prevención en conjunto con la Administración de la Persona Jurídica, que deberá incluir por lo menos con: La identificación de las actividades o procesos de la entidad, sean habituales o esporádicos, en cuyo contexto se genere o incremente el riesgo de comisión de los delitos señalados 
en el artículo $1^{\circ}$; el establecimiento de protocolos, reglas y procedimientos específicos que permitan a las personas que intervengan en las actividades o procesos indicados en el literal anterior, programar y ejecutar sus tareas o labores de una manera que prevenga la comisión de los mencionados delitos; La identificación de los procedimientos de administración y auditoría de los recursos financieros que permitan a la entidad prevenir su utilización en los delitos señalados; la existencia de sanciones administrativas internas, así como de procedimientos de denuncia o persecución de responsabilidades pecuniarias en contra de las personas que incumplan el sistema de prevención de delitos.

4. La comunicación de lo anterior a todos los trabajadores. Esta normativa interna deberá ser incorporada expresamente en los respectivos contratos de trabajo y de prestación de servicios de todos los trabajadores, empleados y prestadores de servicios de la persona jurídica, incluidos los máximos ejecutivos de la misma.

5. La Supervisión y certificación del sistema de prevención de los delitos de forma continua y eficaz, a fin de detectar y corregir sus fallas, así como actualizarlo de acuerdo al cambio de circunstancias de la respectiva entidad.

6. Una certificación estatal: Las personas jurídicas podrán obtener la certificación de la adopción e implementación de su modelo de prevención de delitos, expedidos por empresas de auditoría externa, sociedades clasificadoras de riesgo $u$ otras entidades registradas ante la Superintendencia de Valores y Seguros que puedan cumplir esta labor, de conformidad a la normativa que, para estos efectos, establezca el mencionado organismo fiscalizador. 
Llama la atención el certificado del párrafo anterior. Según la doctrina chilena solamente debe constituir un indicio de que la empresa cumple con los deberes de dirección y supervisión, una especie de presunción iuris tantum, que puede ser desvirtuada por la parte acusadora, puesto que aún y cuando no se establezca así en el texto legal se puede colegir de su origen pues fue ñna propuesta del Ejecutivo en el Senado donde expresamente se le daba al certificado el carácter de presunción legal de la existencia y pertinencia del modelo adoptado. Si bien luego se suprimió esa explicitación, esto fue por meros avatares técnicos, sin que nadie pusiera en duda la función del certificado $0^{918}$. Por el contrario, no es necesaria la implementación del programa del art. 4⿳⺈ de la Ley para demostrar que cumple la empresa con los deberes de dirección y supervisión, pues dispone ñpodrá adoptarò r̃carácter facultativo que carecería de sentido si el ejercicio de la facultad conllevara necesariamente la responsabilidad de la entidad en caso de producirse un delito relevanteo ${ }^{19}$.

Por lo que hace a las Organizational Sentencing Guidelines, es en el parágrafo 8B2.1 donde se describe el contenido del Programa ético y de cumplimiento efectivo, en el que se le exige a la organización, empresa o compañía, rejercitar la diligencia debida para evitar y detectar la conducta delictivaò y ñpromover a través de diversos instrumentos una cultura organizativa que incentive la conducta ética y el compromiso de cumplir con el Derecho. Dichos programas éticos y de cumplimiento deberán estar razonablemente diseñados, implementados y sancionados, de manera que el programa sea efectivo, en términos generales, para prevenir y detectar la conducta delictivaò Los programas éticos y de cumplimiento deberán tener los siguientes requisitos mínimos:

918 HERNÁNEZ, Héctor, "La introducción de la responsabilidad penal de las personas jurídicas en Chile", en Polít. Crim., Vol. 5, Número 9 (julio 2010), art. 5, pp. 207-236, página 227.

919 Ib Ídem, página 226, y nota 88. 
1. Establecimiento de estándares y procedimientos para prevenir y detectar la conducta delictiva (Análisis y gestión de riesgos ñgap analysis).

2. El conocimiento efectivo del contenido y ejecución de los programas de cumplimiento por parte de la Directiva de la Organización, así como el ejercicio de una supervisión razonable sobre su implementación y efectividad.

3. La designación de una persona cuya función sea la de desarrollar, gestionar, implementar, ejecutar y evaluar los programas éticos y de cumplimiento del Derecho (Compliance officers). Deben tener recursos materiales y humanos adecuados, autoridad apropiada y acceso directo a la Directiva de la Organización. Rendirán cuentas diariamente a la alta dirección de la empresa.

4. Los programas deberán ser comunicados, publicados e introyectados a todos y cada uno de los miembros de la empresa, de forma continua y recurrente, evidenciando la importancia de la responsabilidad social y ética.

5. Aseguramiento de la eficacia de los programas incluyendo controles y auditorías para la evaluación periódica del programa.

6. Implementación de los denunciantes cívicos o whistleblowers.

7. Un sistema de sanciones interno para las personas que cometen faltas o infracciones al programa ético y de cumplimiento del Derecho.

8. Una adaptabilidad a la modificación del programa ético tras la detección de una conducta delictiva para prevenir conductas similares.

9. Informar a las autoridades judiciales en caso necesario, y cooperar con ellas en todo lo requerido. 
Por lo demás, y aunque puede resultar un tanto extraña la inclusión de programas de cumplimiento de la legalidad solamente como rãtenuanteò de la sanción, y no como excluyente de la responsabilidad $^{920}$, el inciso d) del 31 bis $4 \mathrm{CP}$ podría tener una estrecha relación con el concepto de r̃ulpabilidad reactivaò que ha estado en boga en el derecho norteamericano ${ }^{921}$, en donde la fialta de adopción de medidas preventivas y correctivas adecuadas como reacción al descubrimiento del delito, constituye la culpabilidad empresarialơ ${ }^{22}$, lo que implica una cierta renuncia al principio jurídico róle que la culpabilidad está relacionada temporalmente con la comisión del delito ï o que es contemporánea a la comisión del mismo delito-. La renuncia a este principio se justifica por la naturaleza dinámica de la acción empresarialö 23.

Vemos que es, mutatis mutandi, muy similar al parágrafo 8C2.5 e), f) y g) de las Organizational Sentencing Guidelines, y tienen influencia una vez que ha sido declarada responsable la empresa. En virtud de que en materia penal federal, en Estados Unidos de América se sigue el sistema de respondant superior (y por tanto, no existe ninguna hipótesis de justificación o inculpabilidad), los programas de cumplimiento solo tienen efectos en forma posterior a la declaración judicial de responsabilidad penal de la empresa, por ello se tiene en cuenta su actuación posterior (como parece que pueda ser el caso legislativo más cercano al inciso d) del 31 bis $4 \mathrm{CP}$ ).

\subsubsection{El contenido mínimo de los programas de cumplimiento}

\footnotetext{
920 GOMEZ TOMILLO, Manuel, Op. Cit., página 142.

921 GÓMEZ JARA-DIEZ, Carlos, La responsabilidad penal de las empresas en los EE.UU., Op. Cit., página 87 y siguientes, especialmente página 91.

922 Ib Ídem, página 91.

923 LAUFER, William S., "La culpabilidad empresarial y los límites del derecho", en GOMEZ JARA-DIEZ, Carlos (Ed.), Modelos de autorresponsabilidad penal empresarial, Thomson Aranzadi, Navarra, 2006, página 77.
} 
De la experiencia sectaria del ordenamiento jurídico español y la jurídica extranjera en esa materia, la doctrina ha ensayado y propuesto contenidos mínimos que deberían tener los programas de cumplimiento.

Recordemos que amén de su contenido, para tomar en serio el significado de estos programas, es menester que estén precedidos por el liderazgo de su implementación, esto es, el convencimiento sincero de los líderes de la empresa de tienen una utilidad supina tanto como su organización misma de producción de productos o servicios que es lo que le da los beneficios, que es el efecto directo que la r̃eubicación del riesgo al patrimonio de los socios de la empresaòtrae consigo, pues r̃ uando los subordinados saben que quien detenta el poder tiene un interés concreto en evitar una sanción, considerará que las medidas internas adoptadas no son mera cosméticaơ ${ }^{24}$. Este sería, en realidad, el primer elemento a evaluar en un proceso penal contra una persona jurídica en relación con la culpabilidad, si la Alta Dirección está comprometida con la creación, gestión, implementación, ejecución y revisión continua del programa ${ }^{925}$.

Alonso Gallo ha elaborado una propuesta detallada de los elementos que deberían tener un programa de cumplimiento, derivado de lo que hemos dicho ya, y basándose en otras fuentes como el Corporate Compliance Answer Book, que es el siguiente ${ }^{926}$ :

1. Una valoración y determinación de las principales áreas de riesgo de cumplimiento en la compañía.

2. Un conjunto de normas y procedimientos escritos.

924 NIETO MARTÍN, Adán, La responsabilidad penal de las personas jurídicas, Op. Cit., página 47.

925 "Un ejemplo muy gráfico que suele ponerse sobre un mero 'programa de papel' es el caso de Enron: cuando los investigadores registraron el despacho del director financiero de Enron, Andrew Fastow, encontraron una copia del programa de cumplimiento de la compañía que estaba aún sin abrir, con la envoltura de plástico con la que había llegado", vid. ALONSO GALLO, Jaime, "Los programas de cumplimiento", Op. Cit., página 162.

926 ALONSO GALLO, Jaime, "Los programas de cumplimiento", página $166 \mathrm{y}$ pássim. 
3. Una definición de las funciones de los órganos de la entidad responsables de su aplicación.

4. Un sistema de formación a los empleados y directivos.

5. Un sistema efectivo de seguimiento de la aplicación del programa.

6. Un mecanismo de comunicación que permita la remisión de denuncias con garantías de protección del denunciante.

7. Un sistema de sanciones disciplinarias.

8. Una política de conservación de los documentos.

9. Un protocolo de actuación en caso de detección de irregularidades.

Estos elementos están también referidos, de una u otra manera, por gran parte de la doctrina que se refiere a ellos ${ }^{927}$. Nosotros quisiéramos concentrarnos y desarrollar brevemente seis aspectos que a continuación desarrollaremos.

\subsection{Normativa del Compliance}

En realidad los programas de cumplimiento no gozan de naturaleza y características diferentes de cualquier otro sistema de control, pues son fundamentalmente normas escritas que se dirigen hacia dentro de la empresa pero que pueden tener implicaciones también hacia afuera de ella. Si queremos encontrar en dónde se encuentra un programa de cumplimiento seguramente lo hallaremos en un documento. Este es el documento que la mayoría de las empresas publican en su webb y dan a conocer a los trabajadores y público en general.

\footnotetext{
927 BACIGALUPO Z., Enrique, Compliance y Derecho Penal, Op. Cit., página 90 y pássim; FEIJÓo SÁNCHEZ, Bernardo, "La responsabilidad penal...", Op. Cit., página 110; GOMEZ-JARA DIEZ, Carlos, Culpabilidad penal de la empresa, Op. Cit., página 257; NIETO MARTÍN, Adán, La responsabilidad penal de las personas jurídicas, $O p$. Cit., página 240 y sigs.; y ZUGALDÍA ESPINAR, José Miguel, La responsabilidad criminal de los entes colectivos, $0 p$. Cit., página 59.
} 
Debe tener una justificación, una razón de ser, que también se expone en el mismo documento. Se trazan los objetivos generales y específicos del mismo, esto es, lo que con él y su implementación se debe lograr. Puede ser un solo programa para toda la empresa, pero cuando ésta es demasiado grande, pueden existir programas de compliance sectoriales para cada división o departamento (ventas, adquisiciones, producción, nuevas tecnologías, etcétera), o en su caso, uno solo pero con ramificaciones de especialización, con lo que se logra una unidad coherente de importancia para todos los miembros de la persona jurídica.

Se recomienda que tenga una base reducida y bien explícita, pues un documento demasiado grande podría perder su eficacia al tratar de abarcar muchos temas y objetivos. Junto a ellos, deben existir aspectos precisos y específicos propios de la persona jurídica, esto es, algo personalizado a ella, para lo cual deberá de ser útil el análisis de riesgos que siempre será un expediente abierto (para darle maleabilidad y posibilidad de adaptarse a los nuevos peligros y riesgos que se presenten continuamente).

Sus mandatos y prohibiciones son dirigidos hacia los propios miembros de la empresa, a sus conductas y a sus procedimientos, pero también pueden tener efectos hacia afuera: socios, clientes, autoridades gubernamentales con las que se relaciona la persona jurídica, medios de comunicación, autoridades judiciales, entre otros.

Es esta la fuente por la que se crean nuevos órganos con nuevas funciones, como los compliance officers o los auditores del programa, y ahí también se les dota de presupuesto, de nivel jerárquico, de espacios, incluso de papelería especial. Se les dota de competencia, de poderes de supervisión y revisión, de funciones y de competencias.

También es en este lugar donde tiene su origen la obligación o necesidad de documentar todo lo que evidencie el cumplimiento del 
programa de cumplimiento, que a su vez son los candados y las garantías de la automatización del programa que se está cumpliendo.

\subsection{Análisis del riesgo}

Es un expediente que tiene la finalidad de personalizar el programa de cumplimiento a la empresa específica. Para ello tiene en cuenta a la persona jurídica misma: su tamaño, el lugar físico que ocupa o ubicación, la normativa administrativa, laboral, financiera, contable, civil o penal que regula su actividad de manera preponderante, su giro, la clase de trabajadores que necesita (mano de obra calificada, grado de preparación, actividades que realizan), el tipo de personas o situaciones con las que se relaciona comúnmente (personas privadas, organizaciones públicas, o internacionales), y su propia historia ${ }^{928}$. Es decir, tiene la finalidad de r̃determinar las áreas en que pueden darse con mayor probabilidad supuestos de incumplimientoo ${ }^{29}$, esto es, áreas de riesgo en que las personas físicas puedan cometer delitos.

Una empresa que se dedique a ofrecer sus servicios de construcción de carreteras a la Administración Estatal y por ello, participe de forma continua en la licitación para ganar concursos y le den el contrato, deberá poner especial cuidado y normar aquellos contactos que su personal tiene con el personal de la Administración Estatal, con el fin de evitar conductas de corrupción al pretender obtener asignación de obras de forma indebida. Podría sustituir de manera continua al personal de contacto, o impedir que nadie en particular inicie y termine un proceso para asignación de obra, sino que el proceso pase por varias personas a la vez, de manera tal que todas ellas se auditen de forma automática una a la otra. Si una compañía

928 NIETO MARTÍN, Adán, La responsabilidad penal de las personas jurídicas, Op. Cit., página 242.

${ }_{929}$ ALONSO GALLO, Jaime, "Los programas de cumplimiento”, Op. Cit., página 167. 
tiene como giro el transporte terrestre de personas de un país a otro, deberá poner especial cuidado en evitar cuestiones de tráfico de drogas o de tráfico ilegal de personas.

\subsection{Creación de nuevos Órganos y funciones}

Prácticamente todas las experiencias de los programas de cumplimiento recomiendan como algo necesario y esencial la existencia de uno o más órganos encargados de la gestión, implementación, ejecución y evaluación permanente y continua del programa. Se trata de personas especializadas en los temas de auditorías y de control que se encarguen de garantizar que el programa esté vivo y llegue a todos los rincones de la empresa.

Generalmente son internos, esto es, delegados o dependientes directos de la Alta Dirección, empleados de la misma persona jurídica, con esa función específica. Tienen línea directa con la Junta Directiva o el Consejo de Administración, y pueden adquirir la forma de un Comité. Es el compliance officer o también conocido como Comité de Auditoría o Comisión o Comité de Cumplimiento.

El informe del Ethics Resource Center sobre el rol del Chief Ethics Compliance Officer (CECO) aconseja que el mismo debe tener las siguientes características: un rol bien definido con recursos adecuados; responder ante el órgano de gobierno de la persona jurídica; independencia para plantear materias objeto de preocupación sin miedo a represalias y sin conflictos de interés, y autoridad suficiente para que sean tomadas en serio sus recomendaciones y decisiones ${ }^{930}$.

También es recomendable contar con la intervención del llamado Gatekeeper, que es un auditor externo que evalúa y certifica el programa de cumplimiento. ña heteroevaluación es constante en

930 ALONSO GALLO, Jaime, “Los programas de cumplimiento”, Op. Cit., página 171. 
materias como la prevención de riesgos laboralesòo el medio ambiente, y sobre la heteroevaluación de la responsabilidad social ña existen normas de auditoría internacionales, concretamente la SA8000, elaborada por la Social Accountability International, que evalúan los controles de la empresa destinados, por ejemplo, a asegurar la vigencia de los derechos humanos básicosơ ${ }^{331}$.

\subsection{Los whistleblowers o denunciantes internos}

En la práctica anglosajona, especialmente la norteamericana, se ha puesto en marcha una estrategia para controlar de forma indirecta las actividades de una empresa que pueden afectar bienes jurídicos individuales o colectivos. Los whistleblowers reciben su nombre por aquellos policías ingleses que al ver a una persona cometer un delito hacían sonar su silbato para llamar la atención y avisar a la población cercana y al resto de sus compañeros policías (el término inglés puede ser traducido rel que hace sonar el silbatoò), y se trata de aquellas personas que tienen relación, y por ello conocimiento directo, con una empresa, y sabe que la misma realiza prácticas que pone en peligro bienes jurídicos y afecta a la población, por lo que acude a las instancias oficiales de persecución del delito o incluso a los medios de comunicación para hacerlo saber, bien consciente del poder sobre él que tienen las empresas para las que trabaja. Ejemplos de ellos los encontramos en el caso de Jeffrey Wigand que denunció en un programa televisivo a nivel nacional en 1995 a la tabacalera Brown \& Williamson imputándoles que habían adulterado con sustancias diversas, algunas cancerígenas, el contenido de cigarrillos con el objeto de agravar la adicción de los fumadores, o el caso Enron o WorldCom, el de los policías del FBI que informaron que antes del 11 de

\footnotetext{
931 NIETO MARTíN, Adán, "Responsabilidad social, gobierno corporativo y
} autorregulación...”, Op. Cit., página 7. 
septiembre de 2011 ya tenían conocimiento de algunas circunstancias que pudieron evitar la tragedia ${ }^{932}$.

La r̃rreciente complejidad de las organizaciones empresariales y administrativas hacen que cada vez resulte más difícil la prevención de las conductas ilícitas que se cometen en su seno. Ante estas dificultades, un buen medio de prevención puede consistir en que el Estado preste atención a posibles informaciones de sujetos dispuestos a desvelar los delitos que el Estado preste atención a posibles informaciones de sujetos dispuestos a desvelar los delitos cometidos dentro de su organizacióno $0^{933}$, como son los whistlelbowers que permiten recuperar r̃el control social sobre las grandes organizaciones que se han hecho con el dominio de la comunidad globalo $0^{34}$, los que han sido introducidos en algunos códigos éticos internos de algunas empresas.

En Estados Unidos de Norteamérica están previstas recompensas para el empleado que denuncie los fraudes realizados por contratistas de la administración en el False Claims Act Federal, y la Sarbanes-Oxley Act protege frete a posibles represalias laborales a los empleados cotizados en bolsa que denuncien las conductas fraudulentas de las empresas, mientras que la Non Fear Act impone sanciones penales a empresarios que toman algún tipo de represalia contra sus empleados informantes ${ }^{935}$. El art. 8.4 de la Convención de Naciones Unidas contra la Corrupción es un ejemplo de la acogida que han tenido los whistleblowers a nivel internacional pues impone a los Estados parte establecer medidas y sistemas p̃ara facilitar que los funcionarios públicos denuncien todo acto de corrupción a las autoridades competentes cuando tengan conocimiento de ellos en el ejercicio de sus funcionesà mientras que el art. 27 de la Directiva

932 Vid. RAGUÉS I VALLÈS, Ramón, “¿Héroes o traidores? La protección de los informantes internos (whistleblowers) como estrategia político-criminal", In Dret, $3 / 2006$, julio de 2006, página 3.

933 Ib Ídem, página 3 y 4.

934 Ib Ídem, citando a CALLAHAN.

$935 \mathrm{Ib}$ ídem, páginas 10 y 12. 
2005/60 sobre blanqueo de capitales y financiación del terrorismo exige a los Estados miembros que adopten medidas apropiadas a fin de proteger frente a toda amenaza o acción hostil a los empleados de las entidades o personas que comuniquen sus sospechas de blanqueo de capitales o financiación del terrorismo; o el Convenio de la OCDE sobre corrupción en las transacciones económicas internacionales que obliga a mejorar los sistemas de los Estados parte en lo referente a la protección de los denunciantes cívicos.

En España no es tampoco tan extraña esta figura. Los arts. $376^{936}$ y $579.4^{937} \mathrm{CP}$ son ejemplo de ello, aunque se refieren a personas que pertenezcan a bandas delictivas de narcotráfico y delincuencia organizada, y ellos mismos haya cometido delitos; el art. $450 \mathrm{CP}$ que impone el deber de denunciar o dar noticia de un delito para impedirlo. Lo más importante que debemos destacar en esta línea es el contenido del art. 30 de la Ley 10/2010, de 28 de abril, de prevención de blanqueo de capitales y de la financiación del terrorismo, que previene la normativa para la protección de los denunciantes cívicos: ñi. Los sujetos obligados adptarán las medidas adecuadas para mantener la confidencialidad sobre la identidad de los empleados, directivos o agentes que hayan realizado una comunicación a los órganos de control interno. Toda autoridad o funcionario tomará las

\footnotetext{
936 "En los casos previstos en los artículos 368 a 372, los jueces o tribunales, razonándolo en la Sentencia, podrán imponer la pena inferior en uno o dos grados a la señalada por la ley para el delito de que se trate, siempre que el sujeto haya abandonado voluntariamente sus actividades delictivas y haya colaborado activamente con las Autoridades o sus agentes, bien para impedir la producción del delito, bien para obtener pruebas decisivas para la identificación o captura de otros responsables o para impedir la actuación o el desarrollo de las organizaciones o asociaciones a las que haya pertenecido o con las que haya colaborado"

937 "En los delitos previstos en esta sección, los jueces y tribunales, razonándolo en sentencia, podrán imponer la pena inferior en uno o dos grados a la señalada por la ley para el delito de que se trate, cuando el sujeto haya abandonado voluntariamente sus actividades delictivas y se presente a las autoridades confesando los hechos en que haya participado, y además colabore activamente con éstas para impedir la producción del delito o coadyuve eficazmente a la obtención de pruebas decisivas para la identificación o captura de otros responsables o para impedir la actuación o el desarrollo de organizaciones o grupos terroristas a los que haya pertenecido o con los que haya colaborado".
} 
medidas apropiadas a fin de proteger frente a cualquier amenaza 0 acción hostil a los empleados, directivos o agentes de los sujetos obligados que comuniquen indicios de blanqueo de capitales o de financiación del terrorismoò

El profesor Ragués i Vallès cita también aquellas sentencias que en materia laboral fueron emitidas en favor de empleados de compañías que denunciaron malas prácticas que ponían en peligro bienes jurídicos de sus empleadores ${ }^{938}$. El Tribunal Central de Trabajo, por ejemplo, determinó que si se despide a un trabajador que da noticia de malas prácticas de una empresa es ir contra la ley, pues rentender lo contrario equivaldría a estimar que el trabajador está obligado a hacerse cómplice de una actuación fraudulenta, que incluso puede llegar a ser delictiva, de la empresa para la que trabajaé nadie puede pensar que la fidelidad a la empresa llega a no poder descubrir fraudes a que está sometiendo a sus clientes en la realización de los trabajos que le han sido encomendadosời

Los medios para incentivar las revelaciones han pasado desde reforzar los deberes de denuncia y las sanciones en caso de incumplimiento a través del Derecho Penal, la recompensa y la protección a los denunciantes. Para Ragués lo más efectivo serían estas dos últimas estrategias ${ }^{940}$. Dos son las medidas para protegerlos, por un lado, un sistema de puertas abiertas (open door) para que se puedan dirigir directamente a los vigilantes del programa de cumplimiento de la empresa, y por otro, que se garantice al denunciante

938 STC 57/1999, de 12 de abril, donde el Tribunal protegió la libertad de información del inspector de la Dirección General de Aviación que tras un accidente aéreo efectuó declaraciones a un periódico denunciando malas condiciones de aviones como el siniestrado y la pasividad de la empresa propietaria y de Aviación Civil. Y la Sentencia del Tribunal Central de Trabajo de 12 de noviembre de 1981 donde un trabajador hizo público que la empresa para la que trabajaba empleaba materiales peligrosos.

$939 \mathrm{Ib}$ Ídem, página 11.

940 Ib Ídem, página 7 y pássim. 
la reserva de su identidad, y que no se imponga al denunciante de buena fe ninguna medida negativa ${ }^{941}$.

La relación entre whistleblowers y la autorregulación empresarial es de alineación y complementación mutuas, y no, en cambio, de pugna o riña. ñLa existencia de denunciantes cívicos es una suerte de sismógrafo bastante fiable para medir la cultura empresarial y supone además un ejemplo excelente de que le ética empresarial y la intervención legislativa son estrategias, no opuestas, sino complementariasơo $^{42}$. Huelga decir que de nada servirían los denunciantes cívicos si no existe, a la par, la obligación del Estado de incentivar a las empresas a adoptar medidas de autoorganización r̃que terminen por facilitar este comportamiento ${ }^{943}$.

\subsection{Sistema de Transparencia y Comunicación}

No habrá un sistema completo si de antemano la persona jurídica no ha tomado la decisión seria y sólida de ser transparente y da a conocer de forma continua y permanente la información de sus sistemas, programas, registros, resultados, ganancias, operaciones, etcétera. Más que una parte del programa de cumplimiento, la transparencia y la comunicación deben ser una de las políticas rectoras de toda la empresa.

Debe incluirse páginas webb, publicaciones periódicas e informes mensuales 0 anuales, que den a conocer a la empresa, a socios, a proveedores, clientes, a la Administración Pública y al público en general el estado de sus finanzas, de sus ganancias, el modo o forma de organizarse, sus compromisos con el medio ambiente o el desarrollo sustentable. Por las exigencias de la función y su importancia

\footnotetext{
${ }^{941}$ ALONSO GALLO, Jaime, "Los programas de cumplimiento", Op. Cit., página 180.

942 NIETO MARTÍN, Adán, La responsabilidad penal de las personas jurídicas, Op.

Cit., página 259.

${ }_{943} \mathrm{Ib}$ Ídem.
} 
se deberá delegar esta función a un órgano específico de la empresa, que amén de contar con el equipo tecnológico necesario, cuente con la autoridad para pedir y tener la información necesaria del resto de los órganos y además la cercanía con la Alta Dirección para entre los dos manifestar posiciones de la empresa respecto de ciertos aspectos que así lo requieran.

Esta parte de los programas del compliance tienen mucho que ver y se relacionan con el siguiente parágrafo, el de la implementación y la introyección de la cultura empresarial hacia los empleados y miembros de la empresa en general, como lo veremos a continuación.

\subsection{Sistema de Implementación, Ejecución y Evaluación Continua}

De nada serviría tener un programa de compliance de excelencia y $\sin$ fracturas cuando no se tiene la voluntad de la Alta Dirección de implementarlo hasta sus últimas consecuencias o no se sabe hacerlo. En la implementación se suelen caer y fracasar las buenas intenciones de mejorar a la empresa.

Si no se quiere que el programa de cumplimiento del Derecho sea nada más un simple papel sin utilidad alguna, el primer aspecto que habrá que cumplir es el compromiso real, serio y permanente de la Junta Directiva y de la Alta Dirección de la empresa, pues si el líder no conoce ni entiende, o si lo conoce no se compromete, o si su compromiso es efímero, o no está dispuesto a llegar a sus últimas consecuencias, entonces todo lo demás fracasará también. Implica que los líderes de las empresas conozcan la importancia del mismo, dediquen tiempo en capacitarse ellos mismos sobre el programa, lo T̃agan suyoò o parte de ellos, y luego generen una agenda de cumplimiento hasta que el programa se considere totalmente integrado 
a la empresa, y luego, una agenda permanente de revisión, auditoría y de ser posible reconducción del mismo.

El reto que se sigue es vencer las inercias de los empleados, vencer el ñirus contra el cambioòque tenemos todas las personas para abandonar nuestras áreas de confort, donde hemos sido hábiles, hacia nuevas perspectivas que implican cambios, donde habrá que aprender a hacer las cosas de forma diferente. Por esto precisamente no se trata nada más de dar a conocer que a partir de ese momento ya todos ñamos a tener una cultura ética de cumplimiento del Derechoò

Se trata de darlo a conocer, desde luego, pero también de hacer reuniones con ese motivo, de imponer la obligación de saberlo y conocerlo e incluso evaluar ese conocimiento a través de exámenes a los empleados, de condicionar el ingreso en la compañía o el mejoramiento en el escalafón si no se conoce y se comprende el programa de cumplimiento. Hay quien se impone metas específicas con respecto a los objetivos del programa y entonces se crean líderes sectoriales del programa con respecto al cumplimiento de esas metas. Las páginas webb, los foros electrónicos de discusión, el intranet, los periódicos murales, o las comunicaciones pequeñas con la entrega de nóminas, en fin, el límite es la imaginación.

Finalmente, una vez que el programa se considere implementado (introyectado a los empleados y miembros en general), entonces es necesario evaluarlo constantemente, pues si es necesario habría que reconducirlo mejorándolo.

\subsection{Atenuantes}

Del subsistema de atenuantes de responsabilidad penal de las personas jurídicas deberán destacarse cuatro características que son comunes a todas ellas, antes de verificar el contenido y alcance de cada una de ellas. 
En principio, el art. 31 bis CP no prevé atenuantes que deban acaecer con anterioridad al hecho delictivo de la persona jurídica, puesto que las cuatro que están previstas en el apartado 4 se refieren a hechos o acontecimientos posteriores al mismo.

En segundo lugar, parece ser que se ha previsto un subsistema de atenuantes con exclusividad para las personas jurídicas, en dos sentidos: solamente las personas jurídicas pueden aprovecharse de las atenuantes previstas en el apartado 4 del 31 bis CP, y no así también las personas físicas que hayan cometido el delito, lo que la doctrina mayoritaria está de acuerdo ${ }^{944}$. Mayor problema es afirmar si solamente esas atenuantes pueden ser aprovechadas por la propia persona jurídica, o en cambio, también puede alegar otras que se encuentran en el sistema de Derecho Penal para las personas físicas, desde luego, las que sean compatibles con ella, por ejemplo, la contenida en la parte $6^{\underline{a}}$ del art. $21 \mathrm{CP}$.

La FGE niega esa posibilidad, pues la exclusividad del art. 31 bis 4 CP ñmpide la aplicación de aquellas circunstancias atenuantes del artículo 21 del Código Penal cuya formulación no se refiere a comportamientos exclusivamente humanos, lo que resulta particularmente llamativo y difícilmente justificable en el caso de la nueva atenuante de dilaciones extraordinarias e indebidas del artículo 21.6 $6^{\text {a }}$ del Código Penal y en la de análoga significación de la atenuante $7^{\text {a }}$ del mismo preceptoơ ${ }^{45}$, aunque no descarta la posibilidad de que los tribunales apliquen, en un futuro, dicha atenuante bajo una interpretación análoga in bonan partem.

944 DIEZ RIPOLLÉS, José Luis, Op. Cit., página 25; DOPICO GOMEZ ALLER, Op. Cit., página 32; GARCÍA ARÁN, Mercedes, "Artículo 31 bis", en CÓRDOBA RODA y GARCÍA ARÁN (Dirs.), Comentarios al Código Penal. Parte General, Marcial Pons, Madrid, 2010, página 405 y 406; GÓMEZ MARÍN, V., "Artículo 31 bis", Op. Cit., página 135; MIR PUIG, Santiago, Derecho Penal, 2010, Op. Cit., página 209; ZUGALDÍA ESPINAR, José Miguel, La responsabilidad criminal de los entes colectivos, Op. Cit., página 83.

945 Circular 1/2011 de la FGE, página 51 y 52. Así también QUINTERO OLIVARES, Gonzalo, "Artículo 31 bis", Op. Cit., página 386, y DIAZ GÓMEZ, Andrés, Op. Cit., página 47 , quien piensa que se ha creado un sistema "paralelo" de atenuantes en relación con el art. $21 \mathrm{CP}$. 
En cambio, una parte de la doctrina admite la aplicación de otras agravantes no contenidas en el apartado 4, pues res evidente que tal afirmación no se puede entender en sentido excluyente de otras posibles causas que pudieran ser de análoga significación, ya que de lo contrario se estarían limitando derechos fundamentales de la persona jurídica ${ }^{946}$, y otros más se muestran más bien dubitativos ${ }^{947}$.

Nosotros creemos que no existe ningún obstáculo en considerar que otras atenuantes que pudieran ser aplicables a las personas jurídicas deberían favorecerles, precisamente por una interpretación analógica in bonam partem amén que el apartado 4 referido puede perfectamente considerarse taxativo en el primer sentido expresado por nosotros, esto es, son atenuantes propias de las personas jurídicas y no así de las personas físicas. De esta forma, la nueva atenuante de r̃dilaciones procesales indebidasò debe favorecerle a una persona jurídica.

En tercer lugar, habría que señalar que todas las atenuantes del art. 31 bis $4 \mathrm{CP}$, con excepción de la del incido d) (programas de cumplimiento del Derecho) son de carácter promocional, atinentes solo a la categoría de la punibilidad ñigada a razones de eficacia, efectividad o eficiencia, según los casosời8.

Por último, la ley exige que el acontecimiento posterior al delito haya sido realizado por ósus representantes legalesô Esta previsión puede resultar, para algunos, innecesaria porque r̃carece de sentido exigir que quien aporte pruebas decisivas para el esclarecimiento de los hechos y la reparación del daño causado a la víctima sea

946 BACIGALUPO SAGUESSE, Silvina, "La responsabilidad penal de las personas jurídicas”, Op. Cit., página 8. En el mismo sentido ZUGALDÍA ESPINAR, José Miguel, La responsabilidad criminal de los entes colectivos, Op. Cit., página 83.

947 ; GÓMEZ MARÍN, V., "Artículo 31 bis", Op. Cit., página 135; MIR PUIG, Santiago, Derecho Penal, 2010, Op. Cit., página 209, pues dicen que "resulta cuestionable si cabe aplicar analógicamente in bonam partem otras circunstancias atenuantes". 948 DIEZ RIPOLLÉS, José Luis, "La responsabilidad penal de las personas jurídicas", Op. Cit., página 25. En el mismo sentido, vid. ; GÓMEZ MARÍN, V., "Artículo 31 bis", Op. Cit., página 135; MIR PUIG, Santiago, Derecho Penal, 2010, Op. Cit., página 209. 
personalmente el legal representante de la sociedado ${ }^{949}$, sin embargo, de esa previsión podríamos de deducir algunos problemas adicionales. Por decir algunos, no tendrían efecto alguno las actividades realizadas por quienes no representen a la sociedad, pero que tengan íntima relación con ella, por ejemplo, socios, accionistas, administradores de hecho, asesores, auditores o trabajadores, a menos que sean por encargo directo del representante legal; ni tampoco tendría efecto alguno la actividad de un representante legal pero que no lo haga en representación de la persona jurídica.

Por otro lado, habría que solucionar los problemas derivados de aquellas situaciones en que un representante legal que sea imputado en la causa penal quiera confesar el delito o quiera pagar la reparación del daño, y deba hacerlo ya sea en representación de la sociedad, lo que excluiría el aprovechamiento de la atenuante en su favor, o en forma personal lo que excluiría el aprovechamiento de la atenuante en favor de la sociedad ${ }^{950}$. La situación de intereses opuestos puede ser al contrario, el representante legal puede confesar al tiempo que hace cargos contra la persona jurídica.

Expresamente dispone el art. 31 bis 4 CP lo siguiente:

4. Sólo podrán considerarse circunstancias atenuantes de la responsabilidad penal de las personas jurídicas haber realizado, con posterioridad a la comisión del delito y a través de sus representantes legales, las siguientes actividades:

a) Haber procedido, antes de conocer que el procedimiento judicial se dirige contra ella, a confesar la infracción a las autoridades.

949 ; GÓMEZ MARÍN, V., "Artículo 31 bis”, Op. Cit., página 135; MIR PUIG, Santiago, Derecho Penal, 2010, Op. Cit., página 209.

950 Así lo plantea DIEZ RIPOLLÉS, José Luis, "La responsabilidad penal de las personas jurídicas", Op. Cit., página 26. 
b) Haber colaborado en la investigación del hecho aportando pruebas, en cualquier momento del proceso, que fueran nuevas y decisivas para esclarecer las responsabilidades penales dimanantes de los hechos.

c) Haber procedido en cualquier momento del procedimiento y con anterioridad al juicio oral a reparar o disminuir el daño causado por el delito.

d) Haber establecido, antes del comienzo del juicio oral, medidas eficaces para prevenir y descubrir los delitos que en el futuro pudieran cometerse con los medios o bajo la cobertura de la persona jurídica.

La atenuante del inciso a) debe ocurrir antes de que se realice, por parte del órgano investigador de delitos, la notificación de existir una investigación criminal $\mathrm{o}$ un procedimiento penal contra la persona jurídica. Esto debe ser a través de una notificación legalmente válida y no, por ejemplo, a través de la prensa. La persona jurídica (su representante legal) debe confesar r̃sus propios hechosò y no la infracción de la persona física ${ }^{951}$, es decir, el injusto de organización empresarial defectuosa. Lo que es coherente con aquellas posiciones que observan un injusto propio de la persona jurídica, pues la confesión es siempre r̃sobre hechos propiosòy nunca sobre hechos ajenos.

La colaboración para el esclarecimiento de los hechos podría ir dirigida a la demostración de la individualización de la persona física que cometió el delito así como a la entrega de pruebas determinantes para ello. No opera la atenuante si la colaboración no fue eficaz ${ }^{952}$ (las pruebas no son determinantes) o no son nuevas ${ }^{953}$.

\footnotetext{
951 Vid. GARCÍA ARÁN, Mercedes, “Artículo 31 bis”, Op. Cit., página 409.

952 Vid. ZUGALDÍA ESPINAR, José Miguel, La responsabilidad criminal de los entes colectivos, Op. Cit., página 84.

953 Vid. GARCÍA ARÁN, Mercedes, “Artículo 31 bis”, Op. Cit., página 410.
} 
La reparación o disminución del daño causado tiene un límite temporal: que sea antes del juicio oral. Seguramente por ser de contenido similar al art. 21.5 $\mathrm{CP}$ los criterios interpretativos del Tribunal Supremo expresados en sentencias serán de gran utilidad ${ }^{954}$.

La última atenuante ha sido explicada líneas arriba cuando hablamos de los compliance programs o programas de cumplimiento. Para la aplicación de la atenuante el límite temporal de inicio es en forma posterior a la comisión del delito de la persona física y antes del inicio del juicio oral.

954 Vid. ZUGALDÍA ESPINAR, José Miguel, La responsabilidad criminal de los entes colectivos, Op. Cit., página 84, y la Circular 1/2011 de la FGE. Las sentencias son de 31 de junio de 2006 (TOL 1.002.338), 15 de febrero de 2007 (TOL. 1.072.203) y 29 de diciembre de 2010 (TOL 2.017.457). 


\section{CONCLUSIONES}

1. La reforma penal operada por la LO 5/2010, de 23 de junio, no inauguró la responsabilidad penal de las personas jurídicas en España, no obstante terminó con el debate doctrinal de si el dogma societas delinquere non potest había sido derogado. A partir de entonces la doctrina española dominante ha elaborado opciones interpretativas del art. 31 bis CP para crear verdaderos sistemas de responsabilidad penal de los entes corporativos, paralelos al sistema de responsabilidad de las personas físicas.

2. La LO $5 / 2010$, de 23 de junio, en materia de responsabilidad penal de las personas jurídicas está ayuna de una exposición de motivos suficiente para comprender mejor al legislador, quien expone solo razones de compromisos con la Unión Europea. Sin embargo, debemos entender que existen y están presentes razones de política criminal, de legitimación y de aplicación práctica, que deben tenerse en cuenta para construir las opciones interpretativas del art. 31 bis CP.

Olvidar y pasar por alto las necesidades político criminales y las razones de legitimación y aplicación práctica del sistema de responsabilidad de las personas jurídicas sería dejar pasar una gran oportunidad 
3. El delito de la persona física, única puerta de entrada a la responsabilidad penal de las personas jurídicas del que hablan los párrafos $1^{\circ}$ y $2^{\circ}$ del art. 31 bis $1 \mathrm{CP}$, no es el fundamento o razón de ser de la responsabilidad del ente colectivo. La persona jurídica, capaz de acción y de culpabilidad, es responsable por su propia acción y su propia culpabilidad. El injusto de la persona física es una condición objetiva de punibilidad.

4. En el r̃defecto de organización empresarialò encontramos el injusto propio de la persona jurídica, y en la no creación de una cultura empresarial de cumplimiento del Derecho su culpabilidad. No nos convencen, por tanto, aquellas opciones interpretativas que derivan del art. 31 bis $\mathrm{CP}$ una responsabilidad vicarial 0 heterorresponsabilidad penal, o aquellas otras que estiman que el injusto de la persona física se atribuye o asigna, bajo algunas condiciones normativas, al injusto de la persona jurídica, afirmando que la culpabilidad es el defecto de organización.

5. El art. 31 bis $\mathrm{CP}$ no es una norma penal que atribuye responsabilidad penal a la persona jurídica a partir de la responsabilidad penal de la física (en una lógica de subsidiaridad o solidaridad). Tampoco es una norma más de autoría y participación que multiplica los tipos penales de la parte especial dando a las personas jurídicas la capacidad de cometerlos participando en el delito de otros. Creemos que el art. 31 bis CP es una norma penal que constituye un delito en sí mismo, un tipo penal específico, un ñnjusto de organización empresarial defectuosaò que se atribuye a determinadas personas jurídicas cuando también ocurre un resultado delictivo (condición objetiva de punibilidad) que es la conducta delictiva de la persona física.

6. El tipo penal de ñnjusto de organización empresarial defectuosaò amén de exigir un injusto objetivo específico, también exige un injusto subjetivo específico que no es otro sino el de imprudencia. De forma tal que el art. 31 bis CP tiene una función similar al diverso $12 \mathrm{CP}$, es decir, un numerus clausus de imprudencia pero específico para el delito de r̃organización empresarial defectuosaò 
7. La imprudencia tiene referencia a la propia organización empresarial defectuosa de la persona jurídica, no a la conducta delictiva de sus miembros (administradores o representantes o los sometidos a la autoridad de éstos) ni al resultado delictivo exigido por el tipo penal que aquellos hayan cometido.

8. La persona jurídica es garante de una organización adecuada, no defectuosa (porque solo sobre ello tiene control), pero de ninguna forma puede ser garante de que las personas físicas no cometan delito (porque no tiene control alguno sobre ellas). La autorregulación regulada es la estrategia estatal de regulación sobre las personas jurídicas en una suerte de control indirecto o control r̃desde afueraò pues es imposible que el ordenamiento jurídico penal pueda gestionar los nuevos riesgos sociales derivados del uso de nueva tecnología y de la organización cada vez más compleja de las organizaciones empresariales. El Estado ha renunciado, en esta parcela del Derecho, a seguir siendo intervencionista y pasar a ser solo garante, delegando a las empresas la gestión de los nuevos riesgos.

9. La organización empresarial defectuosa (el injusto típico) puede ser evitado con una organización adecuada. Diversos baremos auxilian a ese fin, pero poco, o tal vez nada, tienen que ver con este fin los programas de cumplimiento del Derecho (compliance programs), pues estos se relacionan más bien con la culpabilidad de la persona jurídica.

10. La culpabilidad de la persona jurídica se concibe como una cultura corporativa de incumplimiento del Derecho. Es decir, que la organización empresarial defectuosa obedezca a una cultura de incumplimiento del Derecho. Los programas de compliance no organizan adecuadamente a la persona jurídica, sino que son expresión y proclama de la persona jurídica de que quiere cumplir con el Derecho y que, por tanto, no quiere en ninguna medida un defecto en su organización.

11. Por lo anterior, solamente las personas jurídicas con un nivel de complejidad determinado pueden ser sujetos activos del delito de 
organización empresarial defectuosa. En las pequeñas o sin complejidad bastará el Derecho Penal individual para resolver el conflicto político criminal con suficiencia. 


\section{BIBLIOGRAFÍA}

ABOSO, G.E., ABRALDES, S.F., Responsabilidad de las personas jurídicas en el Derecho penal, BdF, Buenos Aires, 2000.

ACHENBACH, Hans, î́Sanciones con las que se puede castigar a las empresas y a las personas que actúan en su nombre en el derecho penalò Fundamentos de un sistema europeo de derecho penal, Libro Homenaje a Claus Roxin, Bosch, Barcelona, 1995.

ALONSO GALLO, Jaime, ños programas de cumplimientoò en DÍAZ-MAROTO Y VILLAREJO, Julio (Dir.), Estudios sobre las reformas del Código penal operadas por las LO 5/2010, de 22 de junio, y 3/2011, de 28 de enero, Civitas-Thomson, 2010.

BACIGALUPO Saggese, Silvina, La responsabilidad penal de las personas jurídicas, Bosch, Barcelona, 1998.

- ña crisis de la filosofía del sujeto individual y el problema del sujeto de Derecho penalò CPC, núm. 67, 1999.

- r̃os derechos fundamentales de las personas jurídicasò Revista del Poder Judicial, núm. 53, 1999, CGPJ, 1999. 
- ñas sanciones del Código penal aplicables a las personas jurídicas en los delitos contra el medio ambienteò en JORGE BARREIRO, Agustín (Dir.), Estudios sobre la protección penal del medio ambiente en el ordenamiento jurídico español, Comares, Granada, 2005.

- îResponsabilidad penal de las personas jurídicasò en BACIGALUPO, Enrique (Dir.), Curso de Derecho penal económico, 2 $2^{\mathrm{a}}$ edición, Marcial Pons, 2006.

- "Los criterios de imputación de la responsabilidad penal de los entes colectivos y de sus órganos de gobierno (art. 31 bis y $129 \mathrm{CP}$ )", Diario La Ley, número 7541, de 5 de enero de 2011.

- ñArtículo 31 bisò en GÓMEZ TOMILLO, Manuel (Dir.), Comentarios al Código Penal, Lex Nova, Valladolid, 2010.

BACIGALUPO ZAPATER, Enrique, r̃Responsabilidad penal de órganos, directivos y representantes de una persona jurídica (el actuar en nombre de otro)ò Comentarios a la Legislación Penal, Tomo V, Volumen I, Madrid, 1985.

- "La responsabilidad penal y administrativas de las personas jurídicas y programas de "compliance" (A propósito del Proyecto de reforma del Código penal de 2009), Diario La Ley, número 7442, 9 JULIO 2010.

- Compliance y Derecho Penal, Thomson Reuters, Navarra, 2011.

BAIGÚN, David, La responsabilidad penal de las personas jurídicas, Depalma, Buenos Aires, 2000.

BAJO Fernández, Miguel, ĩDe nuevo sobre la responsabilidad criminal de las personas jurídicasò $A D P C P, 1981$. 
- Derecho Penal económico aplicado a la actividad empresarial, Civitas, Madrid, 1978.

- Manual de Derecho Penal (parte especial: delitos patrimoniales y económicos), CERA, Madrid, 1993.

- ña responsabilidad penal de las personas jurídicas en el derecho administrativo españolò en Responsabilidad penal de las empresas y sus órganos y responsabilidad por el producto, Bosch, Madrid, 1996.

- ñHacia un nuevo Derecho Penal: el de las personas jurídicasò en IGLESIAS PARADA (Coord.), en Estudios en homenaje al Profesor Aurelio Menéndez, Tomo IV, Civitas, Madrid, 1996.

- Ĩa responsabilidad penal colectivaò en VIEIRA M., F. J., (Dir.), Nuevas posiciones de la dogmática jurídica penal, CDJ VII-2006, Madrid, 2006

- "La vedada responsabilidad penal por el hecho de otro", en Derecho y justicia penal en el siglo XXI, Liber Amicorum en Homenaje al Profesor Antonio González Cuéllar García, 2006.

BARATTA, A., Criminología Crítica y Crítica al Derecho Penal, Siglo XXI, México, 1993.

BARBERO SANTOS, Marino, ז̃ Responsabilidad de las personas jurídicas?ò en Revista de Derecho Mercantil, Madrid, 1957

- ñ Responsabilidad penal de la empresa?ò $A P, 1987$.

BERDUGO GÓMEZ DE LA TORRES, Ignacio, y otros, Curso de Derecho Penal. Parte General, Ediciones Experiencia, Barcelona, 2010.

BLANCO CORDERO, Isidoro, T̃Recensión del libro de Manuel Gómez Tomillo, Introducción a la responsabilidad de las personas 
jurídicas en el sistema españolò en Revista Electrónica de Ciencia Penal y Criminología, Número 13-r2 (2011).

BOLDOVA PASAMAR, Carmen, y ALASTUEY DOBÓN, Carmen, ñas consecuencias accesoriasò Tratado de las consecuencias jurídicas del delito, Valencia, Tirant lo blanch, 2006.

BUSTOS RAMÍREZ J., y HORMAZÁBAL MALAREE, H., Lecciones de Derecho penal, Parte General, tomo I, Madrid, Trota, 1997.

BUSTOS RAMÍREZ, Juan, ña responsabilidad penal de las personas jurídicasò en MORENO HERNÁNDEZ, Moises (Coord.), Globalización e internacionalización del Derecho Penal. Implicaciones político-criminales y dogmáticas, CEPOLCRIM, México, 2003.

BURGOS LADRÓN DE GUEVARA, Juan, ña responsabilidad penal de las personas jurídicasò en Diario La Ley, Número 7625, 9 mayo 2011.

CANCIO Meliá, Manuel, ñ Responsabilidad penal de las personas jurídicas? Algunas consideraciones sobre el significado político criminal del establecimiento de responsabilidad criminal de empresaò Nuevas tendencias en Política Criminal, Madrid, Reus, 2006.

CARBONELL MATEU, J.C., TrResponsabilidad penal de las personas jurídicas: Reflexiones en torno a su r̃dogmáticaò y al sistema de la reforma de 2010à en Cuadernos de Política Criminal, número 101, separata, 2010.

CARDONA ARIZMENDI, E., y OJEDA RODRÍGUEZ, C., Código penal comentado del Estado de Guanajuato, Orlando Cárdenas Editor, México, 1985. 
CARDONA TORRES, Juan, Ĩa responsabilidad penal de las personas jurídicasò en Diario La Ley, Número 7699, 21 de septiembre de 2010.

CARMONA Ruano, Miguel, ña responsabilidad penal de las personas jurídicasò en BAJO FERNÁNDEZ, M. (Dir.), Empresa y Derecho penal (II), Madrid, Consejo General del Poder Judicial, 1999.

CARNEVALI RODRÍGUEZ, Raúl, ña criminalidad organizada. Una aproximación al derecho penal italiano, en particular la responsabilidad de las personas jurídicas y la confiscaciónò en Revista lus et Praxis, año 16, No. 2, 2010, Universidad de Talca, Chile.

CARRANCÁ Y TRUJILLO, Raúl, Derecho penal mexicano, Porrúa, México, 1988.

CARRETERO SÁNCHEZ, Adolfo, r̃Aspectos sustantivos y procesales de la responsabilidad penal de las personas jurídicasò en Diario La Ley, Número 7786, 30 de enero de 2012.

CEREZO Mir, José, Curso de Derecho penal español: Parte General, II, La teoría jurídica del delito/ I, Madrid, Tecnos, 1996.

- r̃Culpabilidad y penaò Anuario de Derecho Penal y Ciencias Penales, Tomo XXXIII, fascículo II, mayo-agosto, 1980.

CLEMENTE CASAS, Israel, y ÁLVAREZ FEIJOO, Manuel, ñ Sirve de algo un programa de compliance penal? ¿y qué forma de le doy? (Responsabilidad penal de la persona jurídica en la LO 5/2010: incertidumbres y llamado por la seguridad jurídica)ò en Actualidad jurídica Uría Menéndez, 28-2011, http://www.uria.com/documentos/publicaciones/2903/documento/articulo UM.pdf?id=2974,última visita 10-02-12. 
CÓRDOBA RODA, Juan, r̃artículo 10ò en CORDOBA RODA, Juan/GARCÍA ARÁN, Mercedes (Dirs.), Comentarios al código penal. Parte general. Madrid, Marcial Pons, 2010.

CUADRADO RUIZ, Ma. de los Ángeles, ña responsabilidad penal de las personas jurídicas. Un paso hacia adelanteé ¿un paso hacia atrás?ò en Revista Jurídica de Castilla y León, número 12, abril de 2007.

DANNECKER, Gerhard, - ñSanciones y principios de la parte general del derecho de la competencia en las comunidades europeasò en V.V. A.A. Jornadas en Honor del Profesor Klaus Tiedemann, Hacia un derecho penal económico europeo, Madrid, BOE, Universidad Autónoma de Madrid, 1995.

- TrReflexiones sobre la responsabilidad penal de las personas jurídicasò $R P$, núm. 7, 2001.

DE LA FUENTE Honrubia, Las consecuencias accesorias del artículo 129 del Código penal, 2004.

DE LA CUESTA ARZAMENDI, José Luis, ז̃Responsabilidad penal de las personas jurídicas en el derecho españolò en Revista electrónica de la Asociación Internacional de Derecho Penal (ReAIDP), 2012.

DEL ROSAL BLASCO, Bernardo, y PÉREZ VALERO, Ignacio, ŕResponsabilidad penal de las personas jurídicas y consecuencias accesorias en el Código penal españolò en HURTADO POZO, DEL ROSAL BLASCO Y SIMMONS VALLEJO (Coords.), La responsabilidad criminal de las personas jurídicas: una perspectiva comparada, Tirant lo blanch, Valencia, 2001.

DEL ROSAL BLASCO, Bernardo, R̃a delimitación típica de los llamados hechos de conexión en el nuevo artículo 31 bis, número 1, del 
Código Penalò en Cuadernos de Política Criminal, número 103, Dykinson, 2011.

- TrResponsabilidad penal de empresas y códigos de buena conducta corporativaò en Diario La Ley, Número 7670, 11 de julio de 2011.

DE DOELDER, H., ĨLa punibilidad de las personas jurídicas en Holandaò en VV.AA., Jornadas en Honor del Profesor Klaus Tiedemann, Hacia un derecho penal económico europeo, BOE, Universidad Autónoma de Madrid, Madrid, 1995.

DE VICENTE MARTínEZ, R., îPersona jurídica y consecuencias accesoriasò RDPP, Número 8, 2002.

- Ĩa responsabilidad penal de las personas jurídicasò en DEMETRIO CRESPO, Eduardo (Coord.), Lecciones y materiales para el estudio del Derecho Penal, Tomo II, lustel, Madrid, 2011.

DÍAZ GÓMEZ, Andrés, Ĩa responsabilidad criminal de las personas jurídicas en el Derecho Españolò http://www.newsmatic.epol.com.ar/usr/721/6159/la_responsabilidad_criminal_de_las_personas jur_dicas_en_el_derecho_espa_ol.pdf.

DIEZ RIPOLLÉS, José Luis, ña responsabilidad penal de las personas jurídicas. Regulación españolaò en InDret, Número 1/2012.

- Derecho Penal Español, en esquemas, Tirant lo blanch, Valencia, 2012.

DOPICO GÓMEZ-ALLER, J., "Capítulo I. Responsabilidad de las personas Jurídicas", en ORTIZ DE URBINA GIMENO (Coord.), Memento Experto Reforma Penal, Ediciones Francis Lefebvre, 2010.

FEIJOO SÁNCHEZ, Bernardo, Ĩa responsabilidad penal de las personas jurídicasò en DÍAZ-MAROTO Y VILLAREJO, Julio (Dir.), Estudios sobre las reformas del Código penal operadas por las LO 
5/2010, de 22 de junio, y 3/2011, de 28 de enero, Civitas-Thomson, 2010.

- Ĩa reforma del art. 129 CPò en DÍAZ-MAROTO Y VILLAREJO, Julio (Dir.), Estudios sobre las reformas del Código penal operadas por las LO 5/2010, de 22 de junio, y 3/2011, de 28 de enero, Civitas-Thomson, 2010.

- Derecho penal de la empresa e imputación objetiva, Madrid, 2007.

- గ̃ Culpabilidad y punición de personas jurídicas?ò El funcionalismo en Derecho penal: Libro Homenaje al Prof. Gunther Jakobs(en Montealegre Lynett, Eduardo, coord.), Universidad Externado Colombia, Colombia, 2003.

- Sanciones para empresas por delitos contra el medio ambiente, Madrid, Civitas, 2002.

FERNÁNDEZ Teruelo, Javier Gustavo, ñas consecuencias accesorias del artículo 129à El nuevo Derecho penal español: estudios penales en memoria del Profesor José Manuel Valle Muñíz, Navarra, Aranzadi, 2001.

- ñAlgunas consideraciones críticas sobre el nuevo modelo de responsabilidad penal de las personas jurídicas introducido por la LO 5/2010à Revista de Derecho Penal, núm. 31, 2010.

- rEl nuevo modelo de responsabilidad penal de las personas jurídicas introducido por la LO 5/2010à en Lex Nova, http://www.reformapenal.es/2010/11/23/algunas-consideracionescriticas-sobre-el-nuevo-modelo-de-responsabilidad-penal-de-laspersonas-juridicas-i/, última visita 3-12-12.

FERRAJOLI, Luigi, Derechos y garantías, la justicia del más débil, Trotta, Madrid, 1998. 
- Derecho y razón. Teoría del garantismo penal, Trotta, Madrid, 1999.

FOFFANI, L., "Bases para una imputación subjetiva de la persona moral ¿Hacía una culpabilidad de las personas jurídicas?", en Revista General de Derecho Penal, número 10, 2010.

- r̃a corrupción en el sector privado: la experiencia italiana y el derecho comparadoò en Revista penal, No. 12, 2003.

GALÁN MUÑOZ, Alfonso, ña responsabilidad penal de la persona jurídica tras la reforma de la LO 5/2010: entre la Hetero- y la Autorresponsabilidadò en Revista General de Derecho Penal, número 16, 2011.

GARCIA ARAN, Mercedes, ñAlgunas consideraciones sobre la responsabilidad penal de las personas jurídicasò El Nuevo Código Penal: presupuestos y fundamentos: Libro homenaje al Profesor don Angel Torío López, (en CEREZO MIR, José, et al, Ed.), Granada, Comares, 1999.

- ñArts. 31 bisò en CORDOBA RODA, Juan/GARCÍA ARÁN, Mercedes (Dirs.), Comentarios al código penal. Parte general. Madrid, Marcial Pons, 2010.

GARCIA Cavero, Percy, La responsabilidad penal del administrador de hecho de la empresa: Criterios de imputación, Bosch Editor, Barcelona, 1999.

GARCÍA LÓPEZ-GUERRERO, Luis, La persona jurídica ante el Derecho Penal, Cárdenas Editor y Distribuidor, México, 2002.

GARÓFALO, Rafael, Criminología, Editorial Ángel, México, 1998. 
GIL GIL, Alicia, LACRUZ LÓPEZ, Juan Manuel, MELENDO PARDOS, Mariano, y NUÑEZ FERNÁNDEZ, José, Curso de Derecho Penal. Parte General, Dykinson, Madrid, 2011.

GIMBERNAT ORDEIG, E., ¿Tiene un futuro la dogmática jurídico penal?, Estudios de Derecho penal, Tecnos, Madrid, 1990.

- Concepto y método de la ciencia del Derecho Penal, Tecnos, Madrid.

GOMEZ-JARA DIEZ, Carlos, La culpabilidad penal de la empresa, Barcelona, Marcial Pons, 2005.

- La responsabilidad penal de las empresas en los EE. UU., Editorial Universitaria Ramón Areces, Madrid, 2006.

- EEl modelo constructivista de autorresponsabilidad penal empresarialò en GOMEZ-JARA DIEZ (Ed.), Modelos de autorresponsabilidad penal empresarial, propuestas globales contemporáneas, Navarra, Aranzadi, 2006.

- FEl nuevo artículo 31.2 del Código Penal: cuestiones de lege lata y de lege ferendaò en GOMEZ-JARA DIEZ (Ed.), Modelos de autorresponsabilidad penal empresarial, propuestas globales contemporáneas, Navarra, Aranzadi, 2006.

- r̃Autoorganización empresarial y autorresponsabilidad empresarial: hacia una verdadera responsabilidad penal de las personas jurídicasò RECPC, número 8, 2005,

- $\tilde{n}$ Imputabilidad de las personas jurídicas?ò Homenaje al Profesor Dr. Gonzalo Rodríguez Mourullo, Civitas, Madrid, 2005.

- ñTeoría de sistemas, ciudadanía corporativa y responsabilidad penal de las empresasò en BAJO FERNÁNDEZ, Miguel (Dir.); BACIGALUPO y GOMEZ-JARA (Coords.), Constitución europea y 
Derecho penal económico, Madrid, Centro de Estudios Ramón Areces, 2006.

- Fundamentos modernos de la responsabilidad penal de las personas jurídicas, Buenos Aires y Montevideo, 2010.

- "La responsabilidad penal de las personas jurídicas en la reforma del Código penal", Diario La Ley, número 7534, de 23 de diciembre de 2010 -versión electrónica-.

GOMEZ-JARA DIEZ, Carlos, y OTROS, Responsabilidad penal de las personas jurídicas. Aspectos sustantivos y procesales, La Ley, Madrid, Marzo, 2011.

GOMEZ MARÍN, V., r̃artículo 31 bisò en MIR PUIG, S. y CORCOY BIDASOLO, M. (Dirs.), Comentarios al Código Penal. Reforma LO 5/2010, Tiran lo Blanch, Valencia, 2011.

GOMEZ TOMILLO, Manuel, Introducción a la responsabilidad penal de las personas jurídicas en el sistema español, Lex Nova, Valladolid, 2010.

GÓMEZ RIVERO, Ma. del Carmen, r̃a responsabilidad penal de las personas jurídicasò en GÓMEZ RIVERO, Ma. del Carmen, (Coord.), Nociones fundamentales de Derecho Penal. Parte General, Tecnos, Madrid, 2010.

GONZALEZ-CUELLAR SERRANO, Nicolás/JUANES PECES, Ángel, "La responsabilidad de las personas jurídicas y su enjuiciamiento en la reforma de 2010. Medidas a adoptar antes de su entrada en vigor", en Diario La Ley, número 7501, de 3 de noviembre de 2010.

GONZÁLEZ SIERRA, Pablo, La responsabilidad penal de las personas jurídicas, Tesis para obtener el grado de Maestro en Ciencias jurídico penales, Universidad de Guanajuato, México. 
GRACIA MARTIN, Luis, El actuar en lugar de otro en Derecho penal. Teoría General (Tomo I), Universidad de Zaragoza, Zaragoza, 1985.

- ña cuestión de la responsabilidad penal de las propias personas jurídicasò en AP, XXXIX, 1993.

- R̃a cuestión de la responsabilidad penal de las propias personas jurídicasò en MIR PUIG, S., y LUZÓN PEÑA, D.M. (Coords.), Responsabilidad penal de las empresas $y$ sus órganos $y$ responsabilidad por el producto, Bosch, Madrid, 1996.

- Tratado de las consecuencias del delito, Tirant lo blanch, Valencia, 2006

GUARDIOLA LAGO, Ma. de Jesús, Responsabilidad penal de las personas jurídicas y alcance del artículo 129 del Código Penal, Valencia, Tirant lo Blanch, 2004.

GUDIN RODRÍGUEZ-MAGARIÑOS, Antonio Evaristo, ñAlcance de la reforma del Código Penal por la Ley Orgánica 3/2011 en relación a las r̃ Ley, Número 7606, 7 abril 2011

HERNÁNDEZ BASUALTO, Héctor, ña introducción de la responsabilidad penal de las personas jurídicas en Chileà en Política Criminal, Volumen 5, Número 9, Julio de 2010, Páginas 207 a 236.

HEINE, Günter, ña responsabilidad penal de las empresas: evolución internacional y consecuencias nacionalesò en HURTADO POZO, DEL ROSAL BLASCO Y SIMMONS VALLEJO (Coords.), La responsabilidad criminal de las personas jurídicas: una perspectiva comparada, Tirant lo blanch, Valencia, 2001.

- rModelos de responsabilidad jurídico-penal originaria de la empresaò en GOMEZ-JARA DIEZ (Ed.), Modelos de 
autorresponsabilidad penal empresarial, propuestas globales contemporáneas, Navarra, Aranzadi 2006.

- Ĩa responsabilidad colectiva: una tarea pendiente a la luz de la reciente evolución europeaò en GOMEZ-JARA DIEZ (Ed.), Modelos de autorresponsabilidad penal empresarial, propuestas globales contemporáneas, Navarra, Aranzadi 2006.

HIRSCH, Hans Joachim, Ĩa cuestión de la responsabilidad penal de las asociaciones de personasò en ADPCP, 1991.

HURTADO POZO, José, ña responsabilidad penal de las personas jurídicas en Perúò en HURTADO POZO, DEL ROSAL BLASCO Y SIMONS VALLEJO (Coords.), La responsabilidad criminal de las personas jurídicas: una perspectiva comparada, Tirant lo blanch, Valencia, 2000.

JAKOBS, Günther, Derecho penal, parte general. Fundamentos y teoría de la imputación, Marcial Pons, Madrid, 1995.

- Sociedad, norma y persona en una teoría de un Derecho Penal funcional, Civitas, Madrid, 1996.

- Sobre la normativización de la dogmática jurídico-penal, Civitas, Madrid, 2003.

- Estudios de Derecho penal, Civitas, Madrid, 1997.

- Suicidio, eutanasia y derecho penal, Tirant lo blanch, Valencia, 1999.

- La imputación objetiva en Derecho penal, Civitas, Madrid, 1999.

- Dogmática de derecho penal y la configuración normativa de la sociedad, Civitas, Madrid, 2004; 
- TrRasgos y crisis del Derecho penal modernoò $A D P C P$, enero abril, 1992.

- r̃Responsabilidad penal en supuestos de adopción colectiva de acuerdosò en MIR PUIG y LUZÓN PEÑA (Coords), Responsabilidad penal de las empresas y sus órganos y responsabilidad por el producto, Bosch, 1996.

- r̃a imputación penal de la acción y la omisiónò $A D P C P, 1996$.

- ña intervención delictivaò CPC, Número 85, 2005.

- ñSobre el concepto de delito contra la personaò Revista del Poder Judicial, núm. 70, Consejo General del Poder Judicial, 2003.

- ñSobre la génesis de la obligación jurídicaò Doxa, Número 23, 2000.

- ña normativización del derecho penal en el ejemplo de la participaciónò Modernas tendencias en la ciencia del derecho penal y en la criminología, UNDED, Madrid, 2000.

- ñ Qué protege el derecho penal: bienes jurídicos o la vigencia de la norma?ò en MONTEALEGRE LYNETT, Eduardo (Coord.), El funcionalismo en Derecho penal: Libro Homenaje al Prof. Gunther Jakobs, Universidad Externado Colombia, Colombia, 2003.

- T̃Personalidad y exclusión en Derecho penalò en MONTEALEGRE LYNETT, Eduardo (Coord.), El funcionalismo en Derecho penal: Libro Homenaje al Prof. Gunther Jakobs, Universidad Externado Colombia, Colombia, 2003.

- ñ:Punibilidad de las personas jurídicas?ò en MONTEALEGRE LYNETT, Eduardo (Coord.), El funcionalismo en Derecho penal: Libro Homenaje al Prof. Gunther Jakobs, Universidad Externado Colombia, Colombia, 2003. 
JESCHECK, T.W., Tratado de Derecho Penal, 1990.

JIMENEZ HUERTA, Mariano, Derecho penal mexicano, t. I, Porrúa, México, 1972.

LANDECHO VELASCO, Carlos María, y MOLINA BLÁZQUEZ, Concepción, Derecho penal español. Parte General, $8^{\text {a }}$ ed., Tecnos, Madrid, 2010.

LAUFER, W. S., ña culpabilidad empresarial y los límites de derechoò en GOMEZ JARA, C., (ed.) Modelos de autorresponsabilidad penal empresarial, propuestas globales contemporáneas, Navarra, Aranzadi, 2006.

LAUFER, W. S., y STRUDLER, A., Întencionalidad corporativa, retribución y variantes de la responsabilidad vicariaò en GOMEZ-JARA, Carlos, (Ed.) Modelos de autorresponsabilidad penal empresarial, propuestas globales contemporáneas, Navarra, Aranzadi, 2006.

LANDROVE DÍAZ, Gerardo, Las consecuencias jurídicas del delito, Madrid, Tecnos, 2005.

LARRAURI, Elena, La herencia de la criminología Crítica, siglo XXI, Madrid, 2000.

LISZT, F., Tratado de Derecho penal, tomo I, trad. Por Luis Jiménez de Asúa de la 18ª . Ed. Alemana, Reus, Madrid, 1999.

- La ldea del Fin en el Derecho penal (1882), trad. Carlos Pérez del Valle, Nota introductoria de José Miguel Zugaldía Espinar, Comares, Granada 1995.

LOPEZ BETANCOURT, Eduardo, Teoría del delito, Porrúa, México, 1999.

LOPEZ BARJA DE QUIROGA, Jacobo, Tratado de Derecho Penal. Parte General, Thomson Reuters, Navarra, 2010. 
LOZANO, Blanca, Ĩa responsabilidad de la persona jurídica en el ámbito sancionador administrativo (a propósito de la STC 246/1991, de 19 de diciembre)ò en Revista de Administración Pública, Número 129, 1992.

LUZÓN PEÑA, Diego Manuel, Curso de Derecho Penal, Universitas, Valencia, 1995.

- R̃as consecuencias accesorias como tercera vía de las sanciones penalesò en DE TOLEDO Y UBIETO, GURDIEL SIERRA, CORTÉS BECHIARELLI, (Ed.), Estudios penales en recuerdo del profesor Ruíz Antón, Valencia, Tirant lo blanch, 2004.

LUHMAN, Niklas, $\tilde{E}$ El derecho como sistema socialò en GOMEZ-JARA DIEZ, Carlos (Ed.), Teoría de sistemas y Derecho penal, Fundamentos y posibilidades de aplicación, Comares, Granada, 2005.

MAGRO SERVET, Vicente, r̂Hacia la necesidad de implantación del plan de prevención jurídica de las empresasò en Diario La Ley, Número 7633, 19 de mayo de 2011.

MALO CAMACHO, Gustavo, Derecho penal mexicano, Porrúa, México, 2005.

MANZANARES SAMANIEGO, José Luis, Código Penal (adaptado a la Ley Orgánica 5/2010, de 22 de junio), tomo I, Comares, Granada, 2010.

MAPELLI CAFFARENA, Borja, ñas consecuencias accesorias en el nuevo Código Penalò en RP, Número 1, Praxis, Enero de 1998.

- r̃artículo 130à en GÓMEZ TOMILLO, Manuel (Dir.), Comentarios al Código Penal, Lex Nova, Valladolid, 2010.

MARTÍNEZ-BUJÁN PÉREZ, Carlos, Derecho penal económico y de la empresa. Parte General, Tirant lo blanch, Valencia, 2011. 
MARTÍNEZ PARDO, Vicente, Ĩa responsabilidad penal de las personas jurídicasò en Revista internauta de práctica jurídica, Número 26, 2011, páginas 61 a 78 .

MARTÍNEZ GARAY, Lucía y MIRA BENAVENT, Javier, ña responsabilidad penal de las organizaciones terroristas con personalidad jurídica. Especial referencia al caso de los partidos políticosò en Revista General de Derecho Penal, número 14, 2010.

MATA BARRANCO, Norberto J. de la, ña responsabilidad penal de las sociedades mercantilesò en Boletin Quantor Contable, número 87, 1 de diciembre de 2010.

MARIN de Espinoza Ceballos, Elena B., Criminalidad de empresa, la responsabilidad penal en las estructuras jerárquicamente organizadas, Tirant lo blanch, Valencia, 2002.

MARRAMO, G., r̂El orden desencantadoò Anales de la Cátedra Francisco Suárez, número 30, 1990.

MERCADO Pacheco, Pedro, ña forma de gobierno de una economía desterritorializadaò en VV.AA., Transformaciones del derecho en la mundialización, Consejo General del Poder Judicial, Madrid, 1999.

MEZGER, Edmund, Derecho penal, parte general, trad. Ricardo C. Núñez, Cárdenas Editor y Distribuidor, México, 1990.

MILITELLO, Vicenzo, ña responsabilidad jurídico-penal de la empresa y de sus órganos en Italiaò en VV.AA., Libro Homenaje a Claus Roxin, Fundamentos de un sistema europeo del Derecho penal, Bosch, Madrid, 1995.

MIR PUIG, S., Derecho penal, parte general, Reppertor, Madrid, 1999. 
- î́Sobre la responsabilidad penal de las personas jurídicasò en DE TOLEDO Y UBIETO, GURDIEL SIERRA, CORTÉS BECHIARELLI, (Ed.), Estudios penales en recuerdo del profesor Ruíz Antón, Valencia, Tirant lo blanch, 2004,

- ñna tercera vía en materia de responsabilidad penal de las personas jurídicasò Revista Electrónica de Ciencia Penal y Criminología, 06-01 (2004), 2004.

- Derecho Penal. Parte General, Reppertor, 9a edición, Barcelona, 2011.

MORALES PRATS, Fermín, "La responsabilidad penal de las personas jurídicas", en QUINTERO OLIVARES (Dir.), La reforma penal del 2010, análisis y comentarios, Aranzadi Thomson, Pamplona, 2010.

- Ĩa responsabilidad penal de las personas jurídicasò en Estudios de derecho judicial, Número 155, 2009.

MORILLAS CUEVA, Lorenzo, Derecho Penal. Parte General. Addenda a la obra, Tomo II, Volumen I, Dikinson, 2008.

MUÑOZ CONDE, Francisco, y GARCÍA ARÁN, M., Derecho Penal. Parte general, Tirant lo blanch, Valencia, 2002.

- Derecho penal. Parte General, 8. ${ }^{a}$ ed., 2010.

MUÑOZ CONDE, Francisco, ñ La responsabilidad de los órganos de las personas jurídicas en el ámbito de las insolvencias puniblesò CPC, Número 3, 1977.

- ז̃Problemas de autoría y participación en el derecho penal económico, o ¿cómo imputar a título de autores a las personas que sin realizar acciones ejecutivas, deciden la realización de un delito en el ámbito de la delincuencia económica?ò en Revista Penal, Número 9 , 2002 
- ña responsabilidad por el producto en Derecho españolò en HASSEMER, La responsabilidad por el producto, Tirant lo blanch, 2000.

NEIRA PENA, Ana, îPrimer auto de procesamiento contra personas jurídicasò en Diario La Ley, No. 7768, Año XXXII, 3 de enero de 2012.

NIETO MARTÍN, Adán, La responsabilidad penal de las personas jurídicas: Un modelo legislativo, lustel, Madrid, 2008

- rResponsabilidad social, gobierno corporativo y autorregulación: sus influencias en el derecho penal de la empresaò en Política Criminal, No. 5, 2008, A3-5.

- ña responsabilidad penal de las personas jurídicas tras la LO 5/2010à en Revista Xurídica Gallega, número 63 (2009).

NUÑEZ CASTAÑO, Elena, Responsabilidad penal en la empresa, Tirant lo blanch, Valencia, 2000.

ORTS BERENGUER, Enrique y GONZÁLEZ CUSSAC, José Luis, Compendio de Derecho Penal. Parte General, Tirant lo Blanch, Valencia, 2010.

PASTOR MUÑOZ, Nuria, ñ Organizaciones culpables?ò Recensión a Carlos Gómez-Jara, La culpabilidad de la empresaò In Dret, Número 340, 2006.

PALIERO, C. E., Tिroblemas y perspectivas de la responsabilidad penal de la persona jurídica en el derecho italianoò $L a$ responsabilidad criminal de las personas jurídicas: una perspectiva comparada, Tirant lo blanch, 2001.

- îProblemas y perspectivas de la responsabilidad penal de la persona jurídica en el derecho italianoò ADP, Lima, Perú, 1996. 
- Ĩa sanción administrativa como medida en la lucha contra la criminalidad económicaò en V.V. A.A., Jornadas en Honor del Profesor Klaus Tiedemann, Hacia un derecho penal económico europeo, Madrid, BOE, Universidad Autónoma de Madrid, 1995.

PEREZ ALONSO, Esteban Juan, ĨLas revoluciones científicas del Derecho Penal: evolución y estado actual de la dogmática jurídico penalò en Estudios penales en memoria del Profesor José Manuel Valle Muñiz, Aranzadi, Navarra, 2001.

PEREZ MANZANO, Mercedes, ÎLa responsabilidad penal de las personas jurídicasò $A P, 1995-1$.

PITCH, Tarman, Teoría de la desviación social, Nueva Imagen, México, 1980.

PLASCENCIA VILLANUEVA, Raúl, Teoría del delito, UNAM, México, 1998.

PRADEL, J., గ̂ta responsabilidad penal de las personas jurídicas en el Derecho francés: algunas cuestionesò $\operatorname{RdDPC}$, núm. 04 , 1999.

- DDerecho penal económico francés: algunos aspectos actualesò Revista del Poder Judicial, núm.49, 1988.

- R̃a responsabilidad penal de las personas jurídicas en el derecho penal francés: algunas cuestionesò $A D P$, Universidad de Friburgo, 1996.

- ña responsabilidad penal de la persona jurídicaò HURTADO POZO, DEL ROSAL BLASCO Y SIMONS VALLEJO (Coords.), La responsabilidad criminal de las personas jurídicas: una perspectiva comparada, Tirant lo blanch, Valencia, 2001.

QUINTERO OLIVARES, Gonzalo, Parte General del Derecho Penal, Aranzadi, Navarra, 2005. 
- Parte General de Derecho Penal, Thomson Reuters, Pamplona, 2010.

- ñArtículo 31 bisò en QUINTERO OLIVARES, Gonzalo (Dir.) y MORALES PRATS, Fermín (Coord.), Comentarios al Código Penal Español, Thomson Reuters, Aranzadi, Navarra, 2011.

RAGUÉS I VALLÈS, Ramón, గ̃ Héroes o traidores? La protección de los informantes internos (whistleblowers) como estrategia político-criminalò en InDret, número 364, 3/2006, Barcelona, Julio de 2006.

ROBLES PLANAS, Ricardo, "¿Delitos de las personas jurídicas?", InDret, 2/2006

- "El hecho propio de las personas jurídicas y el informe del Consejo General del Poder Judicial al Anteproyecto de Reforma del código penal de 2008", InDret, 2/2009.

- ñCrítica del artículo 31 bis CPò en Diario la Ley, No. 7705, Año XXXII, Editorial La Ley, 29 de septiembre de 2011.

RODRIGUEZ MOURULLO, Gonzalo, "La responsabilidad penal de las personas jurídicas y los principios básicos del sistema", en Abogados, septiembre 2010.

- "Hacia la responsabilidad penal de las personas jurídicas en el Código penal español", en Estudios de Derecho penal económico, Thomson Reuters, Civitas, Navarra, 2009.

RODRIGUEZ RAMOS, Luis, rMedidas de seguridad aplicables a las personas jurídicas en el proyecto de Código Penalò Diario La ley, Num. 1, Madrid, 1980.

- Ñuevos aspectos dogmáticos y procesales del principio societas delinquere potestò HURTADO POZO, DEL ROSAL BLASCO Y SIMMONS VALLEJO (Coords.), La responsabilidad criminal de las 
personas jurídicas: una perspectiva comparada, Tirant lo blanch, Valencia, 2001.

- R̃a culpabilidad en los delitos cometidos por la persona jurídica. El r̃delito de sospecha blindadoò y la responsabilidad objetiva ñmpuraò en la Circular 1/2010 de la FGEò en Diario La Ley, Número 7694, Sección Doctrinaria, 14 de septiembre 2011, Año XXXII, Editorial La Ley, 14037/2011.

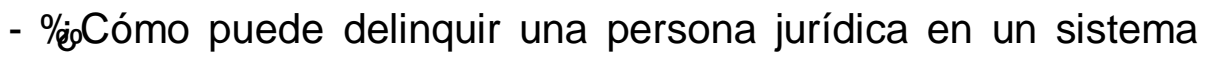
penal antropocéntrico? (La participación en el delito de otro por omisión imprudente: pautas para su prevención)ò en Diario La Ley, Número 7561, 3 febrero 2011.

REYNOSO DÁVILA, Roberto, Teoría General del delito, Porrúa, México, 1997.

ROXIN, Claus, Derecho penal, parte general, Fundamentos, tomo I, trad. Diego Manuel Luzón Peña, Miguel Díaz y García Conlledo y Javier Remesal, Civitas, Madrid, 1999.

- Autoría y dominio del hecho en Derecho penal, trad. Joaquín Cuello Contreras y José Luis Serrano González de Murillo, Marcial Pons, Barcelona, 1998.

- Teoría del tipo penal, tipos abiertos y elementos del deber jurídico, trad. Enrique Bacigalupo, De palma, 1979.

- La evolución de la política criminal, el Derecho penal y el Proceso penal, trad. Carmen Gómez Rivero y María del Carmen García Cantizano, Tirant lo blanch, Valencia, 2000.

- ña culpabilidad como criterio limitativo de la penaò en Revista de Ciencias Penales, enero-abril de 1973. 
- ña determinación de la pena a la luz de la teoría de los fines de la penaò Culpabilidad y prevención en Derecho Penal, Reus, Madrid, 1981.

RUIZ VADILLO, Enrique, Ĩa responsabilidad penal de las personas jurídicas en el Derecho Europeoò en Revista de Derecho Penal y Criminología, Número 1, Universidad Nacional de Educación a Distancia, 1991.

SALDAÑA Y GARCÍA-RUBIO, Quintiliano, Capacidad criminal de las personas sociales (doctrina y legislación), Reus, Madrid, 1927.

SANCHEZ REYERO, David G., rEstudio sobre la responsabilidad de la persona jurídica, el doloso dependiente y el corporate complianceò en Diario La Ley, Número 7653, 16 junio 2011.

SCHÜNEMANN, Bernd, r̃̃uestiones básicas de la dogmática jurídico penal y de la política criminal acerca de la criminalidad de empresaò ADPCP, (Trad. Bruckner y Lascurain), 1988.

- TDel derecho penal de la clase baja al Derecho penal de la clase alta. ¿Un cambio de paradigma como exigencia moral?à Temas actuales y permanentes del Derecho penal después del milenio, Tecnos, Madrid, 2002

- Ĩa punibilidad de las personas jurídicas desde la perspectiva europeaò Hacia un derecho penal económico europeo (en Jornadas en Honor del Profesor Klaus Tiedemann), Madrid, BOE, Universidad Autónoma de Madrid, 1995.

- ña responsabilidad penal de las empresas y sus órganos directivos en la unión europeaò en BAJO FERNÁNDEZ (Dir.), BACIGALUPO, Sivlina y GÓMEZ-JARA DIEZ (Coords.), Constitución europea y Derecho penal económico, Madrid. Centro de Estudios Ramón Areces, 2006. 
- TrResponsabilidad penal en el marco de la empresa. Dificultades relativas a la individualización de la imputaciónò en Anuario de Derecho Penal y Ciencias Penales, Vol. LV, 2002.

SILVA Sánchez, Jesús-María, y ORTIZ de U. Gimeno, Iñigo, ĩEI artículo 31.2 del Código penal, ¿Responsabilidad penal de las personas jurídicas o mero aseguramiento del pago de la pena de multa?ò Revista para el análisis del derecho, www.indret.com, 2/2006, Barcelona, 2006

SILVA SÁNCHEZ, Jesús-María, r̃̃riterios de asignación de responsabilidad en estructuras jerárquicasò Empresa y delito en el nuevo Código Penal (Cuadernos de Derecho Judicial), CGPJ, Madrid, 1997.

- ñartículo 31ò en COBO DEL ROSAL, (Dir.), Comentarios al Código penal, Tomo III, 2000.

- Delitos contra el medio ambiente, Valencia, 1999.

- Ĩa aplicación judicial de las consecuencias accesorias para las empresasò InDret, 2/2006, 2006.

- Ĩa responsabilidad penal de las personas jurídicas y las consecuencias accesorias del artículo 129 del Código penalò en AA.VV., Derecho penal económico, Madrid, CGPJ, 2001.

- r̃Responsabilidad penal de las empresas y de sus órganos en Derecho españolò en SILVA SANCHEZ, J. (Ed.), Fundamentos de un sistema europeo del Derecho penal, Libro Homenaje a Claus Roxin, Bosch, 1995.

- "La reforma del Código penal: una aproximación desde el contexto", La Ley, número 7464, 9 de septiembre de 2010.

SOLÉ RAMÓN, Ana María, Ĩa responsabilidad penal de las personas jurídicas. Hacia una nueva regulación de la persona jurídica 
como sujeto activo del derecho penal y del proceso penalò en RGDP, Número 13, 2010, www.iustel.com, visita 9-01-12.

StRATENWERTH, G., Derecho penal, Parte General I, el hecho punible, Civitas, Navarra, 2005.

TIEDEMANN, K., íEstado actual y tendencias de la ciencia jurídico-penal y de la criminología en la República Federal Alemanaò CPC, núm. 14, 1981.

- îEl concepto de derecho económico, de derecho penal económico y de delito económicoò CPC, Número 28, 1986.

- FEl derecho penal económico en la comunidad europeaò Estudios de Derecho Penal Económico, Editorial Universidad Castilla la Mancha, Castilla la Mancha, 1994.

- îPresente y futuro del Derecho penal económicoò en VV. AA., Hacia un derecho penal económico europeo, Jornadas en Honor del Profesor Klaus Tiedemann, BOE y Universidad Autónoma de Madrid, Madrid, 1995.

- îResponsabilidad penal de las personas jurídicasò $A D P$, Universidad de Friburgo, 1996.

- îResponsabilidad penal de personas jurídicas, otras agrupaciones y empresas en derecho comparadoò en VV. AA., La reforma de la justicia penal: Estudios en homenaje al Prof. Karl Tiedemann, Castelló de la Plana, Publicaciones de la Universitat Jaume I, Madrid, 1997.

- FExigencias fundamentales de la Parte General y propuesta legislativa para un Derecho Penal europeoò RP, número 3, enero 1999.

- T̃Presente y futuro del Derecho penal europeoò Homenaje al Profesor Dr. Gonzálo Rodríguez Mourullo, Civitas, Madrid, 2005. 
UBEDA DE LOS COBOS, Julio José, ñLa responsabilidad penal de las personas jurídicas tras la reforma del Código Penal aprobada por la LO 5/2010, de 22 de junioà en La Ley penal: Revista de derecho penal, procesal y penitenciario, Número 77, 2010.

URRAZA ABAD, Jesús, "La responsabilidad penal de las personas jurídicas tras la reciente promulgación de la LO 5/2010 de 22 de junio, de reforma del código penal; una propuesta de interpretación del nuevo artículo 31 bis", en Res Pública, Portal Jurídico Vasco, consultado en http://rpublica.org/contenidos/704-la-responsabilidadcriminal-de-las-personas-juridicas, última visita 12-01-12.

VALLS PRIETO, Javier, r̃as exenciones de la responsabilidad penal de las personas jurídicas. ¿Son responsables los partidos políticos y sindicatos?ò en Cuadernos de Política Criminal.

VARIOS, La experiencia del penitenciarismo contemporáneo, Comisión Nacional de Derechos Humanos, México, 1995.

VELAZQUEZ V., Fernando, Ĩa responsabilidad de las personas jurídicasò en MORENO HERNÁNDEZ, Moisés (Coord.), Globalización e internacionalización del Derecho Penal. Implicaciones político-criminales y dogmáticas, CEPOLCRIM, México, 2003.

VIDAL MARÍN, Tomás, ĩDerecho al honor, personas jurídicas y tribunal constitucionalò en InDret, 1/2007, enero de 2007.

VILLALOBOS, I., Derecho penal mexicano, Porrúa, México, 1990.

VERVAELE, J. A. E., r̃ de la persona jurídica en Holanda. Matrimonio entre pragmatismo y dogmática jurídicaò en Revista de Derecho Penal y Criminología, Núm. 1, 2ª época, Enero, 1998 
WELZEL, H., Derecho penal alemán, trad. Juan Bustos Ramírez y Sergio Yáñez Pérez, Editorial jurídica de Chile, Santiago, 1993;

- La teoría de la acción finalista, comp. Carlos Fontán Palestra, trad. Eduardo Friker, Depalma, Buenos Aires, 1951.

- Estudios de Derecho penal, trad. Gustavo Eduardo Aboso y Tea Löw, Editorial B de F, editado en Buenos Aires, 2002;

- El nuevo sistema de derecho penal, una introducción a la doctrina de la acción finalista, trad. José Cerezo Mir, Editorial B de F, editado en Buenos Aires, 2001.

ZAFFARONI, Eugenio Raúl, Derecho penal, parte general, Porrúa, México, 2005.

ZAMORA JUMENEZ, Arturo, ñTendencias legislativas sobre la responsabilidad penal de las personas jurídicasò en MORENO HERNÁNDEZ, Moisés (Coord.), Globalización e internacionalización del Derecho Penal. Implicaciones político-criminales y dogmáticas, CEPOLCRIM, México, 2003.

ZUGALDÍA Espinar, J.M., r̃Convenciencia político criminal e imposibilidad dogmática de revisar la fórmula tradicional societas delinquere non potestò CPC, núm 12, 1980.

- r̃́Capacidad de acción y capacidad de culpabilidad de las personas jurídicasò CPC, No. 53, 1994.

-ñna vez más sobre el tema de las responsabilidad criminal de las personas jurídicas (doce años después)ò Hacia un derecho penal económico europeo (en Jornadas en Honor del Profesor Klaus Tiedemann), VV. AA., Madrid, BOE, Universidad Autónoma de Madrid, 1995. 
- ñ Otra vez la vuelta a Von Liszt?à en la Introducción a VON LISZT, F., La idea del fin en el Derecho penal, Comares, Granada, 1995.

-r̃as penas previstas en el artículo 129 del Código Penal para las personas jurídicas (consideraciones teóricas y consecuencias prácticas)Q̀ Cuadernos del Poder Judicial, núm. 46, 1997.

- ñArtículo 129à Comentarios al Código Penal, en COBO DEL ROSAL, Manuel, Tomo IV, Madrid, Edersa, 2000.

- ṙBases para una teoría de la imputación de la persona jurídicaò CPC, 2001.

- NNigencia del principio societas delinquere potest en el moderno Derecho penalò La responsabilidad criminal de las personas jurídicas: una perspectiva comparada, Tirant lo blanch, 2001

- ña responsabilidad criminal de las personas jurídicas en el derecho penal españolò El nuevo Derecho penal español: estudios penales en memoria del Profesor José Manuel Valle Muñíz, Navarra, Aranzadi, 2001.

- Derecho penal, Parte General, en ZUGALDÍA (Dir) y PÉREZ ALONSO (Coord.), Tirant lo blanch, Valencia, 2004.

- Contrarreforma penal (el annus horribilis de 2003) y el Anteproyecto de Reforma del Código Penal de 2006, Inédito.

- Fundamentos de Derecho Penal, Parte General, 4a edición, Valencia, 2010.

- "Societas delinquere potest (Análisis de la reforma operada en el Código Penal español por la LO 5/2010, de 22 de junio)", La Ley Penal. Revista de Derecho Penal, Procesal y Penitenciario. Año VII, número 76, noviembre, 2010 -versión electrónica- 
- La responsabilidad penal de empresas, fundaciones y asociaciones, Tirant lo blanch, Valencia, 2008.

- La responsabilidad criminal de los entes colectivos (personas jurídicas y entes sin personalidad) y de sus directivos y representantes. Análisis de los arts. 31 bis y 129 del Código Penal, Granada, 2012, por publicar.

ZUÑIGA RODRÍGUEZ, Laura, Bases para un modelo de imputación de responsabilidad penal a las personas jurídicas, Aranzadi, Navarra, 2003.

- fEl sistema de sanciones penales aplicables a las personas jurídicasò en BERDUGO GÓMEZ DE LA TORRE, Ignacio (Coord.), Lecciones y Materiales para el estudio del Derecho Penal, Tomo I, lustel, Madrid, 2010. 